\title{
ESPAÇOS PÚBLICOS EM JOÃO PESSOA (1889-1940): FORMAS, USOS E NOMES
}

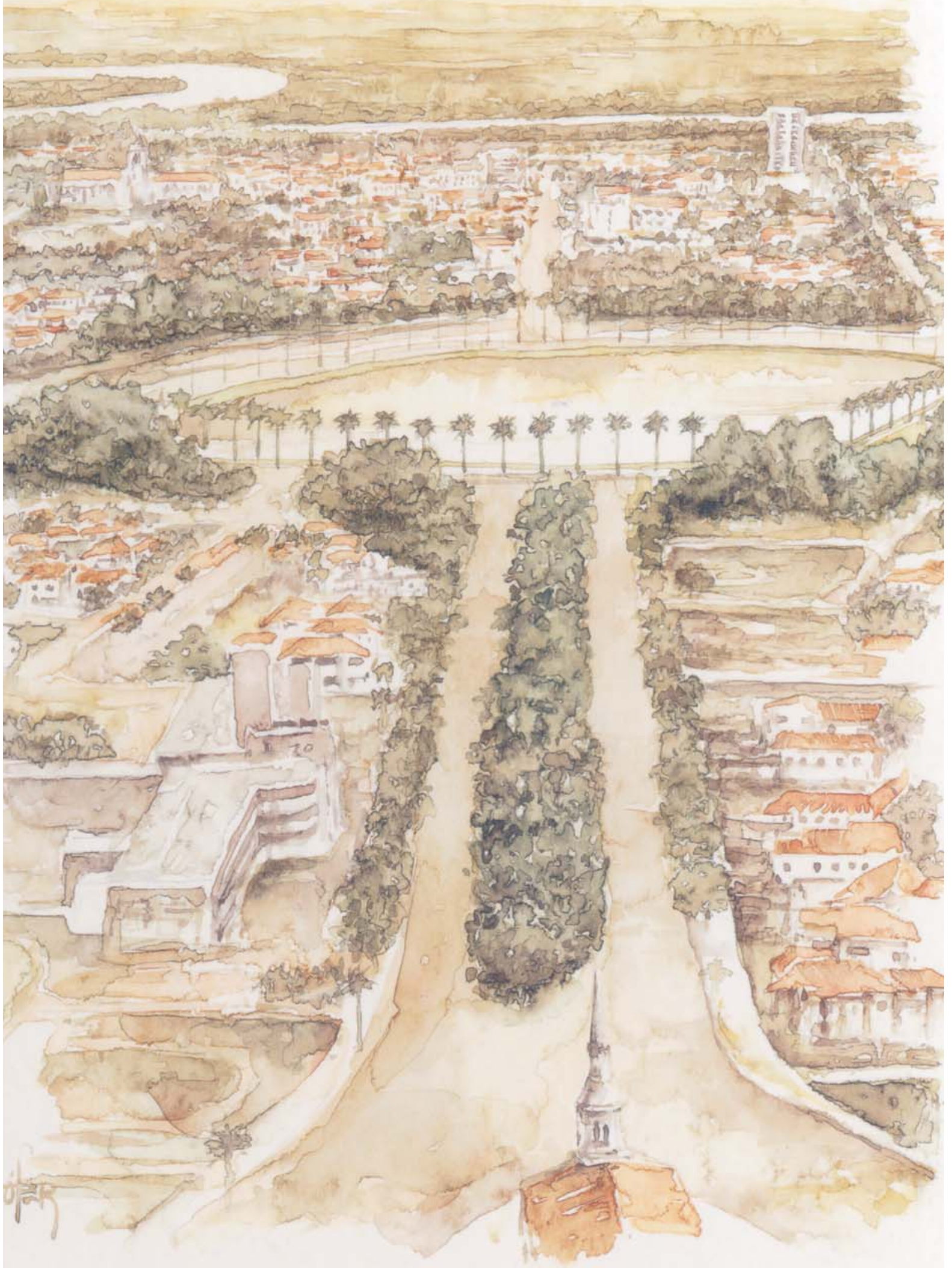

Maria Cecília Fernandes de Almeida orientadora: Dra. Telma de Barros Correia 


\title{
ESPAÇOS PÚBLICOS EM JOÃO PESSOA (1889-1940): FORMAS, USOS E NOMES
}

\author{
Dissertação de Mestrado apresentada ao \\ Programa de Pós-Graduação em Arquitetura e \\ Urbanismo da Escola de Engenharia de São \\ Carlos da Universidade de São Paulo, dentro da \\ área de concentração Teoria e História da \\ Arquitetura e do Urbanismo.
}

Professora Orientadora

Dra. Telma de Barros Correia 
Aos meus pais,

Gonçalo e Vilani, que sempre apoiaram minhas escolhas pessoais e profissionais, a quem devo muito do que sou e do que conquistei. 
"Há lugares dos quais vou me lembrar por toda a minha vida, embora alguns tenham mudado,

Alguns para sempre e não para melhor Alguns se foram e outros permanecem" (My Life - Beatles. Tradução Rita Lee) 


\section{Agradecimentos}

Apesar da solitária e muitas vezes "enclausurante" tarefa de escrever, a atividade do pesquisador envolve colaboradores, pessoas que direta ou indiretamente participam desse processo em alguma de suas fases, que influenciam nas condições e qualidades da pesquisa. Nas linhas por mim escritas, que compõem esta dissertação, está a participação de muitos a quem agradeço, dos quais destaco:

A FAPESP, pelo auxílio financeiro nos dois últimos anos da pesquisa, possibilitando seu enriquecimento e minha dedicação exclusiva a essa atividade.

A professora Dra. Telma de Barros Correia, pela rica orientação e grande colaboração, não apenas em relação ao resultado aqui apresentado, mas inclusive no que diz respeito à minha formação como pesquisadora. Agradeço também pela compreensão nos difíceis momentos e pela força contínua e, principalmente, pela convivência agradável e tranqüila, tornando esse trabalho ainda mais prazeroso.

Os professores membros da banca de qualificação, Dr. Carlos Roberto Monteiro de Andrade e Dra. Beatriz Piccoloto Bueno, pela disponibilidade e contribuição fundamentais para a finalização deste trabalho.

Os funcionários dos vários arquivos percorridos no período de pesquisa, pela disponibilidade e auxílio indispensáveis, em especial os que trabalham no IHGP, na Fundação Espaço Cultural, na Coleção Paraibana da Biblioteca Central da UFPB e na Fundação Casa de José Américo de Almeida, em João Pessoa; no Arquivo Nacional, Biblioteca Nacional, Arquivo Histórico do Exército e IHGB, no Rio de Janeiro; nas bibliotecas da FFLCH-USP e FAU-USP, em São Paulo e na Biblioteca Central da EESC-USP, em São Carlos.

Os professores e funcionários do Departamento de Arquitetura desta Escola que, além dos ensinamentos e auxílio profissional, acolheram-me com grande atenção, em especial à professora Dra. Maria Ângela Bortolucci, que me recebeu com muito carinho.

A professora Dra. Nelci Tinen, admirável profissional, grande responsável pela minha opção pela carreira acadêmica, a quem hoje tenho a honra de chamar de amiga. Apesar da distância, faz-se sempre presente.

Os alunos da EESC, que se tornaram grandes amigos, auxiliando na atividade acadêmica e na empreitada de viver tão longe de "casa", em um local tão diferente. Em especial, a Rodrigo Peronti Santiago, pelo carinho e dedicação, e a Wanessa Cartaxo Soares e Luciene Moraes, grandes amigas e companheiras.

Os amigos que ficaram em João Pessoa e se fizeram sempre presentes, ajudando na coleta de algum dado específico e, principalmente, na constante força que me ajudou a seguir nos momentos difíceis. Em especial a Daniela das Neves Amaral, pela disponibilidade e carinho, e a Luciana Dinoá, sempre presente. 
Os meus pais, Gonçalo e Maria Vilani, e minhas irmãs, Maria Carolina e Marília, diariamente presentes, pelo apoio, amor e dedicação. O constante auxílio na pesquisa, através do intercâmbio de materiais, provocado pelos meus livros que nunca se concentraram nem em João Pessoa nem em São Carlos, é mínimo diante do esforço que também fazem para tornar mais curta a distância que nos separa, tornando-se sempre presentes e participativos.

A cidade de João Pessoa, que me acolheu bem pequena e a quem hoje tenho o prazer de agradecer de forma concreta, estudando-a e reafirmando sua importância nos estudos urbanos brasileiros. 


\title{
Resumo
}

\author{
Abstract
}

\section{RESUMO}

Esta dissertação investiga as transformações dos espaços públicos da cidade de João Pessoa no período de 1889 a 1940, através da análise de suas formas, seus usos e suas denominações, alterados tanto no Império como na República. Observando esses espaços dentro da dinâmica urbana, o estudo os observa tanto como agentes na transformação da paisagem urbana, quanto na condição de vetores de crescimento da cidade, abrangendo sua dimensão física, nos aspectos simbólico e representativo. Para tanto, a trama urbana, a arquitetura, os conceitos estéticos e as formas de apropriação desses espaços constituíram-se vetores de análise dessas transformações. A abordagem é feita em três períodos: a cidade do século XIX; os espaços públicos resultantes das alterações do período conhecido como primeiro ciclo de reformas urbanas (19161926), conduzidos principalmente por questões sanitaristas; e os espaços públicos produzidos na década de 1930, resultantes, sobretudo, de preocupações viárias e da renovação da arquitetura. Abrangendo esses três momentos, estuda-se o caso do Parque Solon de Lucena, espaço público cuja trajetória é tratada no último capítulo.

Palavras-chave: Espaço público - Forma urbana - João Pessoa - Reformas urbanísticas.

\section{ABSTRACT}

This dissertation investigates the transformation of public spaces in João Pessoa city in the period from 1889 to 1940 , through the analysis of its forms, use and denominations, modified in the Empire period as well as in the Republic period. Observing these spaces inside the urban dynamics, the study observes them as urban landscape transforming agents, as well as in the condition of vectors to the growth of the city, enclosing its physical dimension, in the symbolic and representative aspects. For such, the urban raster, the architecture, the aesthetic concepts and the ways of appropriation of these spaces constituted vectors of analysis of these transformations. The approach is made in three periods: the city in XIX century; the public spaces resulting from the alterations of the period known as first cycle of urban reforms (1916-1926), lead mainly by sanitary matters, and the public spaces produced in the 1930 decade, resulting mainly from road concerns and the architecture renewall. Enclosing these three moments, it is studied the case of Parque Solon de Lucena, public space whose trajectory is dealt with in the last chapter.

Key-words: Public space - Urban form - João Pessoa - Urbanistic reforms 


\section{Sumário}

Introdução

$\begin{array}{ll}\text { Capítulo } 1 \text { - Os espaços públicos } & 7\end{array}$

1.1 OS ESPAÇOS PÚBLICOS NA ERA INDUSTRIAL 9

1.2 REPENSANDO OS ESPAÇOS PÚBLICOS 21

Capítulo 2 - A cidade oitocentista 25

2.1 A TRAMAEAS CONSTRUÇÕES 26

2.1.1 A trama 29

2.1.2 As construções 36

2.2 OS ESPAÇOS PÚBLICOS 44

2.2.1 A trama e os espaços públicos desenhando a cidade 44

2.2.2 A arquitetura e os espaços públicos $\quad 49$

2.2.3 Definição da infra-estrutura 50

2.2.4 Usos 55

2.2.5 O discurso sobre a cidade $\quad 60$

2.3 OS ESPAÇOS DO SÉCULO XIX 65

2.3.1 Os espaços de trajeto 66

$\begin{array}{ll}\text { 2.3.2 Os espaços de permanência } & 71\end{array}$

2.3.3 Os nomes dos espaços públicos $\quad 75$

Capítulo 3 - A cidade nas décadas de 1910 e $1920 \quad 79$

3.1 O SANITARISMO E ATRAMA 81

3.2 AS CONSTRUÇÕES 83

3.3 OS NOVOS ESPAÇOS PÚBLICOS 85

3.3.1 Como a trama, suas ruas, avenidas e as praças compõem os novos espaços 85

$\begin{array}{ll}\text { 3.3.2 As praças } & 91\end{array}$

3.3.3 As construções nesses espaços 97

$\begin{array}{ll}\text { 3.3.4 Reforma da infra-estrutura } & 99\end{array}$ 
Capítulo 4 - A cidade dos anos 30

4.1.1 A questão portuária e as intervenções urbanas 126

4.1.2 A trama urbana e o Plano de Extensão 129

4.2ANOVAARQUITETURAALTERANDO AFORMA URBANA 140

4.3 OS NOVOS ESPAÇOS PÚBLICOS 148

4.3.1 As ruas e avenidas 150

4.3.2 As praças 153

4.3.4 Os parques 153

4.3.5 Os usos 155

$\begin{array}{ll}\text { 4.3.6 Os novos nomes } & 157\end{array}$

$\begin{array}{ll}\text { Capítulo } 5 \text { - O Parque Solon de Lucena } & 159\end{array}$

5.1 DA LAGOA DOS IRERÊS AO PARQUE SOLON DE LUCENA 161

5.2 ANOS 30: O PARQUE COMO CORAÇÃO DA CIDADE FUTURA 198

5.3 ENTRE O RIO E O MAR: A LAGOA E A EXPANSÃO DA CIDADE 172

5.4 O PARQUE NO CENTRO DAS ANTENÇÕES 175

$\begin{array}{lr}\text { Considerações Finais } & 177\end{array}$

$\begin{array}{lr}\text { Bibliografia } & 181\end{array}$

$\begin{array}{ll}\text { Anexos } & 193\end{array}$

Mapa da cidade de João Pessoa, destacando suas áreas de expansão referentes aos momentos abordados nesta dissertação

Monographia da Cidade da Parahyba do Norte.

Melhoramentos da capital paraibana (transcrição) 


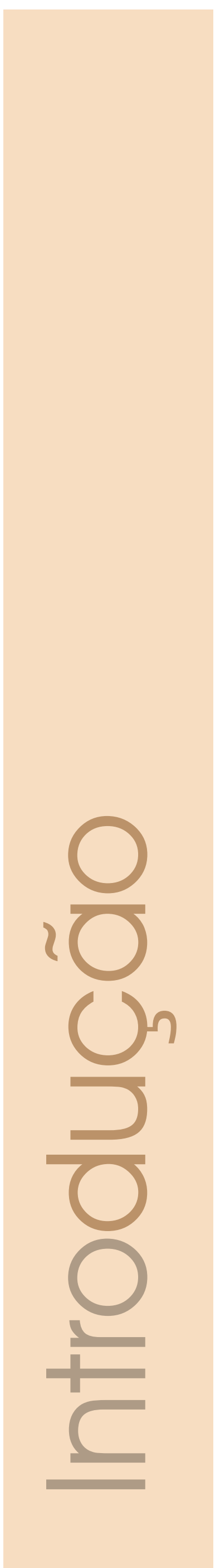




\section{Introdução}

"Não somos mais arruados, nem freqüentadores da rua. Circulamos de nossas casas, edifícios de 'apartamentos', de condomínios horizontais para a loja departamental, do supermercado, para o centro de compras, a casa de cultura, para o centro de exposições, a passarela do samba, até mesmo para a 'Rua 24Horas'”'.

Um problema comum às nossas cidades nos dias atuais é a progressiva redução da utilização dos espaços públicos como local de convivência, encontros e recreação. Esses espaços se estabelecem predominantemente como áreas de circulação: o leito da rua, para veículos; as calçadas, para pedestres apressados. Percebe-se a ampliação da privatização dos espaços de uso coletivo, com a busca de espaços privados para o lazer, consumo, cultura e práticas esportivas.

Há uma proliferação de espaços coletivos privados, sobretudo de shopping centers, os quais redirecionam para si o fluxo de usuários do meio urbano, através da concentração de atividades e serviços em um conjunto edificado:

"As conversas de rua vão passando para o telefone; os jogos vão-se concentrando em escolas, estimulados que são por novas pedagogias. Os clubes particulares aumentam muito de número, assim como os centros esportivos gratuitos, de iniciativa municipal. Festas do calendário, como juninas ou carnaval, que eram preponderantemente de rua, passam a ser preponderantemente de salões."

O discurso da segurança e comodidade para a execução de atividades urbanas, como comércio e lazer, envolve a política de reprodução de espaços privados de uso coletivo e se reflete nos espaços abertos públicos que são, em sua maioria, condicionados a locais predominantemente de passagem, conseqüência também impulsionada pelo novo ritmo de vida urbana.

Diante desse redirecionamento do uso dos espaços urbanos que conduz, de forma geral, ao seu crescente esvaziamento, difundiu-se nos dias de hoje o movimento em busca de reverter esse quadro através de intervenções públicas. Generalizam-se ações no sentido de recuperar os espaços das cidades, buscando resgatar sua história, identidade e memória, atribuindo-lhes novos usos na tentativa de revitalizá-los e reinseriIos na dinâmica urbana, o que ocorre muitas vezes pelo viés do turismo. Esse esforço no sentido de redirecionar o uso dos espaços públicos é um movimento, em certo sentido, contrário ao ocorrido do início do século XX, quando, interferindo na estrutura urbana, alterou-se a forma de utilização dessas áreas.

\footnotetext{
${ }^{1}$ MARX, Murilo. Cidade no Brasil, em que termos? São Paulo: Studio Nobel, 1999. p. 107.

${ }^{2}$ FERREIRA, William Rodrigues. O espaçp público nas áreas centrais: a rua como referência - um estudo de caso em Uberlândia, MG. São Paulo, FFLCH-GE, 2002, p.25 (Tese de Doutorado)
} 
Este trabalho se propõe a estudar a trajetória percorrida pela conformação dos espaços públicos entre o fim do século XIX e o início do século XX, na cidade de João Pessoa. Tem por objetivo observar as transformações das formas, usos e denominações desses espaços nesse período, percebendo como esses três aspectos se modificaram. Busca entender o significado original desses espaços, bem como as alterações na sua configuração e no seu significado ao longo do período em estudo.

Ao tratar de espaços públicos, remete-se aos espaços urbanos, geralmente abertos, de uso coletivo e não-privado. $O$ conceito de espaço público aqui adotado refere-se às áreas urbanas utilizadas pela coletividade, de maneira, a priori, irrestrita. Nesse sentido, abrange ruas, becos, largos, praças, jardins e espaços afins que conformam a estrutura urbana não-privada.

Analisando o caso da cidade de João Pessoa entre os anos de 1889 e 1940, busca-se observar seus espaços públicos, captando as transformações formais e de uso destes lugares. Tal processo revela alterações que podem ser lidas, de forma significativa, nas novas denominações.

Para entrar em sintonia com o novo ritmo que rege a vida do início do século $X X$, o espaço urbano remodela-se atendendo às novas atividades que se difundem. Encurtar distâncias e aumentar velocidade, para "ganhar tempo", torna-se um objetivo constante da reforma urbana:

"De fato, desde o século passado, a velocidade - expressa na pressa dos indivíduos, na rapidez das buzinas impacientes dos carros, na agilidade dos serviços e na produção industrial - tornou-se um elemento importante nas representações das metrópoles, enquanto a busca de uma crescente aceleração converteu-se em uma das preocupações básicas dos indivíduos envolvidos na reforma urbana e da moradia desde então"3.

Essa mudança se reflete claramente no espaço urbano, cuja imagem reformulada tem, nos espaços públicos - becos, travessas, pátios, largos, ruas, avenidas, praças e parques -, o tradutor por excelência dessa transformação, sobretudo através dos resultados obtidos pelas recorrentes reformas urbanas.

A mudança da denominação de tais espaços revela os novos conceitos e significados a eles atribuídos. A toponímia reflete o pensamento do momento em que a denominação é criada ou alterada, constituindo-se um vetor de interpretação desse processo. A leitura a partir desse referencial, observando as mudanças e as permanências topônicas, revela a força de algumas heranças que resistem às inovações ao longo do tempo, bem como sinaliza as tendências e significados de tais transformações.

Adotar a cidade de João Pessoa como objeto de análise, quando essa não dispõe de características comuns às das cidades capitais que se tornam referências para as reformas que marcam o início do século XX - superpopulação e industrialização -, permite discorrer por um outro viés. Suas características urbanas - sua natureza, funções, necessidades, contexto político e econômico, enfim, suas propriedades específicas conduzem seu processo de transformação urbana para além da absorção de "modelos urbanos" que, certamente, direta ou indiretamente, também influenciam esse processo.

A abordagem aqui realizada acerca dos espaços públicos da cidade de João Pessoa se refere ao período entre os anos de 1889 e 1940, onde é primordial perceber o quadro urbano herdado do período colonial, ainda pouco modificado, e o processo de alteração por que passam esses espaços ao longo da primeira metade do século XX, quando ocorrem dois ciclos importantes de reformas urbanas nessa capital.

${ }^{3}$ CORREIA, Telma de Barros. "A gestão do tempo e a organização da cidade moderna". Sinopses. São Paulo, n. 33, jun 2000, pp. 2223 , p. 22. 
O marco inicial - que coincide com o ano da proclamação da República - é definido pela publicação de documentos que denunciam a não-adequação do espaço urbano às atividades nele desenvolvidas: a Monographia da Cidade da Parahyba do Norte, elaborada por Vicente Gomes Jardim, e os artigos intitulados Melhoramentos da capital paraibana, publicados diariamente no jornal local Gazeta da Parahyba pelo engenheiro João Claudino Cruz. O marco final é referente à conclusão das obras realizadas no Parque Solon de Lucena, espaço ao qual é conferido grande significado ao longo da formação da cidade.

A análise dessa trajetória urbana da capital paraibana, que envolve o fim do século XIX e as primeiras décadas do $X X$, é conduzida por questões estruturadas segundo quatro grandes temas que norteiam os objetivos da pesquisa: as transformações das formas urbanas; as novas denominações dos espaços públicos; os novos usos dos espaços públicos; e a relação entre os espaços públicos e a expansão urbana.

Observar as transformações decorrentes do processo de modernização em uma cidade como João Pessoa requer tomar por base os elementos que lhe são peculiares, não sendo possível compreendê-las como simples reflexo das reformas ocorridas nas cidades européias oitocentistas, nem como repetição do modelo emanado desde a capital federal.

A pesquisa abrange publicações que tratam das reformas urbanas nos séculos XIX e XX nas metrópoles européias e, sobretudo, nas cidades brasileiras, e textos sobre a cidade de João Pessoa no período abordado, principalmente documentos e fontes primárias.

Na seleção das fontes de pesquisa busca-se captar as nuances desse processo na capital paraibana, sem se limitar a observá-lo através dos registros oficiais, contidos em mensagens de governo, relatórios técnicos e publicações da imprensa, que tecem um discurso afirmativo de valores apontados como modernos, manifestados no espaço e nas vivências urbanas. As impressões deixadas por viajantes, literatos, cronistas, fotógrafos, poetas, etc, encontradas em mapas, monografias, pinturas, diários de viagens, livros, relatórios, versos e rimas, são fontes de informações usadas para confrontar e complementar os registros oficiais.

Grande parte dssa documentação é localizada em acervos da cidade de João Pessoa: Instituto Histórico e Geográfico Paraibano; Biblioteca Pública Municipal; Fundação Casa de José Américo; Biblioteca Municipal José Lins do Rego; Biblioteca Central da UFPB (Coleção Paraibana Jornal A União, Núcleo de Documentação e Informação Histórica e Regional); Acervo FUNESC (Fundação Espaço Cultural); bibliotecas particulares de Mário de Láscio, Humberto Nóbrega, Walfredo Rodrigues, Wilson Seixas e Maurílio de Almeida; mapoteca da UFPB; e acervo da Comissão do Centro Histórico de João Pessoa. Acervos da cidade do Rio de Janeiro (Arquivo Nacional, Biblioteca Nacional, Arquivo Histórico do Exército e Instituto Histórico e Geográfico Brasileiro) e bibliotecas de universidades das cidades de São Paulo (FAU-USP e FFLCH-USP), São Carlos (EESC-USP e UFSCar), Campinas (UNICAMP) e Recife (UFPE) também fazem parte da coleta de dados realizada nessa pesquisa.

Em toda a documentação consultada busca-se os significados dos espaços públicos, seja no aspecto físico, simbólico ou quanto às suas formas de ocupação. É por meio dessas fontes que, dentro do discurso reformista vigente no período estudado, observa-se como esses espaços são vistos, percebendo as diferentes visões pertinentes a diferentes olhares. Remontando às origens de tais espaços, busca-se recuperar seus processos de significação, através da transformação das palavras que os nomeiam e suas diferentes conotações, de acordo com os momentos de suas enunciações.

Esse estudo é organizado em cinco capítulos, sistematizados cronologicamente segundo as fases do processo de transformação urbana da cidade de João Pessoa: 
O Capítulo 1 trata da questão dos espaços públicos e suas transformações nas cidades, não se detendo especificamente ao caso da cidade de João Pessoa. A partir do conceito adotado de espaço público, nesse capítulo é feito um breve panorama da evolução da forma e dos usos desses espaços nas cidades, com ênfase no período abordado na pesquisa.

O Capítulo 2 retrata a cidade de João Pessoa através de suas características oitocentistas, enfocando o período entre os anos de 1889 e o início da década de 1910, porém recorrendo a períodos anteriores a essa delimitação para embasar a formação de suas características no fim do século XIX. Esse capítulo trata da configuração dos espaços públicos nas cidades brasileiras no período oitocentista, enfatizando o caso da cidade da Parahyba do Norte - atual João Pessoa. Para a leitura desses espaços, parte-se da forma como a trama dessa cidade, no fim do século XIX, desenha a área urbana e seus quarteirões, observando suas modificações referentes à implantação da cidade e às características coloniais. Percebe-se que as reivindicações, gradativamente sendo manifestadas, em prol de transformações urbanas, que renovam sua aparência e funcionamento, tornam-se mais enfáticas nesse período. Ao abordar o espaço público oitocentista, buscando evidenciar suas características formais e de utilização traduzidas em suas denominações, chegase a uma certa 'classificação' desses espaços, entre aqueles de passagem e de permanência, a partir da qual os espaços simbólicos de maior representatividade desse momento são estudados separadamente.

O Capítulo 3 trata da cidade nas décadas de 1910 e 1920 observando, mais especificamente, o período identificado como primeiro ciclo de reformas urbanas (1916-1926). Aborda as transformações dos espaços públicos da cidade de João Pessoa ocorridas nesse momento, as quais são guiadas, sobretudo, por exigências sanitaristas, apresentando os reflexos das intervenções dessa natureza na cidade através da alteração do traçado, da infra-estrutura e de sua relação com os novos espaços públicos construídos. As preocupações higienistas e estéticas influenciam diretamente a aparência dos espaços públicos característicos desse momento, bem como as atividades neles abrigadas. Ao abordá-los, ressalta-se a proliferação de praças no tecido urbano, que se torna o maior marco dessa fase.

No Capítulo 4 é estudada a cidade dos anos 30, enfocando a construção dos seus espaços públicos segundo a ênfase dada naquele momento à expansão da cidade. Nele são abordadas questões como expansão urbana e zoneamento. A trama, que sofre grandes alterações, torna-se, mais uma vez, a condutora da transformação desses espaços, impulsionada, inclusive, pelo interesse de ligar a cidade à praia, devido, entre outras razões, à necessidade de facilitar o acesso ao novo porto oficial do Estado. As avenidas e parkways são os elementos representativos desse momento, que revelam o caráter viário que predomina nas intervenções desse período. Às novas formas dos espaços urbanos vinculam-se novas formas arquitetônicas, que complementam a transformação da aparência da cidade a partir de fortes investidas promovidas pelo interventor Argemiro de Figueiredo.

A organização dos capítulos tem uma ordem cronológica. Porém, este estudo não é guiado apenas pela cronologia, mas sobretudo pelas pautas urbanísticas locais e suas relações com idéias e propostas em pauta em cada momento. Se nas etapas observadas destacam-se elementos e espaços simbólicos, o Parque Solon de Lucena perpassa todas essas fases da história urbana dessa capital, que podem ser referenciadas pelo processo de transformação desse espaço. Dedicar um quinto capítulo deste estudo a esse parque ilustra o processo estudado em relação à cidade, abordando questões abrangentes a partir de um único objeto. Assim, o Capítulo 5 observa o Parque Solon de Lucena desde a fundação da cidade, sua participação na dinâmica urbana e nos discursos urbanísticos de cada fase desse processo de transformações, enfatizando sua participação nas questões higienistas e nas intervenções sanitaristas e viárias. 
As últimas décadas evidenciam, no panorama das pesquisas brasileiras, interesses em estudos sobre história da cidade e do urbanismo, convergindo sobretudo para as transformações urbanas nas quais estão mergulhadas as cidades na passagem do século XIX para o XX. Esse interesse se explicita em trabalhos desenvolvidos por pesquisadores e instituições de ensino superior de diversas regiões do país, bem como na crescente realização de eventos, seminários e encontros, como também no número de teses e trabalhos publicados nessa área, incentivando o desenvolvimento de novos estudos complementares que venham, inclusive, ampliar a abrangência geográfica das análises desse processo, contribuição de grande importância diante da extensão e distinção do território nacional.

A cidade de João Pessoa, assim como muitas outras, a exemplo do Rio de Janeiro, São Paulo, Salvador, Recife, Vitória, Natal, Santos, também participa do quatro de transformações urbanas nacionais em evidência desde fins do século XIX. Porém, é bem verdade que, ao contrário daquelas, o caso da capital paraibana não dispõe de estudos acurados, carecendo de pesquisas que tenham essa cidade, sua constituição física e suas transformações como objeto específico de análise.

É facilmente percebido, no ainda incipiente conjunto de estudos sobre a capital paraibana, a escassez de referências às fontes primárias e de época, como textos de jornais, revistas, relatórios de governo, relatos de viajantes, etc, material de primeira ordem na análise de transformações urbanas, úteis na elucidação de como esse processo se dá localmente, quais seus agentes, ações e atores, bem como suas especificidades, o que torna premente a necessidade de estudos dessa natureza.

Nesse sentido, através do estudo da dinâmica dos espaços públicos pessoenses nas primeiras décadas da República, esta dissertação busca preencher parte das lacunas existentes em relação à história urbana da cidade de João Pessoa. 

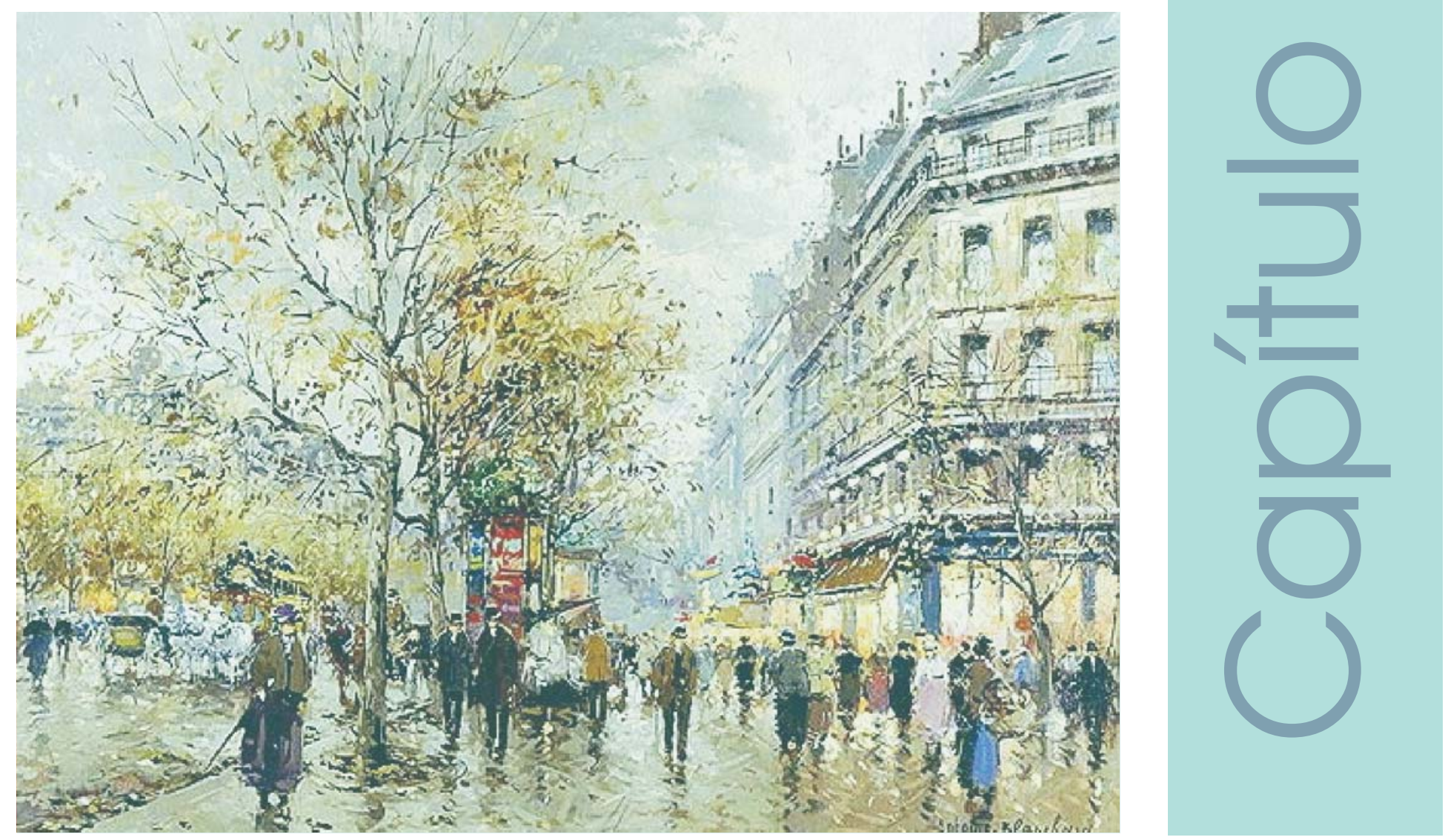


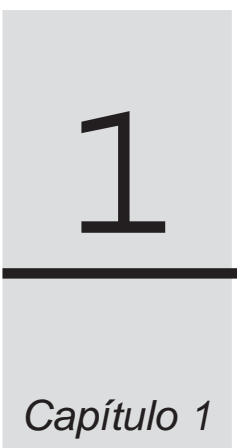

\section{Os espaços públicos}

Os modos de apropriação dos espaços públicos criados nas cidades, vivências e usos por parte da população, dão-lhes valor e significados, atribuindo-lhes a noção de lugar. Para Augé, "o lugar se completa pela fala, a troca alusiva de algumas senhas, na convivência e na intimidade cúmplice dos locutores"4. Assim, o espaço qualificado é síntese de determinações espaço-temporais, com acúmulo de memórias, mitos e tramas coletivas.

Cada indivíduo estabelece várias relações com partes da cidade em que vive, de forma que à sua imagem vinculam-se diversas memórias e significações. O usuário do espaço público não é apenas observador, mas parte atuante, onde os elementos físicos e imóveis em relação com as pessoas e atividades caracterizam os 'lugares' da cidade. A cidade é objeto da percepção dos seus habitantes, ao mesmo tempo em que é também resultado das ações desses.

"Uma estrutura física viva e integral desempenha também um papel social. Pode fornecer a matéria-prima para símbolos e memórias colectivas da comunicação entre grupos" ".

Segundo Rykwert, quando se trada das cidades, sua população é tão agente como paciente do seu processo de formação: "a cidade não havia crescido, como ensinavam os economistas, em obediência a leis quase naturais, mas era um artefato almejado, um constructo humano em que muitos fatores conscientes e inconscientes desempenham seu papel"6. Nesse processo, a relação entre tecido urbano e sociedade é tal que a alteração em um deles reflete em mudança no outro. Diante da diversidade social da atualidade, a cidade abriga muitas etnias, culturas, classes e religiões, o que a torna cheia de contrastes e conflitos, resultando em muitas faces de uma única cidade. Seu sucesso "depende da força inerente do tecido urbano e de sua disponibilidade para as forças sociais que moldam a vida de seus habitantes" 7 .

No espaço público concreto e aberto, destinado ao diálogo e com vistas à construção de parâmetros de igualdade e estabelecimento de interesses comuns, dá-se o verdadeiro regime de autonomia política grega, onde "a vida política pretende ser o objeto de um debate público em plena luz do sol, na Ágora, da parte de cidadãos definidos como iguais e de quem o Estado é a questão comum"8.

O espaço público é local de discussão e deliberação sobre assuntos de interesse comum dos cidadãos da polis. Com sua consolidação desaparece do horizonte grego toda uma forma de vida social centralizada em

\footnotetext{
${ }^{4}$ AUGÉ, Marc. Não-lugares: introdução a uma antropologia da supermodernidade. Campinas: Papirus, 1994, p. 73.

${ }^{5}$ LYNCH, Kevin. A imagem da cidade. Edições 70: Lisboa, p. 14.

${ }^{6}$ RYKWERT, Joseph. A sedução do lugar. São Paulo: Martins Fontes, 2004, p. 5.

7 Ibid., p.10.

${ }^{8}$ VERNANT, J. P. Origens do pensamento grego. Rio de Janeiro: Bertrand Brasil, 1989, p. 6.
} 
torno do palácio e da personagem do Rei divino. Isso se dá a partir da constituição de um novo sujeito social, o cidadão, definido como aquele que tem direito de participar de decisões que dizem respeito aos destinos da cidade. Na antiga Roma,

"mesmo o mais renegado plebeu tinha, na cidade, acesso à animação das palestras, o calor dos banhos, a alegria dos banquetes públicos, a esmola dos ricos e a magnificência dos espetáculos públicos".

Apesar de controlada pela aristocracia e pelo clero e, ao mesmo tempo, em luta contra o sistema feudal, a cidade medieval se constitue em torno de espaços públicos, ainda que controlados por tais instituições. $O$ comércio, as relações e muitas atividades dão-se nas ruas, nos largos, nos pátios abertos. ${ }^{10}$

O problema das sociedades modernas é que "os lugares se embaralharam, as fronteiras se dissolveram, as hierarquias que deveriam articular seus espaços foram subvertidas"11, culminando num processo de desmanche dos espaços públicos e privatização dos espaços urbanos.

\title{
1.1 O ESPAÇO PÚBLICO NA ERA INDUSTRIAL
}

\begin{abstract}
"Portanto, tornou-se essencialmente outro o significado das praças abertas em meio à cidade. Hoje raramente utilizadas para grandes festas públicas, e cada vez menos para um uso cotidiano, elas servem, na maioria das vezes, a nenhum outro propósito além de garantir maior circulação de ar e luz, provocar uma certa interrupção na monotonia do oceano de moradias e, de qualquer maneira, garantir uma visão mais ampla sobre um edifício monumental, realçando seu efeito arquitetônico.Que diferença da Antiguidade! Nas cidades antigas, as praças principais eram uma necessidade vital de primeira grandeza, na medida em que ali tinha lugar uma grande parte da vida pública, que hoje ocupa espaços fechados, em vez das praças abertas"12.
\end{abstract}

O Ministério do Meio Ambiente, ao tratar da sustentabilidade das cidades brasileiras, aponta a necessidade de "ampliação, equipamento e reconquista dos espaços públicos, hoje cercados e transformados em terra de ninguém"13. Essa preocupação revela um percurso inverso ao processo de construção das cidades atuais, que se dá através da reforma desses espaços e da modificação da forma de utilização das áreas públicas das cidades, vinculadas a noções específicas de "modernização urbana":

"Os movimentos do século XIX, de crítica à cidade industrial, analisam as tendências da cidade contemporânea e começam, também, a voltar a atenção para a rua. (...) O desejo de ordem contraposto à 'desordem' era a ideologia dominante. A cidade precisava ser reformulada, saneada. (...) A rua é abolida em nome da higiene e por representar a desordem circulatória. $O$ tráfego é ordenado, criam-se trechos autônomos para a circulação de pedestres. As ruas tortuosas, porém animadas e propícias aos encontros, são substituídas por longas e largas avenidas. O proletário é afastado dos centros urbanos e da própria cidade. (...) O centro da cidade se esvazia de moradias em proveito dos escritórios e a consciência urbana se dissipa com o desaparecimento de ruas, ... e espaços para o encontro" ${ }^{14}$.

\footnotetext{
${ }^{9}$ FERREIRA, William Rodrigues. O espaço público nas áreas centrais: a rua como referência - um estudo de caso em Uberlândia, MG. São Paulo, FFLCH-GE, 2002, p. 15 (Tese de Doutorado).

${ }^{10}$ SPOSITO, apud FERREIRA, op.cit., p. 15.

${ }^{11}$ TELLES, Vera da Silva. Espaço Público e espaço privado na constituição social: notas sobre o pensamento de Hanna Arendt. 1990, p.3.

${ }^{12}$ SITTE, Camillo. A construção das cidades segundo seus princípios artísticos. São Paulo: Editora Ática, 1992, p.15 e 17.

${ }^{13}$ MMA - Ministério do Meio Ambiente. Agenda 21 Brasileira - Cidades Sustentáveis. Brasília: Ministério do Meio Ambiente/ IBAM/ ISER/REDEH, 2000, p. 28.

${ }^{14}$ AZEVEDO, Heloísa P. Lima. Estudo de desempenho dos espaços públicos para o pedestre: um estudo de caso no centro de Taguatinga. Brasília: UNB/URB, 1992. p.11
} 
As reformas efetuadas nas cidades após o início da industrialização têm como meta uma nova ordenação dos espaços urbanos através do estabelecimento de funções específicas, dotando-os de equipamentos que direcionam e restringem seus usos, o que estabelece, segundo os urbanistas, a ordem tão necessária às conseqüências da era industrial nas cidades. Espaços urbanos típicos até então, como largos e pátios, caracterizados por um espaço amplo e sem uma estrutura física definidora de usos, podendo ser apropriados para festas, feiras e outras manifestações ou atividades, passam por intervenções que alteram definitivamente essas características. Os espaços públicos tornam-se condicionadores dos seus modos de apropriação, formados por jardins e passeios que conduzem os caminhos a serem percorridos, além de equipamentos que estipulam os locais de permanência e suas formas de utilização.

Da mesma forma, os becos e as travessas, delimitados pelas necessidades do trajeto cotidiano, são substituídos por vias que passam a priorizar a circulação de veículos. Esse processo acarreta a perda crescente do espaço efetivo de circulação para pedestres e outros meios de transportes que não os motorizados. O pedestre depara-se com a diminuição das áreas para sua movimentação e com um espaço cada vez menos acolhedor. A nova escala urbana, promovida por grandes avenidas, amplas praças e edificações monumentais, desmonta o referencial do pedestre. A atração pela paisagem da cidade dá lugar à preocupação com o tráfego de veículos e com as limitações dos passeios tumultuados e congestionados. Essa nova conjuntura altera a relação da população com a cidade. Segundo Camillo Sitte, ao tratar das intervenções em Viena no século XX, "vinha se formando uma nova neurose: a agorafobia, o medo de atravessar vastos espaços urbanos"15. "As pessoas se sentiam diminuídas pelo espaço, impotentes frente aos veículos a que ele fora entregue. Também perdiam a noção de relacionamento com os edifícios e monumentos"16.

O estabelecimento de funções específicas aos espaços públicos tem como conseqüência a redução da diversidade e flexibilidade de funções que eles abrigam. Tais espaços se transformam, gradativamente, em um cenário de contradições, envolvendo tanto o processo que os origina quanto a forma de apropriação conflitante por parte de diferentes grupos sociais. ${ }^{17}$ A rua se reduz cada vez mais a um espaço de circulação, voltada para as esferas de consumo e trabalho, enquanto a casa é palco da vida privada. Diante do espaço público 'morto', as pessoas procuram um terreno seguro, caracterizando um processo de "'reinvenção' do espaço público, privatizado, trancafiado, excludente, vigiado, intimista e seletivo"18. Constrói-se "um mundo espacialmente e socialmente segmentado - pessoas aqui, tráfego ali; trabalho aqui, moradias acolá; ricos aqui, pobres lá adiante; no meio, barreiras de grama e concreto"19.

Com a crescente privatização dos locais de confraternização, diversão, cultura, lazer e práticas esportivas, vê-se o esvaziamento do espaço público, que passa a ser utilizado como "continuidade do espaço privado de cada um, (...), tanto no que se refere às transformações físicas implementadas como [às suas formas de] apropriação"20.

Os espaços abertos de uso coletivo são constantemente reordenados nas cidades atuais, não desaparecendo do cenário urbano. Porém, eles são, muitas vezes, destituídos de significados espaciais compatíveis com essa denominação, principalmente pelas suas condições de apropriação por parte da população. Esses espaços estão, atualmente, muito distantes dos padrões que os consagram como privilegiados

${ }^{15}$ SITTE, Camillo,apud. SCHORSKE, Carl. E. Viena Fin-de-siècle. São Paulo: Cia das Letras, 1988, p. 81.

${ }^{16}$ SCHORSKE, Carl. E. Viena Fin-de-siècle. São Paulo: Cia das Letras, 1988, p. 81.

${ }^{17}$ FERREIRA, William Rodrigues. O espaço público nas áreas centrais: a rua como referência - um estudo de caso em Uberlândia

- MG, São Paulo, FFLCH-GE, 2002, p.5 (Tese de Doutorado).

18 Ibid., p. 37.

${ }^{19}$ BERMAN, Marshall. (1982) Tudo que é sólido desmancha no ar: a aventura da modernidade. São Paulo: Companhia das Letras, 1999, p. 162.

${ }^{20}$ REGATTI, Décio. "Apropriação social do espaço público - um estudo comparativo". Paisagem e ambiente: ensaios. São Paulo:n.7, p141-197, 1995. p. 193. 
por seu papel simbólico, sua efetiva utilização e sua concepção urbanística e arquitetônica. Esta mudança de sentido, conteúdo e apropriação é reflexo de processos que vêm alterando o modo de vida urbana, o significado de seus espaços e o próprio conceito de cidade.

Trata-se de um longo processo de metamorfose. Os espaços públicos desempenham um papel fortemente simbólico e político no passado, sobretudo através da ágora e do fórum; constituem-se foco da vida cotidiana e da festa na Europa Medieval, e objeto privilegiado da "arte urbana" no barroco. Sofrem grandes modificações a partir dos efeitos da industrialização sobre a cidade, os quais levam ao desmanche de antigas conformações e à proposição de novas questões..$^{21}$ Ao longo desse processo de mutação física e conceitual de cidade, são vários os profissionais do urbanismo que se empenham em repensar esse espaço na nova conjuntura urbana.

O caso clássico de Paris, resultante da reforma conduzida por Haussmann, torna-se referência. A reforma parisiense resulta numa cidade com avenidas largas e arborizadas, sobrepostas à antiga malha urbana irregular, interligando os principais monumentos e praças. Os espaços públicos também são construídos através da criação de parques no contorno da cidade, "cujas variações demonstram a influência do paisagismo inglês: o Bois de Boulogne, o Buttes-Chaumont e o Parque de Vincennes"22. Haussmann busca promover um novo ambiente urbano monumental, através da regularidade de vias largas que se tornam os principais elementos na hierarquia do traçado por ele proposto. Essas avenidas, homogeneamente arborizadas, chamadas de bulevares, ao passarem por monumentos, alargam-se criando espaços públicos geralmete circulares, que se vinculam a outras vias de características semelhantes, distribuindo o tráfego pelas avenidas principais. Nesses percursos, encontram-se as principais praças, monumentos e áreas verdes da cidade.

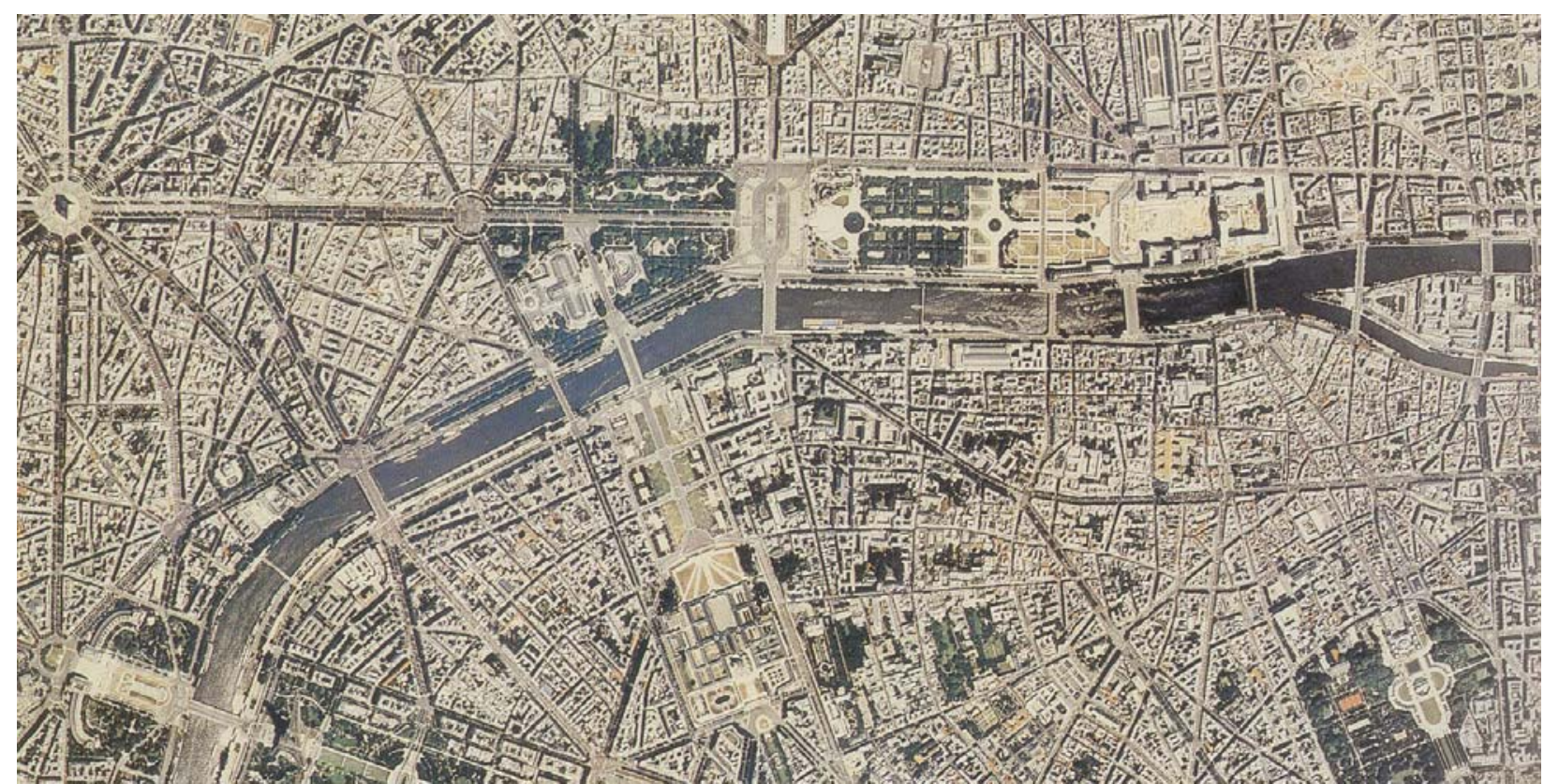

Paris FONTE: http://www.geocities.com/HotSprings/7912/ensanche.html

A insercão de elementos circulares que se vinculam ao conjunto viário torna-se uma solução comum adotada nas intervenções de muitas cidades, na intenção de sistematizar o tráfego. Esse é um artifício divulgado por Hénard, arquiteto francês, que busca, assim como seus contemporâneos, meios de ordenar a cidade. Essas rotatórias, além de encaminhar o fluxo de veículos em uma única direção circular até sua saída na rua adequada, têm o objetivo de "criar um ponto focal nesses círculos com a colocação em seu centro de um obelisco, um pavilhão ou mesmo uma coluna, um poste ou uma fonte"23. Para Rykwert, esse é um marco

\footnotetext{
${ }^{21}$ BARTALINI, Vladimir. Espaços livres públicos. O caso da praça do metro de São Paulo. Prog. Pós-Grad. Arquit. Urb. FAUUSP. São Paulo v.1 n.1 p. 11-22 dez. 1990.

${ }^{22}$ RYKWERT, Joseph. A sedução do lugar. São Paulo: Martins Fontes, 2004, p. 120.

${ }^{23}$ Ibid., p. 133.
} 
na mudança da natureza do espaço público, onde "a rotátória é, essecialmente, um espaço de passagem, e não um espaço para se estar ou habitar"24.

Haussmann usa edifícios novos e antigos como pano de fundo das novas avenidas e propõe a uniformidade arquitetônica das fachadas nas praças e ruas mais importantes, para acentuar o caráter monumental do espaço público. Porém, como resultado, segundo Benevolo,

"a enorme extensão dos novos espaços e o trânsito que os estorva impede de percebê-los como ambientes em perspectiva: os vários espaços perdem sua individualidade e fluem uns nos outros; as fachadas das casas se tornam um fundo genérico, ao passo que os aprestos das ruas que são vistos em primeiro plano - os faróis, os bancos de jardim, as edículas, as árvores - se tornam mais importantes"25.

A monumentalidade promovida em Paris se refere à relação entre a estrutura viária e os novos espaços públicos. As linhas horizontais são enfatizadas, enquanto "as fachadas dos edifícios de apartamentos ao longo das novas ruas portam detalhes mínimos"26. Os espaços produzidos são formados por funções residenciais e comerciais, com "as fachadas uniformes, as fileiras de árvores e o denso tecido comercial, formado por cafés, restaurantes e serviços em geral"27; "também é espaço de lazer, com teatros e locais para o promenade"28. Esses espaços são promotores da segregação social: construídos através de demolições de edificações, têm os proprietários das edificações e os usuários de seu entorno selecionados pela especulação imobiliária.

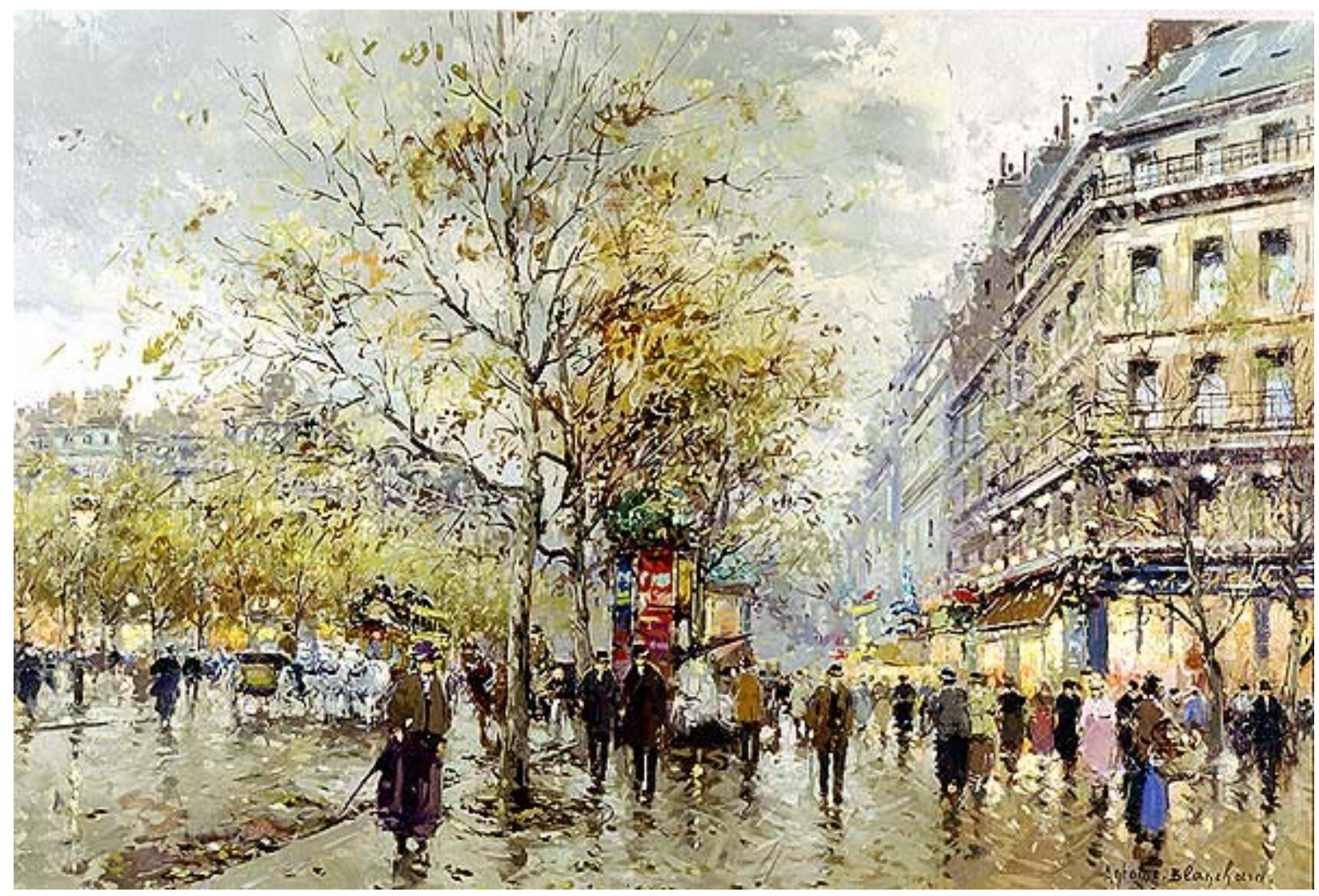

Boulevard Haussmann, por Antoine Blanchard. FONTE: http://www.rehsgalleries.com/view_image.html?image_no=188\&

Outro exemplo de intervenção urbana que referencia esse pensamento urbanístico é a construção da Ringstrasse de Viena. Para a ocupação da esplanada existente entre a cidade de Viena e seu subúrbio, "o

\footnotetext{
${ }^{24}$ RYKWERT, Joseph. A sedução do lugar. São Paulo: Martins Fontes, 2004, p. 134.

${ }^{25}$ BENEVOLO, Leonardo. História da cidade. São Paulo: Perspectiva, 1983. p. 595.

${ }^{26}$ SUTCLIFFE, apud PINHEIRO, Heloísa P. Europa, França e Bahia: difusão e adaptação de modelos urbanos. Salvador: EDUFBA, 2002, p. 78.

${ }^{27}$ PINHEIRO, Heloísa P. Europa, França e Bahia: difusão e adaptação de modelos urbanos. Salvador: EDUFBA, 2002. p. 82.

${ }^{28} \mathrm{Ibid}, \mathrm{p} .83$.
} 
planejamento público se baseava num sistema de grade indiferenciada, exercendo controle apenas sobre a altura dos edifícios e largura das ruas"29.

Assim como em Paris, o espaço construído em Viena também subverte a lógica dos planejadores barrocos: o espaço urbano não propicia mais perspectivas que realçam a arquitetura; os edifícios são construídos com certa uniformidade e com uma escala relativa à rua, o que dá relevo ao espaço público. As árvores que contornam a Ringstrasse acentuam a supremacia da rua, enfatizando-a sobre a moldura das construções, as quais oferecem ao conjunto uma diversidade de estilos históricos.

A rua de formato poliédrico conduz a ocupação da esplanada, constituindo o único elemento independente do conjunto, de modo a não se subordinar a nenhum outro espaço ou edificação. O traçado resultante dessa intervenção é regular e ortogonal, adaptado ao formato do anel que constitue o vazio transformado em Ringstrasse. Seus espaços públicos são formados por vias retas e largas, arborizadas e iluminadas de forma homogênea, mantendo um ritmo constante; e por praças localizadas em frente aos principais edifícios, onde se

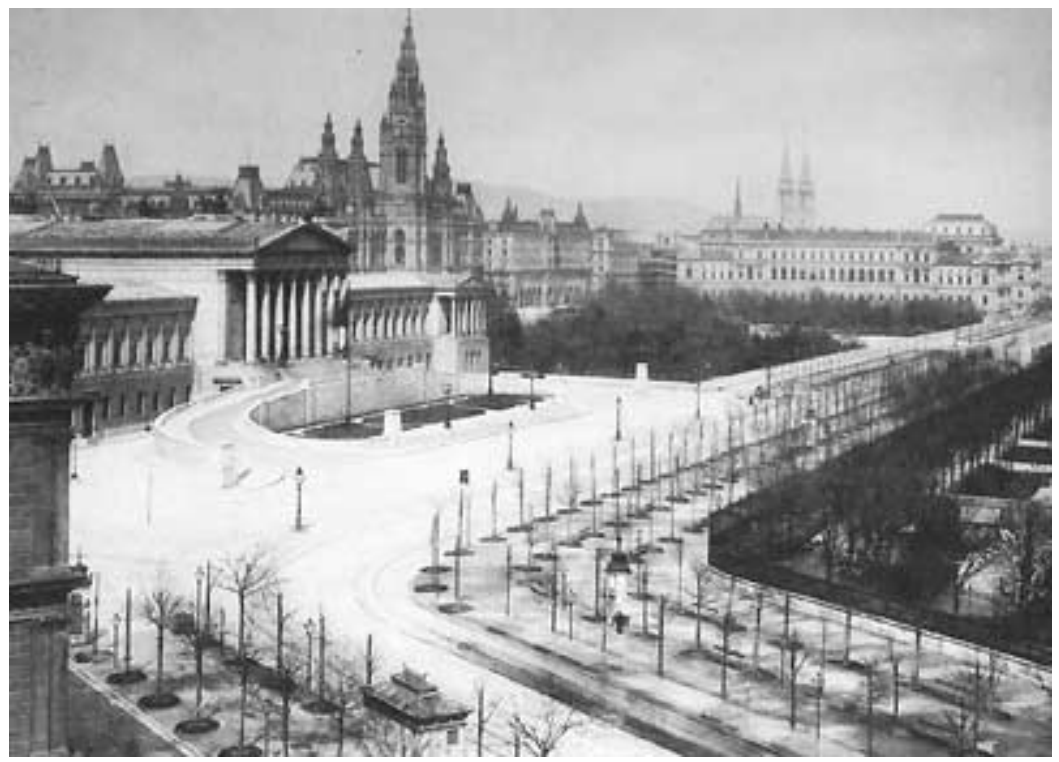

Ringstrasse, 1888. FONTE: http://www.wien-vienna.at/index.php?|D=872 encontram monumentos e fontes, a exemplo dos edifícios do Parlamento e da Universidade.

A rigidez hierárquica desse traçado contrasta essa região com as áreas interna e externa ao anel, anteriormente ocupadas e caracterizadas por uma trama sem vínculos com a ortogonalidade. A implantação de um conjunto urbano nesse vazio não resulta na união da cidade e seu subúrbio. A diferença formal dessa nova área enfatiza a separação das duas porções estabelecidas anteriomente, apesar de se tornarem fisicamente unidas. A forma e escala das avenidas poliédricas fazem com que as vias provenientes dos arredores que nela desembocam não a perpassem, de modo a não apresentar uma penetração significativa que caracterize a unificação da cidade com seu subúrbio. Essa relação é acentuada pela monumentalidade dessa nova área, promovida tanto pelos edifícios como pelos espaços públicos, criando uma hierarquia em relação às àreas vizinhas.

Outro exemplo de intervenção urbana que se torna referência para outras cidades é o plano elaborado em meados do século XIX por Ildefonso Cerdà para a cidade de Barcelona. Trata-se da expansão urbana mediante a definição de uma malha viária regular, a fim de direcionar o crescimento da cidade tradicional. Esse plano desenha uma grelha ortogonal que se estende até os núcleos urbanos vizinhos e envolve a cidade medieval. À essa trama são acrescidas avenidas diagonais, alterando seu ritmo e dando novas formas aos entroncamentos viários, cujos cruzamentos são octogonais, para facilitar o trânsito. No cruzamento das principais vias, sobretudo das diagonais com as ortogonais mais largas da trama, criam-se rotatórias que se constituem áreas verdes, algumas vezes com monumentos, reunindo as funções de espaço público e de circulação viária, uma vez que distribui o fluxo através das principais vias. Nas esquinas dessas diagonais com as vias transversais e nas proximidades dos cruzamentos circulares da trama , são inseridas edificações

${ }^{29}$ SCHORSKE, Carl. E. Viena Fin-de-siècle. São Paulo: Cia das Letras, 1988, p. 45. 
cuja arquitetura enfatiza os espaços públicos a que se avizinham, ao mesmo tempo que esses espaços possibilitam a essas edificações maior amplitude visual.

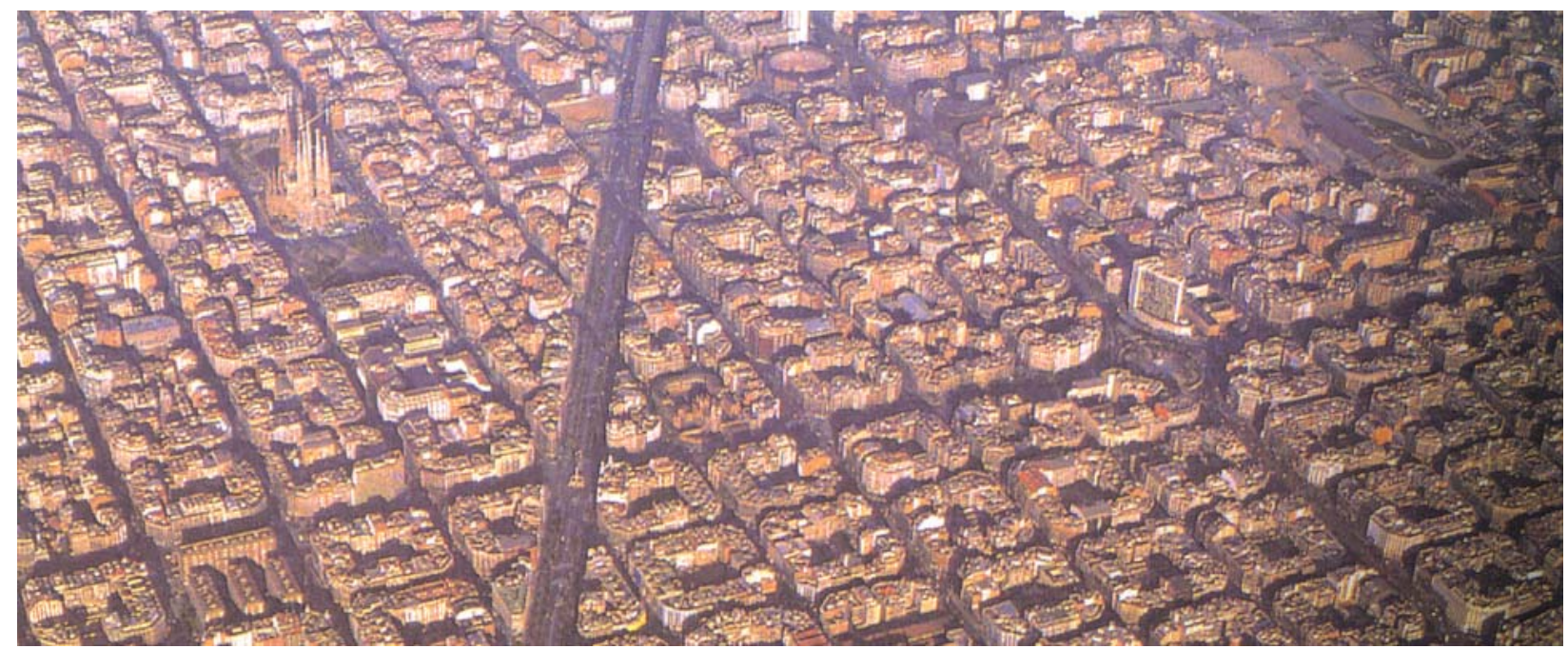

Barcelona. FONTE: http://www.geocities.com/HotSprings/7912/ensanche.html

Os espaços de uso público ou coletivo também se encontram, na proposta elaborada por Cerdà, vinculados individualmente a cada quarteirão. Estes têm suas esquinas chanfradas e o seu interior formado por áreas verdes de uso coletivo com jardins indicação não posta em prática na execução das obras. Essa relação entre as edificações e os espaços públicos das quadras garante baixas densidades, intenção explicitada por Cerdà. Ao

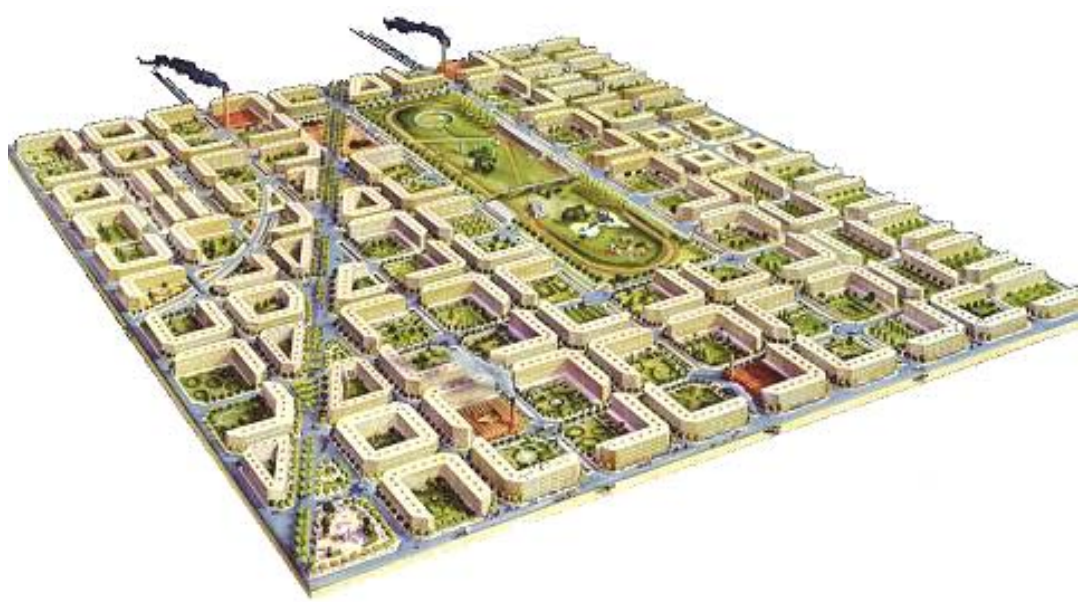

Plano para Barcelona, projeto inicial 1863. FONTE:http://www.geocities.com/HotSprings/ 7912/ensanche.html

longo da trama, outras áreas verdes são destinados para lazer, com dimensões maiores que as dos quarteirões propostos, numa proporção de um parque a cada oito quadras.

Apesar da preocupação em implantar parques, o caráter viário dos planos em geral marca o urbanismo europeu do século XIX, valorizando a circulação e não a permanência nas áreas públicas. Os espaços criados restringem-se cada vez mais a parques e grandes avenidas arborizadas - boulevards e parkways - que prevalecem no cenário urbano, deixando as edificações em segundo plano. As perspectivas valorizadas pelo urbanismo barroco, antes evidentes nas cidades, perdem-se na imensidão dos novos espaços públicos produzidos.

Na busca de modelos alternativos à cidade industrial que emerge no século XIX - com seus problemas sanitários, conflitos sociais e congestionamentos-, homens como Ebenezer Howard, Le Corbusier e Camillo Sitte se dedicam a idealizar propostas urbanas com repercussões profundas sobre a forma e a apropriação dos espaços públicos.

Ebenezer Howard, idealizador do modelo Cidade-Jardim, propõe como solução urbanística a construção de novas cidades, cuja organização limita seu crescimento e separa sua área em setores referentes aos tipos de atividades desenvolvidas, com forte presença da natureza. Em relação aos espaços públicos propostos, o 
modelo apresenta grandes avenidas arborizadas concêntricas, cortadas por bulevares igualmente arborizados que convergem para um jardim localizado na área central, onde se encontram os edifícios públicos. Esse jardim corresponde a um Parque Público "com grandes áreas de recreação e de muito fácil acesso a todos"30, em torno do qual se encontra uma arcada envidraçada que se abre para o parque e possibilita a utilização dessa área ao longo de todas as estações do ano. Das avenidas concêntricas propostas, a última, denominada "Grande Avenida", constitui, segundo Howard, um parque adicional separando da cidade os setores de indústria e de comércio pesado que, situados além da Grande Avenida, encontram-se próximos à linha férrea.

A primeira cidade-jardim construída é Letchworth, cujo plano de implantação é realizado pelos arquitetos Raymond Unwin e Barry Parker. É uma cidade com desenho simples, claro, informal e aberto que, como recomenda Howard, "mantém a continuidade do espaço livre verde da cidade, tornando-a agradável e convidativa" ${ }^{1}$, inclusive pelos cuidados especiais dedicados ao seu paisagismo. Os espaços públicos produzidos na cidade de Letchworth são provenientes de um desenho orgânico das vias, com ruas secundárias de acesso em cul-de-sac. As casas são organizadas em blocos isolados entre si, recuadas em relação à rua e com áreas ajardinadas. Os passeios e as vias secundárias são espaços gramados com arbustos e árvores, característica que se estende aos demais espaços públicos e parques da cidade.

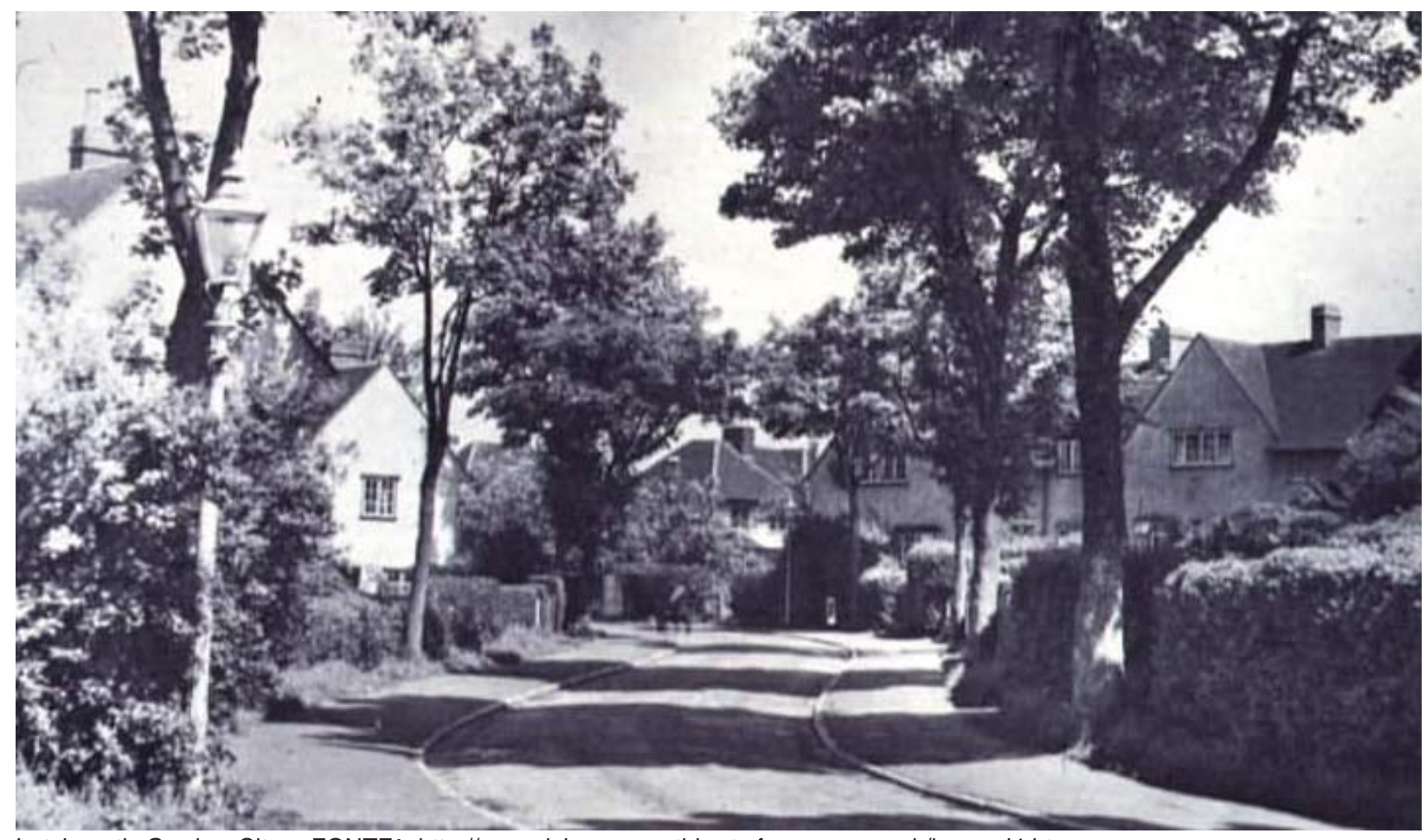

Letchworth Garden City . FONTE: http://www.rickmansworthherts.freeserve.co.uk/howard4.htm

A proliferação dos ideais howardianos ocorre, muitas vezes, com algumas mutações, sendo comum a construção não de cidades mas de subúrbios e bairros-jardins em cidades pré-existentes. Nos Estados Unidos, destacam-se Sunnyside Gardens e Radburn. Quadras com jardins, playgrounds e campos esportivos compõem a área de Sunnyside Gardens. O desenho de seu plano e a disposição de seus edifícios "rompe com o esquema rígido, denso e fechado das quadras de Nova York"32, que tem seu centro a aproximadamente 25 quilômetros dali. Segundo Mumford, Sunnyside é "ajustada à escala humana e seus jardins e parques internos guardam seu ar amistoso"33. Radburn apresenta um tratamento da infra-estrutura no interior das quadras, com parques que promovem o lazer e conduzem as pessoas a diversos locais sem o empecilho do trânsito, o que referencia o conceito de unidade de vizinhança.

\footnotetext{
${ }^{30}$ HOWARD, Ebenezer. Cidades-Jardins de Amanhã. São Paulo: HUCITEC, 1996, p.115.

31 lbid., p.50.

32 Ibid., p. 77.

${ }^{33}$ MUMFORD, Lewis. In: HOWARD, Ebenezer. Cidades-Jardins de Amanhã. São Paulo: HUCITEC, 1996, p.77.
} 
No Brasil, as idéias de cidades-jardins influenciam os planos de algumas cidades, a exemplo do elaborado por Atílio Correia Lima e depois completado por Armando de Godoy para a cidade de Goiânia, mas têm sua proliferação mais explícita na construção de loteamentos-jardins. São exemplos os bairros-jardins criados pela Companhia City em São Paulo, dos quais o primeiro é o Jardim América. Nele, a indicação da proposta de cidade-jardim referente à extinção da separação entre terrenos e rua não é bem sucedida: apenas os tradicionais muros são substituídos por cercas vivas. Da mesma forma, os jardins no interior das quadras não vingam.

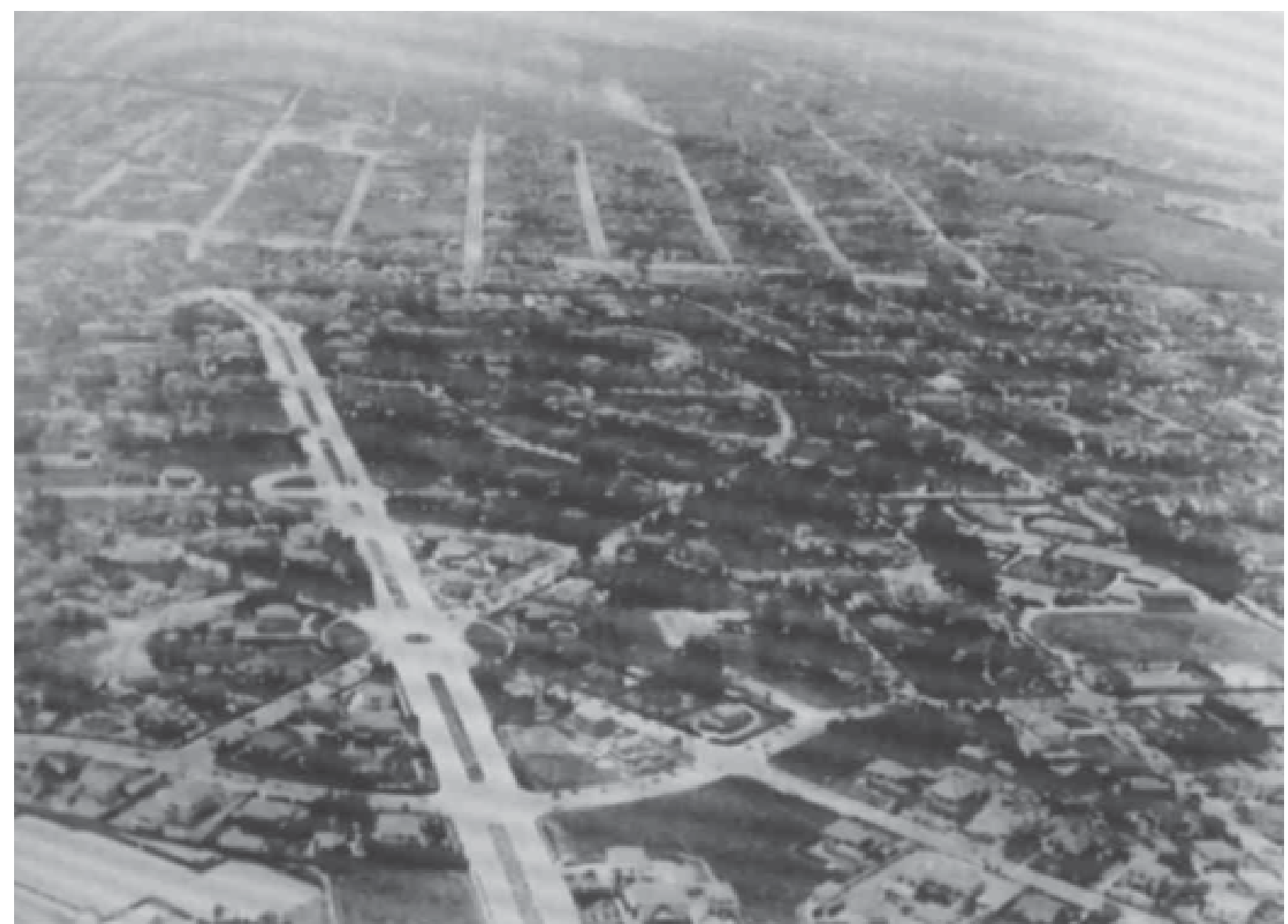

O Jardim América na década de 1940. FONTE: http://www.ub.es/geocrit/b3w-355.htm

Nos diferentes exemplos, independente das peculiaridades da implantação dos ideais de cidade-jardim, são promovidos espaços públicos verdes, de uso restrito, geralmente organizados em setores e, muitas vezes, usados como ornamento urbano.

Outro importante exemplo de estudo da cidade como reflexo e conseqüência da industrialização é a proposta elaborada por Tony Garnier. Concebe e desenha uma cidade inteira, desde as grandes infraestruturas até o mobiliário de suas casas. Nela, os espaços públicos estão, em sua maioria, vinculados ao sistema viário e divididos em duas escalas: as vias principais, retas, largas, com árvores enfileiradas nas calçadas e projetadas para um grande fluxo de veículos; e as ruas

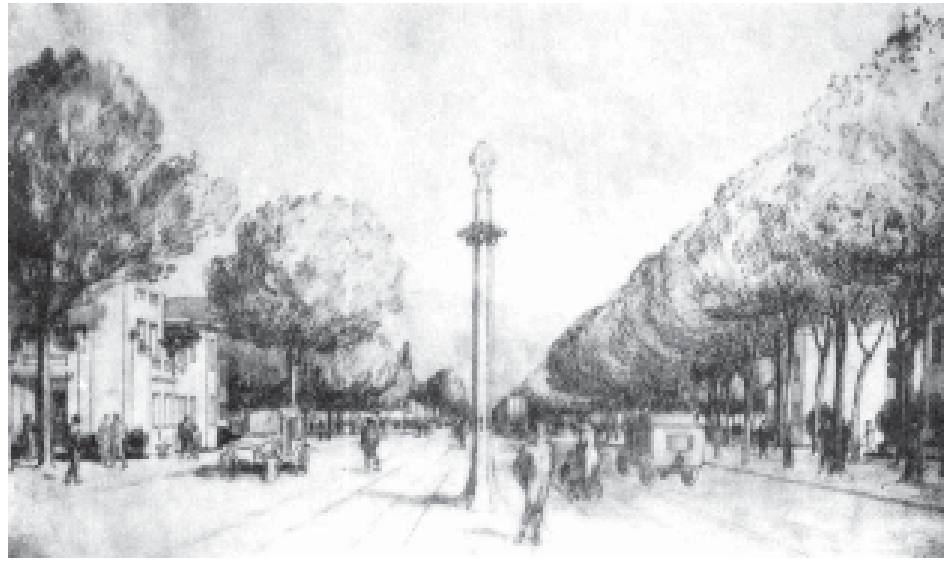

Cidade Industrial. Rua principal. FONTE: AYMONINO, C. Origenes y desarrollos de la ciudad moderna. Barcelona, Gustavo Gili. 
internas, com jardins e passeios, reservadas para pedestres e mais propícias à permanência, como uma espécie de parque. Essas ruas internas criam um espaço público de uso local e são formalmente estabelecidas pela ausência de muros entre as edificações que as delimitam, que, por sua vez, têm alturas, ritmo, espaçamentos e características arquitetônicas padrão.

Outra reflexão sobre as cidades - com impactos profundos na forma e uso dos espaços públicos - vem de Le Corbusier, que tem na concepção da Ville Radieuse, de 1925, sua maior expressão. Sem limitar seu crescimento, propõe uma cidade suspensa com todo o solo dedicado ao pedestre através de um extenso tapete verde - e ao automóvel - por meio de avenidas. Assim, as idéias das ruas como local de domínio do transeunte, espaço privilegiado para a manifestação de vida urbana, para o encontro ou o descanso, não tem mais sentido, pois não há delimitação de ruas, apenas de vias para automóveis. A cidade é formada por "blocos denteados por meio de parques"34. A praça não tem limites, estendendo-se a todos os pontos do imenso plano verde dedicado ao pedestre. Em seu livro Urbanismo, apresenta como princípios

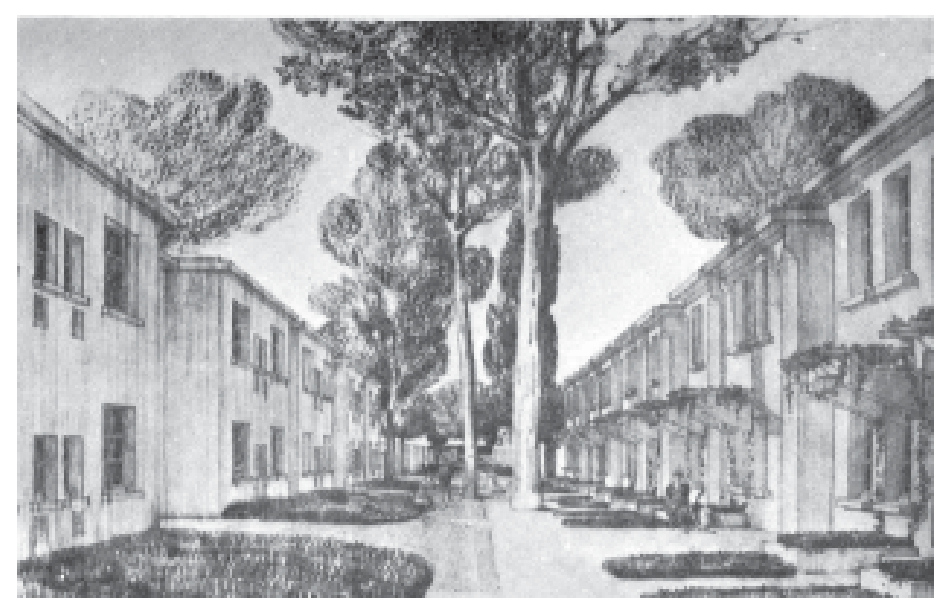

Cidade Industrial. Rua interna, acessível aos pedestres. FONTE: AYMONINO, C. Origenes y desarrollos de la ciudad moderna. Barcelona, Gustavo Gili.

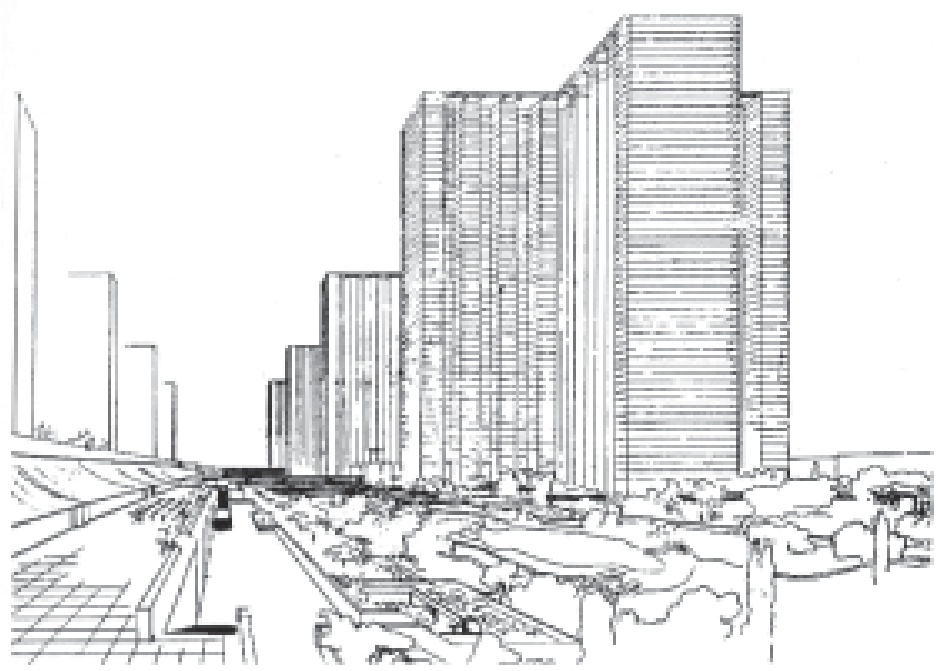

Ville Radieuse. FONTE: BARONE, Ana Cláudia Castilho. Team 10: arquitetura como crítica. São Paulo: Prog. de Pós- Grad. FAUUSP, 2000. (Dissertação de Mestrado), p.35.

fundamentais do urbanismo moderno o descongestionamento do centro das cidades, o aumento de sua densidade, dos seus meios de circulação e das superfícies arborizadas. Defende a rua reta, apesar de reconhecêla monótona para quem transita a pé, porém muito útil para os meios de transportes 'modernos', promovendo agilidade para percorrer as distâncias de uma cidade grande.

"A rua reta é maçante para percorrer a pé. Admito. Mas quando se trata de uma rua de trabalho, metrôs, bondes, ônibus, carros permitem percorrê-la depressa, e depressa precisamente por ela ser reta"35.

Seguindo essa mesma linha de pensamento em relação à cidade, coloca-se o urbanismo do CIAM. A formação desses congressos tem a intenção de unificar os parâmetros do desenho moderno em arquitetura e urbanismo, com o objetivo de consolidar um movimento de vanguarda.

"Os Congressos foram inicialmente propostos por Le Corbusier, um dos maiores defensores da adoção da nova linguagem arquitetônica como solução universal para a questão do espaço na Europa dos anos 20"36.

\footnotetext{
${ }^{34}$ RYKWERT, Joseph. A sedução do lugar. São Paulo, Martins Fontes, 2004, p. 178.

${ }^{35}$ LE CORBUSIER. Urbanismo. São Paulo: Martins Fontes, 1992, p.196.

${ }^{36}$ BARONE, Ana Cláudia Castilho. Team 10: arquitetura como crítica. São Paulo: Prog. de Pós- Grad. FAUUSP, 2000. (Dissertação de Mestrado), p.18.
} 
Trata-se de reuniões que privilegiam os temas da Habitação Social e da Cidade Funcional, apontados como problemas centrais da civilização industrial. Propõem a realização de estudos e a apresentação das soluções mais adequadas à produção e uso dos espaços urbanos, num processo contínuo cuja seqüência aborda a célula de habitação e seu arranjo em unidades ou blocos, chegando à concepção da cidade funcional. Nesse processo, busca-se estabelecer padrões para a indústria da construção e para o desenho das plantas, bem como para as relações entre espaço construído e espaço livre na cidade. Discute-se a escala urbana em termos de proporções, quantidades ótimas e densidades, que caracterizam o urbanismo funcionalista.

Atribui quatro funções básicas à cidade para sua 'devida'ordenação: habitação, trabalho, recreação e circulação. Seguindo essas indicações, os espaços públicos criados são amplos e privilegiam a circulação. As vias são destinadas a grandes velocidades, com a presensença do verde em seu trajeto. Elas interligam as áreas de trabalho e habitação, criando perspectivas marcadas pela linearidade e amplitude das avenidas, contornadas por grandes edificações modernas, cujas formas são captadas na velocidade com que se percorre essas vias. As áreas de lazer são amplos espaços verdes de uso coletivo, localizados nos arredores dos conjuntos de edificações. Para seu acesso estabelecem-se, geralmente, vias internas para pedestres, de menores dimensões em relação aos corredores viários. O espaço público recebe nova nomenclatura referente à forma com que passa a ser visto. Na Carta de Atenas, um dos mais representativos documentos do CIAM, a rua torna-se 'percurso' e o parque passa a ser 'espaço verde'.

De forma diferente em relação às idéias lecorbusianas e ao funcionalismo do CIAM, coloca-se Camillo Sitte algumas décadas antes. Propõe recriar e preservar, na cidade do fim do século XIX, os espaços mais significativos em termos estéticos e de sociabilidade e, com eles, a atmosfera das cidades antigas com seus espaços públicos propícios a uma vida urbana densa. Sua preocupação principal é "a integridade dos espaços abertos"37. Seu livro A Construção das Cidades Segundo os Princípios Artísticos, de 1889, é um marco na teoria urbanística do século XIX. Nele, Sitte se ocupa da dimensão estética da cidade, criticando os que a tomam por um "artefato de necessidades exclusivamente funcionais"38. Polemiza com arquitetos seus contemporâneos em relação aos princípios que norteiam as transformações das cidades.

Sitte critica o projeto da Ringstrasse de Viena, onde aponta o sacrifício da tradição em favor das exigências da vida moderna. Não reprova suas construções monumentais - onde estilos diferentes são adotados de acordo com a finalidade do edifício- mas discorda da falta de cenários apropriados às edificações ${ }^{39}$. Para Sitte, "a mania de espaços abertos - a rua larga que escapa ao olhar, as amplas praças - isolava edifícios e seres humanos" ${ }^{\text {" }}$. Para aquele espaço, ele "criaria praças, ilhas de comunidade humana em meio ao oceano gelado do espaço dominado pelo tráfego. À frente de vários dos grandes edifícios ele propôs a construção de ramificações a partir da estrutura central, que formaria uma praça, a qual emolduraria a fachada principal"41. Assim, sua crítica à Viena refere-se aos grandes espaços abertos, inadequados à apreciação de monumentos e incompatíveis com o uso enquanto ambiente de vivência cotidiana.

Seu trabalho reconhece o êxito tecnológico alcançado na construção das cidades, porém condena a "unanimidade que chega às raias do desprezo e escárnio, dos fracassos estéticos da construção urbana moderna" ${ }^{\text {"2 }}$. Preocupado com a preservação de centros históricos gradativamente extintos por reformas urbanas, Sitte influencia o urbanismo do século XX, tanto na Europa como na América e, inclusive, no Brasil onde as obras de Saturnino de Brito incorporam algumas de suas idéias.

\footnotetext{
${ }^{37}$ RYKWERT, Joseph. A sedução do lugar. São Paulo, Martins Fontes, 2004, p. 167.

${ }^{38}$ ANDRADE, Carlos Roberto Monteiro. In: SITTE, Camillo. A construção das cidades segundo seus princípios artísticos. São Paulo: editora Ática, 1992, p. 5.

${ }^{39}$ SCHORSKE, Carl. E. Viena Fin-de-siècle. São Paulo: Cia das Letras, 1988, p. 80.

${ }^{40} \mathrm{Ibid}$, p. 81.

41 Ibid.

${ }^{42}$ SITTE, Camillo. A construção das cidades segundo seus princípios artísticos. São Paulo: editora Ática, 1992, p. 11.
} 
Com marcante atuação em várias cidades brasileiras durante a República Velha, o engenheiro Saturnino de Brito, segundo Andrade ao comentar sua proposta do "Novo Arrabalde" para a cidade de Vitória, "acentua a dramaticidade do sítio, aproveitando com um traçado clássico suas características topográficas, para criar vistas pinturescas"43. Em sua atuação, Brito assume algumas posições sittianas, a exemplo do posicionamento contra a política de arrasar quarteirões inteiros. Sempre que possível, incorpora em suas propostas ruas e edificações existentes e caminhos delineados pelo tempo.

Em Sitte, as praças e as ruas são tomadas como formas definidoras do traçado urbano, enriquecendo as perspectivas geradas por esses espaços. Assim, ele explora a cidade a partir do fragmento, com intensa valorização da paisagem a partir do posicionamento dos elementos urbanos existentes. Esse processo busca resgatar essas áreas como locais para a vida e espetáculos públicos. Para Sitte, a praça liberta o homem do reinado das grandes vias celebrado no fim do século XIX, transformando o espaço anônimo em cenário humano. A praça se constitui "uma sala ao ar livre, teatro da vida comum" 4 .

Apesar de significativos defensores e seguidores dos ideais sittianos e howardianos, nas intervenções de cidades existentes e nos projetos de cidades novas prevalece o urbanismo funcionalista, com preocupações em delegar funções específicas aos elementos urbanos. Aos espaços livres públicos procura-se imprimir funções e usos específicos - circulação e lazer, sobretudo-, combatendo-se ou restringindo-se usos adicionais.

No Brasil, durante a primeira metade do século XX ocorrem grandes intervenções nas principais cidades, onde se reflete toda essa discussão e crítica à configuração até então vigente nas cidades. O exemplo mais divulgado nesse sentido é, provavelmente, a reforma executada no Rio de Janeiro, a partir do Plano de Embelezamento e Saneamento da Cidade. Conduzida por Pereira Passos, que em 1875 participa do estudo do Plano de Melhoramento, e referenciada nas intervenções do prefeito Haussmann em Paris, a reforma carioca influencia a transformação urbana de muitas outras cidades brasileiras no início do século XX. O plano para o Rio de Janeiro propõe "substituir as vielas por ruas arborizadas, promover melhores condições estéticas e higiênicas para as construções urbanas, sanear, embelezar"45. Tais medidas caracterizam as novas formas de espaços públicos e são efetivadas através de 'cirurgias urbanas'. Com o objetivo de "transformar a capital da república em uma cidade moderna" ${ }^{\text {, a }}$ as avenidas são tomadas como principal instrumento do plano,

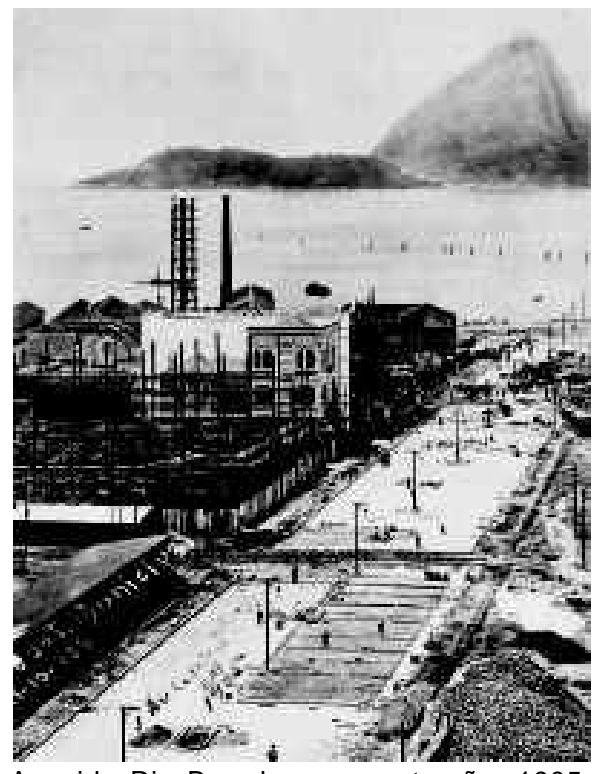

Avenida Rio Brando em construção, 1905. FONTE:www.digitalis.com.br/ vitrine\&espelho/ fotos.htm substituindo vielas sinuosas e alterando a escala do espaço público.

A transformação de muitas cidades brasileiras nesse período se deve ao trabalho de Saurnino de Brito que, atuando de forma abrangente em todo país, elabora projetos para várias cidades paulistas - Campinas, Santos, Ribeirão Preto, Limeira, Sorocaba, Amparo - e cariocas - Petrópolis, Paraíba do Sul, Itaocara, Campos -, participando ainda de intervenções em várias cidades nos estados do Rio Grande do Sul, Distrito Federal, Paraná, Pará, Ceará, Pernambuco, Paraíba e Sergipe. "Seus planos de saneamento, extensão ou melhoramentos criaram um novo cenário urbano, com bulevares, canais a céu aberto ..."47. Em seus projetos,

\footnotetext{
${ }^{43}$ ANDRADE, Carlos Roberto M. de. Saturnino de Brito, um projetista de cidades. Revista AU, n 72, jun/jul 1997, p. 70.

${ }^{44}$ SITTE, Camillo, A construção das cidades segundo seus princípios artísticos. São Paulo: editora Ática, 1992, p. 13.

${ }^{45}$ LEME, Maria Cristina da Silva. Urbanismo no Brasil 1895-1965. Salvador: EDUFBA, 2005, p. 358.

${ }^{46}$ Ibid.

${ }^{47}$ ANDRADE, Carlos Roberto Monteiro de., op. cit., p. 67.
} 
busca inserir um traçado regular, porém, respeitando as declividades do terreno, resulta, muitas vezes, em uma trama mista. Assim, "a regularidade ou não do traçado viário era definida em função das exigências de escoamento das águas..."

Cria espaços públicos verdes, integrando-os aos elementos de funções sanitárias, a exemplo dos canais no perímetro dos morros e do cais de contorno à beira mar do projeto do Novo Arrabalde que, além de desempenharem suas funções sanitárias, interferem na qualidade ambiental e paisagística dos espaços públicos, promovendo-lhes as funções de passeios e contemplação. Percebe-se que seus espaços públicos não têm, de forma mais direta, a inteção de valorizar a circulação de veículos, mas de resolver os problemas sanitários e buscar um cenário pinturesco, aproximando-se dos ideais sittianos. Um dos espaços públicos de maior repercução de suas obras são os "bulevares santistas"49: canais de drenagem das águas pluviais a céu aberto, com calçadas laterais, árvores e gramados, cruzados por pontes.

Em 1930, a cidade do Rio de Janeiro recebe o Plano de Remodelação, Extensão e Embelezamento, também conhecido como Plano Agache. Esse plano toma a circulação como uma das principais funções da cidade, de forma que o sistema viário proposto constitui o esqueleto do plano diretor, onde o conjunto de vias interliga os equipamentos, bairros e zonas de usos diversos. A ordenação da cidade proposta pelo plano se dá através do zoneamento que, segundo Agache, tem por objetivo "evitar o caos, que se estabeleceria, caso o crescimento das cidades fosse deixado à livre iniciativa"50. Entre os espaços públicos resultantes desse plano, destacam-se as áreas

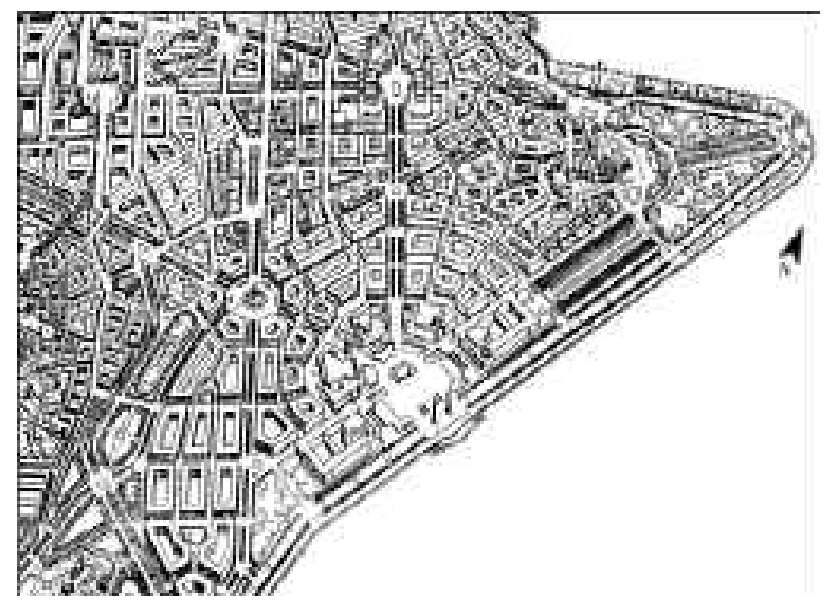

Plano Agache. FONTE:www.digitalis.com.br/ vitrine\&espelho/ fotos.htm circulares interligadas por largas avenidas arborizadas que se cruzam nesses pontos, e jardins localizados em locais específicos da cidade, a exemplo dos projetados para a ponta do Calabouço, de desenho simétrico, com árvores enfileiradas longitudinalmente e passeios entre alamedas arborizadas e jardins que convergem para a praia. São espaços amplos, de escala monumental e com equipamentos que determinam seus usos.

Também em 1930, é publicado em São Paulo o Plano de Avenidas, elaborado por Prestes Maia para esta capital. Esse projeto é baseado no sistema de radiais e perimetrais, através do transporte de superfície. Na sua implantação "dezenas de avenidas são abertas e alargadas, visando a ampliação do centro e a ligação com bairros dele distantes, ocasionando a demolição de um grande número de construções e a escalada dos preços dos terrenos em seu entorno" ${ }^{\prime 1}$. Prestes Maia defende o esgotamento das potencialidades ainda não exploradas da metrópole e o seu

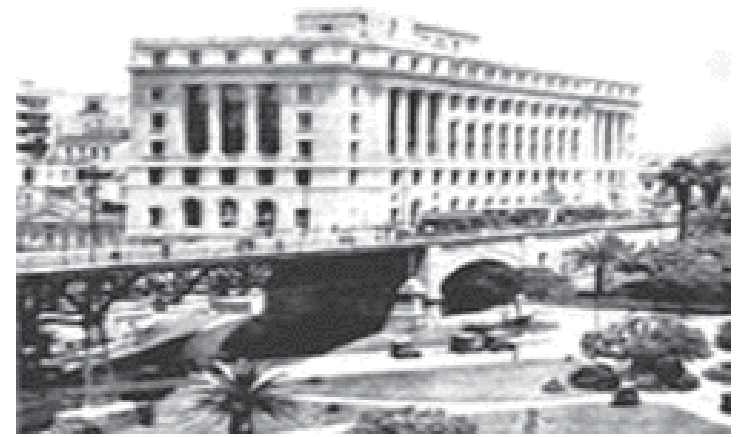
Vale do Anhagabaú - 1930. Fonte: wuw.prodam.sp. gov.br/sitio/polo.htm permanente ajuste às exigências da organização da sociedade moderna. Reformas, cirurgias e remodelações de serviços são, para ele, elementos inerentes ao processo de crescimento da cidade e das transformações da vida urbana. É a favor do desenvolvimento da metrópole através da eficiência do funcionamento urbano. Da

\footnotetext{
${ }^{48}$ ANDRADE, Carlos Roberto Monteiro de. "Saturnino de Brito: um projetista de cidades". Revista AU, n. 72, jun/jul 1997, p. 73.

49 Ibid.

50 Ibid, p. 364

${ }^{51}$ FELDMAN, Sarah. Planejamento e Zoneamento. São Paulo: 1947-1972. São Paulo: Editora da Universidade de São Paulo/Fapesp, 2005, p.18.
} 
mesma forma que ocorre no Plano Agache, no Plano de Avenidas a criação de espaços públicos também se encontra vinculada ao sistema viário, através de alargamentos no cruzamento das vias mais amplas, com função de rotatória. O plano também apresenta "novos e grandes parques propostos para São Paulo"52, além da intervenção no Vale do Anhagabaú, apresentado como sala de visistas. Na proposta, o parque do Anahgabaú apresenta-se com jardins e passeios que direcionam seu uso, e com edificações monumentais contruídas em suas 'margens'.

As tranformações urbanas desse momento têm grande influência do urbanismo americano, inclusive em São Paulo, através dos trabalhos de Prestes Maia e Anhaia Melo. A difusão do urbanismo internacional não se dá como fato isolado no contexto paulistano, divulgando-se nos anos de 1930 por meio de planos, instrumentos e métodos, através de diversos profissionais de diferentes localidades, ativos no debate urbanístico. Durante a administração de Getúlio Vargas, que tem como principal marca o projeto de modernização administrativa, são vários os profissionais que trabalham no campo do urbanismo, pondo em prática as idéias em debate nesse momento. Dentre esses urbanistas, estão Armando de Godoy, Mario de Souza Martins, Washington Azevedo e Nestor de Figueiredo.

Nestor de Figueiredo, que trabalhara com Agache no Rio de Janeiro, tem suas principais interfenções urbanísticas elaboradas para o Recife e a Paraíba - onde realiza planos para as cidades de João Pessoa, Cabedelo, Campina Grande e para a cidade balneária de Brejo das Freiras. Seus planos apresentam a absorção das idéias de zoneamento e fortes características viárias. Neles, os espaços públicos também aparecem vinculados ao sistema viário, que é o principal elemento das propostas. No Plano de Remodelação e Extensão da Cidade do Recife, elaborado em 1932, a Praça da Independência é adotada como o centro de recepção e distribuição do tráfego, e as zonas periféricas são interligadas "a partir de um conjunto de avenidas que se cruzavam em praças e nós espalhados por vários pontos do território"53. O espaço público se apresenta monumental, através de suas praças e conjuntos edificados.

Em meio a essas transformações do pensamento urbanístico, a implantação das idéias correntes, defendidas como 'soluções' para os 'problemas' das cidades de então, resultam na construção de cidades cujos usos de seus espaços são influenciados por legislações, estabelecendo uma nova ordem, através do zoneameto. No tratamento dos espaços públicos, privilegia-se as grandes avenidas de escoamento de tráfego e alguns espaços monumentais em locais de grande visibilidade. Tais espaços resultam em uma nova escala urbana que se reflete na forma de apropriação por parte da população.

\subsection{REPENSANDO O ESPAÇO PÚBLICO}

O urbanismo funcionalista, apesar de sua ampla difusão e aceitação, também é objeto de críticas apoiadas, sobretudo, na avaliação das experiências efetuadas e no tipo de espaço público delas resultante. Dentre os críticos está Lewis Mumford que, em 1960, diz que a função social dos espaços livres nas cidades é reunir as pessoas. Em sua avaliação, o contato entre os usuários de uma cidade é favorecido quando espaços públicos e privados são projetados simultaneamente, como visto nas experiências de Hampstead e Radburn. Porém, ao seu ver, o congestionamento urbano provoca uma reação que supervaloriza um ideal meramente quantitativo de espaços livres ${ }^{54}$.

\footnotetext{
${ }^{52}$ LEME, Maria Cristina da Silva (org). Urbanismo no Brasil 1895-1965. Salvador:UFBA, 2005, p.393.

53 Ibid., p. 403.

${ }^{54}$ BARTALINI, Vladimir. “Espaços livres públicos. O caso da praça do metro de São Paulo. FAUUSP.São Paulo; dez 1990, n.1.
} 
Mas é a Jane Jacobs que cabe uma das mais contundentes críticas a respeito dos rumos dos espaços públicos no século XX. Em sua obra Morte e Vida das Cidades Americanas ${ }^{55}$, defende os espaços de contato entre as pessoas no ambiente urbano, em oposição aos espaços livres abundantes, mas hostis, de cidades americanas. Segundo suas próprias palavras, seu livro é um ataque aos fundamentos do planejamento urbano e da reurbanização então vigentes; é uma ofensiva contra os princípios e objetivos que os moldam. Escreve sobre coisas comuns e cotidianas, observando o funcionamento das cidades, com o intuito de mostrar quais princípios de planejamento e iniciativas de reurbanização conseguem promover a vitalidade das cidades, e quais práticas a inviabilizam. Referindo-se a Nova Iorque, aponta casos que

"de acordo com a teoria do planejamento urbano, não devia ter problema algum, já que possu[em] áreas verdes em abundância, campos, playgrounds e outras áreas livres. Dispõe[m] de muitos gramados. Ocupa[m] terreno[s] elevado[s] e agradáve[is], com magnífica vista do rio. (...) Suas ruas são zoneadas com objetivo de evitar que 'usos incompatíveis' invadam a privacidade dos sólidos e espaçosos apartamentos de classe média alta"56.

Mostra, no entanto, que estas são áreas decadentes, espaços urbanos vazios, sub-utilizados, que acabam por apresentar problemas de segurança e identidade para a população a quem são destinados. Dessa forma, baseada em exemplos e observações de diferentes casos americanos, afirma que,

"Num número cada vez maior de cidades, tornam-se decadentes justamente as regiões onde menos se espera que isso aconteça à luz da teoria do planejamento urbano, [ao passo que] as regiões mais suscetíveis à decadência, segundo a mesma teoria, recusam-se a decair" ${ }^{n 57}$.

Sua maior crítica ao planejamento urbano está na designação de usos distintos para as diferentes áreas da cidade. Defende "a necessidade que as cidades têm de uma diversidade de usos mais complexa e densa, que propicie entre eles uma sustentação mútua e constante, tanto econômica quanto social"58. Confronta a teoria urbanística com os resultados de sua aplicação em áreas urbanas, os quais são apresentados como elementos antagônicos, conforme é explicitado por uma moradora de um dos conjuntos apresentados no livro:

“...há um aspecto ainda mais vil que a feiúra ou a desordem patentes, que a máscara ignóbil da pretensa ordem, estabelecida por meio do menosprezo ou da supressão da ordem verdadeira que luta para existir e ser atendida"59.

As colocações de Jacobs a respeito da "morte" das cidades se centra na alteração de produção e uso dos 'espaços públicos'. Sua obra é contundente a respeito dos estudos, propostas e realizações urbanísticas desenvolvidas nesse contexto, referindo-se, mais explícitamente, às idéias de Howard, Le Corbusier e do movimento City Beautiful. Sua crítica à cidade e aos seus espaços públicos dirige-se, sobretudo, aos efeitos das divisões funcionais do espaço, estimuladas por planos e legislações urbanísticas.

Para ela, a proposta de Howard para resolver os problemas da cidade oitocentista é "acabar com a cidade", através da criação de "cidadezinhas auto-suficientes" ${ }^{\text {, }}$ geridas de forma a evitar a especulação, mudanças no uso e aumento de densidades. Locais "realmente muito agradáveis se os moradores fossem dóceis, não tivessem projetos de vida próprios" ${ }^{1}$. Segundo Jacobs, Howard não contribui para solucionar o crescente problema urbano de reprodução e utilização das áreas públicas da cidade existente.

\footnotetext{
${ }^{55}$ Esse livro é produzido a partir de uma análise de regiões dos Estados Unidos, porém a abrangência da questão a demais países é tal que nas demais edições, a exemplo da brasileira, foi substituído do título o termo Cidades Americanas por Grandes Cidades

${ }^{56}$ JACOBS, Jane. Morte e vida das grandes cidades. São Paulo: Martins Fontes, 2000. p. 4.

57 Ibid.

${ }^{58}$ Ibid., p. 13.

${ }^{59} \mathrm{lbid}$., p. 14.

${ }^{60} \mathrm{Ibid} .$, p. 16.

${ }^{61} \mathrm{Ibid}$., p. 18.
} 
"Howard trouxe à baila idéias efetivas para a destruição das cidades: ele compreendeu que a melhor maneira de lidar com as funções da cidade era selecionar e separar do todo os usos simples e dar a cada um deles uma independência relativa. (...) Concebia o planejamento como uma série de ações estáticas; em cada caso o plano devia prever tudo o que fosse necessário e, depois de posto em prática, deveria ser protegido contra quaisquer alterações. (...) Não tinha interesse em questões como segurança pública, troca de idéias, funcionamento político ou criação de saídas econômicas nas grandes cidades"62.

A autora critica a popularização de idéias urbanísticas onde, segundo sua interpretação, a rua passa a ser considerada um lugar ruim para os seres humanos e, como conseqüência, as edificações devem ser afastadas das vias e voltadas para uma área verde e cercada. Afirma que seus partidários se prendem ao fracasso dos grandes centros, não admitindo seus sucessos e estabelecendo um senso comum de rejeição: Mumford diz que a área central de Nova York é o "caos putrificado"; Stein, considera a aparência das cidades "um acidente caótico (...), um apanhado dos caprichos fortuitos e antagônicos de pessoas individualistas e mal avisadas"63.

Le Corbusier também não passa intacto às colocações de Jacobs, principalmente em relação à proposta da Ville Radieuse, onde transforma a cidade inteira em um parque, com alta densidade urbana e ocupando apenas cinco por cento do solo. Para a autora, trata-se da inserção direta do mesmo planejamento anticidade que ela aponta em Howard, só que "dentro das próprias cidadelas da iniqüidade"64.

Jacobs também discorda do movimento City Beautiful, com suas cidades monumentais e bulevares barrocos, onde se encontram centros administrativos ou culturais. Considera que nas proximidades desses conjuntos a cidade decai, pois as pessoas ficam visivelmente longe deles. Revela, assim, mais uma proposta teoricamente bem embasada, mas que quando se torna parte da cidade, por alguma razão, as coisas não funcionam como na teoria ${ }^{65}$.

Sennett comenta que, nessa segmentação funcional, a construção de uma praça pública pode até ser formalmente declarada, mas a função a ela estabelecida destrói sua natureza, "que é de mesclar pessoas e diversificar atividades"66. Alguns parques ou praças de funções específicas se tornam áreas de passagem, e não de uso. Para ele, permanecer nesse tipo de praça "durante qualquer espaço de tempo, deixa-nos completamente sem jeito, como se estivéssemos em exibição em um vasto hall de entrada vazio"67. Entende que esses espaços são propostos para serem preservados "de incursões acidentais vindas da rua"68.

Com a restrição do uso e a mudança da forma, "o espaço público se tornou uma derivação do movimento"69 e os profissionais do urbanismo "acreditam que, se conseguirem solucionar o problema do trânsito, terão solucionado o maior problema da cidade"70. A movimentação sem restrições do indivíduo é encarada como um direito absoluto, na medida que o

"automóvel particular é o instrumento lógico para o exercício desse direito, e o efeito que isso provoca no espaço público, especialmente no espaço da rua urbana, é que o espaço se torna sem sentido, até mesmo endoidecedor, a não ser que possa ser subordinado ao movimento livre"71.

\footnotetext{
62 JACOBS, Jane. Morte e vida das grandes cidades. São Paulo: Martins Fontes, 2000, p. 18.

63 Ibid., p. 20.

64 Ibid., p. 21.

65 Ibid., p. 19.

${ }^{66}$ SENNETT, Richard. O Declínio do homem público: As tiranias da intimidade. São Paulo: Cia das Letras, 1988, p. 26.

${ }^{67}$ Ibid., p. 27.

${ }^{68}$ Ibid., p. 26.

${ }^{69}$ Ibid., p. 28.

70 JACOBS, Jane, op.cit., p. 6.

${ }^{71}$ SENNETT, op.cit., p. 28.
} 
Em seu livro, Jacobs defende a necessidade da diversidade de usos em diferentes momentos do dia, em uma mesma região, para garantir sua vitalidade permanente. Essa característica também contribui para o uso efetivo das ruas e das calçadas, aumentando a segurança urbana. Nesse sentido, tanto a crítica da autora como as propostas urbanísticas alvos de suas análises, apesar de apontarem para soluções distintas, convergem para a mesma preocupação: o uso do espaço público e seus reflexos na vitalidade da cidade.

Atualmente, a tendência de desertificação do espaço público corresponde ao confinamento de atividades antes feitas a céu aberto, em praças, ruas ou becos, como o teatro, jogos e brinquedos, disputas esportivas, feiras, mas também refeições, conversas e reuniões.

Nos capítulos a seguir, tratando da cidade de João Pessoa, aspectos desse processo de mudança das formas, dos usos e dos significados dos espaços públicos, correlatos ao crescimento da cidade e a intervenções baseadas em planos urbanísticos sobre seu espaço, podem ser verificados. 

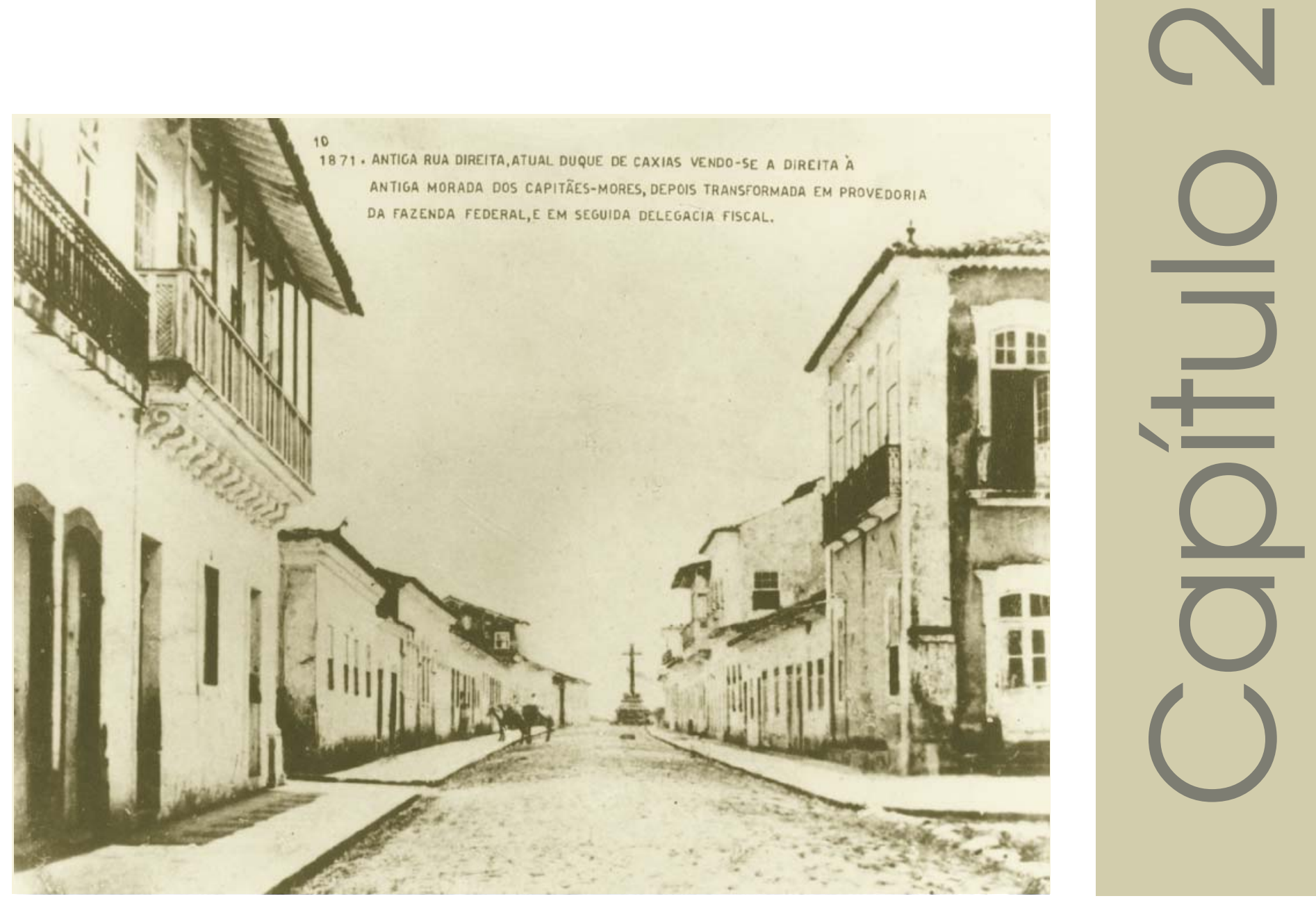


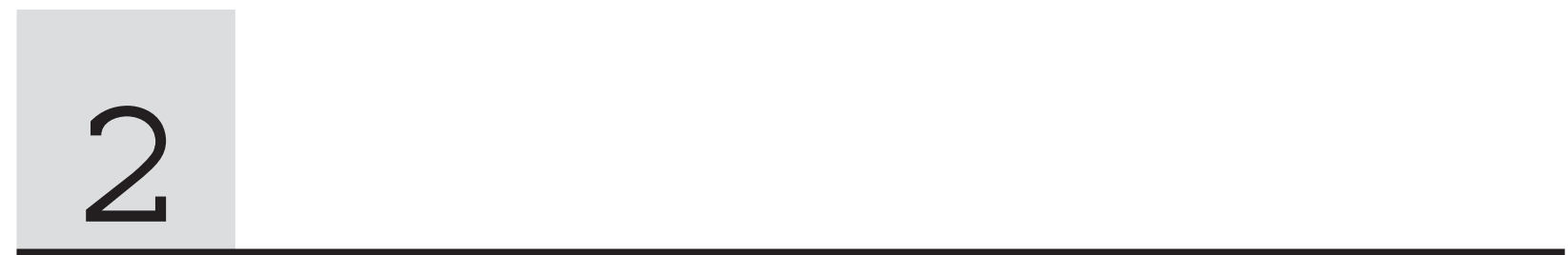

Capítulo 2

\section{A cidade oitocentista:}

\author{
formas e usos dos espaços públicos
} "Em grande parte do século XIX a visão que vamos encontrar
da Cidade da Paraíba pouco difere da descrição feita pelos
primeiros cronistas e viajantes."72

Esta situação, entretanto, altera-se nas últimas décadas do século XIX e primeira metade do século XX, quando emerge e difunde-se entre brasileiros a crença na necessidade de reformar as cidades, sobretudo as capitais. Baseados em valores sanitaristas e estéticos, bem como em demandas vinculadas à circulação, esses defendem reformas urbanas profundas e desenvolvem um discurso crítico acerca da cidade do século XIX, cujas características, em parte herdadas do período colonial, levam a cidade a ser recorrentemente retratada como suja e desorganizada.

\subsection{A TRAMA E AS CONSTRUÇÕES}

A organização da cidade oitocentista pode ser observada como reflexo da forma de constituição das cidades e vilas brasileiras, das quais algumas se formam a partir de doações de terras distribuídas pelas Câmaras sob a forma de lotes, na área urbana, e de pequenas sesmarias, nas regiões mais afastadas, as quais dão origem à formação de chácaras, geralmente de grande interesse para a construção de conventos ${ }^{73}$. Essas duas formas de apropriação da terra geram cidades de aparência mista, com características urbanas nas áreas de ocupação mais densa e um aspecto quase rural em alguns "arredores", conforme é assinalado por observadores das cidades, principalmente viajantes daquele período.

Outra característica comum a essas cidades é a área escolhida para sua implantação, na sua maioria partes planas e altas, que se tornam saturadas em um curto tempo de crescimento urbano, culminando na ocupação de áreas acidentadas, o que contribui para uma organização irregular induzida pelo relevo. Essa característica recebe, no final do século XIX, críticas que relacionam a irregularidade com a idéia de desordem. Salvador expande-se a partir da Cidade Alta, o Rio de Janeiro prolonga-se por planícies e morros contíguos ao Morro do Castelo, Olinda espalha-se pelas suas sete colinas. A capital paraibana também nasce "no topo de um monte" 74 , mas dele logo extravasa para terrenos íngremes em direção às margens do rio Sanhauá. Esse

\footnotetext{
${ }^{72}$ AQUINO, Aécio Vilar de. "O século XIX e a cidade" In: AGUIAR, Wellington, MELLO, José Octávio de A. Uma cidade de quatro séculos. Evolução e roteiro. $2^{\mathrm{a}}$ ed. João Pessoa: A União, 1989, p. 75.

${ }^{73}$ REIS FILHO, Nestor Goulart. Contribuição ao estudo da evolução urbana do Brasil (1500-1720) São Paulo : Liv. Pioneira e Ed. da Universidade, 1968, p. 114.

${ }^{74}$ MENEZES, José Luís da Mota. Algumas notas a respeito da evolução urbana de João Pessoa. Recife: Pool Editora, 1985, s/p.
} 
processo se dá a partir da acomodação das novas áreas urbanas ao relevo local, ampliando a cidade paulatinamente, a partir de sua utilização cotidiana, o que acenta o caráter 'aleatório' a que muitos relacionam sua aparência oitocentista.

Esse 'caráter aleatório', que em fins do século XIX passa mais freqüentemente a ser apontado como indício de 'desordem urbana', representa a ordem da cidade colonial que se mantém até o início do século XX. As características de algumas de nossas cidades, encaradas como 'má herança colonial' por observadores do século XIX, relacionam-se a um conceito de regularidade que se aproxima da ortogonalidade que, nos estudos atuais, é revisto:

\begin{abstract}
"Mas essas discussões, que incluem geralmente uma comparação com as formas do urbanismo hispano-americano, partem do princípio de que regularidade seria a existência de traçado geométrico, obedecendo à forma de xadrez, como em boa parte da América hispânica e das antigas colônias inglesas"75.
\end{abstract}

Nestor Goulart, ao tratar desse assunto, esclarece que o alinhamento das casas não implica necessariamente em ruas retas. Para ele, "regularidade é a existência de repetições de determinadas características"76 e não, necessariamente, ortogonalidade. Assim, as ruas construídas por uma única linha contínua, com construções alinhadas e semelhantes, mas não obrigatoriamente retas, constituem vias regulares e cumprem sua função de delimitar a fronteira entre os espaços público e privado.

"O alinhamento era estabelecido por iniciativa do chamado arruador, que fixava a linha segundo a qual se dividia o espaço público dos espaços privados. As ruas podiam ser curvas, como ocorria freqüentemente na região das minas, em terrenos mais acidentados, onde se procurava acompanhar as curvas de nível ou cruzá-las de forma suave. Mas não se admitia que um dos terrenos se avançasse sobre a rua, estabelecendo um ressalto, em relação às construções vizinhas. Curvas ou retas, as ruas deviam ser definidas sempre por uma única linha contínua, estabelecida pelo arruador"77.

A 'irregularidade' apresentada nas ruas com curvas, que é por certo tempo relacionado à desordem urbana, é formada por uma linha que não costuma ser composta de uma sinuosidade contínua, mas corresponde a um conjunto de pequenas retas. Seccionada em medidas fererentes a cada lote, a linha em curva se torna imaginária, de forma que os lotes têm suas fachadas em linha reta. Como os lotes apresentam, geralmente, pouca frente, esse artifício não é facilmente percebido. Assim, a sinuosidade conseqüente da adaptação do traçado ao relevo, que é uma característica desse processo construtivo da cidade, não se reflete no lote e na construção, o que revela a coerente ordem do pensamento urbanístico de então: "Assim, mesmo nas curvas, havia sempre uma disciplina urbanística, um trabalho de regularização das relações entre os espaços públicos e os espaços privados e das relações entre si"78. Dessa forma, ao contrário das críticas às cidades observadas no final do século XIX, a adoção de traçados de caráter geométrico pode se mostrar menos adequada, em termos de adaptação à topografia, tornando-se mais uma imposição de caráter legal do que em um avanço e aperfeiçoamento em termos de técnica urbanística.

A capital paraibana, fundada no século XVI, tem sua construção norteada pelas diretrizes urbanísticas desse momento, desenvolvendo-se, até fins do século XIX, segundo a lógica que predomina no período colonial e incorporando inovações do período imperial. Assim, com alterações pontuais em relação à sua fisionomia, a capital paraibana mantém, até o fim do século XIX, características marcantes de sua formação colonial,

\footnotetext{
${ }^{75}$ REIS, Nestor Goulart. "A Urbanização e o Urbanismo na Região das Minas". Cadernos de Pesquisa do LAP. Série Urbanização e Urbanismo. Jul-dez 99, n. 30. São Paulo, FAU- USP, p. 19.

${ }^{76} \mathrm{Ibid}$.

77 lbid.

${ }^{78}$ Ibid., p. 21.
} 
principalmente no que diz respeito aos seus espaços públicos. Desde a fundação da cidade, em 1585, percebe-se um lento e gradativo processo de construção desse centro urbano, apresentando parcas e esparsas mudanças no sentido de reordenamento. Ao entrar no século XX, a capital paraibana apresenta-se constituída predominantemente por becos, travessas, largos, pátios e campos, criados por acréscimos e intervenções promovidas por incentivos e ações públicas e, sobretudo, privadas.

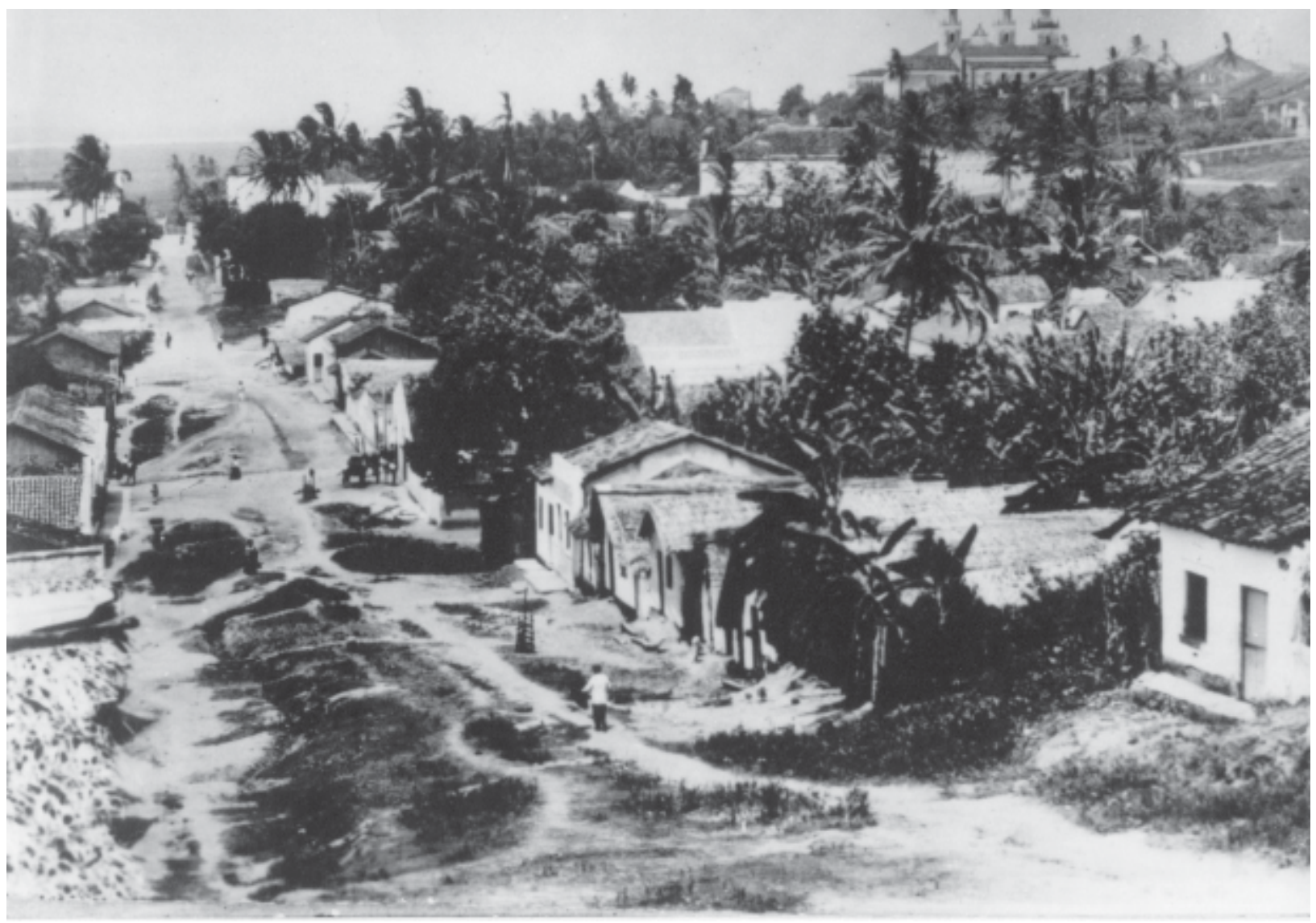

Antiga rua do Melão, atual Beauripaire Rohan - 1909. FONTE: Acervo fotográfico Laudereida Marques.

No processo de estruturação das cidades brasileiras do século XVI ao XVIII, percebe-se a crescente regularização de seus traçados, que culmina na "adopção de traçados regulares, geometrizantes, no planeamento de novas cidades, ou nos planos de extensão de cidades já existentes"79. Já as ações urbanas da segunda metade do século XVIII e início do XIX "apresenta[m]-se como parte de um projeto de criação de um cenário urbano, no qual as paisagens são definidas como conjuntos que resultam de uma disciplina imposta às construções comuns" ${ }^{80}$. Porém, muitas vezes, a não adoção de medidas regularizadoras em algumas cidades tem relação com o "sentido pragmático da administração portuguesa, [que] reduzia o alcance de ação do governo central e das próprias câmaras"81, reflexo da prioridade conferida à posse das terras brasileiras em relação à administração do processo de formação urbana. Assim, a imagem urbana do Brasil colonial pode ser vista como reflexo de limites que nascem flexíveis, onde, muitas vezes, as cidades da colônia prosperam quase à margem dos ditames da Coroa. A própria capital, que se relaciona diretamente com Portugal, evidencia a fragilidade do poder institucional tanto na construção de edifícios como nas atividades de seus habitantes. ${ }^{82}$

\footnotetext{
${ }^{79}$ TEIXERA, C. Manuel. "Introdução". In: TEIXERA, C. Manuel (coord.). A construção da cidade brasileira. Lisboa: Livros horizonte, 2004, p.11.

${ }^{80}$ REIS, Nestor Goulart. "A Urbanização e o Urbanismo na Região das Minas". Cadernos de Pesquisa do LAP. Série Urbanização e Urbanismo. Jul-dez 99, n. 30. São Paulo, FAU- USP, p. 14.

${ }^{81}$ REIS FILHO, Nestor Goulart. Contribuição ao estudo da evolução urbana do Brasil (1500-1720) São Paulo : Liv. Pioneira e Ed. da Universidade, 1968, p. 119.

${ }^{82}$ MARINS, Paulo César Garcez. Através da Rótula. Sociedade e Arquitetura Urbana no Brasil, séculos XVII a XX. São Paulo: Humanitas/FFLLCH/USP, 2001, p. 80.
} 
Nesse sentido, a capital paraibana de fins do século XIX apresenta características de sua formação colonial que convivem com alterações formais conseqüentes dos discursos urbanos de então, onde o higienismo, a salubridade urbana e a necessidade de uma melhor infra-estrutura encontram-se sempre em pauta. Esse período é envolto pelos constantes incentivos no sentido de alterar a aparência urbana da cidade, onde a transformação formal dos seus espaços, os novoas modos de utilizá-los e os novos nomes a eles atribuídos revelam os ideais urbanos vigentes pauta naquele momento.

\subsubsection{A trama}

No final do século XIX, a cidade da Parahyba do Norte ${ }^{83}$ se encontra implantada em dois planos interligados - Cidade Alta e Varadouro ${ }^{84-}$, formando um único núcleo urbano. Nesse momento, a cidade apresenta um traçado formado por ruas tortuosas, que ora se alargam formando largos, ora se comprimem criando becos. Seus espaços públicos são marcado por ladeiras - geralmente ligando essas duas porções da cidade-, caminhos - situados sobretudo nos arredores -, ruas, becos, travessas, pátios, largos, campos e praças, articulados de forma aparentemente espontânea, numa ordem que proporciona perspectivas tipicamente coloniais.

Esses elementos configuram a cidade, relacionando-se de forma peculiar: praças que se comunicam, ruas que, mesmo quando retas, em certos pontos se aproximam para depois se distanciarem, travessas que terminam em largos, becos que simplesmente param, segundo a vontade dos habitantes que desenham a cidade a partir de suas construções. Não há, nesse momento, organização do traçado que remeta a quarteirões regulares, mas grandes áreas de diferentes formatos, delimitadas por vias formadas a partir de edificações, o que resulta em várias porções de terra edificadas em seu perímetro e com o centro não construído, caracterizando os quintais. Esse quadro é comum às cidades coloniais brasileiras, cujas quadras, segundo Nestor Goulart Filho, "quando completamente edificadas, compunham-se de uma linha contínua de construções, dos lados das ruas, com um grande vazio constituído pelos quintais, na parte interior"85.

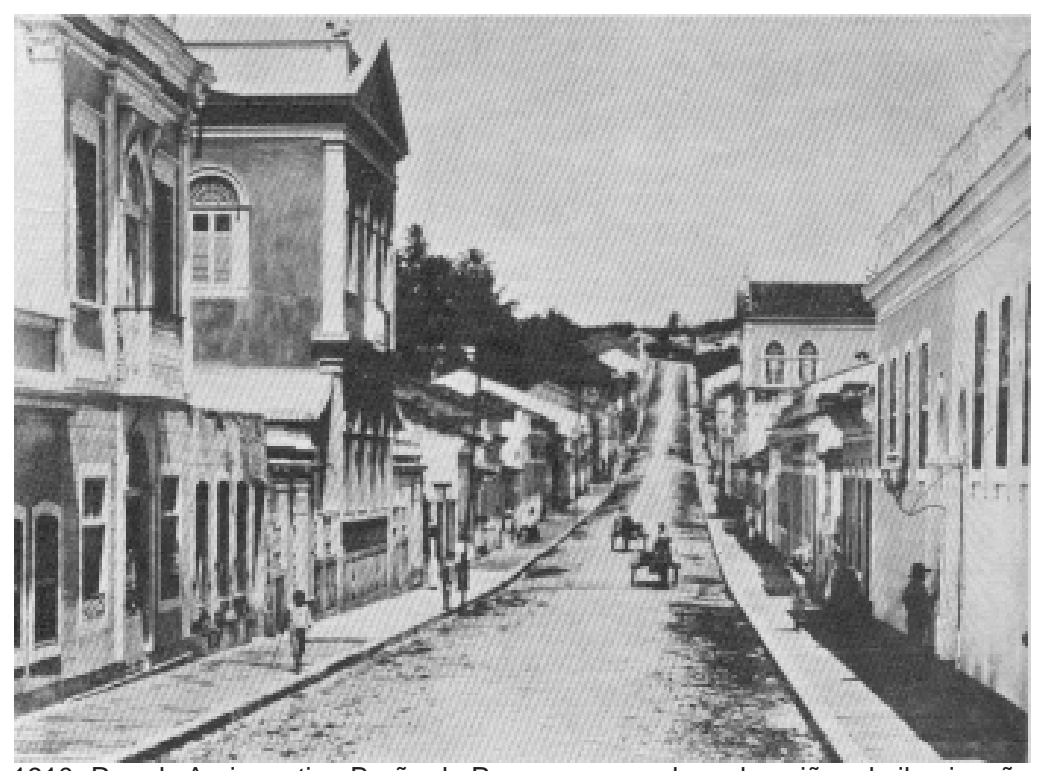

1910- Rua da Areia, antiga Barão da Passagem, vendo-se lampiões da iluminação a querosene. FONTE: Acervo fotográfico Laudereida Marques.

Apresentando tais características bem consolidadas em fins do século XIX, essa forma urbana mantém pouco das feições atribuídas à cidade na sua fundação. Terceira cidade fundada no Brasil, em 1585, a capital paraibana, inicialmente denominada cidade de Nossa Senhora das Neves, tem sua implantação realizada a partir de um traçado regular. Criada para afirmação de posse e defesa das terras portuguesas em território americano, sua conformação inicial indica uma ação de planificação.

\footnotetext{
${ }^{83}$ Nome da capital paraibana naquele momento.

${ }^{84}$ Nome dado à região portuária da cidade, posteriormente chamada também de cidade baixa.

${ }^{85}$ REIS FILHO, Nestor Goulart. Contribuição ao estudo da evolução urbana do Brasil (1500-1720) São Paulo : Liv. Pioneira e Ed. da Universidade, 1968, p.148.
} 
Na conquista das terras brasileiras, após a implantação do sistema de feitorias (1500-1531) e a rápida experiência de criação de capitanias hereditárias e suas vilas (1534-1549), vigora a criação de cidades a partir da instituição do Governo-Geral, centralizado na primeira cidade fundada, São Salvador (1549). Tal iniciativa acaba por proteger a costa da então colônia por meio da criação de outros núcleos urbanos. Esse processo tem continuidade com a implantação das cidades de São Sebastião do Rio de Janeiro (1565) e Nossa Senhora das Neves (1585), seguida de várias outras ao longo da extensa costa brasileira. A fundação dessas cidades "inaugurou a planificação urbana na América portuguesa, inserindo nova dinâmica entre os limites particulare comum na configuração da vida urbana" ${ }^{86}$, de forma que a cidade de Salvador dispõe do "primeiro plano quadriculado para uma fundação urbana realizada pela Coroa portuguesa no Novo Mundo" 87 .

A adoção desse partido para a implantação dessas cidades é reflexo das tendências geometrizantes apresentadas nas experiências urbanísticas européias na época do descobrimento do Brasil. ${ }^{88}$ Segundo Moreira, a intenção desse momento é a construção de uma rede urbana 'tendencialmente regular':

“... não havia a obsessão do ângulo reto nem da geometria abstrata, mas a necessidade prática (e o gosto) de abrir ruas tanto quanto possível paralelas, adaptando-se ao relevo do terreno - a linha da costa, curso dum rio, nível de cota de uma encosta abrigada da intempérie. (...) Sobretudo, já se verifica a tendência ou vontade de uma retícula relativamente rigorosa, de que só haverá a utensilagem mental e capacidade de realizar em época posterior"89.

Apesar da implantação regular de tendência geométrica, essa característica não perdura ao longo do crescimento da capital paraibana, como ocorre em outras cidades brasileiras. Para alguns, esse processo é atribuído a um certo desinteresse na fiscalização do desenvolvimento urbano das cidades brasileiras, que crescem, sobretudo, segundo as diretrizes dos habitantes que as constróem de acordo com seus próprios interesses. Porém, essa formação urbana, que "induzia a uma idéia de informalidade e desordem como sendo características essenciais das cidades portuguesas no Brasil" "1ambém faz parte das "características morfológicas que radicam na tradição urbana portuguesa, [expressa, dentre outras] (...), na dupla vertente vernácula e erudita que caracterizam seus planos" ${ }^{\prime 1}$. Essa síntese é feita no próprio processo de planeamento e construção da cidade, onde o plano apresenta a regularidade afirmada "através de um desenho, de uma geometria ou de uma métrica reguladora"92, e o verdadeiro traçado é o executado no sítio, onde o plano é adaptado às particularidades do terreno.

Percebe-se a gradativa afirmação da componente erudita do traçado dessas cidades entre os séculos XVI e XVIII, chegando a traçados geométricos e ortogonais. Segundo Nestor Goulart Filho, apenas após 1720, percebe-se uma política urbanizadora que torna mais efetiva a regularidade do traçado nas cidades brasileiras.

À época da fundação da atual cidade de João Pessoa, essa região é marcada pelo escambo realizado pelos franceses, possibilitado pela atuação portuguesa concentrada no "controle dos portos e construção de baluartes e fortalezas que assegurassem sua situação comercial"93. A região da capital paraibana se encontra sob poder dos potiguares, cuja relação com os franceses permite àqueles disporem de um fortim e duas

\footnotetext{
${ }^{86}$ MARINS, Paulo César Garcez. Através da Rótula. Sociedade e Arquitetura Urbana no Brasil, séculos XVII a XX. São Paulo: Humanitas/FFLLCH/USP, 2001, p. 52.

87 Ibid., p. 52.

${ }^{88}$ REIS FILHO, Nestor Goulart. Contribuição ao estudo da evolução urbana do Brasil (1500-1720) São Paulo : Liv. Pioneira e Ed. da Universidade, 1968, p. 128.

${ }^{89}$ MOREIRA, Rafael. "AArte da Ruação e a Cidade Luso-brasileira". Cadernos de Pesquisa do LAP. Série Urbanização e Urbanismo. Jan - jun 03, n. 37. São Paulo, FAU- USP, p.11.

90 ITEIXERA, C. Manuel. "Introdução". In: TEIXERA, C. Manuel (coord.). A construção da cidade brasileira. Lisboa: Livros horizonte, 2004, p. 9.

91 Id., "Os modelos urbanos portugueses da cidade brasileira". In: TEIXERA, C. Manuel (coord.). A construção da cidade brasileira.

Lisboa: Livros horizonte, 2004, p. 23.

92 Ibid., p. 29.

${ }^{93}$ MENEZES, José Luís da Mota. Algumas notas a respeito da evolução urbana de João Pessoa. Recife: Pool Editora, 1985, s/p.
} 
ferrarias às margens do rio que dá seu nome à capitania. Certamente, é essa atuação francesa que, assim como em outros lugares do país, leva a Coroa portuguesa a tornar efetiva a posse daquela região. Desde 1575, os portugueses tentam conquistar essa região, partindo de Olinda, centro açucareiro que possue mais da metade dos engenhos de toda a Colônia e área mais importante do Nordeste até então. Após a conquista, em 5 de agosto de 1585 - dia da santa cujo nome é atribuído à cidade-, funda-se a cidade de Nossa Senhora das Neves, cujo núcleo urbano inicial é construído em um monte nas proximidades da margem direita do rio Sanhauá, um dos braços do rio Parahyba.

O traçado de fundação da capital paraibana é regular, com quarteirões retangulares de medidas diferentes, e praças e largos com formas regulares que permitem certa flexibilidade ao traçado, inclusive quando associados às edificações religiosas e administrativas. Sua implantação segue a linha predominante no Brasil do século XVI, cuja tendência geral é a ocupação de sítios elevados, o que não significa, necessariamente, acidentados, mas, sobretudo, áreas mais ou menos planas como ocorre nas capitais da Bahia, São Paulo e Rio de Janeiro. Essa implantação consiste em um sistema defensivo elementar, "solução aplicada a núcleos de importância diversa, das pequenas aldeias às cidades"94. Seguindo também estratégias de segurança, a fundação da cidade da Parahyba do Norte se dá em uma área alta e plana, nas proximidades do rio Sanhauá. ${ }^{95}$ Tal característica é comum no Brasil, assim como ocorre em Portugal, onde a implantação urbana se dá "ou em situações costeiras, à beira de uma baía, ou junto aos rios ou outros cursos de água"96. Essa configuração produz núcleos urbanos em dois planos, "a cidade Alta e a Baixa, que será uma das constantes da cidade portuguesa, no continente como no ultramar"97. A escolha do local de fundação de um povoado expressa a preocupação com sua defesa, acentuada pela presença de fortificações construídas nas proximidades do centro urbano, que também se constituem elementos característicos dessas cidades: “Onde há cidade há fortificação, o braço armado da população"98.

O sistema econômico ao qual a colônia é vinculada cria uma estreita necessidade de comunicação com a Metrópole, o que exige uma localização que facilite essa conexão, geralmente realizada por vias fluviais e marítimas, o que garante o escoamento dos produtos de exportação e a entrada dos manufaturados. Nesse contexto, a capital paraibana é fundada fluvial, abrigada e defendida na foz do rio Paraíba pelo sistema de fortificações, que dificulta sua tomada pelos holandeses - que só ocorre em 1634, após a queda de Olinda. Percebe-se que apesar da cidade da Prahyba do Norte não ser envolvida por muralhas, persiste o ideal de defesa medieval, visível na escolha do local de sua implantação e na construção do forte, este dotado de torres, segundo o mapa intitulado Paraíba ou Rio São Domingos apresentado no Livro da Rezão. Essa localização estratégica é observada em 1639 por Elias Herckman, terceiro governador holandês, ao mencionar que a cidade "esta circundada pelo bosque, e não pode ser vista por quem se aproxima, senão quando se está nela"99.

A capital paraibana é fundada em apenas um plano, que corresponde, após seu crescimento em direção ao rio, à "cidade alta", de acordo com a sua configuração em fins do século XIX. Muitas são as interpretações que afirmam ter sido, essa cidade, fundada em duas áreas, alta e baixa, mas a inexistência de vestígios

\footnotetext{
${ }^{94}$ REIS FILHO, Nestor Goulart. Contribuição ao estudo da evolução urbana do Brasil (1500-1720) São Paulo : Liv. Pioneira e Ed. da Universidade, 1968, p. 125.

95 Segundo Menezes, essa configuração de "cidade alta" e um núcleo portuário na região baixa é observada na legenda de um dos dois mapas sobre a Paraíba existentes na Relação de Praças Fortes do Brasil (1609) de Diogo Campos Moreno - ao que se sabe, documento cartográfico mais antigo referente a essa área. (MENEZES, José Luís da Mota. Algumas notas a respeito da evolução urbana de João Pessoa. Recife: Pool Editora, 1985, s/p).

96 TEIXERA, C. Manuel. "Os modelos urbanos portugueses da cidade brasileira". In: TEIXERA, C. Manuel (coord.). A construção da cidade brasileira. Lisboa: Livros horizonte, 2004, p. 31.

${ }^{97}$ MOREIRA, Rafael. "A Arte da Ruação e a Cidade Luso-brasileira". Cadernos de Pesquisa do LAP. Série Urbanização e Urbanismo. Jan - jun 03, n. 37. São Paulo, FAU- USP, p. 11.

${ }^{98}$ Ibid., p. 8.

${ }^{99}$ HERCKMAN, Elias. Descrição Geral da capitania da Paraíba - 1839. João Pessoa: A União, 1982, s/p.
} 


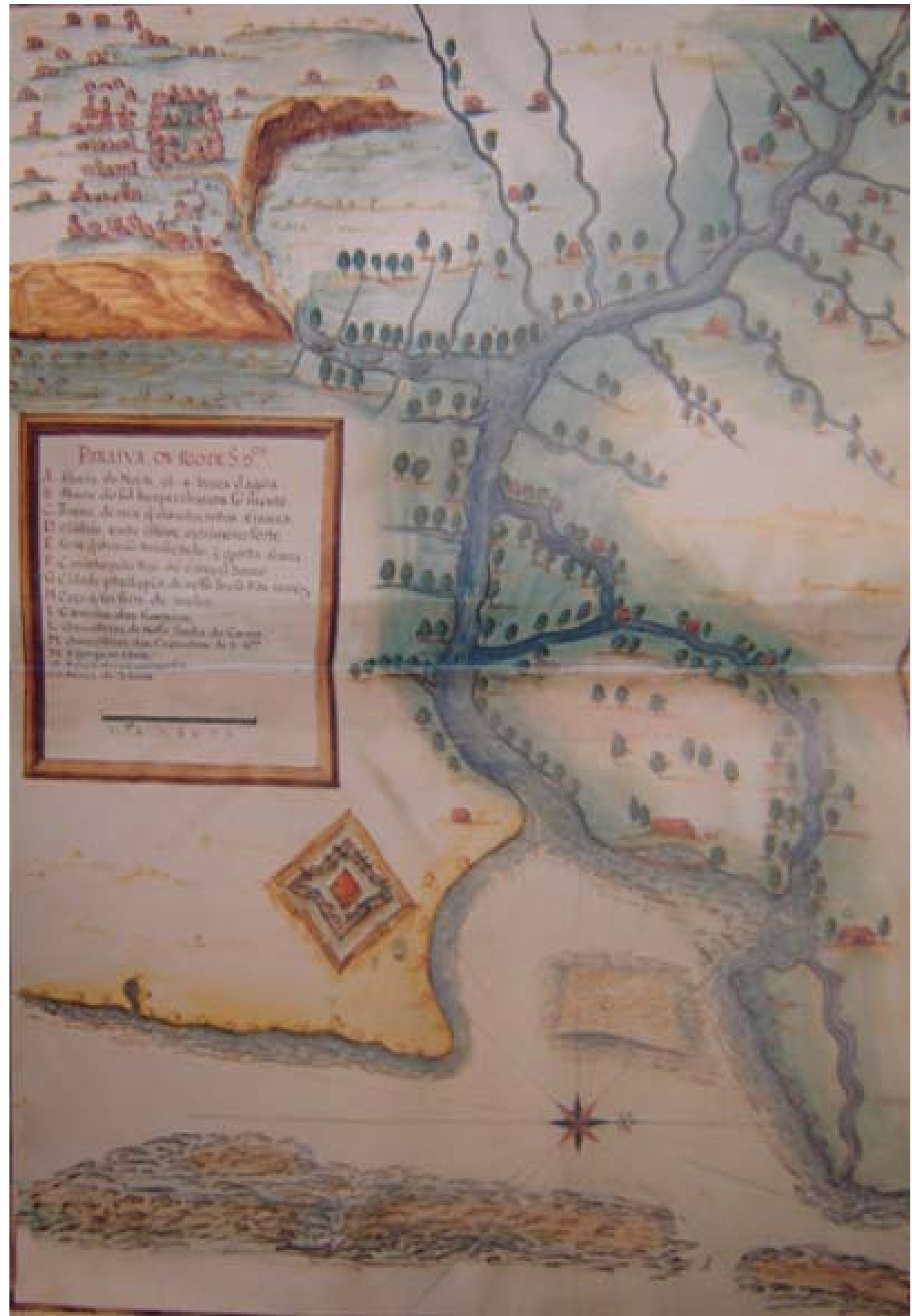

Mapa retirado do "Livro da Rezão do Estado do Brasil no Governo do Norte somente asi como o teve do Giogo de Meneses até o anno de 1612". No canto esquerdo superior encontra-se o núcleo inicial da cidade de João Pessoa, situado em uma área alta, ligado ao rio por um caminho enladeirado. 


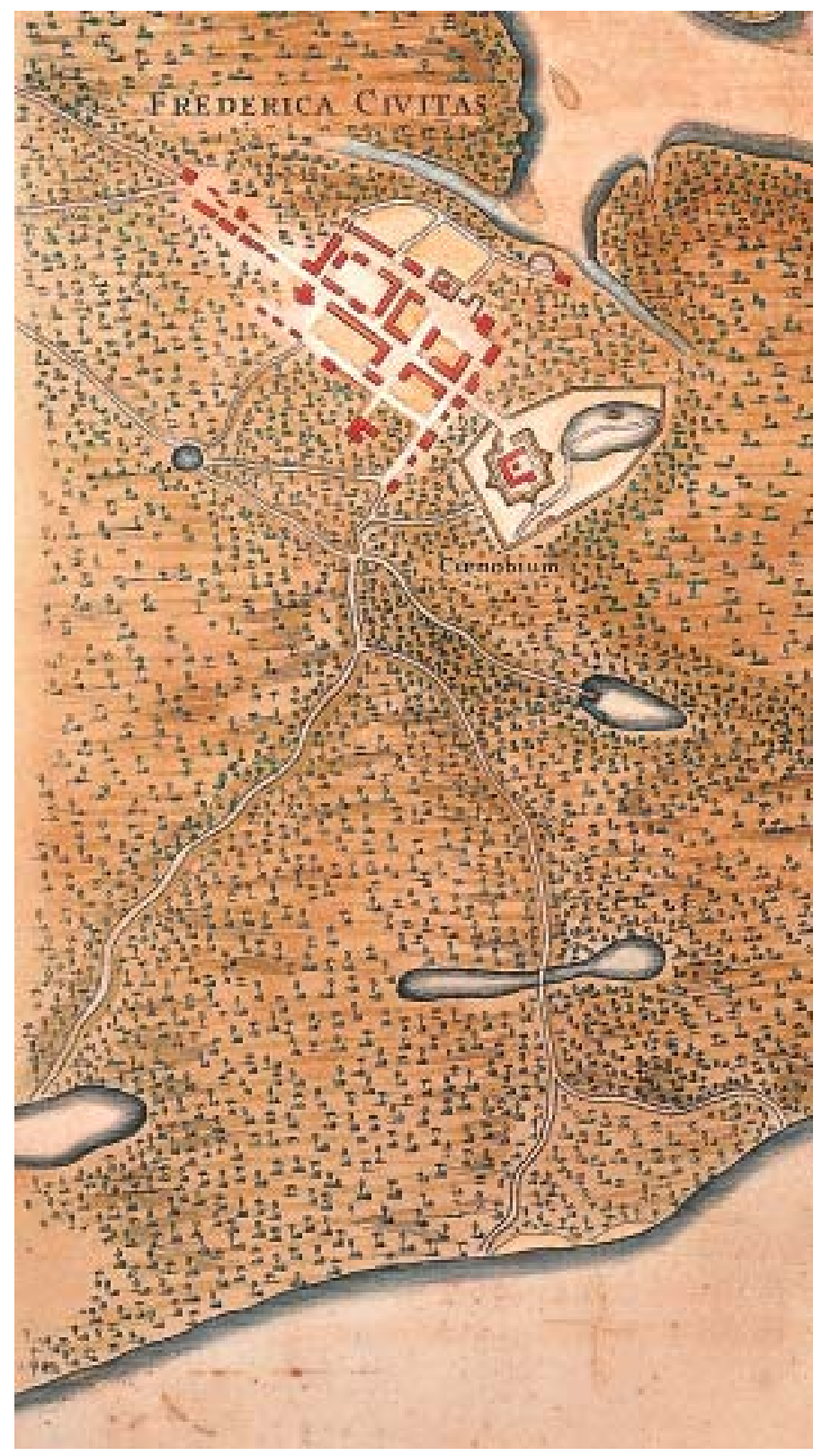

"FREDERICA CIVITAS". AUTOR: Gravura de Jan van Brosterhuisen. FONTE: Detalhe de uma imagem que ilustra o livro de Barlaeus (BARLAEUS - 1647), estampa $n^{\circ} 26$, exemplar da Biblioteca Nacional, Rio de Janeiro. São assinaladas cerca de seis quadras ocupadas de forma incompleta, indicando-se as áreas construídas e os terrenos abertos, além de dois caminhos de saída, a sudeste e a noroeste, com algumas casas isoladas. A cidade de Paraíba teve seu nome alterado durante o período holandês, tendo sido denominada Cidade Frederica, como vem assinalado no desenho.Como nos outros casos, o desenho não é datado nem assinado, sabendo-se apenas que teria sido elaborado com base em levantamento realizado entre 1635 e 1644. (IN: REIS, Nestor Goulart. Imagens de vilas e cidades do Brasil colonial. São Paulo: FUPAM, 2000.)

administração do país colonizador, suas novas terras conquistadas. Porém, suas atribuiçães vão mais além, tornando os mapas peças importantes do processo de conquista. Neles "produzia-se um 'território' limitado e contínuo sobre uma natureza descontínua e ilimitada"105, e através deles, da compreensão visual de uma

${ }_{100}$ TEIXERA, C. Manuel. "Os modelos urbanos portugueses da cidade brasileira". In: TEIXERA, C. Manuel (coord.). A construção da cidade brasileira. Lisboa: Livros horizonte, 2004, p. 31.

101 Ibid.

102 Ibid.

${ }^{103}$ BUENO, Beatriz Piccolotto Siqueira. "A Produção de um território chamado Brasil". In: Laboratório Novo Mundo, São Paulo: Pinacoleca e Imprensa Oficial, 2004, p. 229.

104 Ibid.

${ }^{105}$ Ibid. urbanos na região baixa, resumindo-se inicialmente a poucos equipamentos portuários, aponta para a formação inicial apenas na parte alta, onde, de fato, constitui-se um núcleo urbano.

Nos mapas seiscentistas que retratam a sede da capitania paraibana e seus arredores, é nítida a existência de uma única área edificada, cujo traçado é regular, correspondendo ao que, posteriormente, é intitulado de 'cidade alta', em contraponto à existência de uma 'cidade baixa'. Nesse ponto, parece a capital paraibana fugir ao padrão da maior parte das cidades brasileiras desse período. Segundo Teixeira, "ao longo do mar ou do rio, desenvolve-se a primeira grande via estruturante da cidade"100, "muitas vezes designada Rua Direita"101. Essa parte corresponde à cidadela baixa, enquanto a cidadela alta "é ocupado geralmente pelo castelo, ou por outra situação defensiva, desenvolvendo-se em torno de si um pequeno núcleo construído" ${ }^{102}$. Na capital paraibana, as vias que conduzem seu crescimento se estruturam na parte alta, onde se encontra, inclusive, a Rua Direita.

O século XVII é um período rico em cartografia, sobretudo de produção holandesa. Apesar de não interferirem muito na configuração urbana paraibana, os holandeses deixam muitas informações registradas em mapas e relatos acerca dessa capital. A cartografia é "um dos mais importantes legados do Século das Luzes"103 $^{\text {, }}$ resultando em uma elaboração de mapas que "esteve vinculada à definição dos territórios dos Estados Nacionais europeus e respectivas Conquistas Ultramarinas"104. À produção de mapas do período colonial é atribuída a função de divulgar, para a 
vasta área por eles propiciada, dá-se "a negociação e legitimação da posse de territórios em grande parte"106 . “Mapear significava 'conhecer', 'domesticar', 'submeter', 'conquistar', 'controlar', 'contradizer a ordem da natureza" "107.

Na observação dos mapas da capital paraibana, percebe-se que aqueles produzidos no período holandês abordam uma ampla área, que vai além do conjunto urbano. Essas cartografias revela os arredores da cidade, seus acidentes geográficos e as atividades rurais alí empreendidas, o que indica um estudo de "reconhecimento" da área conquistada, importante para exploração e defesa, além de retratá-la para os conquistadores que permanecem além-mar. Essa postura é ressaltada pelo seu contraste com a produção de mapas no século XIX. No período oitocentista, enfatiza-se a cidade e seus elementos urbanos, evidenciando o interesse em resolver as deficiências que a estrutura de então apresenta em relação às demandas.

Na Paraíba, apesar da maior contribuição em relação aos estudos cartográficos ser holandesa, sua atuação se cocentra no campo documental, não interferindo de forma considerável na constituição urbana, ao contrário do que ocorre no estado vizinho de Pernambuco, cuja atual capital é por eles construída. Assim, se a dominação holandesa no Brasil seiscentista marca a formação de algumas cidades nordestinas, como ocorreu no Recife, na capital da Paraíba essa administração não gera grandes alterações na sua estrutura urbana.

A tomada da Paraíba pelos holandeses se dá apenas em 1634, e a cidade conquistada é retratada através de estampas. Destacam-se a estampa Afbeelding der stadt en fortressen von Parahyba de autoria de Claes Jans Visscher, notável gravador, e a do Atlas van Stolk, referências para análise desse período. Durante o domínio holandês, essa cartografia apresenta a capital paraibana com forma urbana regular, e quadras e traçado de ruas tendencialmente ortogonais, seguindo as diretrizes das cidades derivadas de planos renascentistas.

Nesse momento, a área do Varadouro não dispõe de edificações significativas, além das diretamente relacionadas à atividade portuária. Segundo a Descrição Geral da Capitania da Parahyba, relato do governador da província, o holandês Elias Herckman, nem os armazéns de açúcar construídos anteriormente pelos portugueses se encontram mais nessa região. Esses foram "queimados e abrasados até o chão"108 por ocasião da conquista holandesa. Herckmans, nesse mesmo documento, também apresenta a disposição longitudinal, em relação ao rio, dos elementos urbanos iniciais da sede dessa capitania então denominada Frederica ${ }^{109}$, indicando que "somente há poucos anos é cidade" e situa-se "ao comprido sobre a eminência do monte que fica defronte da baía do Varadouro"110, de onde dista quase um quarto de hora de viagem. Irineu Pinto compartilha essa descrição da área de implantação da cidade: “Ao entrar pela barra do rio São Domingos ou Paraíba, Martin Leitão ‘procurando melhor lugar para
implantar a cidade, escolhe o alto de uma colina, tendo o rio Sanhauá aos pés, a dezoito kilômetros
da foz do Paraíba, defronte ao sítio em que João Tavares havia feito pás com Piragibe”" 111.

Segundo os mapas seiscentistas, a capital paraibana apresenta-se como uma cidade aberta, sem muralhas. Essa configuração não implica numa despreocupação referente à sua defesa, questão tão firmada no contexto urbano brasileiro daquele momento. Isso se verifica logo na sua fundação quando, "para assegurar

\footnotetext{
${ }^{106}$ BUENO, Beatriz Piccolotto Siqueira. "A Produção de um território chamado Brasil". In: Laboratório Novo Mundo, São Paulo: Pinacoteca e Imprensa Oficial, 2004, p. 229.

107 Ibid.

${ }^{108}$ HERCKMAN, Elias. Descrição Geral da Capitania da Paraíba - 1939. João Pessoa: A União, 1982

${ }^{109}$ Ou Frederickstad, nome dado à cidade durante o domínio holandês em homenagem ao Príncipe de Orange.

${ }^{110}$ HERCKMAN, op. cit., s/p.

${ }^{111}$ PINTO, Irineo apud MENEZES, José Luís Mota. Algumas notas a respeito da evolução urbana de João Pessoa. Recife: Pool Editora, 1985, s/p.
} 


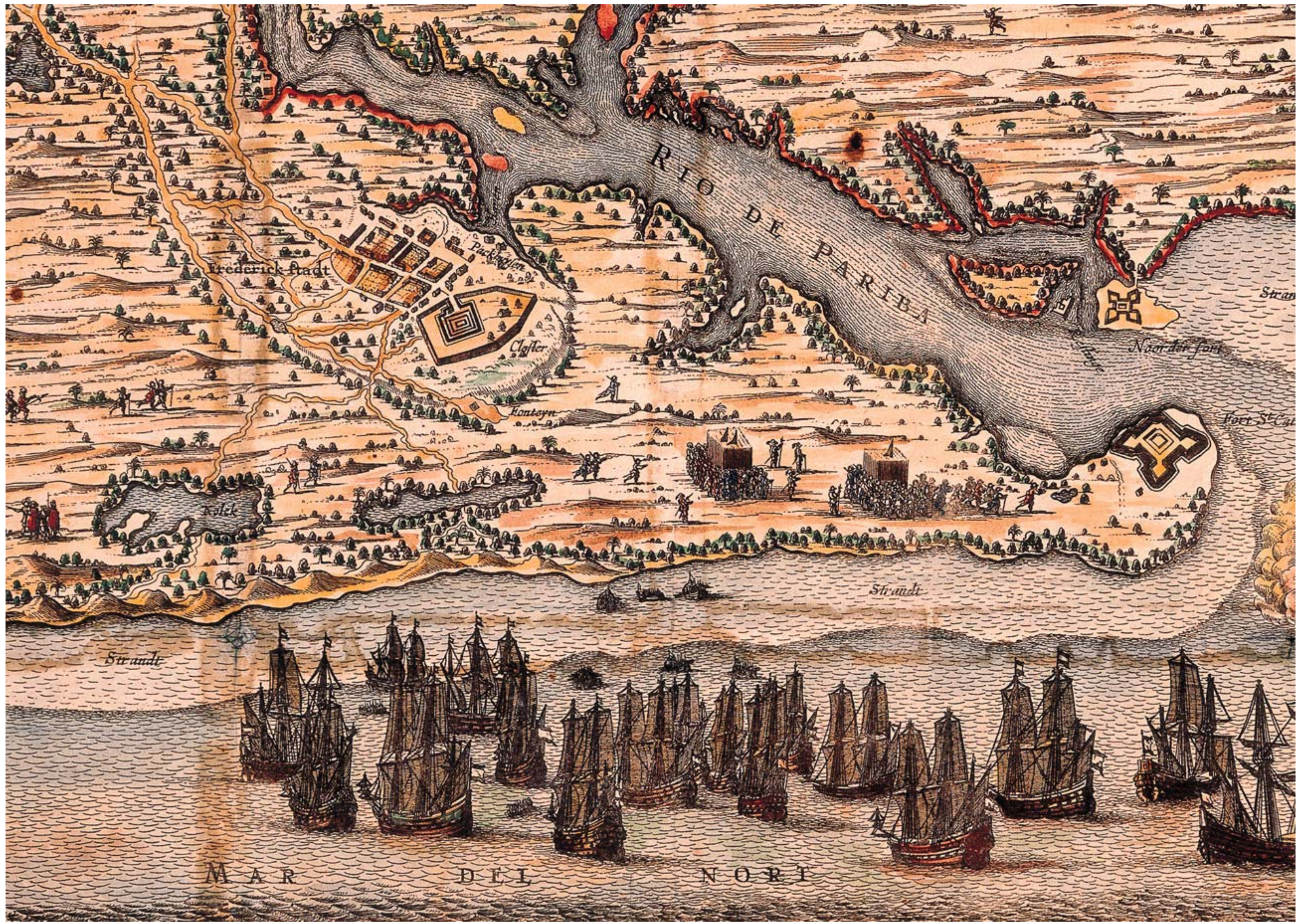

Mapa da PARAHYBA mostrando o núcleo urbano e seus arredores produzido durante a administração holandesa. FONTE: REIS, Nestor Goulart. Imagens de vilas e cidades do Brasil colonial. São Paulo: FUPAM, 2000. 
os seus fundamentos, iniciou[-se] a construção de um forte"112, edificação não mais existente no século seguinte, à época do domínio holandês, porém substituída por várias outras construções de mesma natureza ao longo da sua história, enquanto se faz necessário esse tipo de proteção à cidade.

Segundo um mapa com data de 1647 apresentado no livro de Barleus ${ }^{113}$, naquele momento a capital paraibana dispõe de pequenas dimensões, contando com duas ruas principais, situadas no mesmo sentido em que corre o rio e cortadas por pequenas vias de dois quarteirões. Essa configuração é, para alguns viajantes, incompatível com a sua denominação de cidade.

É justamente esse conjuno urbano de poucas ruas e traçado regular, tendencialmente ortogonal, introduzido pelos portugueses, que se torna imperceptível ao fim do processo de crescimento urbano desenvolvido nos três primeiros séculos da cidade. A capital paraibana chega ao fim do século XIX com uma forma marcadamente regular, porém disvirtuada da ortogonalidade inicial, distribuindo-se para além da colina na qual é implantada, até atingir a área baixa nas proximidades do rio Sanhauá. Seguindo o exemplo das outras cidades brasileiras a ela contemporâneas, a cidade da Parahyba do Norte abriga, na parte baixa, preferencialmente, edificações destinadas às atividades comerciais, enquanto na região alta predomina as residências dos grandes proprietários, edificações administrativas e eclesiásticas.

\subsubsection{As construções}

Em conjunto com o traçado, as edificações revelam especificidades das formas urbanas de uma época. Na capital paraibana oitocentista, o grande número de construções religiosas, os sobrados e as casas térreas assumem formas arquitetônicas que influenciam na aparência de seus espaços urbanos. Seguindo o perfil das cidades da colônia, o elemento arquitetônico de maior ênfase no espaço urbano é a construção religiosa, cujas dimensões e elementos peculiares proporcionam-lhe destaque no cenário citadino, em meio às casas térreas e aos sobrados. Essa configuração tem um viés simbólico, fundamentado no papel preponderante da religião na vida coletiva da cidade de então.

No Brasil colonial, construções religiosas surgem juntamente com as povoações, apresentando-se entre as primeiras edificações instaladas. Seu papel nas formações urbanas ultrapassa o limite da religiosidade, que é um dos pilares da sociedade daquele momento, assumindo funções administrativas por estar vinculada ao Estado ${ }^{114}$. Assim, muito da vida urbana encontra-se sob o comando da Igreja: do nascimento à morte, casamentos, questões familiares, culturais, artísticas e, inclusive, o aprendizado das primeiras letras. Além das "obrigações" religiosas, nela são realizados os eventos mais importantes da vida familiar, o que faz dos pátios na frente das igrejas pontos de reunião e palco da vida urbana. Diante das funções dessa instituição na sociedade de então, não é de se admirar que o conjunto de suas construções sejam de grande representatividade no meio urbano, contrastando com a arquitetura dos edifícios administrativos e, mais ainda, com a das construções residenciais e de trabalho. Esse efeito é acentuado pela sua localização nos centros urbanos, pois a esses conjuntos são reservados, geralmente, os pontos de maior destaque, valorizando as perspectivas nas suas proximidades ${ }^{115}$.

\footnotetext{
${ }_{112}$ MENEZES, José Luís da Mota. Algumas notas a respeito da evolução urbana de João Pessoa. Recife: Pool Editora, 1985, s/p. ${ }^{113}$ Mapa observado em REIS FILHO, Nestor Goular. Imagens de vilas e cidades do Brasil colonial. São Paulo: FUPAM, 2000.

${ }^{114}$ REIS FILHO, Nestor Goulart. Contribuição ao estudo da evolução urbana do Brasil (1500-1720) São Paulo : Liv. Pioneira e Ed. da Universidade, 1968, p. 177.

115 Ibid., p.178.
} 


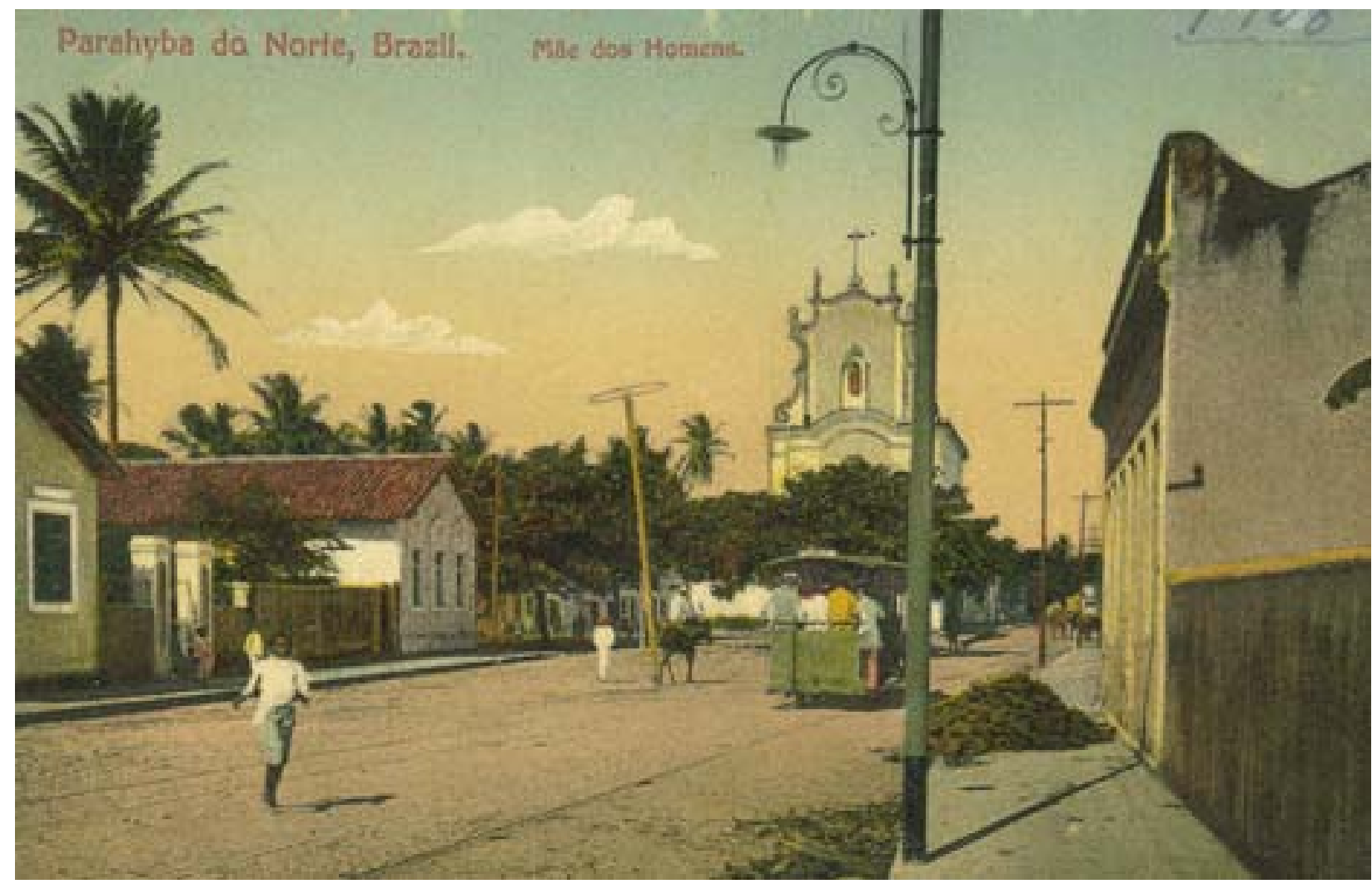

1908 - Igreja Mãe dos Homens. FONTE: Acervo Humberto Nóbrega

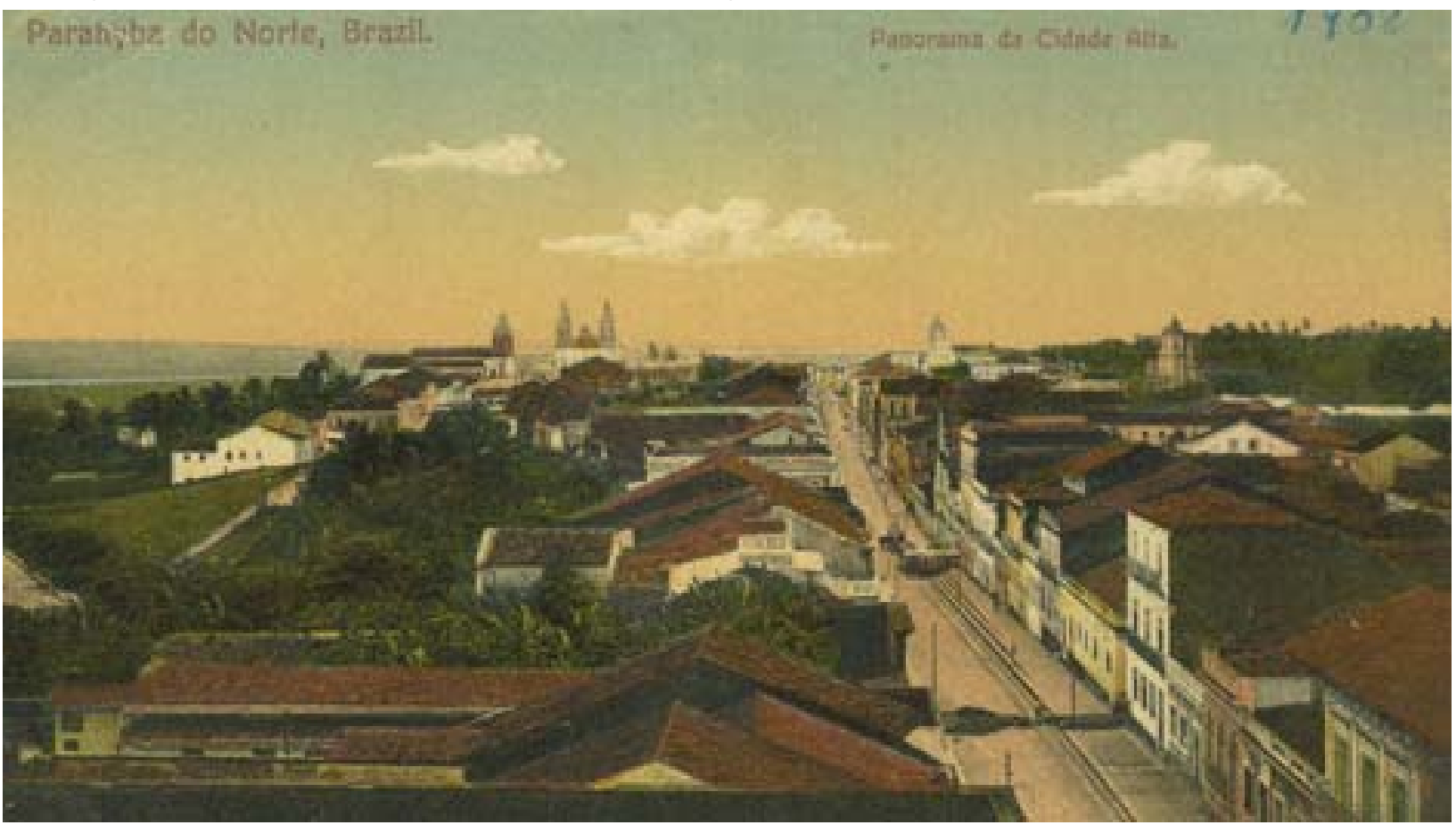

1908 - Panorama da Cidade Baixa. Fonte: Acervo Humberto Nóbrega

O papel das igrejas na forma urbana da capital paraibana se sobressai já nas primeiras décadas após a fundação dessa cidade, que ainda com parcas edificações, tem uma alta concentração de construções religiosas, indispensáveis às principais ruas do núcleo urbano, a exemplo da Rua Direita que, ainda no período holandês, conta com três igrejas. Segundo a Descrição de Elias Herckman, em 1639, a cidade encontrada pelos holandeses é formada por poucas casas térreas, pelourinho, mercado, uma forca "na qual se [costumava] justiçar" ${ }^{116}$, poucas ruas, essas retas e longelíneas, becos e a edificação religiosa como elemento central. "Escassamente edificada e com muito terreno desocupado"117, a cidade conta com seis igrejas e conventos.

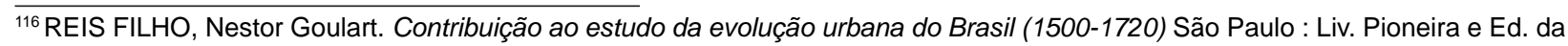
Universidade, 1968, p.179.

${ }^{117}$ HERCKMAN, Elias. Descrição Geral da Capitania da Paraíba - 1639. João Pessoa: A União, 1982, p44. 
No século XIX, a cidade se apresenta com significativo número de construções, as quais consolidam a área urbana de então, ocupando, inclusive, áreas que ultrapassam a parte alta onde é fundada, atingindo a região nas proximidades do rio. Sua aparência ainda se encontra fortemente marcada por edifícios religiosos que, juntamente com os prédios públicos, constituem-se referenciais no cenário urbano. Grande parte dessas edificações é construída em fins do século XVII, quando se desencadeiam intensas alterações na cidade, com o aumento do número de construções. Esse crescimento é comum às cidades canavieiras, reflexo da alta do preço do açúcar por volta da década de 1690, "decorrente da insegurança marítima no Caribe e na Europa, acarretada pelas guerras de Guilherme de Orange e pelos transtornos da Sucessão Espanhola. As constantes ameaças às exportações antilhanas estendiam a majoração do preço do açúcar [brasileiro] até cerca de 1720"118.

O século XVII marca as formas urbanas de várias cidades do país através da arquitetura religiosa, alterando não apenas sua aparência, como também o número de edifícios dessa natureza. Na capital paraibana, ocorre, nesse período, a ampliação e conclusão de grandes construções religiosas e o surgimento de novas igrejas. O Convento de Santo Antônio é reedificado em maiores dimensões, os Beneditinos constróem sua igreja, os Carmelitas ampliam seu convento e o concluem juntamente com a igreja e capela dos terceiros. A igreja da Misericórdia enriquece seu interior, e seu hospital, destruído na ocupação holandesa, é reedificado. A Matriz é reconstruída no século XVIII, assim como a casa dos jesuítas, que é ampliada e elevada em dois corpos, e ao seu lado é construída a igreja de São Gonçalo, em fachada barroca de cantaria.

Muitas outras igrejas são construídas após a retirada dos holandeses, a exemplo da do Senhor do Bonfim, na rua das Trincheiras, a de Nossa Senhora do Rosário, na rua Direita, as de Nossa Senhora Mãe dos Homens e de Nossa Senhora das Mercês. Essas edificações, juntamente com a casa da câmara e cadeia, mercado, tesouraria e residência do guarda-mor - representante da coroa-, situam-se no velho núcleo urbano seiscentista e na pequena expansão que se inicia em direção às Trincheiras e Tambiá. Essa configuração explicita, apesar do grande número de obras realizadas, o pequeno crescimento da cidade entre os séculos XVII e XVIII, quando ainda há uma série de terrenos vazios nas principais ruas: Direita, Nova e da Cadeia.

É justamente nessas principais ruas que se concentram tais edificações, acentuando sua imponência formal pela importância do logradouro no qual estão inseridas. Assim, a rua Direita, no século XIX, conta com as igrejas do Rosário, da Conceição e da Misericórdia, além da presença marcante do convento de São Francisco na cabeceira da rua, sinalizando sua origem. Essa é a edificação religiosa mais descrita pelos viajantes que visitam a cidade. Prende a atenção de Mário de Andrade em sua visita à capital paraibana em 1929, quando afirma que "do Nordeste à Bahia não existe exterior de igreja mais bonito nem mais original que esse", e acrescenta julgar estar diante da "igreja mais graciosa do Brasil - uma gostosura que nem mesmo as sublimes mineirices do Aleijadinho vencem em graciosidade"119.

Além das condições econômicas favoráveis, a abundância de pedra nas redondezas da cidade, de notável importância desde sua fundação, é de grande valia para o desenvolvimento dessas obras. Essa característica local é exaltada desde a escolha do sítio para sua implantação, onde há, segundo relatos da época, "excelente água, pedra e cal para construção"120, e como ressalta também o governador Fernando Delgado Freire de Castilho que, em 1798, atribui a esse fator a viabilidade de crescimento da cidade, pois "a sofrível pedra que é precisa, acha-se bem ao pé da cidade, com muita abundância e pouco custo"121.

\footnotetext{
${ }^{118}$ MARINS, Paulo César Garcez. Através da Rótula. Sociedade e Arquitetura Urbana no Brasil, séculos XVII a XX. São Paulo: Humanitas/FFLLCH/USP, 2001, p71.

${ }^{119}$ ANDRADE, Mário de. O Turista Aprendiz. Belo Horizonte,MG: Itatiaia, 2002, p.276.

120 SOUTO, Jomar Moraes de. "Visão poética numa fundação". In: AGUIAR, Wellington, MELLO, José Octávio de A. Uma cidade de quatro séculos. Evolução e roteiro. $2^{\text {a }}$ ed. João Pessoa: A União, 1989, p. 40.

${ }^{121}$ CASTILHO apud MENEZES, José Luís Mota. Algumas notas a respeito da evolução urbana de João Pessoa. Recife: Pool Editora, $1985, \mathrm{~s} / \mathrm{p}$.
} 


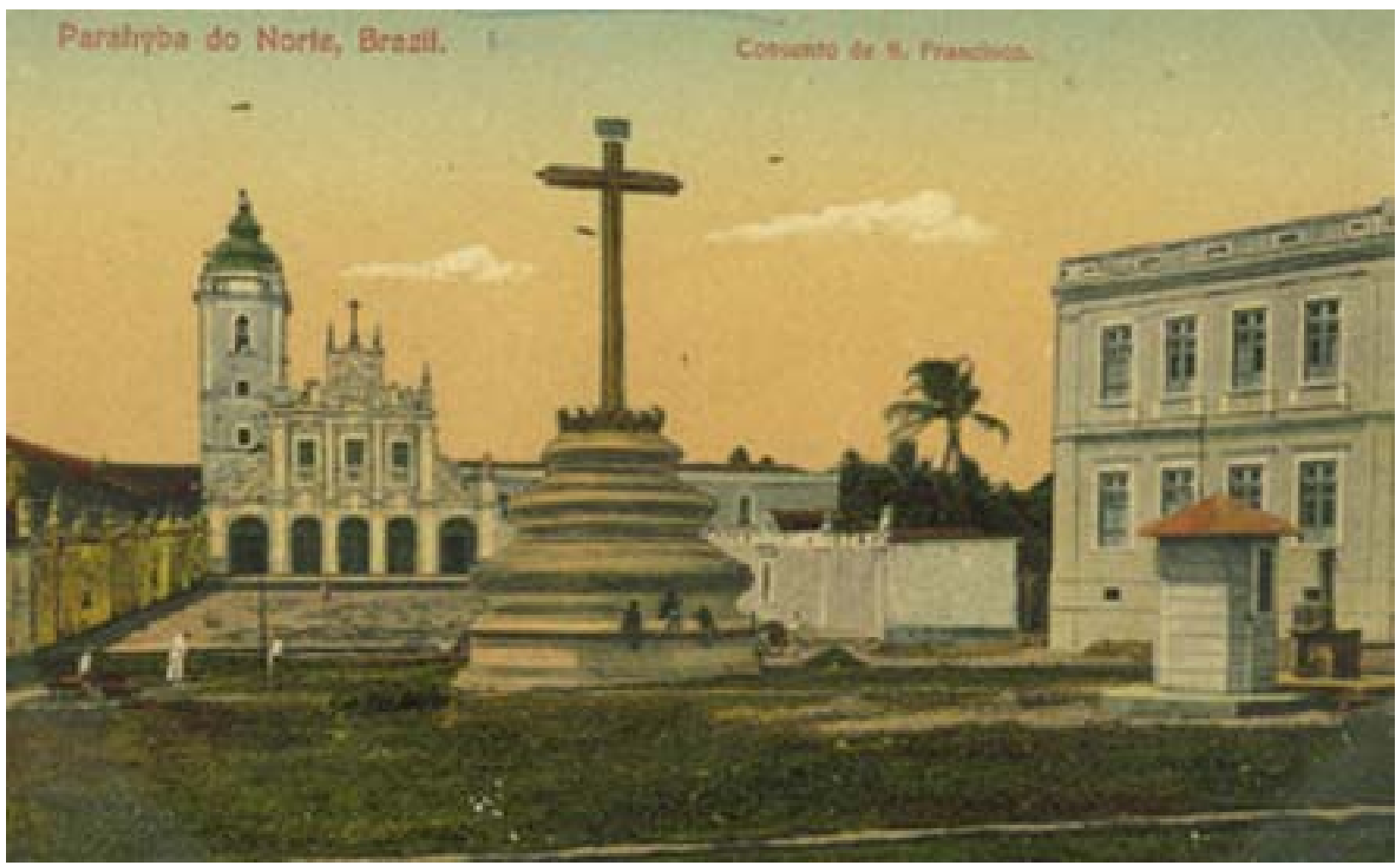

Largo e Igreja São Francisco. FONTE: Acervo Humberto Nóbrega. "Estou assombrado. Paraíba possui um dos monumentos arquitetônicos mais perfeitos do Brasil. Eu não sabia... Poucos sabem". (ANDRADE, Mário de. O Turista Aprendiz. Belo Horizonte, Itatiaia, 2002, p.276.)

No século XIX, a produção de algodão e o posterior "aumento do seu preço no mercado mundial em função da guerra separatista nos EUA [proporcionam] novo alento à economia paraibana". "Aumentou a população ${ }^{122}$, instalou-se uma filial de casa comercial do Recife, e algumas melhorias foram feitas na cidade", "surgiram as mansões dos fazendeiros de algodão, que reforçaram a parte alta da cidade"123, além da construção de um grande número de sobrados nas suas principais ruas. Suas residências, antes casebres e parcas casas de posse dos grandes proprietários da vizinhança que nelas habitam ao longo do inverno ou das estações chuvosas, sofrem intensas modificações. São, até então, na sua maioria

\begin{abstract}
"casas residenciais [que] seguiam a arquitetura típica da época: baixas, beiral lançando na calçada a água descida pelo telhado em dias de chuva, senão no próprio leito da rua, com o aumento dos agentes erosivos que ainda mais dificultavam o trânsito de quantos então procuravam abrigo junto às paredes"124.
\end{abstract}

Essas edificações são construídas sobre os limites do lote, como é comum nas áreas mais antigas da cidade que herdam do período colonial o alinhamento das construções de acordo com as vias públicas, constituindo-se fator responsável pela delimitação da rua. A maior parte do solo urbano é destinada às construções particulares, que servem de habitação a funcionários, proprietários rurais e comerciantes. Esses últimos também utilizam a moradia como local de trabalho, e os proprietários rurais, na maioria, apenas esporadicamente vão à cidade.

Até meados do século XVII, na maioria das cidades brasileiras, as habitações não se destacavam no conjunto das construções urbanas, inclusive pelo direcionamento dos investimentos para o meio rural. Na segunda metade do mesmo século, há uma intensificação da vida citadina, atribuindo novos significados a

\footnotetext{
${ }^{122}$ Nesse momento a população da cidade passa de 1000 a 3000 habitantes, atingindo cerca de 9000 habitantes em meados desse mesmo século. MENEZES, José Luís Mota. Algumas notas a respeito da evolução urbana de João Pessoa. Recife: Pool Editora, $1985, \mathrm{~s} / \mathrm{p}$.

${ }^{123}$ MENEZES, op. cit., s/p.

${ }^{124}$ ALMEIDA, Maurílio de. "Cidade da Paraíba, 1850. - Um pequeno aglomerado urbano". In: AGUIAR, Wellington, MELLO, José Octávio de A. Uma cidade de quatro séculos. Evolução e roteiro. $2^{\mathrm{a}}$ ed. João Pessoa: A União, 1989, p 41.
} 
essas edificações que sofrem alterações numéricas e melhoria do padrão construtivo ${ }^{125}$, adquirindo um tratamento formal mais elaborado.

Se a "disciplina urbanística do século XVII e da primeira metade do século XVIII era sobretudo a disciplina do traçado, de regularidade e alinhamentos"126, mesmo que só claramente perceptível em planta, o urbanismo da segunda metade do século XVIII e das primeiras décadas do século XIX apresenta outras dimensões. Enquanto na primeira fase, as cidades portuguesas no Brasil têm reguladas "basicamente as relações entre os espaços públicos e os espaços privados, evitando a apropriação de parcelas dos primeiros pelos segundos e procurava assegurar a livre circulação de pessoas, animais e veículos, em condições de eficiência"127, no segundo momento, observa-se uma preocupação com a paisagem urbana a partir da regulamentação de sua arquitetura. Busca-se criar conjuntos urbanos, em cujos moldes "os exemplos mais antigos foram construídos na Europa, nos séculos XVII e XVIII" ${ }^{128}$, através da disciplina imposta às construções comuns, padronizando, de certa forma, sua arquitetura. Há a intenção de instaurar uma nova ordem para controlar as formas e aparência das edificações, sobretudo das situadas nas principais ruas e praças.

\begin{abstract}
"Essa disciplina procurava determinar o espaçamento entre as portas e janelas da fachada e a altura dessas aberturas, bem como a altura de cada um dos pavimentos, incluindo regras para que as linhas dominantes de cada um pudessem formar um conjunto com suas vizinhas. Desse modo, sem que a decisão fosse tomada isoladamente por cada u m dos proprietários, as casas de uma rua terminavam por formar um conjunto, como se fosse uma única obra, de maior porte"129.
\end{abstract}

A evidência dessas características só se acentua no século XIX, quando há um processo de desmonte e, na capital paraibana praticamente extinção, dos elementos de recobrimento de janelas e balcões, com urupemas e treliças de madeira, que ocultam, em boa parte, a aparência dos vãos, anulando a maioria dos efeitos da disciplina assim estabelecida.

A aparência dessa cidade passa a ser marcada, de forma mais enfática, pelos sobrados que apresentamse, geralmente, com elementos que 'padronizam' sua aparência, e rapidamente se proliferam no tecido urbano. São predominantemente de um andar e situados principalmente na parte alta da cidade. O sobrado de dois andares é uma edificação quase exclusiva da área comercial, que abriga no térreo o armazém, no primeiro pavimento a família e no segundo os caixeiros, tornando-se um elemento mais comum à "cidade baixa", onde se consolida esse tipo de atividade. A escassez dessa tipologia arquitetônica apresenta uma peculiaridade na sua paisagem, posto que é comum a existência desse tipo de edificações em outras cidades, a exemplo do Rio de Janeiro e de Salvador.

A presença do sobrado no cenário oitocentista está embutida de conotação elitista, concentrando-se em algumas regiões, o que resulta no desmanche da aparência até então típica da cidade, onde edificações "ricas e pobres" se alternam de forma 'aleatória'. Vinculadas à população de alta renda, essas edificações se organizam formando áreas nobres, a exemplo da rua Direita, onde, em 1889, dos 120 prédios, 34 são sobrados. ${ }^{130}$ Esta "setorização" é tal que quando um sobrado aparece em outra área chama atenção, a exemplo da rua batizada de "do sobradinho" pela presença de um exemplar deste tipo de edificação em meio a um conjunto de casas térreas.

\footnotetext{
${ }^{125}$ REIS FILHO, Nestor Goulart. Contribuição ao estudo da evolução urbana do Brasil (1500-1720) São Paulo : Liv. Pioneira e Ed. da Universidade, 1968, p. 159.

${ }^{126}$ REIS, Nestor Goulart. "A Urbanização e o Urbanismo na Região das Minas". Cadernos de Pesquisa do LAP. Série Urbanização e Urbanismo. Jul-dez 99, n. 30. São Paulo, FAU- USP, p. 14.

127 Ibid.

128 Ibid.

129 Ibid., p. 22.

${ }^{130}$ JARDIM, Vicente Gomes. "Monographia da Cidade da Parahyba do Norte". Revista do IHGP. João Pessoa, n.3, p.83-111, 1911.
} 
Na década de 1850, das mil e quinhentas edificações que formam a capital paraibana, cinqüenta são sobrados. Apesar de não compor a maioria das construções, essa tipologia se sobressai na paisagem urbana em meio às casas térreas. Altera a forma dos espaços urbanos, principalmente por se encontrar, geralmente, concentrada e justaposta, compondo um conjunto arquitetônico de grande expressão. Nesse período, "quase duas dúzias [dos sobrados] existiam na Rua Direita, como áreas senhoriais, para orgulho da artéria; em quantidade menor, eles podiam ser vistos no Varadouro e na Rua das Convertidas" ${ }^{131}$. Essas edificações são, posteriormente, adotadas como residências permanentes das famílias abastadas que saem das fazendas e engenhos para a cidade. A posição social inerente aos proprietários dos sobrados é acentuada pelo obstáculo natural que sua arquitetura promove entre a habitação e a rua, resguardando seus habitantes de um contato mais direto com o exterior: "Viver em sobrado queria dizer, portanto, segurança e posição, garantia e status social"132.

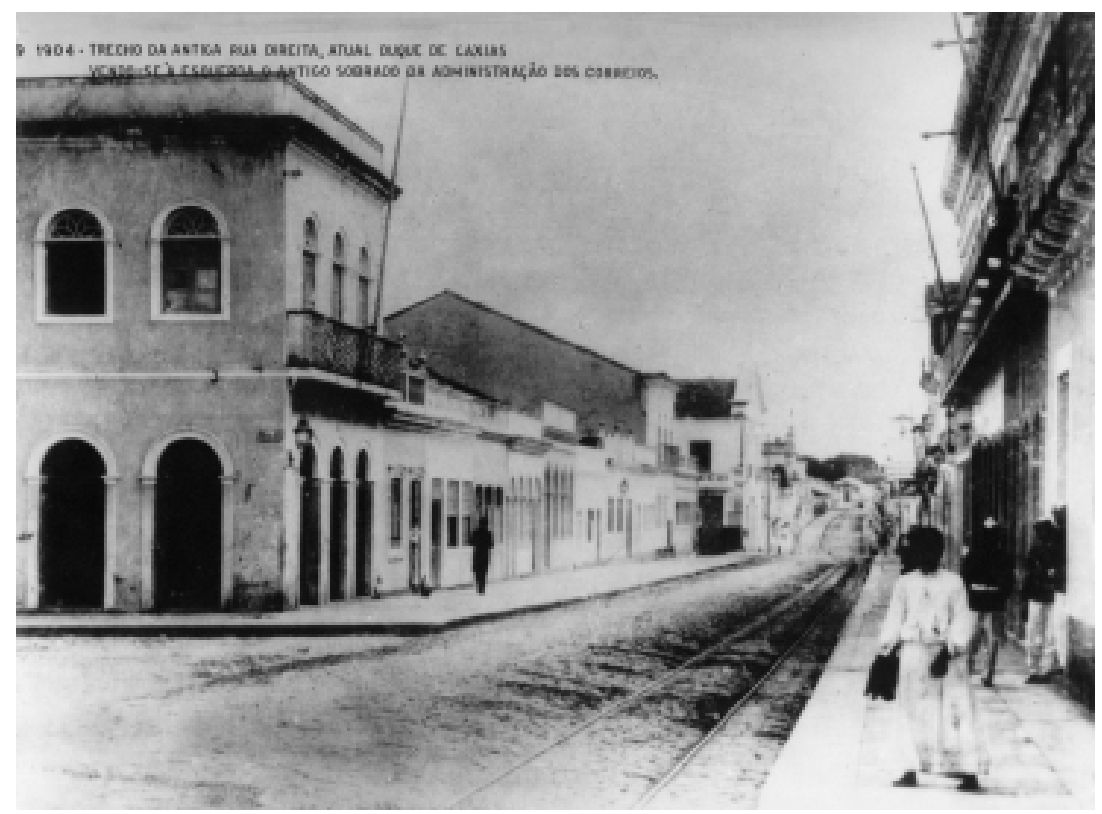

1904 - Antiga rua Direita. À esquerda, o antigo sobrado dos correios. FONTE: Acervo fotográfico Laudereida Marques.

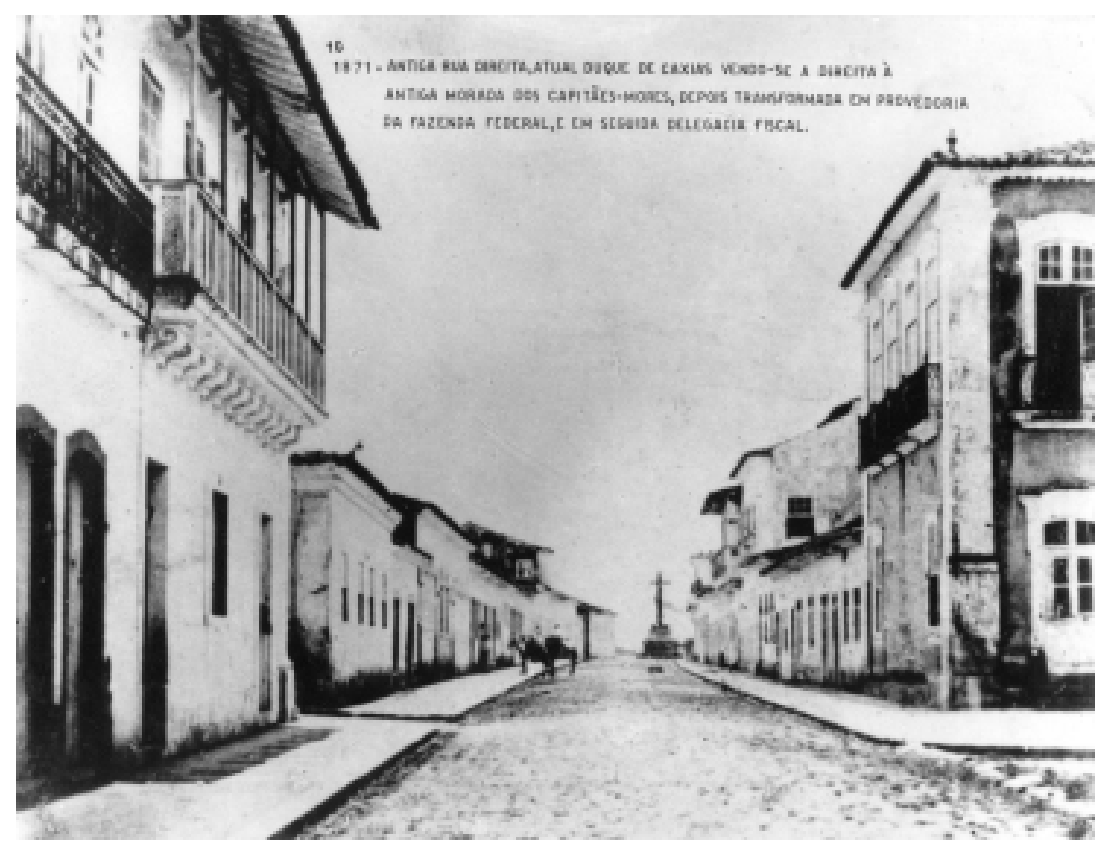

1871 - Trecho da antiga rua Direita, com sobrados e casas térreas. FONTE: Acervo fotográfico Laudereida Marques.

O sobrado é o elemento urbano que passa a simbolizar a presença das famílias abastadas na cidade, alterando sua configuração formal e social, bem como a relação da moradia com a rua. A concentração da zona residencial rica nas ruas Nova e Direita, e do comércio no Varadouro e nas Convertidas, estabelece uma divisão social e funcional do espaço. Morar no sobrado leva a classe alta à cidade, ao mesmo tempo em que a distancia de tudo que se passa na rua, resguardando-a de um contato mais direto como o exterior. Essa morada passa a ser sinônimo de importância, de prestígio e riqueza.

Assim, os espaços urbanos, até então marcados por edificações religiosas e casas térreas, recebem um grande número de sobrados que consolidam a forma apresentada pela cidade no século XIX. Além de

\footnotetext{
${ }^{131}$ ALMEIDA, Maurílio de. "Cidade da Paraíba, 1850. - Um pequeno aglomerado urbano". In: AGUIAR, Wellington, MELLO, José Octávio de A. Uma cidade de quatro séculos. Evolução e roteiro. $2^{\mathrm{a}}$ ed. João Pessoa: A União, 1989, p.7.

${ }^{132}$ BATISTA, Juarez. Caminhos Sombras e Ladeiras. João Pessoa, A União, 1989. p. 107.
} 
residência de elite, eles também abrigam palácios e atividades administrativas, diferenciando-se dos reservados às habitações pela opulência promovida por elementos decorativos acrescentados à sua arquitetura. Os sobrados destacam-se no meio urbano, sobressaindo-se entre as casas térreas e convertendo-se, ao lado das edificações religiosas, em pontos focais das perspectivas urbanas. As principais ruas da cidade passam a apresentar novas formas, um novo panorama proporcionado não apenas pelo seu traçado urbano, mas pelas fachadas que as compõem, estabelecendo uma nova escala a partir do conjunto de sobrados vizinhos.

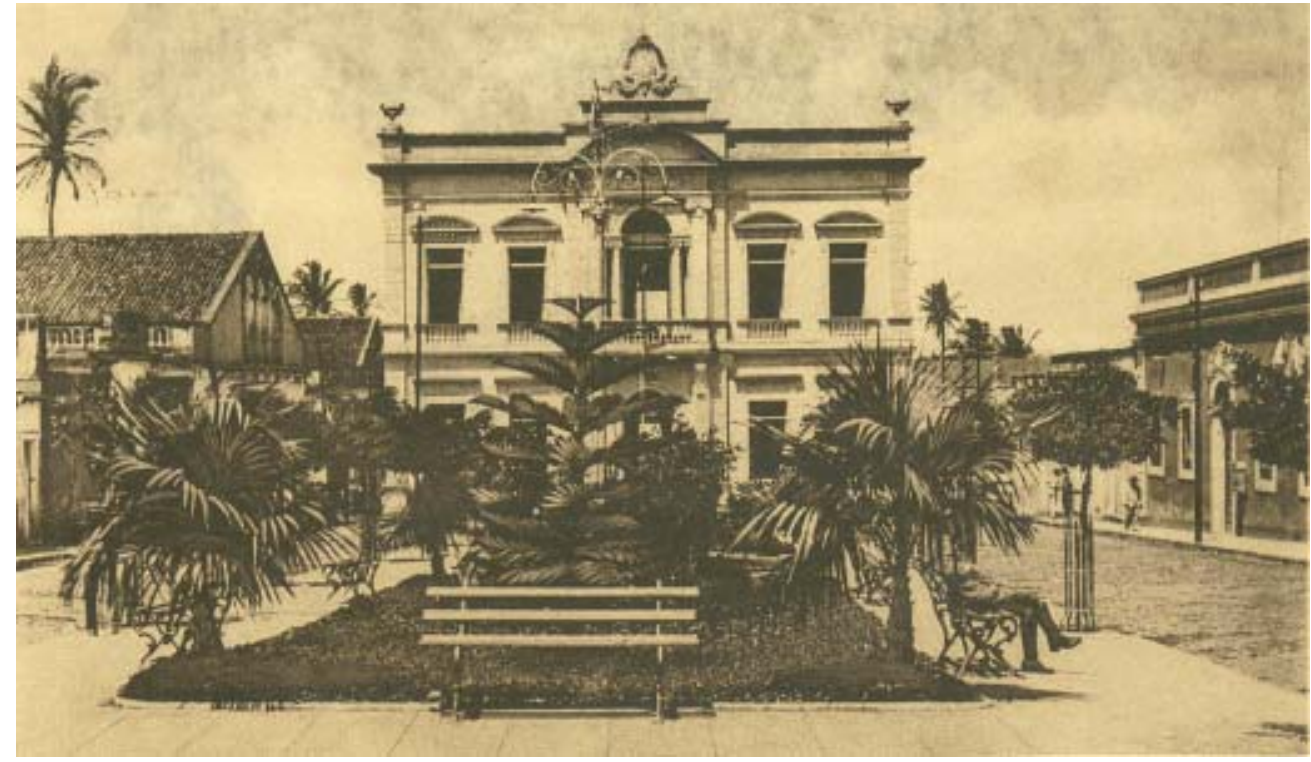

Prefeitura Municipal. FONTE: Acervo Humberto Nóbrega

Nesse momento de crescimento econômico e urbano ocorre a ocupação significativa da área baixa da cidade, até pouco tempo formada pela alfândega, raramente aberta, e algumas casas ligadas ao ancoradouro. Essa região se consolida enquanto área urbana, incentivada pela intensificação do comércio junto ao Varadouro e pela atividade portuária ali desenvolvida. Essa disposição segue a linha das demais cidades contemporâneas à capital paraibana, a exemplo de Salvador, que no processo de crescimento urbano também tem sua área baixa ocupada pelo comércio. Esse crescimento é também impulsionado pela disposição de edificações específicas locadas em posições estratégicas, que influenciam no deslocamento do conjunto urbano, a exemplo do Teatro Público situado na Praça Pedro Américo, da Cadeia Nova, perto da ponte junto ao rio Sanhauá, além da finalização da obra do cais do Varadouro e da construção do Cemitério Público da capital.

A proliferação de edificações desse momento ocorre segundo uma "geometria difusa", sobretudo por esse crescimento se dar em terreno íngreme, que juntamente com o aumento populacional e a inalterada infra-estrutura preexistente, inadequada à nova configuração urbana, resultam numa cidade que passa a ser alvo de críticas e denúncias. O descontentamento acerca dessa estrutura é claramente expresso em reivindicações pela instituição de uma nova ordem urbana, sempre em pauta nos discursos urbanísticos e de governantes, habitantes e visitantes.

Para a rua, abrem-se os balcões dos sobrados e correm seus escravos. Essa são edificações que não permitem muitos dos luxos que trazem as casas-grandes. A elite, antes ocupada apenas com seu engenho, suas terras e seu algodão, passa a lutar por melhoramentos do espaço urbano. Tais reivindicações estão estampadas em documentos oficiais administrativos, cartas de conteúdo pessoal e documentos particulares cheios de reclamações contra os becos escuros, os montes de lixos, as águas podres empoçadas e animais mortos no meio da via pública, além de cães hidrófobos soltos. 

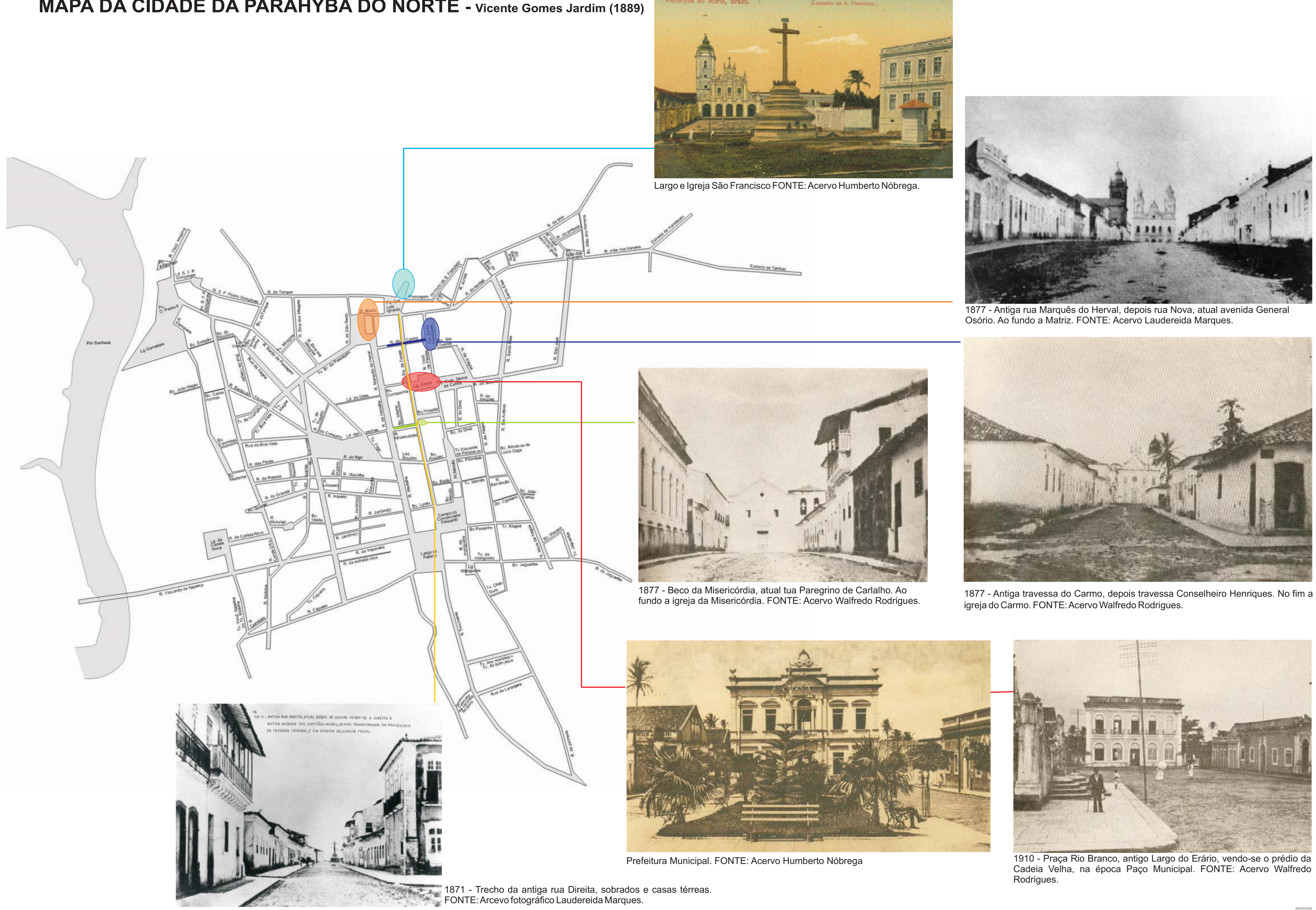
- Antiga rua Marquês do Herval, depois rua Nova, atual avenida General

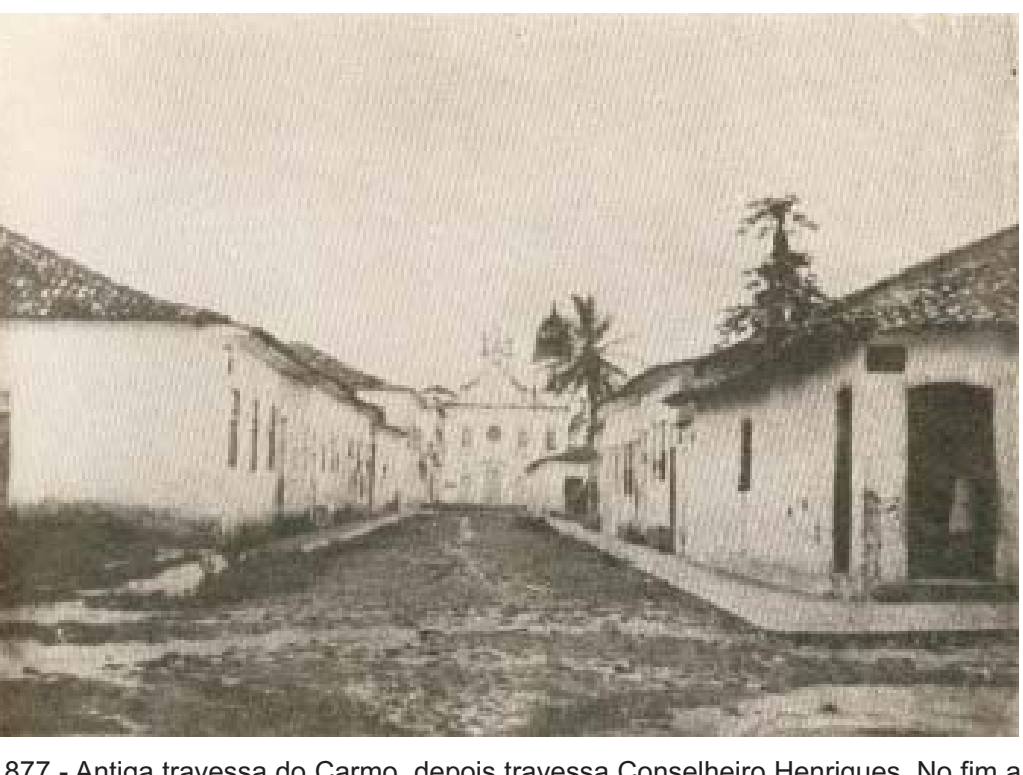
1877 - Antiga travessa do Carmo, depois travessa C
igreja do Carmo. FONTE: Acervo Walfredo Rodrigues.

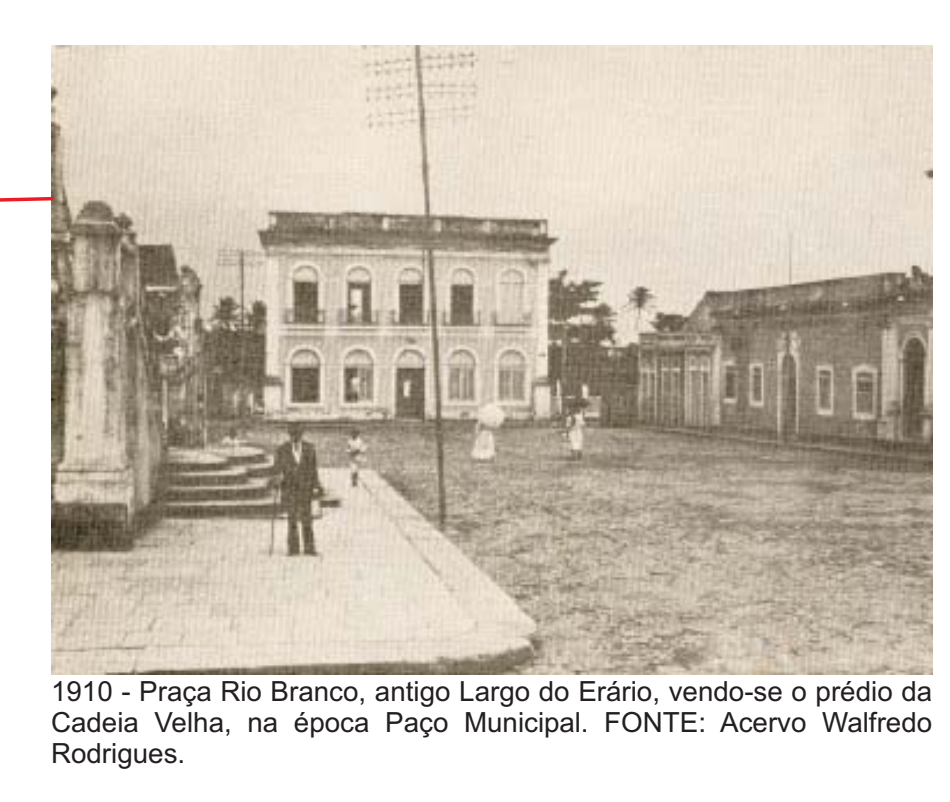




\subsection{OS ESPAÇOS PÚBLICOS}

No Brasil, no fim do século XIX e no início do XX, as intervenções nas cidades se tornam mais enfáticas e evidentes. Na capital paraibana, o século XIX apresenta inovações no trato com o meio urbano, seja em estudos e melhor conhecimento da estrutura urbana, na elaboração de posturas que direcionam a formação da cidade ou intervenções na sua estrutura por meio de ações públicas. Porém, o que se sobressai nesse período, principalmente no final do século, é a crítica à sua infra-estrutura, apontando-lhe deficiências e reivindicando reformas, o que faz desse momento o sinalizador de uma série de transformações urbanas que se desencadeam de forma mais enfática no século seguinte.

Os espaços públicos se constituem como os locais de maior visibilidade desse processo. Neles, projetam -se os discursos e as ações urbanas de então, revelando o percurso urbanístico que a cidade trilha nesse período, a partir da exposição da metamorfose sofrida pelas suas formas, seu usos e suas denominações.

Nesse momento, a capital paraibana se encontra consolidada enquanto espaço de vida urbana, apesar de muitas de suas características físicas se remeterem ao período em que ela é o centro administrativo desse estado e suporte para a vida rural, quando os engenhos abrigam a maior parte da população local.

\subsubsection{A trama e os espaços públicos desenhando a cidade}

Observando-se os mapas e descrições referentes ao primeiro século de formação da capital paraibana, percebe-se que, demarcado o local de sua fundação, edificam-se a fortificação e algumas igrejas em cujas proximidades se instalam os principais equipamentos (cadeia, câmara, açougue) e as primeiras residências. Tais edificações se concentram no entorno dos largos das igrejas, o que os torna focos centrais do núcleo urbano. Com o aumento da população, erguem-se, também nessas imediações, novas habitações, culminando na formação de ruas que, por sua vez, passam a abrigar as principais construções - administrativas e de serviço-, o que Ihes confere, pela localização nas proximidades dos largos e pelas suas edificações, maior importância entre as demais ruas. Assim, "o Largo da Matriz dá lugar ao nascimento da rua Nova, [à] outra que leva ao convento do Carmo, [que recebe o nome de beco do Carmo, e a uma terceira] que corre diante do adro do convento franciscano"133.

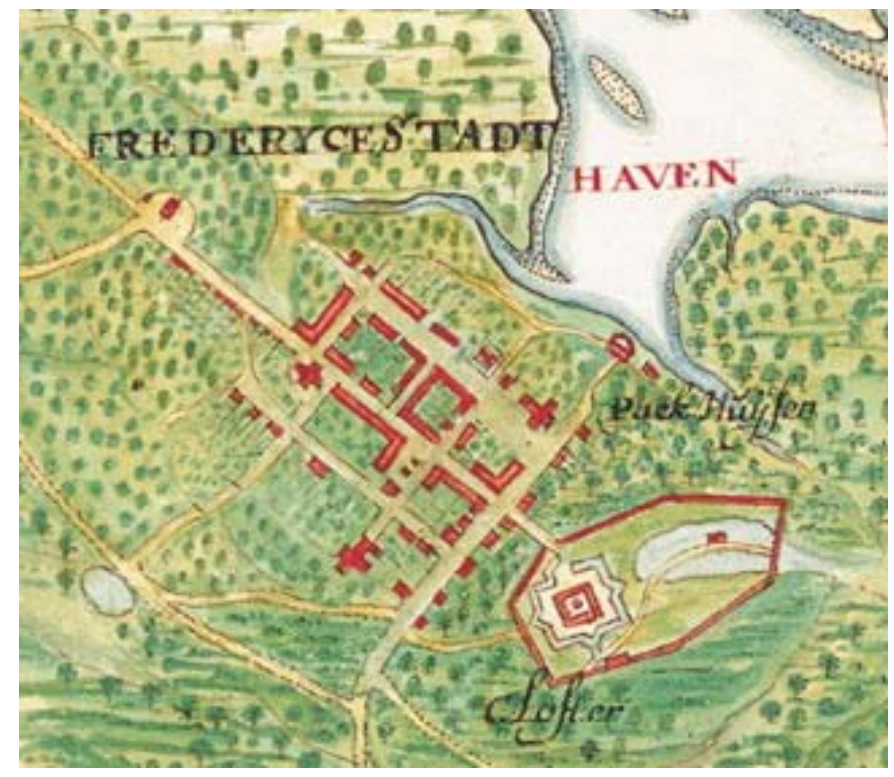

"FREDERICA CIVITAS". Gravura de Jan van Brosterhuisen. FONTE: Detalhe de uma imagem que ilustra o livro de Barlaeus (BARLAEUS 1647), estampa $n^{\circ} 26$, exemplar da Biblioteca Nacional, Rio de Janeiro. Com maior importância, é assinalado o antigo Convento Franciscano, transformado em área fortificada. São assinaladas cerca de seis quadras ocupadas de forma incompleta, indicando-se as áreas construídas, os terrenos abertos, e dois caminhos de saída, a sudeste e a noroeste, com algumas casas isoladas. (IN: REIS, Nestor Goulart. Imagens de vilas e cidades do Brasil colonial. São Paulo: FUPAM, 2000.) 
O traçado proveniente desse processo de construção urbana é regular, cuja trama não resiste às características típicas da expansão da cidade colonial brasileira, resultantes do preceito de respeitar e se adequar às condições topográficas do terreno. A configuração do núcleo original, com forma longitudinal disposta paralelamente ao rio Sanhauá, aponta para essa direção como provável para o crescimento daquele núcleo urbano. Porém, a cidade pouco segue esse direcionamento inicial, logo se desvirtuando do princípio de 'ortogonalidade' e da direção de sua expansão.

O traçado da Parahyba oitocentista apresenta uma cidade com ocupação na região portuária, configuração realizada a partir do desenvolvimento urbano em direção ao rio, e não paralelo a ele, como se dispõe inicialmente. Ao longo desse crescimento, há uma reorientação do traçado urbano desenvolvido até aquele momento. Apesar da cidade se dispor inicialmente no sentido paralelo do rio, com as ruas principais direcionando seu crescimento nesse mesmo sentido, são as estreitas ruas transversais e pequenas vielas que conduzem a expansão da cidade, contradizendo o direcionamento inicial: umas descendo para o Varadouro, outras seguindo em direção às fontes, como a do Tambiá na região que se apresenta, em fins do século XIX, como potencial de expansão da cidade. Nesse momento, essas ruas não se encontram consolidadas enquanto construção urbana, apesar de já sinalizadas em meados do século XIX. Com raras edificações, apresentam-se como caminhos, vetores de acesso aos elementos naturais de utilidade da vida urbana encontrados nas redondezas, como a água.

A disposição não ortogonal das ruas, conformadas através dos trajetos cotidianos construídos segundo uma lógica topografica, é consolidada pelas construções nelas paulatinamente desenvolvidas. Casas térreas e sobrados, construídos nos limites das vias públicas e das divisas laterais do terreno, contribuem para a caracterização do traçado da expansão que se desenvolve naquele momento. Desta forma, a cidade se aproxima do século XX com características bem diversas do que se pode prever observando sua configuração inicial, tanto no que diz respeito à natureza do traçado, onde a regularidade inicial se torna cada vez mais imperceptível diante do todo predominantemente irregular, quanto no direcionamento de sua ocupação.

Após a estruturação da região portuária, sobretudo por edificações comerciais, a cidade passa a se distribuir em dois planos interligados- a 'cidade alta' inicial e a 'cidade baixa' portuária e comercial-, consolidados em uma única área urbana, a partir de ruas, travessas e becos que se adaptaram à geografia local, partindo dos largos e pátios da área alta e atingindo os da parte baixa. Esse processo de crescimento urbano é representado pela formação de um núcleo no Varadouro e pela ligação da cidade propriamente dita à região baixa.

Essa mudança da natureza do traçado urbano durante o crescimento da cidade é fato comum a cidades brasileiras em formação nesse período, onde a regularidade construída, apesar de buscar uma certa ortogonalidade, não a impõe, dando prioridade a um trajeto conduzido pelo relevo, opção ideal de construção da cidade: em áreas planas, a regularidade se estabelece por linhas retas, em áreas acidentadas, é formada por linhas contínuas, porém às vezes curvas.

Além do crescimento consolidado em direção ao rio Sanhauá, a capital paraibana do fim do século XIX sinaliza outros vetores de crescimento. Ruas longas e curvilíneas lançam-se em direção nordeste e sudeste, configurando duas regiões de expansão futura: Tambiá e Trincheiras, respectivamente. A ocupação dessa área reforça a persistência do conceito de regularidade posto em prática pela colonização portuguesa. Pois essas vias que sinalizam a área de expansão da cidade são desenhadas segundo as curvas e os níveis do terreno, sobretudo nas Trincheiras, cujas forma é sinuosa. Nesse caso, há também a influência de outro componente natural na construção desse traçado: a existência de uma lagoa nessa região, de quem, sob influência de questões higienistas, a trama em construção busca se esquivar. 


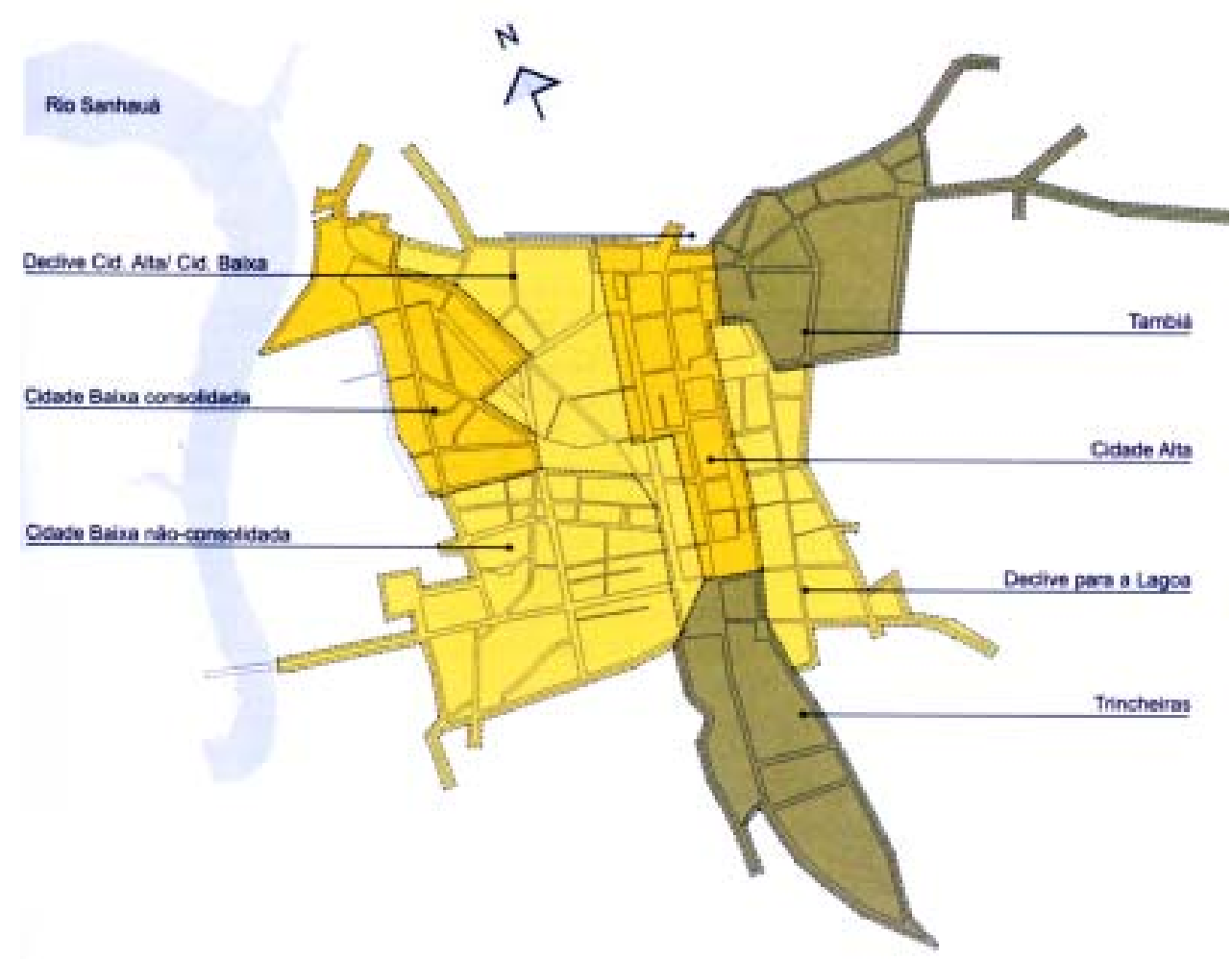

TINEM, nelci (org). Fronteiras, marcos e sinais: leituras das ruas de João Pessoa.João Pessoa: editora Universitária e Prefeitura Municipal, 2006, p.265.

Atingida a região do rio, a cidade busca novas áreas para acomodação de seu conjunto urbano. Aparentemente, a natural direção para esse crescimento é a leste, onde se encontra a Lagoa dos Irerês. Porém, a trama não ocupa essa região de imediato, expandindo-se para o nordeste e sudeste. Essa lagoa é, por muito tempo, apontada como causadora de miasmas e proliferadora de epidemias, o que desencadea, naquele momento, um processo de resistência em englobá-la ao tecido urbano, criando-se outros vetores de expansão - Trincheiras e Tambiá - cujas formas ‘periféricas' à lagoa, denunciam esse processo.

Se durante a consolidação dessa formação urbana, a proliferação de vias e demais espaços públicos seguem formas diversas às da implantação inicial, as relações entre áreas urbanas e as atividades nelas desenvolvidas permanecem semelhantes às instituídas inicialmente. Em fins do século XIX, a região referente à cidade alta concentra em sua extensão as edificações administrativas e eclesiásticas, abrigando ainda o maior número de habitações da cidade, guardando referência à sua implantação, quando, ainda escassamente edificada, firma em seu conjunto igrejas e prédios da administração pública. Já a área do Varadouro, seguindo em direção ao rio, apresenta-se no período oitocentista como área comercial, vinculada à função portuária.

A configuração urbana referente à última década do século XIX revela esse período como referencial, por ser esse o momento em que a cidade se consolida em um único centro urbano, da parte alta até a região portuária. Em 1855, segundo o mapa elaborado pelo engenheiro Alfredo de Barros Vasconcelos ${ }^{134}$ a mando do governador do estado, o tenente Henrique de Beauripaire Rohan, a cidade se expande da colina para a região portuária, através de caminhos com parcas edificações. Tais caminhos são irregulares e ligam o núcleo urbano a elementos naturais locais, como lagos, fontes e o rio, o que mostra a importância da participação desses na dinâmica urbana. Intensificado esse uso, tais percursos são consolidados, integrando-se à malha urbana e recebendo novas edificações.

${ }^{134}$ Elaborada pelo Sr. Primeiro Tenente de engenheiros Alfredo de Barros Vasconcellos, essa planta da cidade é atualmente conhecida apenas por intermédio de sua cópia reduzida, trabalho esse realizado por Arthur Januário Gomes de Oliveira e datada de 1905. O mapa revela a irregularidade promovida pela ocupação das fraldas da colina no trecho entre as cidades alta e baixa, mostrando ainda as ruas abertas por Beauripaire Rohan, as quais contrastam com o cenário formado por becos, travessas, quadras irregulares e ruas desconectas, em meio a um tecido ainda pouco edificado, com muitos vazios. 


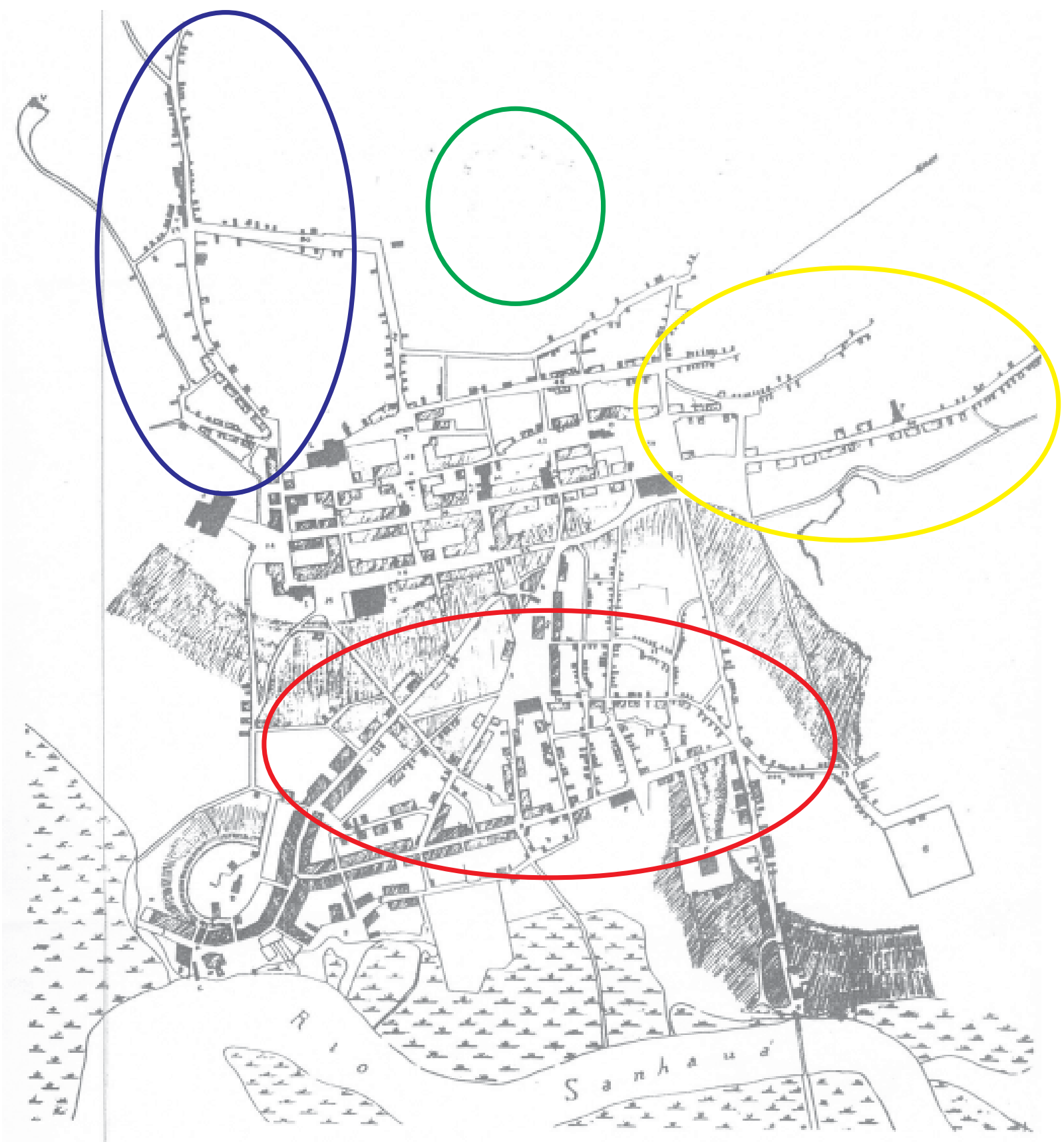

Planta da cidade da Parahyba levantada em 1855 por Alfredo de Barros e Vasconcelos, $1^{\circ}$ Tenente do Corpo de Engenheiros, e reduzida em 1904. FONTE: AGUIAR, Wellington. Cidade de João Pessoa: a memória do tempo. João Pessoa: Idéia, 1993. Em vermelho, área de expansão da 'cidade alta' para a 'cidade baixa', em amarelo, Tricheiras, em azul, Tambiá e em verde, região da Lagoa.

Percebe-se na cidade do final do século XIX, constantes intervenções no traçado de sua área já consolidada, como ocorre em tempos anteriores, sobretudo no Império, mas que nesse momento parecem mais intensas. Há a supressão de alguns elementos da trama e a incorporação de outros, seguindo o mesmo princípio de alinhamento do período colonial, onde "alinhar é tirar saliências, e não retificar"135, porém sempre na busca de, respeitando os limites do relevo, construir de uma cidade o mais regular possível. Esse processo pode ser observado no mapa apresentado por Carvalho, que retrata a cidade em 1889, revelando ruas suprimidas e ruas realinhadas ${ }^{136}$. Já implementadas pelo governador Beauripaire Rohan na década de 1850 e seqüenciadas nas administrações seguintes, medidas sanitárias e alterações formais passam a configurar essa capital, num ritmo progressivamente acelerado que confere a esse período o despertar de uma nova fase da história urbana local.

\footnotetext{
${ }^{135}$ Definição mencionada pela profa. Dra. Beatriz Bueno, no exame de qualificação dessa dissertação, em 22 set. 2005, na ESSC - USP. ${ }^{136}$ O mapa foi construído a partir da planta levantada por Alfredo de Barros e Vasconcelos e da Monografia apresentada em 1889 por Vicente Gomes Jardim. TINEM, Nelci (org.).Fronteiras, marcos e sinais: Leituras das ruas de João Pesoa. João Pessoa: Ed. Universitária/ Prefeitura Municipal de João Pessoa, 2006.
} 


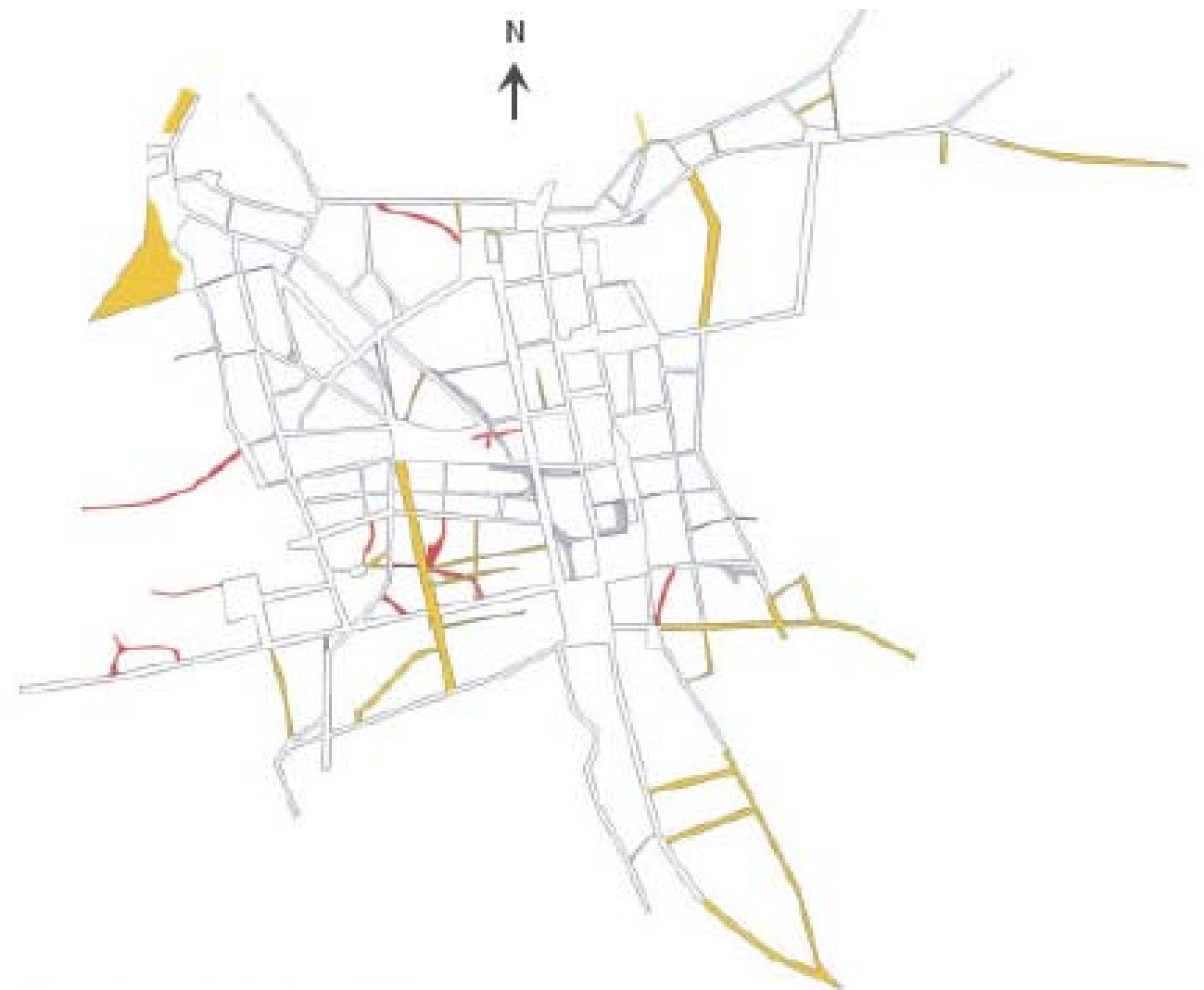

Amarelo - espaços abertos, vermelho - espaços extıntos, cinza - espaços realınhados. FONTE: TINEM, Nelcı (org.).Fronteiras, marcos e sinais: Leituras das ruas de João Pesoa. João Pessoa: Ed. Universitária/ Prefeitura Municipal de João Pessoa, 2006, p.263.

Construindo a cidade seguindo o conceito de regularidade que envolve a construção de cidades portuguesas e suas colônias, a capital paraibana retrata em sua traça, até fins do século XIX, uma das principais características do 'urbanismo' português: a convivência do erudito com o vernacular. Essa cidade, no final da década de 1880, encontra-se formada majoritariamente por ruas "tendencialmente retas", mas que não conformam um traçado ortogonal devido à sua organização no conjunto. Com vias dispostas em sentidos e direções diversos, é corriqueiramente apontada como 'cidade de traçado irregular'. A partir desse momento, percebe-se que o interesse em construir uma cidade regular, sempre presente nas intervenções dessa capital, dá lugar ao emprenho em construi-la de forma ortogonal. As ruas, antes alinhadas, passam a ser retificadas, assim como os demais componentes do espaço urbano. Assim, esse pode ser considerado um momento de transição, onde, à medida em que aumentam as críticas em relação às antigas formas de construir a cidade, altera-se a maneira de intervir no seu espaço e, inclusive, o conceito de regularidade.

O processo de alinhamento das vias anuncia o interesse em uma nova ordem formal urbana. Percebe-se que na cidade do fim da década de 1880 se encontram muitas ruas retas, porém, suas disposições no traçado mascara essa regularidade, pois tais elementos se organizam em direções e sentidos diversos, apresentando, no conjunto, um traçado de aparência predominantemente irregular. Essa fase constitui a etapa inicial do processo de reformulação urbana, baseada no ideal de regularidade formal onde essa transição apresenta uma imagem contraditória, sinalizada pela dualidade referente à irregularidade da malha apesar do alinhamento de cada rua. $\mathrm{Na}$ área entre as partes alta e a baixa da cidade, em meio às vias estreitas e predominantemente retas, encontram-se algumas ruas mais largas e alinhadas que datam dos últimos momentos do século XIX. 


\subsubsection{A arquitetura e os espaços públicos}

A construção formal das cidades brasileiras se dá a partir da imbricação das formas do traçado e da sua arquitetura, que se condicionam mutuamente. Assim, "as ruas eram definidas pelas construções e as construções definidas em função das ruas"137. Com a formação das ruas à medida em que as casas são edificadas de forma justaposta, é comum uma aparência de grande concentração urbana, porém composta por partes diferenciadas, de acordo com as variações de altura das casas térreas, sobrados, edificações religiosas e administrativas. Assim, a aparência das ruas decorre da influência de seu traçado e topografia, e dos planos verticais que correspondem às fachadas de suas edificações. Os edifícios de maior representatividade formal localizam-se, geralmente, no término das vias, cujas perspectivas criam pontos focais na paisagem urbana, além de valorizar a edificação, a exemplo do posicionamento da igreja Matriz da capital paraibana em

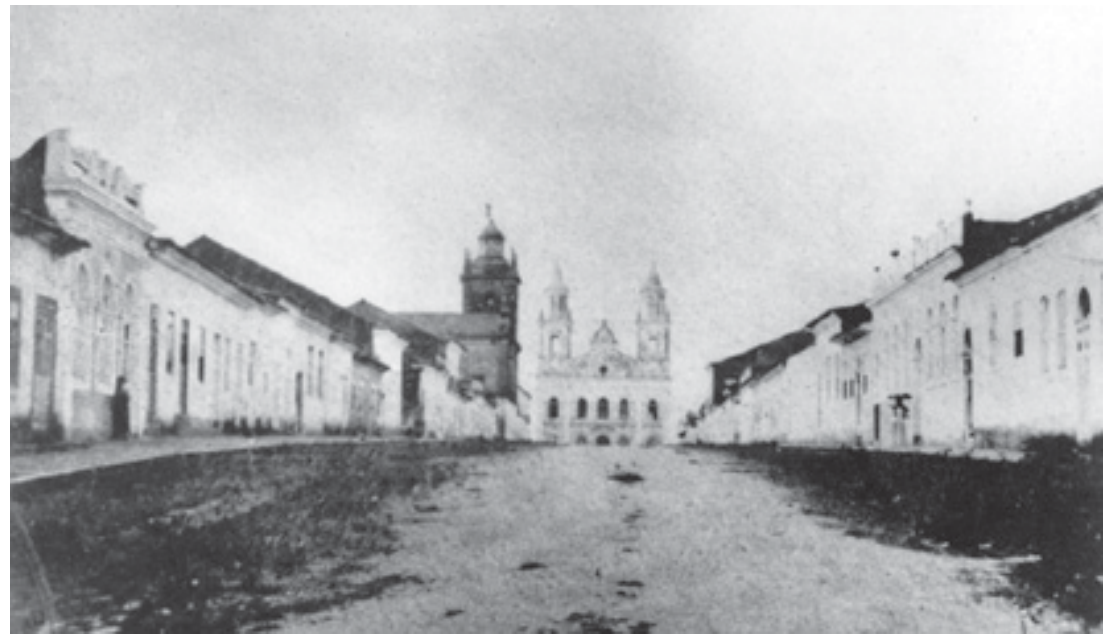

1877 - Antiga rua Marquês do Herval, depois rua Nova, atual avenida General Osório. Ao fundo a Matriz. FONTE: Acervo Laudereida Marques. relação à rua Nova.

As casas térreas são, geralmente, implantadas ao longo das vias; já os sobrados, são mais comum ente encontrados em esquinas ou nas proximidades de largos. Os edifícios administrativos se encontram, muitas vezes, dispostos diante de largos que valorizam a visualização de suas formas que, por sua vez, enriquecem a paisagem desses espaços amplos. Porém, são as construções religiosas que se constituem o foco principal das perspectivas urbanas. Dispostas, muitas vezes, diante ou na lateral de largos e pátios, as igrejas e conventos atraem os olhares, impulsionados tanto pela amplitude do espaço público que lhes evidenciam como pela posição topográfica elevada em que são, geralmente, dispostos, fazendo com que, mesmo à distância, suas formas marquem o meio urbano.

Essas edificações são o foco dos espaços nos quais estão inseridas, sejam largos, pátios, campos e praças, ou ruas. As igrejas, nesse sentido, são as construções de maior destaque nos espaços públicos, quase sempre dispostas diante de um alargamento ou de ruas que convergem para elas, de modo que sua imagem se prolonga por todo o trajeto da via. Assim, na capital paraibana, a Matriz encontra-se de frente a um largo para o qual se abre a rua Nova, da mesma forma que o Convento de Santo Antônio, onde se encontra a Igreja de São Francisco, está voltado para um grande pátio, onde se inicia a rua Direita.

As edificações administrativas também marcam os espaços urbanos de forma significativa. Na capital paraibana, essas edificações encontram-se concentradas, a exemplo do conjunto formado pelo Palácio do Governo, o Lyceu e a Thesouraria da Fazenda, que rodeam o Campo do Commendador Felizardo, transformado em Jardim Público em fins do século XIX.

${ }^{137}$ REIS FILHO, Nestor Goulart. Contribuição ao estudo da evolução urbana do Brasil (1500-1720) São Paulo : Liv. Pioneira e Ed. da Universidade, 1968, p.146. 


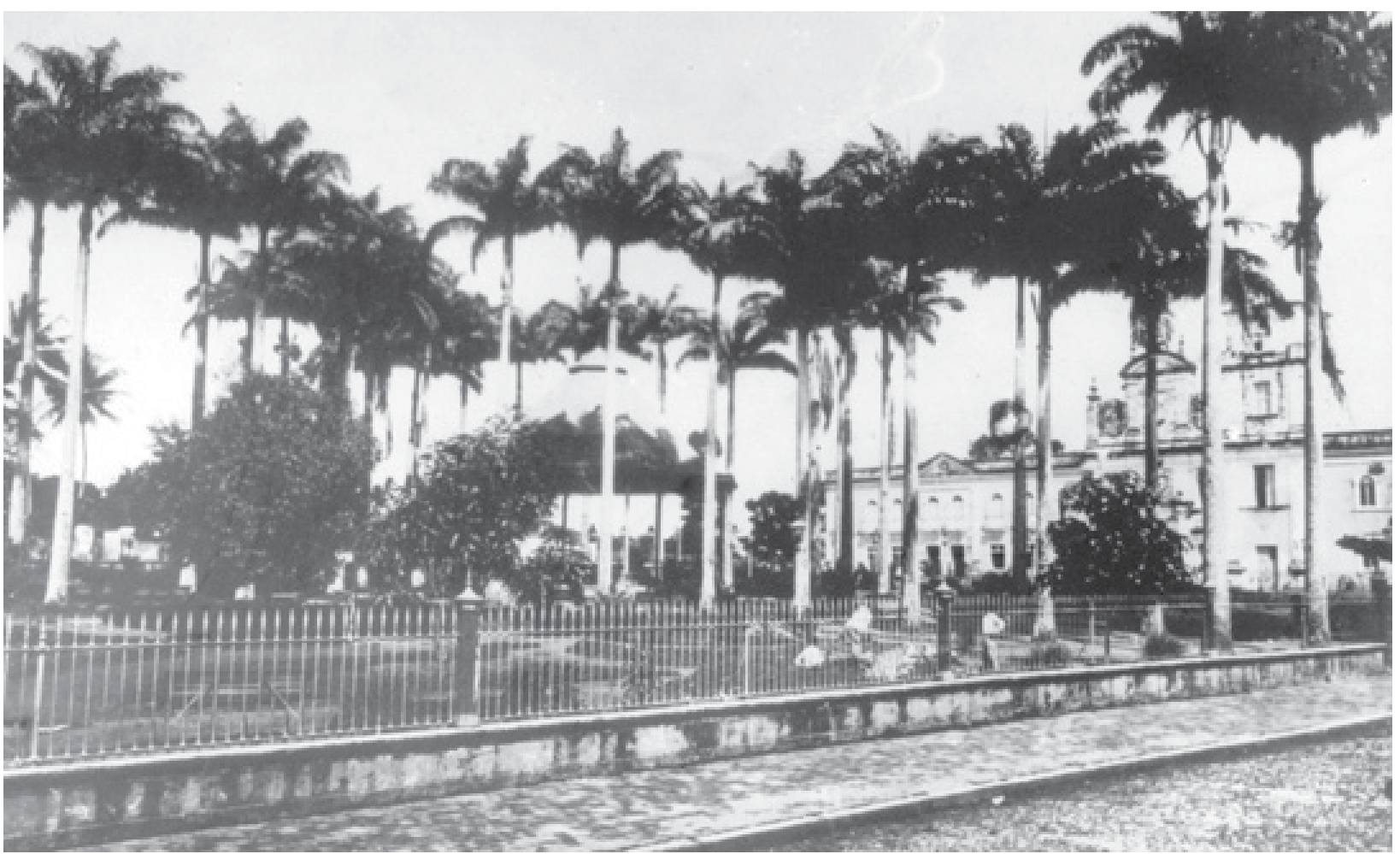

1910- Jardim Público. Ao fundo Palácio do Governo, Igreja da Conceição e Lyceu Paraybano. FONTE: Acervo Laudereida Marques.

\subsubsection{Definição da infra-estrutura}

"O padrão arquitetônico e urbanístico da cidade setecentista brasileira colonial sofrerá transformação substancial durante o oitocentos. Em paralelo a uma arquitetura que antes apresentava-se como predominantemente barroca, passando a incorporar princípios de composição neoclássicos, a cidade também se transforma no Império"138.

No início do século XIX as cidades brasileiras se encontram em condições sanitárias precárias, levando as administrações públicas a debates em busca de soluções para essa situação. Médicos e engenheiros tomam a frente da questão no debate e nas propostas de intervenção, num processo "marcado por forte intercâmbio cultural com a Europa"139.

Um dos fundamentos das intervenções desse período é a teoria miasmática. É da França que vem um importante tratado ${ }^{140}$ referente a essa questão, onde se defende "a necessidade de distanciar sepulturas dos lugares habitados pelos homens baseado nos danos aos quais eles estariam expostos pelas emanações dos cadáveres" ${ }^{141}$. Trinta e quatro anos depois, é publicado no Brasil, por José Corrêa Picanço, a tradução dessa obra.

Outras questões também relacionadas à teoria miasmática e que influenciam as intervenções brasileiras desse momento são as abordadas nas obras de Pirre Patte, "um dos tratados de arquitetura de maior repercussão na França na segunda metade do século XVIII"142. Ele apresenta os meios de operar a salubridade da cidade, a distribuição adequada de suas ruas, a melhor forma de localizar seus esgotos e repartir suas águas,

${ }^{138}$ SALGADO, Ivone. "A modernização da cidade setecentista: o contributo das culturas urbanísticas francesa e inglesa". In: TEIXERA, C. Manuel (coord.). A construção da cidade brasileira. Lisboa: Livros horizonte, 2004, p. 333.

139 Ibid.

${ }^{140}$ De autoria de Vicq d'Azir, publicado em 1778: Essai sur lês lieux et lês dangers dês sepultures.

${ }^{141}$ SALGADO, Ivone. "A modernização da cidade setecentista: o contributo das culturas urbanísticas francesa e inglesa". In: TEIXERA, C. Manuel (coord.). A construção da cidade brasileira. Lisboa: Livros horizonte, 2004, p. 334.

142 Ibid., p. 336. 
propondo uma 'zonificação' da cidade, através da disposição das “atividades ruidosas, rudes e malcheirosas cujos edifícios eram propagadores de doenças" ${ }^{143}$, em áreas mais distantes. Indica também a necessidade da separação dos fluxos, de forma que "a cidade deveria ser cercada no seu entorno com quatro fileiras de árvores, formando um grande arruamento para os veículos e duas alamedas laterais para servirem de passeio"144.

No Brasil do século XIX, essas questões são difundidas e institucionalizadas, explicando-se a propagação das doenças e apresentando as propostas para combatê-las. Em 1808 é fundada a primeira Escola de Medicina do Brasil e no ano seguinte é criado o lugar de Provedor-mór da Saúde da Côrte e do Estado do Brasil, cuja função é cuidar da conservação da saúde pública, fiscalizando o estado dos equipamentos das embarcações vindas de diversos portos.

Em meio às preocupações a respeito da saúde da cidade, as principais medidas divulgadas são em relação à localização de matadouros, hospitais e cemitérios, ao acúmulo de água nas vias - demandando uma "boa distribuição dos declives das calçadas"- e à necessária circulação de ar na cidade:

“...para que a cidade fosse mais saudável e fresca não se deveria consentir que se abrissem ruas com larguras menores que a 60 palmos, de tal forma que se pudessem entrar na cidade grandes colunas de $a r^{\prime 145}$.

É nesse contexto que a legislação do Brasil Imperial consolida essas idéias sobre as intervenções de caráter sanitário nas cidades, difundidas no país desde as últimas décadas do período colonial. É nesse momento que é legalmente entregue às câmaras das cidades e vilas a responsabilidade pelo

"alinhamento, limpeza, iluminação e desempachamento das ruas, cães, e praças, conservação e reparos de muralhas feitas para a segurança dos edifícios, e prisões públicas, calçadas, pontes e aqueductos, chafarizes, poços, tanques, e quaesquer outras construções em benefício commum dos habitantes, ou para o decoro, e ornamento das povoações"146.

Nesse momento, a crescente preocupação em reformular a estrutura urbana da capital paraibana se apresenta no alinhamento de algumas vias, na divisão dos fluxos a partir da introdução dos bondes puxados a burro, na criação de cemitérios e proibição de enterros em igrejas, e em incentivos para extinção de áreas alagadas. Esse processo de renovação dos elementos urbanos corre de forma lenta, de modo que, em fins do século XIX, parte das ruas do centro urbano dessaa cidadea não apresenta calçamento e não dispõe de calçadas para diferenciar os fluxos de pedestres e veículos. Alguns pátios, campos e largos são recobertos por mato, os quais são capinados para as festividades. Nessa época, o suprimento d'água dessa capital, que conta com aproximadamente 20 mil habitantes, é realizado por fontes, bicas e cacimbas dispostas na sua área urbana e nos arredores.

A maior parte desse abastecimento é garantido pela fonte do Tambiá, cuja localização, nos arrabaldes da cidade, torna esse processo dispendioso. Nesse momento, atuam as Leis Provinciais, autorizando o Governo "à encorporar uma companhia, para o encanamento d'agua do rio Marés, e factura de chafarizes nesta cidade, nos lugares convenientes e possíveis" 147 , que não tardam a surgir e marcar a paisagem local. Esse investimento também influi na dinâmica urbana, a partir da proibição da venda d'água em quaisquer fontes, poços e cisternas, a partir do funcionamento dos primeiros chafarizes. Aágua é vendida pela companhia, sob regulamentação do

${ }^{143}$ SALGADO, Ivone. "A modernização da cidade setecentista: o contributo das culturas urbanísticas francesa e inglesa". In: TEIXERA, C. Manuel (coord.). A construção da cidade brasileira. Lisboa: Livros horizonte, 2004, p. 337.

${ }^{144} \mathrm{Ibid}$.

${ }^{145} \mathrm{Ibid}$., p. 343.

146 Posturas Policiais apud SALGADO, Ivone. "A modernização da cidade setecentista: o contributo das culturas urbanísticas francesa e inglesa". In: TEIXERA, C. Manuel (coord.). A construção da cidade brasileira. Lisboa: Livros horizonte, 2004, p. 344.

${ }^{147}$ Coleção das Leis Provinciaes da Parahyba do Norte do anno de 1860. Parahyba: Typographia de José Rodrigues da Costa, 1861. lei 1 
preço do balde d'água por parte do governo. Após 50 anos da construção do primeiro chafariz, todas as arrecadações dessa obra passam ao domínio provincial148.

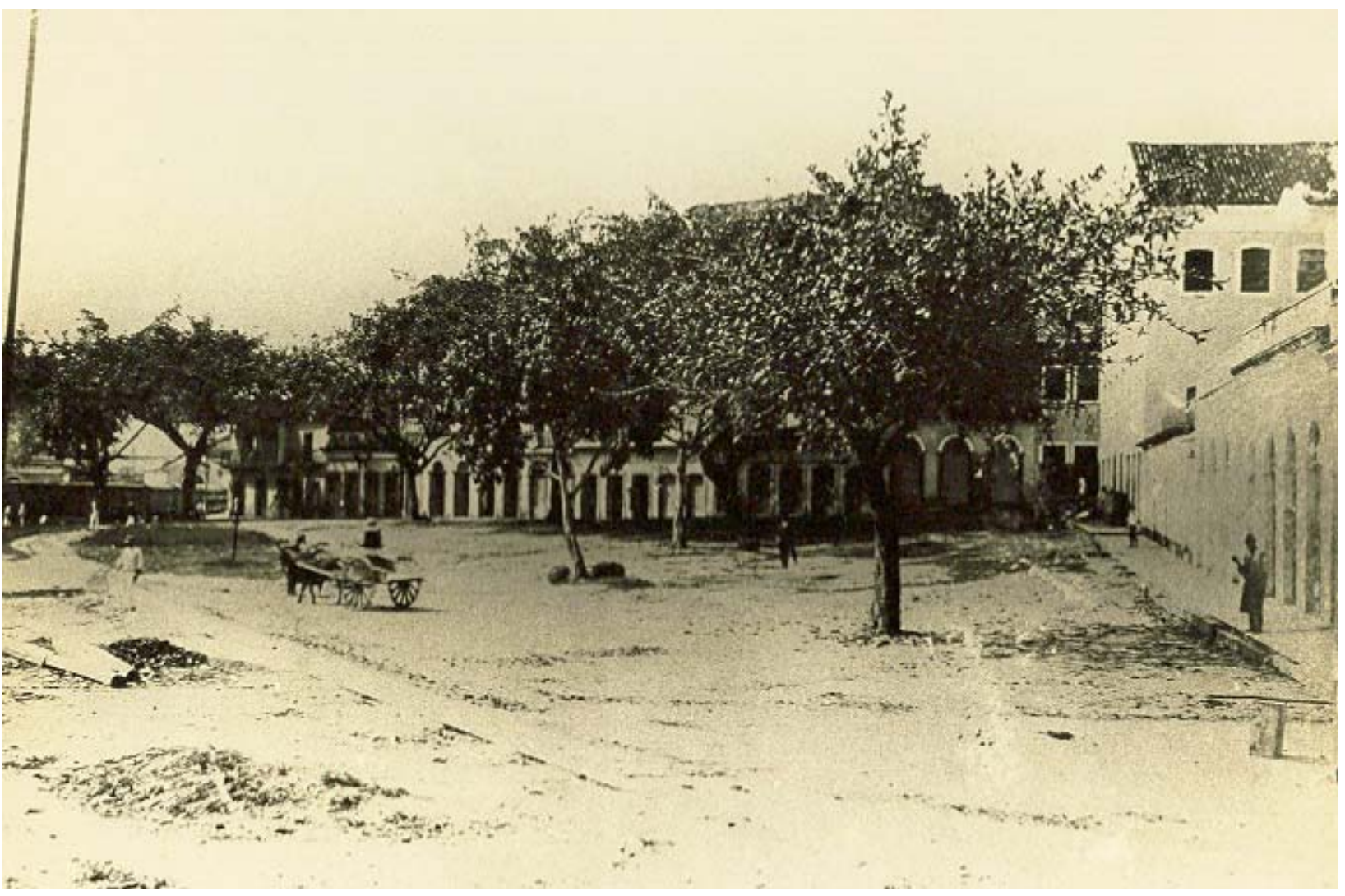

Praça 15 de Novembro e Rua do Ferreiro, atual João Suassuna. FONTE: Coleção Humberto Nóbrega

Nesse momento, Inexistem esgotos sanitários, o que concorre para a aparência insalubre da cidade, conseqüente do lançamento das águas servidas e detritos nos espaços públicos, somando-se ao acúmulo de lixo e presença de animais mortos. A iluminação pública é realizada por alguns lampiões a querosene situados apenas nas vias principais. Seu funcionamento depende da presença do "accendedor de lampeões", que se constitui figura inerente ao cenário da cidade por muito tempo. Dois acendedores - um na parte

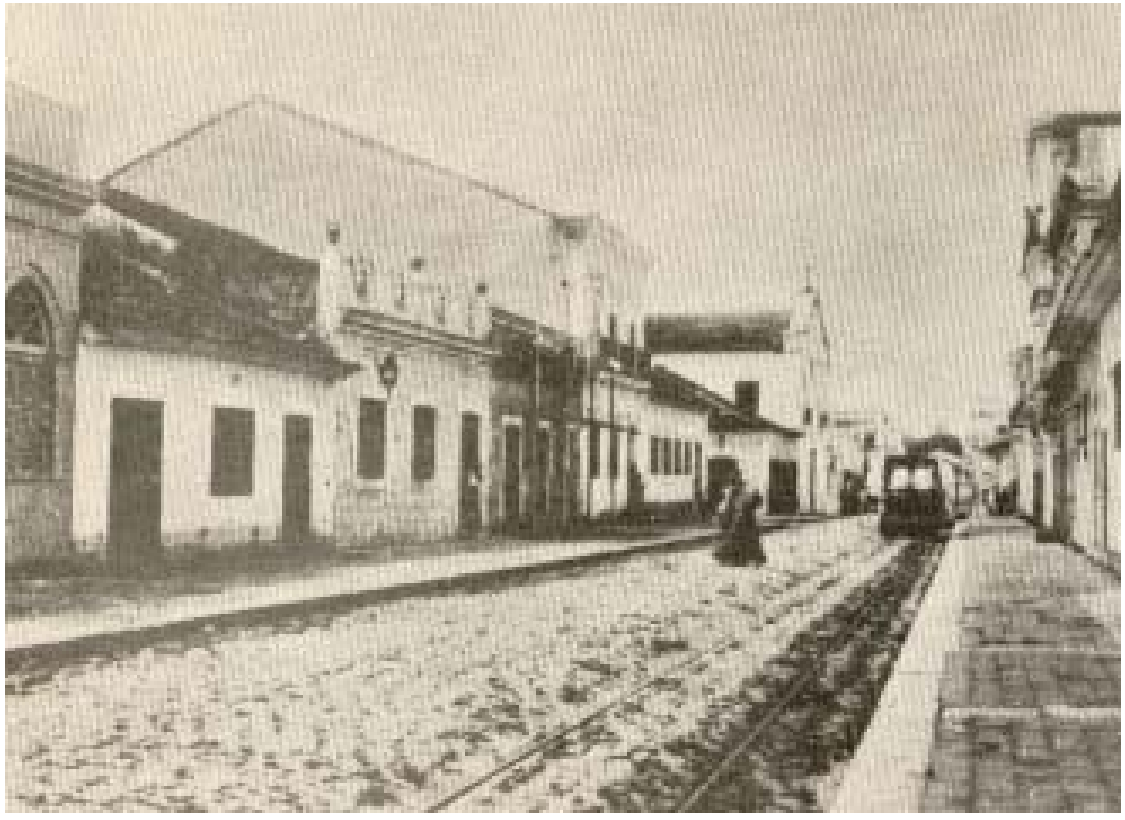

1903 -Antiga rua Direita, trecho entre a Igreja da Misericósria e a praça Rio Branco. Observa-se algumas casas com lampiões. FONTE: Acervo Walfredo Rodrigues.

alta, outro na região ribeira - percorrem os principais pontos da cidade, anunciando o anoitecer.

O significado do fim do século XIX enquanto período de consolidação de um conjunto urbano não se

${ }^{148}$ Coleção das Leis Provinciaes da Parahyba do Norte do anno de 1860. Parahyba: Typographia de José Rodrigues da Costa, 1861 . lei 1. Capítulo 2 - A cidade oitocentista: formas e usos dos espaços públicos 
reflete tanto na inovação de sua infra-estrutura, mas retrata a consolidação da ocupação da parte alta da cidade até o Varadouro. Assim, enquanto forma urbana, elementos típicos da cidade colonial persistem no meio urbano, a exemplo da existência, ainda em fins do século XIX, de chácaras e sítios em meio à área urbana, característica que remete à época em que a vida local se concentrava nos engenhos que se aglomeravam na região, nas proximidades da cidade.

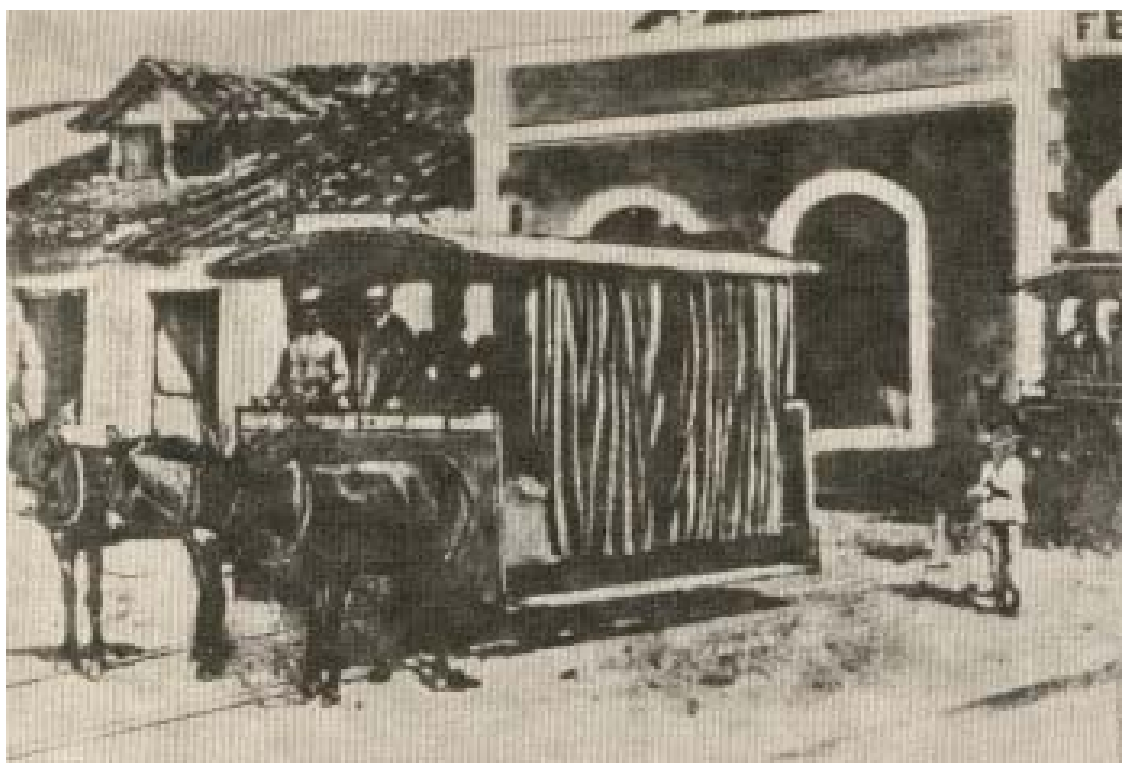

1903 - Bonde de tração animal, saindo da estação Ferro-Carril Paraibana, perto da atual estação R.F.N. FONTE: Acervo Walfredo Rodrigues.

O crescimento populacional desencadeado no século XVIII, sem a correspondente reorganização da estrutura citadina, resulta num estado de precariedade urbana que gera um descontentamento dos habitantes em relação à cidade. Essa insatisfação soma-se às preocupações sanitárias e à difusão de novos conceitos higienistas e urbanísticos, além da influência das intervenções realizadas em algumas cidades nas demais regiões do país, o que desperta grandes críticas à capital paraibana desse período, sejam referentes à aparência ou às formas de apropriação de seus espaços.

Nesse contexto, a administração pública atua no problema da higienização das zonas urbanas, contribuindo para a transformação dessa situação. Esse processo recebe ênfase com a concentração da vida social urbana, quando a elite rural passa a viver na zona urbana, em meados do século XIX. O espaço que os acolhe é formado por ruas esburacadas, as quais eles percorrem "tropeçando em monturos, saltando poças de lama, vendo o mato crescer defronte de casa, sem poder, às vêzes, abrir a porta por causa do máu cheiro de animais em putrefação em plena via pública"149. São, os moradores, também vítimas de febres intermitentes, da varíola epidêmica e da febre amarela, doenças que rondam os centros urbanos oitocentistas sem discriminações de classe. Assim, essa elite, antes preocupada apenas com a prosperidade de seus engenhos, não mais se detém apenas aos problemas políticos e administrativos, mas também às condições em que se encontra a cidade.

Para além do interesse do bem estar geral, a preocupação dessa classe com o espaço urbano estava embasada na inquietação em relação ao reflexo do "caos" da cidade em suas vidas pessoais. Daí a proibição de despejo de lixos na Lagoa dos Irerês e o cuidado com fontes e bicas, com buracos nas ruas, e várias outras providências tomadas, no ano de 1855, por administradores alarmados pela epidemia de cólera-morbus na Província do Pará. Leis provinciais, a Câmara Municipal e o próprio poder executivo da Província zelam pela cidade, sua iluminação, asseio, água potável, calçamento, segurança individual e da propriedade. Nessas preocupações, na sua maioria de natureza higienista, convivem, muitas vezes, objetivos estéticos, como a lei municipal n 243 de 8 de outubro de 1866, que obriga os proprietários de casas e sobrados "a fazerem as fronteiras com cornija e a murar os terrenos nos quintais"150.

\footnotetext{
${ }^{149}$ BATISTA, Juarez. Caminhos Sombras e Ladeiras. João Pessoa, A União, 1989, p. 8. 150 Ibid.
} 


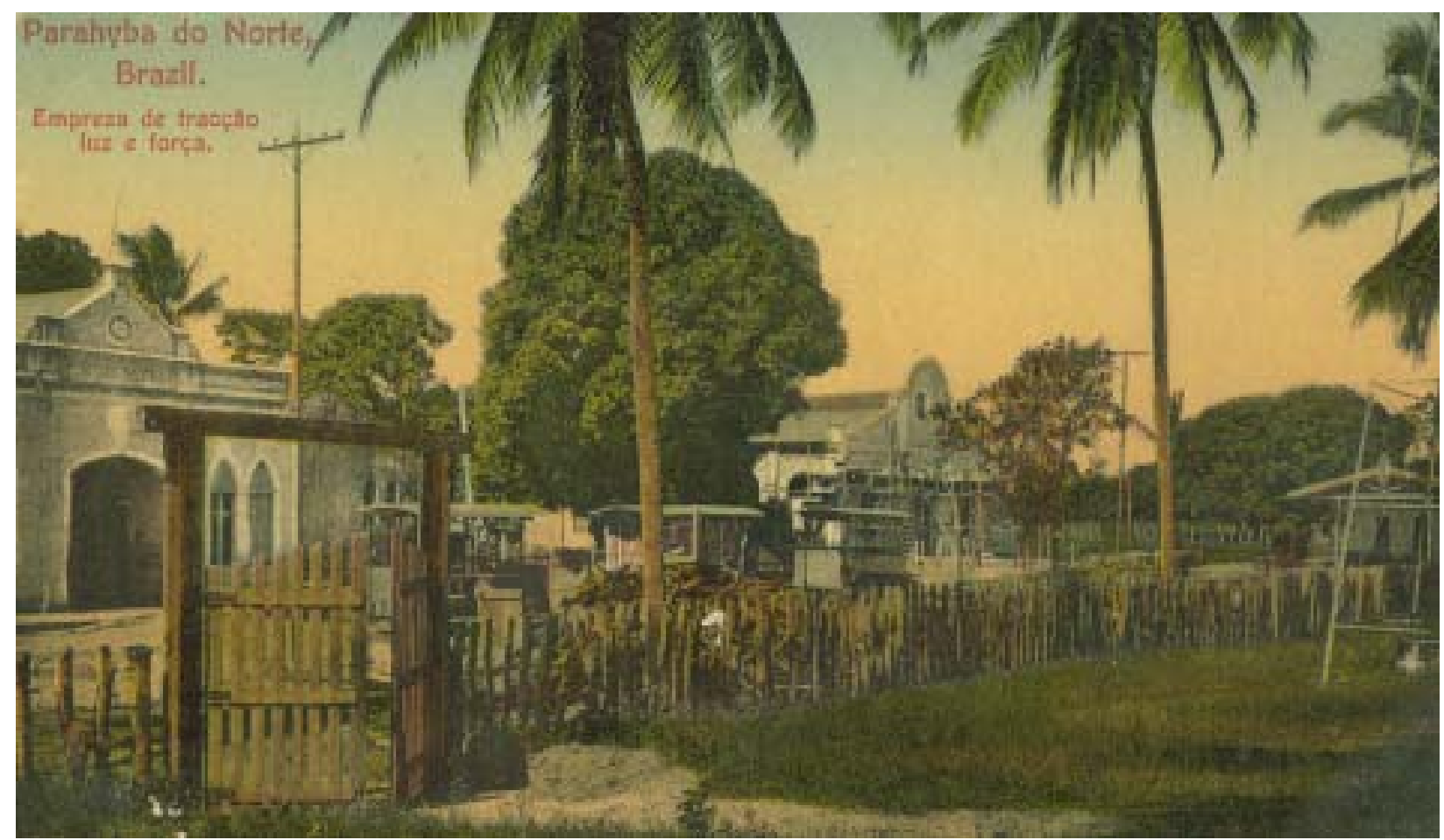

Empresa de Tração, Luz e Força. FONTE: Acervo Humberto Nóbrega

Dentre as atuações administrativas na capital paraibana do século XIX, a do Dr. Flávio Freire e a do Tenente Coronel Henrique de Beaurepaire Rohan, Vice-presidente e Presidente da província da Paraíba em 1887, respectivamente, realizam consideráveis feitos a partir de iniciativas direcionadas à situação sanitária da cidade. Durante sua administração, Flávio Freire toma medidas emergenciais de acordo com os preceitos higienistas, a fim de promover o asseio e a limpeza urbana, além de se preocupar em impor uma nova ordem ao espaço da cidade, disciplinando a localização de equipamentos potencialmente insalubres, como matadouro e cemitério. No mesmo sentido atua o governador Beaurepaire Rohan, promovendo intervenções pontuais no espaço da capital, abrindo novas ruas, alinhando e retificando o trajeto de outras, empenhando-se, sobretudo, no nivelamento da área urbana, com o fim de criar as condições para implantação dos esgotos.

Henrique de Beaurepaire Rohan é descrito como "homem de superior intelligencia e cultura [que] governou a Parahyba de 09 de dezembro de 1857 a 3 de junho de 1859, fazendo uma administração honesta e nobre"151. Nesse período, monta o estabelecimento de educação nesse estado, promove o levantamento de um plano de abertura das ruas da capital e o nivelamento geral das mesmas para viabilizar seu seu calçamento, e cria um jardim botânico. Uma de suas grandes contribuições é a elaboração de uma carta chorographica de parte da província. Sua intensa e inovadora contibuição para o desenvolvimento urbano dessa capital é, certamente, reflexo de sua formação e experiências, que influenciam nas posturas por ele adotadas ${ }^{152}$.

\footnotetext{
${ }^{151}$ BITTENCOURT, Liberato. "Parahybanos Illustres". Homens do Brasil. Vol II, Parahyba Livraria e papelaria Gomes Pereira, Editor, Rua do Ouvidor. N. 91 - RJ 1914. p. 114.

${ }^{152}$ Henrique de Beaurepaire Rohan nasceu em 12 de maio de 1812 no Sítio Sete Pontes, freguezia de São Gonçalo, Niterói, e faleceu em 10 de julho de 1894, no Rio de Janeiro. Era filho dos Condes de Beaurepaire, que acompanharam a Família Real Portuguesa ao Brasil, em 1807. Iniciou no Rio o seu curso preparatório, interrompido por ter de seguir com seu pai para a Bahia, em comissão de inspeção dos diferentes pontos do distrito militar sob o seu comando. Em 1837, terminou seus estudos matemáticos, que constituíam o curso de engenharia, sendo mandado praticar na Província do Rio de Janeiro, sob a direção do Major Henrique de Belle-garde. Partindo em 1838 para a Bahia, o Marechal Calado, que havia vencido a revolta da capital, ordenou-lhe o levantamento da planta das posições ocupadas pelo exército, que foi litografada no Arquivo Militar. Em 1839, durante a guerra civil do Rio Grande do Sul, esteve nessa Província em comissão ativa, levantando a planta do entrincheiramento da cidade de Porto Alegre. Desempenhou depois várias comissões inerentes à sua profissão, retornando à côrte, onde foi empregado como engenheiro diretor das obras da Câmara Municipal. Dos seus serviços nesse departamento, ressaltam-se: a ampliação da área da cidade, o alargamento e o novo traçado de ruas e o nivelamento para o escoamento das águas. Sobre o Morro do Castello, naquela época, o engenheiro se manifestava deste modo: "A base do Morro do Castello occupa uma parte mais extensa que a praça da Acclamação, o que inutilisa grande parte do terreno que poderia servir para edificações, além do que se destinasse para jardim dos convalescentes do Hospital da Misericórdia, recolhidos e expostos. Se se chagasse a arrasar este montinho, muito ganharia a cidade em extensão, salubridade e embelezamento como foi tão claramente demonstrado pelo Dr. Emilio Maria no seu relatório à Academia de Medicina". A obra
} 
As preocupações urbanas latentes no governo paraibano de Beaurepaire Rohan, expressas nas suas atuações, tornam-se explícitas principalmente no extenso relatório por ele elaborado, com informações para o Governo Imperial e para a Assembléia Legislativa, acerca das condições em que se encontram os espaços urbanos da capital. Esse relatório se refere ao abastecimento d'água local, até então realizado por fontes, apontando rios cujas águas podem ser utilizadas para o melhor suprimento dessas necessidades; mostra a urgência da construção de cemitérios para se extinguir o uso das igrejas para esse fim; e expõe sua visão de desenvolvimento da capital, através do embelezamento urbano promovido pela abertura de novas vias e criação de novos espaços públicos.

Sua atuação é de grande importância na história urbana da capital paraibana. Uma de suas grandes contribuições é o levantamento da planta da cidade, que possibilita a criação de novas praças e o alinhamento de ruas, executados ainda em sua administração. Esse levantamento promove o conhecimento da estrutura da cidade, fundamental para promover sua alteração, possibilitando, nesse momento, o estudo e aplicação de algumas intervenções que marcaram o século XIX, as quais são impescindíveis para o desencadeamento das reformas urbanas mais intensas desenvolvidas no século seguinte.

Desenhar a cidade existente não significa simplesmente retratá-la em papel, mas estudá-la e conhecêla, através de um exercício intelectual e de conhecimentos específicos, processo que possibilita planejar as modificações desejadas. Trata-se de "um sofisticado instrumento de raciocício, já que os engenheiros eram formados, no âmbito das aulas de Arquitetura Militar, para não reproduzir acriticamente modelos importados mas para raciocinar e adaptar-se às mais variadas conjunturas encontradas"153.

“ ‘Desegno' era o exercício intelectual que precedia a realização de 'todas as obras que têm invenção, ou forma, ou fermosura, ou proporção'. Não se trata de qualquer exercício intelectual, na medida em que se pressupunha o domínio da aritmética, da geometria e do sistema das proporções que envolvia a concepção das 'fortificações à maneira italiana', das obras ao 'gosto romano' ou 'chãs', das cidades de traçado regular ou tendencialmente regular', em voga em Portugal. Entretanto ‘desegno' era também o exercício mental que precedia a viabilização de qualquer intento, não exclusivamente arquitetônico, elo mediador entre o conhecimento da realidade e a ação sobre ela e, nesse sentido, sinônimo de desígnio"154.

\subsubsection{Usos}

A utilização das áreas urbanas públicas apresenta indicadores das formas de convívio peculiares aos seus moradores. A cidade da Parahyba de fins do século XIX é marcada pelo discurso referente a preocupações, segundo as quais se busca instituir uma nova ordem urbana. A intenção de reestruturação torna-se evidente

do canal do Mangue, realizada em 1858 pelo Barão de Mauá, fôra muito antes projetada pelo Capitão Beaurepaire. Desempenhou ainda relevantes serviços: foi Ministro do Supremo Tribunal Militar, Ministro da Guerra, dignatário de diversas ordens, Vice-Presidente do Instituto Histórico e membro de outras associações científicas e literárias. Atou ainda no Piauí, Paraná, Mato Grosso - de onde escreveu uma corografia publicada no jornal "O Comércio". Foi Diretor do estado de São Paulo-Santos em 1846, presidente da província do Pará, em 1856 e em 1857 é nomeado presidente da província da Parahyba. Faleceu em 1894, deixando diversas obras de grande utilidade para o Brasil, as quais revelam parte de sua experiência: Memórias sobre o ancoradouro da Esquadra de Cabral (1877); Diccionário de Vocábulos Brasileiros (1888); Considerações acera dos melhoramentos de que, em relação às sêcas, são suscetíveis algumas províncias do Nordeste do Brasil (1860); As sêcas do Ceará (1877); O futuro das grandes lavouras e das grandes propriedades do Brasil (1878); Estudos sôbre a organização da Corte Geral e da História física e política do Brasil (1877); Relatório final da Comissão da Corte Geral do Império (1878); O primeiro e atual Porto Seguro (1881); O abolicionismo e suas adversárias (1884); mapas e plantas, alguns organizados na obra Demonstração gráfica da derrota provável de Pedro Álvares Cabral por ocasião da Descoberta do Brasil. (GALERIA NACIONAL. Vultos proeminentes da história brasileira. $2^{\circ}$ Fascículo. Editado pelo "Jornal do Brasil". Rio de Janeiro, Officinas Graphicas do "Jornal do Brasil", 1932. pp. 118 e 119).

${ }^{153}$ BUENO, Beatriz P.Siqueira "Formação e metodologia de trabalho dos engenheiros-militares: a importância da 'ciência do desenho' na construção de edifícios e cidades ". In: TEIXERA, C. Manuel (coord.). A construção da cidade brasileira. Lisboa: Livros horizonte, 2004, p.151.

${ }^{154} \mathrm{Ibid}$., p. 153. 
nos veículos de comunicação e nos discursos oficiais. Apesar de incipiente, percebe-se a sinalização das primeiras mudanças formais do espaço urbano, mais direcionados para alinhamentos das vias, mas quanto à utilização da cidade, há resistência às inovações, permanecendo costumes há muito enraizados.

\section{A capital paraibana} oitocentista apresenta-se, nesse momento, conduzida pelos ditames das famílias agrárias, então presentes no meio urbano, apesar de resguardadas nos sobrados. Guarda características do Brasil colonial, como revela Marins: "se nas lavouras e engenhos as mulheres e crianças podiam gozar de maior trânsito, na cidade era absolutamente necessário formalizar a imagem retórica de ócio e de pudor"155. Nesse contexto, o homem urbano vai à rua, a negócios, e a mulher permanece reclusa, protegida pelas

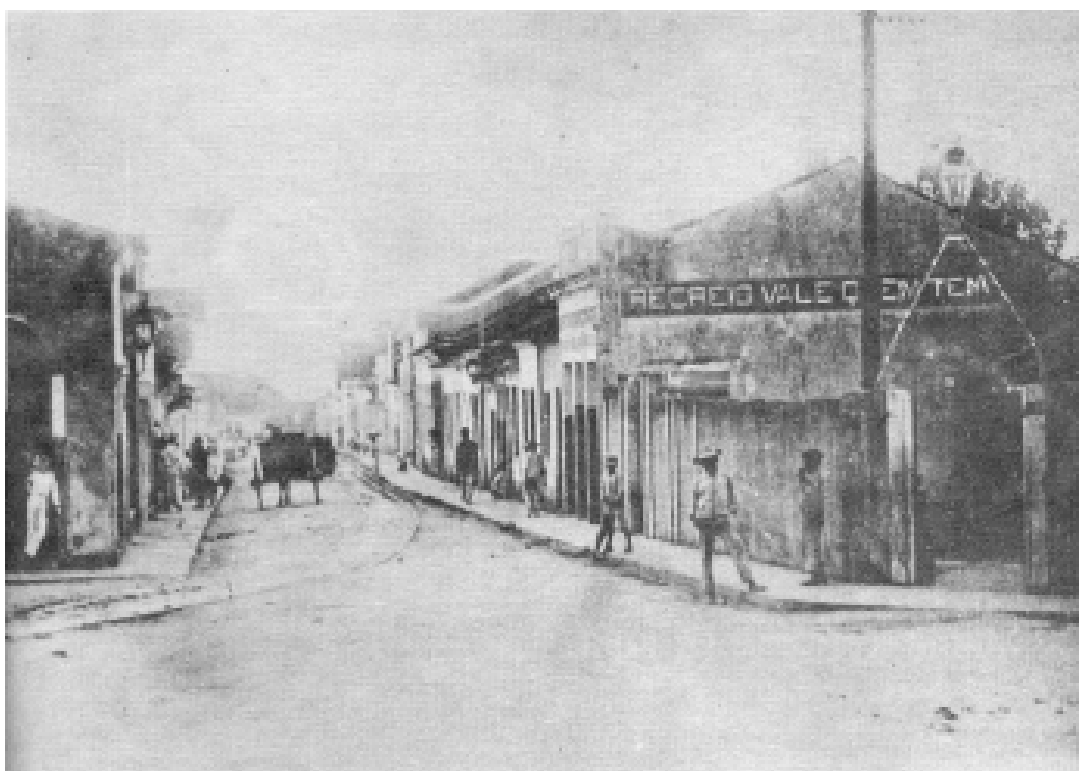

1903 - Antiga Estrada do Carro, atual Barão do Triunfo. FONTE: Acervo Walfredo Rodrigues.

paredes do lar. As ruas, largos, bondes puxados a burros, enfim, toda a área pública da cidade é, nesse momento, majoritariamente ocupada por homens.

A participação da mulher no espaço urbano apresenta-se vinculada, sobretudo, à vida religiosa. Assim, sua presença na cidade encontra-se registrada em largos, quando se está a caminho das igrejas, percurso feito muitas vezes na companhia de serviçais. Os acontecimentos citadinos de natureza outra, que não religiosa, têm uma participação feminina discreta, geralmente marcada por sua presença nas janelas das casas, como se observa nas fotografias do bando precatório em favor das vítimas da Guerra de Canudos, em 1897, onde

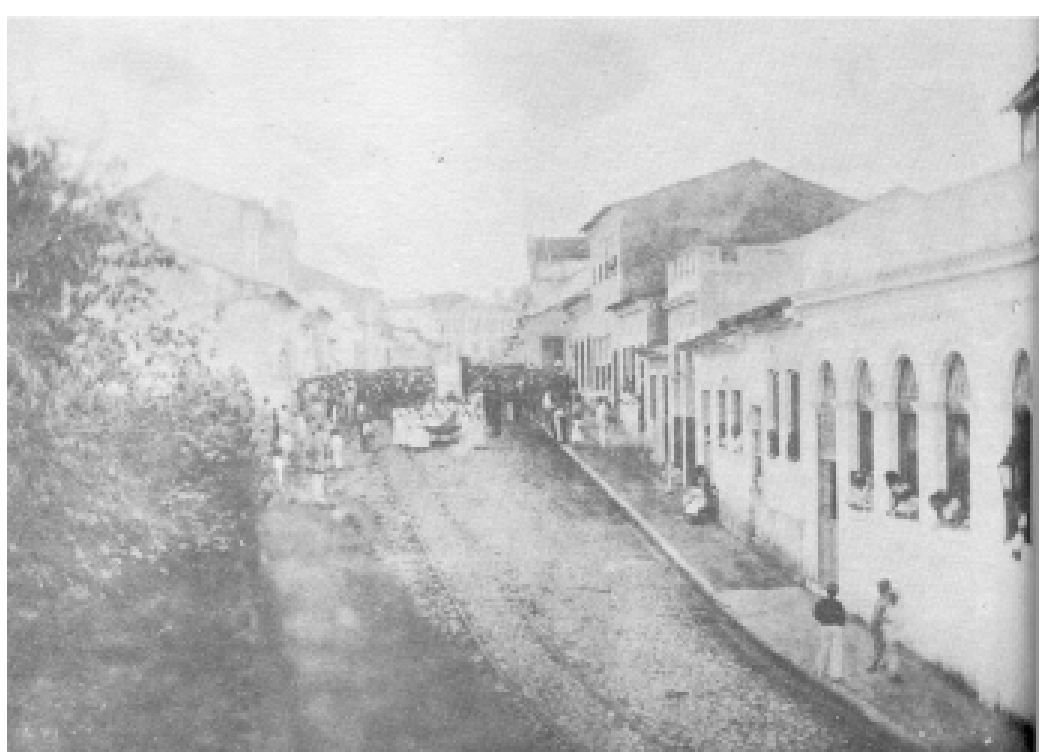

1897 - Estrada do Carro. Precatório em favor da vítimas da Guerra de Canudos. FONTE: Acervo Walfredo Rodrigues. homens observam das ruas e calçadas, enquanto os rostos femininos se resguardam nas janelas.

Toda a preocupação da sociedade em reservar a mulher de elite nas edificações, não extingue a figura feminina do cenário urbano. As ruas e largos são, freqüentemente, percorridos por escravas que realizam vendas, principalmente de produtos caseiros, mas são as lavadeiras as figuras femininas mais descritas nos relatos acerca da cidade de então, sempre movimentando bicas e fontes com conversas e cantorias enquanto trabalham.

${ }^{155}$ MARINS, Paulo César Garcez. Através da Rótula. Sociedade e Arquitetura Urbana no Brasil, séculos XVII a XX. São Paulo: Humanitas/FFLLCH/USP, 2001, p.73. 


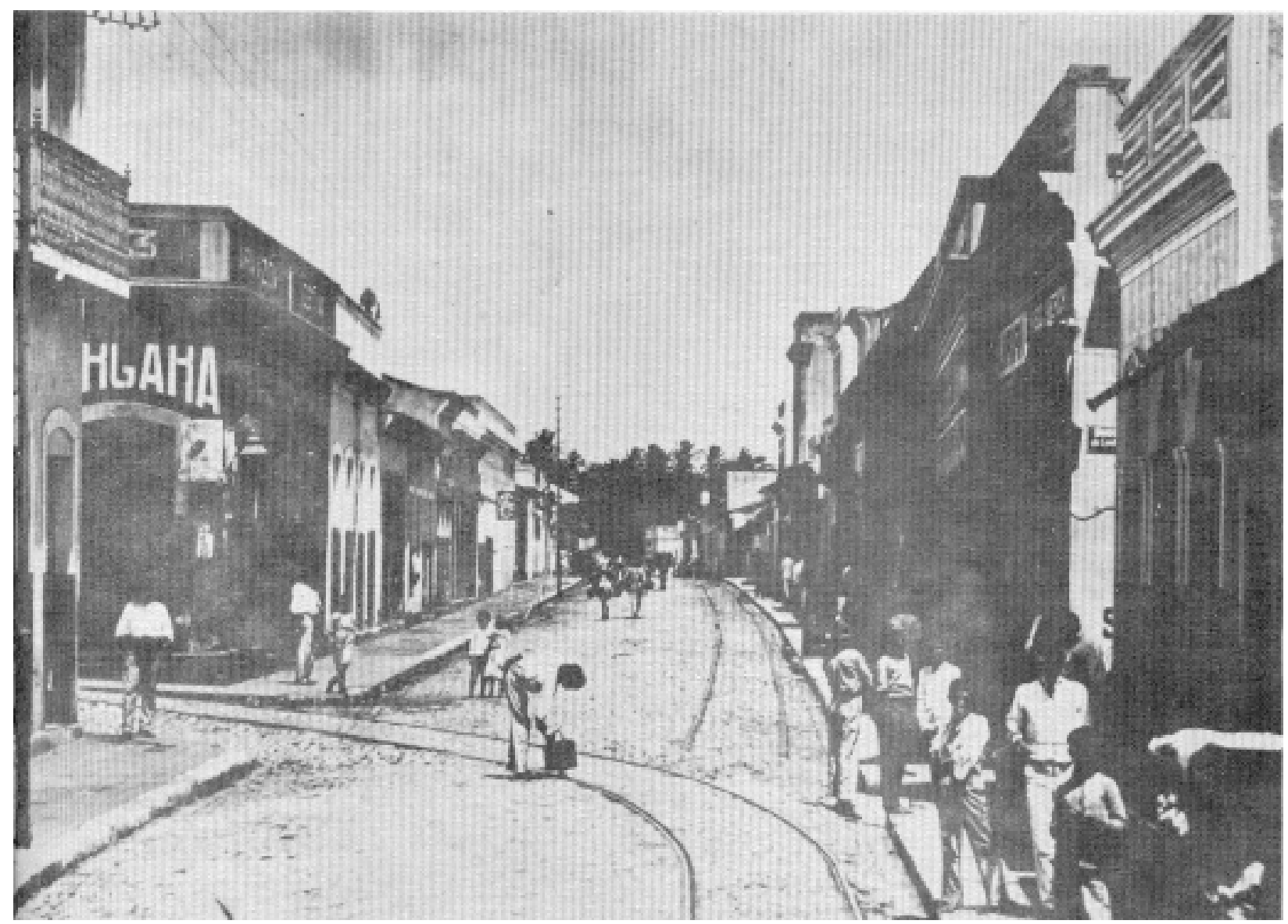

1910 - Rua Marciel Pinheiro, confluência com a rua Barão do Triunfo, vendo-se os trilhos da Ferro-Carril, bondes à tração animal. FONTE: Acervo Walfredo Rodrigues.

\section{Assim como as}

lavadeiras, outras figuras típicas do cenário citadino marcam o meio urbano oitocentista, dentre as quais se destaca 0 acendedor de lampiões, que ronda as principais ruas onde se fixam os poucos lampiões da cidade ${ }^{156}$. Da mesma forma, a circulação de carregadores de água, com tonéis, algumas vezes auxiliados por animais, marca o cotidiano dessa cidade no período oitocentista, o que torna comum aos documentos iconográficos da época, a presença de animais de carga na área urbana e a

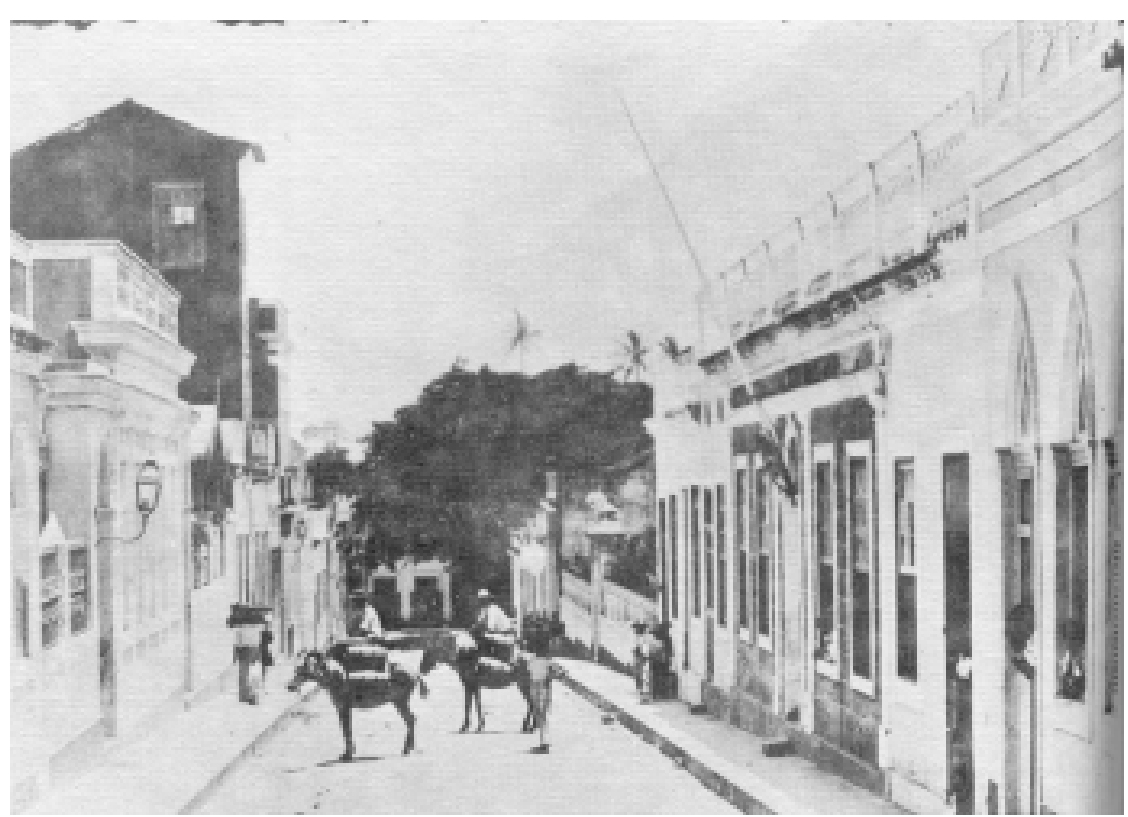

1910- Fornecedores de água à população. Antiga rua da Viração, atual Gama e Mello. FONTE: Acervo Laldereida Marques.

aglomeração de serviçais nas fontes .

${ }^{156}$ O número restrito de lampiões faz necessário o aproveitamento da iluminação lunar. Os horários de acender e apagar essas lâmpadas variam de acordo com a intensidade dessa iluminação natural, e o processo de ativação dos lampiões se dá através de três acendedores na cidade alta e dois na cidade baixa. Nos períodos de crise e aumento do preço do azeite, a iluminação urbana se restringe às ruas das edificações administrativas e residências dos habitantes mais importantes, resumindo-se muitas vezes apenas aos lampiões do Palácio, Quartéis e Cadeia. Irineu Joffily em A Capital da Paraíba, descreve as principais ruas da cidade iluminadas a querosene, sistema que perdurou até 1912. 
Percebe-se que a capital paraibana mantém, até o fim do século XIX, muitos dos costumes consolidados ao longo de sua formação, os quais se encontram vinculados à estrutura urbana. Deste modo, a utilização das áreas públicas da cidade apresenta reflexos das limitações da estrutura urbana, expressa na deficiência de abastecimento d'água, na ausência de rede de esgoto, na escassez de iluminação pública, no calçamento restrito a algumas ruas e no transporte coletivo, realizado desde 1883 por bondes puxados a burro. Nesse sentido, o expresso descontentamento com a ordem urbana não se restringe às formas da cidade, mas também aos modos de apropriação de seus espaços públicos.

No centro da cidade, onde a Rua Nova se encontra com o então Beco da Misericórdia, há um barreiro funcionando como serventia pública, onde se fazem despejos e vão parar toda sorte de detritos e imundícies que não se pode deixar em casa. Os relatórios acerca do espaço urbano da capital paraibana revelam, recorrentemente, práticas dessa natureza, que contribuem para tornar as ruas extremamente sujas.

Um dos mais enfáticos problemas da capital é, por muito tempo, os desmandos noturnos possibilitados pelo ineficiente sistema de iluminação urbana. Em fim do século XVIII, a iluminação da cidade se resume a nichos de esquina instalados pelas famílias abastadas, e fachos e tochas dos lanterneiros e criados que acompanham os patrões em raras saídas noturnas. Essa situação contribui para a atuação de desordeiros e o aumento de crimes. A iluminação implementada em 1822 pela Junta Governativa, composta de vinte lampiões de azeite de mamona, não muda muito esse quadro. O viajante Henry Koster, que se detém sobre questões da cidade da Paraíba do início do século XIX, ressaltado a violência urbana, assinalando que nesse local "prevalecia a tradição de pessoas que passeavam à noite pela cidade, com imensos capotes e crepes no rosto", realizando "práticas irregulares"157. Em busca de assegurar a paz urbana, o Governo regulamenta, em 1827, o limite de horário para permanecer na rua.

Na utilização "desregrada" das áreas urbanas, transparece a ilimitada relação entre atividades públicas e privadas, o que concorre para a precariedade da higiene no processo de apropriação da cidade por parte da população. É comum a realização de banhos por parte dos habitantes nos mananciais onde também se lavam os animais empregados na tração dos veículos ${ }^{158}$. O banho coletivo ocorre, da mesma forma, nas fontes, cuja utilização promíscua exige que famílias e "pessoas de bem" que necessitem delas se aproximarem, enviem anteriormente um mensageiro que recomponha a ordem local. Esse tipo de utilização das áreas públicas é tão comum que até o presidente do Estado, José Peregrino (1900-1904), realiza a prática de banhos na fonte pública em frente do Palácio do Governo, como conta Walfredo Rodrigues, em Roteiro Sentimental de uma Cidade.

Uma marca característica do cotidiano dessa cidade oitocentista é a presença do negro, seja na mãode-obra herdada do período da escravidão, seja mas manifestações culturais e religiosas. Até meados do século XIX, a mão-de-obra escrava é a predominante. Há resistência à sua substituição, e só em 1850 passa a se cumprir as leis de extinção do tráfico. Portanto, em fins do século XIX, encontra-se um grande número de negros na cidade, e muitos traços do regime escravo. Em 1841, a estimativa de escravos na população paraibana é de 13,62\%, e já em 1811, 53,6\% da população livre é negra e mulata. Assim, às vésperas da Independência, a Paraíba é uma capitania majoritariamente negra. ${ }^{159}$

Além do trabalho escravo, os negros têm acesso às Ordens Religiosas, residências senhoriais, oficinas de artesanato e corporações de ofício - sapateiro, ferreiro, marceneiro, alfaiate-, às estivas portuárias, etc. Ao

${ }^{157}$ KOSTER, Henry. In: AGUIAR, Wellington, MELLO, José Octávio de A. Uma cidade de quatro séculos. Evolução e roteiro. $2^{\mathrm{a}}$ ed. João Pessoa: A União, 1989, p. 78.

158 SORIANO, Ana Gabriela Wanderley. Cenários Modernizados: os espaços públicos da Parahyba, 1916-1924. João Pessoa: Universidade Federal da Paraíba, 2001, p. 45. (Trabalho final de graduação do curso de Arquitetura e Urbanismo).

${ }^{159}$ MELLO, Humberto. “Datas e notas para a história do negro na Paraíba”. Revista do IHGP. Ano LXXII, set. 1995, pp.115-122, p.122. 
fim da escravidão, eles estão presentes em vários ramos da vida urbana. No século da Abolição, o Brasil é moreno na pigmentação, nas superstições, no folclore, no fetichismo, no comportamento. ${ }^{160}$

Na Paraíba, as secas e as pestes impedem que a população escrava seja muito ampla, não chegando a pigmentar essa população marcadamente, como ocorre nas principais capitanias, portos de entrada do comércio negreiro: Pernambuco, Rio de Janeiro e Bahia. Mas isso não significa que a população não tenha sofrido influência de sua presença. Abolida a escravidão em 1888, a capital paraibana termina esse século com marcas da vida escrava. Não apenas nos engenhos dos arredores da capital, mas também em suas ruas, o trabalhador negro se encontra com grande evidência. Eles ainda aparecem reunidos como antes, nas fontes onde enchem talhas d'água e lavam roupas, andando pelas ruas da cidade, marcando a paisagem urbana pelo lento andar propiciado pela carga que levam. Além das negras que carregam roupas limpas e sujas no trajeto das casas para as fontes, também destacam-se aquelas que levam nos braços um tabuleiro de vendas, geralmente comida, mantendo na paisagem urbana o papel antes exercido pelas escravas de ganho. $\mathrm{Na}$ iconografia da época, percebe-se que são as crianças negras ou mulatas as que se encontram nas ruas, sozinhas ou acompanhando um adulto em atividade.

Mas não é só em relação ao trabalho que a herança escrava influencia a vida urbana dessa capital. $O$ culto religioso é realizado na Igreja do Rosário dos Pretos apenas para fiéis de cor. E as músicas, danças e instrumentos que compõem muitas das festividades locais, que ocorrem nos recantos da cidade, nas praias e nas ruas, apresentam a influência dessa gente. Não são manifestações puramente afros, mas brasileiras, portanto também afro, a exemplo da popular dança do "côco de roda" e das "batidas do ganzá".

O cotidiano urbano é, em parte, reflexo de sua estrutura, questões estas fortemente imbricadas, apresentando, a cidade de então, peculiaridades de comportamentos inerentes àqueles espaços, que gradativamente são extintas, à medida e velocidade que se intervém na configuração urbana. Em fins do século XIX, são enfáticas as reivindicações acerca de mudanças na cidade. São elaborados documentos específicos nesse sentido, geralmente publicados em veículos de comunicação. Com as novas formas, instituem-se novos usos.

Na década de 1880, enfatiza-se a consolidação de uma sociedade literária na capital paraibana, com intuito de instituir uma vida intelectual na cidade. Nesse sentido, funda-se o Club Literário e Recreativo, "destinado a promover a educação popular, pois não ficava bem a uma capital, berço dum povo civilizado, permanecer indiferente à progressiva manifestação de amor às letras, que rebentava do seio da nação brasileira"161. Do mesmo modo, implanta-se o Centro Literário Paraibano e se empenha, apesar das dificuldades, em construir a Biblioteca Pública, "único meio de tornar o livro acessível a qualquer indivíduo" 162.

À medida que se busca remodelar algumas áreas da cidade, a lei controla a forma de apropriação das mesmas, atingindo principalmente as classes pobres. Para a concretização desse ideal, faz-se mister a construção de uma infra-estrutura urbana que possibilite a todos condições de higiene doméstica, e a reordenação das atividades destinadas às áreas públicas e privadas, visando uma cidade bela, limpa e saudável.

\footnotetext{
${ }^{160}$ As ordens religiosas sempre tiveram escravos. Nos arquivos do Mosteiro de São Bento, são muitas as referências aos escravos beneditinos, a exemplo das notas de aquisição dos escravos. Apesar do fim do comércio escravo ter como marco o ano de 1850 , e a abolição da escravatura o ano de 1888, muitas das características enraizadas do trabalho escravo adentram o século XX. $\mathrm{O}$ reflexo da presença negra não fica apenas no trabalho servil, mas num processo de miscigenação cultural, onde tanto o negro como o branco não conseguem manter intactas suas culturas, o que se reflete na música, na dança, na religião e no cotidiano de muitas de nossas cidades. O negro absorve elementos da cultura dos brancos, principalmente ao tratar dos ritos religiosos. A fim de ganhar os pretos para a Igreja Católica, as Ordens Religiosas permitem que se fundem, junto às Irmandades e Confrarias, as Associações Pias Negras. A festa mais importante era a da Rainha e Rei do Congo, promovida pela Igreja do Rosário dos Pretos, apesar de protestos daqueles que se sentem incomodados com o som das cantorias negras. Por muito tempo, proibem-se as manifestações da cultura africana.

${ }^{161}$ MARTINS, Eduardo. "Instituições Paraibanas de Cultura" - 1880/1941". In: Revista da Academia Paraibana de Letras, n.8, João Pessoa, A União Cia. Editora, 1978, pp175/80. p.175.

162 Ibid., p.176.
} 
O cotidiano urbano de então apresenta apenas as sinalizações desse ideal em formação, não se tornando ainda aparente, na utilização dos espaços urbanos, a concretização desse discurso que ganha peso nesse momento. Nesse sentido, o século XIX apresenta críticas à utilização das áreas urbanas num discurso imprescindível para a concretização das transformações sofridas pela capital paraibana do século seguinte.

\subsubsection{O discurso sobre a cidade}

A crescente preocupação com a ordem da cidade oitocentista e as conseqüentes atuações administrativas no sentido de alterá-la constituem-se a principal pauta urbanística do século XIX. No fim da década de 1880, tais preocupações se tornaram mais enfáticas, com forte exposição na imprensa local, o que fortalece o movimento em prol da reformulação urbana que se desencadeia no início do século XX. A divulgação desses ideais torna-se mais evidente com a consolidação da imprensa local, o que leva a questão a maiores repercussões.

O ideal republicano se expressa fortemente na imprensa paraibana em 1888, quando se cria o jornal diário local Gazeta da Parahyba. Em 1826, é publicado o primeiro jornal da província. A partir de então, presencia-se por vinte anos a circulação de jornais de vida efêmera. À época da criação da Gazeta circulam na cidade dois jornais do partido liberal e um do conservador, extintos com a República, que por sua vez dá "sopro de vida á Gazeta"163. Este jornal

"não mostrava pendor por nenhum dos dois partidos monarchico[s]. Trazia sempre bons romances em folhetins, minuciosas noticias das outras províncias e do interior, criticas dos acontecimentos do dia anterior, chronica aos domingos e uma reportagem. Era, em suma, um jornal moderno, no feitio, e também no fundo, pelas suas tendências abolicionistas e republicanas"164.

Com a Gazeta, evidencia-se a participação da imprensa local na vida urbana, num discurso alinhado com os ideais urbanísticos de então, apontando denúncias e exaltando melhoramentos. Se ao longo da formação urbana da capital paraibana seu núcleo urbano é alvo de descrições, relatos e críticas promovidas, em maior número, por viajantes e governantes, encontradas em livros, diários ou documentos oficiais, o final do século XIX leva visões da cidade para a população, através de jornais e revistas locais.

Tornando-se crescentes as reivindicações acerca da organização urbana, há o aumento gradativo do número de críticos que redigem pequenas notas nos veículos de comunicações locais. Em 1889, ano da proclamação da República e de grandes agitações, a aparência urbana se sobressai na Gazeta da Paraíba. Não são mais pequenas notas, mas extensos artigos acerca do meio urbano local que passam a ser publicados numa seqüência diária no jornal, o que dá um caráter enfático e persistente à documentação, na busca de explicitar a importância do tema. AMonographia da Cidade da Parahyba e a coluna Melhoramentos da capital paraibana, ambas publicadas no jornal Gazeta da Parahyba, reúnem em si um conjunto de preocupações que, há tempos, permeiam a vida urbana paraibana e que apontam as grandes intervenções que marcam o século XX.

Publicados entre os dias 9 de janeiro e 5 de fevereiro de 1889, a série de vinte e um de artigos intitulados Melhoramentos da Capital Paraibana, de autoria do engenheiro militar João Claudino de Oliveira Cruz ${ }^{165}$, dá um panorama da cidade e busca alertar para sua situação sanitária precária, apontando a urgência de algumas

${ }_{163}$ BEZERRA, Alcides. "A Imprensa na Parahyba" In: Revista do instituto Histórico e Geográfico Paraibano. Vol.5, Parahyba, Imprensa oficial, 1922, pp 51- 56. p. 53.

164 Ibid. 
medidas necessárias à vida saudável e confortável. "Escripto expressamente para a Gazeta da Parahyba"166, esse trabalho dispõe de linguagem clara, tornando-se acessível aos leigos leitores, mesmo tratando com relativa profundidade de assuntos específicos como abastecimento d'água, saneamento, iluminação e artes.

O engenheiro realiza uma descrição da cidade, revelando suas qualidades naturais, às quais contrapõe deficiências na sua estrutura urbana. Propõe melhoramentos, apresentando sempre a solução, ao seu ver, ideal, seguida de medidas mais simples porém menos eficientes, o que ameniza a situação por ele criticada. Cada solução abordada é ilustrada com experiências semelhantes já passadas por outras cidades e suas vantagens, além de apresentar discursos e atuações de profissionais especializados, sejam nacionais ou internacionais, a partir dos quais busca legitimar suas proposições.

Apresentadas as riquezas locais, presentes da natureza que "caprichando forneceo-Ihe poderosos elementos"167, o autor revela as deficiências locais segundo um tom conclusivo de que o leitor concorda com seu raciocínio. Essa postura, juntamente com a linguagem acessível, mesmo tratando de questões específicas até então mais restritas ao âmbito administrativo ou relatos pessoais de observadores externos, mostra a relevância inovadora dessa fonte, que busca despertar a população para a necessidade de reivindicar por melhoramentos na cidade, através da implantação de uma nova ordem urbana.

"O distincto povo parahybano que tão bem comprehende a serie de melhoramentos que podem tornar prolongada e feliz a vida humana, não pode deixar de curtir intimamente a dôr que Ihe dilacera, por ver o abandono em que jaz a terra ..."168.

"Como se vê está a cidade da Parahyba do Norte mais que predestinada a receber todos os melhoramentos hoje notados nas regiões mais civilizadas do globo. Uma unica causa poderia procurar obstar esses melhoramentos, e essa é a descrença de uma parte da população. Mas, como não haver essa descrença se o povo parahybano vê constantemente mallogrados todos os emprehendimentos que são tentados? Precisamos portanto vencer esse obstaculo e tornar uma realidade o que para muitos é considerado uma verdadeira utopia"169.

Mostra essa cidade como uma "boa terra" onde tudo faltava, "até mesmo os principaes elementos da vida, isto é, o ar, a água e a luz [que] apresentam-se deficientes ás necessidades do povo"170. Ressalta seus problemas mais urgentes:

"abastecimento d'agua potável, canalisação de esgoto das materias fecaes e aguas servidas, limpeza publica, adopção de um systema aperfeiçoado de illuminação, construcção de um theatro, construcção de carris de ferro, e Jardim Publico"171.

Quanto ao abastecimento d'água em voga em 1889, o engenheiro o taxa de inexistente, pois "a água obtida mal chega para as primeiras necessidade da vida, sendo, senão no todo, ao menos em parte, prejudicada a hygiene da população" ${ }^{172}$. Outro fator é o elevado preço pelo qual essa água é adquirida que, além de limitar o número de consumidores, não é condizente com a qualidade do produto, pois

\footnotetext{
165 "Nascido no ano de 1850, João Claudino de Oliveira Cruz ingressa no exército em 19 de novembro de 1869, faz o curso de engenharia militar pelo regulamento de 1874 , é bacharel em mathematicas e sciencias physicas, tenente-coronel do corpo de engenharia e exerce o cargo de diretor das obras militares de Pernamburo. Escreve a obra "Guia de construções" (Recife, 1894). Neste livro, ocupa-se da construção: suas regras e preceitos a seguir, empreitadas, fiscalização, alicerces, paredes, aragamassa, esquadria, madeiramento e telhado".(BLAKE, Augusto Victorino Alves Sacramento. Diccinario Biibliographico Brasileiro. Rio de Janeiro: Imprensa Nacional, 1895. $3^{\circ}$ vol., p. 397).

${ }^{166}$ CRUZ, João Claudino de Oliveira. "Melhoramentos da capital da Parahyba". Gazeta da Parahyba, n. x, 5 fev. 1889 , p. 02.

167 Ibid.

${ }^{168} \mathrm{Ibid} .$, p. 03.

169 Ibid.

170 Ibid.

${ }^{171}$ Ibid.

172 Ibid.
} 
"extrahida de poços ou cacimbas situadas em lugares diversos, onde não só em relação a constituição dos terrenos que formam o seu leito, como pela falta de cuidado de alguns de seus proprietários, não podem por forma alguma preencher as condições exigidas ás aguas potaveis"173.

Assim, segundo o engenheiro, as águas distribuídas nessa capital, por se encontrarem por vezes repletas de matérias orgânicas, constituem-se "verdadeiro veneno que se vae inocular no organismo do povo e produzir-Ihe desastrosos effeitos" 174 .

Apesar das condições impróprias das águas provenientes de cacimbas ou poços distribuídas nessa capital, possibilitando inclusive o "apparecimento de alguma febre palustre nos individuos que dellas fizerem uso"175, o documento se refere à "excellente água"176 proveniente da fonte do Tambiá. Porém, o volume de água por ela oferecido é insuficiente para a população, além do inconveniente proporcionado pelo longo percurso a ser vencido rumo a essa fonte, localizada nos arredores da cidade. Concluída a explanação acerca das condições de abastecimento d'água da capital paraibana, o engenheiro apresenta as possibilidades de novos sistemas para atender essa necessidade, buscando vencer o preconceito da população, denunciado pela "repugnancia que muitos [tinham] da introdução da canalisação d'agua na cidade"177, e levando os leitores à reflexão das "vantagens que est[avam] gosando tantas cidades do mundo"178.

Enumeradas diversas vantagens a respeito da implantação do sistema de abastecimento d'água da capital, - economia, evitar desgaste físico dos que buscam a água, conveniência de não juntar águas de chuva, etc - é claro o interesse em influir com esse serviço nos hábitos da população, também apresentado como incentivo à "hygiene dos habitantes"179. Esse serviço possibilita a utilização da água a qualquer hora do dia ou da noite, além de evitar, com a construção de banheiros e tanques de lavagem de roupa nas casas, a utilização de fontes e demais áreas públicas para esses tipos de atividade.

Buscando apresentar a viabilidade da implantação desse serviço no local, o engenheiro apresenta os mananciais que podem ser usados para este fim, as medidas de incentivo que devem ser apresentadas por parte da administração, estimando ainda a quantia de água necessária à cidade.

Em relação à "canalização de esgoto das materias fecáes e aguas servidas"180, o engenheiro desenvolve um percurso semelhante ao relativo aos serviços de abastecimento d'água. Aponta as deficiências no tratamento dessa questão, ressaltando inclusive nuances relativas às suas consequências, muitas vezes desconhecidas pela população. Trata-se de um trabalho de conscientização da questão urbana, num claro intuito de difundir os discursos em circulação entre administradores, médicos e engenheiros.

Afirmando "que o peior systema de despejo de materia fécal que pode haver é o empregado nesta cidade"181, João Claudino vai além da denúncia. Ele explica os processos de decomposição das matérias e sua interferência na saúde pública, marcando seu discurso com o tom informativo e esclarecedor dos meios em uso na cidade, suas conseqüências e as vantagens da implantação do novo sistema.

Para legitimar suas proposições, o engenheiro usa discursos externos, de outros autores e referentes a outros lugares. A importância expressa acerca da implantação desses serviços em uma cidade é reafirmada

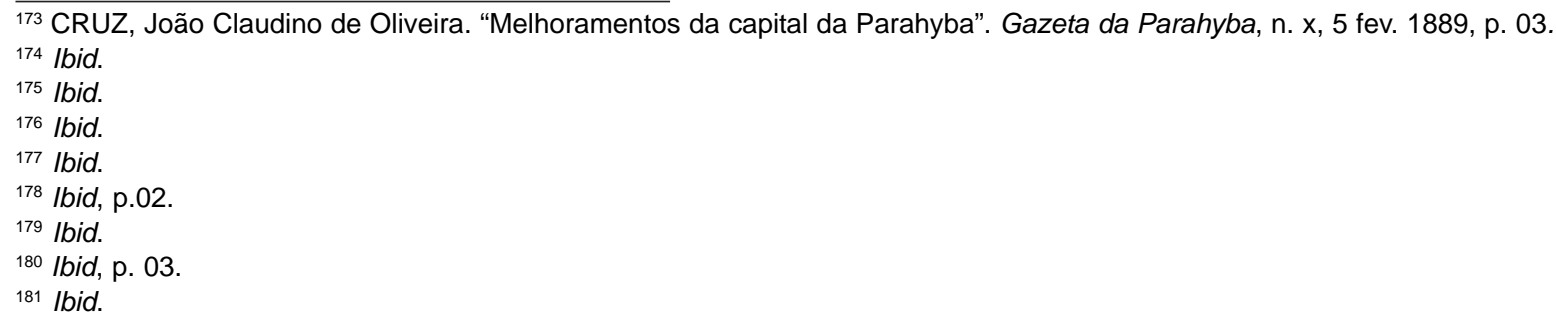


tanto por questões apontadas nos jornais ingleses, a exemplo das observações feitas pelo Sr. Haldane em Bristol, como pelo discurso do engenheiro brasileiro Monteiro de Barros, fiscal do governo junto à companhia City Improvements, ao tratar dos melhoramentos do sistema de esgoto do Rio de Janeiro.

Nesse momento, a capital paraibana não dispõe de encanamento para o escoamento das águas servidas, o que não justifica, segundo o engenheiro,

"o facto de serem ditas aguas levadas para ruas e quintaes. Os depositos que se formam nas sargetas das ruas e nos pateos dos quintaes, só attestam grande falta de observancia aos principios da hygiene. Os ardentes raios do sol actuando directamente sobre esse liquido, que em alguns lugares fica estagnado, operam a decomposição de materias animaes e vegetaes que [contém na] mistura: d'ahi o desprendimento de miasmas que satura a atmosphera e, por conseguinte, prejudica o ar que respira"182.

João Claudino apresenta a implantação do sistema de esgotos dessa cidade como principal solução para reverter esse quadro, o que não é de todo dispendioso pela ajuda da natureza que dota a cidade de um "solo elevado, conte[ndo] entretanto natural declive que permitte o estabelecimento de uma rede de encanamentos destinada a receber todas as materias, e aguas servidas que são despejadas pelos prédios"183. Em complemento a esse serviço, o engenheiro reinvidica a limpeza pública em combate ao "aspecto tristonho que apresenta a accumulação do lixo nos recantos das egrejas, nas sargêtas, das ruas até nas mais publicas"184.

Na ausência completa de um serviço de limpeza pública, o único fator que ameniza o crítico estado da cidade é "a continua corrente de ar que a lava, pode-se dizer, sem interrupção"185. Diante dessa realidade, o engenheiro reivindica, "a exemplo do que se pratica em tantas cidades do mundo, (...) um completo serviço de limpêza publica", podendo ser realizado por "algumas carroças que recebem o lixo das casas, e um saveiro que o conduz para longe da cidade" ${ }^{186}$. A limpeza urbana, para o autor, também está relacionada às características naturais da cidade, onde terrenos pantanosos e com concentração perene de água, a exemplo da lagoa dos Irerês, devem sofrer intervenções, como a proposta de aterramento da mesma.

Se esses três primeiros pontos -serviços de abastecimento d'água, de canalização de esgoto e de limpeza pública- apontados por João Claudino como urgentes à cidade, buscam alterar a parte reconhecida como negativa da cidade, baseando-se em princípios higienistas, os últimos pontos das sete necessidades por ele elencadas se relacionam mais diretamente com os hábitos e o cotidiano urbano. Apresenta exemplos de cidades que desfrutam de tais serviços, especulando a renovação na vida urbana que eles podem proporcionar à capital paraibana. Nesse sentido, a iluminação elétrica, o teatro, o carril de ferro e o jardim público são apresentados como "medidas civilizadoras"187 relacionadas à transformação do uso da cidade, num discurso que instiga a população a desejá-las.

Diante dos pontos explorados pelo engenheiro João Claudino, evidencia-se uma certa repetição de reivindicações antigas, algumas que se remetem ao tempo do Presidente Beauripaire Rohan. Porém, apesar de tratar de questões não inéditas, a forma de abordagem, o tom e os argumentos e, principalmente, seu público alvo - não mais médicos, engenheiros e administradores, mas a população - e a forma que a eles se dirige conferem ao trabalho do engenheiro um caráter inovador. A participação da população em relação aos melhoramentos necessários aos espaços urbanos, a serem realizados pela administração, como sugerido nas entrelinhas de seu trabalho, configura, no século seguinte, as intervenções que transformam parte da

\footnotetext{
${ }^{182}$ CRUZ, João Claudino de Oliveira. "Melhoramentos da capital da Parahyba". Gazeta da Parahyba, n. x, 5 fev. 1889, p. 02.

183 Ibid.

184 Ibid.

195 Ibid.

196 Ibid.

197 Ibid.
} 
forma e da dinâmica urbana dessa capital. Esse incentivo à introdução da população na discussão urbanística, percebida mesmo que discretamente nesse momento, passa a ser um dos principais elementos da atuação do urbanismo nas cidades. "Educar" a população para entender as itervenções que se pretende implantar na cidade e para sua colaboração no funcionamento das propostas, através da instituição de um novo modo de usar os espaços públicos, é uma postura defendida e assumida pelos urbanistas dos século XX. Talvez o maior defensor e divulgador desse ideal seja Anhaia Melo que, sob influência do urbanismo americano, difunde esse ideal em São Paulo nos anos 30.

Essa postura de ampliar a discussão urbanística para a população faz parte do processo de criação de uma nova consciência no habitante letrado, o que é percebido pelo surgimento recorrente do termo cidadão, colocado de forma enfática nos textos dos jornais locais a partir do ano de 1889. A inserção do "cidadão" nas questões urbanas influi na configuração dos espaços públicos, se não na alteração de suas formas, que está mais direcionada às ações administrativas, relacionam-se diretamente aos seus modos de apropriação, que passam a se alinhar com os novos ideais urbanos.

Da mesma forma atua a publicação da Monographia elaborada pelo agrimensor Vicente Gomes Jardim ${ }^{188}$, também difundida pela Gazeta da Parahyba nos anos de 1889 e 1890. Essa documentação tem natureza bem diferente dos artigos publicados pelo engenheiro João Claudino de Oliveira Cruz. Elaborada provavelmente por incumbência do presidente Francisco Luís da Gama Roza, último representante imperial no executivo paraibano, esse documento é uma descrição da cidade, apresentando seus elementos componentes. Apesar de não incluir mapas, plantas topográficas ou outra peça gráfica ilustrativa, ao que parece, a intenção da documentação é, de fato, retratar a cidade. Assim, o agrimensor descreve incessante e detalhadamente cada componente do espaço urbano - rua, travessa, beco, largo, pátio, além de edifícios públicos, civis e religiosos, fontes, bicas e cemitérios -, os quais são elencados, localizados e orientados com precisão, segundo suas disposições no espaço urbano.

Essa iniciativa revela a preocupação em se fazer conhecer a configuração urbana de então, atualizando as informações apresentadas no mapa elaborado em 1855, a mando do Presidente Beauripaire Rohan. Apesar de pertencerem a naturezas distintas - mapa e registro escrito -, a comparação das informações fornecidas pelos dois documentos revela algumas alterações ocorridas nesse período de aproximadamente 30 anos. Quanto ao crescimento urbano, quantitativamente, são poucos os acréscimos realizados, mas são significativas as intervenções formais aplicadas à cidade, efetuadas em relação ao seu traçado, no sentido de dar-lhe uma forma mais regular. Nesse documento, encontram-se já firmados os eixos de expansão da cidade naquele momento, Tambiá e Trincheiras, antes já sinalizados porém pouco consolidados.

A área ocupada pela cidade nesses dois momentos é praticamente a mesma, reservando-se as mudanças, sobretudo, para o alinhamento de alguns elementos urbanos. Apesar da criação de ruas, em sua maioria retas, mesmo que não paralelas entre si, é mais comum, nesse momento, o alinhamento de vias existentes. Entre o mapa de 1885 e a Monographia, percebe-se o desaparecimento de ruas, travessas, becos e caminhos, na sua maioria tortuosos, concentrados sobretudo na região intermediária entre as área alta e baixa da cidade.

A Monographia elaborada por Gomes Jardim, de forma mais discreta que os artigos de João Claudino, também revela a preocupação com a organização urbana de então. Apesar de não reivindicar explicitamente intervenções e melhoramentos, esse trabalho constitui um dos primeiros passos para realizar tais propostas,

${ }^{188}$ Foi agrimensor das terras da Marinha e também se dedicou à literatura. Faleceu a 16 de setembro de 1905 (BITTENCOURT, Liberato. "Parahybanos Illustres". Homens do Brasil. Rio de Janeiro: Parahyba Livraria e papelaria Gomes Pereira Editor, Rua do Ouvidor. Vol II, n. 91, 1914 , pp 307 e308). 
posto que dá um panorama da cidade existente, atribuindo todos os dados necessários para a atualização da planta da cidade ${ }^{189}$. Assim, tanto a Monographia como os artigos, ambos publicados na Gazeta da Parahyba, dialogam entre si e, de certa forma, complementam-se, contribuindo para o processo de transformação urbana. A relação entre esse discurso e a população, ainda incipiente nesse momento, torna-se fundamental para a concretização de uma das facetas das intervenções, que é a transformação dos usos desses espaços a partir da alteração do cotidiano e dos hábitos urbanos, impulsionada através dos veículos de comunicação, a partir de então.

Percebe-se nessas preocupações, mesmo sem fortes reflexos em imediatas interferências urbanas de grande porte, sinalizações do futuro quadro de transformação da cidade, verificadas na ênfase a um olhar crítico em relação à estrutura citadina e fundamentadas na apreciação técnica e científica de suas características, que buscam evidenciar e solucionar problemas identificados no que diz respeito à higiene, salubridade e infraestrutura urbana.

Para além da crítica à cidade, esses documentos retratam características formais e de uso dos espaços de uma época, contribuindo para seu desmanche, a partir do incentivo ao processo que se desencadeia, sobretudo, nas primeiras décadas do século XX. O desmonte de "velhos" usos e formas é, gradativamente, anunciado por novas aparências que respondem a tais reivindicações, evidenciado e reforçado, inclusive, pelas novas denominações atribuídas a esses espaços.

\subsection{OS ESPAÇOS DO SÉCULO XIX}

A capital paraibana do fim do século XIX apresenta como elementos formadores do seu espaço público ruas, travessas, becos, campos, praças, pátios e largos. Esses são espaços característicos da cidade desse momento, revelando muito das heranças da Colônia e do Império que ainda persistem nas formas urbanas de então, convivendo com a intensificação das intervenções que se estruturam no contexto oitocentista.

Dentre esses espaços, encontram-se áreas públicas cujas funções naturais se remetem à passagem, e outras à permanência. Nesse contexto, os largos, pátios, campos e praças são, por definição, locais de permanência, enquanto ruas, travessas, becos e ladeiras são, sobretudo, trajetos. Nesse momento da história da cidade, as funções naturais desses espaços sofrem transformações, emergem novas formas de apropriação e as ruas passam a abrigar aglomerações e novos usuários.

Em sua maioria, as denominações desses espaços referenciam às características coloniais remanescentes na cidade, reforçando as heranças formais e de uso. Tanto o substantivo que as apresenta - beco, travessa, largo, ladeira, etc - quanto os adjetivos que as nomeiam de forma mais específica e singular - travessa do Chão-Duro, beco do Hospital, rua do Major Moreira, largo do Sobradinho - marcam nos espaços urbanos as características desse momento, onde os habitantes, o cotidiano citadino e elementos urbanos referenciais nomeiam a cidade.

\footnotetext{
${ }^{189}$ Ao que se sabe, essa planta não foi feita àquela época. Atualmente, essa atualização encontra-se em TINEM, Nelci (org). Fronteiras, marcos e sinais: leituras das ruas de João Pessoa. João Pessoa: Ed. Universitária e Prefeitura Municipal de João Pessoa, 2006.
} 


\subsubsection{Os espaços de trajeto}

\section{"BÊCCO s.m. Rua estreita"190}

Os becos são espaços muito importantes da cidade colonial e oitocentista. Em vários estudos, eles são apresentados como espaços reveladores das nuances da vida da cidade brasileira desse período, onde se apresentam diversas formas de sociabilidade e de apropriação dos espaços públicos.

Na capital paraibana, esses espaços se encontram em constante evidência. Observando o levantamento da estrutura urbana da cidade realizado em 1855 , percebe-se que esse não é o

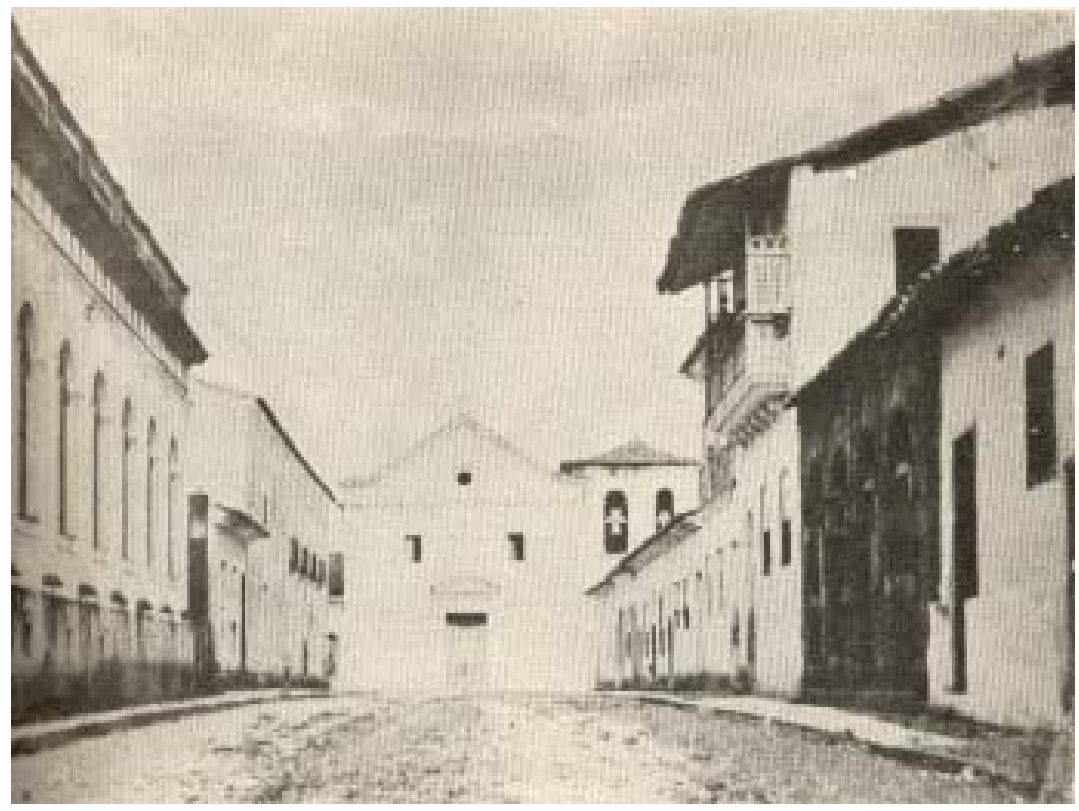

1877 - Beco da Misericórdia, atual tua Paregrino de Carlalho. Ao fundo a igreja da Misericórdia. FONTE: Acervo Walfredo Rodrigues.

espaço predominante quantitativamente no meio urbano de então. Porém, é um dos elementos mais presentes nas descrições dessa cidade naquele momento. Apesar de ser um espaço mais comum ao período colonial, percebe-se, nos relatos e artigos do início do século XX, a proliferação dos becos, que acompanha o crescimento urbano.

São pequenas vielas estreitas, algumas sem saída, outras comunicando dois outros espaços. Aarquitetura nele presente é, geralmente, de pouca projeção formal, constiuída, muitas vezes, por casebres térreos, compondo um ambiente comumente apontado como desordenado e "amontoado". Também podem funcionar como vias sanitárias e locais de drenagem, dando acesso aos quintais. Estas funções, segundo afirma Nestor Goulart referindo-se às cidades brasileiras do período colonial, ocorrem principalmente nas quadras que tendem para a forma de um quadrado e com lotes que se abrem para as duas ruas paralelas, onde "as transversais eram apenas becos ou vielas para drenagem das águas fluviais"191, o que influencia na arquitetura, através da proibição de aberturas, sejam portas ou janelas, no alinhamento dessas passagens.

Os becos algumas vezes abrigam, segundo relatos de época, atividades que entram em conflito com a ordem urbana que se pretende implantar na passagem do século XIX para o XX. Sua constituição formal lhe atribui, geralmente, uma imagem obscura, por muito tempo apontado como o local de concentração da desordem urbana, onde se encontram, mais frequentemente, os amontoamentos de lixo. Ao mesmo tempo, eles abrigam as relações sociais que a administração urbana busca extinguir, pois neles as camadas populares mantém formas próprias de sociabilidade.

No fim do século XIX, quando se fortalece o discurso e as preocupações em relação à ordem urbana, criticando-se de forma mais intensa a estrutura física da cidade, os becos assumem maior evidência na

\footnotetext{
190 VIEIRA, Frei Domingos. Grande Diccionario Portuguez ou Thesouro da Língua Portugueza. Porto: Casa dos editores Ernesto Chardon e Bartholomeu H. de Moraes,1871.

${ }^{191}$ REIS, Nestor Goulart. "A Urbanização e o Urbanismo na Região das Minas". Cadernos de Pesquisa do LAP. Série Urbanização e Urbanismo. Jul-dez 99, n. 30. São Paulo, FAU- USP, p.21.
} 
denúncia desses problemas. Eles se configuram como território dos negros, vagabundos e marginais. É também neles que, durante as festas públicas a exemplo dos carnavais, realizam-se desmandos, como notificado por cronistas que denunciam os que entram nos becos durante as festa, no intuito de praticar algo proibido ou não factível em público. Os becos da capital paraibana também se tornam alvos de críticas, assim como ocorre em várias cidades que passam por esse processo, como aponta Sandra Pesavento a respeito dos becos de Porto Alegre:

\begin{abstract}
"o beco foi identificado como reduto das sociabilidades condenadas, um espaço maldito na cidade, freqüentado pelos "turbulentos" da urbe. A situação se definia tanto mais grave porque tais espaços estigmatizados se achavam encravados no centro da cidade, que se encontrava em processo de renovação e saneamento, tanto técnico quanto moral"192.
\end{abstract}

Na cidade da Parahyba do Norte, um dos becos mais mencionados em documentos de época é o da Misericórdia. Situado na lateral da igreja de mesmo nome, ele é constantemente apontado pelo seu estado de insalubridade e desordem, além das atividades julgadas inadequadas ao meio urbano, lá praticadas. Esse histórico o coloca de imediato nas pautas das reformas locais, incluindo-o no rol dos espaços remodelados no início do século XX, segundo um discurso em prol da salubridade e ordem urbana.

Assim, mesmo não sendo elemento predominante do espaço urbano oitocentista, os becos abrigam muitas das características formais e de usos que se pretende modificar, imagem que se pretende extinguir, o que lhes confere o caráter simbólico da cidade em processo de transformação.

\title{
"TRAVÉSSA s.f. Rua que corta as ruas directas, e principaes. Caminho atravessado"193
}

Como explícito no seu significado, as travessas são ruas secundárias que fazem ligações entre as principais. São elementos marcantes na cartografia oitocentista, onde às vias principais e espaços públicos, como campos e largos, liga-se uma travessa que daqueles recebem o mesmo nome. Observando os mapas e alguns relatos onde são mencionadas, percebese que esses elementos dispõem de pequeno trajeto e são muito usados para encurtar distâncias. Apesar de suas pequenas dimensões e pouca repercussão nos relatos desse período, esses são espaços referenciais por ligarem elementos importantes do conjunto urbano,

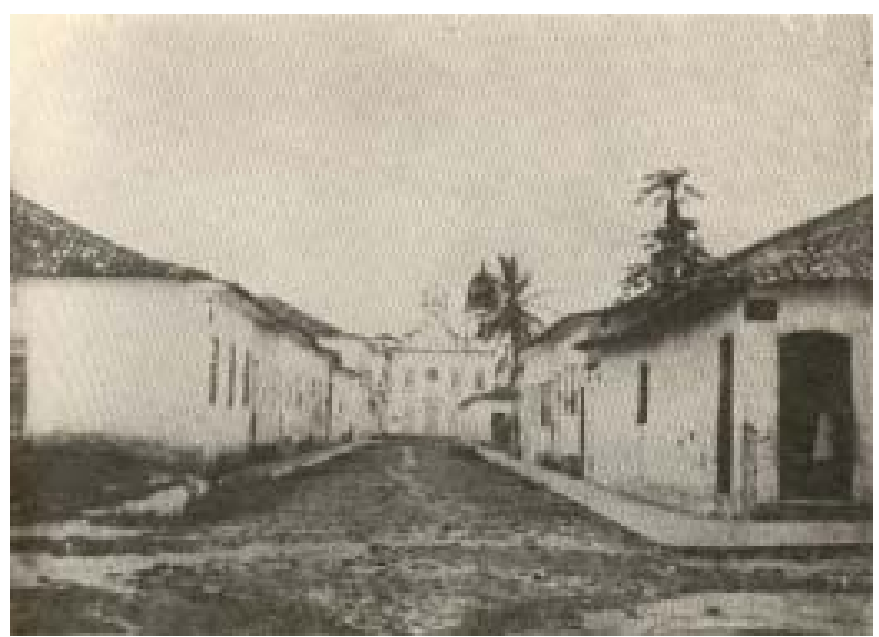

1877 - Antiga travessa do Carmo, depois travessa Conselheiro Henriques. No fim, a igreja do Carmo. FONTE: Acervo Walfredo Rodrigues. relacionando-se a eles pela sua denominação.

Encurtando percursos e ligando os principais espaços do conjunto urbano, muitas dessas travessas são criadas a partir do uso cotidiano das áreas públicas, onde os caminhos trilhados recorrentemente pela população, no trajeto entre os locais de uso mais constante, consolidam-se em travessas que são referenciadas por esses mesmos espaços, que também lhes dão o nome.

\footnotetext{
192 PESAVENTO, Sandra Jatahy. "Era uma vez o beco: origens de um mau lugar". In: BRESCIANI, Maria S. Palavras da Cidade. Porto Alegre: Ed. Universidade/ UFRGS, 2001, p. 98.

${ }^{193}$ SILVA, Antonio de Moraes. Diccionario da Língua portugueza dos vocabulários impressos ate' agora, e nessa segunda edição novamente emendado, e muito accrescentado. Lisboa: Typographia Lacérdina, 1813.
} 
As ladeiras são elementos que marcam as cidades coloniais brasileiras, constituindo-se elementos representativos da expansão desses conjuntos urbanos que têm como característica de fundação a implantação em áreas íngremes. Na capital paraibana, essas vias são os principais consolidadores da estrutura urbana apresentada no fim do século XIX, por serem os principais elos de ligação entre a cidade alta e a região do Varadouro, caracterizando o

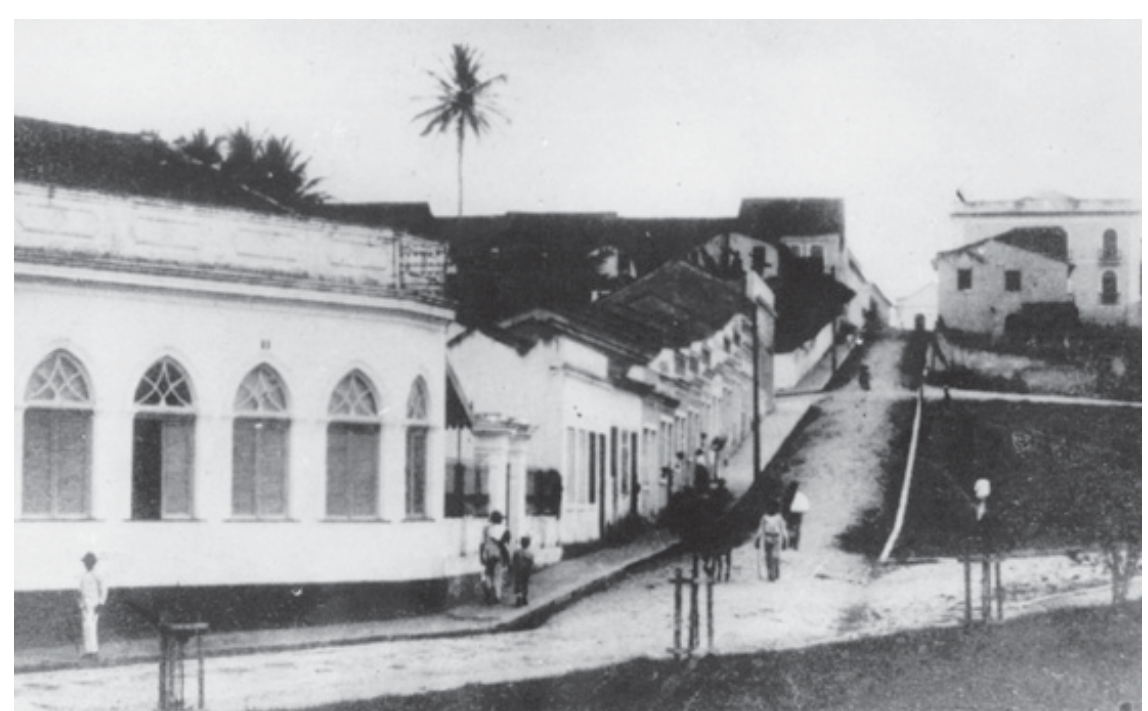

1905- Ladeira das Pedras, depois rua do Consumo e da Carioca, atual rua Peregrino de Carvalho FONTE: Acervo Laudereida Marques. crescimento citadino que forma o conjunto urbano oitocentista.

Criadas a partir da necessidade de levar a cidade às margens do rio, expandi-la e desenvolver as atividades comerciais na região portuária, são responsáveis pela forma irregular que a cidade assume nesse momento, a partir da sua construção segundo uma melhor adaptação ao solo, seguindo um percurso que leva a um trajeto menos íngreme, mesmo que tortuoso.

Das ladeiras dessa capital destacam-se a de São Francisco e da Borborema, as mais extensas e que ligam as duas porções da cidade a partir de pontos referenciais: igreja de São Francisco e Largo da Matriz. Surgidos da necessidade de ligar o núcleo urbano à região portuária, algumas ladeiras nascem junto com o povoado, quando não passam de caminhos para esse fim. Assim, elas se tornam as principais responsáveis pelo abastecimento geral da cidade, posto que a comunicação externa é feita pelo rio Sanhauá, por onde chegam os suprimentos para as necessidades urbanas.

"RUA s.f. Espaço entre as casas, nas povoações, por onde se anda e passeia"195.

Inicialmente, nas povoações brasileiras, as ruas assumem quase que basicamente a função de percurso, ligando prédios e conformando caminhos de homens e animais segundo as condições topográficas mais adequadas. Na sua maioria, não são tidas como lugar de permanência, o que contribui para um movimento reduzido, principalmente à noite. Isso a diferencia do beco que, apesar de, por definição, também ser um lugar de passagem, constitue um ambiente mais propício a aglomerações e sociabilidades. Na antiga João Pessoa, esse perfil urbano pode ser percebido tanto nos relatos de viajantes ao longo do período colonial como na iconografia da cidade do século XIX, onde as ruas aparecem vazias ou, quando muito, com alguns homens, meninos e escravas.

Na passagem do século XIX para o XX, a cidade da Parahyba do Norte passa por transformações no sentido de modificação formal e de uso de algumas ruas, que passam a apresentar uma nova função no

194 SILVA, Antonio de Moraes. Diccionario da Língua portugueza dos vocabulários impressos ate' agora, e nessa segunda edição novamente emendado, e muito accrescentado. Lisboa: Typographia Lacérdina, 1813.

${ }^{195}$ VIEIRA, Frei Domingos. Grande Diccionario Portuguez ou Thesouro da Língua Portugueza. Porto: Casa dos editores Ernesto Chardon e Bartholomeu H. de Moraes,1871. 
espaço urbano. Algumas delas desenvolvem a característica de local de permanência, principalmente as que passam a reunir atividades comerciais e de serviços, o que atrai a população em determinado período do dia, prolongando o tempo de fluxo dos usuários. Segundo essa nova configuração, a rua Maciel Pinheiro se consolida como 'a rua do comércio', tornando-se pioneira desse processo e apresentando, em seu trajeto, uma aparência inovadora da rua no contexto urbano.

As ruas adquirem uma nova importância plástica, onde suas formas, através do alinhamento, construção de calçadas, calçamentos, iluminação e, inclusive, da arquitetura, passam a ser elaboradas com o objetivo de expor coisas e pessoas. As edificações investem em um novo aspecto estético, de forma que a fachada da rua ganha crescente ênfase. Aumenta o interesse formal que ao longo da história se estabelece entre a cidade e as ruas, onde as edificações passam a ser parte constituinte das vias como elemento estético.

A partir do destaque gradativa e crescentemente delegado às edificações diante dos espaços públicos onde estão locadas, percebe-se a construção de uma identidade formal em diferentes ruas, de acordo com a arquitetura e atividades a que se destinam. Alguns exemplos, como as ruas Direita e Nova, tornam-se referência por sua arquitetura predominantemente residencial, com grande número de sobrados e algumas igrejas. Da mesma forma, as ruas Maciel Pinheiro e Convertidas também assumem uma identidade formal específica, promovida pelo conjunto de sobrados comerciais, inclusive apresentando a peculiaridade do sobrado de dois andares,

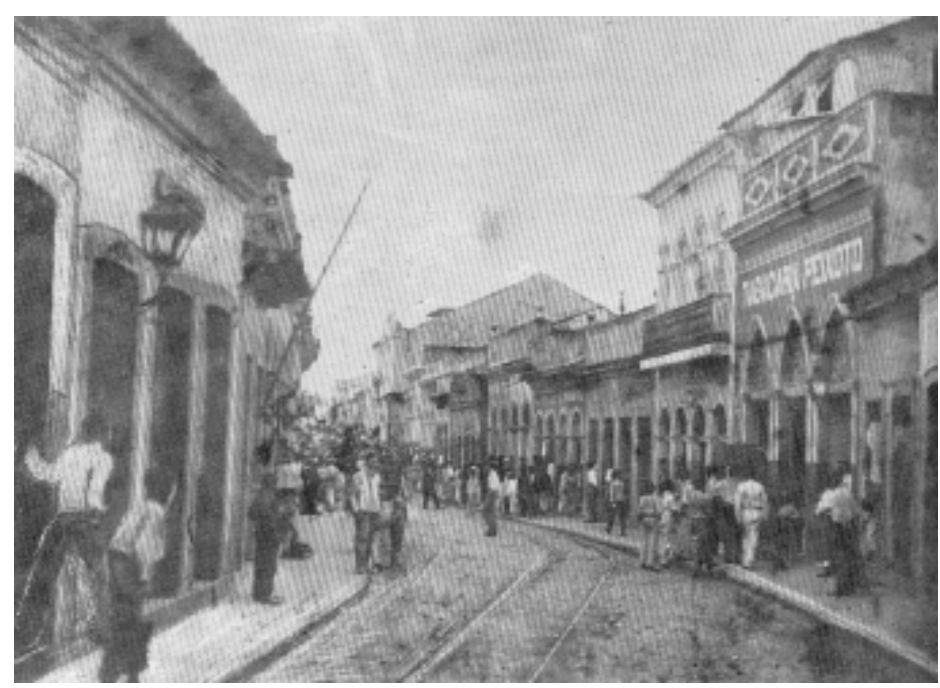

1903 - Antiga rua do Comércio, no Varadouro, atual Marciel Pinheiro. FONTE: Acervo Humberto Nóbrega

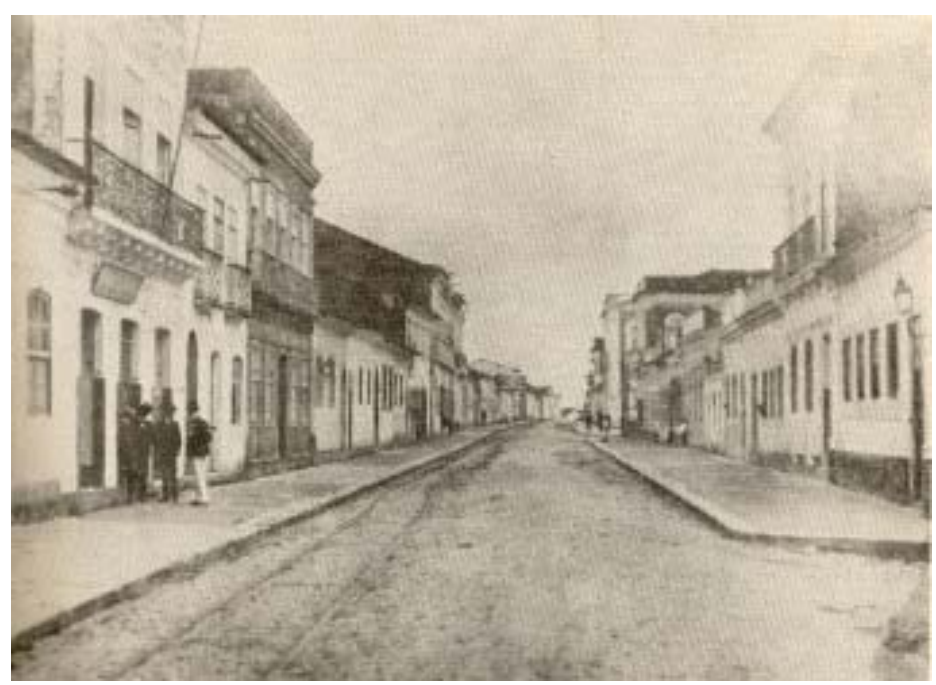

1904 - Rua Direita, atual Duque de Caxias.

FONTE: Acervo Walfredo Rodrigues.

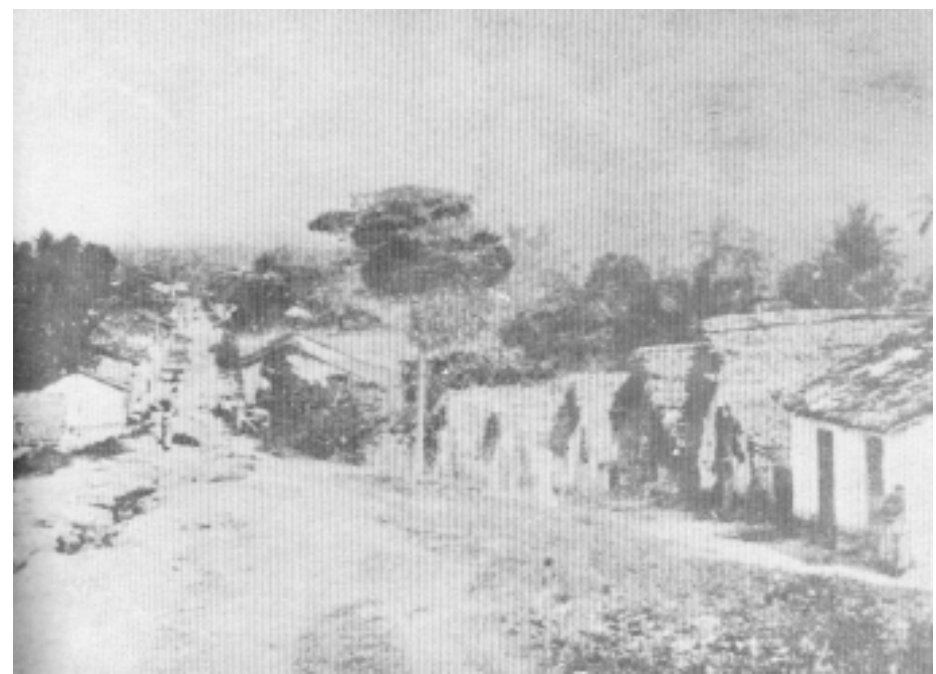

1870 - Antiga rua Imperatriz, atual da República.

FONTE: Acervo Humberto Nóbrega na capital paraibana mais comum às atividades comerciais. Já as ruas localizadas nos arredores da cidade assemelham-se pelo conjunto de casas térreas e casebres, bem como pelos seus poucos transeuntes. 


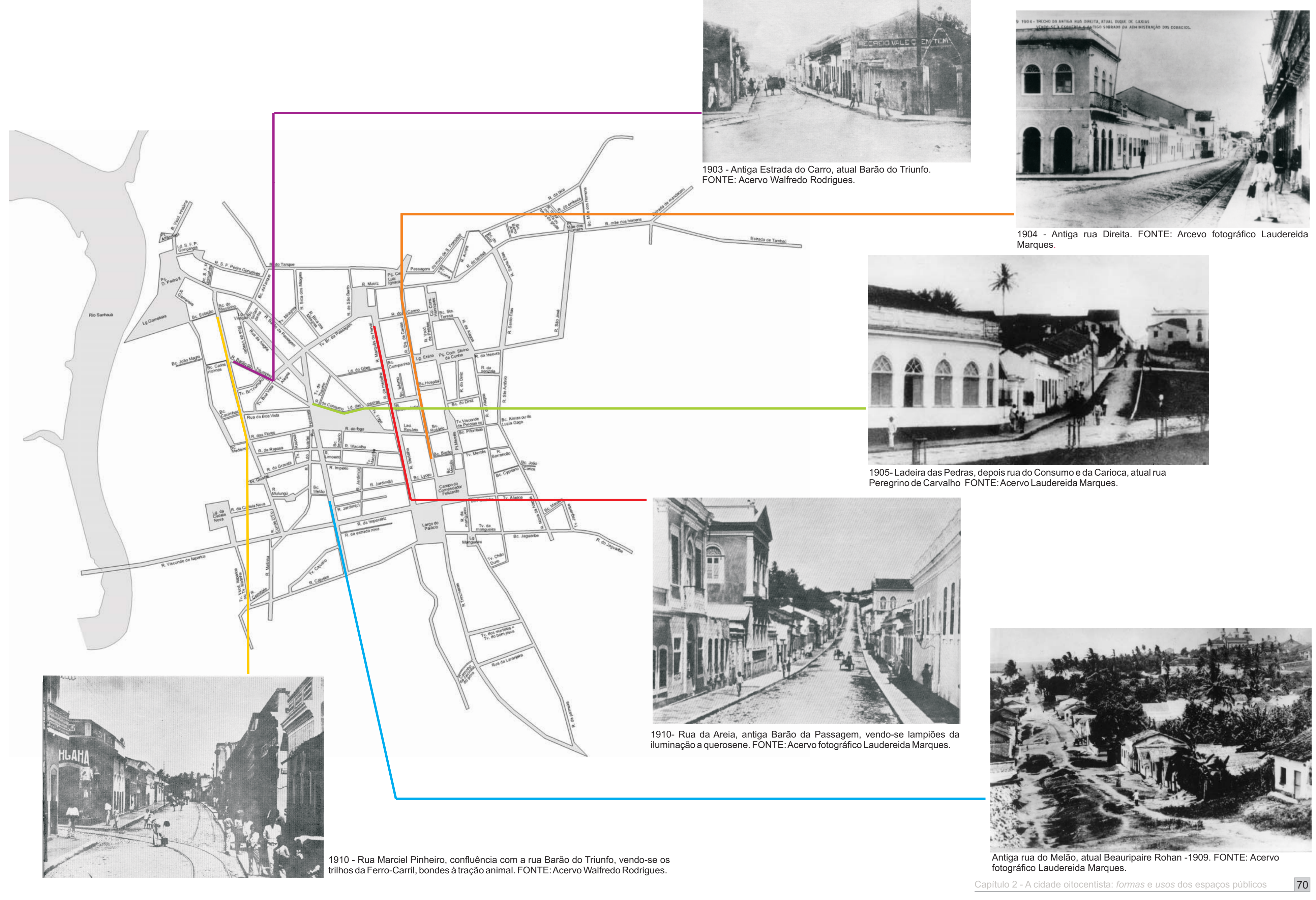


Considerando a hierarquia das formas e dos nomes dos espaços de passagem desse momento becos, travessas, ladeiras, etc-, a rua, pelas suas características formais e representatividade urbanística, é o elemento de maior peso, inclusive quantitativo, do conjunto urbano oitocentista. Em fins do século XIX, a maior parte das vias da cidade da Parahyba do Norte é composta por ruas, muitas delas estreitas e tortuosas, apesar de alguns procedimentos desenvolvidos no sentido de retificá-las.

\title{
2.3.2 Espaços de permanência
}

Na documentação portuguesa relativa à implantação dos primeiros povoados brasileiros, percebe-se, entre os primeiros espaços a serem instalados, a designação de incluir uma praça, para onde convergem alguns dos mais importantes elementos urbanos, sejam vias ou edificações administrativas, eclesiásticas e residenciais.

\begin{abstract}
"Sou servido ordenar-vos que, passando às referidas freguezias, depois de haverdes feito a relação dos moradores que se oferecem para povoar as referidas vilas, convocareis todos para determinados dias, nos quais sendo presente o povo, determineis o lugar mais próprio para servir de praça a cada uma das ditas vilas, fazendo levantar no meio delas o pelourinho, assinando área, para se edificar uma igreja, capaz de receber um competente número de fregueses, quando a povoação se aumentar, como também das outras áreas competentes para as casas, das recreações e Audiências, cadeias, e mais oficinas públicas, fazendo delinear as casas dos moradores por linha reta, de sorte que fiquem largas e direitas as ruas"196.
\end{abstract}

Segundo Manuel Teixera, no Brasil, as primeiras praças geometrizadas surgem no século XVI, vinculadas a espaços religiosos, afirmando-se seu rigor formal ao longo dos século XVII e XVIII. Centralizados na malha urbana, neles se implantam as principais funções da cidade. A partir do século XVII, a praça vai adquirindo o papel de gerador do traçado e passa a ser concebida como "centro simbólico, funcional e formal da cidade”*197.

"As praças, com uma forma regular e localizadas centralmente na malha urbana, assumiam o papel de elemento gerador do traçado: era nelas que se implantavam os principais edifícios institucionais da cidade - nomeadamente a casa da câmara e cadeia, a misericórdia, e a igreja matriz - e era a partir delas que se definiam as principais direcções e o traçado ortogonal das ruas" ${ }^{198 .}$

Nestor Goulart afirma que a organização desses centros utiliza as praças como forma de valorização das áreas de maior interesse da comunidade, onde algumas edificações de importância articulam-se à geração de um espaço livre destinado à aglomeração popular. Essa estratégia, de certo modo, revela uma intenção de controle, onde algumas funções administrativas se concentram em locais específicos, conferindo às ruas as funções de ligação e acesso a esses pontos principais.

Esses locais recebem tratamento especial, assumindo escalas compatíveis com sua importância simbólica. Constituem pontos focais urbanos, possibilitando maior riqueza de perspectivas que valorizam suas formas, através, inclusive, das principais fachadas dos edifícios oficiais ou religiosos que se encontram em seu entorno, além do seu valor simbólico, reservado às reuniões cívicas e, geralmente, abrigando o pelourinho, símbolo da autonomia municipal.

A capital paraibana, não fugindo à regra, também tem seu núcleo inicial reunido numa praça, em torno da qual se concentram as principais edificações do povoado e a partir da qual se desenvolvem as primeiras ruas,

\footnotetext{
${ }_{196}$ Carta Régia de 19/6/1761. In: SANTOS, Paulo Ferreira. Formação de cidades no Brasil Colonial. Rio de Janeiro: UFRJ, 2001, p.57. ${ }^{197}$ TEIXERA, C. Manuel. "Os modelos urbanos portugueses da cidade brasileira". In: TEIXERA, C. Manuel (coord.). A construção da cidade brasileira. Lisboa: Livros horizonte, 2004, p. 29.

${ }^{198}$ Ibid., p. 26.
} 
como também ocorre, segundo Nestor Goulart Filho, em centros urbanos menores. Porém, percebe-se nesse caso específico, no período oitocentista, características que, segundo o mesmo autor, são típicas das grandes cidades em formação, cujas praças ganham especialização, "diferindo segundo funções cívicas ou religiosas"199, como ocorre em Salvador.

$\mathrm{Na}$ toponímia dos espaços públicos da antiga João Pessoa, as praças aparecem como elementos típicos do início do século XX. Até o século anterior prevalecem pátios, largos e campos que, a partir de então, passam a conviver com as praças. Nesse caso, as atribuições e formas conferidas às 'praças' das cidades coloniais são assumidas por esses outros espaços, que condensam em si tais significados. Por outro lado, a praça assume, no século XX, outros significados, formas e funções que refletem um novo contexto urbano. $A$ observação da sua toponímia e dos seus usos aponta para uma provável utilização do termo praça de forma não específica para os demais espaços de uso permanente, assim como se percebe nas descrições desse período, que se referem aos espaços batizados de largos, campos e pátios, através do nome praça.

Dessa forma, nessa cidade, até fins do século XIX, percebe-se a predominância de largos, pátios e campos, enquanto o espaço com a denominação de praça firma-se no início do século XX como um espaço simbólico de novos ideais urbanísticos.

\section{"CÁMPO, pedaço de terra baixa, e plana. Terra fora da cidade. O arraial militar"200.}

Áreas não edificadas e sem tratamento urbanístico, os espaços assim intitulados são, na maioria das vezes, utilizados para fins militares. Instalados na periferia da cidade, não são objeto de uso cotidiano pela população, destinando-se a atividades e treinamento militares. Na capital paraibana, são encontrados, geralmente, nas proximidades dos conventos que, no início, situam-se comumente nas periferias, a exemplo do Campo do Commendador Felizardo, localizado na frente do Convento dos Jesuítas. Com o crescimento urbano, esses espaços são englobados pelo conjunto urbano e passam, gradativamente, a assumir outros papéis no novo contexto em que são absorvidos. Em fins do século XIX, essa cidade apresenta alguns desses espaços antes afastados, que aos poucos desempenham outras funções, recebendo também novas formas e outros nomes, a exemplo do Campo do Commendador Felizardo, nesse momento transformado em Jardim Público e, posteriormente, na Praça João Pessoa. Quando englobados pela cidade, aproximando-se das áreas de movimento cotidiano, os campos deixam de ter função predominantemente militar. Mesmo mantendo a denominação de campo, eles passam a abrigar diferentes tipos de atividades como jogos, feiras e festas.

"LARGO, s.m. pequena praça"201.

Formalmente apresentados na conformação urbana como alargamento de vias diante de uma edificação de referência, os largos da capital paraibana se apresentam, no fim do século XIX, como espaços quantitativamente relevantes e de grande representatividade na cidade. O Largo da Matriz é o primeiro "espaço público" construído na cidade, reunindo as primeiras edificações referenciais do conjunto urbano, o que Ihe confere o papel das "praças" atribuídos pela Coroa portuguesa no processo de formação das cidades brasileiras.

Sua importância na formação da cidade da Parahyba do Norte encontra-se sempre explícita nos primeiros relatos acerca da cidade:

\footnotetext{
${ }^{199}$ REIS FILHO, Nestor Goulart. Contribuição ao estudo da evolução urbana do Brasil (1500-1720) São Paulo : Liv. Pioneira e Ed. da Universidade, 1968, p.136.

${ }^{200}$ SILVA, Antonio de Moraes. Diccionario da Língua portugueza dos vocabulários impressos ate' agora, e nessa segunda edição novamente emendado, e muito accrescentado. Lisboa: Typographia Lacérdina, 1813.

${ }^{201}$ VIEIRA, Frei Domingos. Grande Diccionario Portuguez ou Thesouro da Língua Portugueza. Porto: Casa dos editores Ernesto Chardon e Bartholomeu H. de Moraes,1871
} 
"A casa para Cadeia, Camara e Açougues foi logo também levantada defronte da Matriz e dahi mudada depois. Diversos moradores accolhidos a [sua] sombra estenderam suas edificações rua afora, (...) [formando] a primeira rua construída na Capital"202.

Assim, o Largo da Matriz reune em si um conjunto de funções: administração, comércio, religião e moradia. O largo, conforme assinala Murilo Marx referindo-se às cidades brasileiras da época, abriga a "feira, a procissão, o pretexto de encontro"203. São palcos importantes da vida urbana colonial, legando esse perfil ao período oitocentista.

Geralmente situados em frente às igrejas, mas também nas imediações de edificações de função representativa da ordem urbana ou de outros elementos referenciais - a exemplo dos largos da Cadeia, da Viração, da Gameleira -, os largos atraem para seu entorno as principais atividades e construções do período colonial, ainda visíveis no final do século XIX . Concentrando os principais elementos urbanos, deles partem as primeiras ruas, becos e travessas, estabelecendo perspectivas onde eles podem ser lidos como continuação das vias, que se alargam diante das edificações mais significativas, proporcionando um espaço de aglomeração. Assim, assumem papel de grande representatividade dos espaços urbanos, tanto na relação formal que estabelecem com os demais elementos do conjunto, quanto nas atividades que movem o cotidiano citadino.

Essa participação dos largos na vida citadina também é acentuada pelo papel da Igreja na cidade de então, quando essa instituição é referência essencial para a vida cotidiana. Seu sino organiza o uso do tempo e é mensageiro de boas e más notícias. Os largos são palcos de atividades religiosas e onde se organizam os cortejos.

Além de refletir como a população utiliza os espaços urbanos, os largos são de grande representatividade formal. Como ocorre desde a fundação da cidade, a ascendência de igrejas entre as edificações do conjunto urbano 204 apresenta como conseqüência natural a forte presença de largos no cenário citadino. Esse quadro se

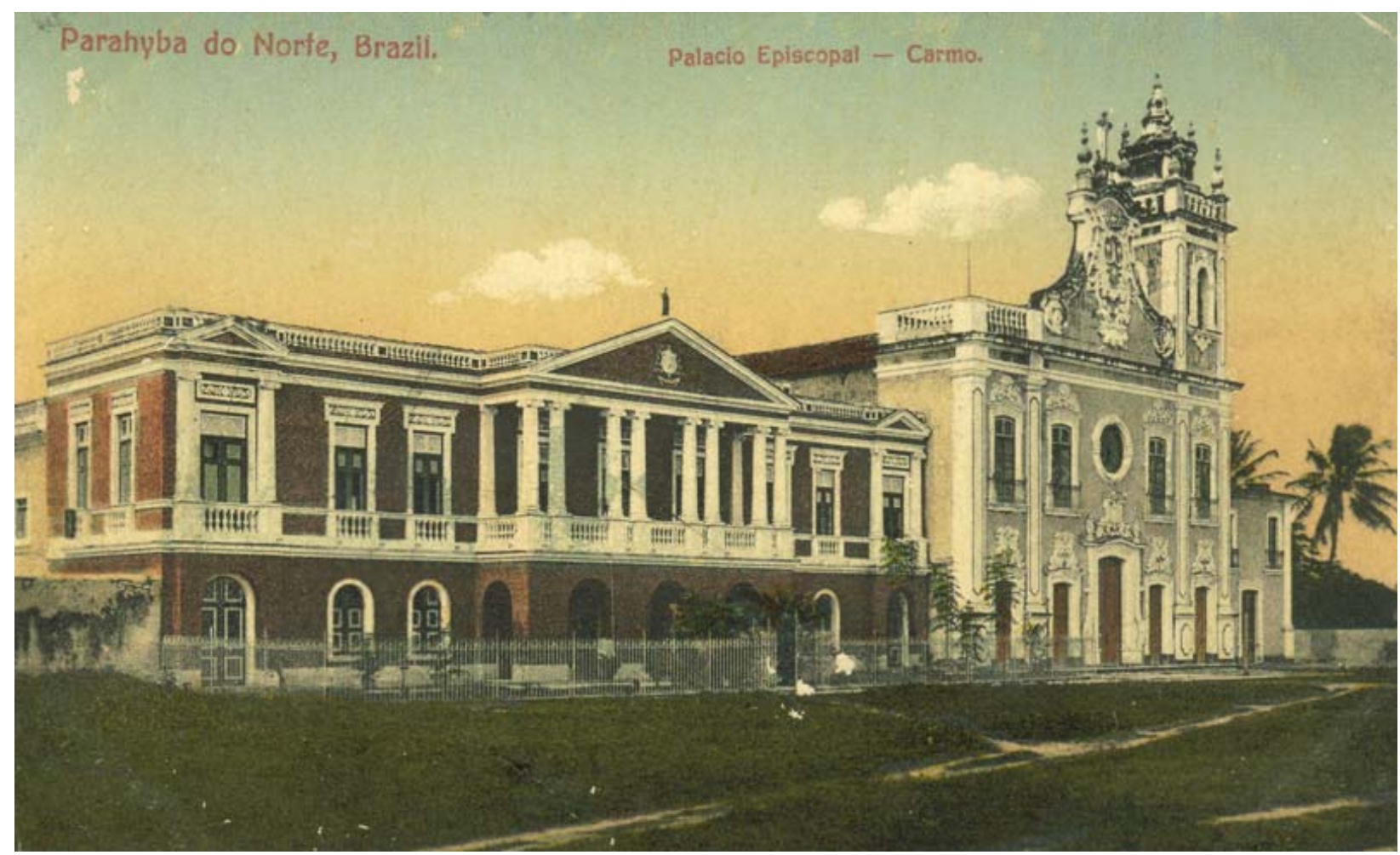

Antigo Largo do Carmo. FONTE: Acervo Humberto Nóbrega

\footnotetext{
202 PINTO, Irineu F. Datas e notas para a história da Paraíba. 2a ed. João Pessoa: Editora Universitária, 1977, p. 22.

${ }^{203}$ MARX, Murilo. Cidades brasileiras - 1945. São Paulo: Melhoramentos: Ed. da Universidade de São Paulo,1980, p.43.

204 Nos relatos e mapas seiscentistas, a cidade da Parahyba do Norte conta com três ruas escassamente edificadas, além de becos

e travessas, e dispõe de seis edificações eclesiásticas, entre igrejas e conventos, número que se multiplica no século XVIII.
} 
estende até fins do século XIX, como se verifica no ano de 1889, quando dos vinte "espaços públicos"205 existentes nessa capital, assinalados por Vicente Gomes Jardim, oito eram largos ${ }^{206}$.

"PRÁÇAS, s.f., lugar público, descoberto, espaçoso nas villas, ou cidades, onde se fazem feiras, mercados, leilões; onde se tratão coisas de commercio"207.

Percebe-se que até o século XIX a praça é descrita muito mais pelo tipo de apropriação desse espaço, enquanto palco de atividades urbanas, que pela sua organização formal. No século seguinte, esses espaços destacam-se, na capital paraibana, como renovadores do conjunto urbano. Até então em minoria, entre largos, pátios e campos, as praças passam a predominar nesse cenário. Nesse momento, elas se comportam mais como anunciadoras do interesse de remodelação das formas urbanas que como consolidadoras desse ideal, pois apesar de assim intituladas, sua aparência pouco se diferencia da

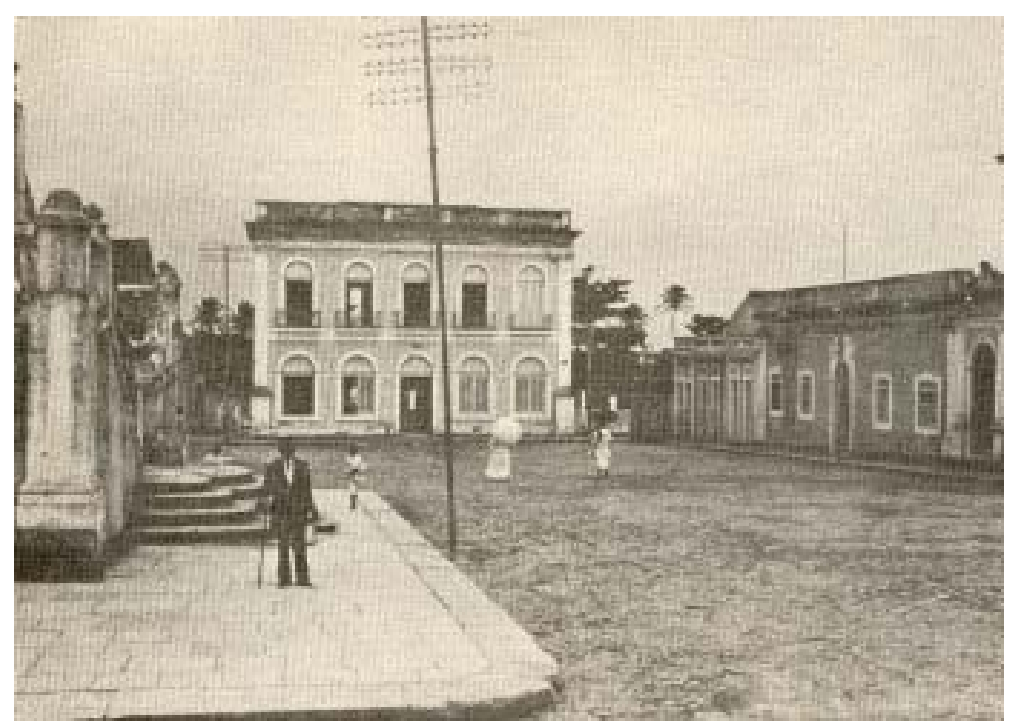

1910 - Praça Rio Branco, antigo Largo do Erário, vendo-se o prédio da Cadeia Velha, na época Paço Municipal. FONTE: Acervo Walfredo Rodrigues. daqueles espaços tipicamente coloniais, o que ocorre, de fato, no início do século seguinte.

A praça, não mais idealizada como espaço aberto propício às atividades comerciais, passa a ser vista como um espaço predominantemente de lazer e contemplação, formada por uma área dotada de jardins e coretos, e destinadas a atividades de recreação. É nesse momento que surge o primeiro Jardim Público na cidade: "o jardim público, com as palmeiras imperiais, arvoredos altos, renques de pitangueira, fechado em gradil de ferro (...) foi construído pelo vice-presidente padre Galvão cerca de 1870"208.

Na passagem do século XIX para o XX o espaço urbano da capital paraibana sofre intervenções pontuais, no intuito de transformar os 'traços da cidade colonial' que nela permanecem. Algumas vias são alinhadas e calçadas, e, principalmente nas décadas de 1910 e 1920, é visível a inserção de elementos precursores da nova etapa de reestruturação do cenário da cidade, onde praças se instalam em antigos largos, pátios, e campos.

Praças passam a ser dotadas de elementos como jardins, bancos, rink de patinação, coretos, etc, o que Ihes conforma um uso inovador de lazer e contemplação. Muitos são os artigos e as crônicas que revelam a mudança da utilização e do significado desses espaços para a sociedade, onde as novas formas urbanas e os diferentes tipos de apropriação revelam a transformação das áreas públicas nesse período.

Largos, pátios e campos dão lugar às praças que dispõem de grande dimensão simbólica diante do contexto em que se encontram. Elas não representam apenas um espaço, mas o anúncio de uma concepção de cidade que se constrói e se põe em prática naquele momento, representada pela sua forma, pelos usos a ela conferidos e pela sua denominação. Sinalizando as alterações das 'formas coloniais', a aparição desses

\footnotetext{
${ }^{205} \mathrm{O}$ termo espaço público é utilizado no sentido de espaços urbanos de uso público, onde se enumeram largos, campos, pátios, praças, etc. 206 JARDIM, Vicente Gomes. "Monographia da Cidade da Parahyba do Norte". Revista do IHGP. João Pessoa, n.3, p.83-111, 1911 207 SILVA, Antonio de Moraes. Diccionario da Língua portugueza dos vocabulários impressos ate' agora, e nessa segunda edição novamente emendado, e muito accrescentado. Lisboa: Typographia Lacérdina, 1813.
}

208 MARIZ, Celso. Evolução econômica da Paraíba. João Pessoa: A União, 1978. p.89. 
elementos no espaço urbano, em fins do século XIX, é de grande significado para o processo de intervenções que se desencadea nessa cidade nas primeiras décadas do século seguinte, onde a praça é a principal inovação da forma urbana.

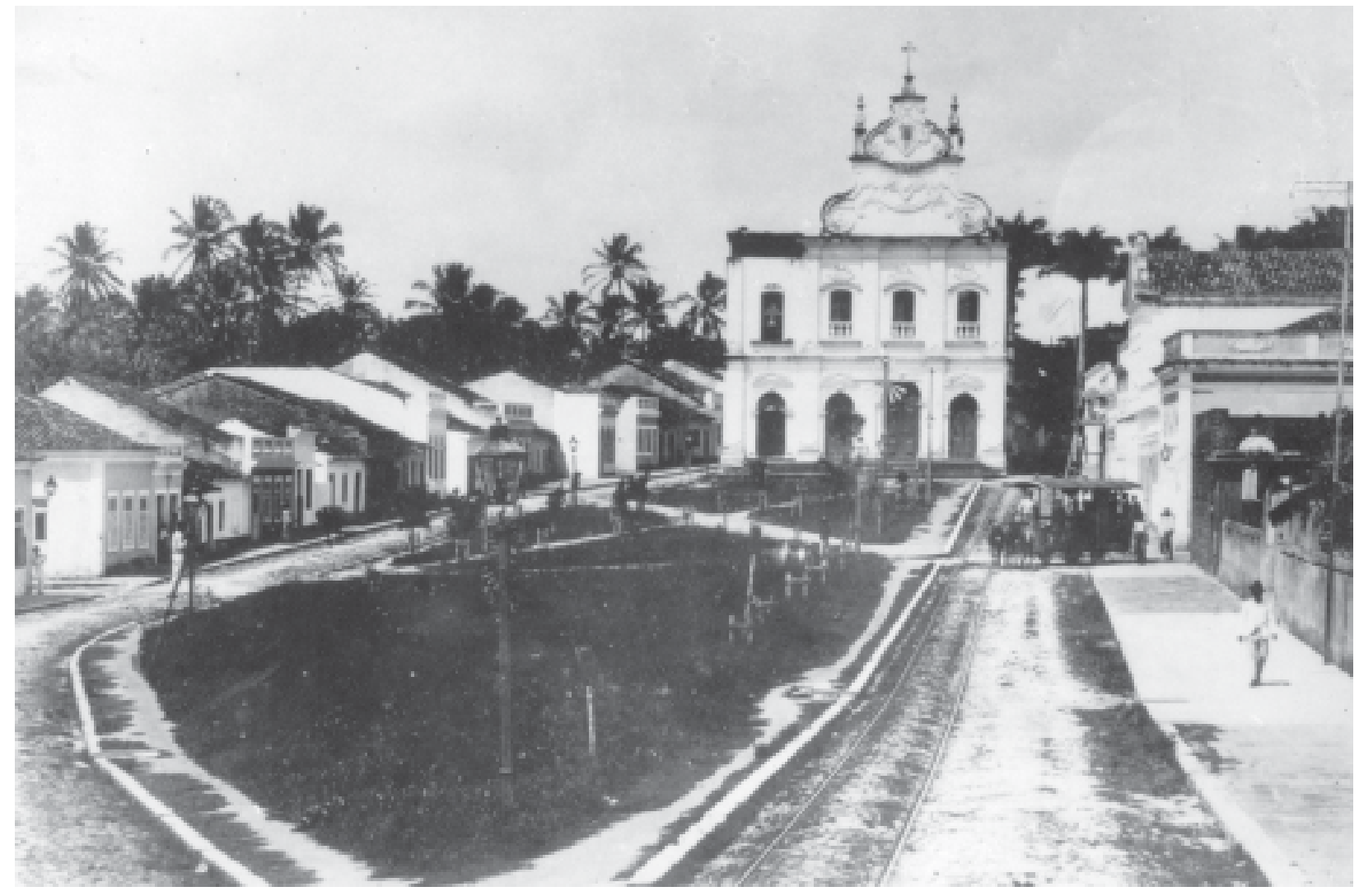

1910 - Antiga Praça das Mercês, atual praça 1817. Observa-se a implantação incial de arborização ordenada e a delimitação dos passeios. Porém, ainda guarda forte relação com a 'ordem' dos espaços públicos de antes. Vê-se também, à esquerda, um bonde à tração animal. FONTE: Acervo Laudereida Marques.

\subsubsection{Os nomes dos espaços públicos}

"Com efeito, um topônimo aparece em um determinado lugar, às vezes não se sabe dado por quem, fruto da população anônima, entranha-se de tal forma ao lugar que passa a incorporar o significado do local, como se um e outro fossem a mesma coisa, verdadeira imagem mimética do referente, reprodução de suas características; por mais de uma geração, o nome pode permanecer definindo a área até que fatos posteriores, aleatoriamente ou não, acabem por imprimir novo rumo ao chamamento." 209

O sistema denominativo é um reflexo de tudo aquilo que representa, cumulativamente, hábitos, usos, costumes, moral, ética, política e religião. Os parâmetros são proporcionais às impressões provocadas por um conjunto de circunstâncias comuns ${ }^{210}$. No processo denominativo inicial das partes das cidades do Brasil colonial é comum que a natureza e a religião sejam referenciais denominativos, evidenciando, inclusive, na religião a crença do português, e na natureza o que lhe salta aos olhos como diferencial da nova terra. Com a formação dos núcleos urbanos, os 'cantos' das cidades são paulatinamente batizados também pela população, que imprime nos espaços nomes que revelam suas especificidades através de seus atores, cotidiano,

${ }^{209}$ DICK, Maria Vicentina de Paula do Amaral. A Dinâmica dos Nomes na Cidade de São Paulo 1554-1897. São Paulo: Annablume, 1996, p.22..

${ }^{210} \mathrm{Ibid} ., \mathrm{p} .13$. 

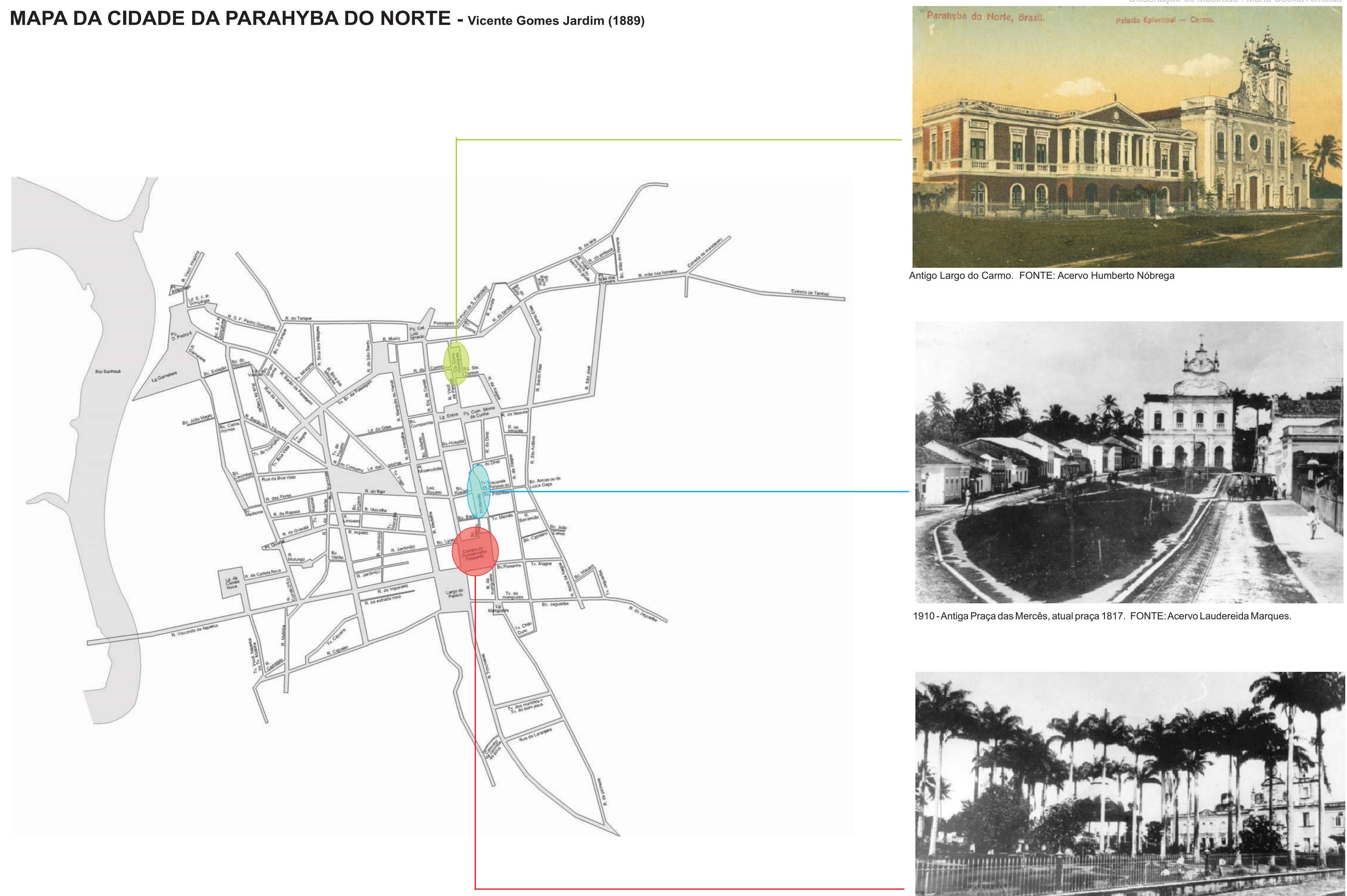

1910 -Antiga Praça das Mercês, atual praça 1817. FONTE: Acervo Laudereida Marques.

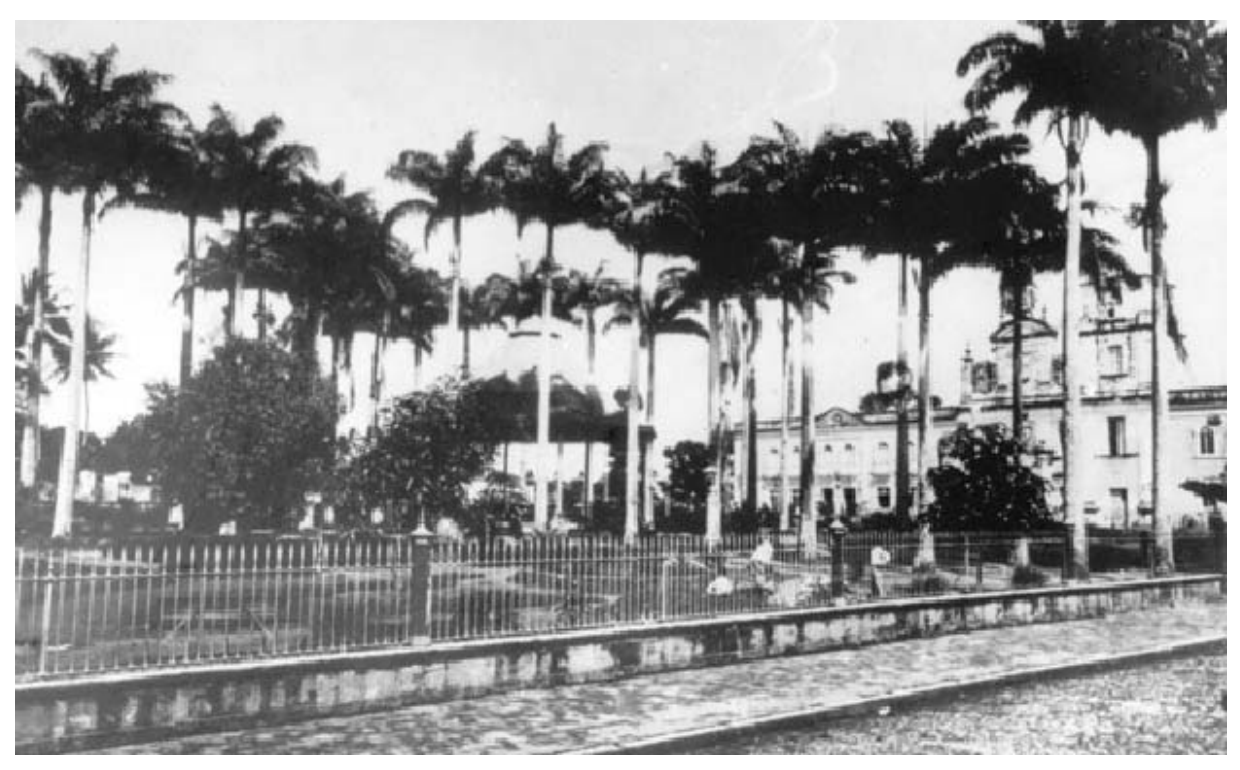


acontecimentos locais, etc.

Considerando a comum ocorrência da fundação de cidades nos cursos de rios, pela necessidade de comunicação com outras terras e de atividades portuárias, é recorrente a influência recíproca da denominação da terra e do rio. Assim, muitas vezes, o rio empresta seu nome à localidade urbana que lhe surge às margens. A exemplo da relação entre os rios Acre e Amazonas e os estados que esses banham, o rio Parahyba deixa seu nome não apenas no estado, mas também na sua capital.

No tempo dos portugueses, quando essa região é feita capitania, que significa "província onde tem mando um capitão" ${ }^{211}$, essa terra é batizada de Parahyba, palavra que significa

"um mar corrompido, uma água má, outrossim, um porto mau para se entrar , e, segundo explicam as pessoas mais versadas nessa língua, quer dizer um porto sinuoso, cuja entrada é má; pois Pará quer dizer rio ou porto com uma curva, e Yba significa máu, donde se segue que esse rio, o maior dessa região, tira seu nome da boca ou entrada sinuosa que tem, e por sua vez a região tira seu nome do rio, que se chama Paraíba"12.

A capital do estado da Parahyba do Norte, banhada por um dos braços do rio de mesmo nome, por sua vez batizado de Sanhauá, recebe no momento de sua fundação o nome de cidade de Nossa Senhora das Neves, "por causa dos incômodos que passaram, de tormentas e ventos, até o dia em que começaram a estabelecerse aí e a construir casa"213, dia esse, segundo o calendário religioso, reservado a essa santa. Mais tarde, recebe o nome de Felipéia de Nossa Senhora das Neves, em homenagem a Felipe, rei da Espanha, nome que se conserva até a tomada da cidade pelos holandeses, quando, em homenagem ao Príncipe Orange, substitui-se a denominação pela de Frederica ou Frederikstadt. Expulso os holandeses, a capital passa a ser homônima do estado a que pertence, chamando-se Cidade da Parahyba do Norte até a morte do governador João Pessoa, em 1930, de quem herda o nome até os dias atuais.

Percebe-se que as alterações denominativas da cidade contam parte de sua história, onde cada nome simboliza um acontecimento, uma referência que justifique seu batismo. Da mesma forma, os nomes dos espaços que compõem a cidade em diferentes períodos, ao serem designados ou alterados, revelam os valores e as preocupações urbanísticas de cada momento, tornando-se uma veia de interpretação das transformações urbanas.

A capital paraibana de 1889, segundo a Monographia apresentada por Gomes Jardim, é uma cidade formada por espaços denominados de ladeiras, becos, ruas, travessas, pátios, campos, caminhos, praças e largos. Apesar da presença ainda marcante de becos e travessas no cenário urbano, as reformas ainda incipientes naquele momento, além de sinalizarem alterações formais, apresentam os primeiros ajustes referentes aos nomes dos espaços públicos, a fim de alinhá-los com os ideais que os conduzem às novas formas.

"O fenômeno se opéra na Paraíba, como alhures, ora à razão de transformações materiais, ora pela idéia de consagrar vultos e fatos da História, só raramente por méros preitos pessoais ou por simples ogerisa de ouvido a velhas denominações"214.

Muitos desses espaços ainda têm nomes provenientes de referenciais do entorno no qual estão inseridos, como edificações ou elementos da natureza, e ainda que se remetem a alguma personagem local ou um fato

\footnotetext{
${ }^{211}$ HERCKMAN, Elias. Descrição Geral da Capitania da Paraíba - 1939. João Pessoa: A União, 1982 , p. 40.

212 Ibid.

${ }^{213}$ MENEZES, José Luís Mota. Algumas notas a respeito da evolução urbana de João Pessoa. Recife: Pool Editora, 1985, s/p.

${ }^{214}$ MARIZ, Celso. Cidades e Homens. João Pessoa: A União, 1945.
} 
característico do lugar. Dessa forma, a Rua da Bica dos Milagres "foi assim chamada porque ali existia, jorrando abundante água, uma fonte que abastecia a população desde o começo da cidade"215.

Esse tipo de noomenclatura é comum até meados do século XIX, quando a população e o uso do espaço público têm o poder de oficializar a denominação urbana. Assim, surgem o beco do Hospital, o Largo do Palácio, a rua da Cadeia Nova, a travessa do Chão Duro, o beco das Almas ou de Luzia Gaga, etc. É também comum a existência de vários espaços próximos com o mesmo nome, a exemplo da rua, da travessa e do largo da Mangueira, onde o nome se remete a uma característica específica da área.

Registros mostram que, a partir de 1870, as denominações dos espaços públicos não mais são criadas de forma tão vinculada aos elementos urbanos, mas, sobretudo, em homenagem a personagens históricos e políticos, geralmente não locais. Sob esse parâmetro, os antigos nomes são alterados. A referência a elementos locais característicos daqueles logradouros específicos dão lugar aos nomes de duques, barões, marqueses, viscondes, etc, que mais à frente também são novamente trocados, homenageando, dessa vez, políticos locais. Assim, a rua Direita passa a Duque de Caxias, a rua da Ponte torna-se Visconde de Pelotas, a rua da Areia passa, na década de 1870, a Barão da Passagem e na década de 1890, a Dr. Aristides Lobo.

"A rua Silva Jardim outrora se chamou Rua da Palha, pois suas casinhas eram feitas desse material. Silva Jardim destacou-se como republicano histórico e inspirado orador. Nasceu no estado do Rio de Janeiro"1216.

Apesar de poucas alterações formais, os largos passam a se chamar praças, mudando também seus nomes, a exemplo do Largo do Erário, que em 1890 torna-se Praça Cel. João Vieira, e o Largo Conselheiro Diogo Velho, convertido na Praça João Vieira. A alteração toponímica dos espaços públicos faz parte da política de transformação urbana que se acelera com a chegada do século XX. Porém, essa intervenção também passa a interessar à população, que algumas vezes não concorda nem incorpora no seu cotidiano tais mudanças e outras vezes as enaltece e até as solicita, a exemplo da mudança de nome da Rua da Lagoa para Rua Pedro Américo, a pedido dos moradores ${ }^{217}$.

De meados do século XIX até a primeira década do século XX, a interferência formal em logradouros existentes é mais enfatizada que a abertura de novos espaços públicos. Dessa forma, os novos nomes que anunciam esses espaços são, geralmente, provenientes da alteração de sua denominação, e não do batismo inicial de um espaço. A mudança denominativa anuncia o novo pensamento de reordenação da cidade, de forma que, muitas vezes, a alteração toponímica não corresponde a uma transformação formal. Apesar de anunciar tais alterações referentes às denominações dos espaços públicos de então, a cidade desse momento ainda apresenta muito dos nomes que se remetem a seu passado, acentuado tais modificações de forma mais incisiva a partir da década de 1920.

Apesar de poucas alterações formais e seus ainda leves reflexos nos usos e nos nomes dos espaços públicos da capital paraibana, essa etapa é essencial para o desencadeamento das reformas urbanas. É um momento rico em críticas e sugestões acerca da organização da cidade, com questionamentos a respeito de seu funcionamento e de sua estética. O levantamento da cidade através de mapas e descrições revela essa preocupação, tornando-se elemento fundamental para as intervenções que culminam nos ciclos de reformas urbanas ao longo da primeira metade do século XX.

\footnotetext{
${ }^{215}$ AGUIAR, Wellington. "Velhas Ruas". Revista do IHGP. ANO n 33, p63-69, p. 74.

${ }^{216}$ Ibid., p. 75.

${ }^{217}$ AGUIAR, Wellington., A cidade de João Pessoa. A memória do Tempo. João Pessoa: Gráfica e Editora Persona, 1992 , p. 347.
} 

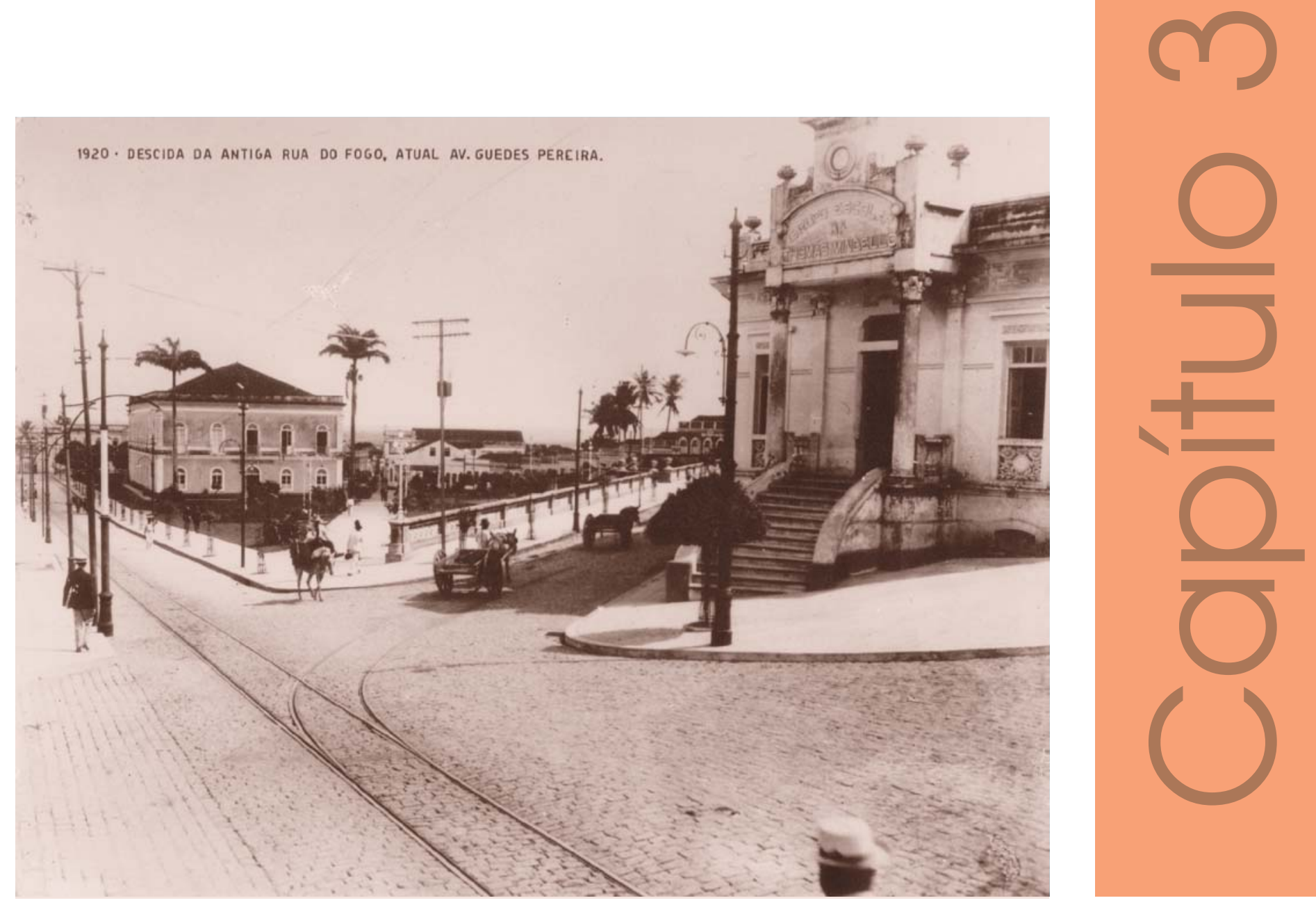


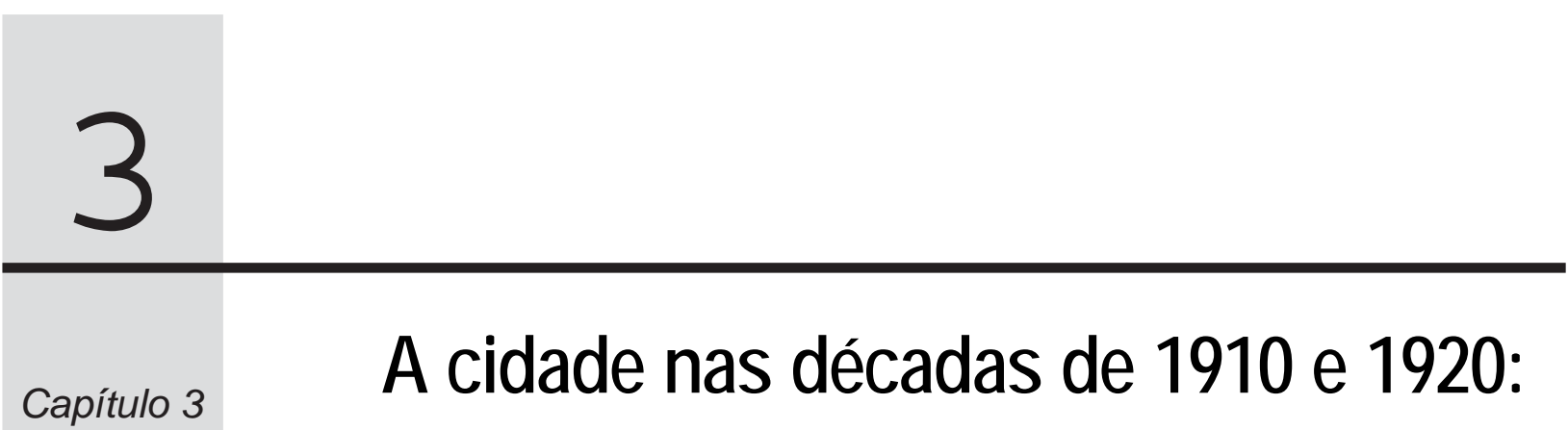

\author{
a transformação dos espaços públicos segundo o discurso higienista
}

Se o fim do século XIX é marcado por denúncias e reivindicações acerca da configuração da capital paraibana, cujo espaço urbano vinha sofrendo lentamente esparsas intervenções, no século XX, esse discurso proferido reverte-se em ações de efeitos mais enfáticos na cidade. Esse momento se distingue dos séculos anteriores tanto pela intensidade e velocidade das alterações urbanas, como pela marcante participação administrativa do poder público nesse processo.

Alinhadas com as reivindicações amplamente defendidas ao longo do século XIX, as intervenções no início do século seguinte, sobretudo até meados da década de vinte, encontram-se revestidas do ideal higienista, já observado nas cidades oitocentistas. Nesse momento, a teoria bacteriana se impõe na condução das intervenções, suplantando as teorias miasmáticas. As preocupações e justificativas que permeiam as obras urbanas desse momento, expressas sobretudo nas mensagens de governo, são direcionadas pelos ditames da salubridade e embelezamento, onde as atividades sanear e alinhar reconstroem a paisagem da cidade. Assim, o mesmo tom das reivindicações divulgadas desde o século anterior pelos diversos porta-vozes, passa a constituir os discursos oficiais, sempre apoiados em conhecimentos médicos e técnicos, além da participação de intelectuais, que também contribuem com esse processo.

Nas primeiras décadas do século XX, as intervenções se dão em diferentes partes da cidade e de forma pontual, alterando-se em cada rua, cada praça, cada espaço individualmente, os quais são raramente tratados de forma integrada. Há um grande empenho em estabelecer melhorias no espaço urbano, aprimorando sua infra-estrutura e compondo um quadro de intervenções as quais também se encontram vinculadas à intenção de alterar a aparência que se remete ao 'passado colonial', esse revestido de conotações negativas no pensamento urbanístico desse momento. Ocorrem grandes investimentos na infra-estrutura citadina, que passa a ser dotada dos serviços de abastecimento d'água, iluminação e transporte público movido à eletricidade. Porém, é a retificação, o alargamento e a abertura de ruas, juntamente com a criação de praças e parques, que despertam mais atenção.

Tais intervenções não têm na proclamação da República impulso ou incentivo que acelere o lento ritmo que vinha marcando as transformações da cidade. O novo quadro administrativo não implica em alterações imediatas que se sobrepusessem aos tempos do Império. A questão urbana só ganha espaço de maior relevância quando se reverte a situação política, a partir da redução do poder das antigas oligarquias, em 1912, com Álvaro Machado na presidência estadual e João Machado na administração da capital.

Mesmo com o aumento das atribuições políticas e administrativas dos estados pela Constituição Federal de 1891, incluindo a organização e a implementação de serviços urbanos, e ainda com a influência 
modernizadora das demais cidades brasileiras, principalmente Rio de Janeiro, São Paulo e a vizinha Recife, sobre a capital paraibana, as condições financeiras do Estado não permitem, de imediato, grandes cirurgias urbanas. As rendas públicas provenientes da produção agrícola têm o clima como forte condicionante, além dos limites impostos pela precariedade da infra-estrutura viária, obstáculo para a utilização do porto local para escoar a produção. Deste modo, a exportação se dá através dos portos pernambucano e cearense, o que restringe, para o estado da Paraíba, a apropriação de parte da renda proveniente das suas atividades agroexportadoras.

Além de fatores como o crescimento da classe burguesa e a influência de outras cidades brasileiras palcos de reformas urbanas, o quadro político-econômico também é um dos vetores de desencadeamento desse processo de reconfiguração da cidade. A busca de investimentos que proporcionem o progresso econômico do estado induz a transparecer uma imagem de prosperidade do poder público, que tem no espaço urbano seu melhor expositor. Assim, estrategicamente, a pretendida situação econômica é exposta em empreendimentos de visibilidade através de obras públicas, resultando numa aparência que também reforça a burguesia local. Nesse sentido, essa cidade se torna alvo da construção de uma nova aparência, símbolo da prosperidade estadual. A execução de obras de vulto passa a ser uma iniciativa do governo do estado, que promove grandes empreendimentos ou atua num regime de colaboração com a administração municipal, cuja arrecadação não dispõe de orçamento suficiente para tais realizações.

A atuação estadual na capital é verificada nas mensagens de governos enviadas à Assembléia Legislativa, cujo teor busca legitimar sua "modernização", baseando-se, sobretudo nas primeiras décadas do século XX, no discurso higienista e no embelezamento urbano. Essa atuação se dá ao longo de um quadro oscilante, caracterizado por diferentes formas e intensidades de intervenção. Esse processo resulta na concentração de obras mais intensas entre meados das décadas de 1910 e 1920, configurando o primeiro ciclo de reformas urbanas da cidade.

Assim, apesar das iniciativas oitocentistas no sentido de alterar a situação sanitária e a também criticada aparência da cidade de então, é só nas primeiras décadas do século XX que se observa investimentos e obras expressivas que refletem, de forma mais significativa, uma nova ordem urbana. Entre os anos de 1916, quando Camillo de Holanda assume o governo do estado, e o ano de 1926, quando são finalizadas as obras de saneamento da capital, é de grande evidência a intenção de sanear a cidade, interferindo tanto nos espaços públicos quanto privados, transformando suas formas e usos de modo mais intenso e veloz.

Essa mudança ocorre a partir do aperfeiçoamento dos principais serviços de infra-estrutura, a exemplo do abastecimento de água e da energia elétrica, introduzidos na cidade desde o início do século XX, e principalmente com a implantação do sistema de saneamento, uma das obras mais representativas desse período.

\subsection{O SANITARISMO E A TRAMA}

"O anno derradeiro foi o anno em que mais se abriram novas ruas e novas avenidas nesta capital. Em numero realmente consideravel. Até egrejas fôram postas abaixo para dar logar ao espaço das praças confortáveis"218. 
Referido ao ano de 1924, este trecho de matéria publicada na Revista Era Nova expressa bem o tipo de intervenção que vinha sendo realizada na capital paraibana. A atuação governamental das primeiras décadas do século XX é amplamente embasada no discurso higienista, sempre implícito nas documentações oficiais referentes às obras, sobretudo nas mensagens de governo. A institucionalização de serviços e atividades, a exemplo da regulamentação da Repartição de Hygiene, responsável pela "execução de medidas preventivas de moléstias infecciosas (...) e divulgação dos preceitos gerais de higiene pública e privada" ${ }^{219}$, e do Serviço de Hygiene Municipal, responsável "pelo saneamento local; pelo enxugo do solo, dessecamento e drenagem dos terrenos úmidos e pantanosos; calçamento, arborização, asseio e irrigação de vias públicas; remoção e incineração do lixo"220, criadas em 1911, ressalta bem essa postura.

As preocupações sanitárias também incentivam a intervenção administrativa através da manifestação de intelectuais, médicos, engenheiros e demais profissionais que enfatizam a necessidade de higiene e conforto para os usuários da cidade. As obras realizadas também são refletidas em publicações, promovendo uma grande quantidade de artigos divulgados em jornais e de matérias literárias apresentadas em Almanaques.

Os serviços até então recorrentemente reclamados como indispensáveis à organização sanitária "abastecimento d'agua, esgottos e illuminação, que acarre[tam] como consequencia immediata o calçamento das ruas, a viação electrica, arborisação, deposito, remoção e destruição de lixo, que representam medidas complementares de alto valor"221 - realizam-se no governo de João Machado (1908-1912). Já em 1908 é publicado um edital de concorrência para execução dos serviços de esgotamento sanitário, iluminação pública e particular, eletrificação das linhas de bonde e abastecimento d'água.

Atrelada a esses serviços, a intervenção no meio urbano prolonga-se nas formas das ruas, praças e edificações, segundo os discursos higienistas que impulsionam e justificam tais modificações. As novas formas elencadas a esses elementos urbanos renovam a trama, apontando uma nova postura urbanística que, a partir de então, redesenha de maneira mais regular 0 traçado da cidade, distinguindo-o daquele consolidado ${ }^{222}$. Nesse sentido, um dos marcos dessa administração é a abertura da avenida João Machado,

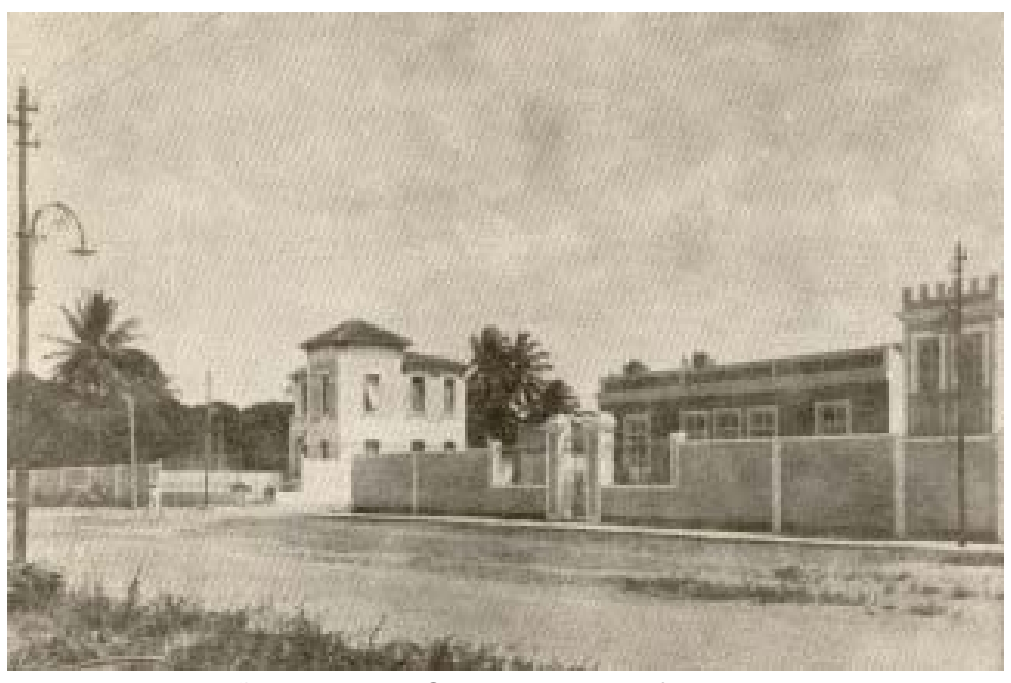

1920 - Avenida João Machado. FONTE: Acervo Walfredo Rodrigues. "com 22 metros de largura e 1350 metros de extensão"223. Para além de sua importância pelo destaque no cenário urbano, promovido por suas características físicas diante da predominância de vielas estreitas e algumas vezes tortuosas, está seu papel fundamental de vetor de expansão da cidade, que até então crescia de forma inibida, a partir do núcleo urbano original, nas proximidades do Tambiá e das Trincheiras ${ }^{24}$. A avenida João Machado acentua o direcionamento do crescimento urbano para a região das praias.

\footnotetext{
${ }^{219}$ PARAHYBA DO NORTE. Mensagem apresentada à Assemblea Legislativa do Estado, em $1^{\circ}$ de Setembro de 1911, por ocasião da abertura da $4^{\mathrm{a}}$ Sessão da $5^{\mathrm{a}}$ Legislatura, pelo presidente do estado dr. João Lopes Machado. Imprensa Official, MCMXI, p.60. 220 Ibid.

${ }^{221}$ PARAHYBA DO NORTE. Mensagem apresentada à Assemblea Legislativa do Estado, em $1^{\circ}$ de Setembro de 1910, por ocasião da installação da $3^{a}$ Sessão da $5^{a}$ Legislatura, pelo Presidente do estado dr. João Lopes Machado. Imprensa Official, MCMX, p.28.

${ }^{222}$ Apesar do traçado de implantação da cidade ter sido regular, no referido momento em análise são as formas irregulares que prevalecem no conjunto urbano, consolidadas na aparência geral da cidade.

${ }^{223}$ PARAHYBA DO NORTE. Mensagem apresentada à Assemblea Legislativa do Estado, em $1^{\circ}$ de Setembro de 1911, op.cit., p.60.

${ }^{224}$ Como mostrou o Capítulo 2.
} 
O processo gradativo de intervenção urbana promove um volume tal de obras que leva o governo Castro Pinto (1912-1915) a criar a Directoria de Obras Publicas. Inicialmente, esse órgão existe mais a nível legal que de atuação, porém constitui um importante marco no processo de intervenção no espaço dessa capital, efetivando suas atividades articuladoras com a intensificação das obras a partir de 1916, ano que marca o início do primeiro ciclo de reformas.

A criação desse órgão já vinha sendo reivindicada, como se observa nos artigos publicados em 1889 pelo engenheiro João Claudino, que atribui inclusive à "ausencia de uma directoria de obras publicas", "o atraso da provincia"225. A forma desarticulada de intervir no espaço urbano, a partir de uma organização administrativa aleatória e descentralizada, é denunciada pelo engenheiro que mostra a inviabilidade do bom funcionamento de uma estrutura provisória, formada a cada trabalho em andamento. Assim, segundo João Claudino, "de todas as provincias do Imperio é esta a unica talvez que não conta [com] uma repartição de obras publicas, e este é um dos motivos que concorrem para a decadencia de varios importantes serviços"226.

"Parece que a provincia realisa grande economia não tendo ao menos um engenheiro que se encarregue dos diversos trabalhos que a toda hora apparecem. Seria de todo preferivel ter ella um funccionario que Ihe pertencesse, a viver mendigando os serviços de uns e de outros"227.

A atuação desse órgão se acentua a partir do ano de 1916, com o aumento de execução das obras, as quais apresentam as primeiras mudanças que alteram de forma significativa a trama urbana. As administrações consecutivas de Camillo de Holanda e Solon de Lucena - esse último atuando em parceria com a administração municipal de Guedes Pereira, chamado de "Pereira Passos parahybano" - apresentam as principais intervenções desse momento, reordenando a trama e a aparência dos espaços públicos a ela articulados.

\subsection{AS CONSTRUÇÕES}

Apesar dos espaços públicos representarem os principais alvos das reformas, tomados como principais expositores das novas formas urbanas, as edificações também participam desse processo de embelezamento da cidade, passando por diversos melhoramentos, a exemplo de reparos, limpeza, aumento do número de aberturas, o que se reflete na aparência urbana. Assim, orientados pelos preceitos higienistas e por conceitos estéticos em renovação, ainda sob influência dos novos hábitos burgueses, as edificações recebem alterações na sua organização interna e nas suas fachadas.

Tais intervenções se dão nas casas e na suntuosidade dos edifícios públicos, que assumem maior ênfase no meio urbano. No conjunto desses melhoramentos, a capital paraibana tem como destaque em seu espaço urbano as intervenções no Teatro Santa Roza, a reconstrução do prédio da Escola Normal e a ampliação do Mercado de Tambiá.

Durante o governo Castro Pinto, são construídos prédios escolares, justificados pelas deficiências desse setor, cujas atividades são desenvolvidas em casas "com capacidade acanhadissima para uma collectividade de crianças, sem rigoroso asseio"228, pois "desde 1889 o único predio escolar construido pelo governo do Estado foi o da Cruz das Almas, subúrbio desta Capital, o que demonstra o nosso atrazo nesse departamento

\footnotetext{
${ }^{225}$ CRUZ, João Claudino de Oliveira. "Melhoramentos da capital da Parahyba”. Gazeta da Parahyba, n. 196, 9 jan. 1889, p. 9.

226 Ibid.

227 Ibid.

${ }^{228}$ PARAHYBA DO NORTE. Mensagem apresentada à Assemblea Legislativa do Estado, em $1^{\circ}$ de Setembro de 1913 , por ocasião da abertura da $3^{a}$ Sessão Ordinaria da $7^{a}$ Legislatura, pelo presidente do estado dr. João Pereira de Castro Pinto. Parahyba, 1913, Estabelecimento Graphico Torre Eiffel. p.10
} 
administrativo"229. Essa postura fez de Castro Pinto, "no regimen republicano, o administrador que creou o maior numero de escolas neste Estado"230.

A renovação arquitetônica através da recuperação dos edifícios públicos também tem como viés o interesse em transparecer a prosperidade administrativa, a exemplo do Palácio do Governo, Lyceu Parahybano, Chefatura de Polícia e Cadeia Pública, reformados repetidas vezes, em diferentes administrações.

A participação da arquitetura no processo de reformulação do cenário urbano ocorre por construções, reformas e reconstruções. O intuito de apagar os

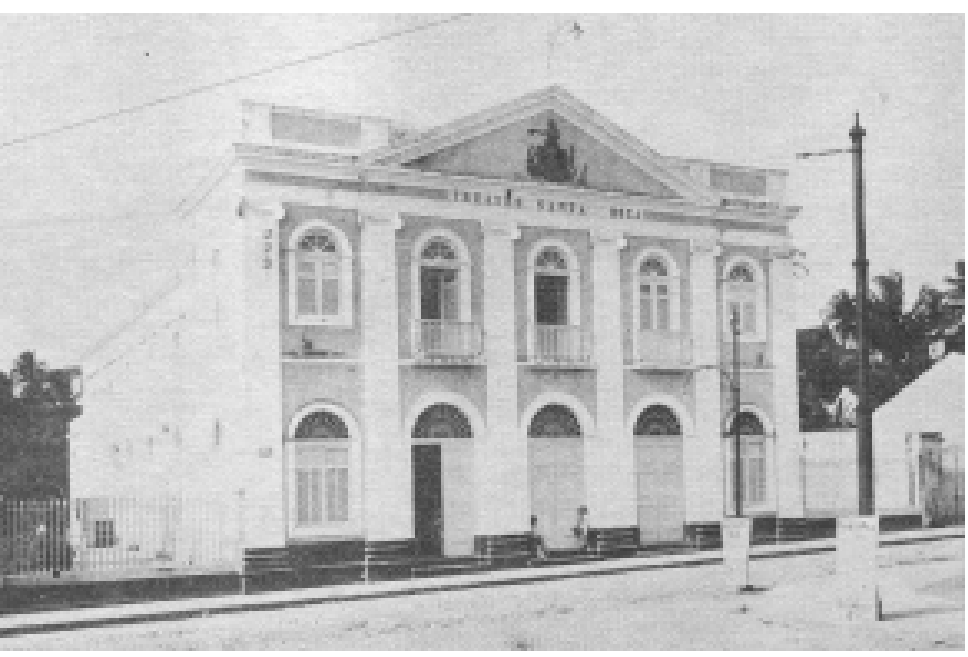

Teatro Santa Rosa. FONTE: Acervo Walfredo Rodrigues."Os teatros eram pontos de reunião dos grupos sociais mais importantes em toda colônia. As Casas de Ópera ofereciam oportunidade e espaço para uma convivência intelectualmente mais elaborada, dos vários membros desses segmentos sociais. Mas eram também um ensejo de crítica social e de articulações políticas. Assim também existiam teatros em Salvador e Rio de Janeiro, Recife e Belém" (REIS, Nestor Goulart. "A Urbanização e o Urbanismo na Região das Minas". Cadernos de Pesquisa do LAP. Série Urbanização e Urbanismo. Jul-dez 99, n. 30. São Paulo, FAU- USP, p.9). sinais do passado, que referenciam a cidade de características coloniais, passa a ser explicitado nas freqüentes demolições promovidas pela administração pública. Esse processo busca o embelezamento e saneamento da cidade, criando praças e jardins geralmente sobre os escombros de construções seculares. As novas formas estabelecidas e os discursos que as legitimam apresentam uma transformação da paisagem urbana dessa capital marcada por um caráter "modernizador", onde embelezar expressa os valores de uma sociedade com pretensões de "modernidade", que apaga marcas materiais de sua história.

Empenhadas no que julgam uma melhoria do espaço urbano, sucessivas administrações passam a eliminar os 'obstáculos' ao processo de reforma, utilizando-se da legislação municipal para legalizar desapropriações justificadas pela "utilidade pública", onde são extintas as edificações que se configurem como empecilho para o embelezamento da cidade. Esse tipo de intervenção recebe apoio de parte da população que reivindica medidas administrativas para extrair da paisagem urbana características indesejáveis, inclusive a presença de "pardieiros sem hygiene", os quais, "com pequenas indemnisações a Prefeitura podia ir desapropriando (...), onde seriam construidos edificios simples, mas que não envergonhassem o povo"231. Dessa forma, a administração exclui uma parcela da população formada por pobres e miseráveis: “...desapropriei por utilidade pública, seis casebres na rua Marciel Pinheiro, em cuja área está sendo construída uma pequena praça a ser embellezada pelo futuro edifício da Associação Commercial;,..."232.

Tal postura revela que parte dos habitantes, moradores de 'casebres' também chamados de pardieiros, representa um estorvo para a administração e incômodo para as elites, jogados para o mundo das "hierarquias naturais" composto por exclusões e discriminações, onde "o povo é figura ausente e o indivíduo é reduzido à pessoa desprovida dos atributos da razão, da moralidade e da autonomia"233. De fato, a igualdade expressa nas leis de desapropriação legitima a desigualdade e, excluindo as maiorias, proclama uma justiça social

${ }^{229}$ PARAHYBA DO NORTE. Mensagem apresentada à Assemblea Legislativa do Estado, em $1^{\circ}$ de Setembro de 1914, por ocasião da abertura da $3^{a}$ Sessão Ordinaria da $7^{\mathrm{a}}$ Legislatura, pelo presidente do estado dr. João Pereira de Castro Pinto. Imprensa Official, MCMXIV, p.4.

${ }^{230}$ PARAHYBA DO NORTE. Exposição apresentada ao coronel Antônio da Silva Pessoa, $1^{\circ}$ vice-presidente do Estado, em 24 de julho de 1915, pelo presidente do Estado João Pereira de Castro Pinto. Parahyba: Imprensa Oficial, 1915, p. 10.

${ }^{231}$ AS CASAS de palha. A União, Parahyba, n 8, p1, 12 jan. 1.

${ }^{232}$ Mensagem apresentada à Assembléia Legislativa do Estado, em 1917, pelo presidente do Estado Dr. Francisco Camillo de Holanda. ${ }^{233}$ TELLES, Vera da S. A cidadania inexistente: incivilidade e pobreza. São Paulo: FFLCH/USP, 1992. (Tese de Doutorado), p.23 
ao mesmo tempo em que bloqueia os direitos igualitários das relações sociais. Assim, a questão da aparência urbana estabelecida no início do século XX tem um viés social que se vincula à intenção de prosperidade aparente que, por sua vez, não condiz com a heterogeneidade social e econômica que compõe o quadro urbano.

São inúmeras as intervenções executadas nesse período, construindo um cenário urbano que, se não em tudo, muito difere da cidade apresentada no fim do século anterior. Para tanto, muitas das ruas realinhadas, alargadas, prolongadas ou abertas, assim como várias praças criadas, são viabilizadas por meio de desapropriações e remoções de casebres e demais edificações que julga-se ferirem a estética da cidade ou se configuram empecilhos à expansão e instalação de novos espaços.

\subsection{OS NOVOS ESPAÇOS PÚBLICOS}

Diante dos esforços urbanísticos para transformar a aparência da cidade, são os espaços públicos as áreas que melhor evidenciavam essas ações. A configuração de uma nova trama a partir da abertura, alinhamento e alargamento de vias, articula-se com a reformulação e criação de praças que, juntamente com as fachadas das novas edificações e a inserção da natureza domesticada, representam a consolidação de uma

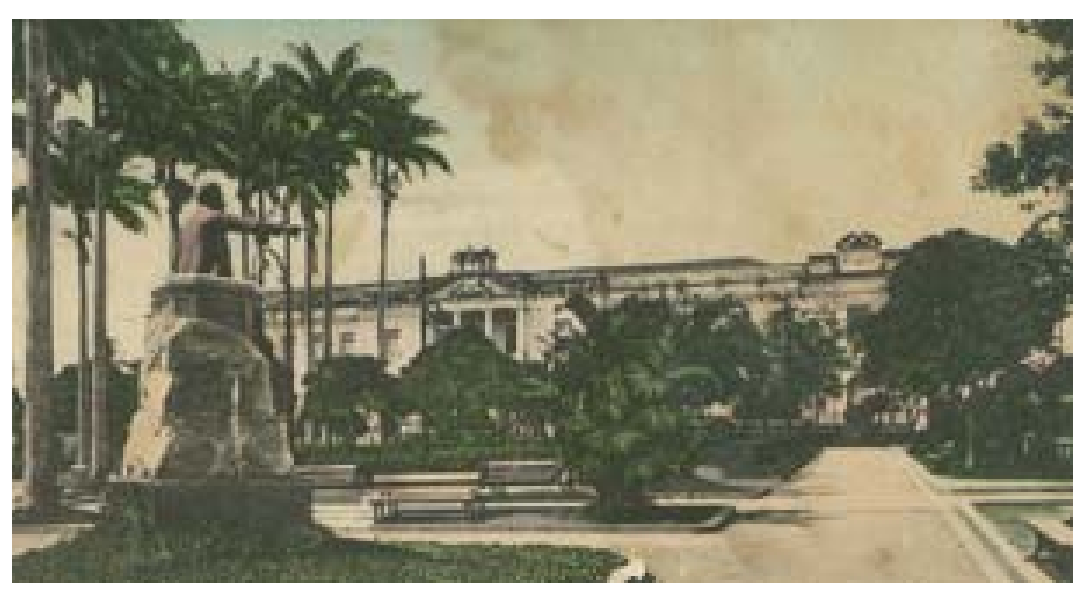

Praça Felizardo Leite. FONTE: Acervo Humberto Nóbrega.

nova forma da cidade. Nesse momento, a rua e a praça assumem significados e funções distintas daquelas a elas atribuídas até então. Surgem avenidas com calçadas bem definidas e torna-se evidente a separação do tráfego de veículos -inclusive do bonde elétrico - e pedestres, dando continuidade e aprimorando a divisão dos fluxos estabelecida no Império, quando se insere o bonde à tração animal. Por trás dessa nova denominação de via, estão novos elementos formais, como calçadas, postes de iluminação e canteiros com árvores, que direcionam outras formas de utilização desses espaços.

\subsubsection{Como a trama, suas ruas, avenidas e praças compõem os novos espaços}

As intervenções do primeiro ciclo de reformas dessa capital contribuem para a alteração da sua trama urbana, através tanto de uma nova extensão assumida pela cidade, como pela configuração regular dessa área expandida. Essas novas áreas não se dotam de imediato de elementos urbanos característicos daquele momento, sejam eles praças, equipamentos urbanos ou edificações simbólicas. Porém, sua importância se revela por essas vias imprimirem na cidade, através da regularidade da trama que delas resultam, uma nova configuração formal. As novas avenidas retas e largas, formadoras de um traçado mais ortogonal, abrigam, posteriormente, uma arquitetura e equipamentos urbanos que dialogam com sua natureza. 


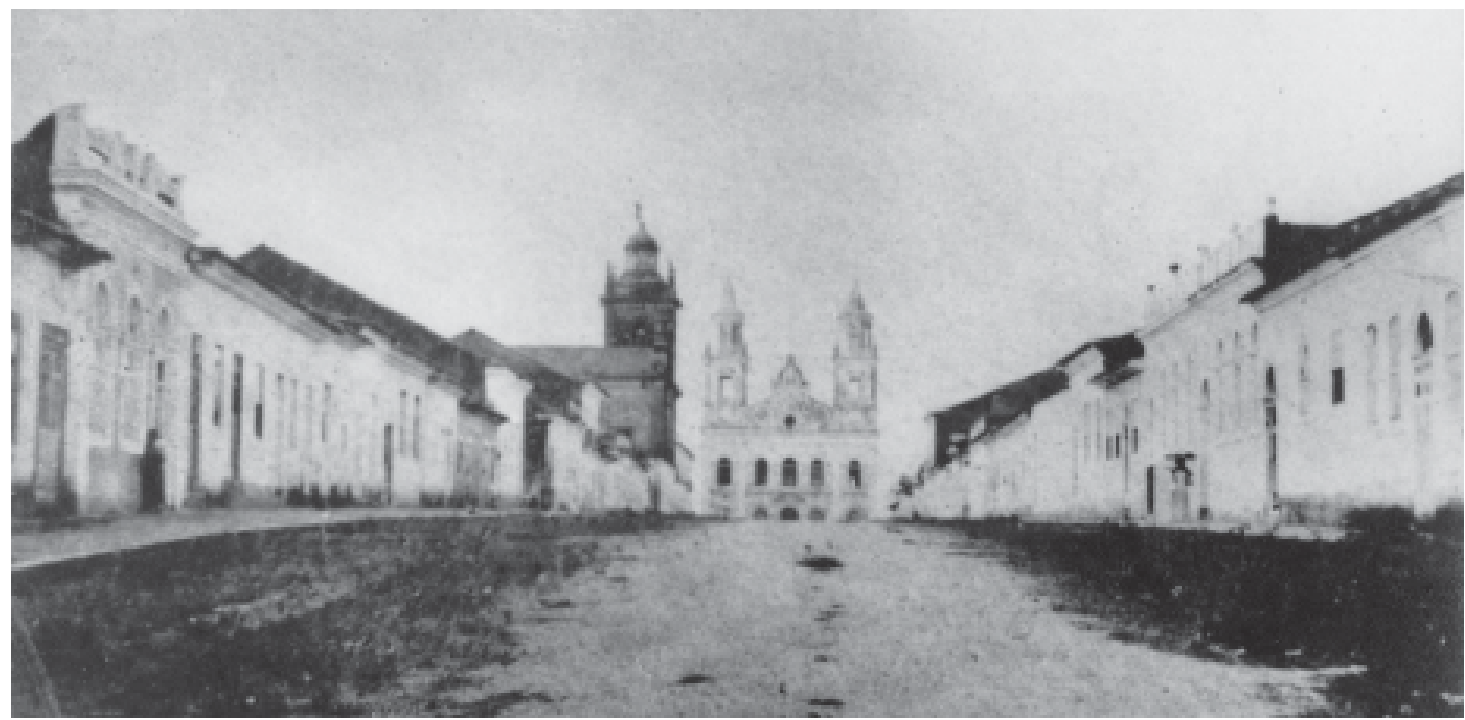

1877 - Avenida General Osório. FONTE: Acervo Laudereida Marques

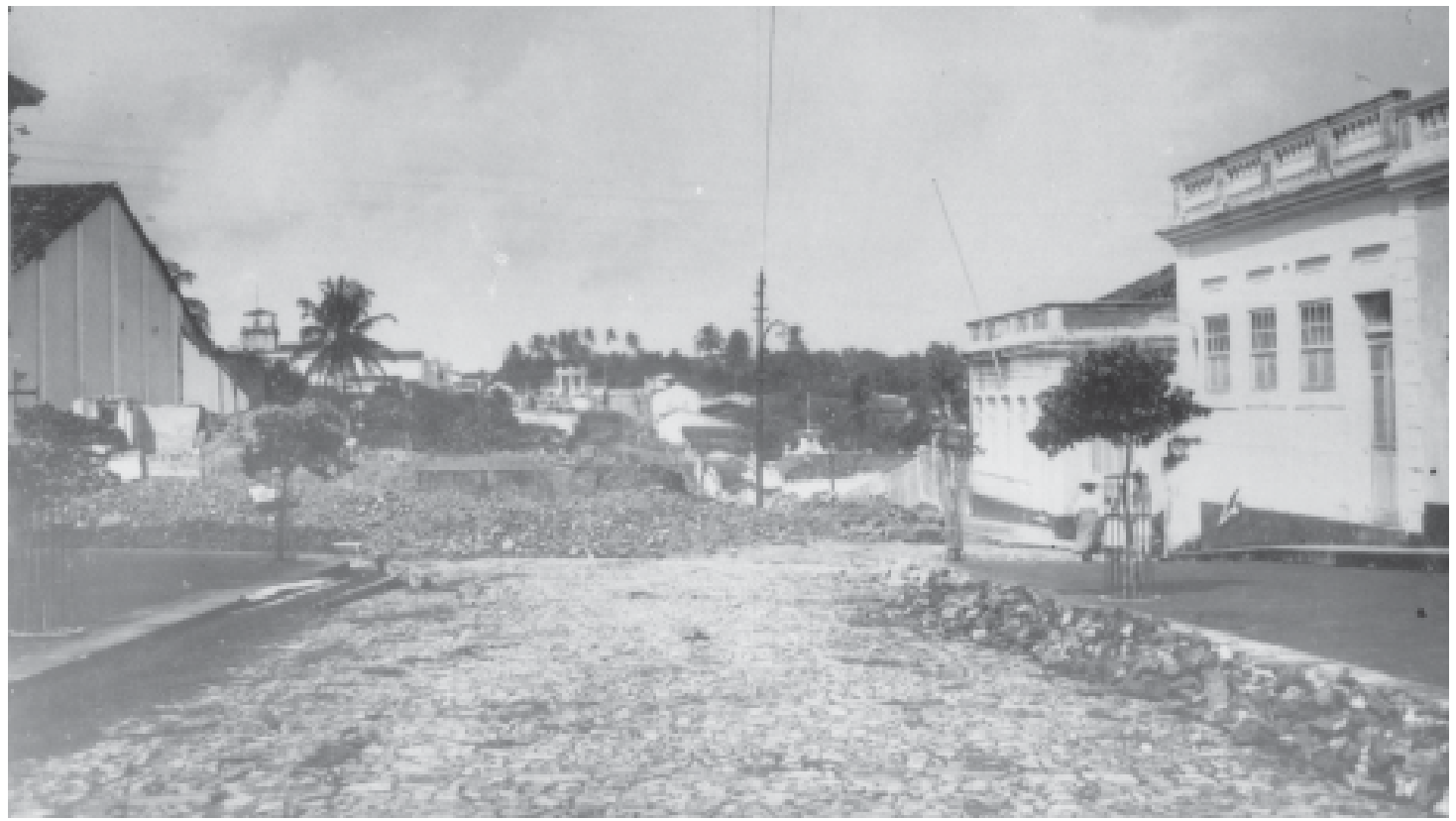

1918 - Demolição na avenida General Osório. FONTE: Acervo Laudereida Marques

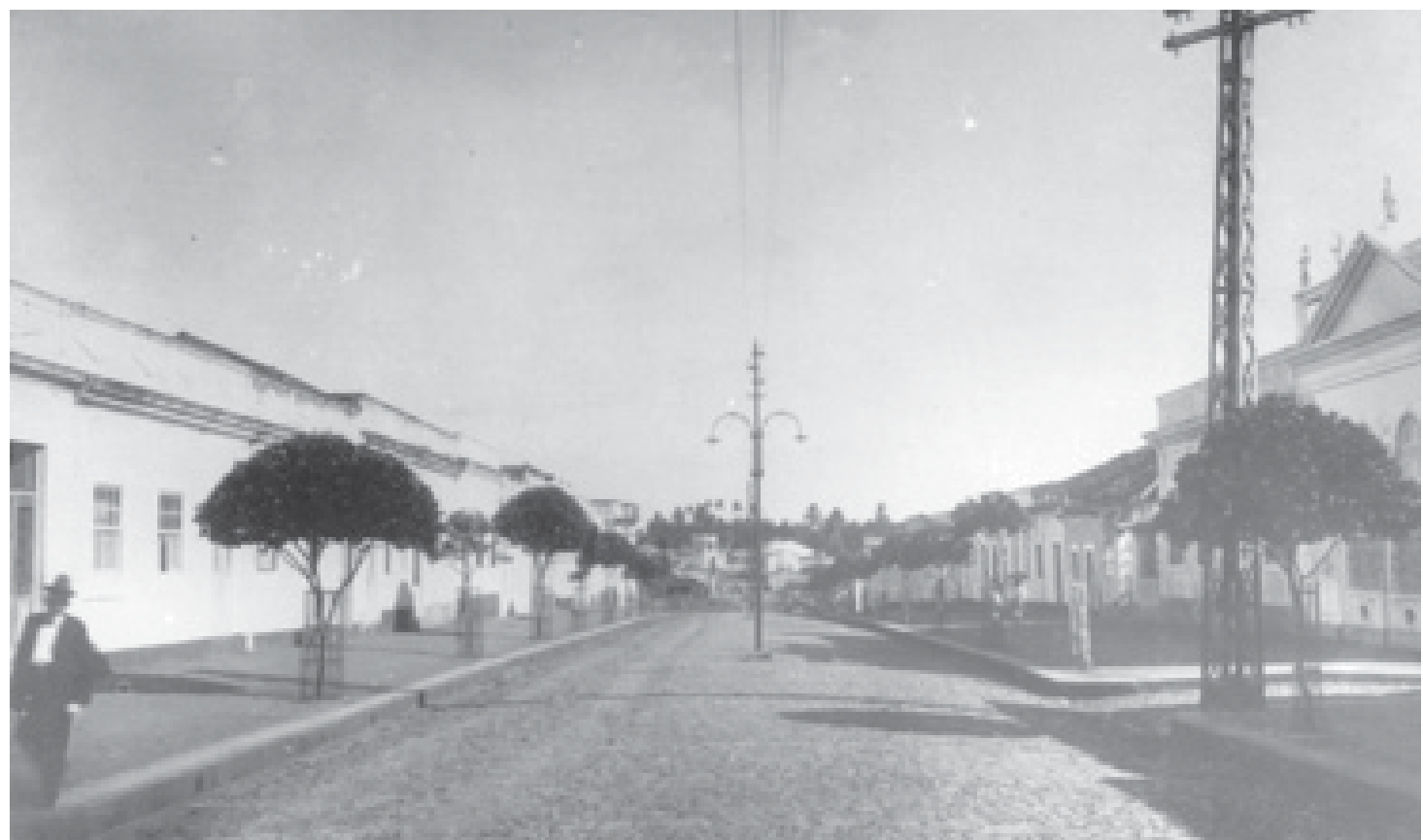


Apesar da abertura de novas vias, possibilitando o aumento da mancha urbana, as intervenções desse momento se concentram mais nas áreas já consolidadas da cidade. Na grande maioria, as reformas e criações de praças e parques, bem como a alteração da arquitetura de seus entornos, limitam-se a regiões há tempos já inseridas no conjunto urbano, mudando as feições dos espaços antigos e criando novos espaços nos vazios existentes nessas áreas. Nessa parte central da cidade, concentra-se, até fins da década de 1920, o maior número de edificações reformadas, algumas passando por repetidas intervenções. Nessa área articulamse as praças reformadas ou construídas, as novas edificações e as antigas ruas com nova aparência.

Em fins do século XIX, como se observa no mapa de Vasconcelos e em relatos e monografias ${ }^{234}$, a cidade ocupa a área entre a colina em que ela foi fundada e a região baixa nas proximidades do rio Sanhauá, retendose aí inclusive pela presença da Lagoa dos Irerês que inibe a penetração da cidade em seus arredores. Na década de 1920, observa-se o processo de consolidação da ocupação dessa área antes evitada. A trama construída nesse momento revela uma cidade que se expande com formas regulares, diferenciando-se do seu passado quando retida em uma pequena área formada por ruas tortuosas.

Observando o mapa levantado em 1923 durante a administração municipal de Guedes Pereira, percebese que o tecido urbano em ampliação engloba em seu conjunto a região da lagoa dos Irerês e a ultrapassa,

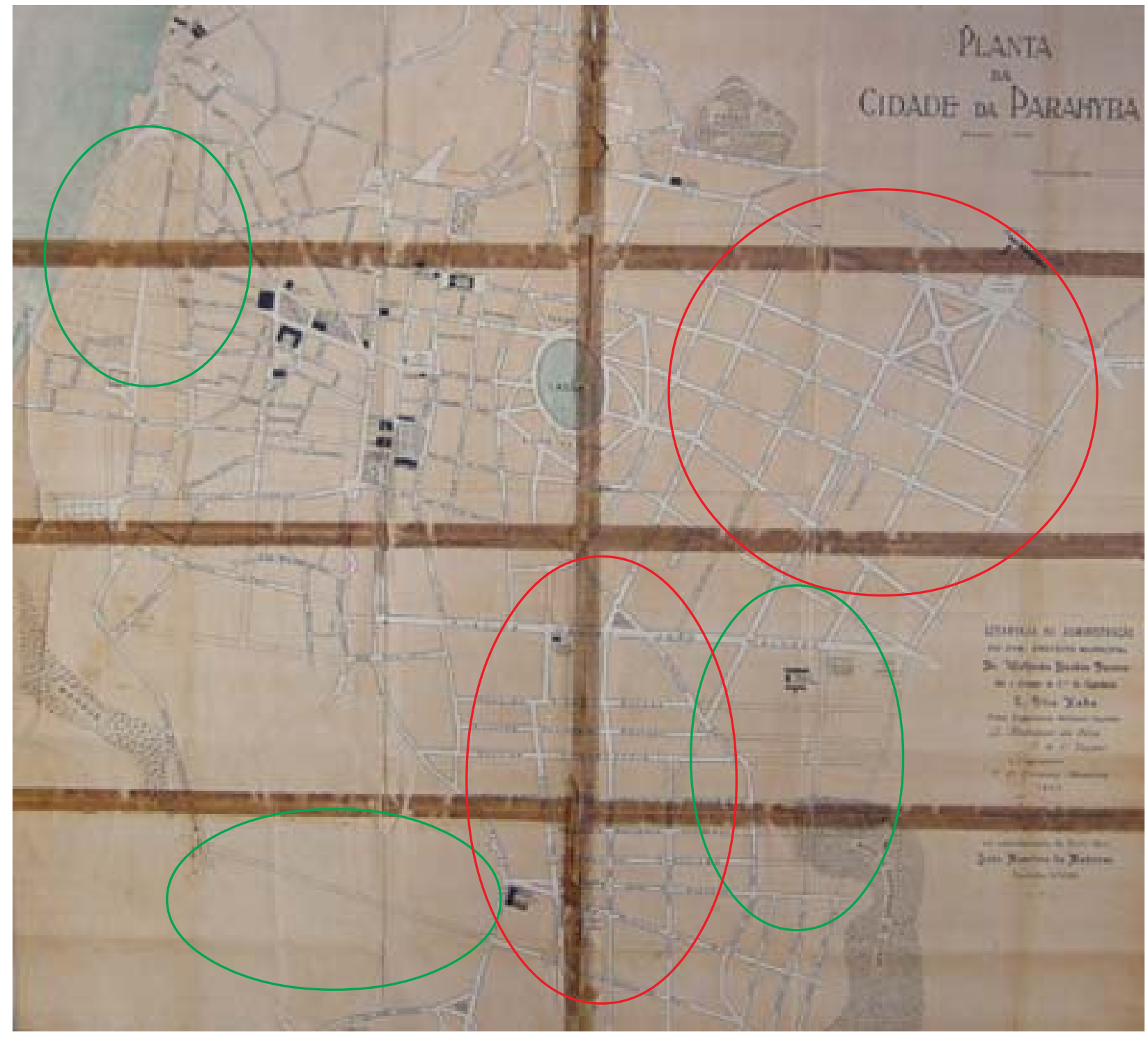

Mapa levantado em 1923, na a administração do Prefeito Guedes Pereira. Sinaliza alterações propostas para o tecido urbano através de linhas tracejadas (em verde), e apresenta a expansão já consolidada e regular (em vermelho). FONTE: Mapoteca IHGP

${ }^{234}$ Essa documentação foi tratada no Capitulo 2. 
apesar de não haver demarcação de edificações nessa área ${ }^{235}$, as quais se concentram na porção urbana consolidada em fins do século XIX. O mapa explicita o grande volume de alinhamentos, prolongamentos e alargamentos a serem implantados, buscando eliminar as vielas tortuosas e os pequenos becos que se remetem à configuração urbana do passado.

O traçado introduzido na malha urbana apresenta as novas formas que a cidade passa a assumir através de seus espaços públicos. As ruas são delimitadas por calçadas que referenciam o trânsito do pedestre; algumas são demarcadas por trilhos, para os bondes elétricos, outras são revestidas de calçamento, para os demais transportes.

A linearidade que guia as novas formas urbanas é acentuada pelo alinhamento dos postes de iluminação inseridos no cenário urbano desde 1912, bem como pelo plantio de árvores enfileiradas nas calçadas, incentivando maior uso dos espaços públicos através do conforto térmico durante o dia e da segurança noturna. Nesse momento, a introdução do verde apresenta-se segundo o interesse de criar uma nova natureza de caráter "urbano", que se alinhe à ordem dos novos espaços e não mais se apresente de forma aleatória, como nos campos e nas chácaras característicos do tecido urbano passado.

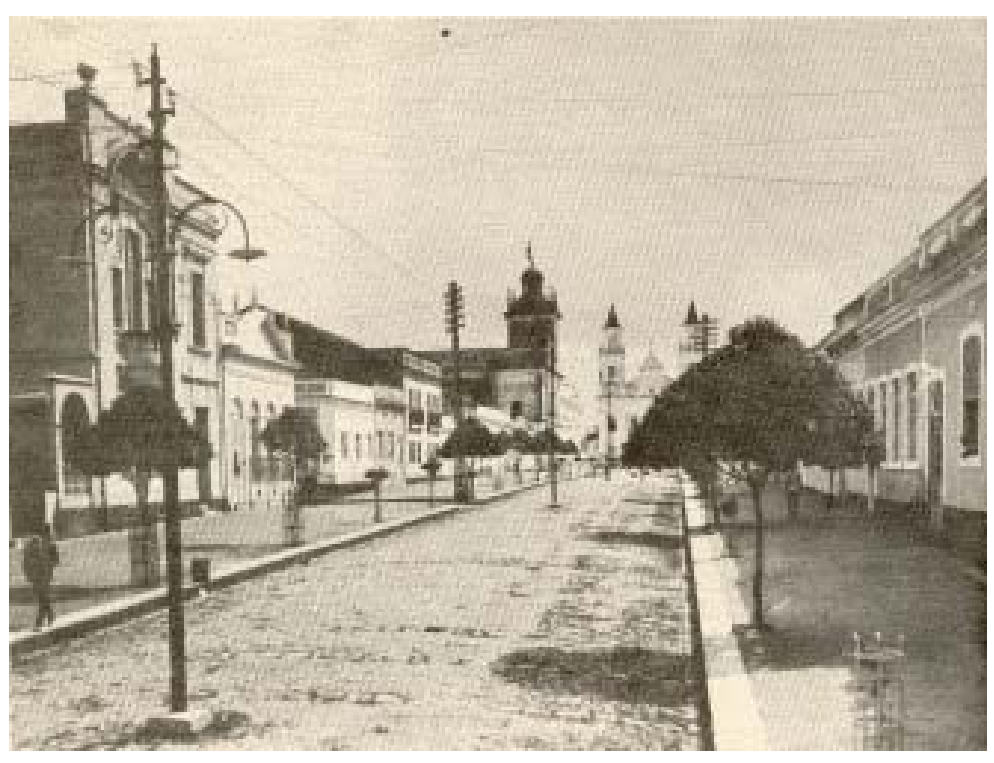

1920 - Rua General Osório, antiga rua Nova. FONTE: Acervo Walfredo Rodrigues

As formas que a cidade se reveste no início do século XX revelam, de fato, grandes contrastes com a cidade oitocentista, que por sua vez também se empenha, sem grandes resultados aparentes, em reformular suas características herdadas do período colonial. Se nesse momento são enfáticas as transformações das formas urbanas pela linearidade inserida nas ruas, de maior repercussão são as inovações promovidas nas praças, algumas antigos largos, que concentram em si um conjunto de elementos referentes aos novos ideais urbanos. A reforma das praças ocorre de forma conjunta com a alteração de outros elementos como as ruas, seus equipamentos urbanos e as edificações cujas fachadas contribuem e influenciam na composição da paisagem local. Toda essa cadeia de mudanças converge para as praças que passam a simbolizar esse momento, como se observa na predominância de artigos publicados que versam sobre o assunto, a exemplo dos rotineiramente apresentados pela revista Era Nova, sobretudo nos anos de 1920 a 1925, onde as praças sobressaem-se dentre os demais elementos alvos das reformas urbanas.

Além da reforma de uma praça vincular-se às intervenções de outros elementos do cenário urbano, ela também influencia na criação de outras praças. Assim, é muito comum na capital paraibana a proximidade entre praças novas e reformadas. A repercussão dessas intervenções é acentuada pelas pequenas distâncias entre os espaços com novas características, incentivando a criação de um entorno praça-rua-praça reúne edificações novas ou reformadas, produzindo um cenário singular. Essa é uma características das partes antigas da cidade, não englobando as novas áreas em expansão, pois apesar de muitas, as praças

\footnotetext{
235 Nesse mapa não há a marcação de todas as edificações da cidade, como no levantamento realizado por Vasconcelos no século XIX. Nele, observa-se apenas a indicação dos edifícios públicos, além das ruas e espaços públicos em geral. Assim, essa leitura mostra que nas áreas de expansão e nos arredores da Lagoa não há concentração de edifícios públicos, o que não significa que fosse uma área despovoada.
} 
concentrarem-se em partes específicas da cidade. Percebe-se nesse momento dois tipos básicos de intervenções no espaço urbano: na trama e nos novos espaços públicos.

Das áreas de maior concentração de intervenções desse momento, a de maior destaque é a região das imediações da rua Direita, uma das primeiras ruas abertas na cidade. Nela surgem quatro novas praças: a Rio Branco, antigo Largo do Erário; a Vidal de Negreiros, onde se localiza a antiga Igreja do Rosário dos Pretos; a Commendador Felizardo, antigo Largo do Colégio, jardim público da cidade; e a Venâncio Neiva, antigo Largo do Palácio. Esses espaços acabam por criar uma relação entre si, consolidando um conjunto com uma linguagem urbana renovada. Da mesma forma, a praça Pedro Américo,

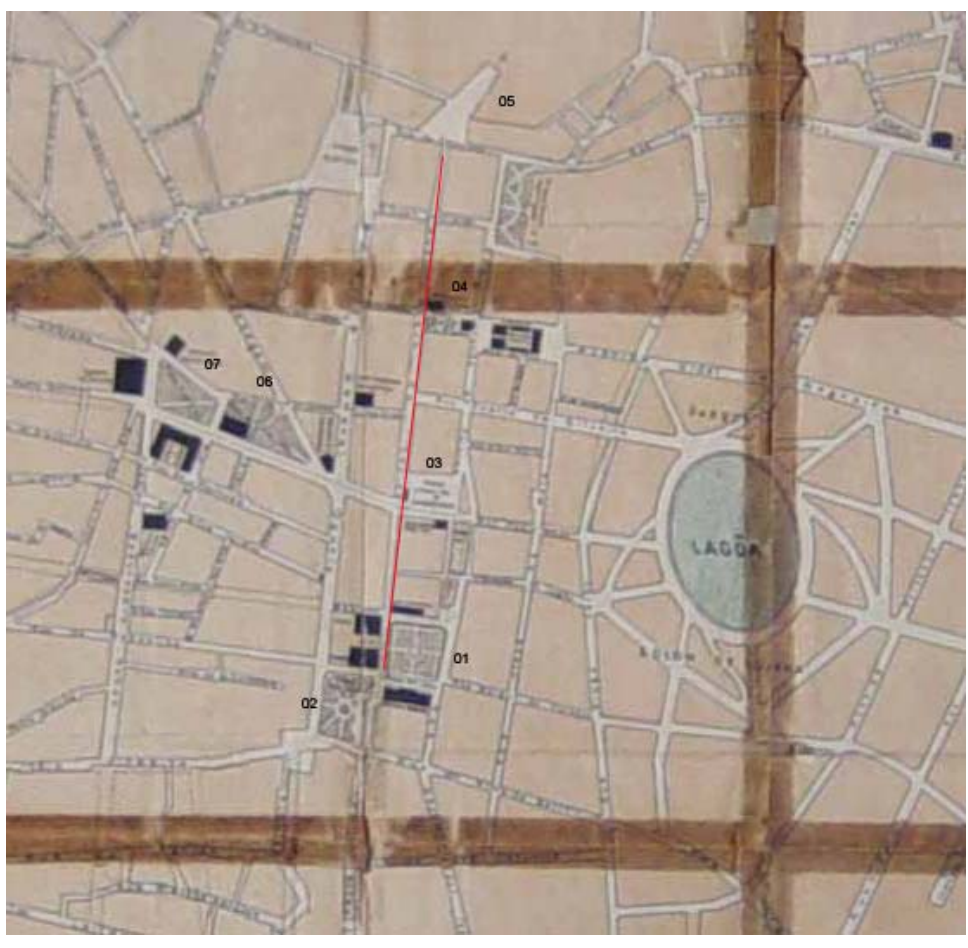

Recorte do Mapa elaborado em 1923, na adminsitração de Guedes Pereira. Em vermelho a Rua Direita; 01- Praça Venancio Neiva; 02-Jardim Público; 03 Praça Vidal de Negreiros; 04 - Praça Rio Branco; 05- Largo de São Francisco; 06- Praça Pedro Américo; 07- Praça Aristides Lobo. FONTE: Mapoteca IHGP. antes Campo do Conselheiro Diogo, e a Praça Aristides Lobo, situadas nos limites entre as áreas alta e baixa da cidade, também mantêm uma relação de proximidade e interação visual.

Essa concentração de elementos que promovem a renovação urbana proporciona uma atmosfera de euforia a respeito das obras em andamento, gerando discursos que projetam uma transformação total e generalizada da cidade. Trata-se, entretanto, de uma ação concentrada na área antiga da cidade, praticamente ausente das regiões de expansão da cidade.

Das alterações atribuídas às áreas urbanas de então, entre reformulações de ruas, edificações e praças, são essas últimas que recebem ênfase nesse momento. Nelas se concentra o maior número de equipamentos e atividades que anunciam os novos tempos, tornando-se palcos importantes da vida urbana. As praças criadas no início do século XX são embelezadas com equipamentos diversos, refletindo progressos tecnológicos, além de promover sua utilização ordenada. Alguns desses espaços já recebem, no século XIX, a denominação de praças, porém sua configuração é de campos de terra batida com vegetação crescida, e quando apresentam árvores, essas se dispõem de forma espontânea. A população geralmente trafega nessas áreas, cruzando-as de forma a marcar caminhos mais curtos que os direcionados pelas ruas.

Pode-se considerar como primeira iniciativa no sentido de reformulação dos espaços públicos dessa cidade a transformação do Campo do Commendador Felizardo, também conhecido como Largo do Collégio, em Jardim Público, em fins do século XIX. Porém, as precárias instalações desse espaço, enquanto jardim público da capital, proporcionam-Ihe grandes críticas, como pode ser verificado nos artigos de autoria de João Claudino de Oliveira Cruz, publicados em 1889, onde ele enumera a implantação de um jardim público entre as sete das mais urgentes necessidades urbanas da capital.

No século XX, foi o Jardim Público um dos primeiros espaços a sofrer transformações. O governo João Machado apresenta sua intenção administrativa de sanear o espaço urbano intervindo nesse Jardim. Nesse momento, ele é "higienizado e embelezado" e recebe um novo coreto. Passa a ser chamado de praça. Mais 


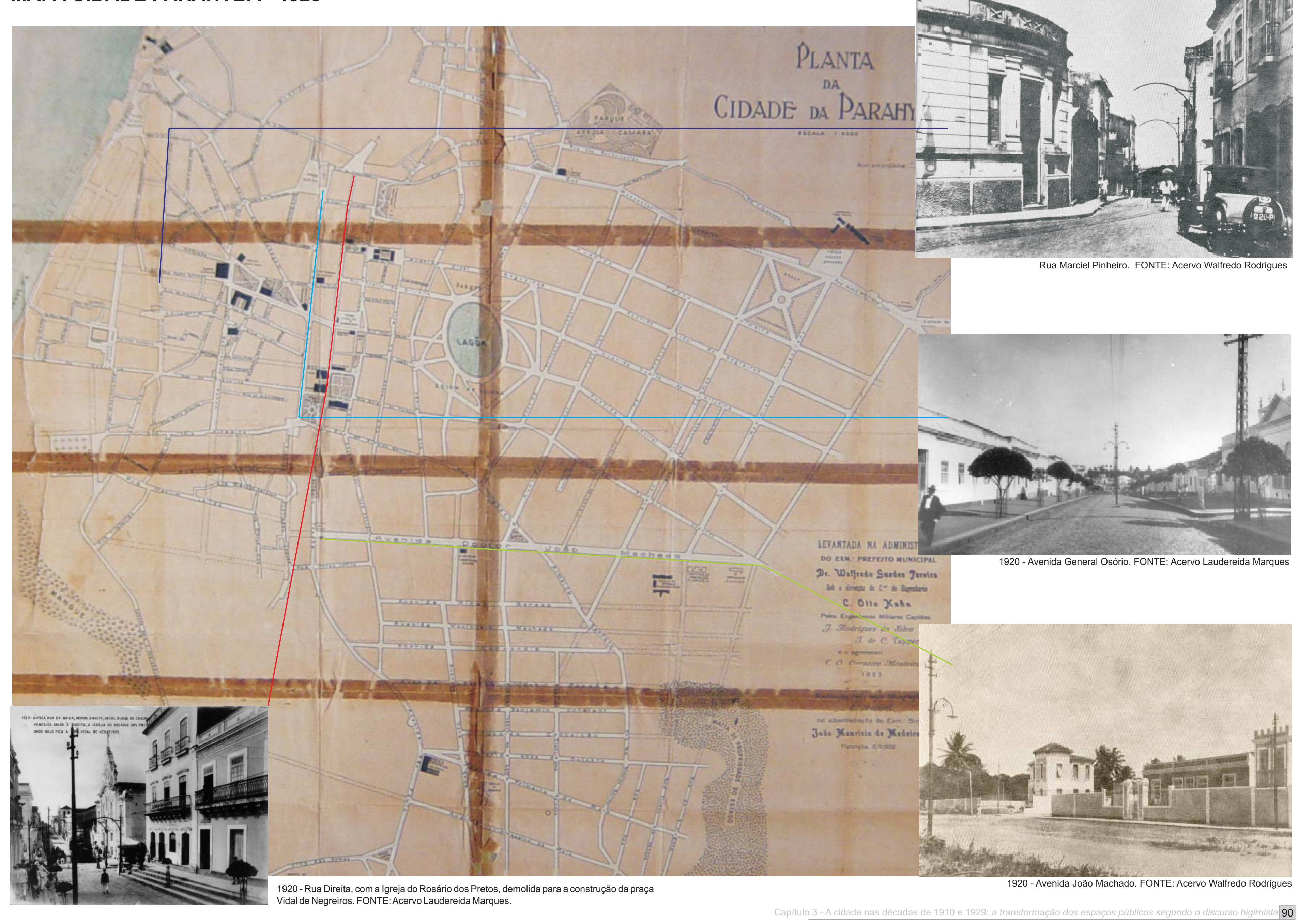


tarde, o governo Castro Pinto também Ihe promove novos melhoramentos, provendo-o de "um novo e elegante pavilhão de ferro e numerosos bancos de assentos duplos em sua maioria"236, o que atribui ao local, segundo interpretação da época, um caráter "moderno". Nessa mesma administração, ruas e praças são arborizadas e melhor iluminadas.

Os espaços públicos do século XIX adquirem no século seguinte uma nova ordem, através de elementos embelezadores que também afetam a utilização dessas áreas. As imagens das praças mostram que, além da implantação de bancos e postes de iluminação,

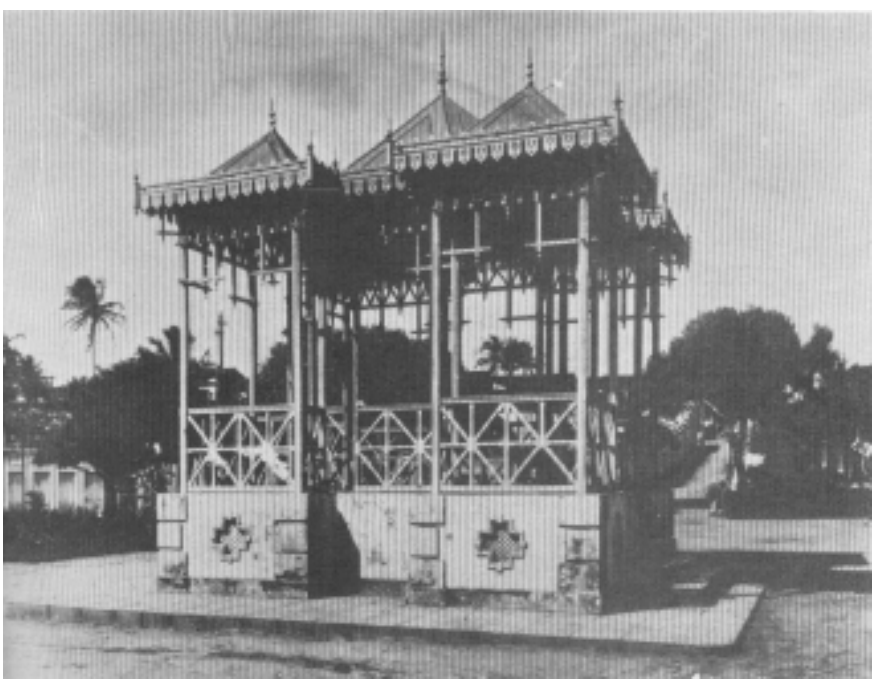

Coreto praça Pedro Américo, construído por Camilo de Holanda. FONTE: Acervo Walfredo Rodriges seus jardins seguem, muitas vezes, desenhos semelhantes. A maioria delas apresenta traçado formado por um desenho radial, com um elemento circular no centro - abrigando uma fonte, um coreto ou esculturas - de onde partem passeios radiais pavimentados, como ocorre nas praças Commendador Felizardo, Venâncio Neiva e da Independência.

A presença do coreto é algo típico na Parahyba - e no Brasil - desse período. A maioria das praças criadas ou reformadas nesse momento dispõe desse elemento que, além de marco estético -alguns de ferro e outros de alvenaria-, vincula-se à emergência da prática das retretas. Alguns coretos localizam-se no centro das praças, como ocorre na Commendador Felizardo, outros na esquina, como na praça Venâncio Neiva, que reservou a área central para uma fonte, dispondo ainda de um rink de patinação. A instalação de equipamentos de incentivo ao esporte é reflexo dos novos conceitos de saúde, desenvolvidos no fim do século XIX em países ocidentais.

Até o século anterior é comum procurar esquivar-se da presença do sol, para manter a aparência pálida, "sinal de distinção dos que não precisavam trabalhar sob o sol"237. No novo ritmo de vida proporcionado pelas inovações do século XIX, a intenção é de denotar trabalho e ação. Assim, sombrinhas, chapéus, luvas são substituídos por banhos de mar, banhos de sol, caminhadas, difundindo-se assim a atividade esportiva, que por sua fez influencia a moda, que troca longas vestimentas de várias peças sobrepostas por roupas que permitam maior contato com o sol e liberem os movimentos. Essa nova atitude frente à natureza se evidencia nos elementos das praças.

\subsubsection{As praças}

Substituindo largos, campos e pátios que formam a capital paraibana oitocentista, as praças podem ser consideradas espaços representativos da paisagem e da vida dessa cidade ao longo do processo de reformas por ela passado nas décadas de 1910 e 1920, constituindo-se ícones urbanos desse momento. Sem vínculos predominantemente religiosos, como ocorre com os largos, as praças sinalizam um novo tempo,

${ }^{236}$ PARAHYBA DO NORTE. Mensagem apresentada à Assemblea Legislativa do Estado, em $1^{\circ}$ de Setembro de 1914, por ocasião da abertura da $3^{a}$ Sessão Ordinaria da $7^{\text {a }}$ Legislatura, pelo presidente do estado dr. João Pereira de Castro Pinto. Imprensa Official, MCMXIV, p.24-25.

${ }^{237}$ SEVCENKO, Nicolau. "A capital irradiante: técnicas, ritmos e ritos do Rio". In: SEVCENKO, Nicolau. História da Vida Privada no Brasil. Vol. 3. São Paulo: Companhia das Letras, 2003, pp. 513-619, p. 561. 
representado pela consolidação de ideais de cidade saudável.

As praças se tornam pontos focais da cidade, a partir da remodelação formal do espaço público que se dotam de novos equipamentos e jardins, juntamente com os suntuosos edifícios instalados em seu entorno. Algumas praças, cívicas, são símbolos do poder local. Outras são anunciadoras dos novos hábitos, da difusão do lazer e do esporte. A proliferação de praças públicas promove a renovação das áreas urbanas tanto em relação à sua construção formal quanto à sua utilização, num processo vinculado ao ideal de formação de uma nova paisagem segundo os ditames do "embelezar" e do "sanear".

À nova aparência da cidade, que se apresenta em processo de elaboração, corresponde uma nova postura. A utilização da energia elétrica na cidadeda Parahyba, a partir de 1912, inovando o sistema de iluminação e de transporte urbano, é de grande contribuição para a renovação dos hábitos da população. Porém, são nos bancos, coretos, jardins e passeios das praças públicas que se evidencia uma nova dinâmica urbana, contrapondo-se ao cotidiano citadino de outrora. As praças se tornam uma amostra referencial dos novos espaços públicos criados nesse contexto, palcos de novas vivências e práticas que compõem o cenário dessa nova etapa urbana.

Nesse momento, juntamente com a predominância das praças em meio aos largos, ocorre a gradativa substituição de ruas estreitas e irregulares, becos e travessas por avenidas e ruas largas, retas e arborizadas. Esses novos elementos se distribuem de modo a sinalizar, além de uma nova forma, um outro ritmo de crescimento urbano, a partir do qual a cidade ocupa novas áreas, desencadeando o início de uma expansão do tecido urbano, que em pouco tempo assume áreas muito maiores que as conquistadas ao longo dos quase três séculos e meio de formação da cidade até então. Na nova configuração urbana em construção, as praças tanto podem remodelar a cidade já existente como contribuir para a consolidação do tecido urbano em expansão.

O caráter simbólico desses espaços, que nas suas formas e usos traduzem a transformação do posicionamento oficial em relação à cidade, influenciados pelos discursos urbanísticos então difundidos, explicita-se, já de início, nas denominações a eles atribuídas.

As primeiras praças criadas na capital paraibana localizam-se nas áreas mais antigas da cidade. Em conseqüência da natureza regular da malha urbana de implantação inicial dessa cidade, tais espaços apresentam contornos regulares, segundo a trama na qual se inserem. Em sua maioria, não passam de áreas livres, sem equipamentos e com vegetação nativa, apresentando regiões de alagamento no período chuvoso. Essa aparência desordenada, juntamente com as preocupações higienistas que apontam esses locais como uma ameaça à saúde pública, reforçam o interesse sua reformulação.

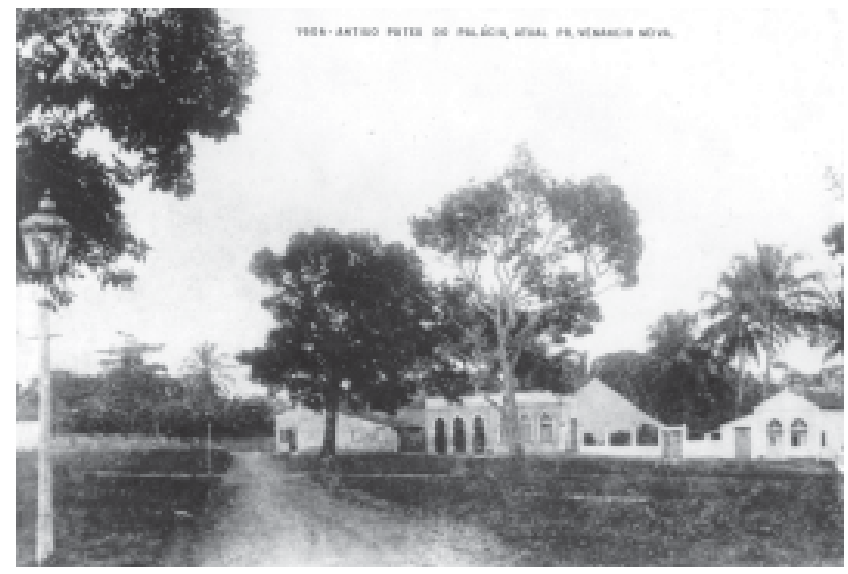

1906 - Pátio do Palácio, depois praça Venâncio Neiva. FONTE: Acervo Laudereida Marques.

Esses espaços, já existentes em fins do século XIX, sofrem alterações formais no século seguinte, acompanhadas da criação de novos espaços cravados no tecido urbano, seja em vazios ou em áreas antes edificadas. O ponto de partida desse processo, no sentido de "adequar" o espaço público às novas formas de apropriação urbana, é o Campo do Commendador Felizardo. Apesar de reformado em fins do século XIX, quando é transformado no Jardim Público dessa capital, esse espaço entra no novo século sofrendo críticas 
nas quais é apontado como de aparência não condizente com um jardim público.

Ao longo do século $\mathrm{XX}$, o Jardim Público passa por novas intervenções, recebendo alguns equipamentos, dentre os quais um coreto onde são realizadas retretas e para onde converge a elite local. As edificações em seu entorno também passam por reformas e o velho sobrado colonial dá lugar à arquitetura eclética. Para essa praça convergem edificações monumentais que se destacam no conjunto urbano, também revestidas de um valor simbólico pelas atividades nelas desenvolvidas: Escola Normal, Palácio do Governo, Igreja Nossa

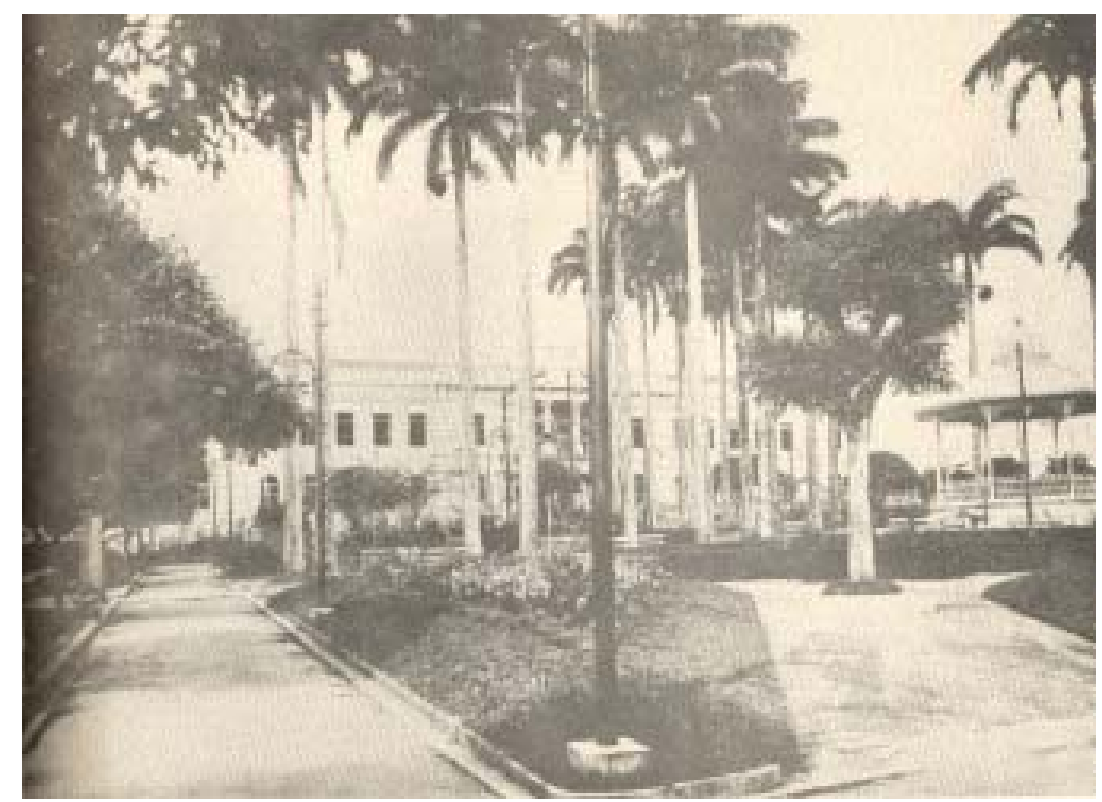

1920- Antigo Jardim Público, vendo-se ao fundo a Escola Normal em construção. FONTE: Acervo Walfredo Rodrigues

Senhora da Conceição - posteriormente demolida - , Liceu Paraibano e Imprensa Oficial.

Esse conjunto simboliza a criação de espaços de lazer laico, sem a presença da igreja e dos usos religiosos a ela associados. O caráter cívico a ele atribuído pelas edificações que o circundam é realçado pela monumental arborização de palmeiras que percorrem as alamedas que ligam tais edifícios ao centro da praça, contrastando com a vegetação de baixo porte distribuída no resto da área ajardinada. O desenho do jardim é formado por alamedas ortogonais e diagonais associadas, o que se repete nas demais praças constuídas ou reformadas nesse momento, a exemplo da Venâncio Veiva, Independência, Pedro Amérioco e Aristides Lobo. Segundo Rykwert, a associaçado de avenidas diagonais com traçados ortogonais é muito usada pelos planejadores tanto de cidade como de jardins, a exemplo do jardim de Versalhes e "suas imitações por toda Europa"238. Segundo o autor, esse partido tornou-se modelo após a reforma de Roma (1585-1590), que sobrepôs diagonais ao traçado antigo, marcando seus cruzamentos com monumentos.

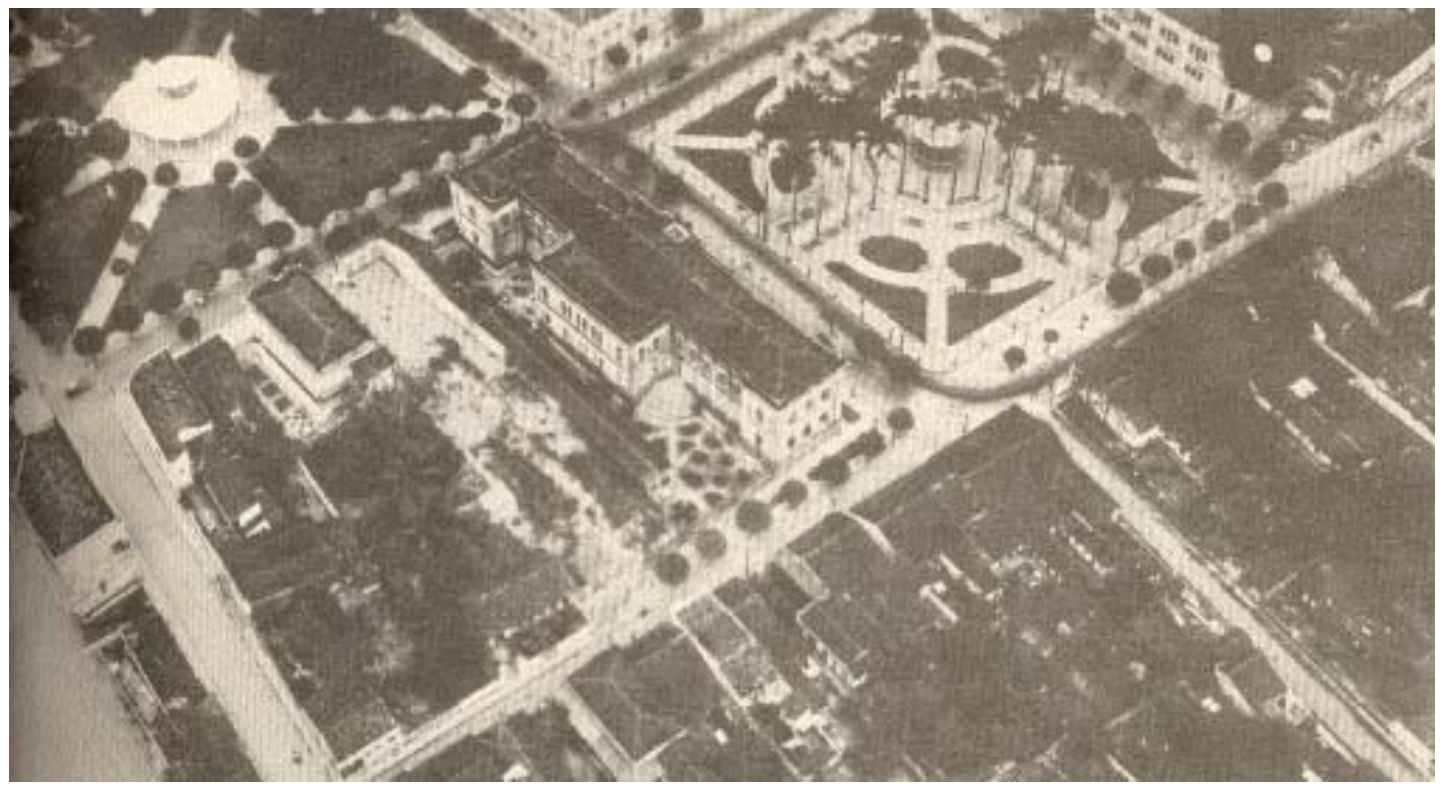

Praça Venancio Neiva - com a fonte substituída pelo coreto central-, e o antigo Jardim Público. Vista aérea. FONTE: Acervo Walfredo Rodrigues.

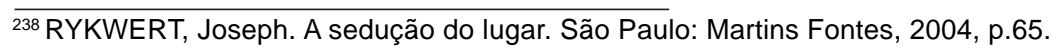


Nas proximidades dessa praça se encontra a Venâncio Neiva, que tem como fachadas as laterais do Palácio do Governo, da Escola Normal e a esquina da Academia de Commercio, cuja cúpula constitui-se elemento de destaque na paisagem. Esse espaço é, até 1917, "um desconfortável logradouro, [com] capime lama de permeio, a lembrar um campinho de futebol distrital"239, quando é convertido em praça. A disposição de seus jardins e passeios é semelhante à da praça Commendador Felizardo, porém o conjunto muito difere do anterior. A implantação de árvores frondosas, uma parte nos contornos das vias, distribuída alinhadamente, outra dentro dos jardins, organizadas de forma mais aleatória, não direciona ênfase monumental às construções ou a algum elemento de destaque maior, apenas à fonte situada no seu centro. Os equipamentos nela inseridos e suas disposições no conjunto conferem ao espaço um caráter menos rígido, remetendo-se a uma relação de lazer: a fonte recebe a posição central, espaço geralmente reservado aos coretos que nesse caso é deslocado para a esquina. Dispõe ainda de um rink de patinação, reforçando sua tendência para atividades de lazer. Assim, as duas praças vizinhas e de formas semelhantes, inclusive no desenho de seus caminhos e jardins, assumem papéis distintos na configuração do espaço urbano.

Das praças criadas nesse momento, é certamente a Vidal de Negreiros a que melhor reflete os novos ideais urbanos. O caráter simbólico a ela conferido é percebido tanto pelos equipamentos e por sua forma, como pelo processo como se deu sua implantação, a partir da extinção de espaços antigos.

\section{Construída em 1924 para} abrigar a confluência das três linhas de bonde da cidade, função que já a reveste de novos significados, essa praça é implantada a partir da demolição da Igreja do Rosário dos Pretos e de um conjunto de sobrados da rua Direita. Enquanto espaço público, a praça substitui o pequeno largo daquela igreja, diferenciando-se dele não só por suas dimensões, mas também pelos equipamentos inseridos $\mathrm{e}$ sua consequente utilização.

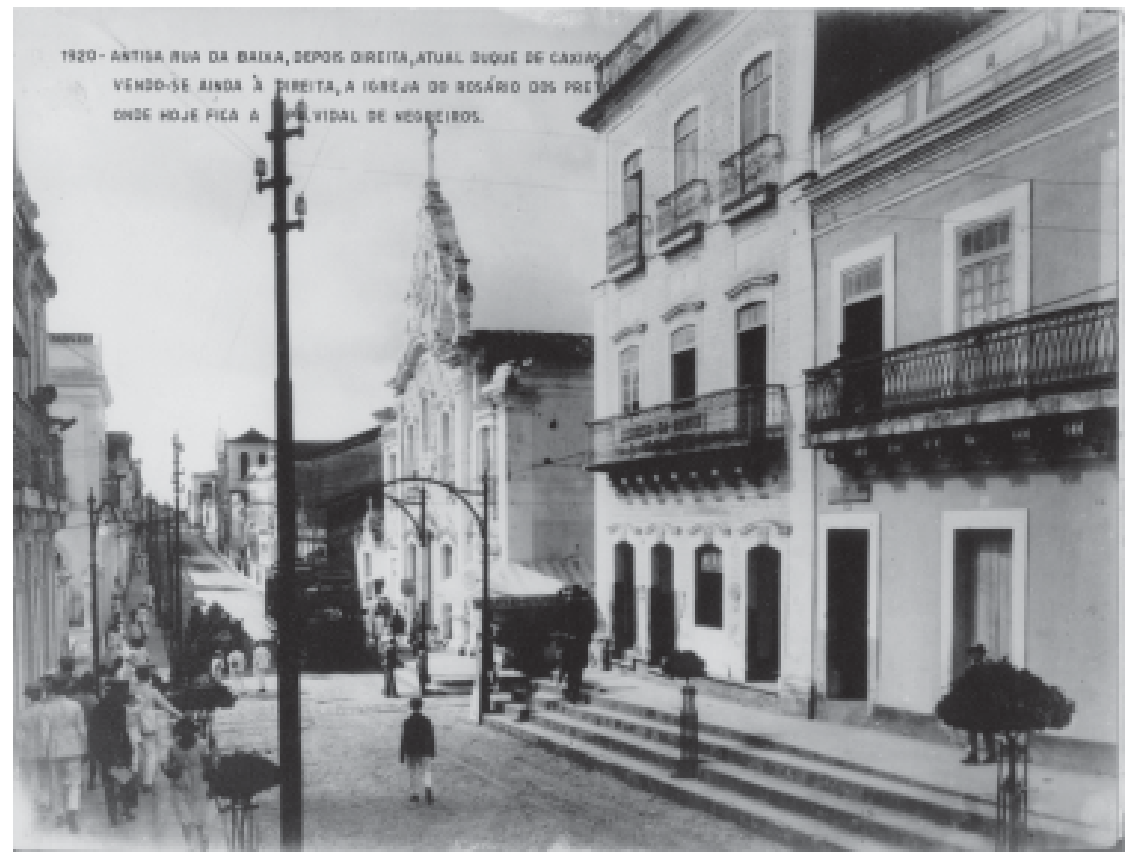

1920 - Rua Direita, com a Igreja do Rosário dos Pretos, demolida para a construção da praça Vidal de Negreiros. FONTE: Acervo Laudereida Marques.

Nessa praça é construído um pavilhão de apoio ao serviço de transporte, onde também se instalam uma bombonière, banheiros públicos e uma tabacaria. A presença de um grande relógio na fachada do pavilhão faz referência ao novo ritmo de vida. Além da figura do bonde, esse espaço é marcado pela concentração de automóveis, por também abrigar um estacionamento para carros de aluguel, o que imprime uma atmosfera inovadora, concentrando grande número de frequentadores, além dos usuários do transporte público.

A maior parte das alterações do espaço urbano realizada na cidade ocorre de forma concentrada, sobretudo, nas imediações da rua Direita. A criação da praça da Independência, entretanto, foge desse padrão pela sua localização, apesar de manter os demais princípios formais assumidos pelas praças desse período. Ela é implantada numa região pouco edificada, formada por vias que compõem uma traça regular situadas na

${ }^{239}$ CAVALCANTI, A cidade da Parahyba na época da independência: aspectos socioeconômicos, culturais e urbanísticos em volta de 1822. João Pesso: Editora Universitária, 1972, p.38. 


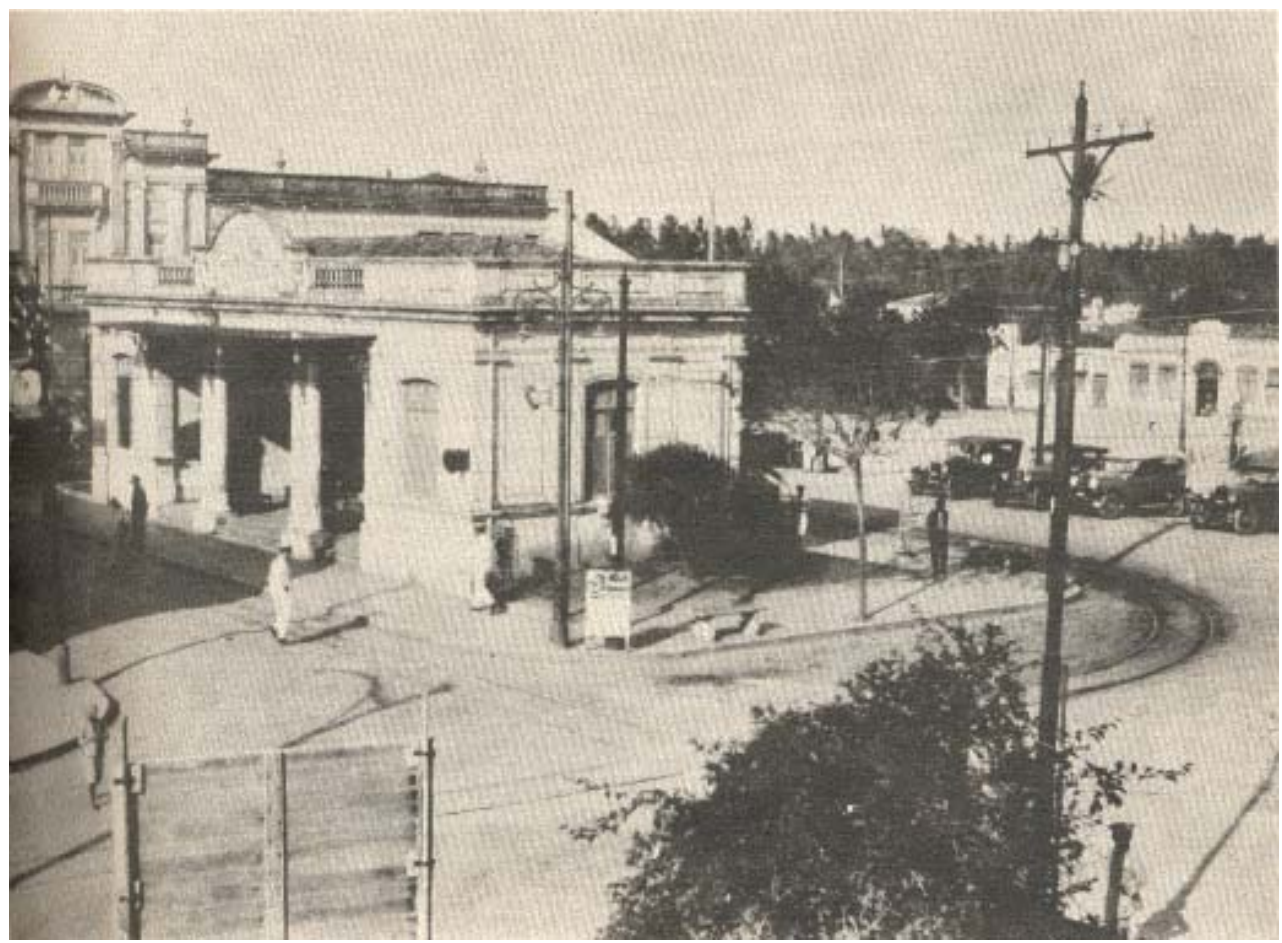

Pavilhão da praça Vidal de Negreiros, construída na administração de Guedes Pereira. FONTE: Acervo Walfredo Rodrigues

região de expansão da cidade, de onde partem, posteriormente, as vias de acesso à região praieira. Construída na administração de Guedes Pereira, em comemoração ao centenário da Independência, essa praça surge como marco da expansão nessa direção, posto que sua construção impulsiona a ocupação urbana nessa área, iniciando uma vertente de intervenções expansionistas que se efetiva, de fato, apenas nos anos trinta.

Essa ação viabiliza a formação de bairros residenciais para a elite, que passa a se instalar em ruas no entorno dessa praça, efetivando o crescimento da cidade naquela direção. Essas características ocupacionais - residenciais de alto padrão- dão continuidade à consolidação do tecido urbano ao longo do processo de espraiamento.

A organização formal dessa praça segue a disposição de passeios e jardins da praça Venâncio Neiva e do Jardim Público, porém seu coreto, retangular e de grandes dimensões, implantado em uma de suas laterais, muito difere dos construídos nas outras praças da cidade. No que se refere ao uso desse espaço, há também uma inovação em relação às demais. Sem realização de retretas e de pouco uso cotidiano, a praça da Independência é utilizada para eventos esporádicos, geralmente de natureza

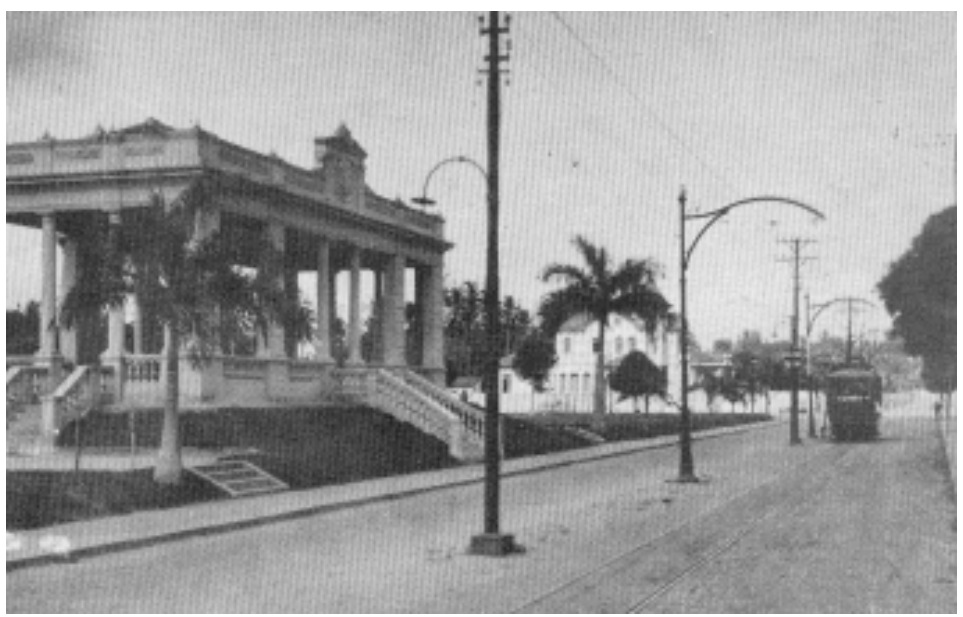

Coreto praça da Independência FONTE:Acvervo Humberto Nóbrega política e, usualmente, de grande porte.

A aparência urbana construída a partir desses novos espaços públicos, fruto das intervenções desse período, também guarda forte relação com as edificações do seu entorno, onde as praças se diferem pela forma do espaço livre e pelas fachadas das edificações que as rodeiam. Assim, geralmente, à renovação de 


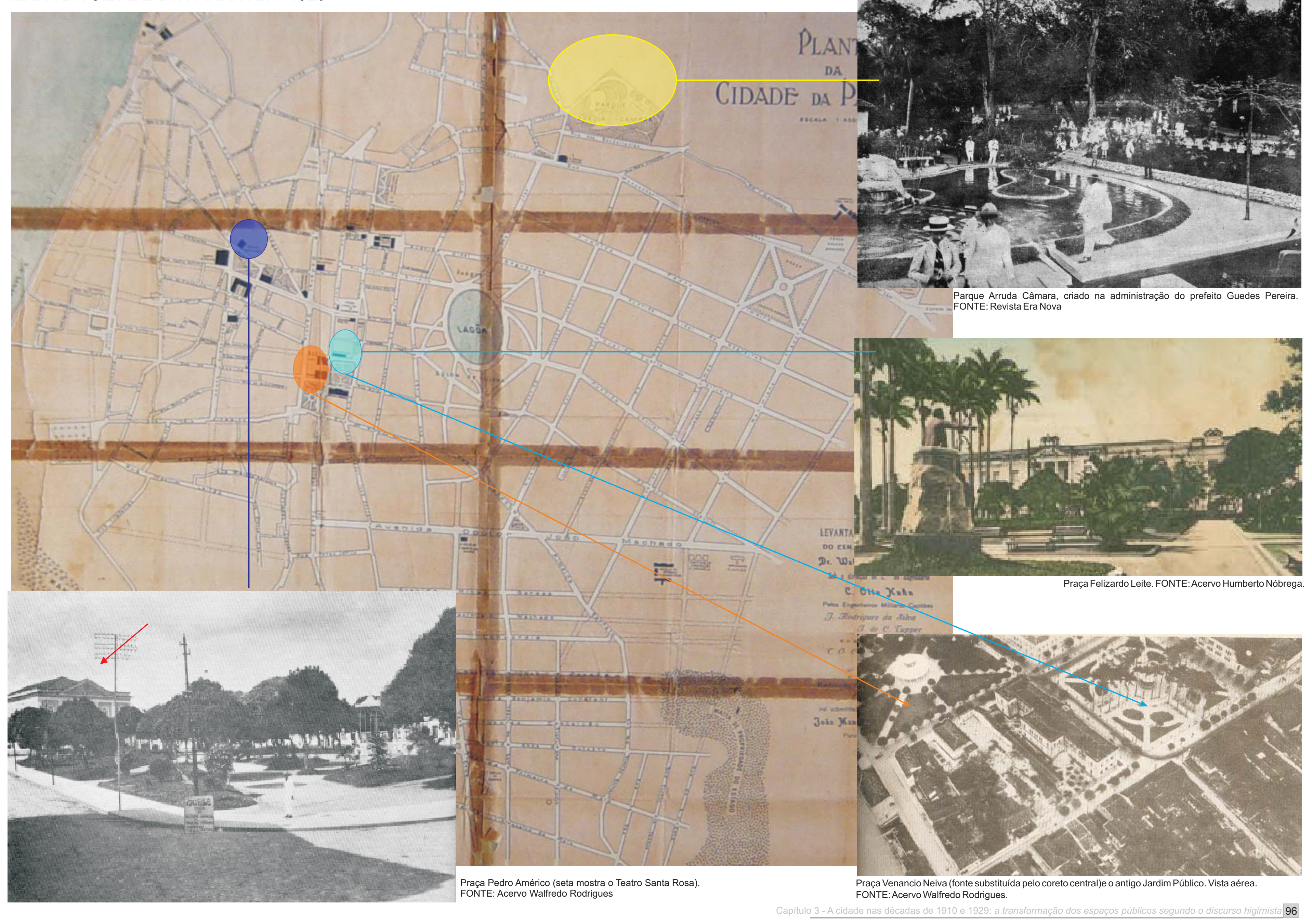


uma praça ou à criação de um novo espaço urbano dessa natureza vincula-se uma edificação simbólica, seja pela sua arquitetura e ou pelas atividades nelas abrigadas.

\subsubsection{As construções nesses espaços}

A influência da arquitetura na constituição dos novos espaços dá-se, de forma mais significativa, através das edificações públicas. Sua projeção no meio urbano ocorre tanto pela escala da edificação como pelo seu valor simbólico. Nesse conjunto, destacam-se as construções que abrigam as atividades administrativas, assim como teatros, escolas, clubes, mercados públicos, correios, etc.

A renovação formal desses elementos é também impulsionada pela periódica chegada de novos profissionais da engenharia e da arquitetura na cidade, o que possibilita aperfeiçoamentos técnicos e renovação estética, ocorrendo o incentivo à inovação do repertório arquitetônico. Nas primeiras décadas do século XX, há um movimento intenso de remodelação de edificações existentes e de inserção de novas construções no cenário urbano, essas, geralmente, implantadas nas proximidades de espaços já remodelados, evidenciando a renovação urbana a partir da formação de alguns "núcleos modernizados", constituídos por praças e edificações.

Na década de 1920, as recorrentes reformas das edificações dão espaço à execução de construções que assumem números representativos, contemplando, principalmente as funções vinculadas ao poder administrativo e às atividades econômicas em expansão. A implantação de muitos desses edifícios se dá, estrategicamente, no entorno das praças criadas ou reformadas. A cidade configura um cenário marcado por praças cívicas, a exemplo do conjunto formado pelo Jardim Público e os suntuosos prédios do Palácio do Governo, da Imprensa Oficial e da Escola Normal, os quais constituem as "fachadas" desse espaço público. A relação entre as praças e as construções monumentais públicas que as rodeiam faz dessas edificações uma espécie de fechamento das praças, gerando um espaço que Sitte chama de um "salão de festas"240.

Na área entre as partes alta e baixa da cidade, ainda nas proximidades da rua Direita, o cenário urbano é marcado por um conjunto de edifícios públicos monumentais formado pela Assembléia Legislativa, Quartel, Teatro Santa Rosa e Correios e Telégrafos. Esse panorama arquitetônico estimula a intervenção no então Campo do Conselheiro Diogo, a fim de torná-lo compatível com a forma dos edifícios de seu entorno. Assim, a área recoberta por vegetação nativa marcada por caminhos é transformada na praça Pedro Américo, com jardim, pavimentação, equipamentos - bancos e iluminação- e árvores. Além do coreto em estrutura metálica com teto e guarda-corpo importados, a praça incorpora um pequeno

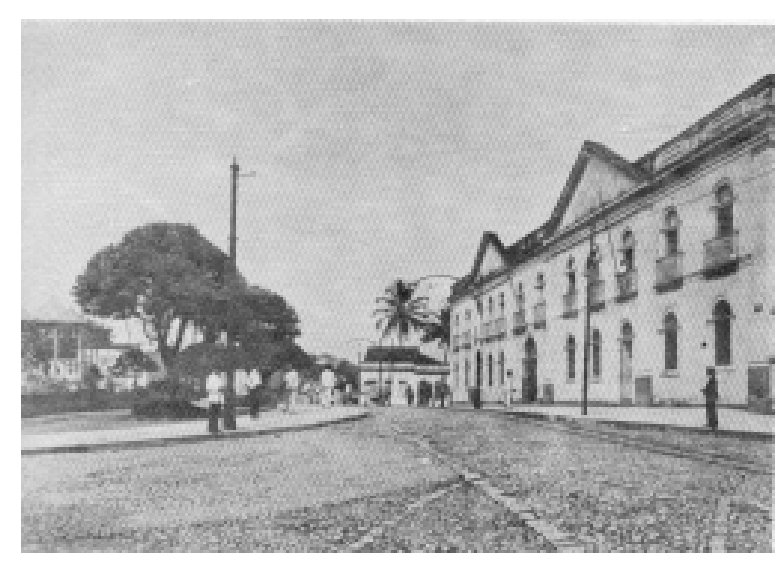

1920 - Quartel da Polícia Militar do Estado. Praça Pedro Américo. FONTE: Coleção Walfredo Rodrigues lago no formato do mapa do estado da Paraíba, dotada de uma ponte.

\footnotetext{
${ }^{240}$ Ao tratar desse fechamento, Sitte faz referência ao Fórum Romano, onde construções monumentais públicas e a escassa interferência de ruas criam essa espécie de "salão": "o fórum está para a cidade inteira assim como para a casa de família está o átrio, a sala principal bem disposta e ricamente mobiliada". Assim, Sitte toma a praça como elemento fundamental da cidade, onde se verifica a "vivacidade da vida pública", contribuindo para a construção urbana segundo o princípio que "uma cidade deve ser construída para tornar o homem ao mesmo tempo seguro e feliz". (SITTE, Camillo. A construção das cidades segundo seus princípios artísticos. São Paulo: Editora Ática, 1992, p. 14-17.)
} 


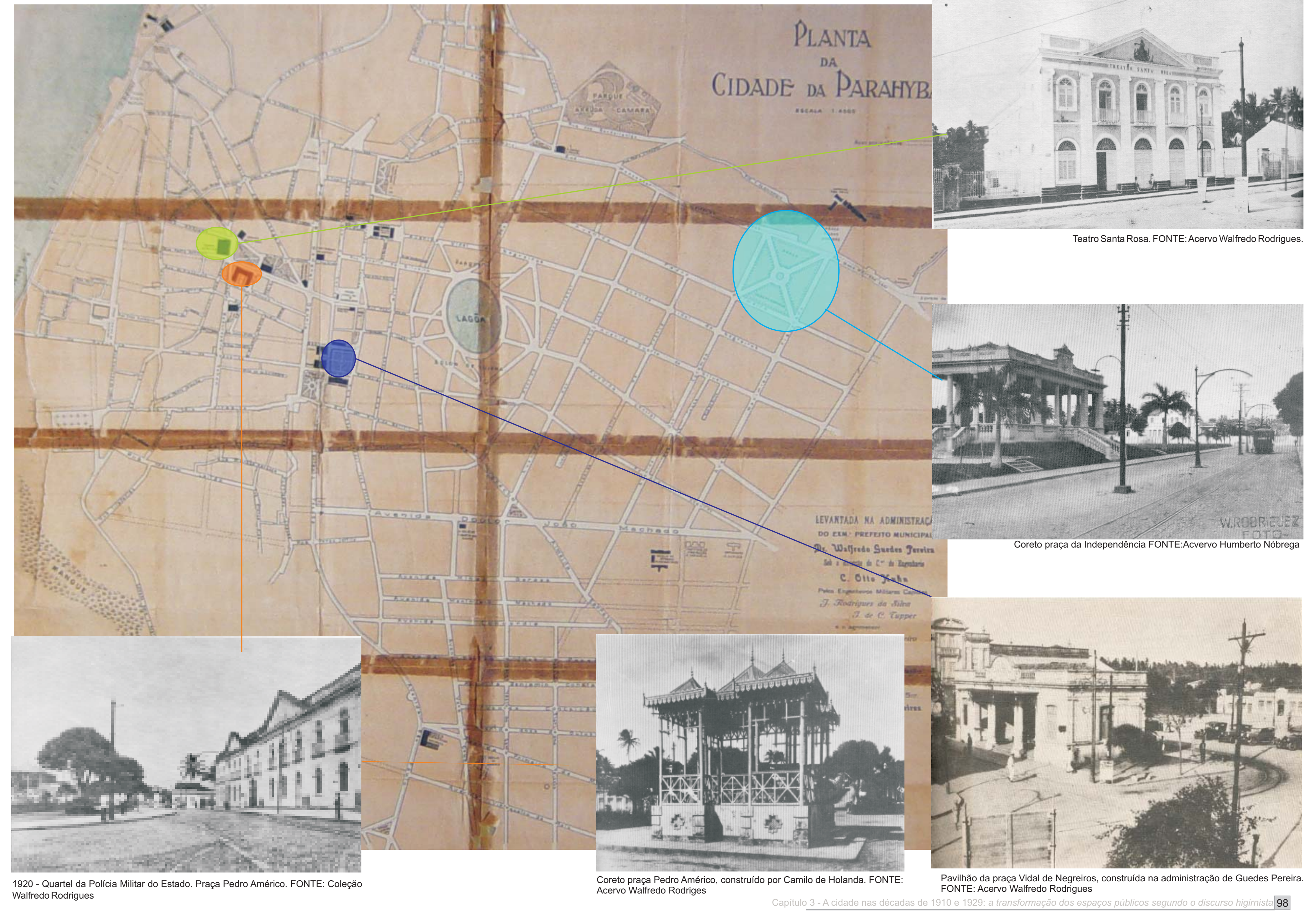


No mesmo sentido, dá-se a construção da praça Aristides Lobo, inaugurada em 1918. Formada por uma área de uso indefinido e coberto por mato, esse espaço recebe tratamento paisagístico, delimitando passeios, bancos, jardins, iluminação e arborização regulares. Sua localização na vizinhança da praça Pedro Américo e dos edifícios do Tesouro do Estado e do grupo escolar Thomaz Mindello parece ter sido fundamental para a decisão de sua reforma.

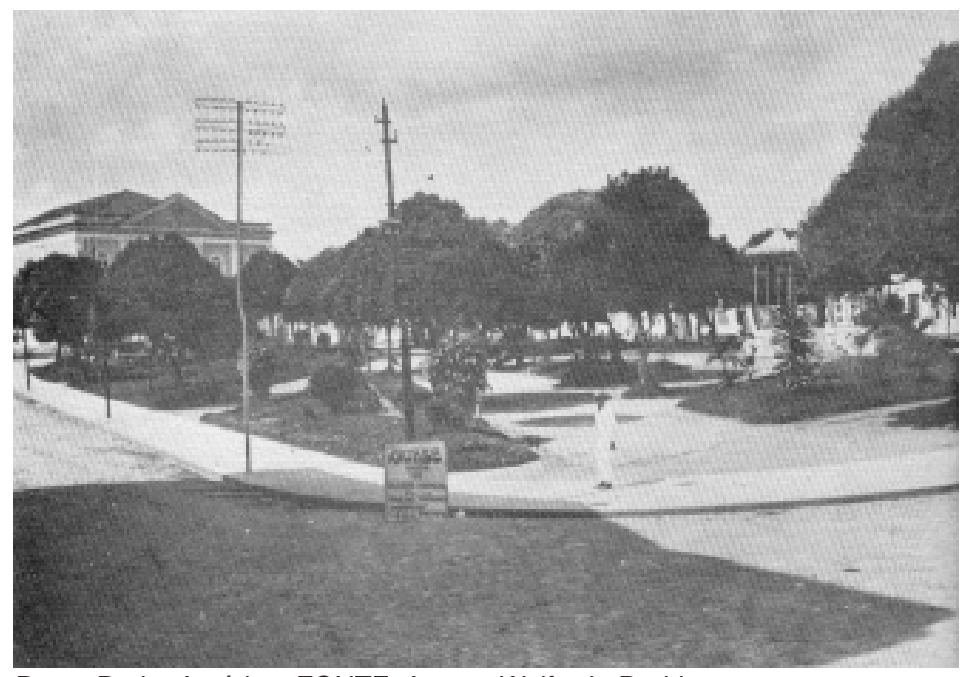

Praça Pedro Américo. FONTE: Acervo Walfredo Rodrigues

\subsubsection{Reforma da infra-estrutura}

As recorrentes críticas à precariedade da infra-estrutura urbana, intensificadas no fim do século XIX, recebem, nesse momento, respostas mais enérgicas. As primeiras administrações do período se ocupam mais do alargamento de vias, limpeza de áreas vazias onde se acumula mato e lixo, melhoria do sistema de iluminação e da qualidade da água que abastece a cidade. Juntamente com o alargamento e alinhamento de vias, e com a criação de praças, há uma gradativa alteração no processo de iluminação pública e no abastecimento d’água, questões sempre em foco nas mensagens de governo e em decretos e leis locais.

Em 1913, é feito um convite pelo chefe do governo Castro Pinto ao engenheiro Saturnino de Brito para a realização do plano de esgoto e abastecimento de água dessa capital. Apesar da cidade ser dotada de um sistema de abastecimento d'água, sua área de abrangência é limitada e a qualidade da água é suspeita, segundo denúncias no jornal A União em 1913. Nesse momento, a cidade é alvo de uma proposta de intervenção ampla, incluindo ações abrangentes e não mais pontuais e fragmentadas como ocorrido até então.

Francisco Saturnino Rodrigues de Brito, engenheiro civil formado pela Escola Politécnica do Rio de Janeiro (1886), tem marcante atuação no Brasil: "percorreu 53 cidades brasileiras, onde pôde expor suas idéias e principalmente aplicá-las na área de saneamento e embelezamento das cidades"241. Planeja áreas de expansão urbana, com engenhosas soluções sanitárias que "visavam sempre à economia de recursos e ao automatismo no funcionamento da cidade" ${ }^{42}$. Defensor do crescimento planejado das cidades, sua atuação é, segundo Andrade, "fator decisivo para a instauração da prática do planejamento urbanístico no Brasil" 243.

Saturnino de Brito vai à capital paraibana quando se ocupa do plano de saneamento do Recife. Nos seus projetos de reforma de cidades, as soluções sanitárias constituem-se a base do desenho urbano. No plano elaborado para a cidade da Parahyba em 1913, como na maioria de seus trabalhos, relaciona preocupações relativas aos esgotos e à expansão urbana, propondo um projeto de infra-estrutura que se constitui como base para o desenvolvimento e crescimento de novas áreas da cidade, indicando ainda melhoramentos para as áreas já consolidadas.

O plano é elaborado em "parcas horas em certos dias e à noite"244, devido às ocupações do engenheiro

\footnotetext{
${ }^{241}$ LEME, Maria Cristina. Urbanismo no Brasil 1895-1965. Salvador: EDUFBA,2005. p. 455.

${ }^{242}$ ANDRADE, Carlos Roberto Monteiro de. Saturnino de Brito, um projetista de cidades. Revista AU, n. 72, jun/jul 1997. p. 68.

$243 \mathrm{lbid}$.

${ }^{244}$ Ibid. p. 191.
} 


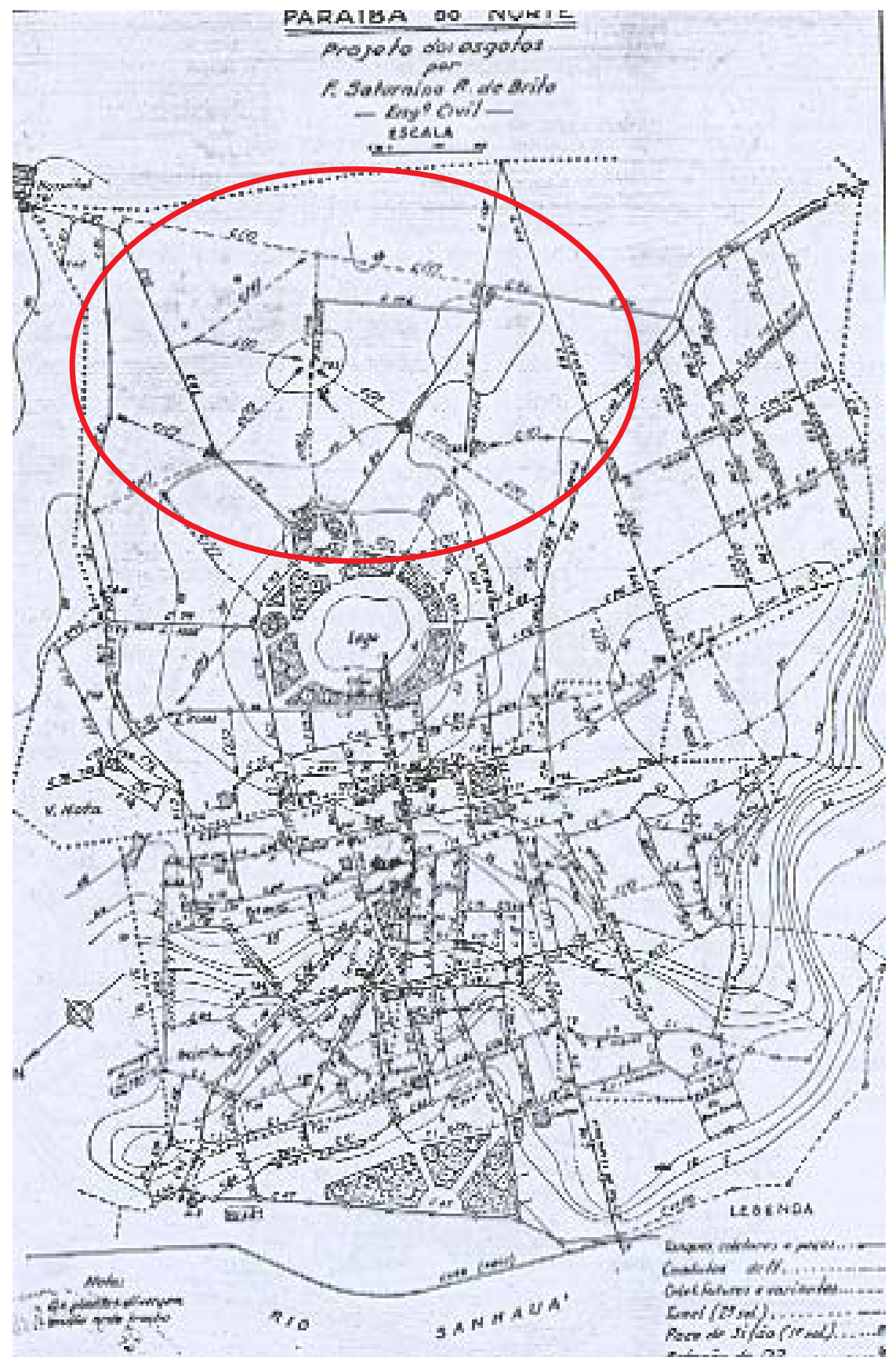

Plano elaborado por Saturnino de Brito para João Pessoa. FONTE: Brito, Francisco Saturnino Rodrigues de. "Saneamento de Parahyba do Norte". Obras Completas. Volume 5. Rio de Janeiro: Imprensa Oficial, 1943. Em vermelho, exemplo do "traçado sanitátio". relativas aos trabalhos em andamento em Santos, na Bahia e no Pará, além de viagens à Europa "para estudar questões importantes relativas ao caso de Recife" ${ }^{245}$. Para a capital paraibana, aconselha 0 alargamento de ruas com o intuito de promover uma fácil distribuição do trânsito, projeta ruas novas não necessariamente retas, longas e ortogonais, mas dispostas "de modo a terem todas uma declividade favorável ao escoamento [das águas] pluvia[is] e à execução dos esgotos" ${ }^{246}$. Como se constata no plano, na área mais propensa ao crescimento, Brito propõe uma expansão baseada em quadras triangulares, adaptadas à topografia da cidade e mais propensas à instalação de redes sanitárias, o que ele chama de "traçado sanitário" ${ }^{247}$.

Essa irregularidade do traçado proposto, justificada por questões sanitárias, abrange uma área de expansão, em cujas proximidades se encontra consolidada uma trama viária regular, construída poucos anos antes da elaboração do plano proposto por Brito. Apesar de elementos que justificam o partido proposto, percebe-se no plano que essa região de desenho flexível contrasta com as áreas vizinhas recém construídas, bem como com a também vizinha área inicial da cidade, de malha 'ortogonal'.

Além da clara intenção de Brito em ordenar o fluxo das águas e esgotos se utilizando do traçado da cidade, há uma forte preocupação em criar espaços verdes. Para tanto, reserva, nas áreas de expansão, "alguns quarteirões para praças, jardins ou parques, aos quais os higienistas [atribuíam] as funções de pulmões da cidade"248. Atestando a permanência do pensamento higienista, a inserção de áreas arborizadas na malha

${ }^{245}$ BRITO, Francisco Saturnino Rodrigues de. "Saneamento de Parahyba do Norte". Obras Completas. Volume 5. Rio de Janeiro: Imprensa Oficial, 1943, p. 291.

246 Ibid.

247 Ibid.

248 Ibid. 
urbana atua tanto para o embelezamento urbano como para o arejamento da cidade. Segundo Montaner ${ }^{249}$, a Revolução Industrial desperta a avidez burguesa em tirar rápido e produtivo proveito do meio, transformando continuadamente seu entorno e influenciando nos conceitos relativos à natureza e à cidade, que se torna sinônimo de foco dos males sanitários, enquanto a natureza passa a ser idealizada. É na Inglaterra, berço dessa revolução, que mais se desenvolve a estética do pitoresco, onde parques buscam imitar a natureza virgem, num processo de regate do bem escasso através de propostas de reformulação para o meio urbano. Ao longo do século XIX, com o desenvolvimento médico-científico, as cidades européias passam por grandes transformações permeadas pelo discurso higienista, consolidando a preocupação em criar áreas verdes nas cidades, implantando praças, parques, passeios, jardins e avenidas arborizadas. Torna-se recorrente a criação desses espaços, muitas vezes ocupando interstícios urbanos em áreas afastadas dos centros da cidade, a exemplo de Moorfields, em Londres, onde "parcela da área alagadiça foi legada à cidade, para uso e gozo dos cidadãos"250. Mas "o parque urbano não era um ainstituição nova. Jardins reais haviam sido abertos ao público desde o século XVI"251, a exemplo dos jardins de Versalhes, das Tulherias e os de Luxemburgo, assim como muitos claustros conventuais e canteiros palacianos. Outra contribuição européia é a plantação de linhas de árvores nos passeios, como os de Antuérpia e os bulevares parisienses. "Contudo, o primeiro parque público, comprado e especialmente ajardinado para o público às cusats das autoridades locais, foi aberto em 1834, em Birkenhead, perto de Liverpool"252. Em 1840, firma-se também nos Estados Unidos um movimento a favor de parques. Um importante contato com a produção européia se dá através de Frederick Law Olmsted, que visita vários parques londrinos ${ }^{253}$, promovendo nos Estados Unidos em meados do século XIX vários debates sobre o assunto. O projeto de Olmsted para o Central Park de Nova lorque constitui uma etapa importante do urbanismo americano, a partir do qual a questão dos parques urbanos se converte em tema central acerca do papel da verba pública em relação aos serviços sociais. "Na França, a provisão de parques públicos se tornou uma prioridade oficial, seguindo o exemplo de Napoleão III em Paris"254.

No Brasil, em fins do século XIX, a prática de ruas e parques arborizados é amplamente difundida, relacionada não apenas à dimensão da saúde como ao caráter cívico. A nova relação cidade-natureza aparece recorrentemente nas primeiras décadas do século XX, nas propostas de melhoramentos das cidades, estendendo-se para as reformas efetuadas ao longo da primeira metade desse mesmo século. Nesse sentido, destaca-se o Plano Geral de Melhoramentos da cidade de Salvador (1910), onde, além da abertura, alargamento e retificação de ruas, prevê também "intervenções pontuais e coordenadas" 255 que incluem, entre outros elementos, praças e jardins. A reforma urbana do bairro do Recife rasga sobre o tecido urbano duas grandes avenidas que "confluem majestosamente para uma imponente praça que persegue as formas dos bulevares"256. As propostas e a intervenção efetuada na área do Vale do Anhagabaú, em São Paulo, constituem outra manifestação urbana desse período, que explicita claramente a intenção de redefinir o lugar da natureza no tecido urbano. Ao vale que abrigava quintais é recomendada a criação de jardins que dialoguem esteticamente com novas avenidas, pontes e edificações implantados no seu entorno.

As intervenções na cidade da Parahyba também têm como uma das metas a criação de novos espaços arborizados como parques, jardins e praças. As indicações feitas no plano de Brito a esse respeito certamente influenciam na configuração urbana que marca a cidade década de 1920. O verde se expressa fortemente nessa cidade através de seus espaços públicos, capital cuja grande vocação, segundo Gonzaga Rodrigues, "é a de ser urbs e bosque"257. Essa relação firmada entre o verde e esses espaços lega à cidade o título de

\footnotetext{
${ }^{249}$ MONTANER, Josep Maria. A modernidade Superada. Barcelona: Editorial Gustavo Gili, S.A., 2001, p.194.

250 SEGAWA, Hugo. Ao amor do público: jardins do Brasil. São Paulo: Studio Nobel; FAPESP, 1996, p.43.

${ }^{251}$ RYKWERT, Joseph. A sedução do lugar. São Paulo, Martins Fontes, 2004, p.121.

252 Ibid.

${ }^{253}$ Olmsted visitou os parques de Londres em 1850, 1856 e 1859.

${ }^{254}$ RYKWERT, Joseph. op., cit., p.121.

${ }^{255}$ LEME, Maria C. da S. (coord.) Urbanismo no Brasil - 1895-1965. São Paulo: Studio Nobel; FAU-USP; FUPAM, 1999, p.280.

${ }^{256}$ Ibid., p.287.

${ }^{257}$ RODRIGUES, Gonzaga. “A cidade o rio e o mar”. In: MELLO \&, RODRIGUES. Paraíba, conquista e povo. João Pessoa: Grafset, 1993, p.190.
} 
Cidade dos Jardins, com o qual a cidade é descrita, enaltecida e recordada em poemas, notas, crônicas e reportagens fotográficas.

Apesar da importante contribuição do governo Castro Pinto ao convidar o engenheiro Saturnino de Brito, sua ação restringe-se à iniciativa de elaboração do plano. Apenas em 1922, quase dez anos depois da apresentação da proposta é que se executam as obras de saneamento, cuja conclusão se dá em 1926.

A não execução imediata das obras propostas para o saneamento da cidade é decorrente de crises financeiras que abalam a economia local, limitando a atuação administrativa. Em 1915, a seca prolongada no nordeste influi fortemente na economia agro-exportadora, e, conseqüentemente, nas finanças públicas paraibanas. Nesse momento, o orçamento referente às obras públicas cai pela metade, o que provoca a diminuição das intervenções, que só não são paralisadas de imediato por ser, segundo o presidente Castro Pinto, uma atitude desastrosa, postura que evidencia serem as obras urbanas prioridades administrativas.

Nesse mesmo ano, transformações políticas locais promovem a oligarquia conduzida pelo então senador federal Epitácio Pessoa, levando ao governo do Estado da Parahyba seu irmão Antônio Pessoa, que busca reordenar a administração a partir de um controle maior da economia. No âmbito das intervenções urbanas, são suspensos todos os melhoramentos em execução. Posteriormente, apenas as obras do edifício do Palácio do Governo são retomadas.

A pausa das intervenções governamentais não esmaece os ideais urbanos circulantes na classe dominante, fruto do compromisso de reordenação da cidade que prioriza uma imagem bela e saudável. Assim, quando o estado fica à margem, a sociedade age por meio de instituições filantrópicas, impulsionadas pelo desejo de livrar-se de mendigos flagelados, doentes e órfãos que enchem as ruas. Nesse momento, são construídos o Asilo de Mendicância, Policlínica Infantil e o Orfanato D.Ulrico, todos localizados, estrategicamente, em áreas afastadas do núcleo urbano, o que reafirma a dupla função dessa ação: embelezamento da cidade com novos edifícios e exclusão desse cenário de grupos indesejados. Trata-se de uma postura de viés "higienista" e excludente, instituindo-se novos elementos urbanos que "ordenam" e restringem o uso comum do espaço público.

A atuação administrativa no meio urbano é retomada com fervor em 1916, quando assume o governo do estado da Parahyba o militar e médico formado pela Faculdade de Medicina da Bahia, Camillo de Holanda. A situação econômica local se encontra mais estabilizada devido ao estímulo econômico proporcionado pela alta do preço do algodão, principal produto de exportação da região, ao longo da Primeira Guerra Mundial, e ainda pelos recursos provenientes da Inspetoria de Obras Contra as Secas (IOCS).

A reordenação econômica estadual não se reflete, de imediato, na situação referente à municipalidade, que ainda não dispõe de recursos para operar obras de vulto na capital, o que é amplamente realizado pelo governo do Estado. Porém, a administração local contribui para a reformulação urbana a partir da produção de posturas municipais e através de decretos elaborados pelo Conselho Municipal. As obras de maior vulto são empreendidas pelo Estado, este conduzido por Camilo de Holanda, que toma como meta principal para a administração estadual a realização de obras públicas ${ }^{258}$, sobretudo a remodelação da capital, com preocupações claramente formais, como pode ser constatada na mensagem por ele apresentada à Assembléia Legislativa do Estado, em 1917:

\footnotetext{
${ }^{258}$ Sua intenção de promover uma forte atuação na área urbana da capital, durante a administração a que Ihe era confiada, já transparece na realização de visitas a São Paulo e Minas Gerais, anteriores a sua posse, para conhecer o funcionamento administrativo daqueles estados. A esses conhecimentos somava-se seu repertório urbano proveniente de viagens à Europa, além de ter, provavelmente, presenciado a referencial atuação de Pereira Passos, em virtude de sua estada no Rio de Janeiro como deputado federal, nos anos de 1909,1912 e 1915. (SARMENTO, Cristiane Finizola. Sob o signo da modernidade: arquitetura oficial na Parahyba (1910-1924) João Pessoa, UFPB, 2000. Trabalho de Graduação.)
} 
"O restante da minha actividade governamental tem-se empregado exclusivamente na remodelação da cidade, na conservação e reforma de seus edifícios publicos, na construção das suas praças, no calçamento de certas vias de transito e outras providencias menores exequidas por intermedio da diretoria de Obras"259.

Mesmo com alterações já executadas no espaço urbano, permeadas por discursos "modernizadores", a idéia de caos e insalubridade ainda prevalece nas referências sobre a capital paraibana ao longo das primeiras décadas do século XX. Essa administração atua incisivamente no espaço urbano da capital, reativando a Directoria de Obras Publicas que é ampliada e reordenada sob a direção de Raphael Holanda, engenheiro recém chegado da Inglaterra, onde se formara. A partir de então, a Directoria se responsabiliza pelas obras públicas segundo dois setores de atuação: abastecimento d'água e serviços gerais. Os últimos englobam as praças e jardins, edifícios estaduais, horto florestal e agropecuária ${ }^{260}$.

O novo cenário urbano promovido pelo alinhamento e abertura de ruas bem como pela construção de novas praças é construído a partir de demolições, processo comum às cidades que adotam reformas urbanas para a reconstrução de seus espaços, onde se apagava as referências do passado para dar lugar a símbolos de um novo tempo.

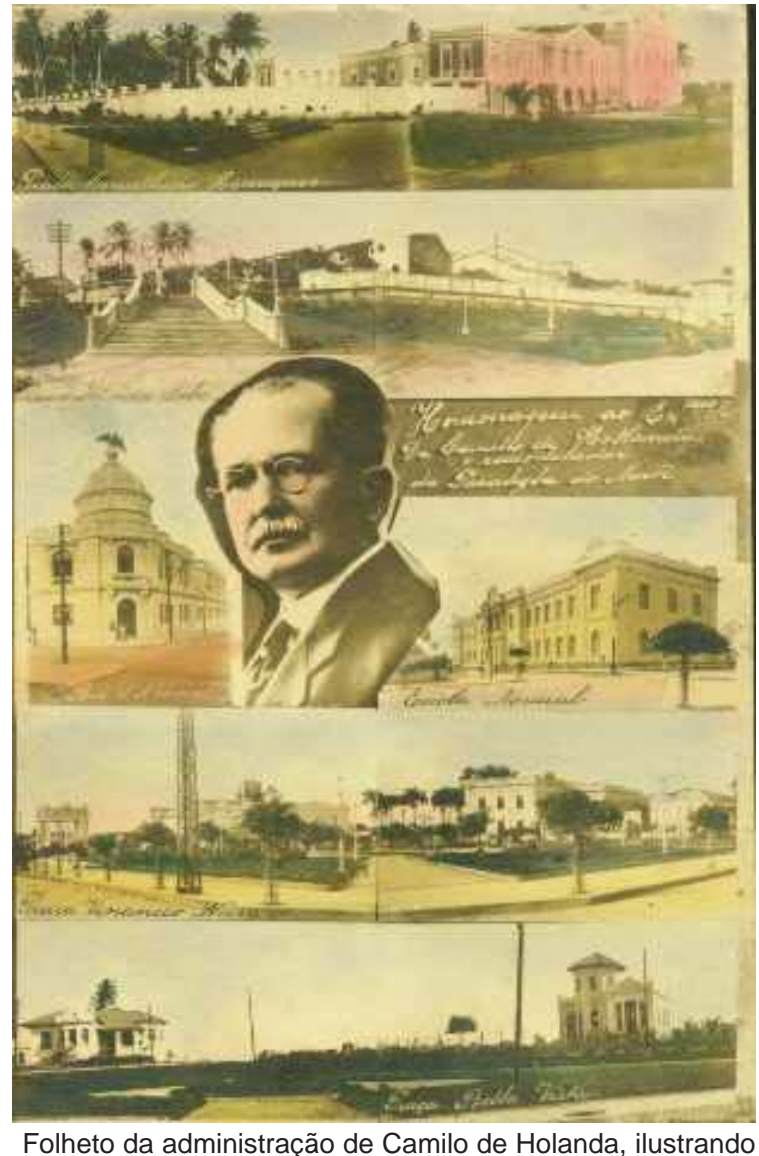

Folheto da administração de Camilo de Holanda, ilustrando algumas de suas realizações. FONTE: Revista Era Nova.

Esse tipo de atuação de melhoramentos na cidade a partir de demolições, detectado nesse primeiro ciclo de reforma urbana, é característico das décadas de 1910 e 1920 em todo o país. Verifica-se nas propostas e obras desse período uma espécie de "bota abaixo", onde edificações e elementos da natureza são extintos para dar lugar à construção de uma nova aparência urbana.

Assim, pode-se apontar como exemplo, no Rio de Janeiro, a abertura da avenida Rio Branco e o desmonte do morro do Castelo. Se a criação dessa avenida desloca aproximadamente 20 mil pessoas ${ }^{261}$, é também ela quem impulsiona o desmonte do morro, onde grande quantidade de pessoas perdem suas residências: "Como estava situado na área de maior valorização do solo da cidade (próximo à avenida Rio Branco) o prefeito Carlos Sampaio decide demoli-lo em nome da estética e da higiene" 262.

Da mesma forma, as propostas para o vale do Anhagabaú, elaboradas entre 1907 e1912, envolvem demolições, seja na região do vale, onde casas e seus quintais são extintos, como nas suas proximidades, a exemplo do alargamento e nivelamento proposto para a rua Líbero Badaró, segundo o projeto apresentado pela prefeitura municipal. A reforma do bairro do Recife segue essa mesma característica: "A reforma consistiu em uma extensa demolição do casario e do antigo traçado urbano colonial irregular, para dar lugar, entre

\footnotetext{
259 PARAHYBA DO NORTE. Mensagem apresentada à Assembléia Legislativa do Estado, em 1917, pelo presidente do Estado Dr. Francisco Camilo de Holanda. Parahyba do Norte: Imprensa Oficial, 1917, p.18.

${ }^{260}$ SARMENTO, Cristiane Finizola. Sob o signo da modernidade: arquitetura oficial na Parahyba (1910-1924) João Pessoa, UFPB, 2000. (Trabalho de graduação), p. 184.

${ }^{261}$ Segundo Carlos Kessel, na palestra Araújo Viana, entre o ecletismo e o neocolonial ministrada na EESC- USP em $17 / 06 / 2005$.

262 LEME, Maria C. da S. (coord.) Urbanismo no Brasil - 1895-1965. São Paulo: Studio Nobel; FAU-USP; FUPAM, 1999, p. 294.
} 
outros melhoramentos, a duas grandes avenidas radiais"263.

A nova aparência paraibana pretendida legitima a destruição de construções, viabilizada pela administração local que autoriza o prefeito a promover "amigavel ou judicialmente, as necessárias desapropriações"264. Assim, muitas das obras desse período são realizadas por meio de remoções de casebres e demais edificações que julgam ferir a estética da cidade ou configurar empecilhos à expansão e instalação de novos espaços.

O "rebuliço" proveniente da intensidade das obras gera um clima de grande expectativa em torno da nova configuração da cidade e um ufanismo presente em habitantes e veículos de comunicação locais. Poemas, artigos, livros e mesmo documentos oficiais, cheios de orgulho pela nova cidade que se descortina aos olhos dos seus habitantes, são recorrentemente publicados pela imprensa paraibana, que salienta os reflexos das transformações físicas da cidade na vida urbana.

Essa reação é, de certa forma, instigada pela postura oficial que, para a exaltação e divulgação dos seus feitos, publica correntemente no jornal A União, sob o título de As visitas do Sr. Presidente, artigos que aliam a figura da administração à renovação urbana, apresentando o pretenso clima de prosperidade do estado. O efeito dessa atuação se revela também no mesmo jornal que, em resposta à postura administrativa ante a cidade, apresenta a satisfação dos habitantes, a exemplo do poema de Américo Falcão dedicado ao governador Camilo de Holanda, onde é mencionada uma espécie de "Ressurreição" da cidade que "renasce virtuosa e plácida"265.

Apesar das intervenções desse momento serem pautadas nos ideais higienistas, e o discurso do governo sempre citar a situação sanitária da cidade, ressaltando inclusive as causas das epidemias e suas profilaxias, a atuação dessa administração se direciona muito mais às soluções de efeitos mais vinculados ao embelezamento urbano que àquelas mais restritas à salubridade. O empenho em transformar ruas e praças antigas, muitas com mato nativo, lixo e desenho irregular, em espaços "saudáveis", ou seja, limpos, de traçado regular e arborizados, preterindo a realização dos serviços de esgotos da capital, ponto fundamental da salubridade urbana, reafirma a postura administrativa privilegiadora da aparência urbana.

Mesmo estando os planos de implantação do saneamento da capital já elaborados desde 1913 por Saturnino de Brito, Camilo de Holanda pouco enfatiza essa questão, apenas enunciando em uma de suas mensagens de governo a impossibilidade financeira para a execução de tais serviços. No entanto, realiza dispendiosas obras, inclusive avenidas que impulsionam a futura expansão da área urbana, criando uma imagem contraditória de progresso onde a cidade cresce sem a simultânea expansão dos serviços básicos para seu bom funcionamento: água e esgoto.

O plano elaborado por Saturnino de Brito para a capital paraibana só é executado no governo de Solon Barbosa de Lucena (1920-1924). Diante das dificuldades encontradas para a execução de obras públicas, devido ao orçamento administrativo, o presidente do Estado delega prioridades para sua administração, onde, ao contrário do governo anterior, o esgoto da capital é o principal elemento contemplado.

"Reputo uma das maiores senão a maior de nossas necessidades, o esgoto desta capital. Sem ele parecem burlados todos os esforços no sentido de mantermos aqui um estado mediano de salubridade. É a maior aspiração do meu governo e a obra que considero inadiável, mau grado a situação precária das finanças do Estado."266

\footnotetext{
${ }^{263}$ LEME, Maria C. da S. (coord.) Urbanismo no Brasil - 1895-1965. São Paulo: Studio Nobel; FAU-USP; FUPAM, 1999, p. 282.

${ }^{264}$ O CONSELHO Municiapl da Parahyba decreta. A União, n8, p.2, 11 jan. 1918.

265 FALCÃO, Americo. "Ressurreição". A União. Parahyba, n188, s/p 27 ago 1917.

266 PARAHYBA DO NORTE, Mensagem apresentada à Assembléia Legislativa do Estado da Parahyba, na abertura da $1^{a}$ sessão ordinária da $9^{a}$ legislatura, a $1^{\circ}$ de março de 1924, pelo dr. Solon Barbosa de Lucena, presidente do Estado. Parahyba do Norte: Imprensa Oficial, 1924, p.3.
} 
A dedicação do governador Solon de Lucena para com a questão sanitária da capital, expressa na execução das obras de abastecimento de água e dos esgotos, é, provavelmente, influenciada pelo seu vicepresidente, Flávio Maroja, médico e fundador da Sociedade de Medicina e Cirurgia da Paraíba em 1924, que desde o começo do século se dedica a essa questão, publicando, inclusive, diversos artigos em jornais e revistas da época, nos quais a necessidade do saneamento da capital se constitui em objeto central. ${ }^{267}$

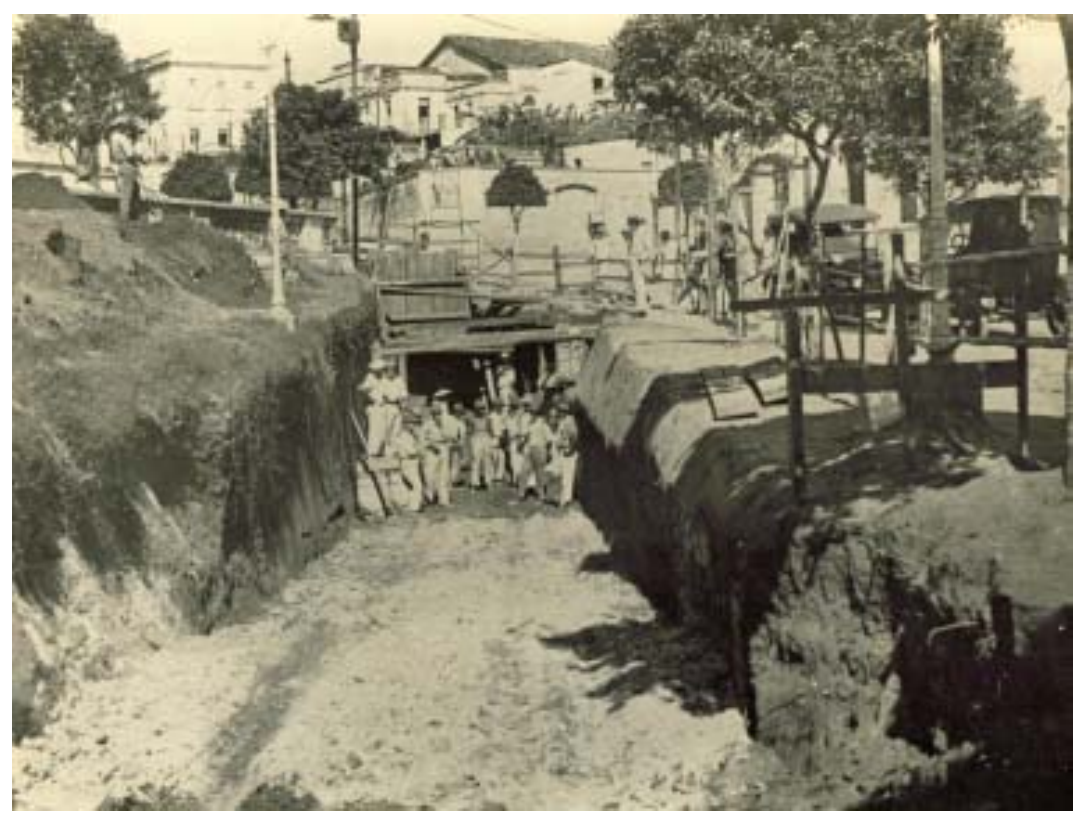

Obra de saneamento - abertura do túnel (1923). FONTE: Acervo Humberto Nóbrega.

Ao mesmo tempo em que se implantam as alterações urbanas, visando implementar as orientações de Saturnino de Brito, há uma enfática ação, também de cunho higienista, no sentido de arborizar a cidade, promovida pela municipalidade em em um trabalho sincronizado e em parceria com a administração estadual. A implantação do verde, vinculada à remodelação e criação de novos espaços públicos, é uma das metas empreendidas pelo prefeito Guedes Pereira que com

"a cooperação do illustre dr. Solon de Lucena, sempre solicito às coisas de interesse geral, [conseguiu] grande número de mangueiras, rosa e espada, bem crescidas, compradas pelo Estado ao dr. José Vinagre, já tendo sido feita, até agora, a arborização das avenidas João Machado, Maximiano de Figueirêdo, Vidal de Negreiros, D. Pedro I, Capitão José Pessoa; praças Caldas Brandão e da Cadeia e ladeira da Borburema"268.

A criação de espaços arborizados na cidade se associa ao incentivo governamental, no sentido de instituir o hábito do "culto" ao verde pela população, como ressalta o prefeito Guedes Pereira em 1921:

"Com pesar vos digo que mal comprehendido ainda é esse culto, embora interesseiro, que todos nós devemos ter pelas plantas em geral e, muito especialmente, pelas árvores; pois constantes são os meus dissabores constatando estrago na arborização de nossas ruas, praças e jardins". ${ }^{269}$

Em meio a vultosas obras, abertura de ruas, criação de praças e parques, alinhamento da trama, a cidade é transformada em um verdadeiro "canteiro de obras". Essa situação propicia grandes expectativas a respeito da sua futura aparência, cujos resultados podem ser observados com a conclusão das obras de saneamento, em 1926 durante o governo João Suassuna, no qual a Lagoa dos Irerês é transformada em parque urbano.

\footnotetext{
${ }^{267}$ TRAJANO FILHO, Francisco Sales. D.V.O.P.: Arquitetura moderna, Estado e Modernização (Paraíba, década de 1930). São Carlos: Escola de Engenharia de São Carlos, 2003 (Dissertação de Mestrado), p. 68.

268 PARAHYBA DO NORTE, Mensagem apresentada ao conselho municipal da capital do Estado da Parahyba em dezembro de 1921, pelo prefeito Dr. Walfredo Guedes Pereira. Parahyba do Norte, Imprensa Oficial, 1921, p.18.

269 PARAHYBA DO NORTE, Mensagem apresentada ao conselho municipal da capital do Estado da Parahyba em dezembro de 1921, pelo prefeito Dr. Walfredo Guedes Pereira. Parahyba do Norte, Imprensa Oficial, 1921, p.18.
} 


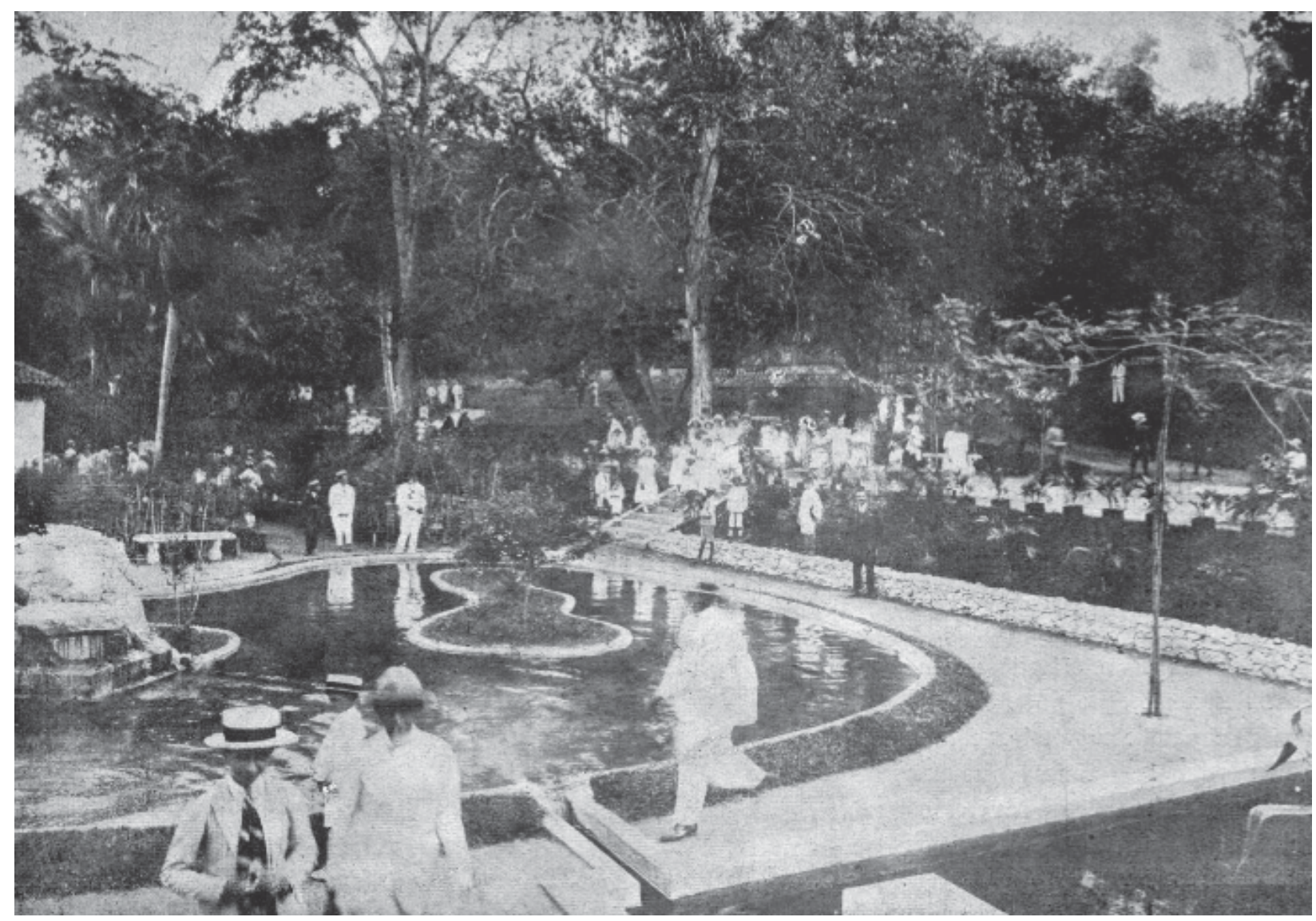

Parque Arruda Câmara, criado na administração do prefeito Guedes Pereira. FONTE: Revista Era Nova.

Joaquim Ignácio, viajante proveniente do estado vizinho do Rio Grande do Norte, chega à capital paraibana em 1924 e presencia esse processo ainda em andamento. Em seus relatos, transparece a atmosfera de expectativas provocada por esse quadro de intervenções:

"Contava recolher ensinamentos proveitosos nesta minha viagem; mas, por melhor que fosse minha expectativa ao encetar esse passeio, confesso, com imenso prazer, que ela foi, quase sempre, excedida diante da grandeza da obra que está se realizando por ali, [...]"270

São essas as primeiras palavras do livro Notícia de uma viagem à Paraíba, em 1924, onde Joaquim Ignácio registra as impressões da sua visita à capital paraibana, cujos "objectivos são bem nítidos: a observação da visinha capital"271. Em seus relatos, salienta o ritmo de reforma urbana da capital que se remodela, testemunhando o conjunto de ações governamentais que atuam incisivamente na transformação de sua paisagem e estrutura. A surpresa, já facilmente percebida nessas primeiras frases do visitante, revela a expectativa em relação à cidade, tom também unânime nos discursos administrativos, nas mensagens oficiais de governo e em revistas e jornais locais.

O viajante flagra o ápice do primeiro ciclo de reformas urbanas dessa capital. Ao cruzar as portas de saída da Estação Ferroviária, que define como "coisa provisória"272, descortina-se, ao olhar curioso típico de visitante recém chegado, o cenário de reformas composto pela aglomeração de material de construção e pela movimentação inquieta de carros e materiais direcionados às obras.

"A'quella hora de um dia inteiramente luminoso, não era muito crescido o movimento da gare, mas nas adjacências da Estação passavam caminhões, carros arrastados por muares, repletos de mercadorias e especialmente de material para as construções da cidade"273.

\footnotetext{
270 INÁCIO, Joaquim. Notícias de uma viagem à Paraíba, em 1924. Mossoró: 1987, p. 3.

${ }^{271} \mathrm{Ibid}$.

$272 \mathrm{lbid}$.

$273 \mathrm{Ibid}$.
} 
Instigado por essa primeira impressão, o olhar do viajante percorre a cidade observando as obras acabadas e em execução, além das atividades que movimentam as ruas, atendo-se à grandeza dos serviços e ao conjunto das transformações nas quais a capital escontra-se mergulhada. É clara a ênfase por ele dada às obras portuária, com a dragagem do rio Sanhauá e a reforma do porto do Varadouro, que desempenha essa função desde a fundação da cidade, em 1585.

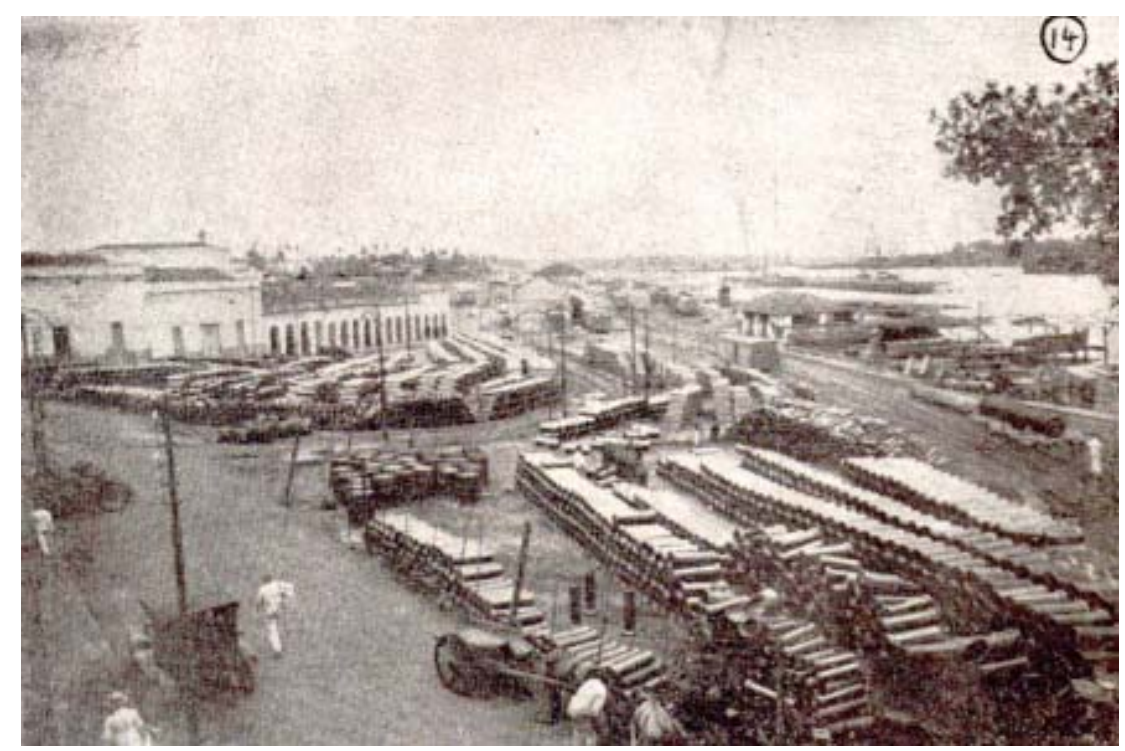

Material para obras de saneamento - região portuária. FONTE: Acervo Walfredo Rodrigues

Em Ignácio, a imagem portuária na região do Varadouro - com "grandes dragas [que] descansavam, por ali, placidamente, do intenso trabalho que vinham de realizar aprofundando a vasa lamacenta do rio", e com a exposição "pelo vasto caes, em galpões ou em céu aberto, [de] uma grande quantidade de material para o porto"274 - gera grande impressão. Entretanto, estas intervenções pouco contribuem para transformar a imagem e a dinâmica local, posto que, vista de sua inviabilidade, são interrompidas.

Outro ponto que prende a atenção do viajante é a mobilização ocasionada pelas obras de saneamento. A abertura de novas vias e a reforma das existentes, e, inclusive, a construção do túnel que leva as águas recolhidas na Lagoa ao rio Sanhuá, movem grande quantidade de terra. A descrição que o viajante elabora a respeito dessas obras, a partir de uma visita realizada em companhia de uma comitiva formada por membros da administração, revela sua representatividade no processo de reformas dessa cidade.

O grande número de praças criadas nesse momento e, principalmente, a concentração delas, causa grande impressão ao visitante, que se refere à cidade como "uma capital ganglionada de praças públicas muito bem arborizadas"275.

Ignácio revela uma cidade de novas ruas largas, retas e arborizadas, e com prédios regulares às suas margens, praças, edifícios monumentais, bonde elétrico e muitas obras civis em andamento. Observa residências e palacetes, hospitais, escolas, cinemas e cafés, buscando perceber como o novo ideal de cidade se reflete no estilo da vida da classe mais abastada. Porém, são os equipamentos urbanos e as edificações públicas ou de uso coletivo que seduzem seu olhar:

\begin{abstract}
"Assoberba a tudo, porém, n'aquela praça, o prédio dos Correios e Telégrafos, cuja construção está em via de ser ultimada. Possue diversos andares. E' um prédio muito magestoso, de plena actualidade durante muitos lustros, pelo futuro a dentro"276.
\end{abstract}

A capital paraibana, em meio ao seu primeiro ciclo de reformas urbanas, apresenta-se ao viajante revestida dos ideais reformistas presentes em cidades brasileiras em fins do século XIX e início do XX. O cenário que encontra instiga sua imaginação e guia sua previsão acerca da expansão da cidade em áreas ainda não edificadas, as quais visita na companhia de João Suassuna, Guedes Pereira e José Américo de Almeida:

\footnotetext{
${ }^{274}$ INÁCIO, Joaquim. Notícias de uma viagem à Paraíba, em 1924. Mossoró: 1987, p. 4.

275 Ibid., p. 6.

${ }^{276} \mathrm{Ibid}$., p. 5.
} 
"onde minha vista se embebia nas magnificências das paisagens e o meu espírito sonhava a grande cidade que se projectará por ali, um dia"277.

Diante do quadro de intervenções urbanas captado pelo seu olhar de viajante, Inácio se reporta ao futuro dos lugares que visita, imaginando as mudanças que os feitos que ele presencia proporcionariam. Seus relatos transparecem o impacto que essas obras causam à população, diante do clima de mudanças estabelecido, como também ocorre nas manifestações da imprensa oficial.

\subsubsection{Os novos nomes dos espaços públicos}

As intervenções urbanas ocorridas na capital paraibana a partir da segunda década do século XX promovem a ampliação do seu tecido urbano. A partir de então, tornam-se mais escassas as alterações dos nomes dos espaços existentes, ao passo que as denominações de novas áreas seguem o processo de inovação toponímica que se inicia no fim do século anterior. Desse modo, denominações referentes aos períodos colonial e imperial passam a conviver com as novas nomenclaturas locais.

A ampliação da área urbana tem, como espaços representativos, as avenidas abertas e as praças criadas ou reformadas a partir de campos, largos, etc. O batismo de "avenida" anuncia a ampliação e remodelação do sistema viário, sinalizando o direcionamento do fluxo e do crescimento da cidade, o novo ritmo urbano e os novos parâmetros de velocidade. A denominação de "praça" apresenta uma nova forma de utilização do espaço público, através de ambientes arborizados e formalmente organizados para direcionar as atividades neles desenvolvidas.

A esses novos logradouros são dados nomes que homenageiam personagens da política e da história local, e não mais barões e viscondes sem relação próxima com o lugar. Surgem as avenidas João Machado e Guedes Pereira, a rua João Maurício e o parque Solon de Lucena, legando aos espaços os nomes dos administradores que os criam ou de políticos homenageados por atuações anteriores. Nesse tipo de denominação é comum e, muitas vezes, necessário que colunistas dos jornais locais, após a designinação toponímica oficial, "venham pelos jornais do dia seguinte, erguendo a figura do conterrâneo ilustre" ${ }^{278}$, contando parte de sua história e sua importância para a cidade, para o conhecimento e aceitação popular.

Apesar do empenho administrativo em associar as transformações urbanas a novos nomes, a influência da população na consolidação das denominações ao longo do tempo torna, muitas vezes, antigas denominações persistentes. Assim, mesmo na área de expansão da cidade, surgem travessas e becos, além de denominações dadas a esses espaços pela população que, de tão usadas, tornam-se mais conhecidas que as oficiais.

A inovação toponímica que indica um novo repertório urbano é anunciada em jornais e sinalizada por placas urbanas que, muitas vezes, tornam-se inúteis "por que ficará predominando sempre a denominação que 'Zé Povo' quiser"279. Desta forma, percebe-se que a rua Duque de Caxias, uma das primeiras vias da cidade, assim denominada desde 1870, é ainda hoje referida por muitos dos habitantes da cidade pelo seu primeiro nome, Rua Direita. Do mesmo modo, o Parque Solon de Lucena, criado em torno de um lago existente desde a fundação da cidade e assim batizado na conclusão das obras de saneamento (1920-1926), é até hoje chamado de Lagoa, como ocorre desde os primeiros anos da cidade.

\footnotetext{
277 INÁCIO, Joaquim. Notícias de uma viagem à Paraíba, em 1924. Mossoró: 1987, p. 8.

${ }^{278}$ MARIZ, Celso. Cidades e Homens. João Pessoa: A União, 1945, p. 6.

${ }^{279}$ CAVALCANTI, Itagiba. "O Ponto de Cem Réis". Illustração, n. 19, 15.02.1936, p.23.
} 
"O povo quando entende baptisar uma arteria ou um logradouro publico qualquer, não tem prefeito mais energico que dê geito. (...) O povo quer e acabou-se, não tem remédio a dar"280.

Um dos exemplos mais marcantes da interferência popular na denominação dos espaços públicos é o caso do Ponto de Cem Réis, nome dado pela população à região que engloba a Praça Vidal de $\mathrm{Negreiros}^{281} \mathrm{e}$ parte da rua Direita. A praça, construída a partir da demolição da Igreja do Rosário dos Pretos, é, por muito tempo, o ponto de confluência das três linhas de bonde que servem a cidade e local de lazer e encontro da população nos fins de semana. Tal denominação é justificada pela relação com o bonde, cujo cobrador, segundo alguns historiadores locais, ao passar nesse ponto menciona os cem réis.

\begin{abstract}
"Assim de nada teem servido o passado e as glorias do Duque de Caxias para impôr ao parahybano a supremacia do seu heroico nome á parte daquella arteria que teimam em chamar "Ponto de Cem Réis", que do mesmo modo não é bem visto pelo secular Vidal de Negreiros, também em parte desconsiderado pelo veredictum popular"282
\end{abstract}

A denominação dos logradouros da cidade em pleno ciclo de reformas urbanas mostra que, apesar da euforia provocada pelo ideal de reformulação da vida urbana apresentado, inclusive, nas formas e nos usos dos espaços públicos, em alguns momentos persiste a ação popular, como também ocorre com as forma de apropriação desses espaços.

\title{
3.3.6 Os usos dos novos espaços públicos
}

\begin{abstract}
“(...) a Parahyba de quando ainda usava lampeão de azeite, a Parahyba de quando a mulher ainda não usava decote até aos joêlhos. (...) Em 1910 alcancei um ar delicioso de ingenuidade e pitoresco: um como um carater que parecia nunca desapparecer desta cidade. Mas desappareceu; começou a desapparecer com o abastecimento d'agua; foi augmentando vôo com a vinda do bonde e da luz electrica; e o cinema revolucionou tudo. Completou a remodelação. A mentalidade social passou a regular-se conforme $o$ que surgia nas telas (...)"283.
\end{abstract}

À medida em que a renovação urbanística ganha força, a dinâmica urbana é alterada. As novas velocidades possibilitadas pelas largas e retas vias de circulação para automóveis, a alteração da forma de percepção do tempo, o gosto pela atividade física, inovações na moda, dentre outras novidades, influem na reformulação dos hábitos da sociedade urbana, alterando, inclusive, a postura da mulher no meio urbano e a relação da população com a natureza.

A cidade da Parahyba apresenta os reflexos das transformações trazidas pelo século XIX ao mundo, quando "as inovações tecnológicas, a expansão européia, a instabilidade internacional e o conseqüente fluxo de mudanças desencadeadas nas sociedades por toda parte"284 alteram a ordem das cidades em geral, a

\footnotetext{
${ }^{280}$ CAVALCANTI, Itagiba. "O Ponto de Cem Réis". Illustração, n. 19, 15.02.1936, p.23.

${ }^{281}$ André Vidal de Negreiros foi um paraibano que, no século XVII, participou da excussão contar os holandeses, e abraçou a carreira das armas. Homem rico, atuou na Bahia, em Pernambuco, onde foi Governador, e no Maranhão, capitão geral.(BITTENCOURT, Liberato. "Parahybanos Illustres". Homens do Brasil. Rio de Janeiro: Parahyba Livraria e papelaria Gomes Pereira Editor, Rua do Ouvidor. Vol II, n. 91, 1914 , p. 32)

${ }^{282}$ CAVALCANTI, op. cit.,p.23.

${ }^{283}$ VIDAL, Adhemar. Chonica Revista Era Nova. Parahyba, n.76, 01 abr. 1925.

${ }^{284}$ SEVCENKO, Nicolau. "A capital irradiante: técnicas, ritmos e ritos do Rio". in: SEVCENKO, Nicolau. História da Vida Privada no Brasil. Vol. 3. São Paulo: Companhia das Letras, 2003, pp. 513-619, p. 532.
} 
partir da divulgação e absorção de uma nova forma de viver. Tais transformações trazem consigo um "fenômeno geral de aceleração" onde o referencial de tempo é alterado. "A partir do último quarto do século XIX 'os relógios andam muito mais depressa', e com a pressa dos relógios, a pressa dos homens"285, levando a vida urbana a novos ritmos que causam uma certa desorientação inicial à população, como demonstra Machado de Assis em uma crônica em 1894:

"Mas então que é o Tempo? É a brisa fresca e preguiçosa de outros anos, ou esse tufão impetuoso que parece apostar com a eletricidade? Não há dúvidas que os relógios, depois da morte de [Solano] López, andam muito mais depressa"286.

Nesse momento, o novo ritmo de vida que desponta influencia a conformação das cidades, sobretudo das metrópoles, onde a busca da aceleração, do "ganhar tempo", torna-se uma das preocupações fundamentais que guiam as reformas urbanas e da moradia. Assim, a cidade passa a ser alterada pelas diretrizes simultâneas da organização concomitante do tempo e do espaço da sociedade.

"A difusão do relógio urbano a partir do século XVIII e do relógio de pulso neste século, a tendência à secularização do calendário e à rigidez das jornadas de trabalho são algumas das evidências desse longo processo de afastamento de um tempo regido pela natureza e pelo calendário religioso em direção a um tempo presidido pelas demandas da produção fabril e por novas tecnologias"287.

Às novas formas implantadas na cidade correspondem novos usos, que passam a competir com os anteriores. O tráfego de veículo se intensifica, assim como o de pedestres. Praças e jardins possibilitam maneiras até então inéditas de uso de espaços públicos, associadas ao lazer e a novos tipos de sociabilidade.

A utilização doasáreas urbana é marcada pelo salto da produção e consumo de mercadorias ocorrido no século XIX em todo o mundo, influenciando o desenvolvimento de técnicas publicitárias que divulgam os novos produtos. Essa difusão a partir da Europa associa-se à adoção de 'códigos europeus' para a incorporaçãao de novos modos de apropriação dos espaços públicos, como revela Sevcenko ao tratar da utilização da nova Avenida Central pela população carioca:

"Como corolário, as pessoas que não pudessem se trajar decentemente, o que implicava, para os homens, calçados, meias, calças, camisa, colarinho, casaco e chapéu, tinham seu acesso proibido no centro da cidade. Mais que isso, nas imediações, as tradicionais festas e hábitos populares, congregando gentes dos arrabaldes, foram reprimidos e mesmo o Carnaval, tolerado não seria mais o do entrudo, dos blocos, das máscaras e dos sambas populares, mas os dos corsos de carros abertos, das batalhas de flores e dos pierrôs e colombinas bem-comportados, típicos do Carnaval de Veneza, tal como era imitado em Paris"288.

A essa época, as lentes das câmeras fotográficas já captam mulheres transitando livremente pelas ruas da capital paraibana, sem se dirigirem, necessariamente, às igrejas e sem a presença de um serviçal de companhia, como é comum em tempos anteriores. Elas se encontram nas praças e jardins, participando de retretas, e são apontadas como o encantamento que embeleza a cidade e a nova vida social. São elas as principais porta-vozes das novas modas no espaço urbano, portando novos modelos e chapéus, a partir das novidades encontradas nas revistas em circulação e nos cinemas, um dos maiores difusores das novidades das grandes capitais. Nas cidades em geral, nesse momento,

\footnotetext{
${ }^{285}$ SEVCENKO, Nicolau. "A capital irradiante: técnicas, ritmos e ritos do Rio". in: SEVCENKO, Nicolau. História da Vida Privada no Brasil. Vol. 3. São Paulo: Companhia das Letras, 2003, pp. 513-619, p. 557.

${ }^{286}$ ASSIS, Machado apud Ibid., p.532

${ }^{287}$ CORREIA, Telma de Barros. "A gestão do tempo e a organização da cidade moderna". Sinopses São Paulo n.33 p.22-23 jun. 2000. p. 23.

${ }^{288}$ SEVCENKO, Nicolau. "O prelúdio republicano, astúcias da ordem e ilusão do progresso", in: SEVCENKO, Nicolau. História da Vida Privada no Brasil. Vol. 3. São Paulo: Companhia das Letras, 2003, p. 7-48, p. 26.
} 
"O que passa por gosto é na verdade moda. (...) O momento é o de afinar-se com o tempo, com as notícias rápidas, com a circunstância européia atualizada pelo dernier bateau ou, em breve, pela americana do último filme"289.

A mulher passa a ser a figura urbana alvo de maiores exaltações pelos seus encantos e pela sua participação na dinâmica da cidade. Anunciadora das novas modas e de uma renovação no cotidiano, sua presença pública torna-se objeto de artigos, assim como o aparecimento das praças, automóvel, cinema, etc. É a praça que expõe todas essas novidades, tornando-se, segundo um cronista urbano, um "écran aonde vão filmar os mais bellos sorrisos, os mais bellos olhares das nossas girls, aonde os poétas vão deixar, num improviso, os seus versos mais lindos e talvez mais sinceros" ${ }^{290}$. O novo ambiente urbano torna-se propício ao novo contexto social.

O cenário urbano muda, assim como suas personagens. Fontes e cacimbas não são mais locais de aglomeração. As praças e jardins abrigam o lazer da elite. Cacimbeiros, carregadores de água e acendedores de lampiões somem do meio urbano, enquanto vendedores de jornais, podadores de árvores, varredores de rua e cobradores de bonde marcam a nova paisagem, denunciando uma outra dinâmica. A cidade ganha novos movimentos, anunciados tanto pelo automóvel como pelos pedestres que circulam em números inéditos.

Seguindo tendências presentes em outras capitais do país, o lazer da cidade liberta-se dos limites e ditames do calendário religioso, diversificando-se e inovando-se. Referindo-se ao Rio de Janeiro nas décadas de 1920 e 1930, Nicolau Sevcenko escreve:

\begin{abstract}
"Vicejam os filmes de ação e aventura (...) Os clubes pululam, com o destaque para o futebol, mas envolvendo todos os esportes. As modas mudam para se tornar esportivas, leves, curtas, coladas ao corpo, expondo amplas áreas para a respiração e a insolação, exibindo os músculos e formas torneadas do físico"291.
\end{abstract}

Na nova conjuntura urbana, a vida pública e os novos hábitos se apresentam nas praças e nas ruas paraibanas, principalmente durantes os festejos de carnaval. Mesmo com a considerável expansão da área urbana, as novas atividades se concentram nos espaços reformados nas proximidades das ruas Direita e Nova. Ao mesmo tempo, ocorre uma forte proliferação de espaços privados coletivos onde se desenvolve o lazer, conseqüêntes das inovações trazidas pelo século XIX.

A população passa a freqüentar cinemas, clubes e cafés, direcionando para esses locais parte do lazer urbano. Esses estabelecimentos se encontram, geralmente, no entorno das principais praças, espaços recentemente construídos ou reformados que atraem para seus arredores as atividades de lazer da cidade, sejam elas permanentes, como bares e cinemas, ou eventos festivos temporários, como o carnaval.

Revestidas de uma conotação "moderna", as praças influenciam a implantação de uma nova ordem urbana tanto em relação às formas quanto aos usos, atraindo para si a população e para seu entorno novas atividades. Na rua Direita estão as praças Rio Branco, Vidal de Negreiros, Felizardo Leite e Venâncio Neiva, que, para além da proximidade entre elas, destacam-se pela grande concentração de atividades de lazer.

A rua Direta em si, ao longo de sua extensão, é, na primeira década do século XX, a mais movimentada da capital, que não tem "quase vida nocturna. Ahi [ficam] os dois clubes elegantes - Astréa e Juventude - e ainda o melhor botequim - o Café Chic"292. Ela testemunha vários carnavais proporcionados pelos "bandos ${ }^{289}$ SEVCENKO, Nicolau. "A capital irradiante: técnicas, ritmos e ritos do Rio". In: SEVCENKO, Nicolau. História da Vida Privada no Brasil. Vol. 3. São Paulo: Companhia das Letras, 2003, pp. 513-619, p. 538.

${ }^{290}$ DANíZIO, Paulo. "A praça que é o sorriso da cidade". Era Nova, Parahyba, n. 90, nov. 1925c, s/ p.

${ }^{291}$ SEVCENKO, Nicolau. op. cit., p. 569.

292 VEIGA JÚNIOR, J. “O Café de Joça Aranha”. In: Illustração, n.03,1935, p.23. 
alegres [que] atravessavam a rua Direita, arrastando os pés, exageradamente, exhibindo as bisnagas de estanho"293, pelo corso puxado a carroça e, tempos depois, pelo automóvel.

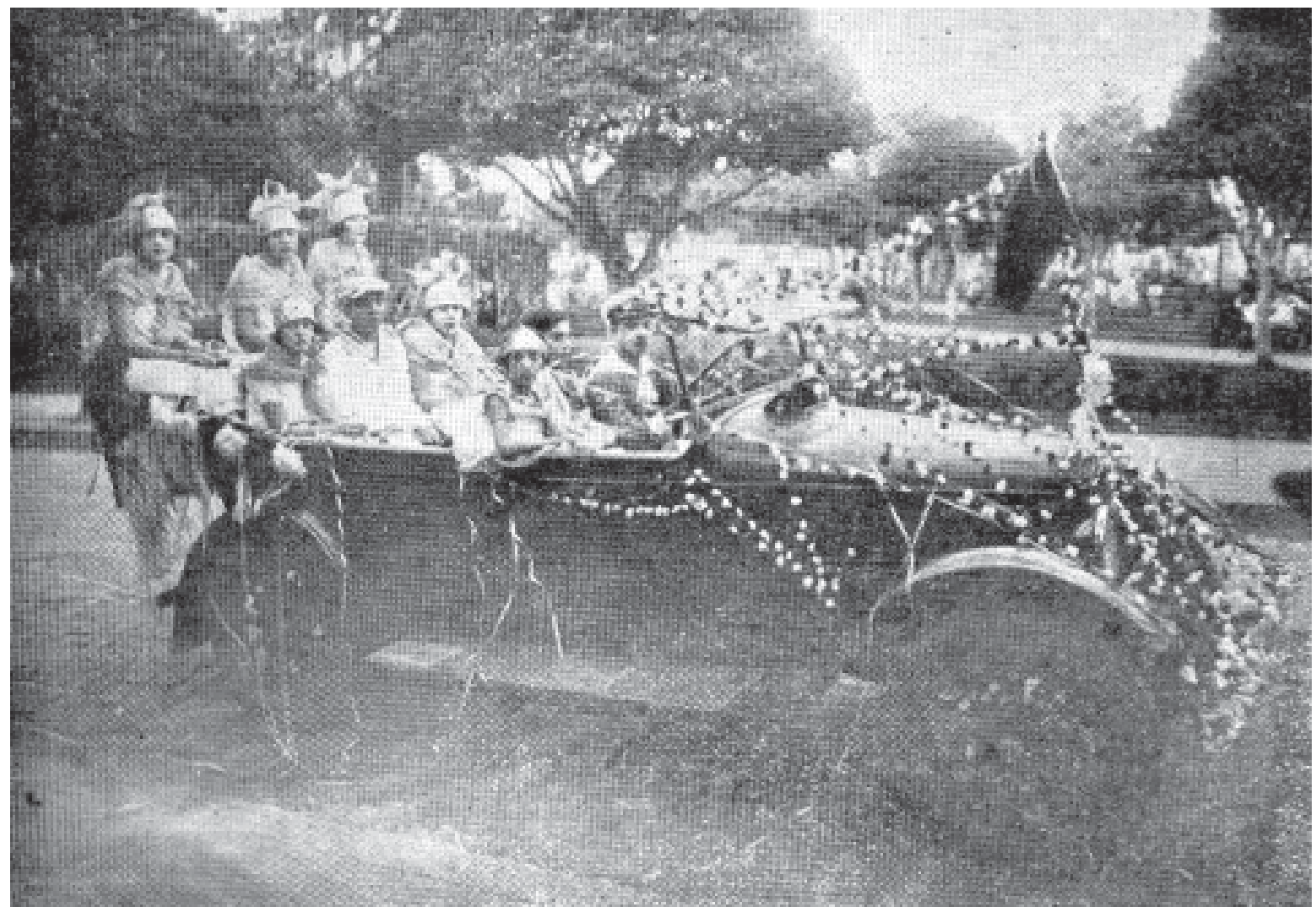

Década de 1920 - Carnaval na rua. FONTE: Revista Era Nova.

"Foi esta sempre a [rua] privilegiada. Para ella affluiam todos os foliões, todos os grupos carnavalescos puxados ou não a realejo, como todos os 'divertimentos' populares: a guelinha, o congo, o bumba-meu-boi"294.

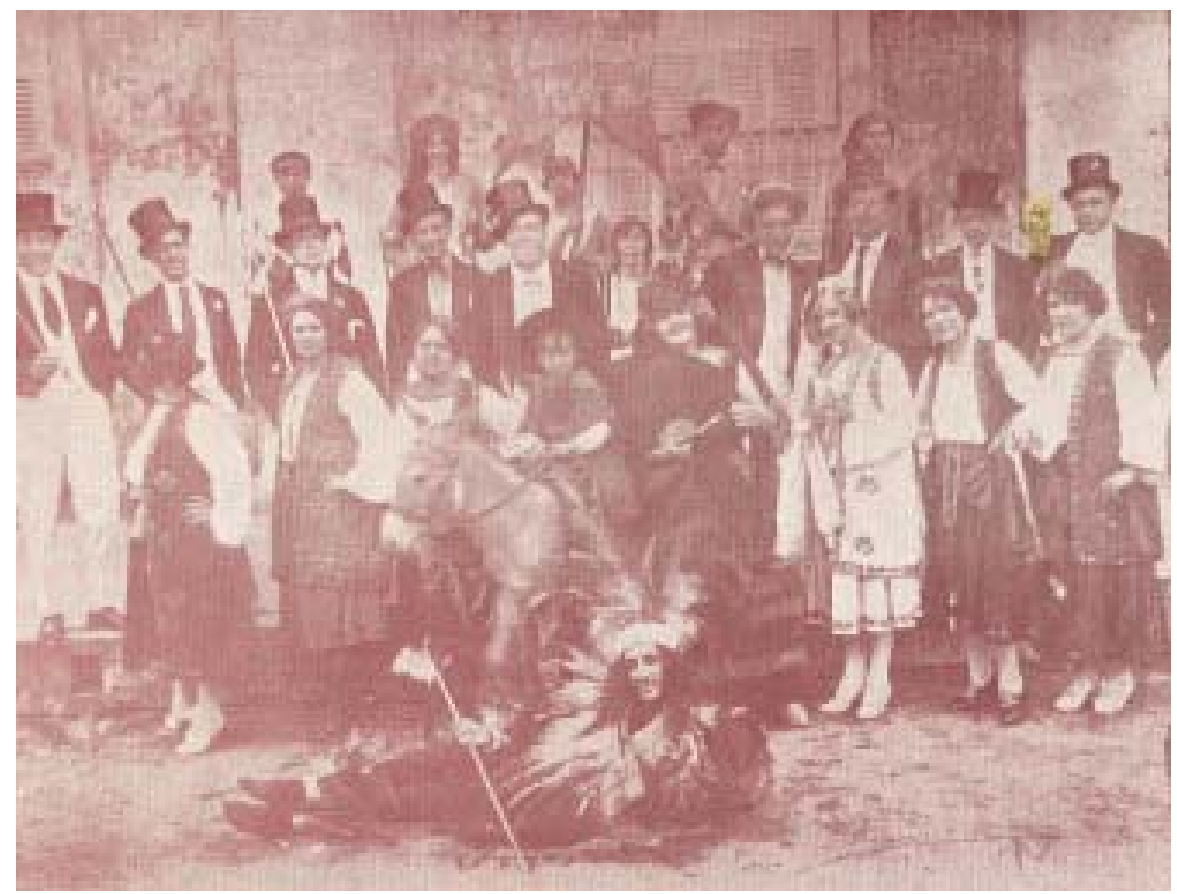

Década de 1920 - Carnaval na rua. FONTE: Revista Era Nova.

${ }^{293}$ PIRAGIBE, Aderbal. “Carnaval de vinte annos passados...". Illustração, João Pessoa, n.19, fev. 1936, p.1.

${ }^{294}$ MEDEIROS, Coriolano de. "Carnaval de hontem, Carnaval de hoje". Illustração, João Pessoa, n.20, fev. 1936, p.18. 
Lá também estão os primeiros cinemas da cidade, o Cinema Rio Branco e o Cine Rex, cujas matinês proporcionam um fluxo constante de jovens nos fins de semana, criando um forte movimento entre os cinemas e as praças Vidal de Negreiros e Commendador Felizardo. O cinema, além da divulgação das novidades, proporciona ao expectador uma experiência inédita, "uma estranha sensação vendo mover-se figuras de tamanho natural no écran onde a luz se fixou"295, afetando a percepção visual e a imaginação.

Essas praças esmaecem o papel dos largos que não são extintos da paisagem, mas que também não participam com igual intensidade da nova vida urbana, resumindo-se, sobretudo, a passarelas para as igrejas. O lazer passa às praças. Retretas realizam-se no Jardim Público, com a banda no coreto e a população dançando ao seu redor.

Nesse contexto, fundam-se associações e clubes desportivos que incentivam a prática do esporte, a exemplo do Centro de Desportos Náuticos, Clube do Remo e Esporte Clube Cabo Branco, onde o remo e o futebol são as modalidades mais praticadas. A divulgação dessas atividades é feita em jornais e revistas, a exemplo da revista Era Nova que dispõe de uma coluna batizada de Pelo mundo dos despostos e outra reservada ao Clube do Remo, onde circulam informações acerca dos acontecimentos esportivos como competições e torneios locais e de outras localidades. É comum a cerimônia de inauguração de aquisições e equipamentos desses estabelecimentos, a exemplo das

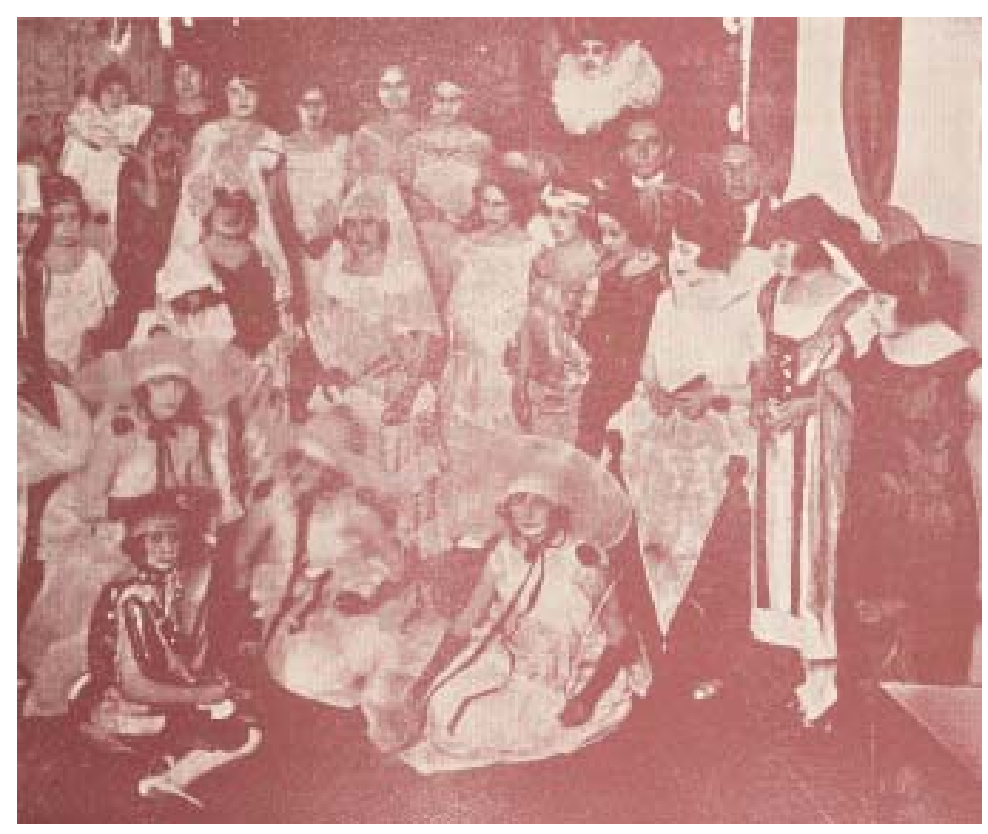

Década de 1920 - Carnaval na rua. FONTE: Revista Era Nova.

festividades do clube do Remo, onde a frota de canoas compradas é, simbolicamente, oferecida a madrinhas que realizam a cerimônia, seguida de uma competição realizada no rio Sanhauá. Nas revistas são expostas fotografias e relatos das festas, além de imagens dos esportistas com suas vestes específicas, incentivando o culto ao corpo e difundindo novos padrões de beleza e lazer.

Esses clubes e associações também promovem atividades e festas sociais que movimentam a vida urbana. A festa de maior destaque é o Carnaval, que é realizado nos clubes, reservados às elites, em contraponto ao carnaval de rua, para toda a população. Segundo relatos da revista Era Nova, esse é um momento em que a cidade se modifica. A população sai às ruas, e a mulher expõe-se mais aos olhares, desfila nas ruas, nos corsos, com maquilagem, máscaras e laça-perfumes.

Diante desse movimento de maior vivência do espaço urbano, uma prática comum aos moradores dessa capital frea um pouco esse processo, ao mesmo tempo em que reafirma a nova relação homem-natureza que se intensifica: o veraneio. É comum a presença de relatos da cidade pacata que se apresenta no verão, sem a juventude nas praças nem o movimento das ruas e nas portas dos cinemas. Grande parte da população se muda durante o verão para as praias nos arredores da cidade, principalmente para as praias de Tambaú, onde se concentra a elite, e do Poço. 


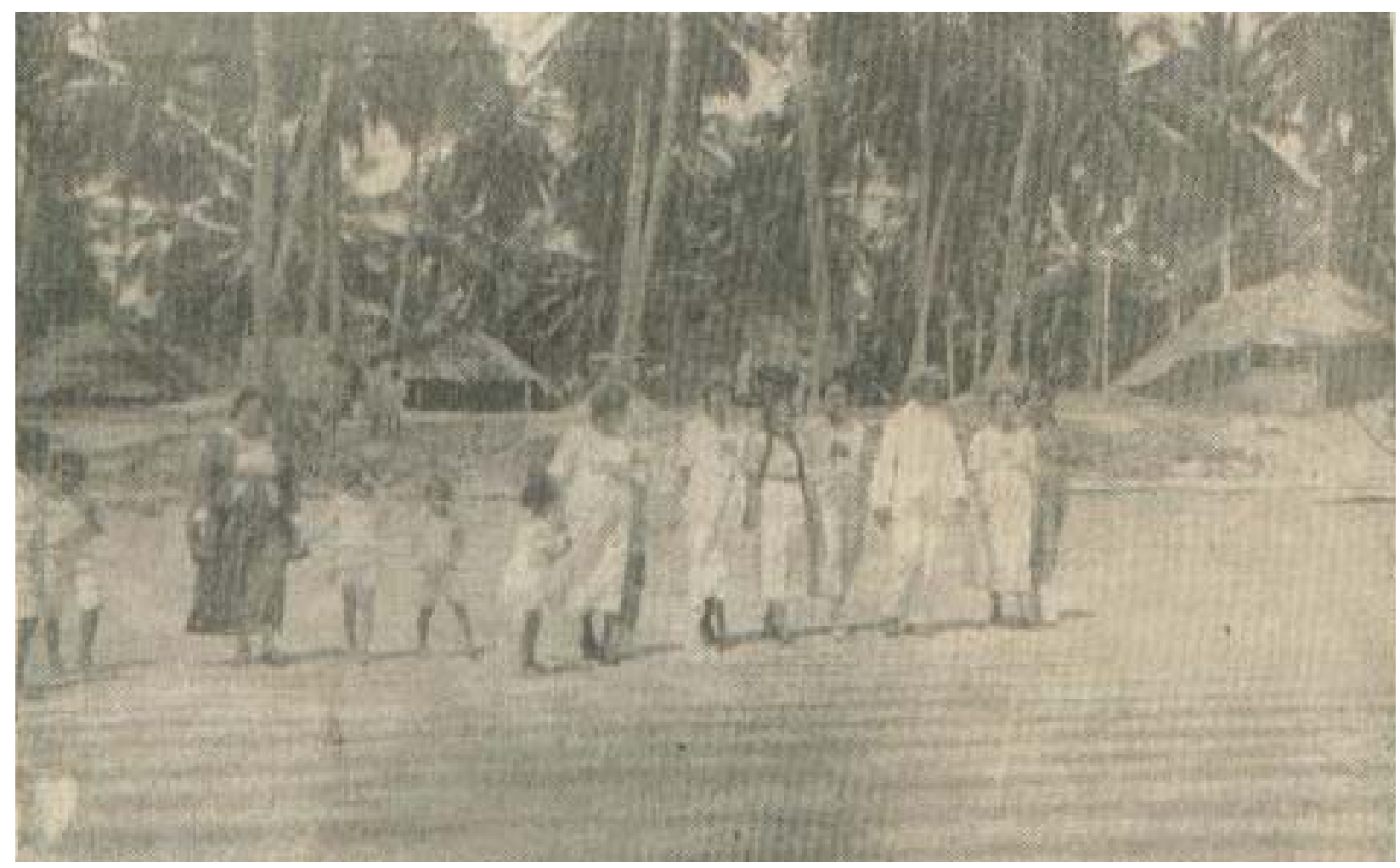

Veranistas da Praia do Poço. FONTE: Revista Era Nova.

Findo o verão, a cidade recebe na sua dinâmica urbana reflexos dos hábitos próprios à estação balneária. É nesse contexto que José Américo de Almeida flagra, em plena avenida João Machado, um grupo de garotas dançando o côco, dança típica da região que ainda persiste na área praieira, mas incomum ao meio urbana. ${ }^{296}$

A cidade da Parahyba dos anos dez e vinte apresenta grandes inovações nas suas vivências e seus ideais urbanos, porém, a divulgação dessas mudanças, tanto nos documentos governamentais como nos demais veículos de informações, é tão enfática que muitas vezes generalizam características ainda pontuais. Assim, as transformações mais concentradas na região das ruas Direita e Nova e em seus usuários específicos são, em alguns momentos, divulgadas como características de toda a cidade. Uma visão diversificada e não pontual desse processo mostra que a cidade de então apresenta faces diversas.

A complexidade desse momento pode ser percebida na diversidade de abordagens dos artigos e crônicas da revista Era Nova e do jornal A União, nas mensagens de governo e nos relatos de viajantes. As transformações são ora exaltadas, ora preteridas diante do saudosismo despertado pela nova vida urbana.

Mário de Andrade, chegando à capital paraibana em 1929, capta sinais de antigos costumes persistentes no meio urbano em pleno processo de "modernização". Envolvido nas questões de "identidade nacional"297 que marcam as preocupações de intelectuais brasileiros na década de 1920 e anunciador fervoroso dessas discussões, ele procura conhecer mais profundamente a cultura do seu país, visitando algumas cidades brasileiras.

Suas viagens o permitem conhecer intérpretes musicais, presenciar ensaios e representações de danças, estudar a religiosidade, a fala popular e outras expressões genuínas do povo. As observações, anotações dispersas e as impressões obtidas na viagem são registradas em um diário de viagem que serve de base para

\footnotetext{
${ }^{296}$ ALMEIDA, José Américo de. "A invasão do côco". Era Nova. n.25, 01 mai. 1922, s/p.

${ }^{297}$ A década de 1920 é de questionamentos inéditos, travando-se a crise da "identidade social" entre a intelectualidade, onde o ano de 1922 assume o papel de marco simbólico. Mário de Andrade, um dos anunciadores dessas novas discussões, apresenta esse debate presente internacionalmente, com a cor local e mostrando como torna-se um fenômeno 'nosso': "Hoje estamos preocupados em voltar à nascente de nós mesmos e da arte" (LAHUERTA, In: LORENZO, Helena Carvalho e COSTA, Wilma (org). A década de 20 e as origens do Brasil Moderno. São Paulo. Editora da UNESP, 1997).
} 
o livro "O Turista Aprendiz". Os interesses etnográficos e de cronista não escapam à figura do aprendiz de turista, mas se mostram de imediato. Já no primeiro dia na capital paraibana, em um passeio sob a lua cheia, é surpreendido pelos sons de um coco, que logo Ihe indicam "a possibilidade de um bom trabalho musical por aqui. O que é, o que não é: era uma crilada gasosa cantando e dançando na praia"298. Em Tambaú, nos arredores da cidade, flagra uma expressão cultural que o fascina, representada no ritmo dançado e cantado nas areias da praia: "gente predestinada para dançar e cantar, isso não tem dúvida"299. A música e os movimentos próprios daquela gente impressionam o turista que "custa a sair dali", percebendo a perfeição artística de crianças, um "pessoalzinho dos 5 aos 13, no mais!" ${ }^{300}$. Através de danças dramáticas, como Cabocolinhos, dança do tombo, dança do cipó, dança do Reis, peleja de guerra, dança das frechas, retiradas, e de instrumentos primários, a exemplo do ganzá, bombo e gaita de quatro furos, Mário de Andrade capta "movimentos melódicos simples e lindos" ${ }^{301}$ que mostram a riqueza cultural da nação. Esse é o Brasil que ele busca conhecer na Parahyba.

Porém, essa expressão popular encontra-se reprimida por ações da administração local que luta para construir uma cidade "moderna", livre dessas manifestações que resgatam o seu passado. Os novos espaços reformulados não comportam esse tipo de atividade, levando a administração a impor obstáculos às formas de expressão de suas raízes culturais, onde é necessário uma população pobre pagar licença para viver sua brasilidade de forma livre, nas ruas. A instituição de uma taxa a ser paga para utilização do espaço "público" para manifestações populares é interpretada pelo aprendiz de turista como um "conceito mesmo idiotissimamente nacional de Civilização" 302 .

A repressão à expressão popular no espaço público faz parte do processo de reformas da imagem urbana, onde não apenas a largura das ruas e configuração das praças são alteradas, mas também seu uso pela população. Assim, apagar o passado que sinaliza atraso, interferindo tanto na organização da cidade como nos hábitos da população, representa o "progresso" local. A cidade oficial é construída pela repressão de manifestações da vida tradicional.

Mário de Andrade observa tudo. Conversando com populares e discutindo com intelectuais, capta as peculiaridades do sertão, das cidades, das fazendas e dos mocambos, participando, quando possível, dos ritos a serem registrados de forma sensitiva. Frases, fotografias e relatos expressam a emoção de conhecer o próprio país que na simplicidade se mostra exótico e na peculiaridade de sua extensão se torna incógnito para seus próprios habitantes.

São escassos os relatos em seu diário de viagem sobre essa cidade. Assim, os espaços mais representativos desse processo de transformação, praças, parques e jardins, não prendem o seu olhar de que percorre, em suas andanças, particularmente, as áreas periféricas em relação a essa "urbs moderna". A "cidade oficial" escapa aos seus interesses de pesquisador, que pretendem descobrir e registrar as manifestações representativas da cultura popular, nesse momento expulsas da cena urbana oficial como resquício indesejado do passado. Seu olhar percorre os arredores cidade sem se deter em observações acuradas acerca da cidade oficial.

Em meio ao entusiasmo pelo trabalho, na coleta de danças, ritmos, cantos, crenças e ritos, e apesar do olhar do turista não se fixar logo na cidade, há nela algo que o surpreende, fixando-o por momentos de admiração: o Convento de São Francisco. Admira seu exterior, observa seus detalhes e guarda sua imagem

\footnotetext{
${ }^{298}$ ANDRADE, Mário de. O Turista Aprendiz. São Paulo: Duas Cidades, Secretaria da Cultura, Ciência e Tecnologia, 1976, p. 308.

299 Ibid.

${ }^{300} \mathrm{Ibid}$.

${ }^{301} \mathrm{lbid}$.

302 Ibid., p. 320.
} 
na memória, em seus escritos e na sua Kodak ${ }^{303}$. A atenção dedicada por Mário de Andrade em observar o convento e perceber seus elementos arquitetônicos, reconhecendo-lhe valor e ressaltando-o, provém do seu interesse em buscar o sentido da arquitetura colonial na formação de uma identidade nacional, preocupação que se evidencia numa série de quatro artigos publicados em 1928 no Diário Nacional - do qual é crítico de artes plásticas, música e literatura. Neles o autor se pergunta, em meio às idéias e tendências modernas, se era "um bem ou um mal estarmos trabucando por um estilo nacional de arquitetura no tempo de agora?"304 Assim, a busca do papel da arquitetura colonial na nova conjuntura direciona sua atenção para o convento de São Francisco, comparando-o com os demais por ele conhecido, contribuindo para o conjunto de sua reflexão em relação à nova arquitetura. Enquanto o passado é negado pelas ações oficiais, é nessa edificação que ele busca sentido para refletir acerca da modernidade em pauta naquele momento.

Ao descrever a capital paraibana, Mário de Andrade o faz de forma comparativa, tomando como referência a cidade de Natal, capital do estado vizinho do Rio Grande do Norte por onde ele passa anteriormente. Para ele, apesar de maior, a Parahyba "é bem menos compreensível"305. Uma cidade "muito desmantelada com tudo de mistura" ${ }^{306}$, impressão causada talvez pela permanência de características coloniais ainda fortes convivendo com o cenário resultante das intervenções desse período, despertando no turista uma impressão enigmática da cidade, que não Ihe deixa "resolver se é bonita se é feia"307.

Para ele, a cidade passa uma impressão de desorganização dos serviços urbanos, que transparece no sistema de transporte mantido pela Empresa de Tração, Luz e Força, com escassos e precários bondes, pelo calçamento antiquado e mesmo pelo calor insuportável. Porém, a cidade da Parahyba também lhe reserva encantos, como o Parque Arruda Câmara, criado pelo prefeito Guedes Pereira, descrito por ele como um "parque delicioso onde fica a fonte do Tambiá", que possui "pra mais de 20 ipês seculares que quando estão florados imaginem só a magnificência"308.

As "antiguidades arquitetônicas esplêndidas" e os "edifícios novos excelentes"309 dessa cidade, a exemplo do prédio dos Correios e Telégrafos, chamam igualmente a atenção do visitante. Porém, esses atrativos não são suficientes para desmanchar a sensação ambígua que a cidade lhe provoca, acentuada inclusive pelos "muitos mocambos e bairros operários mal amanhados, desruados" 310 , casinhas pequenas que explicitam a pobreza e o sofrimento do povo.

Na heterogeneidade da imagem urbana, à margem das exaltadas praças, avenidas e suntuosas edificações públicas, também permanecem casebres, caminhos, e vielas. Para além dos novos hábitos e novas modas, sobrevivem também a cultura local e velhos costumes.

A coexistência desses usos de natureza dual - os velhos costumes e os novos hábitos que tenta-se implantar na cidade - revela o momento de transformação e, de certa forma, de transição por que passa a cidade. Um olhar revelador dessa característica é o do cronista urbano. Atuando a partir de um ponto de vista interno, ele vivencia a cidade. Toma o passado como referencial e apresenta a nova dinâmica urbana ainda em formação. Ora saudosista, ora envolvido com a nova configuração urbana, percebe-se no conjunto de sua obra uma certa avaliação em relação às perdas e ganhos resultantes das inovações trazidas pelo século XX.

\footnotetext{
${ }^{303} \mathrm{~A}$ imagem ilustrada na página 199 do livro O Turista Aprendiz, organizado por Telê Ancona Lopez, conta como Convento de Igaraçu, na verdade é o Convento de São Francisco da cidade da Parahyba.

${ }^{304}$ ANDRADE, Mário de. "Arquitetura Colonial". In: Arte em Revista. n.4, ago. 1980, pp.12-14, p.13.

${ }^{305}$ Id. O Turista Aprendiz. São Paulo: Duas Cidades, Secretaria da Cultura, Ciência e Tecnologia, 1976, p. 315.

306 Ibid.

${ }^{307}$ Ibid.

${ }^{308} \mathrm{Ibid}$.

${ }^{309} \mathrm{Ibid}$., p. 316.

${ }^{310} \mathrm{lbid}$.
} 
Diante do quadro de metamorfose típico das cidades entre os séculos XIX e XX, é comum vê-las pulsando nas penas de cronistas. Se a cidade do Rio de Janeiro se revela através das palavras de Machado de Assis, Raul Pompéia, Olavo Bilac e, especialmente, João do Rio, e Recife se mostra nas palavras do cronista e memorialista Mario Sette, é Peryllo de Oliveira, sob o pseudônimo de Paulo Danísio, quem vai apresentar a Cidade dos Jardins ${ }^{311}$, a Parahyba dos anos de 1920.

Por intermédio das penas de Peryllo de Oliveira a capital paraibana é representada como écran, tela de projeção onde o presente se contrapõe ao passado, que por sua vez deixa marcas visíveis, se não aos olhos dos habitantes, aos olhos do cronista. É o olhar do passante, do observador atento em busca de flagrantes do cotidiano citadino, que Peryllo de Oliveira registra em suas crônicas sobre a Parahyba dos anos vinte, publicadas na revista Era Nova.

Percebe nuances da realidade urbana da capital paraibana no início do século XX, tanto no que diz respeito às transformações formais como às mudanças de hábitos e práticas cotidianas. Escritas na primeira metade da década de 1920, período de intensas remodelação dessa cidade, essas crônicas revelam os novos espaços criados pelas obras de embelezamento e constroem um olhar ao mesmo tempo crítico e nostálgico acerca da cidade que se transforma.

Na qualidade de cronista urbano, Peryllo de Oliveira vivencia a cidade sobre a qual escreve. Observando-a "de dentro", busca as nuances das intervenções urbanas e seus reflexos na vida dos habitantes. Diferente dos viajantes, ele não olha com a curiosidade do visitante, com avidez em ver o desconhecido, mas observa o espaço que já pertence ao seu dia-a-dia, buscando compreender e denunciar suas alterações, relacionando-as ao seu passado.

Para registrar suas percepções sobre a cidade da Parahyba, presenciando a metamorfose urbana por que passa essa capital, o cronista se apropria de personagens representativas da sociedade e da própria cidade. A imagem é captada e divulgada por Paulo Danízio, mais uma personagem por ele criado, que não só faz parte do écran urbano, mas é também o espectador que responde por seus escritos, sob o anonimato do pseudônimo. A utilização de 'atores' para encenar a realidade, bem como para observá-la e torná-la pública, assumindo sua autoria, confere uma certa liberdade às críticas e reflexões, considerando que "as pessoas quando estão vestidas em fantasias falam sem travas na língua" ${ }^{312}$.

Na Cidade dos Jardins, o olhar de Danízio acompanha a Parahyba que se modifica em 'corpo', a organização urbana, e 'alma', os costumes citadinos. Lembra do passado ao buscar compreender a metamorfose do momento, num olhar muitas vezes nostálgico que se perde em meio à euforia provocada pela transformação urbana. Apesar de suas crônicas serem

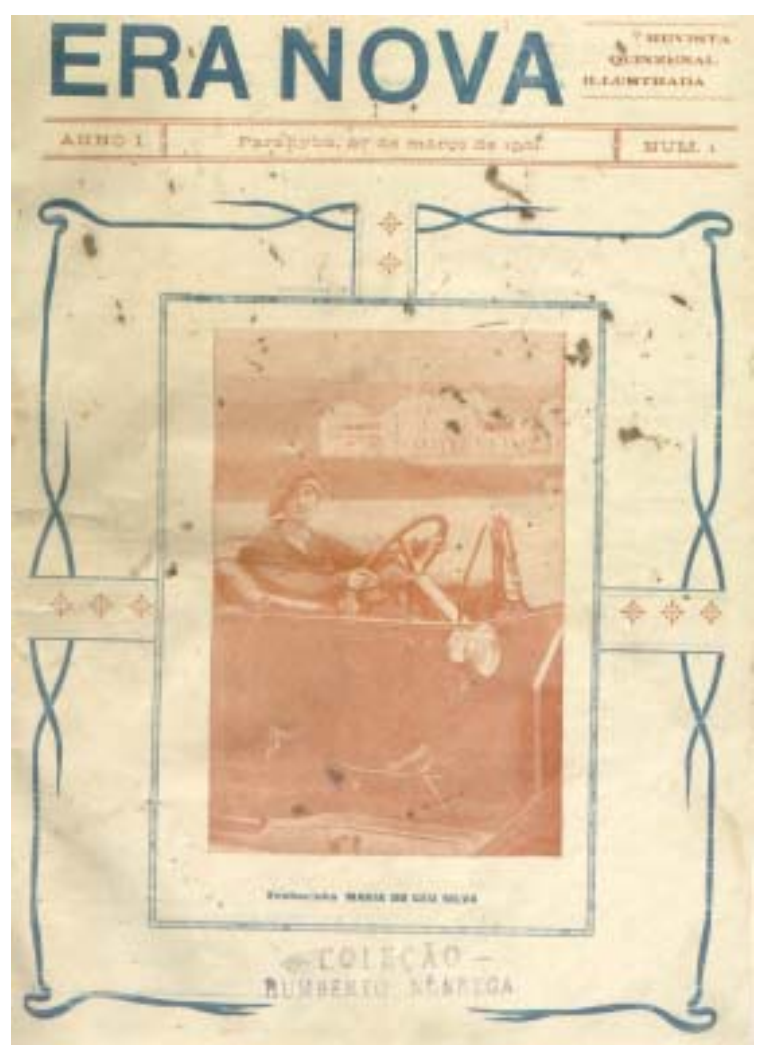

Capa do primeiro exemplar da revista Era Nova - 1921. FONTE: Revista Era Nova

${ }^{311}$ Título da coluna da Revista Era Nova reservada às crônicas de Perylo de Oliveira.

${ }^{312}$ Arthur Helps apud SEVCENKO, Nicolau. "A capital irradiante: técnicas, ritmos e ritos do Rio". In: SEVCENKO, Nicolau. História da Vida Privada no Brasil. Vol. 3. São Paulo: Companhia das Letras, 2003, pp. 513-619, p. 514. 
publicadas na revista Era Nova, veículo de plena divulgação dos ideais modernizadores, num período de total empolgação com os novos elementos urbanísticos e desejo de uma vida a eles alinhada, suas crônicas, em alguns momentos, desmistificam esses ideais tão enaltecidos naquele contexto. Apresenta uma realidade onde as 'personagens' não correspondem ao 'cenário' no qual se inserem, retratando uma sociedade que, apesar de buscar a 'modernização' da cidade, não vive uma vida efetivamente moderna.

Diante das intervenções que alteram os espaços coloniais, apagando ou sobrescrevendo becos, travessas e largos, o cronista pára e vê a cidade. Seu olhar busca a vida urbana, percebendo que ela não mais converge para a Igreja, mas é absorvida pelos novos espaços públicos. No passado, a relação da Igreja com a cidade torna essa instituição o centro difusor de informações e elemento que rege o ritmo citadino. O badalar confere aos seus sinos o papel de "intérpretes das alegrias e das tristezas da Cidade"313. A nova configuração urbana dispensa-Ihe esse papel. Os relógios nas praças passam a simbolizar os novos ritmos de vida, e parques e praças tornam-se locais de aglomerações para atividades de lazer, substituindo os largos das igrejas.

O olhar de Paulo Danízio é saudoso ao buscar resquícios da cidade passada em meio às transformações urbanas que presencia, percebendo que ela não mais guarda a mesma escala, tão pouco os mesmos valores, costumes e ritmo de vida. Percebe no meio urbano elementos do passado que se apresentam deslocados do contexto, a exemplo dos sinos das igrejas que, dispensáveis na nova dinâmica urbana, encontram-se "condenado[s] à eternidade do silêncio"314. Seu olhar perpassa os mesmos lugares já descritos por outras penas, porém capta significados diferentes: observa a cidade como lugar de vivências e convivências, de diversidade de personagens, buscando perceber como ela conta sua própria história.

A cidade se mostra ao cronista através da combinação de suas formas com sua cultura e costumes, onde ele se empenha em buscar o fio condutor do passado ao presente, enfocando a relação das transformações com a nova dinâmica urbana. Resgata os atores desse ambiente, evidenciado as personagens anônimas que dele participam e constroem sua identidade. O cronista leva a refletir como esses atuantes são extintos e recriados, muitas vezes esquecidos pelos valores da vida "moderna", mas extremamente necessários ao seu funcionamento e à sua configuração como tal. É nesse contexto que se enquadra a imagem do acendedor de lampiões, extinto da paisagem urbana pela introdução da luz elétrica, um dos marcos da nova organização dessa capital que, por outro lado, delega vida a outros atores, como o vendedor de jornais e o varredor de ruas, gente humilde da cidade, inerentes à realidade e às necessidades urbanas.

Paulo Danízio também retrata as diferenças sociais, descrevendo a elite e a gente humilde constituinte dessa sociedade, onde "grandes, médios e pequeninos" ${ }^{\prime 315}$ concretizam no cotidiano a desigualdade das classes. As inovações tecnológicas e artigos de conotação luxuosa, que passam a compor o cenário urbano, revelam uma cidade de contrastes, da qual a população desprovida de posses tem usufruto restrito. O automóvel, o charuto, a diversidade de roupas que marcam uma hierarquia social, os bondes e as praças constróem ambiente que seleciona seus usuários.

"O sr. toma o bonde aqui e, nesta esquina, e ... Então me lembrei que ele não podia entrar no bonde, lembrei-me de que não temos bonde de segunda classe!!!" ${ }^{316}$

Em meio a novos costumes, ritmos e velocidades que orientam a cidade, novos sons surgem e se misturam, organizando-se numa hierarquia articulada à sua nova ordem de funcionamento. O cronista identifica os sons próprios à cidade, geralmente ignorados no seu cotidiano, mesmo no amanhecer onde "o silêncio,

\footnotetext{
${ }^{313}$ DANÍZIO, Paulo. "Cidade dos Jardins. O silêncio dos sinos vencidos". Era Nova, Parahyba, n. 61 mai. 1924, s/ p.

314 Ibid.

${ }^{315}$ Id."Cidade dos Jardins. Os grandes, os medios, os pequeninos". Era Nova, Parahyba, n. 65, jun. 1924c, s/ p.

316 Ibid.
} 


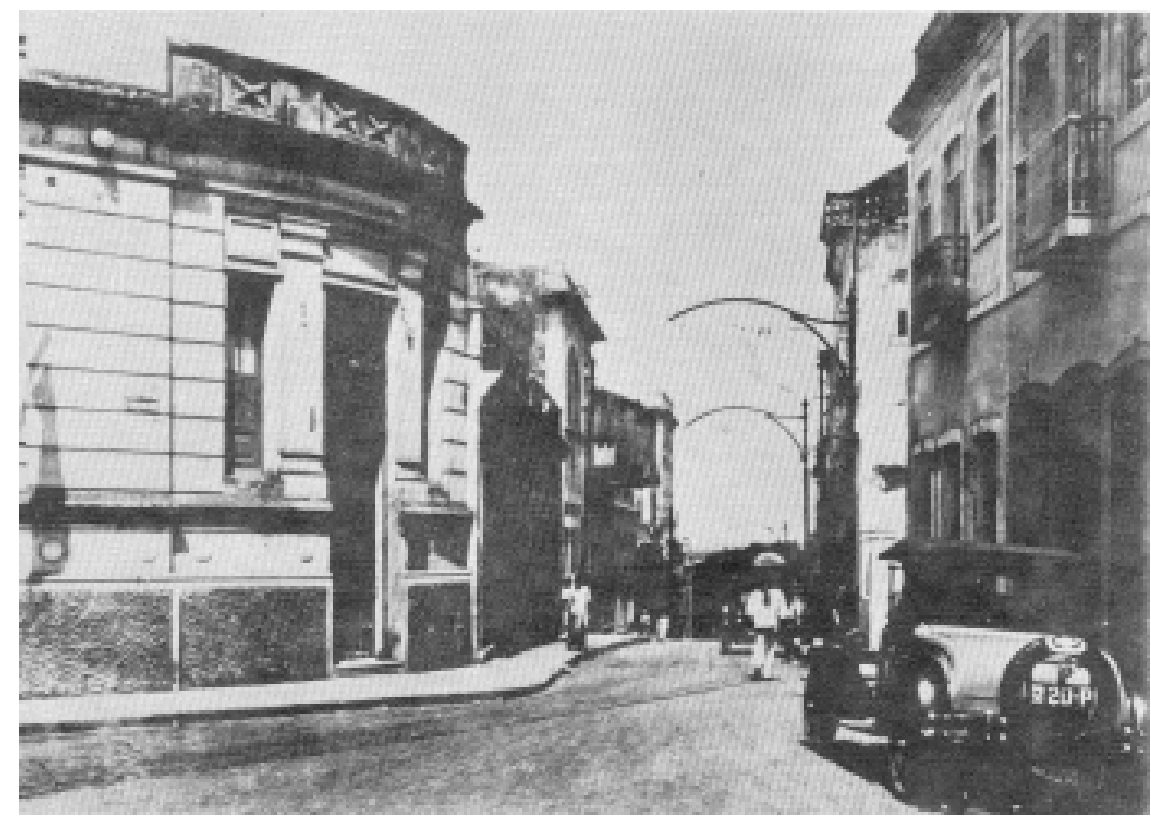

Rua Marciel Pinheiro. FONTE: Acervo Walfredo Rodrigues.

inutilmente, se esforçava para abonar a voz entrecortada da cidade em movimento" ${ }^{317}$. O ritmo acelerado da cidade em transformação reduz a percepção dos seus sons mais peculiares, abafados hierarquicamente por um conjunto de ruídos novos, onde o barulho do carro abafa o som da carroça, que por sua vez cala o grito da pedra por ela deslocada.

Entre os novos espaços, com novos usos e significados, seu olhar busca lugares de tempos passados que permitem recordar a vida de outrora, seu ritmo e costumes, talvez sem sentido para novas gerações, mas repletos de significados para aqueles que buscam referências do seu passado, que provem sua existência em meio a um mundo novo. Nas praças antigas, como a Pedro Américo, encontra-se o provincianismo ingênuo do passado; nela está a diversidade que compõe a cidade em busca de recordação - "a comédia humana da cidade" ${ }^{\prime 18}$.

\begin{abstract}
"Nesta praça [Pedro Américo] refugiou-se o que de mais pittoresco existiu em o provincianismo ingênuo dos nossos avós. Ella é e será ainda por muito tempo a praça dos que recordam, dos que não poderam galgar os cimos da existencia senão na belleza ephemera, illusoria dos sonhos que tiveram. Sim, repito, essa praça é o refugio dos que recordam"319.
\end{abstract}

Apesar dessa visão nostálgica, ele reconhece nos espaços novos uma conotação progressista. São palcos de novos valores e costumes recorrentes do viver juvenil, para onde convergem suas esperanças de "vitória para o futuro". São lugares condizentes com os novos ideais e a visão otimista de futuro, vistos pelo cronista como "miniatura psychologica da Cidade". Freqüentar esses novos lugares significa compartilhar conhecimentos sobre prélios desportivos, modelos dos últimos figurinos e cortes de vestidos, desfrutando de elementos pertencentes a uma sociedade 'moderna'.

"A praça Venâncio Neiva é um cartaz. Um grande cartaz luminoso que o progresso bataclanisou, coloriu, encheu de sol e de tintas varias, com a mesma inspiração tumultuaria de um pintor impressionista" 320 .

A adoção de novos costumes que retratem um novo cotidiano urbano não condiz, conforme expressa o

\footnotetext{
${ }^{317}$ DANÍZIO, Paulo. "Cidade dos Jardins. A mais pungente das cem mil dores anonymas da cidade". Era Nova, Parahyba, n. 71, dez. 1924e, s/ p

${ }^{318}$ /d. "Refúgio dos que recordam". Era Nova, Parahyba, n. 89, out. 1925b, s/ p.

$319 \mathrm{lbid}$.

${ }^{320} \mathrm{Id}$., "A praça que é o sorriso da cidade". Era Nova, Parahyba, n. 90, nov. 1925c, s/ p.
} 
cronista, com o ideal moderno, apresentando uma sociedade que, apesar do desejo de atingi-lo, "[tateia] no encalço de um vocabulário adequado" ${ }^{321}$ que se reflita em sua vida e costumes. Peryllo de Olivera observa a preocupação de ordem estética presente na elite sempre disposta a discutir os "nossos" hábitos elegantes, baseada em uma tradição que não é a sua. As atividades realizadas pela população com o intuito de se mostrar "moderna", em uma cidade que só tem praças e cinemas como locais de diversão, revela ao cronista uma impressão de uma sociedade que parece viver em dois mundos, que apesar de buscar se desprender do passado, ainda não é 'moderna' no seu todo.

O quadro urbano que a capital paraibana apresenta em fins dos anos vinte reflete o papel primordial que as praças têm na configuração desse conjunto urbano, reordenando e concentrando em si novas formas e usos dos espaços públicos. Tais elementos simbolizam essa etapa de reformulação dessa cidade, onde a praça é retratada como "o sorriso da cidade" 322 , segundo o cronista Paulo Danízio. Nelas se apresenta a população renovada em seus hábitos cotidianos, enquanto o Estado redesenha a cidade. Nesse contexto, a praça assume, também segundo o mesmo cronista, o papel de "écran" da cidade, tela de projeção das transformações urbanas. 


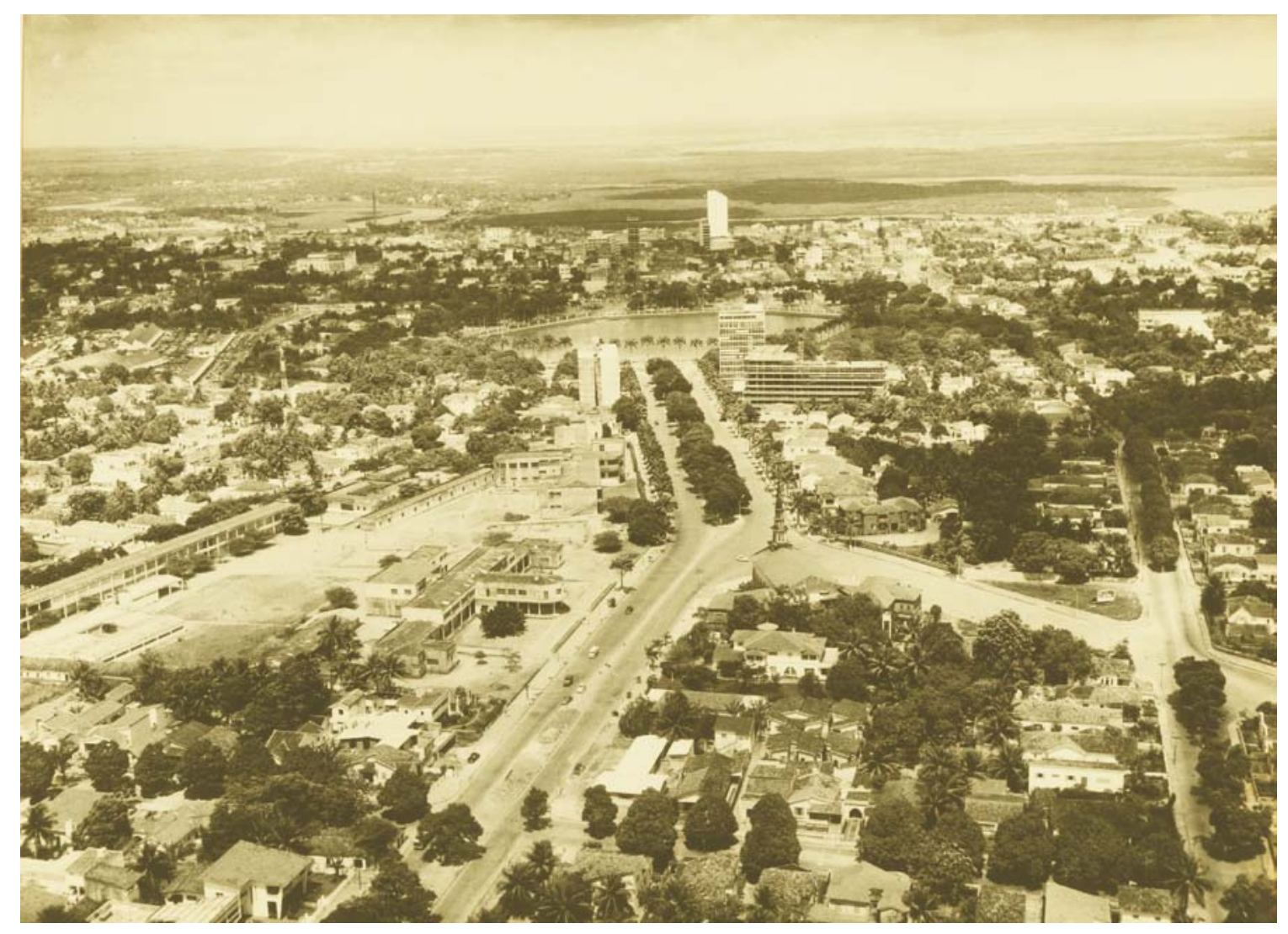




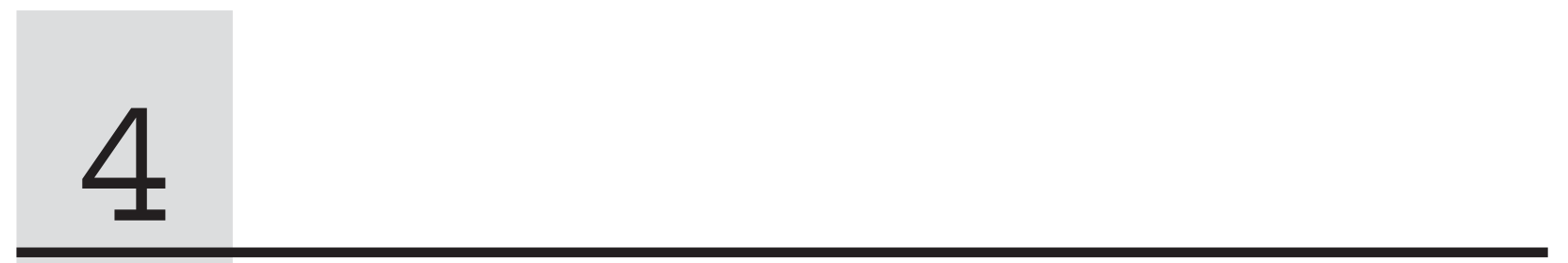

Capítulo 4

\title{
A Cidade dos Anos 30
}

\author{
A construção dos espaços públicos \\ segundo os interesses expansionistas
}

Se as primeiras décadas do século XX marcam a cidade de João Pessoa por intervenções pontuais e, sobretudo, de caráter estético e higienista como fica evidenciado nos discursos e nas ações administrativas das décadas de 1910 e 1920, os anos 30 apresentam, de forma mais enfática, preocupações relativas ao sistema viário, influenciadas pelos novos ritmos que referenciam cada vez mais as grandes cidades. Nelas, as novas velocidades proporcionadas pela indústria e seus produtos, que alteram o ritmo da vida urbana, e a crise provocada por seus crescimentos inéditos desde fins do século XIX são sucedidas por grandes reformas voltadas a favorecer a circulação, onde o interesse em reduzir o tempo de deslocamento revela-se uma questão central do urbanismo. Nesse contexto, novos ritmos tornam-se os direcionadores das intervenções urbanas, onde a idéia da economia do tempo faz-se presente por meio da ênfase ao transporte, à criação de equipamentos coletivos e serviços sanitários que contribuem para facilitar as tarefas domésticas, e à neutralização dos espaços públicos que acabam por serem convertidos em meros lugares de passagem ${ }^{323}$.

A questão viária, vinculada à intenção de viabilizar o novo ritmo que se difunde, transformando as cidades, é acompanhada por uma nova estética urbana que enfatiza e simboliza esses novos conceitos. Assim, juntamente com as novas funções às quais os novos espaços são dirigidos, também Ihes são atribuídas novas formas, acentuadas, inclusive, pela nova arquitetura construída em seus arredores, que sinaliza formalmente o anúncio de uma nova etapa da construção urbana.

A cidade que naquele momento é levada a uma reordenação, apresentando uma estrutura intitulada caótica e configurando-se como um local onde as pessoas "se comprimem e se empurram nas ruas" 324 , apresenta ainda outras deficiências funcionais decorrentes da disposição e das características de alguns de seus elementos .

O século XIX presencia inéditas transformações urbanas das grandes cidades, onde o caso clássico de Paris torna-se o mais evidente. Os principais exemplos, geralmente cidades com grande aumento populacional e alto índice de industrialização para a época, influenciam outros centros urbanos que posteriormente passam por esse processo, diferenciando-se pela influência de seus condicionantes históricos. Nesse contexto, as cidades pioneiras dessas transformações são, muitas vezes, intituladas de 'modelo'.

\footnotetext{
${ }^{323}$ CORREIA, Telma de Barros. "A gestão do tempo e a organização da cidade moderna”. Sinopses. São Paulo n.33p.22-32 jun. 2000, p. 24. 
A cidade de João Pessoa, ao realizar suas intervenções mais intensas ao longo da primeira metade do século XX, também está revestida dos discursos e idéias provenientes de exemplos referenciais: não apenas o de Paris mas, certamente, mais influenciada pelo Rio de Janeiro, então capital federal, São Paulo e Recife, o que se verifica, inclusive, na presença de profissionais com atuação nacional, como Saturnino de Brito e Nestor de Figueiredo ${ }^{325}$, este atuando na elaboração do plano de expansão nos anos 30, aquele contribuindo com uma proposta de melhoramentos sanitários nas décadas de 1910 e 1920.

À época da elaboração do plano por Nestor de Figueiredo, a capital paraibana participa de uma discussão comum a várias outras cidades, movida pelos ideais de velocidade e de uma nova ordenação das atividades urbanas que vão alterando suas formas. Nesse momento, muitas de suas características se diferem das apresentadas nas grandes cidades que também passam por esse processo. Sem altos índices populacionais nem industrialização consolidada, a intenção de reformar a capital paraibana está, de certo, também calcada nos objetivos de criar uma imagem de referência ao ideal de 'modernidade' em voga e de direcionar o crescimento urbano segundo tais princípios, sanando as dificuldades impostas pela estrutura já consolidada, que são significativas apesar de não configurarem um quadro de iguais proporções ao das metrópoles.

A intenção de alterar formalmente a cidade, vinculada ao ideal de "modernidade", pode ser verificado no plano elaborado por Nestor de Figueiredo. Elemento urbanístico representativo desse período, esse plano se refere mais às áreas de expansão da cidade, ordenando seus fluxos em conjunto com as novas zonas de atividades que estabelece, que às intervenções nas regiões já consolidadas, a fim de ajustá-las às novas necessidades e solucionar as possíveis insuficiências da estrutura urbana em uso. Essa proposta de espansão, quando executada, tem uma lenta ocupação, o que mostra uma demanda a longo prazo, e não uma exigência imediata.

Além da intenção de atender a um novo ritmo de vida e da questão estética, a transformação do espaço urbano também se encontra vinculada à economia do Estado, que interfere diretamente nas ações urbanísticas desencadeadas nessa capital. A ênfase viária dada às intervenções desse momento está também relacionada ao acesso ao porto e ao interesse em agilizar escoamento de produtos locais, o que interfere diretamente na economia local. Essa questão há tempos que se encontra presente nas pautas dos discursos de políticos locais, abordada inclusive por José Américo de Almeida em seu livro A Paraíba e seus problemas, publicado em 1923. As discussões urbanísticas do momento uniem-se aos interesses econômicos do Estado, de forma que a questão portuária torna-se um dos pivôs das propostas urbanas desse momento, enfatizando seu caráter viário. Ligar o porto à capital é uma das questões que lidera as discussões sobre a cidade.

O contexto urbano desse momento leva as transformação da cidade a assumirem formas e proporções inéditas na história local, consequentes do processo urbanístico desenacadeado no passado e que assume, em cada período, características próprias. Assim, essa é mais uma etapa do processo e não uma ruptura com uma estrutura supostamente fixa e estática. A intenção de transformar o meio urbano torna-se parte de uma meta ampla de governo, que vem se construindo e se revelando a cada administração. Nesse contexto, muitas vezes políticos e intelectuais assumem juntos a coordenação dos meios de transformação da cidade e da sociedade, mesmo que em alguns momentos esses dois grupos apresentem divergências em relação a essas questões.

Nesse sentido, os anos trinta apresentam um quadro político-social complexo. Se por um lado os políticos buscam de forma cada vez mais acentuada transformar a cidade, mostrando a eficiência e "modernização" do

${ }^{325}$ Nestor Egydio de Figueiredo, pernambucano radicado no Rio de Janeiro, forma-se na Escola de Belas Artes, onde mais tarde leciona a disciplina Evolução dos Planos das Cidades. Atua junto ao Instituto Central de Arquitetos e à Associação dos Artistas Brasileiros, colaborando ainda em periódicos como Arquitetura e Urbanismo, Urbanismo e Viação e Architectura e Construç̧ões. Capítulo 4 - A cidade dos anos 30: a construção dos espaços públicos segundo os interesses expansionistas 123 
aparelho estatal, por outro lado camadas intelectuais se propõem a participar ativamente da transformação da cidade, envolvendo-se em diferentes setores administrativos.

O processo de reformulação urbana é conduzido por profissionais do urbanismo, políticos e intelectuais que se unem na administração pública por perceberem a oportunidade de concretizar ações que julgam necessárias. Nesse sentido, o perfil do Brasil dos anos 30 é formado pela inclusão na administração pública de artistas e intelectuais ligados à renovação das artes, a exemplo de Mario de Andrade, Manuel Bandeira, Carlos Drummond de Andrade e José Américo de Almeida, entre outros. Intelectuais e políticos buscam resgatar a identidade cultural brasileira e, envolvidos pelo espírito nacionalista, aliam-se em algumas questões, embora muitas vezes ocorram divergências na forma de defender e concretizar seus objetivos.

Essa interação e movimentação para transformar a imagem do país fica evidente no governo Vargas, iniciado em 1930 e prolongado de 1937 a 1940, a partir de um golpe de Estado. Após o golpe, são depostos os governadores dos estados brasileiros, substituídos por interventores federais indicados pelo governo central. Devido à influência de José Américo de Almeida ${ }^{326}$, intelectual paraibano de grande projeção política, a atuação de um civil, e não de um militar, no cargo de interventor do estado da Paraíba é aceita. Assim, permanece no poder o governador Argemiro de Figueiredo, à frente da administração desse estado desde 1935.

Argemiro de Figueiredo, paraibano nascido em 1901 e filho do líder perrepista Cel. Salvino Figueiredo, forma-se em direito pela Faculdade do Recife, atuando como advogado em associações operárias de Campina Grande. Participa da fundação do Partido Democrata da Paraíba em 1928 e do Partido Progressista da Paraíba em 1933, é deputado estadual em 1930 e depois é nomeado Secretário do Interior e Justiça. Indicado por José Américo de Almeida, em 1934 é candidato para o governo do estado pelo Partido Progressista, mas só é eleito no ano seguinte, pela Assembléia Legislativa. Com o golpe do Estado Novo em 1937, confirma-se seu cargo de interventor, do qual é exonerado em 1940. Sua administração é um dos momentos mais ricos em realizações do estado, que vive um ritmo intenso de transformação.

A administração de Argemiro de Figueiredo tem muito do perfil assumido pelo governo Vargas. A postura do governo brasileiro naquele momento reflete o interesse na 'modernização' da economia e da administração nacional e tem a promoção de uma nova estrutura urbana como seu maior expositor. Esse processo é conduzido por um governo autoritário e populista que assume um caráter paternalista através da figura de Vargas. De modo análogo dá-se a administração conduzida por Argemiro de Figueiredo, que apresenta um perfil semelhante ao do interventor nacional. A construção de uma nova estrutura urbana e, inclusive, de uma nova arquitetura que abrigue os órgãos administrativos criados ou remodelados nesse momento, é tomado pelo governo paraibano como anunciadores da renovação econômica e administrativa. Assim como ocorre no governo Vargas, as obras de arquitetura e urbanismo são ligadas à figura do administrador local, Argemiro de Figueiredo, que promove sua imagem a partir dessas realizações. As principais obras por ele promovidas são inauguradas nos

\footnotetext{
${ }^{326}$ Nascido no Brejo de Areia, na Paraíba, em 10 de janeiro de 1887, filho de Inácio Augusto de Almeida e Josefa Leopoldina Leal de Almeida, José Américo de Almeida ingressa aos quinze anos no Seminário da Capital, onde conclui o curso secundário. No Liceu Paraibano conclui o curso de humanidades e, em 1908, o curso de direito na Faculdade do Recife. Começa sua vida profissional como promotor público na cidade de Souza, sertão paraibano, e em 1911 exerce o cargo de Procurador Geral do Estado. Durante a administração estadual de João Pessoa, é nomeado Secretário Geral do Presidente, "braço direito do governante paraibano". Em 1930, torna-se "chefe civil da revolução no norte e nordeste". Assume o Ministério da Viação e Obras Públicas durante o governo provisório de Getúlio Vargas, realizando grandes obras para o Nordeste, a exemplo da construção de grandes açudes, "objetivando redimi-lo do flagelo secular de estiagem". "Candidato à Presidência da República, em 1937, foi banido da vida política, no mesmo ano, em virtude do golpe de estado". Recusa alguns cargos, a exemplo do de embaixador junto a Santa Sé, ao qual foi nomeado em 1934, e Senador, eleito indiretamente pela Paraíba em 1935. É Ministro do Tribunal de Contas e, em 1945, é novamente eleito Senador pela Paraíba. Em 1950, elege-se Governador da Paraíba, permanecendo até 1955, quando aceita novamente o convite de Getúlio Vargas para o Ministério da Viação e Obras Públicas, retornando à Paraíba após o suicídio de Vargas para assumir o governo. Em 1958, é candidato ao Senado, perdendo a vaga para Rui Carneiro e finalizando sua carreira política. Retira-se da atividade política e administrativa, e vai morar na praia de Tambaú, onde morre em 10 de março de 1980. (MILANEZ, Altamir. José Américo - "O homem e a obra". Regista do IHGP João Pessoa, dez 1991, n. 23, ano LXXXII, p. 47)
} 
seus aniversários natalícios, nos do seu governo e até nos aniversários natalícios do presidente Vargas. Ao lado das imagens divulgadas das obras concluídas é apresentada a fotografia do governador, vinculando a sua figura pessoal à nova imagem da cidade.

O governo de Argemiro de Figueiredo é de intensas realizações. Sua atuação revela, assim como a postura de Vargas em relação ao país, uma voracidade em transformar a aparência urbana através de ações que promovem a imagem do interventor. Essa meta administrativa tem na arquitetura um potencial propulsor, onde os estilos históricos são deixados de lado, substituídos pela busca de uma nova estética que denote um país "moderno", independente e em princípio de industrialização ${ }^{327}$, de acordo com os "ideais revolucionários".

O concurso para o prédio do Ministério de Educação e Saúde no Rio de Janeiro, realizado no ano de 1935, representa esse momento da discussão arquitetônica no Brasil, constituindo-se um marco da arquitetura moderna no país. Nesse mesmo período, na cidade de João Pessoa, também patrocinado pelo poder público, como ocorre com o edifício do Ministério, e no mesmo estilo arquitetônicos, realiza-se um conjunto de obras que incluem os edifícios da Secretaria de Finanças, da Rádio Tabajara e do conjunto do Instituto de Educação. Essa sincronia ultrapassa a produção arquitetônica, estendendo-se às outras ações administrativas locais.

Assim como o governo nacional de Getúlio Vargas realiza diversas reformas administrativas, com a criação de novos ministérios, secretarias e departamentos, da mesma forma atua a administração paraibana. Um dos pontos estratégicos dos governos tanto nacional como local é a ampla divulgação de suas realizações, a fim de reafirmar sua gestão e vincular a inovação refletida nos espaços públicos à figura do interventor e ao progresso político e econômico. Assim, dos órgãos criados nesse momento, destacam-se o Departamento de Propaganda e Difusão Cultural, depois transformado em Departamento de Imprensa e Propaganda, a nível nacional, e o Departamento Oficial de Propaganda e Publicidade, a nível estadual.

O Departamento de Estatística e Publicidade do Estado da Paraíba é responsável pela divulgação das realizações feitas na administração de Argemiro de Figueiredo, desenvolvendo um material de alta qualidade, amplamente ilustrado com imagens das obras concluídas e em execução, sempre acompanhado da imagem do interventor. Essa divulgação é ampla e freqüente, apresentando de forma exaustiva as realizações locais. Do material produzido destaca-se uma espécie de dossiê, com texto explicativo breve e com muitas imagens das principais obras dessa administração em todo o estado. Esse material é publicado, em 1938, sob o título de "Realizações do Governo Argemiro de Figueiredo".

A característica propagandista do governo de Argemiro de Figueiredo, que viabiliza o vínculo entre as ações administrativas e a imagem pessoal do administrador, é comprovada pela mudança da postura do governo imediatamente após sua posse, ao tratar da construção do edifício da Secretaria de Finanças. Essa é a primeira edificação caracterizada pela arquitetura moderna na capital paraibana, cuja construção é iniciada na administração de Antenor Navarro, anterior à de Argemiro de Figueiredo. Naquele momento, a divulgação dessa obra nos veículos de comunicação local se resume a duas notas pouco enfáticas publicadas em jornal local. Concluída no governo de Argemiro de Figueiredo, torna-se marco inovador da arquitetura, amplamente anunciada pela imprensa como início de grandes mudanças e símbolo de 'modernizaçao'. A partir de então,

\footnotetext{
${ }^{327}$ No governo Vargas há o fechamento dos portos e o incentivo à industrializaçãonacional, bem como o interesse em modernizar a economia local. Essa postura de valorização do produto nacional também é verificada na administração de Argemiro de Figueiredo, tanto pela situação do porto local como pelo incentivo à agricultura e à exportação de seus produtos, como se observa nas manchetes do jornal A União desse período: "1ª Exportaçao de abacaxi para a agricultura" (ago.1939); "Venda de algodão para o Japão" (set. 1939); "O Desenvolvimento da Cultura, da Indústria e da Exportaçao Agrícola na Paraíba" ( set.1939); "Chegou ontem ao Rio a primeira partida de abacaxis paraibanos"(out. 1939); "Essas, as diretivas retilíneas do programa de desenvolvimento econômico da nossa terra, posta em prática pelo sr. Argemiro de Figueiredo desde os primeiros dias da sua dinamica administração. Diretivas que colocaram a Paraíba em posição destacada quanto à sistematização de medidas de fomento agrícola no País, conforme ficou exuberantemente verificado no impressionante discurso pronunciado pelo presidente Vargas, por ocasião da Conferência dos Interventores, em novembro do ano passado (...)" (mar. 1940)
} 
todas as realizações desse governo são enfaticamente estampadas no jornal local e em publicações específicas produzidas pelo governo.

As semelhanças nas posturas administrativas de Argemiro de Figueiredo e Getúlio Vargas, a exemplo do marcante o uso da arquitetura como meio de divulgação e propaganda dos ideais modernizantes de governo, apresentam-se de forma consciente e pública, onde o interventor do estado da Paraíba menciona, recorrentemente, exemplos da administração nacional.

A postura administrativa desse momento, bem como suas realizações e as formas com que essas fazem parte de uma estratégia de governo, mostra que a capital paraibana participa do debate nacional, não se resumindo a um simples reflexo das realizações que envolvem o eixo Rio de Janeiro - São Paulo. Assim, o pensamento político-econômico local e as realizações urbanísticas e arquitetônicas que alteram a aparência e a funcionalidade dos espaços públicos dessa capital participam desse momento da história urbana nacional.

\subsection{A EXPANSÃO E A TRAMA}

Na década de 1930, um dos principais pontos do discurso urbano da capital paraibana é a expansão dessa cidade. Envolvendo um universo de questões, de naturezas política, econômica, funcional, formal e ideológica relacionadas às situações portuária, viária e de zoneamento, a discussão sobre a expansão urbana da cidade de João Pessoa promove a divulgação local das idéias discutidas em todo o país, através da participação de profissionais atuantes em várias localidades. Esse debate ocorrido a nível nacional, do qual a capital paraibana também participa, dá-se a partir da análise de cada caso específico onde se quer intervir, para o qual soluções adotadas anteriormente em outros locais são mencionadas ou reapropriadas, e o discurso proferido em outros lugares são utilizados para legitimar a nova proposta.

Esse é um momento muito rico da história urbana local, onde as discussões resultam em críticas e propostas para intervir no espaço urbano. As idéias apresentadas, a criação de planos e a intenção de alterar a forma da cidade, mesmo que ainda não executados, constituem-se objetos de análise formal do pensamento da época. Assim, para além das transformações dos espaços públicos desse momento, os projetos e as idéias em geral promovidas e debatidas nesse período, executadas ou não, assumem importância na análise da transformação da cidade aqui proposta.

\subsubsection{A questão portuária e as intervenções urbanas}

A questão portuária se arrasta por décadas. O porto inicial da capital é no Varadouro, o preferido do estado desde a fundação dessa cidade e, por muito tempo, elogiado por suas condições naturais que proporcionavam segurança, inclusive pela localização deste núcleo urbano em relação a esse estuário. Apesar dessas vantagens, pelo fato da "cidade est[ar] situada fora da estrada principal dos sertões, a maior parte das mercadorias vão directamente para o Recife, sem necessitar dos intermediarios da Parahyba”328. Porém, a qualidade do porto é tal que é comum a idéia de que "se se fizessem bôas estradas para lá, este porto poderia deslocar parte considerável dos negócios do Recife"329.

328 "Notas Dominicaes", trad. De Alfredo de Carvalho, na Revista do Inst. Archeol. E Geog. Pernambucano, vol. XI, n 61, p 461, apud ALMEIDA, José Américo de. A Paraíba e seus problemas. 4ª ed. Brasília: Senado Federal, 1994, p. 415. 329 Ibid. 
Apesar das favoráveis condições naturais do porto do Varadouro, a falta de manutenção desse espaço vai extinguindo tais vantagens, diminuindo gradativamente a profundidade do seu ancoradouro e do seu canal. É comum encontrar nas mensagens dos presidentes da província "apelos intermináveis para a conclusão desse serviço [do porto], sempre adiado ou atacado, incompleta e lentamente, por insuficiência de verbas"330, levando-o a condições precárias de funcionamento em relação à demanda.

O porto, antes descrito pelos visitantes da província como local de excelentes qualidades naturais para a função nele exercida, encontra-se, em 1889, em condições precárias, levando-o a ser apontado como

“... pequeno parapeito com honras de caes, já arruinado e, dentro em pouco, caindo aos pedaços, separando do elemento liquido uma estreita faixa de terra firme, com um barracão chrismado de alfândega e rodeado de meia dúzia de armazéns, (...) que pode ser tudo o que quizerem, menos um porto de mar, digno de uma provincia como esta"331.

Entre 1891 e 1893 são realizados estudos para reforma desse porto, visando reverter esse quadro. Concluídos as análises, diante do orçamento dispendioso, opta-se por promover melhoramentos no porto de Cabedelo ${ }^{332}$, que se constitui uma obra mais viável. Iniciados em 1908, esses trabalhos estendem-se por alguns anos, "mas esse porto não acudia ao ideal de emancipação econômica da Paraíba"333. Essa situação leva o governo federal, em 1918, a autorizar a construção do porto na enseada de Tambaú, que dista seis quilômetros da capital. Porém, também

“...seriam dispendiosíssimas as obras necessárias para ahi fundar um porto abrigado e sufficientemente profundo, pela construcção de quebra mares capazes de enfrentar o assalto das vagas de tempestade e pela dragagem em fundo marítimo, coalhado de concreções rochosas" ${ }^{\prime 334}$.

Com o paraibano Epitácio Pessoa à frente da presidência do país, é elaborado e orçado um projeto pela Inspetoria de Portos, aprovado em outubro de 1920. Esses estudos, realizados pelo engenheiro Lucas Bicalho, analisam todo o percurso do rio Sanhauá ao longo do trajeto que liga a cidade de João Pessoa à então vila de Cabedelo, reconhecendo a superioridade das condições naturais portuárias do rio nessa região vizinha em relação ao porto da capital. No entanto, fica esclarecido no parecer do projeto que "o que se deve ter em vista não é a construção de um porto barato, mas sim um porto util, que possa attender ao movimento de exportação e importação de mercadorias de ou para a zona que Ihe compete servir"335. Apesar da consciência das dificuldades de execução dos melhoramentos no porto da capital, obra de grande vulto ${ }^{336}$, e mesmo com sua onerosidade, ela é levada adiante. Assim, sua execução é iniciada em 1921, ficando a cargo da firma C.H. Walker \& $C^{\circ}$. São apresentadas avaliações da obra em andamento, mostrando os gastos e a lentidão dos serviços, que superam as expectativas.

Apesar do empenho, do tempo e do dinheiro já aplicado em insistentes obras que dragam a várzea do rio

\footnotetext{
330 ALMEIDA, José Américo de. A Paraíba e seus problemas. 4a ed. Brasília: Senado Federal, 1994, p.416.

${ }^{331}$ RETUMBA, apud ALMEIDA, José Américo de. ALMEIDA, José Américo de. A Paraíba e seus problemas. $4^{\mathrm{a}}$ ed. Brasília: Senado Federal, 1994, p.416.

${ }^{332}$ Cabedelo é um município vizinho a João Pessoa, ligado, naquele momento, à essa capital pelo rio, mar, ferrovia e rodovia de qualidade questionável.

${ }^{333}$ ALMEIDA, José Américo de., op.cit., p.417.

${ }^{334}$ Parecer da Comissão chefiada pelo engenheiro Cláudio da Costa Ribeiro, apud ALMEIDA,José Américo de., op. cit., p.417.

${ }^{335}$ Relatório da Inspetoria Federal de Portos. In: ALMEIDA, José Américo de. op. cit., p. 421.

${ }^{336}$ O plano das obras, aprovado pela Inspetoria de Portos em 1920, consta, resumidamente, dos seguintes itens: Execução de um canal de navegação desde a entrada até a cidade da Parahyba com 22 quilômetros, incluindo o porto de Cabedelo; Balisamento do canal e cortinas de faixa para a proteção das margens de alguns lugares; Caes de atracação; Enrocamento dos dois lados do caes; Dois armazéns de 80 metros de comprimento por 30 de largura com doze guindastes rolantes; Cinco guindastes de pórtico; Linhas férreas. Esse plano é ampliado em relação à extensão do caes, incluindo ainda a abertura de uma avenida de acesso ao porto. Nesse projeto admitia-se "como porto conjugado o de Cabedelo, só para serviço rápido de passageiros, que por si só não exige a construcção de um porto apparelhado, visto ser fácil o respectivo transbordo, mesmo sem taes melhoramentos". In: ALMEIDA, José Américo de., op.cit, p.421 a 424.
} 
na região do Varadouro, a intervenção é suspensa ao constatar-se sua inviabilidade. Por fim adota-se, na administração estadual de Anthenor Navarro (1931-1933), o porto de Cabedelo como porto oficial do estado, cujas condições naturais possibilitam atender às demandas portuárias locais, ainda com possibilidade de realizar obras de ampliações e reformas, fazendo dele, ainda hoje, o porto oficial da capital. São realizadas obras de melhoramentos e ampliação na estrutura existente desse porto que, influenciando na economia local, é reconhecido como um dos principais empreendimentos do momento, solucionando uma questão há muitos anos discussão, sem uma solução efetiva.

"Esse grande emprehendimento, que se deve à decidida orientação do sr. Anthenor Navarro, constitue o maior passo do seu governo para a liberação econômica do Estado, jungido, por cirrcunstancias varias, aos Estados vizinhos, por onde escoa grande parte de suas riquezas" ${ }^{\prime 337}$.

Adotado o porto de Cabedelo como porto oficial, o passo seguinte é ligá-lo à capital. Por ter sido sempre este o porto de mar do estado, são recorrentes as manifestações a respeito da necessidade de uma estrada de rodagem que o ligue à capital. Segundo Anthenor Navarro, essa intervenção viária, unindo a cidade de João Pessoa à Cabedelo, é uma obra complementar à construção do porto ${ }^{338}$.

Além da questão portuária, as preocupações com a estrutura urbana existente também impulsionam o debate sobre a necessidade de ordenar o crescimento da cidade. Esta questão se encontra recorrentemente mencionada não apenas pelos representantes da administração mas também por jornalistas, literatos, médicos e demais cidadãos. A ordenação da expansão da cidade recebe grande ênfase na década de 1930:

"Entre nós urgia a acção civilizadora da urbanização. De algum tempo a esta parte eram sensíveis as tendencias expansionistas da cidade de João Pessoa, mas os seus anceios, neste sentido, se exerciam sem ordem, sem disciplina, sem continuidade. A cidade crescia ás tontas, desorientadamente"339.

O recorrente discurso atrelando modernização e urbanização se vincula à idéia de expansão urbana, que passa de reivindicações e rumores a metas administrativas, divulgadas nos veículos de informação. Há uma difusão, nos meios de comunicação locais, de questões a respeito da disciplina do urbanismo e das experiências de intervenção urbana desenvolvidas em outras cidades.

\begin{abstract}
"O urbanismo moderno tem uma accentuada tendência para a systematização das cidades, cujo aspecto mais interessante é o zoneamento que consiste na divisão racional da dessas agglomerações sociaes em zonas apropriadas á vida e aos misteres da sua população. Toda a cidade fica dividida em areas, como sejam: centros residenciaes, centros commerciaes, centros industriaes, centros operativos, centros administrativos. (...) entre si,os diversos centros se articulam por faceis vias de comunicação, havendo algumas que, por força de sua interdependência, devem se aproximar tanto quanto possível" 340 .
\end{abstract}

Esse artigo, publicado em jornal local, mostra que os diversos profissionais que se ocupam da cidade não divulgam apenas suas críticas à configuração urbana de então. Além de descrever a estrutura que forma a cidade naquele momento, apontando suas deficiências para atender às necessidades, mostram a existência de 'soluções' para alteração do quadro que gera insatisfação. São comuns, nesse momento, entre os artigos que apontam peculiaridades dessa cidade, textos explicativos sobre teorias urbanísticas, bem como as experiências de intervenção executadas em diversos locais segundo tais princípios.

\footnotetext{
337 "Porto de Cabedelo". A União, João Pessoa, 12 jan 1932, n. 8, p. 1.

338 PARAíBA. Administrações dos interventores Anthenor Navarro e Gratuliano da Costa Brito. Decreos de $1^{\circ}$ de Janeiro a 30 de julho de 1932 - Actos do Interventor Federal. João Pessoa: imprensa Oficial, 1932. Decreto n.o 261, de 9 de março de 1932 , p18.

339 MAGALHÃES, Josa."“Urbanização de João Pessoa e Cabedelo". A União. João Pessoa, 15 mar 1932, nº 56, p.1.

340 Ibid.
} 
Para proporcionar um crescimento planejado para a capital, como reivindicado e também como já detectado em outras capitais brasileiras, assim como para ligá-la ao porto, o interventor paraibano Anthenor Navarro convida, em 1932, o engenheiro-arquiteto pernambucano radicado no Rio de Janeiro, Nestor de Figueiredo, que naquele momento atua em Recife ${ }^{341}$. Naquela ocasião o chefe do Estado, salienta

"a necessidade de ser organizado um plano de desenvolvimento systematico que discipline a expansão da capital e remodele aquela villa litorânea [de Cabedelo], cujas condições de vida vão assumir notavel importancia com o funccionamento do porto"342.

Nestor de Figueiredo elabora o Plano de Remodelação e Extensão da cidade de João Pessoa, a partir do qual reordena as atividades sobre seu tecido urbano. A cidade é pensada na sua totalidade, diferenciando-se da maioria das intervenções nela executadas anteriormente ${ }^{343}$, quando essa capital passa por alterações pontuais, apesar de intensas, no seu espaço urbano.

O plano elaborado por Nestor de Figueiredo, assim como o Plano Agache para Rio de Janeiro e o Plano de Avenidas de Prestes Maia para São Paulo, norteia e ordena o conjunto das intervenções urbanas. Esse momento da história urbana brasileira é marcado pela compreensão abrangente da cidade, suas atividades e fluxos; um instrumento capaz de gerir o planejamento urbano como um todo ${ }^{344}$. A reestruturação das atividades da capital paraibana, segundo o plano elaborado por Nestor de Figueiredo, é feita através da priorização do sistema viário, a partir do qual as atividades são distribuídas na área proposta para expansão urbana. Da mesma forma ocorre no Plano de Avenidas, publicado em 1930, onde Prestes Maia deixa clara a preocupação viária, sobretudo em relação ao trânsito e aos transportes públicos, mas também inclui outros aspectos como legislação do uso do solo e de áreas verdes.

Nsse momento, em algumas cidades brasileiras, os transportes urbanos assumem a posição fundamental. A questão viária substitui o "binômio saneamento embelezamento"345 que guia o urbanismo do período anterior. "Tanto os planos quanto as realizações foram orientados no sentido de dar uma estrutura de transportes moderna para a cidade, capaz de viabilizar sua contínua expansão"346, como ocorre em São Paulo entre meados das décadas de 1920 e 1940.

\subsubsection{A trama urbana e o Plano de Extensão}

"João Pessôa é uma das poucas cidades que possuímos com um pittoresco tão accentuado dentro de seu conjuncto regional inconfundivel. Ella tem recursos naturaes para ser mais linda. O mar, o rio, a planicie e a montanha, juntaram-se, pedindo a mão do homem para harmonizal-a. (...) Faltava, porém, o plano coordenador que unificasse o rythmo e realizasse a obra de conjunto que deve ser o plano de uma cidade" ${ }^{347}$.

\footnotetext{
$\overline{3^{411}}$ Nestor de Figueiredo trabalha, naquele momento, no Plano de Remodelação do Bairro de Santo Antônio e no Plano de Remodelação e Extensão da Cidade do Recife, ambos apresentados em 1932.

342 “Urbanização de João Pessoa e Cabedelo" A União. João Pessoa, 10 mar 1932, n. 56, p. 1.

${ }^{343}$ Nos anos 10 e 20, a cidade passa por alterações no seu meio urbano, as quais se tornam, gradativamente, mais intensas. A profusão de demolições, ruas abertas, alinhadas, alargadas, criação de praças, etc, de forma geral não faz parte de um plano urbanístico, mas de uma intenção administrativa de alteração geral da trama urbana, que é feito por partes, sem um estudo que as una. A exceção dessa atuação é o plano elaborado por Saturnino de Brito em 1913 e implantado entre 1924 e 1926. Executado em meio a muitas ações pontuais, esse plano é mais direcionado ao sistema de saneamento, além de não pensar uma grande área de expansão, como o fez Nestor de Figueiredo. Assim, a proposta deste urbanista é aqui abordada como pioneira nessa visão global da cidade e de sua extensão futura.

${ }^{344}$ LEME, Maria Cristina da Silva (org.). Urbanismo no Brasil - 1895-1965. Salvador: Edufba, 2005, p.20 - 38.

345 OSELLO, Marcos Antônio. "Planejamento urbano em São Paulo: 1899-1961. Revista Projeto. n. 87 ano 1986. p. 81.

346 Ibid.

347 “O Plano de desenvolvimento sustematico desta capital e da villa de Cabedelo”. A União. João Pessoa, 4 fev 1932, n. 27 , p. 3.
} 
A idéia de instituir uma nova ordem às cidades, direcionando seu crescimento, ganha crescente espaço entre os urbanistas do século XX. Nas décadas de 1920 e 1930 as referências urbanísticas européias ainda prevalecem entre os urbanistas paulistanos. Porém, Anhaia Mello é um dos principais profissionais que defendie a adesão ao urbanismo americano, onde se destaca a organização de governo aos instrumentos e planos. É incentivada a elaboração de planos, cuja principal referência é o Regional Plan of New York and its Envirom, de 1920. As idéias nele contidas difundidas por Anhaia Melo ao longo de trinta anos, apresentando-se posteriormente em sua proposta "O Plano Regional de São Paulo - uma contribuição da universidade para o estudo de Um Código de Ocupação Lícita do Solo", apresentada em 1954. Assim, a década de 1930 pode ser considerada um momento importante de difusão do urbanismo americano entre profissionais brasileiros. Essa referências é visível nos textos de profissionais brasileiros, influenciando também os planos e a formação profissional de urbanistas.

Nesse momento, outros centros urbanos, como Rio de Janeiro, Recife e São Paulo passam por reformulações de grandes dimensões. O caso de São Paulo tem como um dos focos o Plano de Avenidas, elaborado por Prestes Maia e publicado em 1930. Esse plano é responsável pela abertura e alargamento de avenidas para promover a "ampliação do centro e a ligação com bairros dele distantes, ocasionando a demolição de um grande número de construções e a escalada dos preços dos terrenos em seu entorno"348.

Delimitar áreas para usos específicos e estudar a forma de interligá-las torna-se algo cada vez mais recorrente, contribuindo, principalmente nos anos trinta, para a prática e divulgação do zoneamento, que tem na figura de Anhaia Melo um grande difusor. Acompanhando essa questão a nível internacional, principalmente quando se trata dos Estados Unidos, ele a divulga em São Paulo, através de seus estudos urbanísticos, já nos anos 20, colocando-a em prática nos anos 30, através da implantação de leis de zoneamento. Segundo ele, o zoneamento busca evitar o caos na Metrópole, promove a garantia da propriedade, evita densidades incovenientes e promove o trânsito fluido e descongestionado.

\begin{abstract}
"Nada mais detestável sob todos os pontos de vista, do que, numa avenida de palacetes senhoriaes, bombas de gazolina e engraxatadores de automóveis; as esquinas, que são, justamente os pontos de melhor perspectiva, manchadas de armazens, vendas e emporios; garagens alternando com escolas; fabricas e officinas entremettidas com residencias e mais disparates" ${ }^{139}$.
\end{abstract}

Grande conhecedor do urbanismo americano, Anhaia Melo admira a experiência americana de envolvimento da população civil na ordenação da cidade, considerando o urbanismo uma questão de educação. Nesse sentido, defende a idéia que as leis e os planos devem ter o apoio do poder público e da população. Sua intenção é conter o crescimento da cidade, utilizando-se, inclusive, do cinturão verde como elemento de contenção, pois ao seu ver, o crescimento indefinido da cidade é patológico, gerando sua decadência.

Prestes Maia tem outra postura diante do crescimento da cidade: “... defende o esgotamento das potencialidades ainda não exploradas da metrópole e a remoção dos problemas por meio de novas obras e novos planos" ${ }^{350}$, ou seja, promover um ajuste permanente e contínuo da metrópole às novas exigências da sociedade. Para ele, não se deve evitar o crescimento das cidades, mas possibilitá-lo através da implantação de uma infra-estrutura adequada. Assim, entende que reformas, cirurgias e remodelações de serviços são inerentes ao processo de crescimento ordenado da cidade. No Plano de Avenidas, introduz a questão do zoneamento, sugerindo áreas de maiores possibilidades de verticalização e de instalação de atividades específicas.

${ }^{348}$ FELDMAN, Sarah. Planejamento e Zoneamento. São Paulo: 1947-1972. São Paulo: Editora da Universidade de São Paulo/Fapesp, 2005, p. 18.

${ }^{349}$ Anhaia Melo, apud FELDMAN, Sarah. Planejamento e Zoneamento. São Paulo: 1947-1972. São Paulo: Editora da Universidade de São Paulo/Fapesp, 2005, p. 32.

${ }^{350}$ FELDMAN, Sarah., op.cit., p. 22. 
Na Paraíba, elaborado por Nestor de Figueiredo em 1932, o plano de Remodelação e Extensão da Cidade João Pessoa, é o primeiro passo nesse sentido. Nele, percebe-se um forte caráter viário e a intenção preliminar de zonear a cidade, em consonância com os trabalhos executados em outras capitais. Nestor de Figueiredo é enfático ao anunciar a importância dessas questões:

“... não se admite nem um nucleo de população superior a dez mil habitantes que não tenha organizado o seu plano de remodelação e desenvolvimento systematico, da mesma forma as cidades actuaes não surgem mais ao acaso, desenvolvendo-se em torno da sinuosa estrada de origem"351.

Na Paraíba, essas questões são difundidas nos jornais locais, a exemplo dos artigos publicados por Josa Magalhães, que esclarece questões sobre o urbanismo, sua natureza e suas formas de atuação nas cidades:

"Sob o duplo aspecto de sciencia e arte, póde ser elle [o urbanismo] considerado. Como sciencia trata da construcção das cidades, discutindo os phenomenos de ordem espiritual, economica, social e política. Como arte se interessa pelo traçado das ruas, a disposição das praças e a physionomia das edificações" ${ }^{\prime 352}$.

A divulgação do pensamento urbanístico nos jornais locais busca legitimá-lo, influenciando a receptividade das intervenções por parte da população, que passa a assimilar os novos ideais em relação à configuração da cidade. Assim, os discursos urbanos, associados às intervenções promovidas pelas administrações, ampliam o campo de atuação dessa disciplina, incluindo novas localidades, a exemplo dessa capital, na ordem do dia da história urbana brasileira, como explicita Nestor de Figueiredo:

"A cidade de João Pessoa e a villa de Cabedello vão incorporar-se ás organizações urbanas universaes e constituirão, com mais algumas cidades do Brasil, a vanguarda do movimento urbanista de nossa patria" ${ }^{53}$.

O Plano de Remodelação e Extensão da cidade de João Pessoa é, de certa forma,legitimado por matérias sobre urbanismo divulgadas nos jornais locais, que reivindicam uma nova postura administrativa em relação à intervenção e ao direcionamento do crescimento dessa cidade. Os discursos são reforçados por críticas à estrutura urbana local, diretamente relacionadas à falta de planejamento.

São vários os críticos locais que apresentam, nos meios de comunicações, uma relação entre o contexto urbano paraibano e as intervenções realizadas em outras partes do país. Nesses discursos, fica explícita a troca de conhecimento de profissionais locais e de outras regiões a respeito das inovações urbanísticas, como se constata nos artigos de Josa Magalhães. Nestor de Figueiredo, em um momento anterior, trabalha com Alfredo Agache, experiência que influencia em seus planos posteriores. Também "entrou na discussão da urbanística moderna recifense ao apresentar um esboço de um plano urbanístico para a cidade no IV Congresso de Arquitetura, realizado no Rio Janeiro em 1930"354. Na passagem pela Paraíba, detém-se a três casos: João Pessoa e Cabedelo, Campina Grande e Brejo das Freiras. Sua atuação é de grande representatividade nas análises urbanísticas desse momento, como apresenta o jornal A União:

"Dr. Nestor de Figueiredo, que é engenheiro architecto laureado pela Escola Nacional de Belas Artes, presidente do Instituto Central de Architectos, da Associação dos Artistas Brasileiros, já ocupou idêntico posto em várias outras comissões nacionaes e internacionaes, nos domínios de sua especialidade, tendo, ultimamente sido convidado para presidir a comissão designada

\footnotetext{
351 "O Plano de Desenvolvimento Systematico desta Capital e da Villa de Cabedello". A União. João Pessoa, 4 fev 1932, n. 27, p.1.

352 MAGALHÃES, Josa."Urbanização de João Pessoa e Cabedelo”A União. João Pessoa, 15 mar 1932 , n 56, p.1.

353 "O Plano de desenvolvimento sustematico desta capital e da villa de Cabedelo", op.cit., p.1.

${ }^{354}$ LEME, Maria Cristina da Silva (org.), Urbanismo no Brasil - 1895-1965. Salvador: Edufba, 2005, p. 401.
} 
pelo nosso conterraneo dr. José Américo de Almeida, ministro da Viação, a fim de estudar a localização e programma para elaboração dos planos do futuro Palácio dos Correios e Telegraphos do Rio de Janeiro. Tem ainda s. s. a laurear-Ihe o nome outras honrosas designações, obtendo medalha de ouro na VI Exposição Pan-Americana de Architectura, Primeiro Premio no concurso para o monumento à Marinha, Grande Prêmio na Exposição Internacional do Centenário, etc. Membro fundador e honorário de diversas associações de Architectura do país e do estrangeiro, o nome do dr. Nestor de Figueiredo está assim ligado ás mais honrosas iniciativas e organizações daquele gênero"355.

Essa forma de apresentar o urbanista no jornal da cidade em que está intervindo, expondo um currículo extenso e "vitorioso", com ampla atuação na área e projeções e nacional e internacional, reflete a intenção de anunciar o momento de prosperidade administrativo e sua sintonia com os acontecimentos urbanísticos de outras localidades. Essa imagem é reforçada pela ênfase dada, nessa mesma matéria, à utilização de um avião da Marinha de Guerra para possibilitar ao urbanista uma visão global da área a ser estudada.

Em relação à capital paraibana, ao apresentar um esboço do plano em duas plantas à Comissão do Plano, no dia 9 de março de 1932, o urbanista deixa claro "não se trata[r] de uma iniciativa de execução immediata" ${ }^{356}$. A intenção é finalizá-lo ao longo de um ano de estudos e combinações, acompanhados de relatórios parciais fornecidos pela Comissão, com sugestões de ajustes e modificações.

A Comissão do Plano da Cidade, segundo Prestes Maia, tem caráter cívico e é "destinada a traduzir as necessidades e aspirações mais geraes da população, propagar a idéa, zelar pela regularidade dos estudos e pela execução do plano"357. Deve ter perfil técnico, com profissionais de vários ramos e um urbanista chefe, que deve coordenar as atividades e introduzir idéias próprias. Seu corpo técnico deve ser dividido em duas secções, consultiva e de serviço, e dispor da colaboração das repartições públicas.

A Comissão do Plano da Cidade de João Pessoa é apresentada à população através do jornal A União no dia 9 de março de 1932. Segundo Fábio Gutemberg, "nela tinham assento todos os grupos e instituições a quem aqueles senhores atribuíam interesse pelo empreendimento"358. É formada pelo governador Antenor Navarro, pelo prefeito Borja Peregrino, o arcebispo, diretores de obra do estado e do município, diretores de saúde, água e esgoto, ensino primário, Escola Normal, Lyceu Paraibano, presidentes da Sociedade de Medicina, do Instituto Histórico e Geográfico da Paraíba, diretores de diversos jornais, representantes do comércio, da indústria e dos proprietários, gerente da Empresa de Tração Luz e Força, o capitão dos portos e um representante das classes operárias. Esse último incluído na Comissão três meses após essa apresentação no jornal.

Durante a sua passagem pela cidade de João Pessoa, Nestor de Figueiredo expõe suas observações a respeito dessa capital e apresenta à população, através do jornal local A União, o plano por ele elaborado. Em seu discurso, o urbanista explicita suas preocupações, declarando que seu trabalho é de natureza "social, hygienica, economica, e esthetica" ${ }^{359}$. O plano apresentado abrange a área existente da cidade de João Pessoa, uma grande área de expansão e a vila de Cabedelo, sendo as maiores e mais enfáticas intervenções as propostas para a área de expansão da capital.

Na intervenção proposta por Figueiredo, a cidade é organizada em duas áreas, "cidade existente" - área urbana já consolidada e objeto de intervenções anteriores, para a qual ele faz indicações para intervenções pontuais - e "cidade futura" - área proposta para expansão do tecido urbano -, esta formada por núcleos de

355 "O Plano de Desenvolvimento Systematico desta Capital e da Villa de Cabedello". A União. João Pessoa, 4 fev 1932, n. 27 , p. 1.

356 “Urbanização de João Pessoa e Cabedelo"'A União. João Pessoa, 10 mar 1932, n. 56, p. 1.

${ }^{357}$ MAIA, Prestes, AZEVEDO, Washington. Relatórios dos Drs. Prestes Maia e Washington Azevedo sobre os trabalhos do Dr. Nestor de Figueiredo. Recife: Prefeitura do Recife e Livraria Imperatriz, p. 4.

${ }^{358}$ SOUSA, Fábio Gutemberg Ramos Bezerra de. Cartografia e Imagens da Cidade: Campina Grande - 1920-1945. Campinas: Universidade Estadual de Campinas, 2001 (Tese de doutorado), p. 248.

359 "O Plano de Desenvolvimento Systematico desta Capital e da Villa de Cabedello". A União. João Pessoa, 4 fev 1932, n. 27, p. 1. Capítulo 4 - A cidade dos anos 30: a construção dos espaços públicos segundo os interesses expansionistas 132 
atividades articuladas pelo sistema viário, estendendo-se até a região praieira.

Um dos primeiros pontos comentados pelo urbanista em relação a esse plano é a respeito da entrada na cidade pela estrada de ferro Great Western que vem do interior, apresentada por ele como de "aspecto defeituoso e pouco attrahente"360. Esse é um dos pontos que denuncia a postura estética do urbanista, que fica evidente em vários outros aspectos dessa mesma proposta. Essa é uma questão comum a muitos planos desse período, a exemplo do plano elaborado por Agache em 1930 para o Rio de Janeiro, denominado de remodelação e embelezamento.

Para alterar a aparência da entrada da capital pela estrada de ferro, Nestor de Figueiredo propõe modificações na área baixa da cidade, próxima ao rio Sanhauá, sugerindo, inclusive, o recuo da estação Great Western. Para essa área, onde se encontram terrenos devolutos, o urbanista apresenta uma grande esplanada e a praça da estação, denominada no plano de Praça de Desembarque, com objetivo de promover "a melhor impressão para as pessoas que chegam aqui pela primeira vez pela via ferrea"361. Em relação aos usos, destina essa área baixa da cidade às atividades da indústria e do comércio: bairro comercial, setorizado em armazéns grossistas na região mais próximo ao rio, e comércio a varejo na parte mais próxima à cidade; mais adiante da estação, reserva para a implantação de estabelecimentos industriais. A parte alta da cidade fica destinada aos núcleos comerciais de bairro e às zonas residenciais, que se estendem em diferentes regiões, inclusive com a indicação de um bairro jardim em Cruz das Armas, região das Trincheiras. Essa disposição segue a ocupação inicial da cidade, onde a parte baixa é destinada às atividades portuárias e comerciais, e a parte alta à habitação, administração e clero.

As indicações de setorização, comentadas pelo urbanista na apresentação do plano, encontram-se em uma planta de zoneamento e são organizadas "a fim de que as atividades de uma não prejudiquem o trabalho da outra" ${ }^{362}$. Ao que se percebe nos artigos publicados na imprensa local, Nestor de Figueiredo descreve sua proposta a partir de um plano preliminar, com várias questões apontadas mas nem todas definidas de forma exata. Um dos pontos que, no momento da entrevista de apresentação do plano, não está detalhado é a planta de zoneamento. O plano apresentado naquela ocasião ainda é um documento preliminar, constando de idéias gerais e da promessa de serem, posteriormente, complementadas de forma mais detalhada.

Também faz parte dessa proposta a ampliação das ligações entre as cidades baixa e alta, criando novas vias que seguem os caminhos de menores inclinações entre as duas cotas. Mas é na parte referente à área de expansão da cidade que o plano propõe maiores intervenções, abrangendo a região a partir do Parque Solon de Lucena em direção à praia. Dele, segundo o plano, partem avenidas arborizadas com áreas diferenciadas para os tráfegos de veículos, pedestres e equitação, em concordância com a praça Vidal de Negreiros, que por sua vez se liga à Lagoa por uma avenida larga, formalizando, nesse conjunto, a união da cidade antiga com a área de expansão, articuladas pela avenida circular que contorna a Lagoa.

A ênfase dada ao sistema viário, atribuindo-lhe a função de ordenar a cidade e conduzir seus usos e ocupações em setores diferenciados, é comum aos planos desse período. Da mesma forma, a hierarquia das vias, destinando-as a usos distintos, é uma característica desse urbanismo moderno. Nesse sentido, a terceira perimetral do plano de Prestes Maia para São Paulo é composta, principalmente, pelas marginais do Tietê e Pinheiros, onde "à margem direita do rio Tietê seria reservada às vias férreas e à esquerda destinada à circulação de luxo com calçamento, arborização e iluminação apropriadas"363. Da mesma forma, a avenida Centenário, construída em 1949, em Salvador, tem

\footnotetext{
360 “Que será de futuro a cidade de João Pessoa”. A União. João Pessoa, 2 out 1932, p.3.

361 Ibid.

362 Ibid.

${ }^{363}$ LEME, Maria Cristina da Silva (org). Urbanismo no Brasil - 1895-1965. Salvador: Edufba, 2005, p.347
} 
"Sua concepção base[ada] nas chamadas parkways e caracteriza-se por ter duas pistas em cada sentido, com canteiro central, onde, no talvegue corre um riacho que coleta as águas pluviais da bacia. Esse eixo central é ladeado por pista de acesso local às edificações residenciais"364.

Ao longo do sistema viário proposto para a capital paraibana, são Indicadas a locação de centros de atividades propostos. Da Lagoa, a avenida-parque se bifurca em direção ao Centro Cívico, que é destinado à administração do Estado, e ao Centro Universitário, ambos propostos pelo urbanista. A área em torno do Parque Sólon de Lucena é destinada ao Centro Municipal, cujos serviços são de contato mais direto com a população. Entre os centros Universitário e Municipal é locado o Bairro de Saúde, próximo à Maternidade e ao Hospital de Isolamento já existentes. No Centro Municipal, onde se dá a bifurcação viária para outros centros, Nestor de Figueiredo prevê a construção de um "Arco do Triumpho do Presidente João Pessoa" ${ }^{365}$, visível tanto a partir da ramificação viária para os centros como na região da praça Vidal de Negreiros. Esse elemento aponta o caráter monumental da proposta do urbanista.

Essa característica também é apresentada pela disposição formal dos centros, integrados às parkways e em evidência no conjunto devido à locação e escala de seus elementos que enfatizam sua importância funcional e sua hierarquia sinalizada pelo nível de destaque no tecido urbano e nas proximidade do parque. Considerando a lagoa o elo entre a área consolidada da cidade e sua região de expansão, nela fica o Centro Municipal, de maior acessibilidade e visibilidade. $O$ direcionamento dos demais centros segue a partir de uma avenida congruente à que liga a praça Vidal de Negreiros ao Parque Solon de Lucena, localizada na região de expansão. Assim, o trajeto entre as duas porções da cidade apresenta uma linearidade articulada e não interrompida pela Lagoa, que possibilita, diante da área urbana ainda de pouca ocupação, uma relação visual dos centros com o parque e com a cidade consolidada, que se encontra em região mais alta que a área de expansão . O Centro Municipal é o foco das perspectivas urbanas, o que valoriza sua visibilidade diante dos demais conjuntos que são organizados segundo uma hierarquia referente às funções que eles abrigam: Centro Municipal, Centro Cívico, Centro Universitário, Centro de Saúde; e na parte antiga da cidade a Praça de Desembarque.

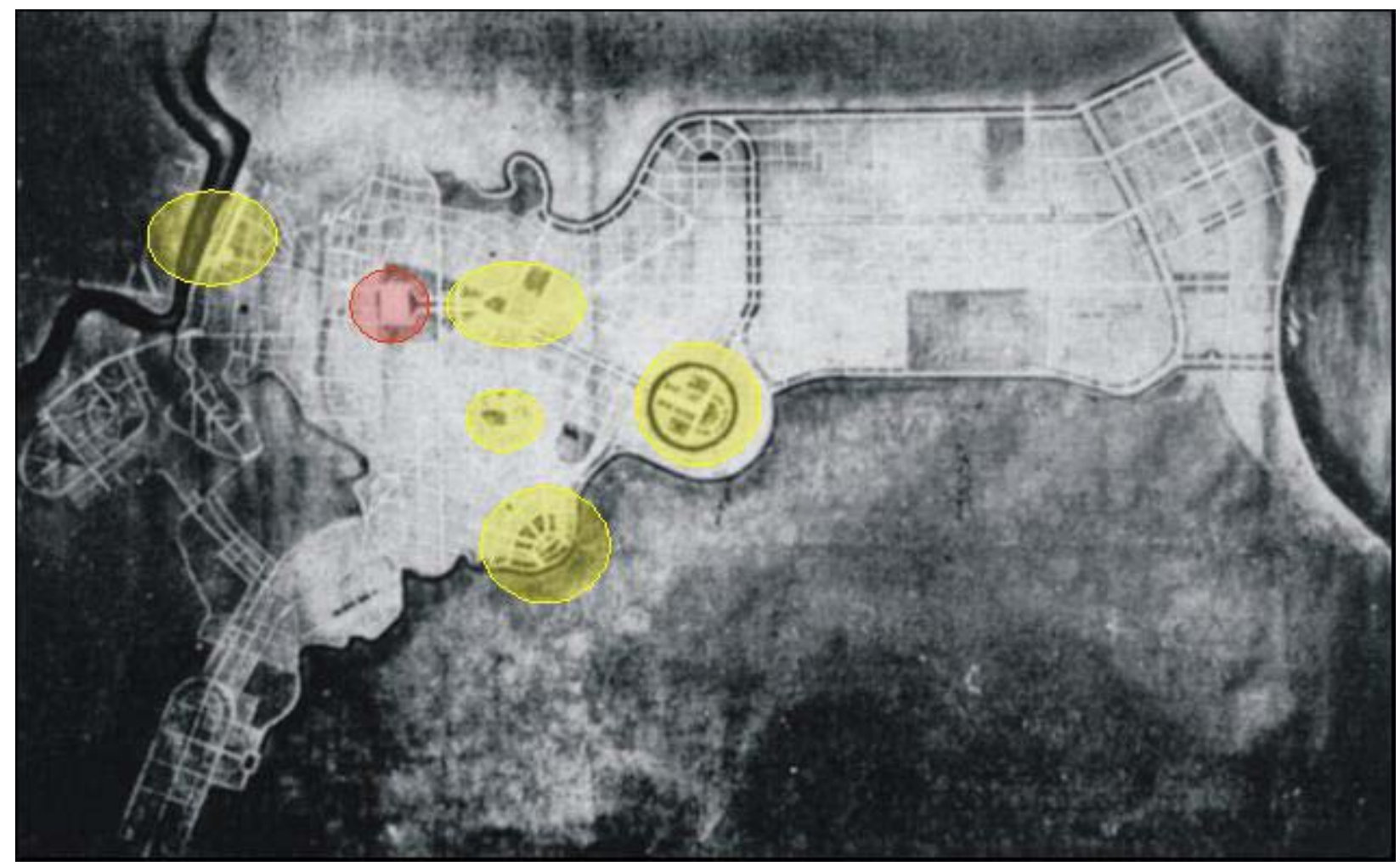

Plano de Remodelação e Extensão da Cidade de João Pessoa. FONTE: Jornal A União (Vermelho - Centro Municipal, amarelo - demais Centros)

364 LEME, Maria Cristina da Silva (org). Urbanismo no Brasil - 1895-1965. Salvador: Edufba, 2005, p. 353.

365 "Que será de futuro a cidade de João Pessoa". A União. João Pessoa, 2 out 1932, p.3. 
A monumentalidade proporcionada por esse tipo de proposta é acentuada pelo arco a ser implantado no Centro Municipal, simbolizando a entrada da cidade futura, bem como pelas edificações específicas de cada centro. Porém, apesar de sugerir elementos e construções de grande visibilidade nessas áreas, a escala viária conduz para si a monumentalidade, ofuscando os elementos arquitetônicos, que não se sobressaem na perspectiva do conjunto, mas apenas nos arredores de cada centro. $\mathrm{O}$ tratamento diferenciado em pontos específicos do tecido urbano, concentrando nos 'centros ideais' equipamentos e uma infra-estrutura diferenciada, prevê uma conseqüente valorização dessa região, principalmente nas proximidades dos centros Cívico e Administrativo. Esse processo, segundo afirma o urbanista ao apresentar o plano, leva a uma ocupação elitizada dos arredores dessa região, com usos e modos de apropriação de seus espaços conduzidos pelas classes que os ocupam.

\section{"Serão esses dois pontos [Centro Cívico e Centro Administrativo] os mais importantes de João Pessoa, em torno dos quaes será desenvolvida a parte residencial de maior valor"366.}

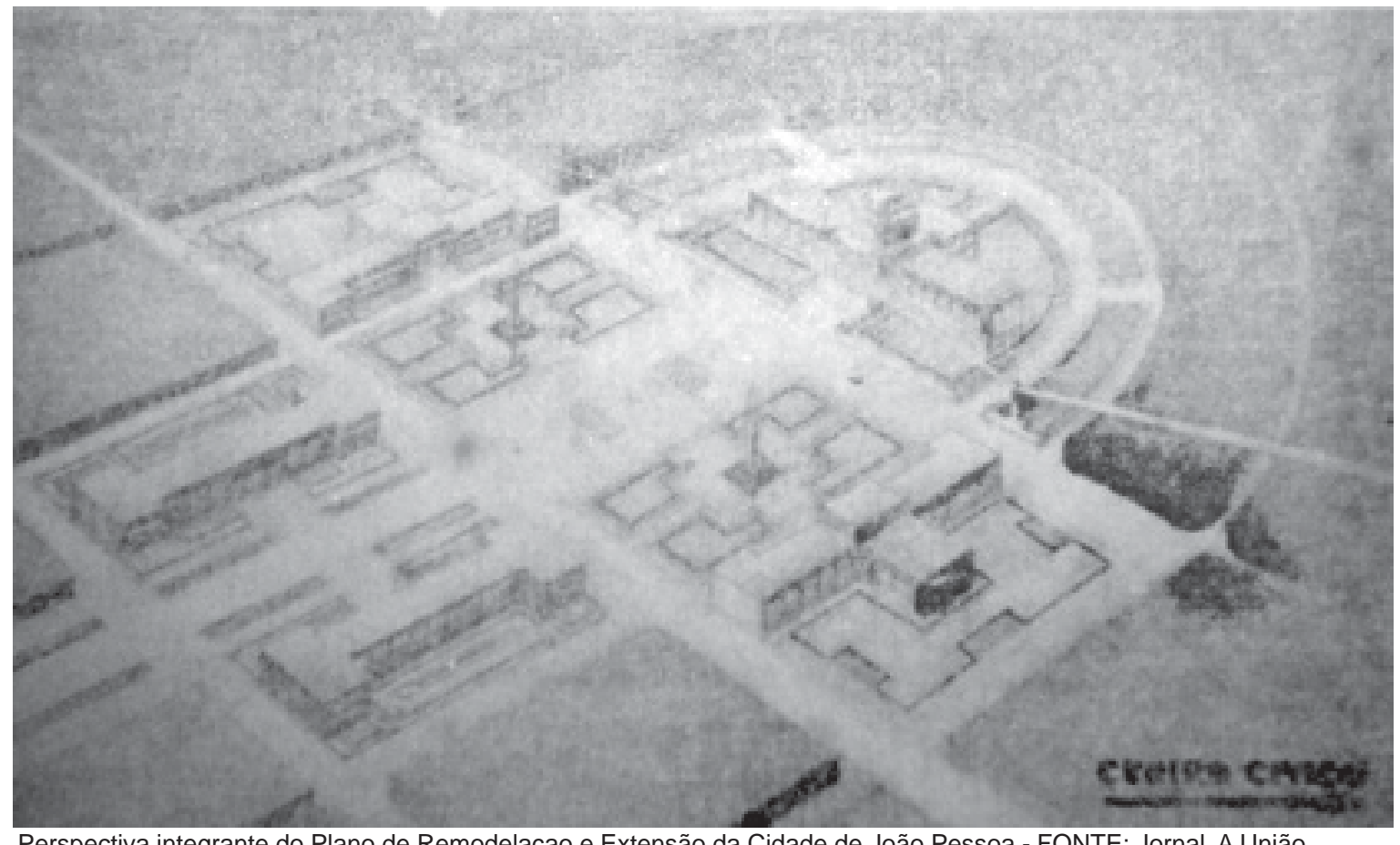

Perspectiva integrante do Plano de Remodelaçao e Extensão da Cidade de João Pessoa - FONTE: Jornal A União

Esses centros, situados em locais até então de baixa ocupação, funcionam como propulsores e direcionadores do crescimento urbano, ordenando a distribuição das principais atividades - portuária, administrativas, de saúde, educação, etc- em áreas específicas do tecido urbano. O plano apresentado naquele momento pelo urbanista não detalha os centros que abrigam essas atividades, detendo-se praticamente a localizá-los e descrevê-los sucintamente, justificando suas existências e ilustrando-os através de perspectivas.

Essa reordenação do crescimento da didade de João Pessoa vincula-se à vila de Cabedelo tanto economicamente, pela questão portuária, quanto fisicamente, pelo direcionamento do crescimento urbano para a praia ${ }^{367}$. A comunicação da capital com o porto de Cabedelo era feita, naquele momento, pelas estradas de ferro e de rodagem, as quais são criticadas pelo urbanista, que propõe alterações nesses dois sistemas. O transporte ferroviário local é considerado por Nestor de Figueiredo insuficiente para as necessidades comerciais da capital, e o trajeto oferecido pela rodagem para ligar essas duas cidades exige, naquela época, a travessia do centro da capital para alcançar a avenida de Tambaú, acesso à vila de Cabedelo. O Plano de Remodelação

366 "Que será de futuro a cidade de João Pessoa". A União. João Pessoa, 2 out 1932, p.3.

$367 \mathrm{O}$ crescimento da cidade para a praia de forma mais imediata se deu para a região de Tambaú e Cabo Branco (litoral sul), mas posteriormente a expansão em direção à Cabedelo (litoral norte) foi intensa, ocupando áreas bem maiores que o processo anterior. Capítulo 4 - A cidade dos anos 30: a construção dos espaços públicos segundo os interesses expansionistas 135 
e Extensão propõe uma outra ligação rodoviária da capital à Cabedelo através da criação de uma avenidaparque perimetral que limita a extensão urbana sobre os vales do Jaguaribe e Sanhauá e, vinculada à avenida Mira-Mar, possibilita os veículos de carga contornarem a cidade de João Pessoa, evitando passar pelo seu centro. Essa via circunda toda a capital pelo vale do Jaguaribe, onde encontra a avenida Mira-Mar, num percurso que o urbanista considera "linha de maxima expansão prevista no espaço de uma geração"368.

Essa avenida-parque perimetral corta a cidade no sentido transversal, delimitando duas zonas residenciais distintas: a principal, sujeita ao Código de Posturas, e a secundária, que acompanha a avenida Epitácio Pessoa até Jaguaribe e é regida por legislação suave por ser uma área, naquele momento, quase rural. $A$ proposta é menos detalhista em relação às questões residenciais que às áreas públicas. O setor habitacional é tratado de forma tangencial, com apenas indicações do uso residencial, mas sem apontar áreas específicas, bairros ou estimativas populacionais. As áreas destiandas para esse fim são as das proximidades do Parque Solon de Lucena, onde, em feveriro de 1932, já edifica-se o conjunto residencial Montepio, como mostra o jornal A União:

\begin{abstract}
"O Montepio dos Funccionarios Publicos estaduaes vae iniciar por estes dias a construcção de casas para os seus constribuintes, prehenchendo assim mais uma das suas finalidades. Possuindo optimos terrenos, nas proximidades do Parque Solon de Lucena, restava encarar o problema da construcção dos predios. Essa face em questão acaba de ser resolvida com a assignatura do contracto para a edificação de dez casas, celebrado entre a directoria do Montepio e o engenheiro Giovani Goia. (...) O lote de casa cuja construcção vae ser iniciada compõe-se de dez predios dos typos A,B, C e F"369.
\end{abstract}

De certa forma, a questão residencial assume um papel secundário na proposta de expansão e zoneamento, podendo-se ainda apontar uma postura contraditória em relação ao ideal de planejar as áreas a serem ocupadas, pois justamente para a área destinada à expansão é indicada uma forma mais livre de apropriação, regida por legislações mais flexíveis, o que possibilita uma formação menos controlada da cidade futura. Essa postura não condiz com os interesses patentes nos discursos daquele momento, que pretendem conduzir o crescimento da cidade e instituir-Ihe uma nova ordem, principalmente por ser a área de expansão, regida por uma legislação mais flexível, também, contraditoriamente, a que concentra o maior número de propostas do urbanista, da "cidade futura" almejada. Nestor de Figueiredo não propõe grandes alterações na zona residencial em formação, o que ele justifica pela busca de dispêndio mínimo, além da intenção de respeitar a cidade existente, segundo ele "intelligentemente construída" ${ }^{370}$. Apesar de não se constituir um ponto relevante desse plano, a questão habitacional recebe importante destaque no Brasil.

A questão da habitação social no Brasil passa por um intenso processo de reflexão e produção a partir da década de 1930, "influenciado pelo debate internacional e pelas realizações da social-democracia européia no período entre guerras, cujos pressupostos foram explicitados nos CIAMs do final dos anos 1920"371. As discussões realizadas nesses congressos, que tratam inclusive da questão habitacional - o $2^{\circ}$ Ciam foi sobre habitação para o nível mínimo de vida e o $3^{\circ}$ tratou das tipologias habitacionais -, e a produção internacional sobre habitação social dos anos vinte são amplamente divulgadas no Brasil através de revistas de arquitetura, a exemplo da arquitetura alemã, com destaque para os Siedlungs, divulgados pela revista Arquitetura e Urbanismo em 1936. Apesar da ampla divulgação e discussão dessas questões no Brasil, segundo Bonduki, a ação habitacional implementada pelo governo nacional reduz o impacto e a abrangência da questão, com

\footnotetext{
368 "Urbanização de João Pessôa e Cabedelo". A União. João Pessoa, 10 mar 1932, no 56, p. 1.

${ }^{369} \mathrm{O}$ Montepio dos Funcionários estaduaes vae iniciar a construcção do primeiro grupo de casas para os seus contribuintes. $A$ União, 7 fev 1932, n. 30, p.1.

370 “Urbanização de João Pessôa e Cabedelo". A União. João Pessoa, 10 mar 1932, n. 56, p.1

${ }^{371}$ BONDUK, Nabil. Origens da habitação social no Brasil. São Paulo: Estação liberdade, 1998, p. 134.
} 
"uma incorporação apenas parcial dos princípios da arquitetura moderna, perdendo-se os generosos e desafiadores horizontes sociais, onde o resultado econômico não devia se desligar da busca de qualidade arquitetônica e urbanística, e da renovação do modo de morar, com a valorização do espaço público"372.

Os novos ideais que envolvem a questão da moradia se refletem nas formas dos espaços públicos, sobretudo pela influência das tipologias preferencialmente adotadas. Nesse momento, a então conservadora idéia da casa própria é criticada, postulando-se a locação como principal forma de acesso às moradias em conjuntos habitacionais. Prevalece entre arquitetos modernistas a opção por blocos de edifícios coletivos, com equipamentos sociais e comunitários.

Uma das frentes de atuação brasileira em relação ao problema habitacional do período são os conjuntos construídos pelos Institutos de Aposentadorias e Pensões (I. A. P.s), que apesar de apresentarem uma produção qualitativamente desigual, têm exemplos que revelam inovações importantes nos projetos arquitetônicos e na implantação.

O governo de Getúlio Vargas envolve-se com a questão da moradia, abordando-a como um dos serviços que pretende oferecer ao trabalhador. O presidente trata do tema em seus discursos o tema da habitação, ressaltando as vantagens das tipologias arquitetônicas e dos métodos construtivos. No entanto, "a produção habitacional no período populista não chegou a se destacar enquanto ação social, como aparentemente pretendia o ditador"373, principalmente se comparadas às cidades européias governadas pela social-democracia ou às realizações do peronismo na Argentina. Porém, a produção habitacional desse momento no Brasil não é insignificante, com um número considerável de ações pelos I.A.P.s e exemplos exponenciais e participantes da renovação cultura arquitetônica, urbanística e habitacional do país, bem como da consolidação da arquitetura moderna.

Essa questão não se encontra aprofundada em vários planos desse momento, mas é mencionada com mais ênfase por alguns profissionais que por Nestor de Figueirdo. Segundo Leme, no plano Agache essa questão é secundária se comparada à abordagem sanitária, apresentando-se como um dos problemas a serem solucionados, mesmo que como conseqüência do plano e não um ponto específico dele:

"É idéia geral do plano [Agache] que a cidade necessita de várias tipologias habitacionais, sendo que o zoneamento, a construção de habitações populares e uma política territorial bem conduzida irão ajudar a resolver os problemas habitacionais" ${ }^{374}$.

Se no plano para o Rio de Janeiro a forma com que Agache trata esse assunto é considerara secundária, no Plano de Remodelação e Extensão da Cidade João Pessoa, Nestor de Figueiredo a encara de forma ainda mais superficial, sem propostas específicas nem menção da sua relevância. Mesmo sem estar presente no plano que conduz as principais intervenções paraibanas daquele momento, a questão da moradia é adotada pelo governador Argemiro de Figueiredo com mais interesse e ações que as propostas pelo urbanista. Seguindo a política da presidência da República, há a participação da administração do estado da Paraíba na política habitacional, com intensas construções residenciais nos anos trinta. O governador Argemiro de Figueiredo incentiva essas obras através da doação de terrenos e facilidades tributárias, como se percebe nas obras do I.A.P. dos Bancários, em agosto de 1939:

"Empenhado na realização dessa importante medida, o Governo do Estado fará doação de terenos e concederá ao mesmo isenção dos impostos para todas as construções levadas a

\footnotetext{
372 BONDUK, Nabil. Origens da habitação social no Brasil. São Paulo: Estação liberdade, 1998, p. 134..

373 Ibid., p. 136.
}

${ }^{374}$ LEME, Maria Cristina da Silva (org).Urbanismo no Brasil - 1895-1965. Salvador: Edufba, 2005 , p. 364. 
feito pelos I.A.P., visando assim, a solução do magno problema que diz respeito à habitação operária"375.

Essa postura revela a sintonia do administrador local com o Estado Novo, que inaugura "uma fase de atendimento das demandas sociais, com o intuito de diminuir a crescente adesão dos trabalhadores aos apelos dos partido esquerdistas"376.

Outro ponto da proposta de intervenção urbana feita nesse plano para a cidade João Pessoa é a respeito das preocupações em resgatar a presença da natureza no meio urbano. Assim, no plano, parques, avenidasparques e bairros-jardins buscam proporcionar à cidade e aos cidadãos uma vida saudável e bela, dando continuidade às ações aplicadas à cidade na década de 1920, quando o verde é introduzido nas formas urbanas. Porém, nesse segundo momento, essas ações não se apresentam predominantemente em canteiros de jardins, praças e ruas, mas compondo novos elementos urbanos com uma nova escala, através de parques e parkways.

A inserção de grande quantidade de verde na área urbana não é uma inovação desse momento, como se observa nas idéias do movimento cidade-jardim, porém, na elaboração desses planos urbanos, inclusive de forte caráter viário, esse elemento assume outro sentido. Em São Paulo, em 1919 Barry Parker, trabalhando para Companhia City, propõe isolar a área urbanizada de São Paulo através de um cinturão de parques, idéia que inspira Prestes Maia, em 1930, quando elabora um sistema de radiais-prerimetrais no qual o terceiro anel viário é batizado de "circuito de parkways":

"uma orientação americana, moderna e feliz, a de ligar entre si os parques de uma cidade por meio de avenidas amplas que conservem alguns caracteres que lembram os parques, taes como arborização, ajardinamento, casa afastadas"377.

No Plano de Nestor de Figueiredo para a cidade de João Pessoa, o Parque Solon de Lucena assume semelhante papel: não pretende conter o crescimento mas, pelo contrário, implulsiona a expansão urbana ao articular o sistema viário que liga os principais pontos da cidade, como as praças Vidal de Negreiros e da Independência.

Da mesma forma, esse urbanista propõe para a capital pernambucana um sistema de parques e jardins, além de um bosque que margea o canal principal, marcando o limite entre o centro expandido e a zona estritamente residencial do Recife. Também em Salvador, na construção da avenida Centenário, é abundante a utilização do verde, onde "a noção de verde-contínuo está presente tanto no canteiro central como nas encostas laterais" 378.

No projeto elaborado por Nestor de Figueiredo para a capital paraibana, algumas vias são indicadas como avenidas-parque, dentre as quais estão a avenida perimetral do Parque Solon de Lucena e a que liga os centros Municipal e Cívico. São propostos alguns bairros-jardins e ainda, nas áreas próximas ao mar, como Tambaú, "cidades balneáreas", enfatizadas no discurso do urbanista pela importância de valorizar, acentuar e preservar as riquezas naturais locais.

"Uma grade avenida-parque perimetral, limitará a extensão da cidade sobre os valles do Jaguaribe e do Sanhauá, defendendo o nosso principal manancial de abastecimento d'agua potavel dos perigos resultantes da aproximação residencial e conservando o bello panorama da vasta planicie que dum lado da cidade se estende até Cabedello"379.

\footnotetext{
375 "A construção de casas nesta capital pelo Instituto de Aposentadoria e Pensões". A União, ago 1939, n. 183, p. 1.

${ }^{376}$ LEME, Maria Cristina da Silva (org). Urbanismo no Brasil - 1895-1965. Salvador: Edufba, 2005, p. 352.

377 Ibid., p. 305.

${ }^{378}$ LEME, Maria Cristina da Silva (org).op. cit., , p. 353.

379 "O que será de futuro a cidade de João Pessoa". A União. João Pessoa, 2 out 1932 , p. 3.
} 
"Todos esses conjuntos residenciais se desenvolverão dentro dos mais modernos principios de cidade jardim, onde o elemento paisagístico predominará"380.

A natureza está presente em vários pontos desse plano, usada geralmente em harmonia com a monumentalidade, sem ofuscar as edificações e destacando o espaço público, sobretudo o sistema viário. É usada de forma a enfatizar esses elementos, principalmente pelo ritmo e padronização a ela aplicada, o que não é mensionado no discurso do urbanista mas pode ser percebido nas ilustrações apresentadas no plano. Para Nestor de Figueiredo, a relação da natureza com a nova cidade que surge a partir da elaboração do plano é tal que, "a cidade de João Pessôa não dev[ia] perder a personalidade do seu lindo pittoresco", mas isso "não de[ia] perturbar as grandes composições de massa edificada que a sua evolução futura exigirá" ${ }^{381}$.

Indica a construção de bairros-jardins, além da inserção do verde no meio urbano. Defende a valorização da natureza urbana e ressalta a importância de incluir parques e jardins em seu plano, mas não designa os locais para tais implantações nem menciona as praças, jardins e parques existentes e suas formas de integração com a área de expansão indicada. Assim, ao mesmo tempo em que aponta essas propostas ao comentar a elaboração do plano, não as aprofunda no documento.

Além de ligar a capital à cidade de Cabedelo, o plano se detém a ordenação também desta cidade, indicando áreas para os usos residencial, comércio varejista, comércio atacadista e bairro industrial. Para Nestor de Figueiredo, "Cabedelo é um dos casos mais urgentes de urbanização immediata"382, pois as obras do porto despertam a população para o valor econômico da cidade no futuro, aumentando o número de construções e, "de subito, a villa se viu na iminencia de um grave perigo de se desenvolver desordenadamente" Para evitar essa situação, a intenção do urbanista é englobar a vila como parte do projeto de remodelação da capital. Ao apresentar o plano, comenta as linhas gerais que guiem o crescimento da cidade de Cabedelo e suas zonas de usos específicos, que se apresentam, de certa forma, flexíveis, sobretudo em relação ao uso residencial384.

\section{“... projectaremos [para Cabedelo] uma cidade moderna, ligando o ancoradouro ao futuro bairro industrial e à zona commercial em connexão com esses dois centros, e a zona residencial, que se desenvolverá naturalmente acompanhando a orla do mar" 385 .}

O plano de Nestor de Figueiredo para a cidade de João Pessoa tem como peça chave o Parque Solon de Lucena, responsável pela articulação da cidade existente com a área indicada para expansão. Desta forma, essa proposta delega grande importância e simbologia a esse espaço, assim como ocorre no plano elaborado por Saturnino de Brito para essa cidade duas décadas antes. Apesar de ambos adotarem o mesmo elemento como principal, as duas propostas abordam o parque de formas distintas.

$\mathrm{Na}$ intervenção apresentada por Figueiredo, o Parque Solon de Lucena articula as duas partes da cidade por ele designadas: a cidade existente e a cidade futura. O urbanista toma o parque como fechamento da cidade existente e "porta de entrada da cidade do futuro" ${ }^{386}$, como ele mesmo expressa. O parque Solon de Lucena, a parkway que o circunda, as edificações locadas em seus arredores e o portal proposto pelo urbanista também expressam a monumentalidade característica de sua proposta. Já o plano elaborado por Saturnino de Brito toma esse mesmo espaço como centro e símbolo urbanístico do sistema de saneamento da cidade, que aborda questões de infra-estrutura para viabilizar o crescimento ordenado e 'saudável' da cidade, detendo-se

380 "O que será de futuro a cidade de João Pessoa". A União. João Pessoa, 2 out 1932 , p. 2.

381 "O Plano de Desenvolvimento Systematico desta Capital e da Villa de Cabedello". A União. João Pessoa, 4 fev 1932, n. 27 , p. 1.

${ }^{382} \mathrm{Ibid}$.

${ }^{383} \mathrm{Ibid}$.

${ }^{384} \mathrm{Na}$ pesquisa documental não foi encontrado um projeto detalhado dessa proposta.

385 "O Plano de Desenvolvimento Systematico desta Capital e da Villa de Cabedello". A União. João Pessoa, 4 fev 1932, no 27, p. 1.

${ }^{386}$ AS OBRAS de embelezamento da Capital. A União, N. 93, P.01-02, 28 br. 1938, ano XLVL, p. 1. 
principalmente aos serviços de água e esgoto. O foco da obra de Brito é prover a cidade de uma infra-estrutura fundamental para seu desenvolvimento, apesar de não apontar grandes áreas para o crescimento urbano. Já a proposta de Nestor de Figueiredo, numa postura de certa forma oposta, indica uma ampla expansão para a capital, sem explicitar a forma promover uma infra-estrutura básica essas áreas.

Apesar da significativa extensão das áreas novas propostas por Figueiredo, os problemas urbanos latentes nos anos trinta, como o descompasso entre o crescimento urbano e o suprimento da infra-estrutura básica, não são por ele explicitados. A capacidade de atendimento dos serviços de água e esgoto existentes no momento de elaboração do plano e as demais questões relativas à infra-estrutura, transporte ou habitação popular não são consideradas no plano ou mencionadas em entrevistas à época da sua elaboração. Dessas questões, apenas é sugerida a implantação de um bairro operário, porém em local já dotado de uma predisposição para esse tipo de uso, e de bairros-jardins cujas localizações não são especificadas.

O plano de Nestor de Figueiredo não é de pronto posto em prática, mas executado apenas no Governo de Argemiro de Figueiredo (1935-1940), governante que "pôz aos hombros a penosa tarefa de mudar o aspecto da nossa terra, realizando então a obra formidável que ahi temos aos nossos olhos"387. Vinculada à execução do plano, dá-se a integração da área da Lagoa à dinâmica da cidade e à utilização pública, transformando-a, de fato, em um parque urbano. Essa é uma administração de feitos exaustivos e quase ininterruptos, favorecida pela economia paraibana nos anos de 1934 e 1935, quando se acentua o processo de "modernização" da imagem da capital paraibana, concretizada em novos edifícios públicos, na infra-estrutura, nos serviços de transporte, iluminação e telefonia e no sistema viário.

A ação modernizadora promovida pelo Estado se dá por um conjunto de trabalhos desenvolvidos por órgão técnicos, dos quais a Diretoria de Viação e Obras Públicas (D.V.O.P.) assume um papel singular devido à abrangência de sua atuação, tanto na construção de símbolos arquitetônicos como em serviços de urbanização, pavimentação e viação urbanas. É a responsável pela execução do plano de Remodelação e Extensão da cidade que, na prática, se contém à área que abrange do Parque Solon de Lucena e ao local em que se ergue o Instituto de Educação, ícones da atuação dessa administração que formam juntas o "coração da cidade futura". Apesar da execução do plano se limitar às imediações do Solon de Lucena, o desenvolvimento posterior da cidade assume, de modo geral, as diretrizes do plano de 1932.

\subsection{A NOVA ARQUITETURA ALTERANDO A FORMA URBANA}

Nos anos trinta, os novos conceitos e necessidades urbanas alteram a forma da cidade, promovendo-lhe uma nova escala que acaba se refletindo na construção dos seus espaços públicos. Essa transformação também ocorre através da arquitetura, que é renovada através dos avanços tecnológicos, da mudança conceitual e da alteração nas necessidades de uso. Na conjuntura urbana apresentada nesse momento, além das questões e discussões que envolvem uma nova arquitetura, produto de um processo há tempos em curso, sua aparência reformulada contribui para a alteração da aparência dos espaços públicos de então.

Em todo o país, a década de 1930 apresenta a consolidação da nova arquitetura, que é marcada pelo incentivo público a essa nova produção. Assim, a inovação formal, viabilizada pela situação tecnológica e dos novos conceitos estéticos e arquitetônicos referentes às suas formas e aos seus usos, encontra-se imbricada ao momento político e econômico do país, caracterizado pelo empenho em construir uma nova imagem 
nacional. A cidade de João Pessoa, não diferente do contexto nacional, também tem na arquitetura desse momento um agente de transformação da aparência dos seus espaços públicos, assim como tem na conjuntura política incentivo e promoção desse processo.

O governo federal se empenha em alterar a estrutura política, econômica e urbana do país, justificada por um discurso 'modernizador'. Simultaneamente, diversos estados passam por reformas na estrutura administrativa. Nesse sentido, destacam-se os órgãos de atuação direta nas obras públicas como a Diretoria de Obras Públicas do Estado de São Paulo, a Diretoria de Engenharia da Prefeitura do Distrito Federal e a Diretoria de Arquitetura e Construção de Pernambuco, essas duas últimas com participação direta, respectivamente, de Affonso Reidy e Luís Nunes. Em João Pessoa, a Repartição de Agricultura e Obras Públicas, a partir de uma reforma administrativa comum nesse momento nos estados brasileiros, é desvinculada da Secretaria de Fazenda, Agricultura e Obras Públicas, tornando-se Diretoria de Viação e Obras Públicas (D.V.O.P.), que adquire autonomia e assume papel fundamental no processo de transformação do espaço urbano dessa capital.

Atingindo o ápice de sua atuação a partir 1935 no governo de Argemiro de Figueiredo, a D.V.O.P. apresenta à cidade uma nova orientação estética, desenvolvendo obras de arquitetura e urbanismo. A aceitação dessa arquitetura inovadora pelo poder público é fortalecida, além do discurso ideológico administrativo, pelo argumento da economia e funcionalidade dessas construções. Realizando a maior parte das obras da capital e promovendo-Ihe novas formas arquitetônicas, a D.V.O.P. torna-se órgão fortalecedor da estrutura política desse governo, que tem na promoção da nova aparência urbana seu elemento principal de legitimação.

\begin{abstract}
"Nenhuma repartição tem mais árduas obrigações a cumprir do que a Diretoria de Viação e Obras Públicas, a cujo cargo está a conservação da vasta rede de estradas de rodagem que corta a Paraíba em todos os sentidos; a construção e a conservação dos prédios públicos; a abertura de novas vias de comunicação e outros serviços que se entrelaçam, contribuindo para o nosso adiantamento e progresso econômico"388.
\end{abstract}

À D.V.O.P. cabe a tarefa de viabilizar todo o processo de renovação urbana, ficando à frente da elaboração dos projetos, do cálculo estrutural e da construção das obras. Quando se trata de edificações, algumas vezes também é responsável pelo seu mobiliário. A atuação dessa Diretoria se dá de acordo com a política inovadora adotada pelo governo, que viabiliza seus ideais graças ao perfil de seus profissionais, dos quais se destacam o arquiteto Clodoaldo Gouveia ${ }^{339}$ e o engenheiro Ítalo Joffly ${ }^{390}$. Das obras executadas pela D.V.O.P. destacam-se os edifícios da Secretaria de Finanças, da Rádio Tabajara, do Instituto de Educação e parte do Plano de Melhoramento e Extensão elaborado por Nestor de Figueiredo.

Apesar das preocupações expansionistas expressas nos discursos urbanísticos desse período e na apresentação do plano elaborado em 1932, as obras de renovação dos espaços públicos, principalmente quando se trata da inclusão de uma nova arquitetura, concentram-se mais nas áreas que, naquele momento, já estão consolidadas. De fato, essas obras alteram, numa proporção até então inédita, a aparência dessa capital. Porém, a intervenção mais externa à 'cidade existente' é na região do Centro Municipal, limite da parte

\footnotetext{
${ }^{388}$ ANNUARIO da Parahyba. João Pessoa: 1935, p.45.

${ }^{389}$ Nascido em Vitória, Espírito Santo, em 1887, Clodoaldo Augusto de Sousa Gouveia estuda na Escola Nacional de Belas Artes, no Rio de Janeiro, formando-se no início da década de 1920, o que possibilita um provável contato com Lúcio Costa, formado pela mesma escola em 1922. Viajava freqüentemente à Paraíba devido a laços familiares, sendo chamado para trabalhar na cidade de João Pessoa por volta de 1922, juntando-se a outros arquitetos envolvidos na transformação urbana em andamento. Atua inicialmente na prefeitura da capital e na prática privada, ingressando no início da década de 1930 na D.V.O.P. Falece em 1948 , vítima de um ataque cardíaco.

${ }^{390}$ Formado na Escola Politécnica do Rio de Janeiro entre o fim dos anos 20 e o início dos anos 30, chega à Paraíba na administração de Antenor Navarro. "Amigo de engenheiros e arquitetos que estiveram intimamente relacionados à implantação da arquitetura moderna no Brasil, como Oscar Niemeyer e Joaquim Cardoso, Joffily era consciente tanto das novas técnicas construtivas como da ideologia e da estética do movimento moderno". (TRAJANO Filho, Francisco Sales. Vanguarda e esquecimento:a arquitetura de Clodoaldo Gouveia. João Pessoa: UFPB, 1999 - Trabalho Final de Graduação)
} 
consolidada do tecido urbano com a 'cidade futura'.

Não implantar os edifícios representativos desse momento nas novas áreas planejadas, vinculandoos com o ideal de expansão da cidade, não significa que sua inserção no tecido urbano é aleatória. De fato, alinhado com o pensamento administrativo de usar a arquitetura para valorização da aparência urbana e, conseqüentemente, para a promoção da idéia de eficiência administrativa, a introdução dessa nova arquitetura pretende articulá-la ao espaço público, realçando as regiões de maior importância da cidade consolidada.

A arquitetura produzida na capital paraibana em meados dos anos vinte já apresenta transformações referentes aos novos conceitos estéticos, às novas possibilidades tecnológicas e à adaptação do programa das edificações às novas necessidades e hábitos. Porém, o marco da produção arquitetônica paraibana alinhada com os princípios da produção de vanguarda européia, conhecida como estilo internacional, é representado pelo prédio da Secretaria de Finanças. Obra produzida através da D.V.O.P. pelos arquiteto Clodoaldo Gouveia e o engenheiro Ítalo Joffily, projetada nos anos de 1932 e 1933, é edificada no fim do governo de Antenor Navarro e concluída na administração de Argemiro de Figueiredo, quando é apresentada nos jornais locais como a primeira edificação moderna do estado, simbolizando uma inovação não só urbana, mas econômica e administrativa.

Geralmente, a viabilidade dessa produção arquitetônica, sua divulgação e promoção são realizadas, sobretudo, pelo poder público, tanto a nível nacional como estadual. Essa questão não pode ser reduzida a uma imitação do ocorrido na capital nacional para as outras cidades, pois, em muitos casos, as realizações dessa natureza correm de forma praticamente simultânea. Se em 1936 é construído o prédio do Ministério de Educação e Saúde, considerado o marco da arquitetura moderna no Brasil, um ano antes, em 1935, é inaugurado o prédio da Secretaria de Finanças em João Pessoa, com o mesmo significado apresentados localmente.

A relação do poder público com a produção da nova arquitetura reforça o interesse em renovar a aparência urbana, refletindo também a modernização em outros aspectos, como a política e a economia. Assim, a arquitetura moderna, produzida na Paraíba basicamente através da construção de prédios públicos, é locada em pontos da cidade de João Pessoa que tornam mais evidentes a renovação formal dos espaços públicos. $O$ interesse em vincular a alteração das áreas urbanas à imagem do governo impulsiona a produção e divulgação da arquitetura moderna, através de obras públicas em várias cidades do país.

Com a difusão da arquitetura moderna através da nova política administrativa, há também uma gradativa transformação do repertório arquitetônico das edificações privadas, que se alinha com os princípios dessa nova arquitetura. Os novos bairros construídos naquele momento se formam através de edificações, que muitas, vezes incorporam elementos da arquitetura moderna.

Localizado no bairro do Varadouro, região consolidada da cidade e de importância urbana, nas proximidades da rua Marciel Pinheiro que é ponto de referência comercial, ao prédio da Secretaria de Finanças é reservado um terreno triangular formado pelas ruas Cardoso Vieira e Gama e Melo. A implantação enfatiza a visibilidade da edificação que, por se tratar de uma arquitetura inovadora, já se constitui um destaque. Com projeto elaborado no mesmo ano da concepção do plano de Remodelação e Extensão da cidade, essa edificação, além das questões formais e construtivas que a vinculam à arquitetura moderna, insere-se no plano administrativo que busca complementar o pensamento de Nestor de Figueiredo. Se o urbanista reserva às áreas de expansão as mais intensas transformações formais na cidade, por outro lado, a administração pública insere no meio urbano já consolidado uma arquitetura que modifica essa região, inserindo-a também no processo de renovação em curso. 
A arquitetura da Secretaria é inovadora. Seu terreno a expõe à rua e sua implantação nos limites do lote fortalece essa relação de proximidade com o espaço público. O sentido de renovação urbana inerente a essa intervenção é acentuado pela demolição de pequenas casas do açougue lá instalado, para dar lugar a uma nova edificação e a um novo uso. $O$ ato de demolir o passado, de alterar a escala daquele espaço urbano e substituir o uso comercial pela implantação de um órgão administrativo acentua a intenção de alterar a aparência local e relacioná-lo ao setor administrativo.

Assim como a construção do prédio da Secretaria de Finanças, as localizações dos edifícios da Rádio Tabajara e do Instituto de Educação, também representativos dessa época, têm o mesmo perfil simbólico: a questão administrativa vinculada à imagem da nova arquitetura, pois os meios de comunicação e o sistema de ensino pertencem à frente estratégica da nova política administrativa.

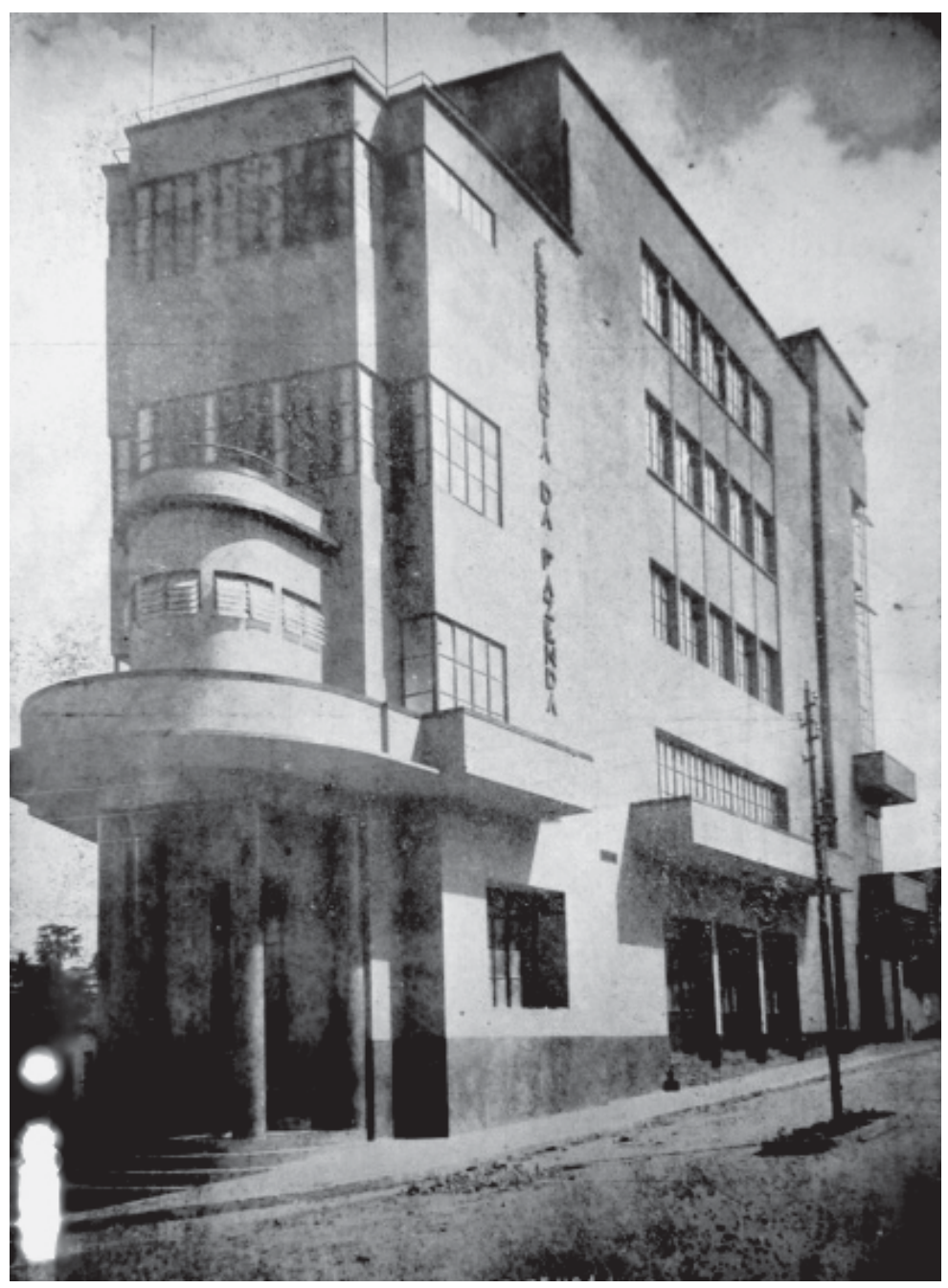

Prédio da Secretaria - FONTE: Livro das Realizações de Argemiro de Figueiredo

Construído o prédio da Secretaria de Finanças como primeiro exemplar da arquitetura moderna na cidade de João Pessoa, há a continuidade desse processo com a produção de outras edificações com características arquitetônicas e funcionais similares. Patrocinadas também pelo poder público, essas construções atendem aos interesses administrativos, pondo em evidência sempre órgão públicos numa política propagandista anunciada pela nova aparência urbana.

Outro empreendimento que marca esse momento da história urbana local é a construção dos prédios da Rádio Tabajara (PRI-4). A administração de Argemiro de Figueiredo, assumindo o mesmo perfil do governo varguista, também delega aos meios de comunicação em massa um papel fundamental na sustentação política e na disseminação da ideologia revolucionária, buscando apoio popular. Assim como Vargas cria o Departamento de Propaganda e Difusão Cultural, depois transformado em Departamento de Imprensa e Propaganda, Argemiro de Figueiredo também organiza sua frente de difusão para a população, implantando, em 1937, o Departamento Oficial de Propaganda e Publicidade, para "dirigir e orientar todas as atividades artísticas oficiais em matéria de propaganda e publicidade"391.

O rádio, apesar de inicialmente ter seu potencial aliciador descoberto pela publicidade em sua destinação comercial, tem, posteriormente, grande utilidade política: "Já no início dos anos 20, o populismo descobrira no 
rádio a sua pedra filosofal, capaz de transformar a massa amorfa de ouvintes na força agregada da paixão política"392. Sua introdução no Brasil se dá no início dos anos vinte, porém com problemas técnicos de transmissão, difusão, qualidade de sinal e programação. Só a partir dos anos trinta, solucionados estes problemas, o Rádio se firma no país.

Nesse momento, quando a difusão da notícia nacional por intermédio do governo através da Rádio Nacional, criada em 1935, é uma importante ferramenta política através da qual se apresenta para todo o Brasil o pronunciamento diário do presidente Getúlio Vargas (em A Hora do Brasil), a instalação de uma emissora oficial na Paraíba reforça a sintonia desse estado com a política nacional:

\section{"Com este vultoso empreendimento a Paraíba vai se colocar definitivamente entre os mais progressistas estados da Federação. A PRI-4 passará a divulgar ao país inteiro o que é o progresso do nosso estado com o ritmo febril de uma vida de realizações magníficas" ${ }^{\prime 393}$.}

Para abrigar a nova emissora, dois edifícios são construídos: um para a estação transmissora e outro para o estúdio, ambos de arquitetura moderna. Nesse período, também são implantados vários edifícios dessa natureza em outras capitais, a exemplo dos de Recife, Rio de Janeiro e Porto Alegre. Porém, apesar de todas essas emissoras participarem da mesma política nacional de divulgação dos ideais administrativos e da difusão de uma imagem ideal de governo e do país, a única em que o edifício segue os padrões da arquitetura moderna é a de João Pessoa.

O edifício da estação transmissora, localizado nas proximidades da Mata do Buraquinho, é construído entre 1935 e 1937 pela D.V.O.P. e projetado pelo arquiteto Clodoaldo Gouveia. As características desse edifício revelam a atuação de Gouveia na linha da arquitetura moderna, contribuindo com o projeto administrativo de renovação a aparência urbana. Da mesma forma, o edifício para abrigar o estúdio da rádio, construído entre 1937 e 1939 pela mesma diretoria, também faz parte da afirmação dessa arquitetura nessa capital. Implantado no terreno de esquina formado pelas ruas Rodrigues de Aquino e Almeida Barreto, assim como ocorre com o prédio da Secretaria de Finanças, o estúdio da Rádio Tabajara se insere nos limites do lote, cujo formato influencia seu partido arquitetônico. A esquina é valorizada pela sua forma e pelo letreiro inserido na fachada, de modo a se vincularem mais diretamente ao espaço público.

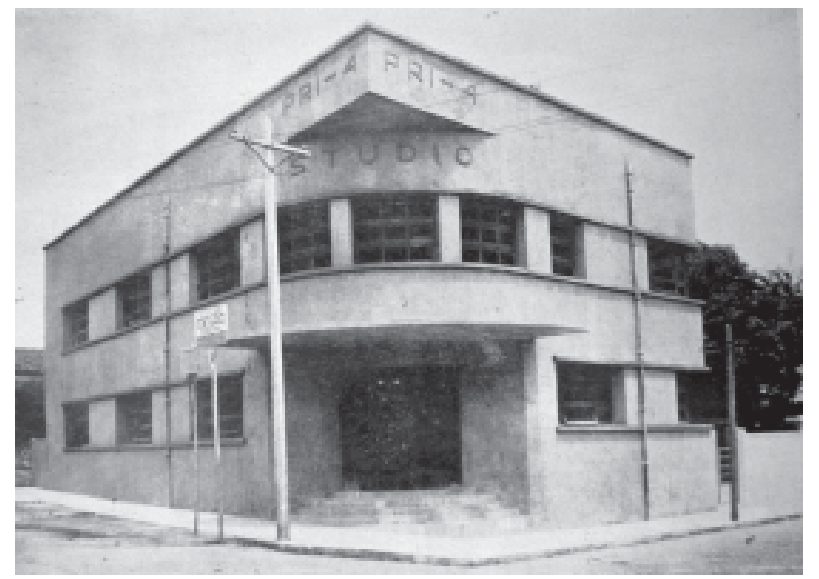

Estúdio da Rádio Tabajara. FONTE: Livro das Realizações de Argemiro de Figueiredo

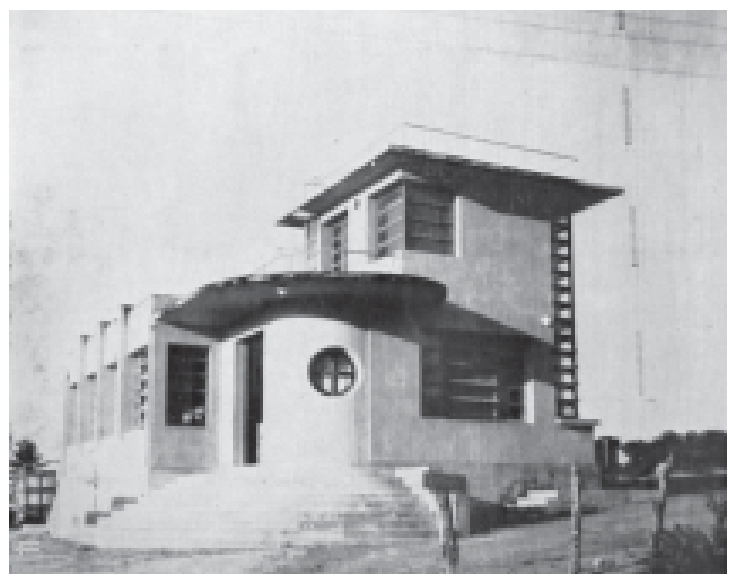

Estação Transmissora Rádio Tabajara. FONTE: Livro das Realizações de Argemiro de Figueiredo

Das edificações produzidas nesse momento, certamente a de maior repercussão e destaque no espaço urbano, tanto pela sua arquitetura como pela sua localização, é o conjunto do Instituto de Educação.

\footnotetext{
${ }^{392}$ SEVCENKO, Nicolau. "A capital irradiante: técnica, ritmos e ritos do Rio". In: SEVCENKO, Nicolau (org.). História da Vida Privada no Brasil, vol. 3, São Paulo: Companhia das Letras, 1998, p.587.

${ }^{393}$ A União 25 jan 1937, p. 2.
} 
Umas das obras de maior representatividade da D.V.O.P., também projeto do arquiteto Clodoaldo Gouveia, esse conjunto faz parte de um plano de ação do governo, que objetiva uma reforma escolar.

Nesse momento, há uma reformulação do sistema de educação nacional promovido pelo Ministério de Educação cujo reflexo imediato no meio urbano é a renovação das edificações escolares, com o objetivo de 'modernizá-las', adequando-as aos novos padrões pedagógicos atuantes no país. A D.V.O.P. constrói, em várias cidades do estado da Paraíba, uma série de escolas cujos resultados formais refletem a fundamentação técnica e teórica desenvolvidas pela Diretoria de Ensino juntamente com a Diretoria de Obras do Estado de São Paulo ${ }^{394}$ e difundidas no país. Esses estudos buscam formalizar normas para projetos escolares, reanalisando os programas e funcionalidade dos mesmos, reajustando questões como conforto ambiental e reestudando os elementos responsáveis pela iluminação e ventilação naturais, bem como os aspectos higiênicos a partir do papel da arquitetura na educação e introdução de novos hábitos.

\begin{abstract}
“... a iniciativa de construir edificações de ensino espelha com maior fidelidade a preocupação que uma sociedade tem em organizar o sistema educacional para os fins conceituados por ela mesma. Todavia, não se trata de saber quantas salas de aula foram construídas. Importa reconhecer a qualidade dessas salas, no que elas podem estar materializando as intenções, os anseios e as perspectivas para as futuras gerações e para seu próprio futuro" ${ }^{395}$.
\end{abstract}

A mais representativa obra desse projeto escolar na Paraíba é o conjunto Instituto de Educação edificado na capital. Formado por cinco edifícios (Edifício Central, Escola de Aplicação, Jardim da Infância, Escola de Puericultura e Estádio), esse complexo educacional é uma iniciativa do governo de Argemiro de Figueiredo, construído pela D.V.O.P. e projetado pelo arquiteto Clodoaldo Gouveia. Apenas o Edifício Central e o Jardim da Infância são concretizados por essa administração. A Escola de Aplicação só é construída em meados da década de 1950, iniciada no governo de José Américo de Almeida e concluída no de Flávio Ribeiro. É ocupada hoje pela Escola Estadual de Primeiro Grau Olívia Olivina.

Esse conjunto de edificações é projetado para um terreno na avenida Getúlio Vargas, uma das parkways sugeridas por Nestor de Figueiredo para a expansão da cidade em direção à orla, executada também pela D.V.O.P. durante o governo de Argemiro de Figueiredo. Dos cinco edifícios, o Edifício Central, a Escola de Aplicação e o Jardim da Infância são agrupadas no mesmo terreno, delimitado pelas avenidas Monteiro da Franca, Tiradentes, Tabajaras, Duarte da Silveira e Getúlio Vargas. As outras edificações são locadas num terreno vizinho ${ }^{396}$.

A localização exata do conjunto é escolhida pelo governador, que vê nesse empreendimento uma das principais obras de sua administração. A importância desse complexo para o governo fica evidente quando, durante a execução do projeto do Parque Solon de Lucena, alguns equipamentos do projeto são excluídos da obra, para que, por não se saber ainda a localização exata do Instituto na avenida Getúlio Vargas, nenhum obstáculo seja erguido no campo de visibilidade entre o Instituto e o Parque. O Instituto é implantado no início da parkway desse parque, de forma a estabelecer uma relação visual com o Parque Solon de Lucena. Assim, o parque e a avenida-parque enfatizam o edifício e virce-versa.

O edifício do Jardim da Infância, com construção iniciada no ano de 1937, e o da Escola de Aplicação,

\footnotetext{
${ }^{394}$ Esses estudos foram realizados no período entre 1934 e 1937, através de um trabalho conjunto da Secretaria de Educação e Saúde com a Secretaria de Viação e Obras Públicas do estado de São Paulo, para a elaboração de um plano para a construção de prédios para grupos escolares. Os estudos foram feitos por professores, pedagogos, médicos, engenheiros e arquitetos, onde foram analisadas as condições das edificações em uso, seus turnos de ocupação, sua lotação, dimensionamento e aproveitamento de suas salas de aula, dimensionamento e posicionamento de janelas, tipos de pisos e revestimentos em geral, compartimentos anexos, insolação dos prédios e estilo arquitetônico. (SEGAWA, Hugo. "Arquiteturas escolares". Revista Projeto. n. 87, 1986, pp. 64-65, p. 65)

${ }^{395}$ SEGAWA, Hugo. "Arquiteturas escolares". Revista Projeto, n. 87, 1986, pp. 64-65, p.64.

${ }^{396}$ As informações obtidas a seu respeito são muito vagas.
} 
construído apenas na década de 1950, são elementos secundários em relação ao Edifício Central, único do conjunto com acesso principal voltado para a avenida Getúlio Vargas. Apesar dos três edifícios serem importantes exemplares da produção da arquitetura moderna nessa capital, o Edifício Central é, além de o maior e o mais suntuoso do conjunto, o que mais se destaca e se relaciona com o espaço público.

Construído entre 1935 e 1939, esse edifício é de grande representatividade simbólica para o governo de Argemiro de Figueiredo e seu plano de alterar a imagem da cidade. Sua inauguração se dá em comemoração ao aniversário do presidente Getúlio Vargas, juntamente com a nova avenida-parque onde o Instituto está inserido e que recebe, nessa ocasião, o nome do presidente da nação. Esses dois empreendimentos que se inter-relacionam representam o dinamismo dessa administração no estado da Paraíba e, principalmente, de sua atuação na capital. Essa edificação também simboliza a reforma educacional promovida pelo governo e os demais edifícios construídos com essa finalidade.

O edifício é pensado em conjunto com sua funcionalidade, prevendo possibilidades de ampliação e baseando-se na inovação formal de acordo com os novos conceitos estéticos do estilo internacional e com uma solução construtiva econômica. Essa renovação conceitual da arquitetura e sua relação com as transformações do ensino brasileiro se refletem a partir do edifício no meio urbano, alterando o espaço público de seu entorno e, conseqüentemente, a aparência da cidade. Nesse sentido, a relação do novo espaço público ali produzido, representado sobretudo pela parkway juntamente com o Parque Solon de Lucena, com a nova arquitetura presente no Instituto de Educação denunciam a renovação da maneira de pensar e construir a cidade.

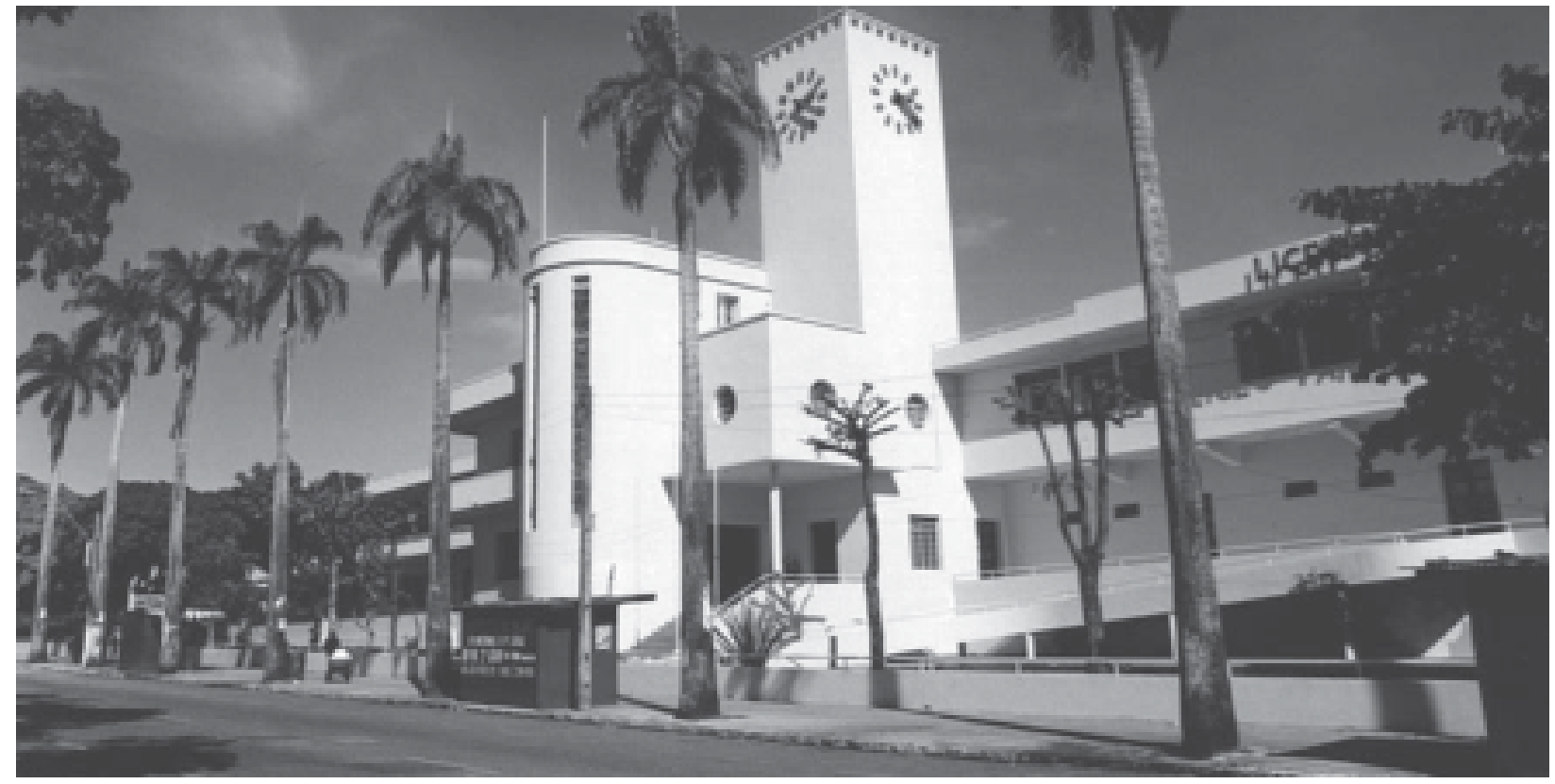

Edifício Central do Instituto de Educação - FONTE: Coleção Humberto Nóbrega

Para o Parque Solon de Lucena converge uma perspectiva de acentuada monumentalidade, composta pelo cenário formado pelo Instituto de Educação e o percurso ascendente da parkway em sua direção, ligando esse conjunto arquitetônico ao Parque. O complexo edificado conforma, em meio ao clima de euforia e orgulho pela imagem urbana em construção, um "conjunto empolgante, digno de uma urbs moderna que tem ansia de embelezar-se, crescer e ter mais intensa vida" ${ }^{397}$. Dos empreendimentos de Argemiro de Figueiredo é, certamente, as obras do Instituto de Educação e do Parque Solon de Lucena, as realizações de maior repercussão.

${ }^{397}$ COM A INALGURAÇÃO de importantes obras e serviços públicos, a Parahyba comemora hoje o $5^{\circ}$ aniversário do Govêrno Argemiro de Figueiredo. A União, $\mathrm{n}^{\circ}$ 19, 25 jan. 1940, p.3. 


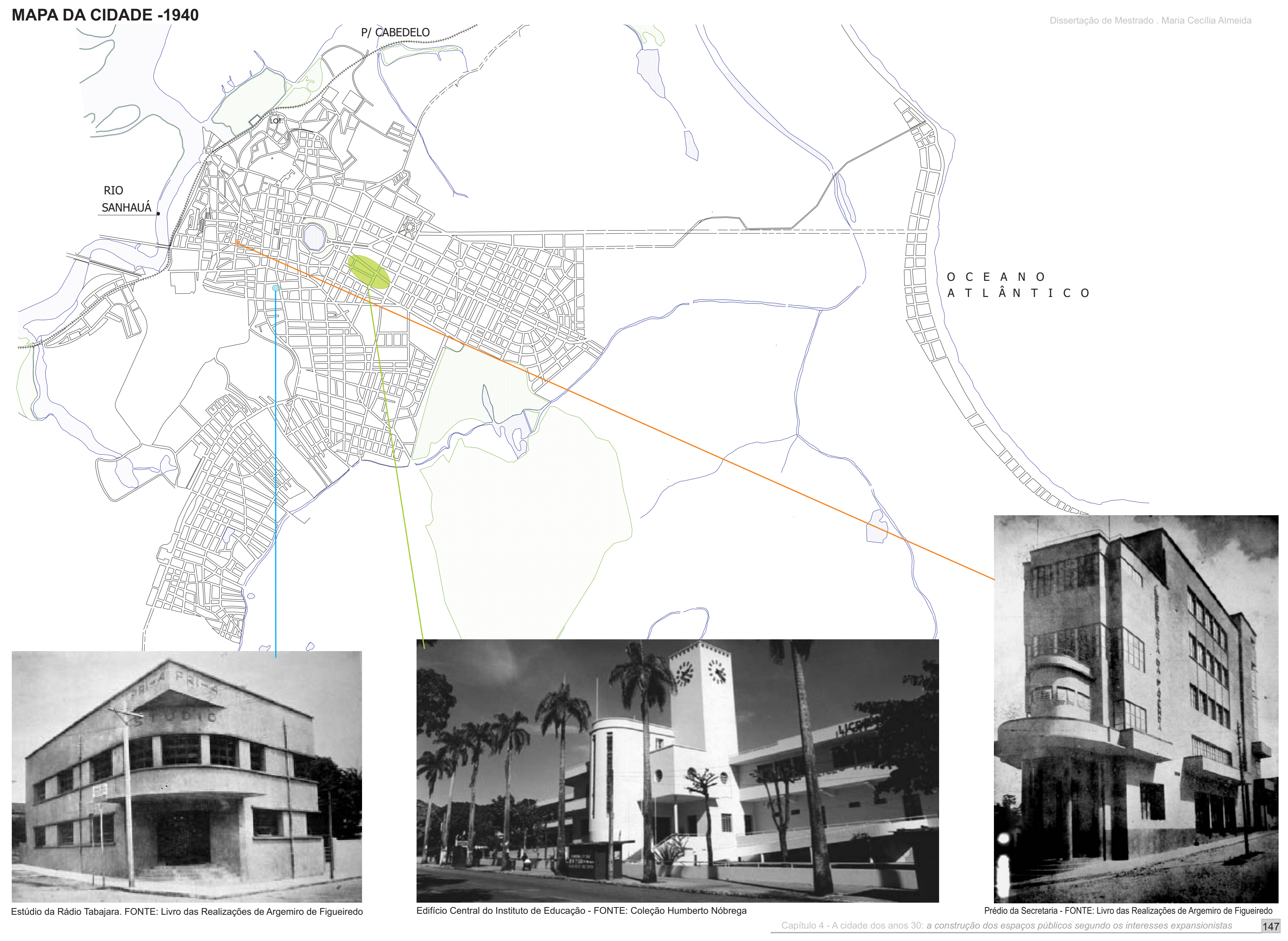


A relação do edifício do Instituto de Educação com o sistema viário no qual ele é inserido apresenta a interação da arquitetura com a velocidade, ou seja, a edificação cujas formas e elementos podem ser percebidos mesmo durante um rápido deslocamento. Assim, de imediata compreensão pelo olhar, esse tipo de construção promove a difusão dos códigos formais da arquitetura moderna brasileira diante do novo ritmo de vida urbana.

Além dessas edificações de maior projeção na área urbana, sobretudo pela sua inovação formal, essa capital recebe várias outras edificações públicas, a exemplo do Manicômio Judiciário, da Maternidade Cândida Vargas e do Hospital São Vicente de Paula. Esse último é construído no final da Avenida João Machado, como idealizado no plano de Nestor Figueiredo. O cenário da capital mais uma vez recebe obras de infra-estrutura e de embelezamento, incluindo reforma de edificações existentes. $O$ antigo prédio do Tesouro ganha mais dois pavimentos, passando a funcionar como Palácio das Secretarias. O Palácio da Redenção recebe uma ampla reforma, apresentando os novos conceitos estéticos não só na sua arquitetura, mas também no jardim lateral nele inserido através da demolição da Igreja Nossa Senhora da Conceição. Além do interesse na inserção do verde, questão presente na maioria das áreas públicas criadas ou remodeladas nesse momento, a construção desse jardim também tem o fim de exaltar a memória do ex-governador João Pessoa, através da criação de um memorial em sua homenagem, onde seu corpo encontra-se sepultado.

\subsection{OS NOVOS ESPAÇOS PÚBLICOS}

"Em cerca de dois anos o aspécto de João Pessoa se modificou sensivelmente. Antigas viélas e matagais desapareceram e em seu logar surgiram avenidas e largas ruas de ótima pavimentação. O Parque Solon de Lucena, outróra virtualmente abandonado, se transforma em magnífico passeio publico de perspectiva admirável, ao mesmo tempo que virá contribuir na solução de grande parte do problêma de tráfego da Capital. Zonas antigamente inhabitadas cobrem-se de prédios residenciais por força dos melhoramentos de iniciativa do poder público" ${ }^{398}$.

Seguindo mais um ciclo de transformações urbanas, a década de 1930 promove nos espaços públicos da cidade de João Pessoa mais um processo de renovação. Conforma essa cidade segundo os novos conceitos urbanos em desenvolvimento, utilizando-se das novas ferramentas urbanísticas características desse período. Os espaços públicos de permanência e os de passagem sofrem alterações em suas formas e em seus usos, influenciando, inclusive, no vocabulário urbano.

As ruas e praças em geral recebem melhoramentos, num processo de continuidade às transformações ocorridas na década anterior. Ruas são alargadas, prolongadas e seus calçamentos são trocados. As praças recebem novos equipamentos e nova pavimentação. De todos esses melhoramentos feitos na infra-estrutura urbana, os mais característicos desse momento se dão no sistema viário e em um conjunto de obras a ele vinculado. Desses empreendimentos, destacam-se os executados a partir do Plano elaborado por Nestor de Figueiredo: o sistema de avenidas e parkways, com destaque para a avenida Getúlio Vargas, a parkway que circula a lagoa e as obras do Instituto de Educação e do Parque Solon de Lucena vinculadas a esse sistema.

${ }^{398}$ VIDAL, Adhemar. "Chronica", Revista Era Nova, n. 76, 01 abr. 1925, s/p. 
A intervenção no Parque Solon de Lucena e a construção do sistema de parkways implantado em seus arredores constitui a obra mais representativa desse período. Essas intervenções proporcionam grande respaldo ao governo de Argemiro de Figueiredo, devido ao grau de transformação pelo qual passa esse espaço em sua administração, refletindo no conjunto da cidade que vivencia num processo de grandes mudanças referentes a sua delimitação urbana. Essa obra impulsiona o espraimento do tecido urbano sinalizado nos anos vinte com a abertura de parte da atual avenida Epitácio Pessoa, que sofre novas intervenções, reforçando a expansão para a praia. Esse processo certamente recebe influência da Avenida Beira-Mar, construída no fim dos anos vinte na capital do vizinho estado de Pernambuco, a partir da qual "o mar é associado definitivamente como um signo de modernidade e a nova avenida surge como uma espécie de bulevar tropical"399.

Nesse momento, também há investimentos em outros setores da infra-estrutura urbana que, indiretamente, interferem nas formas e nos usos dos espaços urbanos. São construídas galerias de águas pluviais em algumas áreas da cidade, há a ampliação das linhas de bonde e melhoria do serviço com a troca dos equipamentos, a exemplo da substituição dos trilhos do centro da cidade, duplicação das linhas do Varadouro e das primeiras secções das Trincheiras e do Tambiá e a criação das linhas férreas circulares dos bairros de Cruz das Armas e Jaguaribe. É construído um cruzamento giratório da praça Vidal de Negreiros.

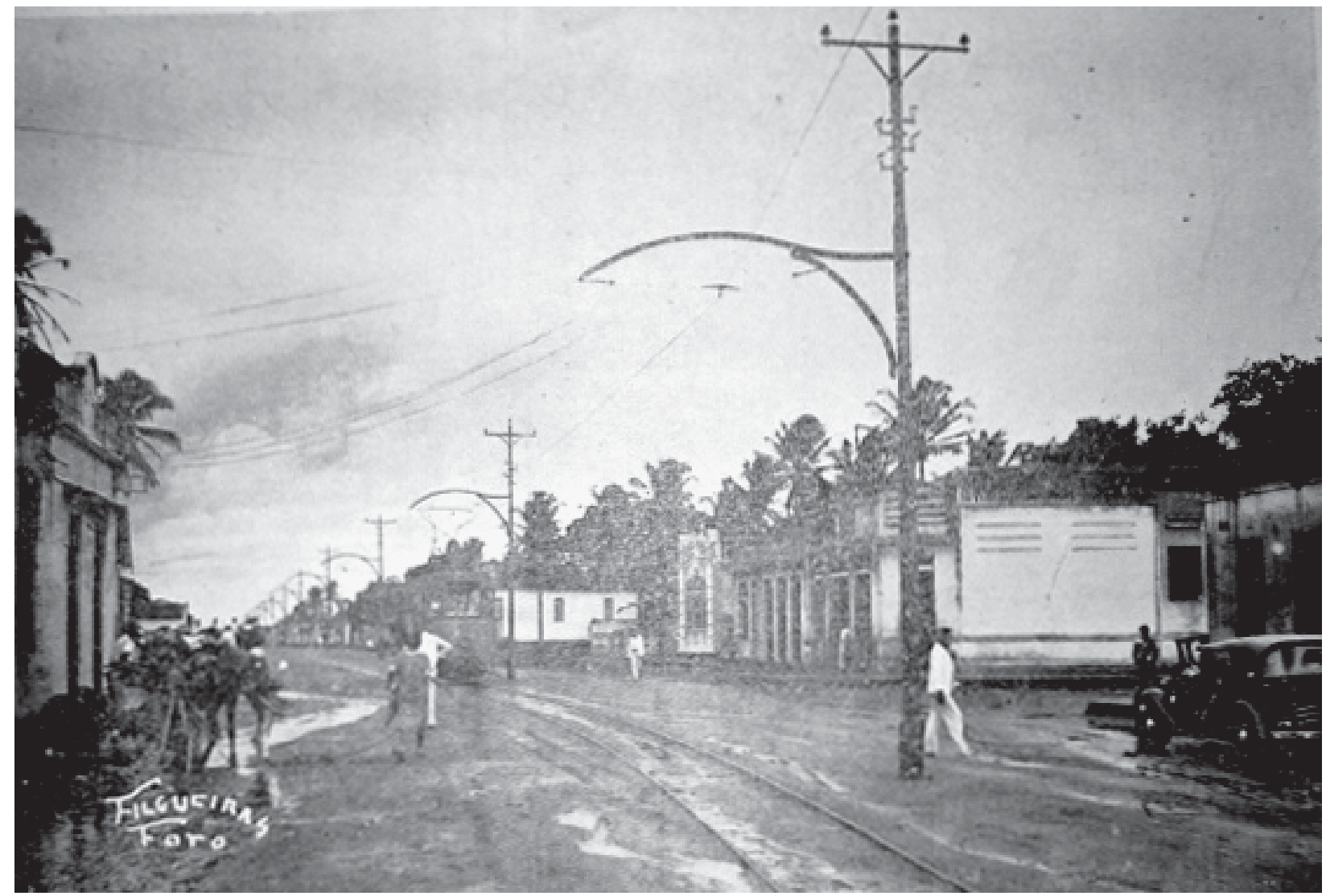

Serviços Elétricos. Linha de Bonde Cruz das Armas. FONTE: Livro das Realizações de Argemiro de Figueiredo.

Esse investimento no sistema de transporte férreo na capital paraibana com melhoramento e ampliação dessa infra-estrutura contraria as tendências de outras capitais. Em São Paulo e no Rio de Janeiro, busca-se e ampliar o sistema viário e intervir na atuação das empresas dos transportes férreos, diminuindo sua área de atuação. No Plano de Avenidas, Prestes Maia indica a utilização de um "sistema de parkways" e apresenta argumentos contra a renovação do contrato de viação feita pela companhia canadense Light\&Power. Da mesma forma atua Agache no Rio de Janeiro, que vê o sistema de transporte como 
"um sistema integrado, e sua reformulação é explicada pela necessidade de suprimir a maior parte dos bondes, que saturam a cidade, de encontrar as artérias principais, que entrem até o centro da mesma, de criação de vias de comunicação entre bairros e de construção de uma rede metropolitana" ${ }^{\prime 400}$.

Há também um grande investimento no setor elétrico. A energia elétrica, até então majoritariamente fornecida pela Fábrica de Tecido de Tibiri e complementada pela antiga usina Cruz do Peixe, é insuficiente. Em 1935, começa a funcionar a Central Elétrica, que no governo de Argemiro de Figueiredo recebe melhoramentos complementares, dos quais se destacam a construção das redes de transmissão para a Fábrica de Cimento, a Sub-Estação, as praias do Poço e Tambaú e a Rádio, além da retificação e ampliação das redes do circuito geral da cidade.

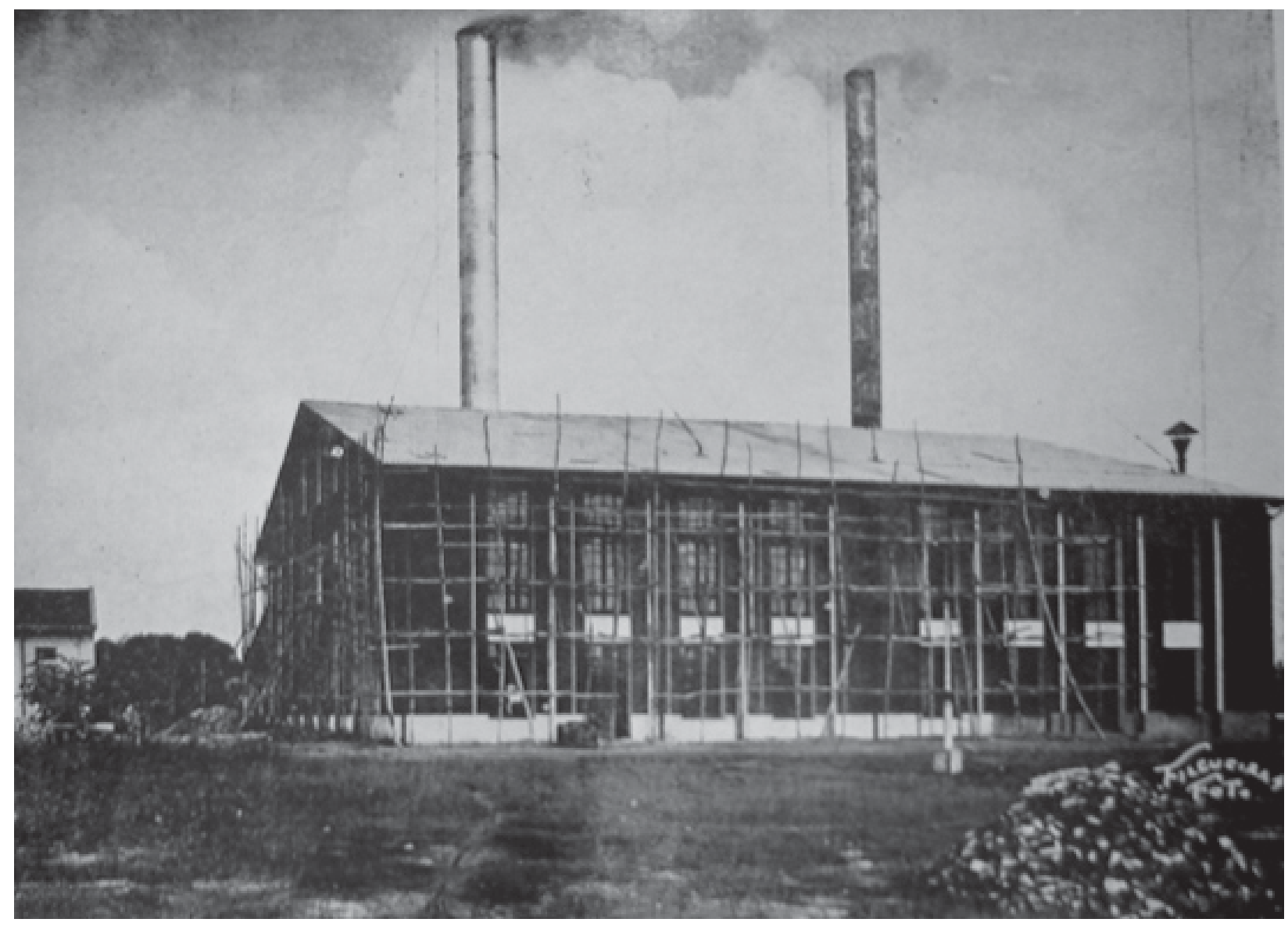

Ampliação da Central Elétrica - FONTE: Livro das Realizações de Argemiro de Figueiredo.

Também são reralizadas fortes investidas no setor de comunicação, com melhoramentos no sistema de transmissão de notícias através da Rádio Tabajara e melhorias no setor de imprensa, além de investimentos na estrutura gráfica do jornal $A$ União, que se torna mais ágil com a chegada de novos equipamentos, além da reforma e ampliação de seu edifício.

\subsubsection{As ruas e avenidas}

Em 1933, dando continuidade à obra iniciada na década de 1920, o engenheiro Ítalo Joffily coordena, através da D.V.O.P, as operações para reiniciar a abertura definitiva da avenida Epitácio Pessoa que se estendem até o ano de 1936, na administração de Argemiro de Figueiredo. Partindo das imediações da praça

400 LEME, Maria Cristina da Silva (org).Urbanismo no Brasil - 1895-1965. Salvador: Edufba, 2005, p. 364. 
da Independência em direção à praia de Tambaú, essa avenida traça, em áreas ainda não povoadas, um novo eixo de ocupação em direção à região praieira, retificando o trajeto de um caminho irregular existente e assumindo uma configuração retilínea. Esse trecho, trabalhado inicialmente por Camilo de Holanda em 1920, traz daquele período uma grande inflexão além da marcação indefinida, ambos corrigidos pela atuação da D.V.O.P. Aproximadamente na metade do trajeto que a avenida ocupa após a conclusão das obras, um grande corte é feito no final do platô que desce para as margens do Rio Jaguaribe, suavizando a inclinação da via em construção e viabilizando o aterro das áreas encharcadas da planície costeira de Tambaú. As margens do Jaguaribe são aterradas e seu leito assoreado perde parte de sua largura. Nesse processo, abrem-se loteamentos a partir da compra de fazendas por parte do governo, onde surgem, posteriormente, os bairros de Tambaú até o Cabo Branco, ocupando a região beira mar na direção sul.

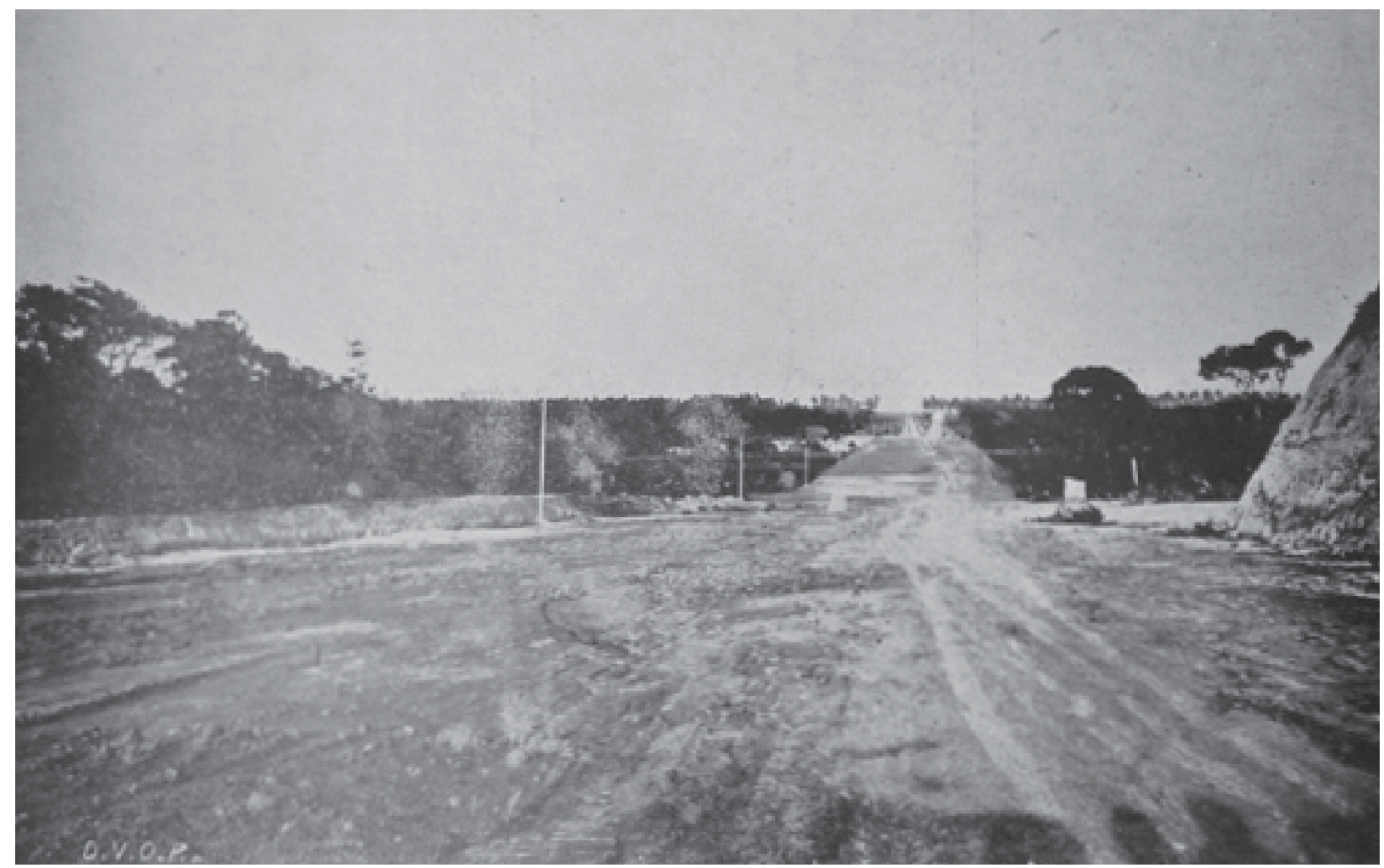

Avenida Epitácio Pessoa - Aterro do Vale do Jaguaribe. FONTE: Livro das Realizações de Argemiro de Figueiredo.

A abertura dessa via facilita a ligação com a praia da Tambaú, onde são comuns as atividades de veraneio e pesca. Grande parte do trajeto dessa avenida, entre o Parque Solon de Lucena e a praia, apresentase, por algum tempo, despovoada, com propriedades de características rurais.

Outro marco viário desse momento é a abertura da avenida Getúlio Vargas. Traçada a partir do Parque Solon de Lucena e seguindo as diretrizes do plano elaborado por Nestor Figueiredo, essa avenida dispõe de 52 metros de largura, apresentando-se subdividida segundo os diferentes fluxos a que se destina que concretizam a hierarquia funcional no sistema viário defendida pelo urbanismo de então. Suas calçadas têm 6 metros de largura e se destinam aos pedestres. O canteiro central, com 10 metros, é planejado para abrigar uma arborização feita com ipês amarelos, caracterizando o sistema de parkway. Há ainda duas pistas com 15 metros de largura cada, proporcionando três faixas de rolamento de cada lado e duas faixas para estacionamento em cada lateral. A construção dessa avenida está formalmente vinculada ao Parque Solon de Lucena e ao Instituto de Educação, que constituem o espaço público mais representativo desse período.

Além das avenidas abertas em áreas ainda desocupadas, que acabam por apresentar maior destaque no conjunto urbano, ao longo de toda a administração de Argemiro de Figueiredo se observa um amplo trabalho 
de reestruturação das ruas já existentes, dando continuidade ao processo desenvolvido pelas administrações anteriores. Muitas delas recebem nova pavimentação, dentre as quais destacam-se: Miguel Couto, Duque de Caxias, Guedes Pereira, Padre Meira e rua das Palmeiras, essa última denominada nesse momento de Peregrino de Carvalho. Outras são também alargadas, como a rua Cardoso Vieira (1937) e a Gama e Melo (1936), esta com demolições e terraplanagens intensas.

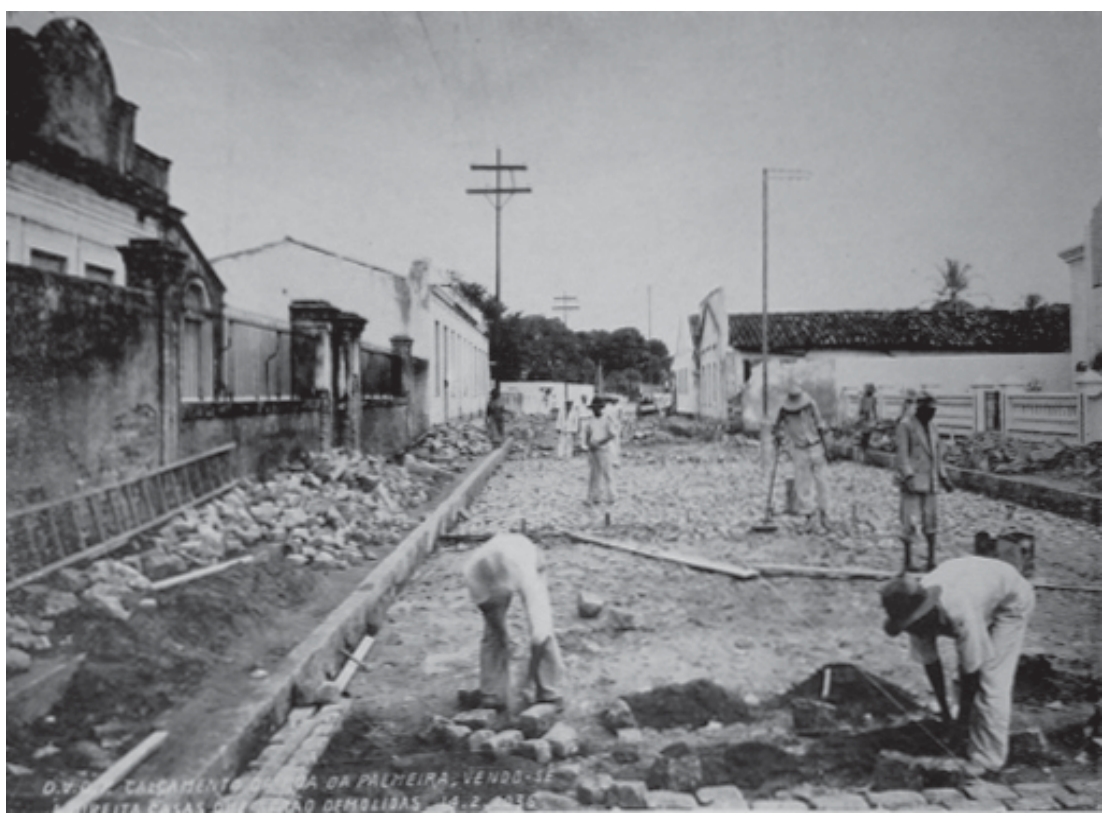

Nova pavimentação da rua Duque de Caxias. FONTE: Livro das Realizações de Argemiro de Figueiredo

Além do embelezamento proporcionado pelas novas dimensões e pelo novo material, a aparência das ruas também é renovada pela implementação de novos equipamentos no seu trajeto, a exemplo da avenida General Osório, cuja iluminação foi "completamente modernizada", e a rua Duque de Caxias, que teve sua iluminação "substituída por elementos dos mais elegantes, com canalização subterrânea" ${ }^{01}$.

Observa-se ainda o investimento em algumas ligações da cidade com municípios vizinhos. Nesse período, o sistema viário passa por reformas no trajeto para Santa Rita e Bayeux, além do novo revestimento aplicado à estrada João Pessoa-Cabedelo em 1936. Percebe-se a atuação administrativa em vários aspectos do sistema viário da capital, apesar das principais inovações se encontrarem nas grandes avenidas direcionadas para expansão do tecido urbano e nas parkways, renovando mais uma vez a aparência e a forma de utilização dos espaços públicos.

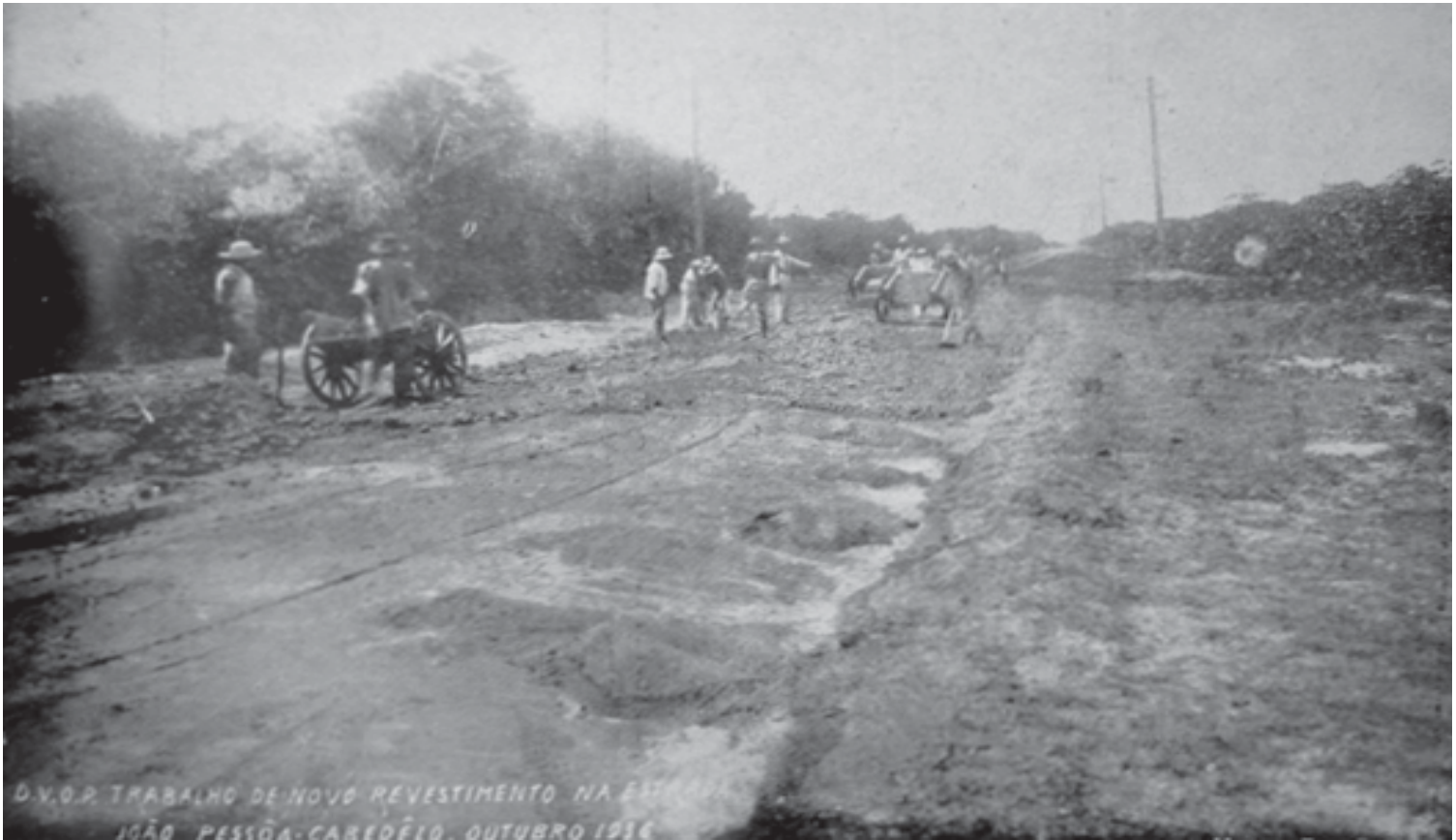

Estrada João Pessoa - Cabedelo. FONTE: Livro das Realizações de Argemiro de Figueiredo.

${ }^{401}$ DEPARTAMENTO DE ESTATÍSTICA E PUBLICIDADE DO ESTADO DA PARAÍBA. Realizações do Govêrno Argemiro de Figueirêdo. João Pessoa: Imprensa Oficial, 1939, s/p. 


\subsubsection{As praças}

As praças são os espaços públicos que mais sofrem alterações na década de 1920. Nos anos trinta, esses espaços também participam do processo de reorganização urbana, porém com menos ênfase que na década anterior. Percebe-se que as intervenções nas praças nesse segundo momento se encontram vinculadas ao sistema viário, refletindo a intensidade dessa questão no urbanismo de então. Uma das formas de alterar a aparência de muitas das praças se dá através das ruas que as rodeiam, algumas vezes alargadas e, na maioria, com seu calçamento trocado, como ocorre na praça Venâncio Neiva. Também é comum a mudança da pavimentação da praça, a exemplo da praça 1817 e da D. Ulrico.

A praça Vidal de Negreiros, além das transformações no sistema dos bondes que nela tem sua confluência, também recebe, nesse momento, o Parahyba Palace Hotel, obra iniciada pelo governador João Pessoa que, além de apresentar dimensões imponentes na fachada para a praça, é inovador na cidade no que diz respeito à estrutura hoteleira, inserindo ali um novo uso que influencia na dinâmica da praça. Dos equipamentos inseridos nas áreas púbicas dessa natureza também se destaca o Pavilhão do Chá, construído no centro da praça Venâncio Neiva.

Apesar da maioria das praças receberem nesse momento melhoramentos indiretos, geralmente em seus arredores, influenciando suas formas e funções, e não necessariamente na sua própria estrutura, a praça João Pessoa é a de maiores mudanças e maior repercussão no espaço urbano. Antigo Jardim Público e depois Praça Comendador Felizardo, ganha nova iluminação e perde o gradil que cerca o seu perímetro ao longo de várias décadas, resultando, segundo publicação oficial, em um "aspecto moderno"402. Além da questão formal, a intervenção sofrida por essa praça tem reflexos nos seus modos de apropriações por parte da população, o que lhe imprime um caráter simbólico. A retirada do gradil promove o desmanche da organização hierárquica de utilização desse espaço, liberando tanto a entrada antes restrita às camadas mais abastadas como os espaços internos, também regidos por hierarquia de utilização ${ }^{403}$. Certamente, a localização dessa praça em frente ao Palácio do Governo influenca tais mudanças, retratando o novo momento político e os ideais de transformação da sociedade, reforçados pelos anúncios oficiais que batizam de 'moderno' esse espaço reformulado.

\subsubsection{Os parques}

A preocupação em implementar o verde na estrutura urbana, tanto nas vias como em praças e parques recebe ênfase desde a década de vinte. Nos anos trinta, o discurso referente à importância e necessidade arborizar as áreas públicas se encontra mais vinculado ao sistema viário. Assim, nesse momento há a continuidade do processo de inserção de arborização e ajardinamento verde das áreas urbanas, agora embutido na questão viária, onde se destacam as parkways.

O Parque Solon de Lucena é o espaço público de permanência que passa pelas maiores intervenções desse período. Esse parque, que já canaliza as águas pluviais do seu entorno, tem sua infra-estrutura reforçada com investimentos em equipamentos urbanos e paisagísticos. Por ser adotado como ponto de integração viária da cidade, interligando a área já estabelecida e a parte em expansão e, principalmente, por ocupar uma

\footnotetext{
${ }^{402}$ DEPARTAMENTO DE ESTATÍSTICA E PUBLICIDADE DO ESTADO DA PARAÍBA. Realizações do Govêrno Argemiro de Figueirêdo. João Pessoa: Imprensa Oficial, 1939, s/p.

403 Essa organização rígida que disciplina o uso da praça é apresentada no Capítulo 3.
} 


\section{MAPA DA CIDADE -1940}
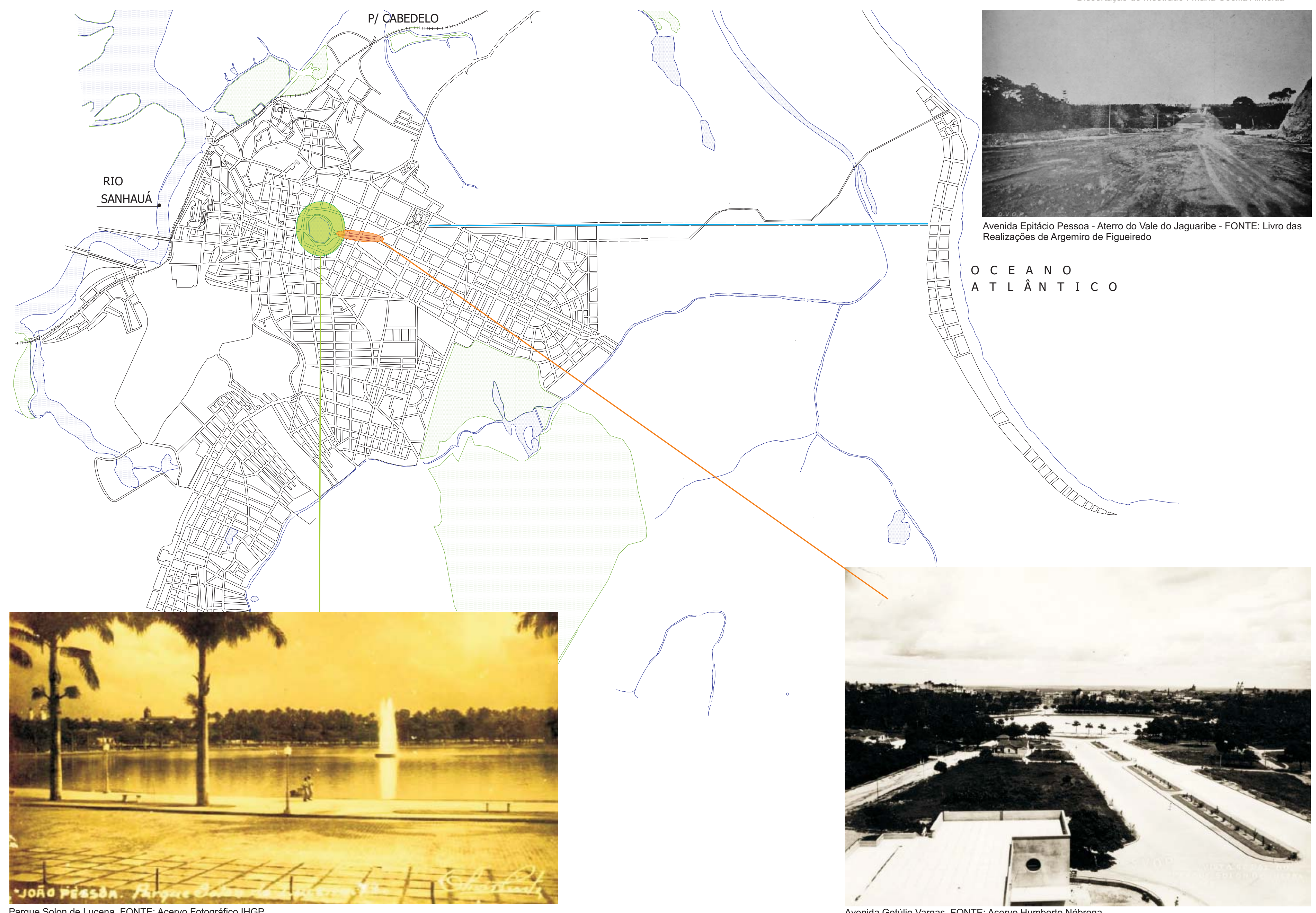

Avenida Epitácio Pessoa - Aterro do Vale do Jaguaribe - FONTE: Livro das de Argemiro de Figueiredo

O C E A N O

A T L ÂN T I C O

Parque Solon de Lucena. FONTE: Acervo Fotográfico IHGP. 
posição de destaque nas perspectivas provenientes do sistema de parkways, esse parque recebe uma série de melhoramentos que o transformam de fato em um parque urbano, como almejado na década anterior.

\subsubsection{Os uso}

Em relação aos espaços públicos, os anos de 1930 a 1940 são de continuidade às obras de alteração da infra-estrutura urbana como ocorre com intensidade na década de 1920, só que com mais ênfase para o sistema viário. As mudanças mais visíveis no cotidiano, como reflexo dessas ações, são em relação aos deslocamentos dentro da cidade, devido à ampliação das linhas de bondes e do sistema viário.

Como ocorria na década anterior, as praças permanecem sendo utilizadas para o lazer. Das praças da cidade, parece ser a praça João Pessoa a mais mencionadas nos artigos publicados nas revistas de circulação local. Ela é o "recanto onde se toma o pulso da cidade"404. Apesar da grande transformação na sua aparência, ela guarda hábitos e formas de utilização da década anterior, sobretudo pelos "dias de retreta, aos domingos ou nos feriados, [quando] ella se torna mais attraente, mais seductora"405.

Mesmo mantendo o mesmo como principal atração a retreta, há uma mudança significativa na forma de apropriação desse espaço por parte das diferentes camadas sociais. A retirada do gradil de ferro de seu entorno desmancha não só o controle de quem o freqüenta, mas também a hierarquia social promovida pela sua estrutura. A liberdade de uso tornando-a mais popular é ressaltada pelos que a descrevem, enfatizando a mudança: "Há de tudo. Gente da alta, da média e da baixa, meio-termos, romanticos, scepticos, matadores do tempo, raça branca, preta, amarella e tricolor"406.

Apesar do movimento concentrar-se na praça João Pessoa, as demais praças também atraem usuários, estimulados por melhoramentos em sua estrutura e em seus arredores. Porém, percebe-se uma notável diminuição na divulgação desses espaços, na sua exaltação e no incentivo à sua ocupação em comparação ao que ocorre na década anterior. Jornais dão prioridade às obras viárias e arquitetônicas empreendidas pelo governo naquele momento, divulgando os ideais e os estilos denominados 'modernos'. As revistas, ao tratarem das praças e antigas ruas, revelam uma nostalgia através de "flagrantes da cidade no começo deste século" 407 e da descrição da "physionomia das ruas" ${ }^{408}$ que busca traçar as características das ruas construídas em diversos momentos. Apresenta as vias antigas que se modificam para acompanhar os novos tempos, como a "rua Direita, quarentona que não se quer entregar. Retoca-se aqui e alli. Usa 'maquillage' discreta nas fachadas. Tem cuidados especiaes com os calçados" 409 . Mostra também as novas ruas que, apesar da nova aparência, falta-lhes o conteúdo adquirido ao longo da história, a exemplo de "Theresópolis. Menina moderna. Sem cérebro. Cabeça ôca"410. Os artigos produzidos nesse momento revelam um saudosismo evidenciado pelas lembranças de tempos anteriores, dos modos que a população se apropria desses espaços.

Apesar da importância das reformas realizadas nos espaço já de tradição, dando-lhe novos significados, são as obras relacionadas à expansão urbana as mais inovadoras desse período. Dessas obras, é a implantação de parte do Plano de Nestor de Figueiredo, nas imediações do Parque Solon de Lucena, a intervenção de

\footnotetext{
${ }^{404}$ RIBEIRO, Beatriz. "Rabiscos" In: Illustração, n.03, p.21, 15 mai 1935

${ }^{405}$ SANTOS, Alberto. "A vitrine da cidade" In: Illustração n. 10, p. 06, 15 set 935.

${ }^{406}$ RIBEIRO, op.cit., p.21.

407 Illustração. João Pessoa, n.3, 15 mai 1935, s/p.

${ }^{408}$ MONTEIRO, Alice de Azevedo. "Physionomia das Ruas". Illustração. João Pessoa, 15 set 19935, n. 3, s/p.

$409 \mathrm{Ibid}$.

${ }^{410}$ Ibid.
} 
maior repercussão no contexto urbano. Esses trabalhos só são concretizados no final desse período, o que não permite uma avaliação completa de seus reflexos no cotidiano da cidade de imediato. Inicialmente, esse espaço é incluído nas atividades laicas da população, principalmente nas datas festivas e suas respectivas comemorações. Porém, percebe-se que não se torna de imediato um espaço de lazer permanente e, nas festividades, é um dos pontos de passagem e não de permanência, como ocorre no carnaval. Alguns anos depois, essa área é incluída no lazer cotidianos, inclusive como parque de diversões infantil. Mas essa função não perdura, caracterizando-se até hoje esse espaço como um espaço de passagem.

Nos primeiros momentos após a conclusão dos trabalhos da Avenida Getúlio Vargas, do Instituto de Educação e do Parque Solon de Lucena, percebe-se a intensa utilização dessa área por incentivo da administração. As solenidades festivas, a exemplo dos desfiles do dia 7 de Setembro, são realizadas nessa área. Os carnavais também ocupam essa região, mas ainda vinculados à tradição dos corsos nas ruas antigas e das festas nos clubes, reunindo no trajeto percorrido, a área central da cidade e o Parque. Em 1940, jornais e revistas mostram que o carnaval ainda tem seu principal ponto na Rua Direita - que recebe iluminação especial-, com a presença de clubes, blocos, cordões e organizações individuais, ao som das orquestras, bandas de música, fanfarras, bombos, tambores, cuícas e pandeiros e com a concentração na praça Vidal de Negreiros.

"Várias bandas de música percorrerão a rua Duque de Caxias, arrastando as massas, até que o Rei Momo ordene que a multidão avance e se poste em frente ao Cassino do Parque Solon, onde êle se recolherá para o novo e profundo sono até sábado" ${ }^{411}$.

No carnaval de 1940 "não deixaram de aparecer os 'caboclinho', (índios), que constituem uma nota típica do carnaval paraibano pelo sugestivo da caracterização e de suas exibições coreográficas" ${ }^{\text {"12. }}$. O Parque fica cheio de gente e a fonte luminosa no centro da lagoa derrama água e luz.

A festa popular tradicional apresenta-se modificada pelos avanços tecnológicos. Há uma ampliação do percurso e dos recursos do carnaval que fica cada vez mais motorizado, inclusive com uso de carros alegóricos. Por outro lado, há maior fiscalização por parte da administração, restringindo fantasias e burocratizando a construção de blocos, antes com maior liberdade como proclamado nos anos vinte. A Chefia de Polícia fica responsável pela fiscalização e punição dos participantes do carnaval.

"Só serão permitidas fantasias que não ofendam à moral pública, não sendo tolerada criticas alusivas as autoridades civis e militares e representantes de quaisquer ordens ou seitas religiosas. Os blocos e cordões carnavalescos só poderão se exibir munidos de licença que Ihes serão fornecidas pelas respectivas delegacias"413.

Esse controle, apesar de buscar promover a segurança, também extingue, aos poucos, muitas das tradições das festas de rua locais por censura ao pudor ou ao poder, ao passo que são inseridos, nessas festividades, novos costumes e elementos que representam os avanços tecnológicos, a exemplo dos carros.

A presença do automóvel se torna algo marcante e inovador na sociedade e no cotidiano urbano desse momento. Os jornais e revistas estampam as novidades automobilísticas, incluindo-as nas novas necessidades urbanas. Isso se reflete na cidade que passa

\footnotetext{
411 "Carnaval", A União, 01 fev de 1940, n. 15, p. 2.

412 Ibid.

413 “Instruções da Chefia de Polícia para o carnaval”. A União, 01 fev de 1940, n. 15, p.3.
}

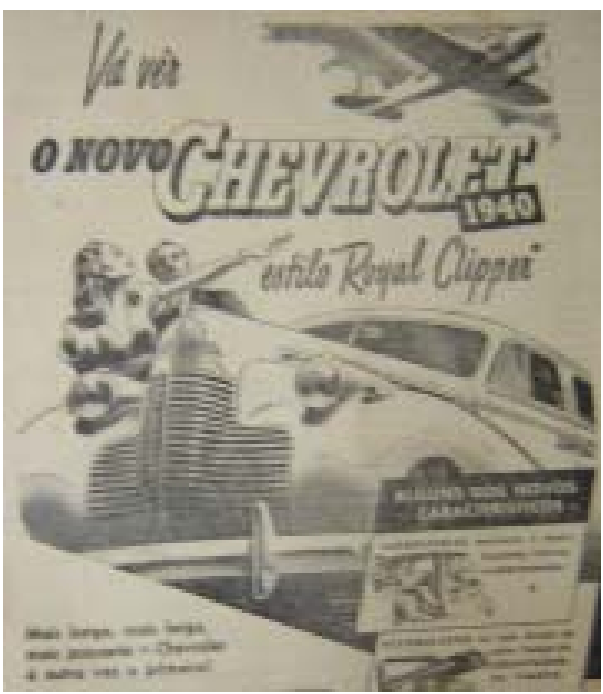

Propaganda. FONTE: Jornal A União 1939 
a ter pontos de concentração desses novos elementos, a exemplo da praça Vidal de Negreiros, que tem um estacionamento de carros de aluguel.

Em relação aos conceitos estéticos, a noção de beleza se encontra vinculado à saúde. O esporte permanece, como na década anterior, um dos símbolos de saúde, beleza e energia. É muito comum, nas propagandas apresentadas nos jornais e revistas, o incentivo do consumo de remédios para obter beleza e disposição. Os "magros de nascença" devem tomar remédio para engordarem e não se aparentarem doentes. As crianças devem tomar "biotônico" para crescerem

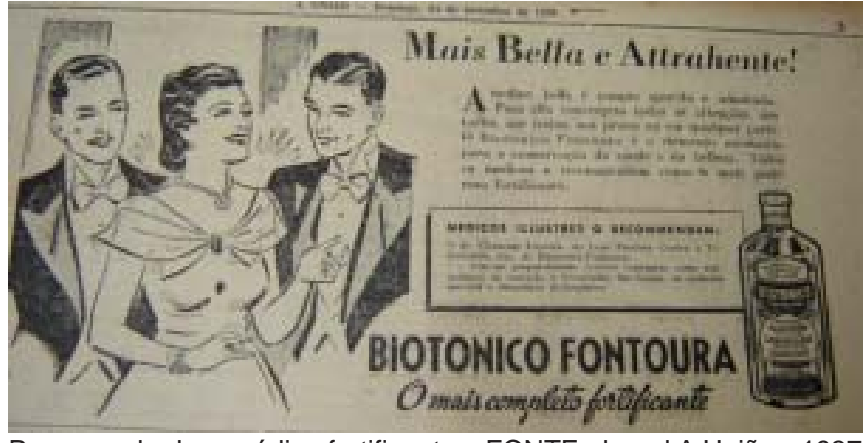

Propaganda de remédios fortificantes. FONTE: Jornal A União - 1937 fortes, e as mulheres para ficarem belas e elegantes. Há um grande incentivo aos exercícios físicos, não apenas à prática de esportes, mas à ginástica. Os jornais divulgam as competições esportivas - a exemplo das de basquete, futebol, natação- e as atuações dos clubes locais. Há a ampliação do número de clubes e de suas atividades, alterando a natureza do lazer urbano e, consequentemente, influenciando no uso dos espaços públicos.

Ao mesmo tempo em que a cidade vai se 'modernizando', a sociedade busca construir o homem 'moderno' para ser inserido nesse espaço, onde esporte, saúde e beleza estão vinculados a todas as novidades urbanas em construção e às inovações apresentadas no comércio: "Para sahir de casa disposto, com uma physionomia attrahente, deve o homem moderno fazer três coisas, todas as manhãs: a gymnastica, o banho e a barba"414.

A difusão de inovações no comércio e, principalmente, a ampliação do número de automóveis na cidade alteram a escala dos espaços urbanos em relação ao pedestre e modificam a dinâmica urbana, contribuindo para o processo de esvaziamento dos espaços públicos. A isso junta-se o aumento do número de clubes, de suas atividades e do incentivo à sua utilização. Essas mudanças, que nesse momento são encaradas como modernização da cidade que cresce, trata-se da sinalização do processo de transformação dos usos dos espaços públicos, que posteriormente são alvos de críticas.

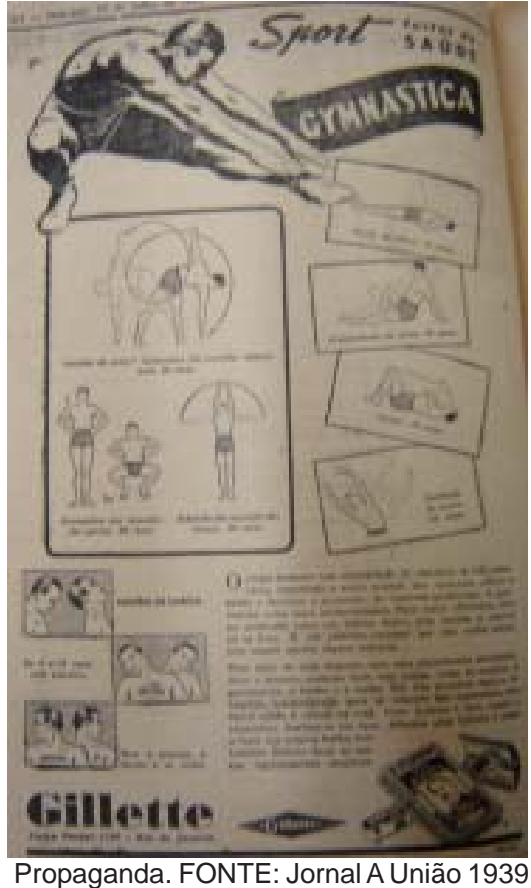

Propaganda. FONTE: Jornal A União 1939

O parque Solon de Lucena, espaço público de maior representatividade desse período, não tarda a se tornar um local de passagem no centro da cidade. Ele pode ser adotado como marco desse processo, incentivando a expansão urbana e o espraiamento impulsionados a partir dos anos quarenta.

\subsubsection{Os novos nomes}

Na década de 1930, a grande inovação do vocabulário referente à cidade relaciona-se às atividades do urbanismo. A prática de planos, zoneamento e expansão são questões que inauguram novos conceitos que, 
conseqüentemente, inserem novos nomes na dinâmica urbana. Essas novas denominações, apesar de divulgadas em jornais para a população apresentando-lhes os novos elementos urbanísticos, não transparecem no dia-a-dia da cidade, ficando mais restritos aos discursos de especialistas.

A cidade dos anos trinta traz como inovações toponímicas as avenidas e, principalmente, as parkways, influenciadas pela questões que guiam as transformações da cidade nesse momento: locomoção, velocidade e sistema viário.

\section{AVENIDA}

\section{"[do Fr. Avenue, pelo esp. avenida] s.f. Via urbana mais larga que a rua, em geral com diversas} pistas para circulação de veículos"415.

Observando o sistema viário construído nesse momento, percebe-se que as avenidas são vias largas e geralmente de grandes extensões. Apresentam-se, na maioria da vezes, exercendo a função de expandir a cidade, ligando áreas distantes através de um traçado em áreas desabitadas. Podem ainda serem abertas no tecido urbano já consolidado, o que exige demolições e desapropriações que possibilitem suas características físicas, principalmente largura e regularidade. Esse processo de criação de avenidas é muito comum nas cirurgias urbanas, a exemplo da abertura da Avenida Rio Branco no Rio de Janeiro. Na cidade de João Pessoa desse momento, é mais evidente a construção de avenidas que traçam expansões, a exemplo da Getúlio Vargas e da Epitácio Pessoa, apesar de existirem algumas delas também na área central da cidade, a exemplo da avenida Guedes Pereira. Ligando a cidade alta à baixa e seguindo até as proximidades da praça Venâncio Neiva, o processo de construção e remodelação desta via se estende pelos diversos ciclos de reforma dessa cidade, recebendo diferentes denominações até assumir a designação de avenida.

\section{PARKWAY416}

Unindo o sistema viário à introdução do verde na cidade, a parkway é, geralmente, uma avenida de dimensões amplas e com subdivisão dos seus usos referentes aos diferentes fluxos, o que lhe promove uma certa hierarquia. Mas é a presença de uma arborização ampla e homogênia, criando um "verde contínuo", que caracteriza essas vias. É comum encontrá-las ligando-se a praças e parques, desenvolvendo um percurso amplo que une as diversas regiões de uma cidade ou de parte dela. Na cidade de João Pessoa, são muitas as avenidas amplamente arborizadas, mas só o sistema viário que envolve o Parque Solon de Lucena é denominado de avenida-parque, por muito tempo chamado de parkway da Lagoa. Esse sistema se liga à praça Vidal de Negreiros - espaço público representativo do transporte por meio de bondes-, envolvendo também a avenida Getúlio Vargas, que posteriormente alcança a região praieira, no Cabo Branco.

\footnotetext{
${ }^{415}$ FERREIRA, Aurélio Buarque de Holanda. Novo Dicionário da Língua Portuguesa. Rio de Janeiro: Nova Fronteria, 1995.

416 O termo parkway não foi encontrado em dicionários da língua portuguesa.
} 


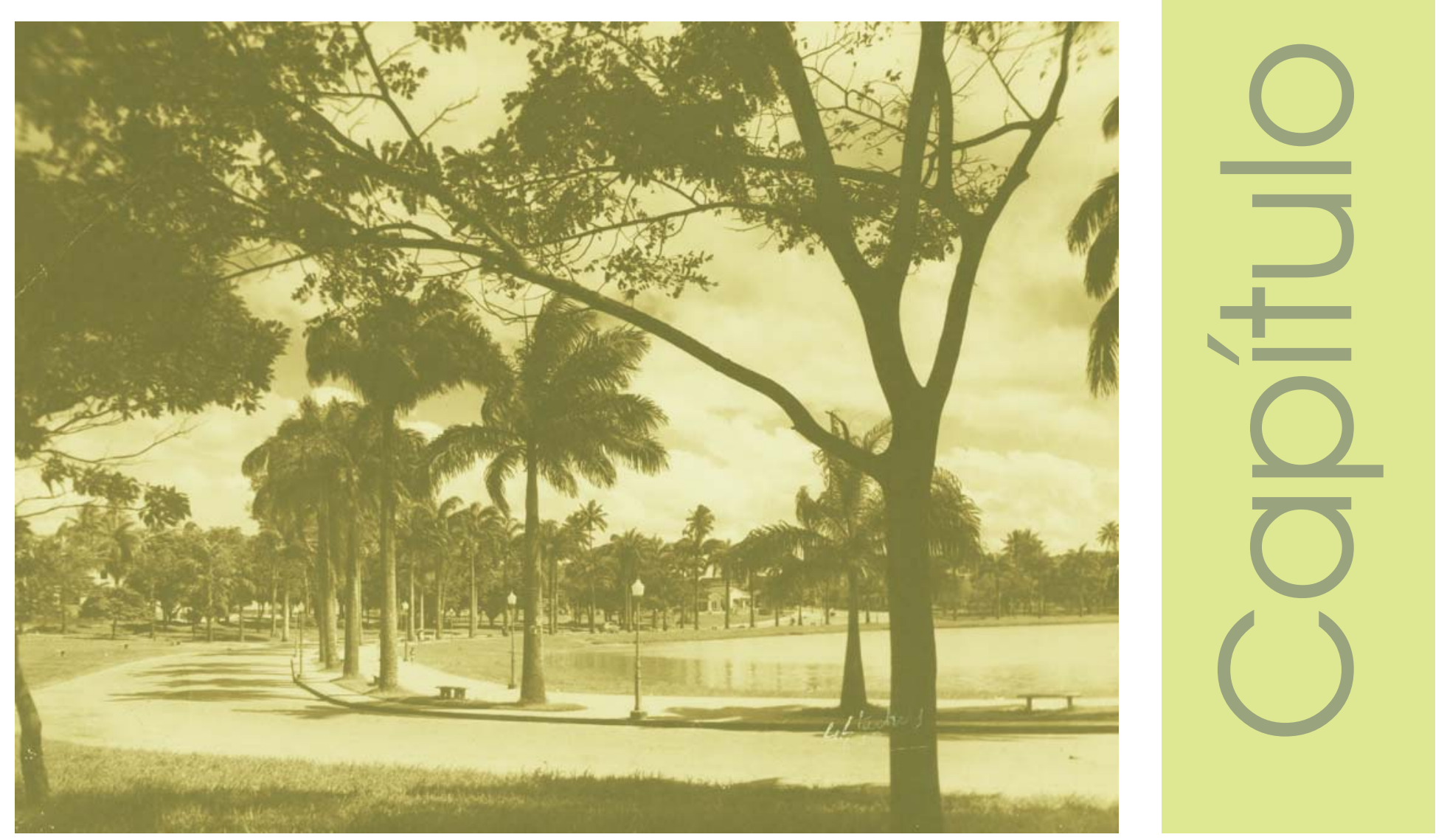




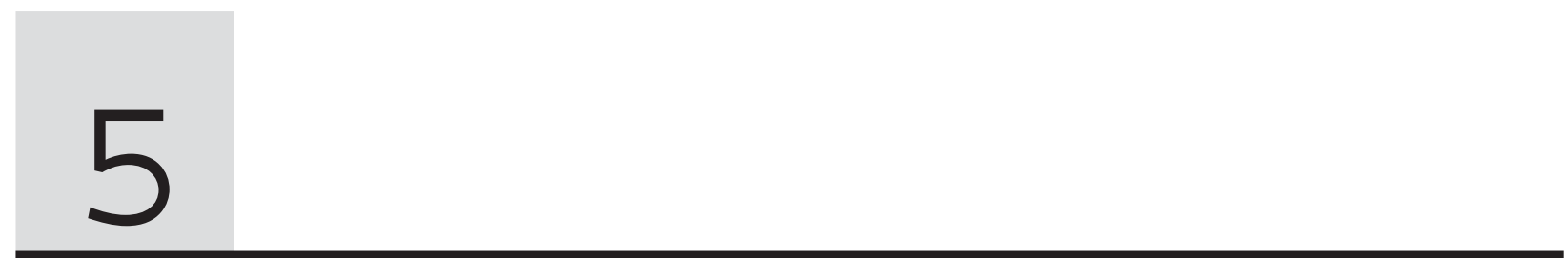

Capítulo 5

\section{O Parque Solon de Lucena}

As transformações promovidas nas cidades brasileiras ao longo do século XIX e início do XX, impulsionadas pelas preocupações higienistas e pelas novas exigências de uma sociedade em transformação, conduzem também ao empenho em atribuir-lhes áreas verdes através da "eleição da natureza domesticada em elemento de valorização da paisagem urbana"417, implantando praças, parques, passeios, jardins e avenidas arborizadas. Esses espaços são criados para conviver com grandes vias que proporcionam a rapidez dos fluxos, em resposta às novas necessidades de velocidade impostas pelo ritmo de vida da cidade industrial. Nesse contexto, tais espaços apresentam um caráter muito mais relacionado à passagem e ao trânsito que à permanência dos seus usuários.

Essa transformação é fruto de um processo caracterizado a cada etapa por diferentes preocupações que alteram as formas e os usos dos espaços públicos. A cidade de João Pessoa, assim como outras cidades brasileiras, promove reformulações na sua área urbana associadas às idéias urbanísticas em circulação, adotadas por profissionais que atuam em várias localidades, divulgando e consolidando no território nacional novos conceitos referentes à organização urbana. Essas intervenções, já sinalizadas no século XIX, tornamse mais intensas a partir da segunda década do século XX, onde os períodos de 1916 a 1926 e de 1935 a 1940 podem ser considerados, respectivamente, o primeiro e o segundo ciclo de reformas urbanas dessa capital.

Ao longo desse processo, intenso porém fragmentado, de reformulação da estrutura urbana da cidade de João Pessoa, muitos espaços são criados e reformulados. Dentre eles, uma lagoa situada nas proximidades do seu núcleo urbano, que desde início do século XIX faz parte dos discursos urbanísticos da capital, recebe, no século XX, atenção especial. Nos dois ciclos de reformas urbanas dessa cidade, ela assume um papel central e articulador das intervenções em andamento.

O primeiro ciclo de reformas é marcado por intervenções pontuais e tem como expoente o Projeto de Melhoramentos e Saneamento da Parahyba do Norte, elaborado por Saturnino de Brito, no qual a Lagoa dos Irerês, assim conhecida devido aos marrecos que lá habitam, é peça central e articuladora do sistema de esgoto. O segundo ciclo tem como norteador o Plano de Remodelação e Extensão da cidade de João Pessoa, elaborado em 1932 por Nestor de Figueiredo, que explicita a ênfase dada à questão viária. Nele, a Lagoa, como ficou conhecido esse espaço ao longo dos anos, também ocupa o lugar de destaque, desempenhando mais uma vez uma forte centralidade na estrutura urbana dessa capital.

Ao longo da primeira metade do século XX, a Lagoa dos Irerês tem, em diversos momentos, sua imagem vinculada à da cidade, assumindo o papel de cartão postal e peça determinante do direcionamento e ritmo da

${ }^{417}$ CORREIA, Telma de Barros. "A gestão do tempo e a organização da cidade moderna". Sinopses. São Paulo n.33p.22-32 jun. 2000, p.24. 
expansão do tecido urbano, retardando-o e impulsionando-o em diferentes momentos. Diante da forte relação desse espaço com a cidade ao longo do processo de formação urbana, ele é aqui adotado como um caso representativo das transformações dos espaços públicos dessa capital nesse período, refletindo os significados a eles conferidos. Desta forma, a questão particular da Lagoa dos Irerês é tomada como um vetor de compreensão da transformação dos espaços públicos nesse processo de 'modernização' urbana, constituindo um ponto de análise de questões abrangentes a partir de um caso específico.

\subsection{DA LAGOA DOS IRERÊS AO PARQUE SOLON DE LUCENA}

Fundada por volta de 1585, a cidade Nossa Senhora das Neves tem seu núcleo urbano formado pela Cidade Baixa ou Varadouro e pela Cidade Alta, a leste do qual existe uma lagoa que aparece nas descrições e nos mapas da capitania e que, gradativamente, é incorporada ao tecido urbano.

Na cartografia datada do século XVII relativa à capital paraibana, imagens encontradas no livro de Barleus (1647) e no Atlas de J. Vingboons (1660 e 1665) ${ }^{418}$, além da representação do núcleo urbano, de parte da vegetação e relevo local, mostram ao longe uma lagoa que, diferente dos outros elementos geográficos dos arredores, inclusive outros lagos, encontra-se ligada à cidade por meio de caminhos. Esse vínculo, apesar da distância que a separa do núcleo urbano, retrata uma indicação provável de sua importância no suprimento d'água dessa capital a despeito da proximidade do núcleo urbano em relação ao rio, cujo acesso é certamente preterido devido às dificuldades inerentes às características íngremes do terreno nessa direção.

Ao longo do século XIX, a cidade passa a se prover progressivamente de fontes, bicas e cacimbas espalhadas pela área urbana e arredores, que ao findar do século abastecem a população, como a Cacimba do Povo e as bicas dos Milagres, do Gravatá e do Tambiá. Essa última, segundo o agrimensor Vicente Gomes Jardim na Monographia da Parahyba do Norte de 1889, abastece metade da população da cidade em fins do século XIX.

A disponibilidade desses novos suprimentos d'água e o conseqüente abandono da Lagoa para esse fim, acrescida dos discursos higienistas fortemente presentes nos debates daquele período, concorrem para manifestações acerca dos males que a Lagoa dos Irerês é acusada de causar. Ela passa a ser tomada por elemento perturbador do quadro sanitário da cidade, como observa o tenente-coronel Henrique Beaurepaire Rohan, Governador da Província, na Chorografia da Província da Parahyba do Norte, em 1857:

"em todo o tempo que estive na Parahyba do Norte, observei que os médicos a encaravam com desgosto, attribuindo aos miasmas que se formavam uma ingerencia perniciosa na saúde dos moradores ambientes e quiça de grande parte da cidade"419.

Nesse período é recorrente a descrição da cidade com ênfase nos seus problemas e irregularidades, onde se critica a lógica da ordem urbana colonial e imperial, atribuindo-lhes uma aparência desordenada, muitas vezes intitulada de caótica. Ao longo do século XIX, essa interpretação de uma imagem urbana deficiente denuncia o objetivo de despertar interesse e ações no sentido de modificá-la, o que acaba se firmando como meta no início do século XX.

Assim, a segunda metade do século XIX é marcada por registros da fisionomia e do funcionamento dessa cidade, alvo de críticas de cunho higienista, através de documentos descritivos que transparecem a

${ }^{418}$ Ver REIS, Nestor Goulart. Imagens de vilas e cidades do Brasil colonial. São Paulo: FUPAM, 2000, p. 114-121.

${ }^{419}$ ROHAN, Henrique de Beaurepaire. Chorografia da Província da Parahyba do Norte. In: Revista do Instituto Histórico e Geográfico da Parahyba, ano II, vol.3. Parahyba: Imprensa Oficial, 1911, p.189. 


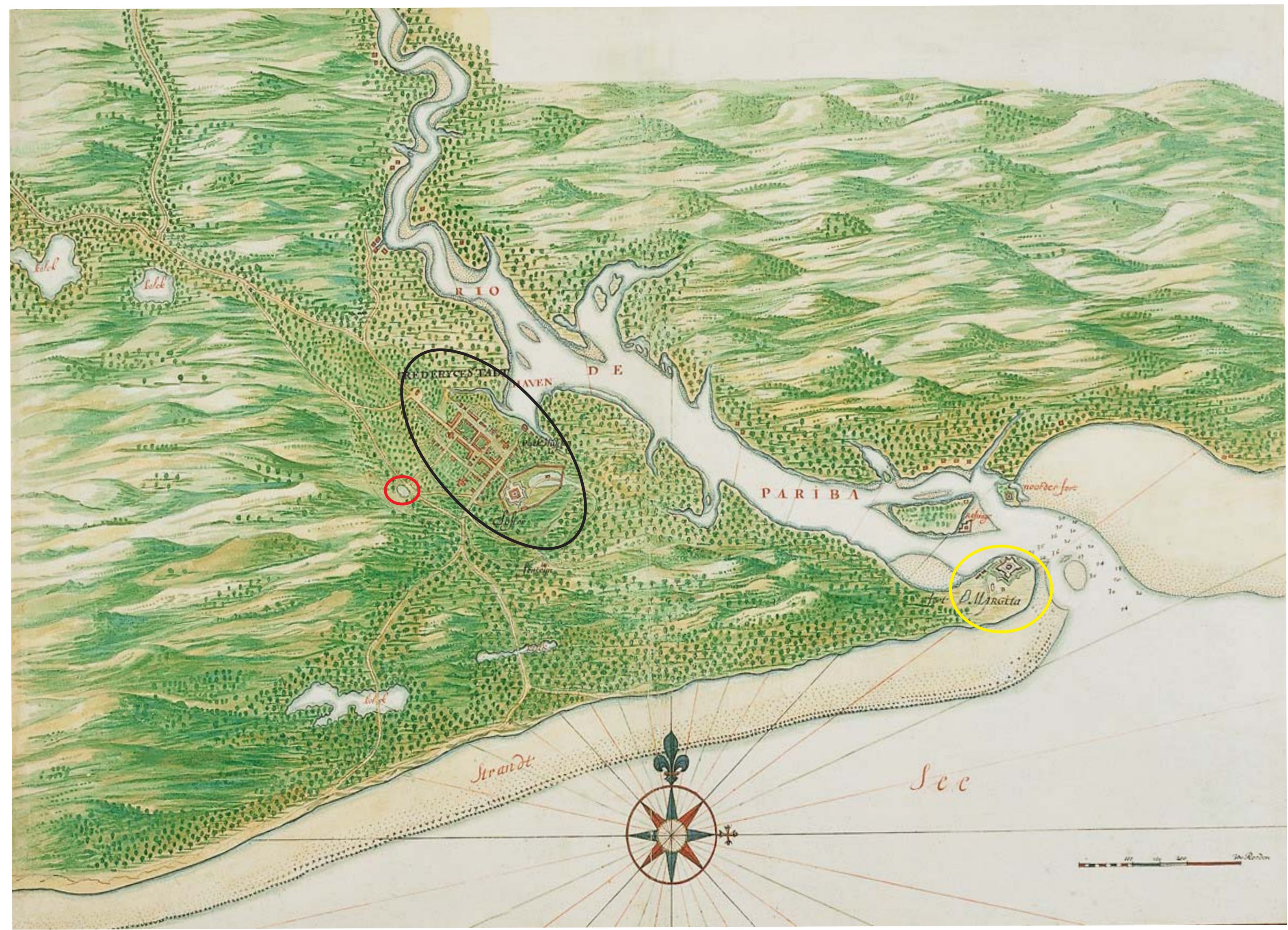

"FREDERYCE STADT". autor: Johannes Vingboons.fonte: Detalhe de original manuscrito, do atlas de J. Vingboons, existente no Algemeen Rijksarchief, Haia. IN: REIS, Nestor Goulart. Imagens de vilas e cidades do Brasil colonial. São Paulo: FUPAM, 2000. O mapa mostra, envolvida por uma linha preta, a área correspondente ao conjunto urbano, e por um alinha vermelha, a Lagoa dos Irerês. Entre eles estão caminhos que as unem. Apresenta ainda caminhos que ligam o connjunto urbano à região das praisa crescimento da cidade, como se observa ao longo do capítulo. 
intenção de evidenciar uma necessidade de intervenção no tecido urbano. A capital paraibana neles retratada é uma cidade de

"ruas desencontradas, com alinhamentos ora obliquando-se à esquerda ora à direita, ora reduzindo, ora ampliando sua largura, abrindo-se em largos e fechando-se em becos, formando ziguezague em direções diversas" ${ }^{\prime 20}$.

Esses registros apontam questões de salubridade que, reforçadas pelos relatórios das comissões médicas, advertem a respeito dos males causados pelo acúmulo de lixo nas ruas e terrenos baldios, animais em decomposição a céu aberto e pelo desleixo da população no trato com as questões de higiene, assim como pela existência de rios, pântanos e maceiós dispostos nos arredores. Em meio a esse quadro urbano, a maioria dos documentos de época que descreve essa capital compartilha a opinião acerca dos malefícios causados pela Lagoa dos Irerês, como indica a comissão médica nomeada em 1869 pelo presidente da província Sr. Venâncio José de Oliveira Lisboa, que atribui em parte à lagoa existente nas proximidades do centro urbano a responsabilidade pelo mau estado de salubridade da capital.

Dos documentos que retratam a Parahyba oitocentista destacam-se a Monographia elaborada por Gomes Jardim em 1889, os artigos publicados, no mesmo ano, na Gazeta da Parahyba pelo engenheiro João Claudinho de Oliveira Cruz e o mapa da cidade levantado pelo engenheiro Alfredo de Barros Vasconcelos em 1857, a mando do então governador Beaurepeire Rohan. Ao que se sabe, esse mapa é o primeiro documento cartográfico empenhado em demarcar a configuração urbana da capital. Seu traçado não abrange a Lagoa dos Irerês, como o faz a cartografia seiscentista que o precede, apesar da distância entre essa área e a cidade, que cresce mesmo que ainda lentamente, ter certamente diminuído entre o século XVII e o XIX, nos quais esses documentos são elaborados.

Os mapas do século XVII ocupam-se mais em situar e relacionar o núcleo urbano com seu entorno, relevo e vegetação, possibilitando a análise dos melhores acessos, da segurança e o conhecimento da área até então pouco explorada, incluindo em sua abrangência a Lagoa dos Irerês. Já o mapa promovido por Beaurepeire Rohan revela que as intenções administrativas do governador da província encontram-se mais direcionadas ao perímetro urbano propriamente dito, desconsiderando as áreas periféricas, inclusive a Lagoa.

As idéias higienistas e os rumores da população acerca dos malefícios provenientes dessa lagoa criam um certo temor por parte dos habitantes em relação a esse espaço que passa a ser tratado com ressalvas, observando-se uma certa esquiva em habitar em suas proximidades. Isso acarreta um certo retardo no crescimento da cidade nessa direção, apesar de se constituir "justamente [essa a] região que melhor se oferece à sua expansão"421, como nota o engenheiro Saturnino de Brito ao visitar a cidade em 1913 a convite do presidente do estado, sr. Castro Pinto, para elaboração do plano de esgoto dessa capital.

No plano elaborado por Brito, além da clara intenção em ordenar o fluxo das águas e esgotos se utilizando do traçado da cidade, há uma forte preocupação em criar espaços verdes. Para tanto, reserva, nas áreas de expansão, "alguns quarteirões para praças, jardins ou parques, aos quais os higienistas atribuem as funções de pulmões da cidade"422. Dentre os parques e praças ajardinadas por ele propostos para a capital paraibana, é, certamente, a intervenção na Lagoa dos Irerês a obra de maior vulto. Nela está reunida a função conferida ao verde na área urbana e o tratamento do esgoto da zona de expansão da cidade, considerando ainda que se trata da transformação de uma área de grande repulsa por parte da população que a considera foco gerador de epidemias.

${ }^{420}$ TRAJANO FILHO, Francisco Sales. A cidade das sete necessidades. João Pessoa, 2003 (Mimeo), s/p.

${ }^{421}$ BRITO, Francisco Saturnino R. de. "Saneamento de Parahyba do Norte". Obras Completas. Volume 5. Rio de Janeiro: Imprensa Oficial, 1943, p.292.

${ }^{422}$ Ibid. 


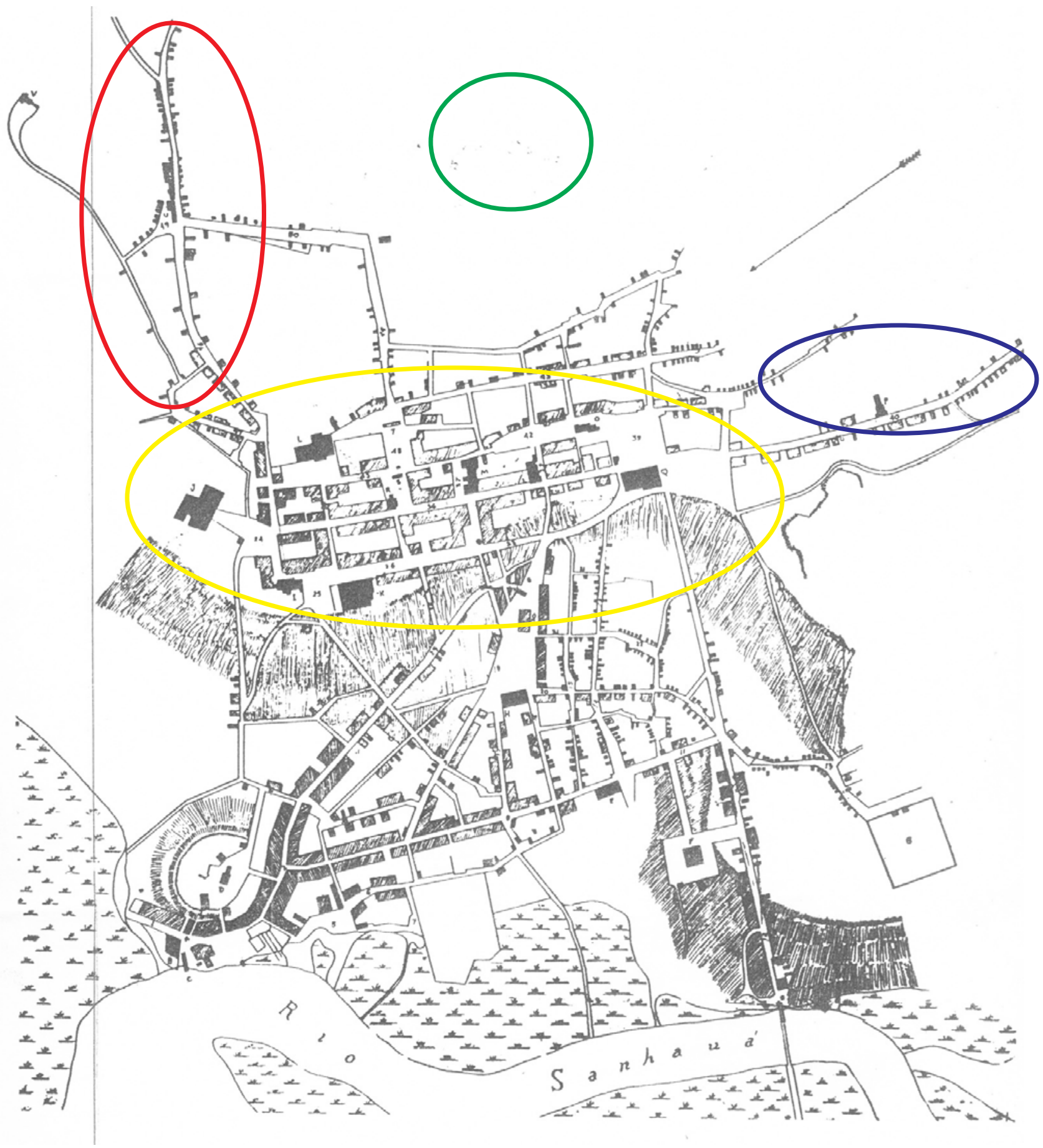

Planta da cidade da Parahyba levantada em 1855 por Alfredo de Barros e Vasconcelos, $1^{\circ}$ Tenete do Corpo de Engenheiros, e reduzida em 1904. Fonte: Aguiar, Wellington. Cidade de João Pesso: a memória do tempo. João Pessoa: Idéia, 1993.O mapa mostra a capital paraibana na segunda metade do século XIX. A região marcada de amarelo corresponde à área de implatação da cidade, com característica regular, tendencialmente ortogonal. Anterior a essa área está a parte baixa, desenvolvida a partir do crescimento urbano para a região portuária. Essa região é marcada por quarteirões 'irregulares', sem a ocupação no meio da quadra. Acima da região marcada de amarelo está a área que sinaliza a expansão futura, marcado pela região das Trincheiras (vermelho) e Tambiá (azul). A configuração dessas duas áreas revelam a esquiva do traçado em seguir a direção do crescimento que vinha sendo desenvolvido anteriormente, apresentando vazia a área da Lagoa (verde), que não consta no mapa, como elemento constituinte da cidade. 
Nesse plano, a Lagoa é adotada pelo engenheiro como um dos pontos centrais do sistema sanitário proposto. Apesar da população se esquivar em utilizar essa região, Brito, em 1913, encontra em suas proximidades algumas ruas povoadas formadas por casebres. Nessa área ele propõe a abertura de muitas outras ruas e algumas avenidas, cujos calçamentos, ao impermeabilizarem o solo, aumentam o volume das águas da chuva que já convergem para a lagoa. Apesar de indicar uma certa regularidade para algumas áreas existentes, nas imediações dessa lagoa Brito propõe uma expansão baseada em quadras triangulares, adaptadas à topografia dessa região, o que ele chama de "traçado sanitário" ${ }^{232}$. A Lagoa dos Irerês é convertida no reservatório regularizador caudal de uma galeria de condução das águas pluviais, na qual, a partir da construção do túnel de 405m de extensão, dá-se o esgotamento dessa área da cidade, com o encaminhamento desse material até as margens do rio Sanhauá.

Além de ser tomada como parte integrante do sistema de esgotos da cidade, nesse projeto a Lagoa è designada para desenvolver também o papel de parque urbano. Às suas margens, Brito propõe "taludes revestidos de cimento armado, até uma certa altura, e depois gramado"424, além de um bosque e jardins marginais, promovendo o saneamento e o embelezamento do lago que, deste modo, deixa de ser "pezadello de todas as administrações que n'ella viam um perigo permanente, u'a ameaça constante á saude publica"425.

Apenas em 27 de dezembro de 1922, na administração estadual de Solon Barbosa de Lucena, é iniciada a execução do plano elaborado por Saturnino de Brito em 1913. As obras são concluídas em 24 de abril de 1926, no governo de João Suassuna, representando o fechamento do primeiro ciclo de reformas urbanas dessa capital. Imbuída de preocupações sanitaristas e de embelezamento, vinculando o verde dos espaços públicos à vitalidade urbana, é a essa administração que se deve a urbanização da Lagoa dos Irerês, transformando-a no parque urbano saneado e embelezado proposto por Brito e que, em homenagem ao governador do Estado, passa a se chamar Parque Solon de Lucena.

No período de quase uma década entre a elaboração e a execução do plano de saneamento, presenciase o primeiro ciclo de reformas dessa cidade, com grande transformação no seu espaço urbano. O crescimento que ocorre concomitante às intervenções não segue as indicações propostas por Brito em 1913, o que exige uma revisão e readaptação do projeto de saneamento antes de sua execução. Apesar dos ajustes necessários, a função sanitária da Lagoa e seu papel de parque urbano não são alterados.

A implantação do sistema de saneamento transforma as ruas dessa capital em imensos canteiros de obra, onde se destacam as construções do túnel que liga a Lagoa ao rio Sanhauá, das galerias pluviais e do pavilhão sanitário sobre o poço de bombas nas proximidades desse rio. Porém, é a urbanização da Lagoa dos Irerês, empreendimento promovido pelo prefeito Guedes Pereira com intuito de convertê-la em um espaço limpo, verde e de farta utilização pela população, que encontra o maior destaque nas obras de saneamento. $O$ sentido negativo sempre agregado a esse espaço e as expectativas criadas a seu respeito pela divulgação das intervenções e pelas idéias de parque urbano dão ênfase a essa obra, impressionando a população talvez mais pela sua grandiosidade enquanto canteiro de obra, que pela sua transformação em espaço de uso público.

\footnotetext{
${ }^{423}$ BRITO, Francisco Saturnino R. de. "Saneamento de Parahyba do Norte". Obras Completas. Volume 5. Rio de Janeiro: Imprensa Oficial, 1943, p. 291

${ }^{424} \mathrm{Ibid}, \mathrm{p} .288$.

${ }^{425}$ IGNÁCIO, Joaquim. Notícia de uma viagem à Paraíba, em 1924. Mossoró, 1987, p. 9.
} 


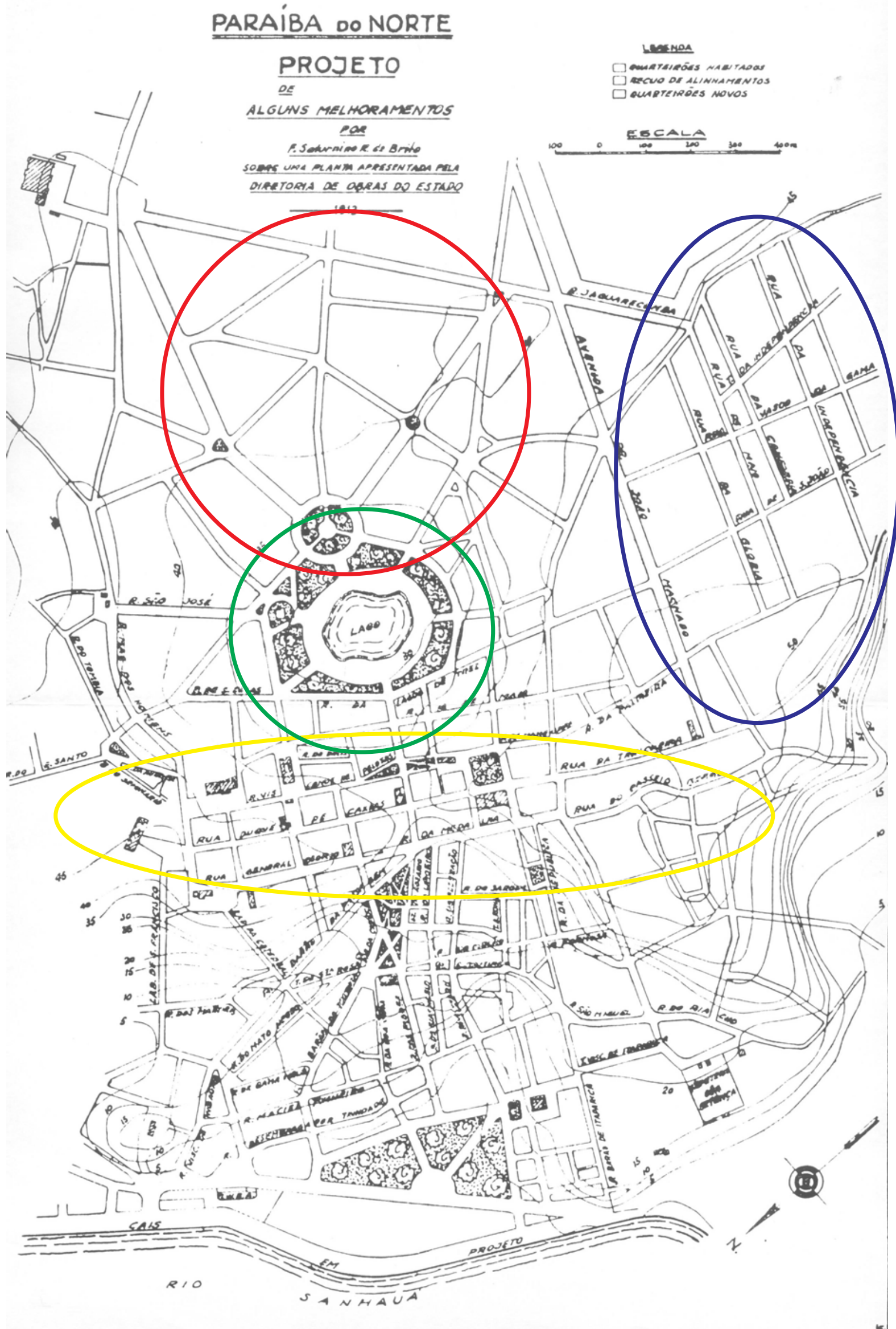

Plano elaborado por Saturnino de Brito para João Pessoa. Fonte: BRITO, Francisco Saturnino Rodrigues de. "Saneamento de Parahyba do Norte". Obras Completas. v. 5. Rio de Janeiro: Imprensa oficial, 1943. No mapa, marcado em amarelo está a área de implantação da cidade; em verde a lagoa, e acima dela, em vermelho, a área referente ao "traçado sanitário". À direita, está a parte ortogonal da malha, implementada no início do século XX e já consolidada à época da elaboração desse plano. 


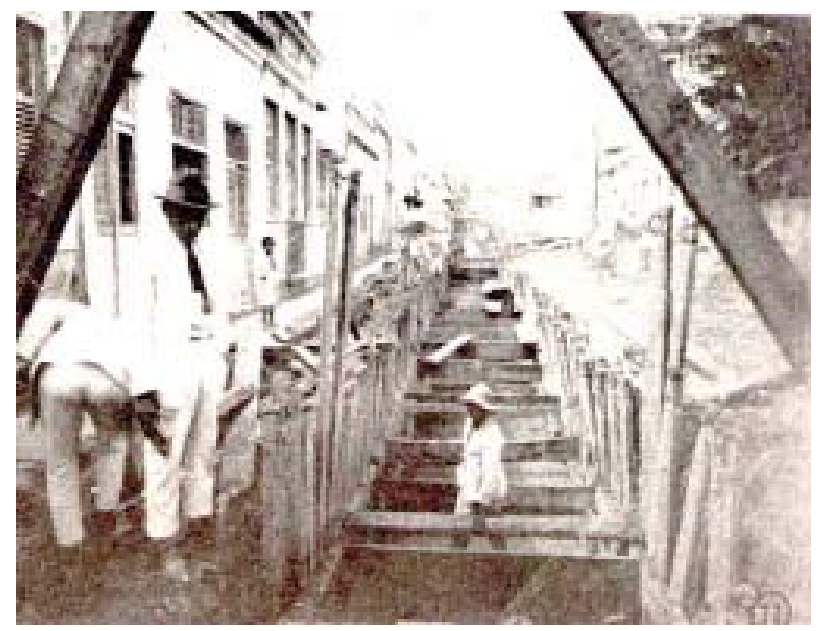

Construção do canal de drenagem. FONTE: Acervo Walfredo Rodrigues

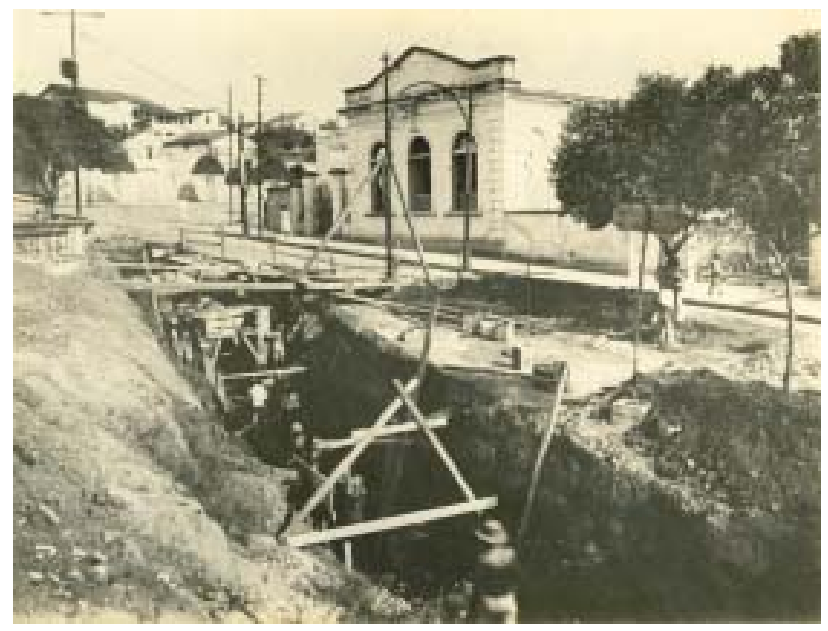

Obra de saneamento: construção do túnel. FONTE: Acervo Humberto Nóbrega.

A Lagoa é saneada, porém, mais importante que os melhoramentos estéticos, que como resultado final são pouco atraentes, o saneamento do parque reúne grandes significados, invertendo a relação entre esse espaço e a cidade, que deixa de repudiá-lo, não o relacionando mais a 'males urbanos', mas vinculando-o à salubridade, como peça central do sistema de saneamento da capital. Essa etapa constitui parte fundamental para a viabilização da inserção do parque na dinâmica urbana, que se consolida a partir de ações direcionadas à expansão e à modernização da aparência da cidade nos anos trinta.

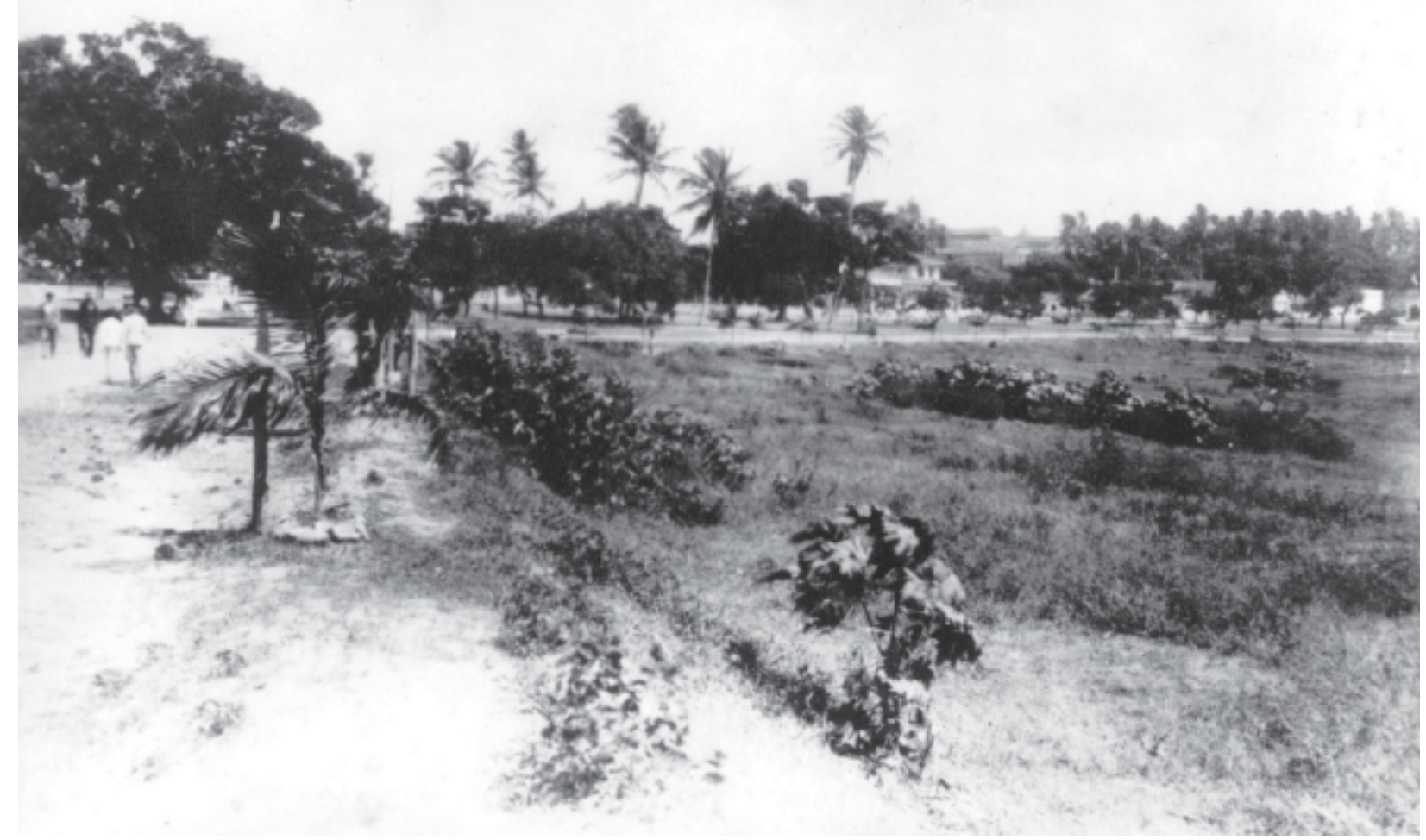

1928 - Parque Solon de Lucena. FONTE: Acervo Humberto Nóbrega 


\subsection{ANOS 30: O PARQUE COMO CORAÇÃO DA CIDADE FUTURA}

Diante do quadro urbano que a capital paraibana apresenta na década de 1930, revestido de preocupações viárias e expansionistas, colocando nas pautas urbanas o direcionamento e a ordenação do seu crescimento e estabelecendo intervenções no sistema viário e intenções de zonear a cidade, a Lagoa aparece mais uma vez como foco dessa discussão e peça importante das propostas de intervenções.

Um dos principais elementos do debate urbano desse momento é o Plano de Remodelação e Extensão da Cidade de João Pessoa, elaborado por Nestor de Figueiredo e contendo propostas de melhoramentos e de expansão da cidade. Nesse plano, o Parque Solon de Lucena assume papel fundamental, tornando-se mais uma vez elemento central de mais um ciclo de reformas urbanas dessa capital.

Nesse plano, Nestor de Figueiredo propõe intervenções na área da cidade já consolidada e demarca a área de expansão, onde concentra as principais propostas, com a criação de núcleos para as diferentes funções interligados por um conjunto viário. Na união dessas duas áreas, "cidade existente" e "cidade futura", está o Parque Solon de Lucena, que assume o papel de elemento articulador dessas duas regiões. Esse papel atribuído ao parque é marcado pela monumentalidade formal, apresentada principalmente pela conformação viária ao seu redor, que marca a diferença entre a cidade existente e a cidade que está para se construir, e pelos conjuntos arquitetônicos que enriquecem as perspectivas. Nesse sentido, o Parque é apontado pelo urbanista, ao apresentar sua proposta, como portal de entrada para a cidade futura. Nele estão o centro Municipal e uma parkway circular que penetra o parque, situando-se entre o lago e a área ajardinada e integrando o sistema viário do tecido urbano consolidado ao da área de expansão conduzida pela avenida Getúlio Vargas.

A questão estética é característica de muitos planos desse período, a exemplo do plano Agache onde esse ponto recebe destaque especial. Nele, assim como ocorre no plano de Nestor de Figueiredo para a capital parabaina, o sistema viário alia os valores de funcionalidade e embelezamento. As mesmas características apresenta o Plano de Avenidas elaborado por Prestes Maia para São Paulo, onde, ao longo das marginais do sistema de radiais-perimetrais, são previstos conjuntos monumentais como a nova estação central, instalações esportivas e indústrias. Seguindo os mesmos princípios é elaborado o plano do Recife, capital do estado vizinho, onde se percebe, segundo Cristina Leme, a "influência do urbanismo formal francês, e de Agache: seu aspecto maciço, cênico, com muitas perspectivas e visuais, avenidas em $Y$, praças e conjuntos monumentais e, sobretudo, a idéia de que o edifício forma a cidade" ${ }^{" 26}$.

À época do Plano de Nestor de Figueiredo para João Pessoa, o Parque Solon de Lucena, urbanizado na década anterior, pouco reflete em sua aparência o título e a função a ele conferidos. A execução do plano de saneamento não é suficiente para mudar seu aspecto pouco convidativo, visualmente resumido a uma lagoa tomada por mato e contornada por palmeiras imperiais que seguem um passeio de terra batida. Assim, mesmo saneado, o parque não é incorporado de imediato ao cotidiano urbano.

A má impressão acerca desse espaço, que permanece após o insucesso das vultosas obras nele realizadas em busca de transformá-lo em parque, reforça a necessidade de uma nova intervenção e a aceitação do plano elaborado por Nestor de Figueiredo, onde esse sítio é destinado a abrigar atividades de lazer. Por ser essa uma área considerada inadequada para a utilização pela população, a proposta do urbanista recebe críticas que apontam o parque ainda como um espaço longínquo e inviável para o abrigo de atividades urbanas diárias. Assim, as novas propostas para ele concebidas são encaradas como audaciosas, devido à inserção

${ }^{426}$ LEME, Maria Cristina da Silva (org) Urbanismo no Brasil 1895-1965. Salvador: Edufba, 2005, p. 401. 
do empreendimento em local "cheio de asperêzas naturais de terra abandonada" 427 .

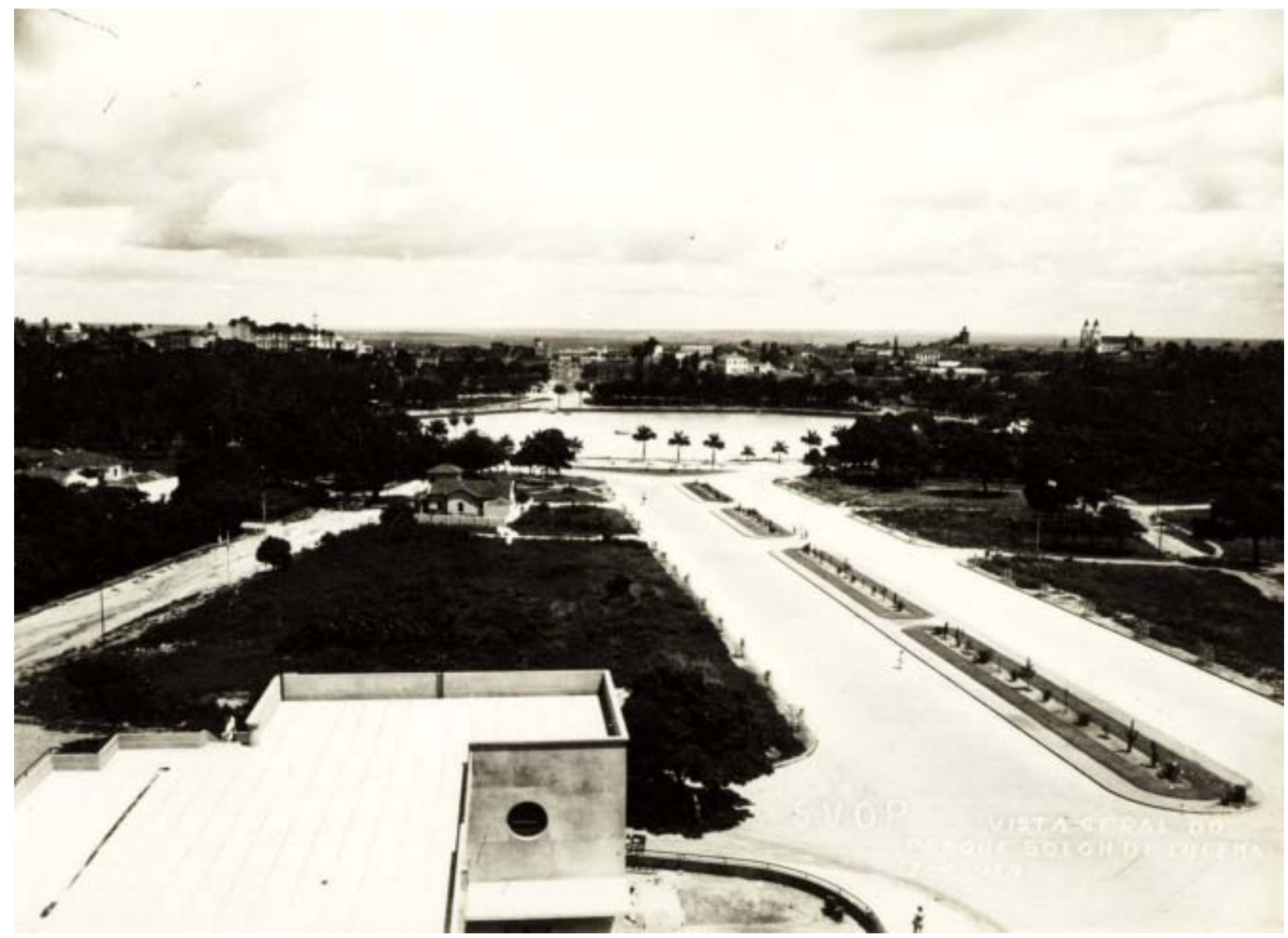

Parque Solon de Lucena visto do terraço do Edifício Central do Instituto de Educação. FONTE: Acervo Humberto Nóbrega. Recém implantados, o Instituto, o Parque, e a parkway - Avenida Getúlio Vargas, apresentam-se em uma área pouco construída, região ainda não consolidada enquanto espaço urbano, o que evidencia a intenção de direcionar sua expansão para essa área.

Mesmo assim, o Parque Solon de Lucena assume o papel de articulador das duas "cidades", ponto central de onde parte o novo sistema viário da capital a partir de um sistema de parkways para expansão em direção ao mar. Simbolizando o portal de entrada da cidade futura, é concebido pelo urbanista como "centro de irradiação" ou "centro de distribuição da cidade futura", assumindo essa posição quase que naturalmente, devido à configuração do crescimento urbano nas décadas anteriores. Esse "centro de irradiação" é formado pelo conjunto parquesistema viário que constitui o esqueleto do plano na zona de expansão, onde o espelho d'água da lagoa assume o papel de rotatória que conduz a via em direção à praia.

No mesmo período da elaboração do Plano de Remodelação e Extensão da Cidade de João Pessoa, onde é estabelecida a função viária da lagoa na distribuição dos fluxos e ampliação da cidade, articulando-a com a área já consolidada, outros projetos com características semelhantes são elaborados. Nesse sentido, pode-se citar o Avant Projet d'amenagement et extension de la ville de Niterói, tese de doutorado de Atílio Correia Lima, no Institut d'Urbanisme de Paris, onde, dentre outras pontos, propõe a construção de uma praça no centro da cidade de Niterói "com um sistema de circulação giratório que distribuiria de forma contínua o fluxo de carros"428. Outro exemplo é o Plano de Remodelação e Extensão da Cidade do Recife, também elaborado em 1932 por Nestor de Figueiredo, onde há a utilização de um espaço público de reordenação do sistema viário: "propôs um novo desenho para o bairro no qual a praça da Independência seria o centro de recepção e distribuição de tráfego"429.

\footnotetext{
${ }^{427}$ AS OBRAS de embelezamento da Capital. A União, N. 93, P.01-02, 28 br. 1938, ano XLVL, p.01.

${ }^{428}$ LEME, Maria Cristina da Silva (org) Urbanismo no Brasil 1895-1965. Salvador: Edufba, 2005, p. 384.

$429 \mathrm{Ibid}$., p. 401.
} 
Executado apenas no Governo de Argemiro de Figueiredo (1935-1945), o Plano de Remodelação e Extensão da Cidade de João Pessoa tem como concretização imediata basicamente o Parque Solon de Lucena e seus arredores. A execução dessa parcela do plano promove a integração da área da Lagoa à dinâmica da cidade e à utilização pública, transformando-a de fato em um parque urbano. Para sua reurbanização, é convidado pelo prefeito da capital Antônio Pereira Diniz, em 1935, o arquiteto George Munier. De provável origem e formação francesas e com atuação na cidade do Recife, ele elabora também uma proposta de reforma para o Parque Arruda Câmara. No Parque Solon de Lucena, Munier valoriza três dos seus elementos - o lago central, as palmeiras imperiais dispostas perifericamente e a avenida circular de contorno - que, para ele, designam o caráter do lugar e a feição pitoresca que ele busca reforçar.

Em sua proposta, delimita o espelho d'água do lago a partir de um muro de arrimo construído até o nível da avenida que o circula, no qual se fixa uma balaustrada de ferro. A criação de dois poços artesianos proporciona a regularização do espelho d'água que tem uma fonte ao centro. A imagem do parque por ele proposta é centralizada na circunferência do espelho d'água formada pelo muro de arrimo, a partir do qual estão situados, respectivamente, os seguintes elementos igualmente circulares e concêntricos: uma faixa de passeio para pedestres, as palmeiras circundantes e a avenida circular de contorno. Munier indica ainda, no entroncamento da avenida circular com a parkway que dela parte, "ponto altamente attractivo e esthetico "430 alguns equipamentos dentre os quais estão um coreto, uma sorveteria, um café e um restaurante.

Com algumas alterações, acrescentando e excluindo alguns elementos, a intervenção no Parque Solon de Lucena executada pela Diretoria de Viação e Obras Públicas (D.V.O.P.) parece ser a proposta por Munier, porém sem aqueles equipamentos no encontro das parkways. Isso se dá pela preocupação do governador Argemiro de Figueiredo em proporcionar para o Instituto de Educação, um dos ícones de sua administração, uma visão monumental do Parque, o que reforça a idéia da sua importância para a cidade naquele momento. Como o

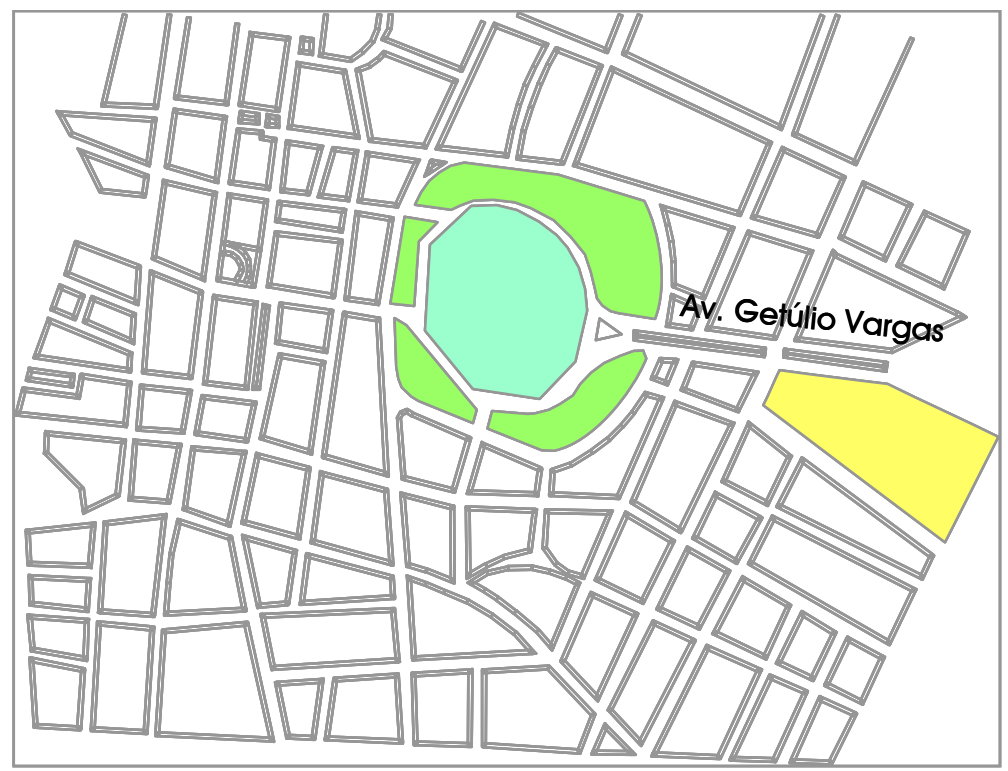

Mapa esquemático localiazando o Edifício Central do Instituto de Educação (amarelo) em relação ao Parque Solon de Lucena e a av. Getúlio Vargas. local de implantação do Instituto de Educação ainda é indefinido, opta-se por suspender a construção dos equipamentos do parque, evitando, dessa forma, futuros empecilhos em relação à construção de uma paisagem comum entre o parque e o prédio do Instituto.

No parque, sobre a superfície da laje de um reservatório construído para a lagoa e para abrigar o maquinário que jorra os jatos d'água da fonte, resolve-se implantar um bar e um dancing, idéia que remete, de certa forma, aos equipamentos propostos por Munier. A intenção se consolida na construção do Cassino de Verão, mais conhecido como "Cassino da Lagoa" mesmo sem nunca desempenhar tal função. Esse empreendimento é projetado por João Corrêa Lima, arquiteto-engenheiro formado pela Escola Nacional de Belas Artes e com

${ }^{430}$ George Munier, apud PREFEITURA MUNICIPAL DE JOÃO PESSOA. Mensagem Apresentada à Câmara Municipal de João Pessoa pelo prefeito interino, Dr. Oscar Oliveira Castro. João Pessoa: Imprensa Oficial, 1936, p.14. 
experiência em trabalho conjunto com Luís Nunes na Diretoria de Arquitetura e Urbanismo no Recife. Apresentando uma arquitetura moderna, o Cassino dialoga com seu entorno: o Instituto de Eduçação e a natureza dos espaços públicos de seus arredores. Trata-se de uma edificação cujo partido arquitetônico é definido pela estrutura formada por um conjunto de pilotis dispostos perimetralmente, nos quais se apóia uma laje plana, compondo um conjunto de características facilmente observadas mesmo na velocidade dos usuários das parkways.

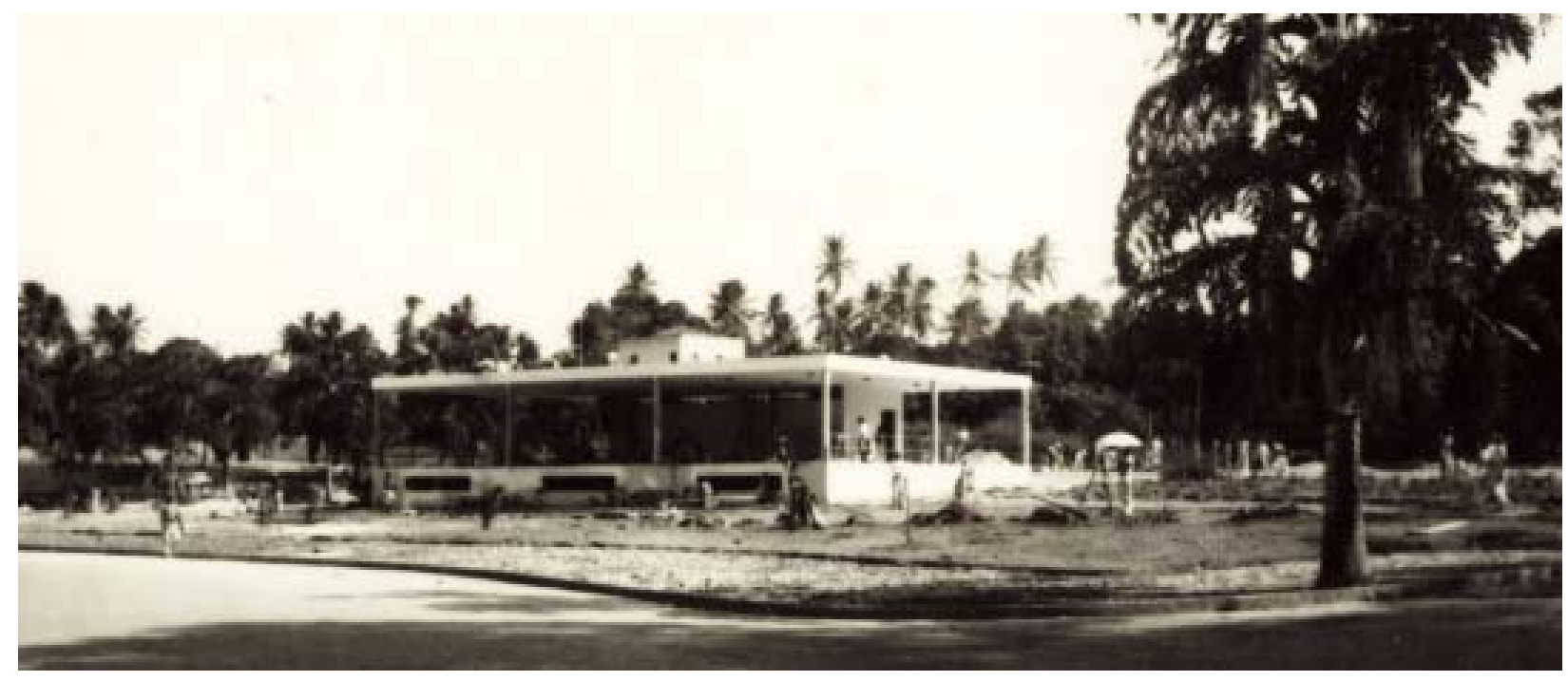

Cassino de Verão. FONTE: Acervo Humberto Nóbrega.
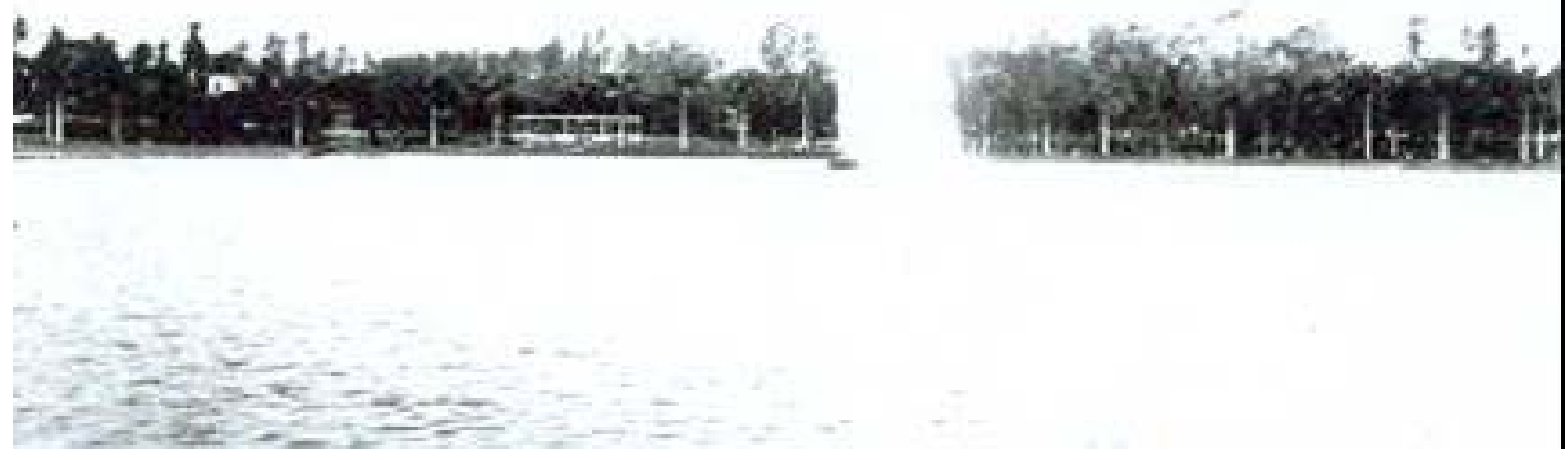

Fonte no centro do lago do Parque Solon de Lucena vista do terraço do Edifício Central do Instituto de Educação. FONTE: Acervo Humberto Nóbrega.

Em meio às comemorações do quinto aniversário do governo Argemiro de Figueiredo, no dia 25 de janeiro de 1940, são inaugurados o Cassino e as obras de melhoramento do Parque Solon de Lucena, inclusive com os trabalhos de ajardinamento realizados pela Prefeitura. Esse fato é testemunhado por uma multidão que nele se acomoda, concluindo, com esse marco, o segundo ciclo de reformas urbanas da capital paraibana.

Como resultado da obra, para o Parque Solon de Lucena converge uma perspectiva de acentuada monumentalidade, composta pelo cenário formado pelo Instituto de Educação e o percurso ascendente da parkway em sua direção. Essa via é inaugurada juntamente com o Instituto parcialmente construído - Edifício Central e Jardim da Infância - nas festividades em alusão ao aniversário natalício do presidente Getúlio Vargas, 
recebendo seu nome. O complexo edificado conforma, em meio ao clima de euforia e orgulho pela paisagem urbana em construção, um "conjunto empolgante, digno de uma urbs moderna que tem ânsia de embelezarse, crescer e ter mais intensa vida" ${ }^{\prime 31}$.

Dos empreendimentos de Argemiro de Figueiredo, certamente é a obra do Parque Solon de Lucena, juntamente com o Instituto de Educação, de certa forma a ele integrado, a realização alvo de maior repercussão. A Lagoa converte-se em uma das principais referências visuais da cidade, um dos seus cartões postais. A intervenção no parque proporciona grande respaldo ao governador devido ao grau de transformação pelo qual passa esse espaço em sua administração, refletindo na conjuntura total da cidade que está prestes a incorporar grandes mudanças relativas à sua delimitação urbana. A partir de então, desenrola-se um processo de espraimento do tecido urbano, possibilitado pela mudança da relação da cidade com a Lagoa, antes empecilho de crescimento urbano.

\title{
5.3 ENTRE O RIO E O MAR: A LAGOA E A EXPANSÃO DA CIDADE
}

\begin{abstract}
"O mar, que em três séculos e meio tinha o povo passando longe e ao largo, agora se transforma no grande centro de interesses e de lazer. O rio, que foi rota de sagas, de riquezas e até do rei, desce hoje solitário, o desprezo assoreando mais que a lama e o mangue"432.
\end{abstract}

Fundada às margens do rio Sanhauá em 1585, durante muito tempo a capital paraibana tem esse rio como seu meio de comunicação com outras terras. "Tudo dependia do rio. Dele se esperava desde o aviso da carga à bombarda inimiga" ${ }^{433}$. Para ele converge parte da dinâmica urbana e dele vem o nome da terra. Nele

"navegaram o índio, o colonizador fidalgo ou degredado, as armas, os mantimentos, os materiais de construção, inclusive as pedras trazidas do Rio de Janeiro para calçar a rua Direita, além de outros menos grosseiros. Suas águas mansas coalhadas de lama foram portadoras do açúcar, do fumo, de todas as cabotagens [pra lá] atraídas"434.

Ainda no início do século XX, a cidade mantém uma relação muito estreita com o rio, característica de sua fundação e que perdura por séculos, mesmo com o aumento da área urbana, como verifica o viajante do estado vizinho do Rio Grande do Norte, Joaquim Inácio que ao chegar à capital paraibana, em 1924, logo de manhã, flagra nas proximidades da estação de trem, a movimentação da área portuária e seu entorno.

A forte relação entre o rio e a cidade permanece até meados do século XX, período em que essa capital tem seu crescimento urbano lento e contido nas proximidades do Varadouro. Essa configuração geográfica contida é incentivada pela presença da Lagoa dos Irerês nos arredores da cidade, que, apesar de se situar na região mais favorável à expansão, constitui-se em obstáculo nesse sentido. Assim, sob pressão do pensamento higienista que Ihe atribui a responsabilidade pela disseminação de miasmas e epidemias, a Lagoa é um dos colaboradores para o retardo da expansão do tecido urbano da cidade de João Pessoa em direção ao mar.

\footnotetext{
${ }^{431}$ COM A INAUGURAÇÃO de importantes obras e serviços públicos, a Parahyba comemora hoje o $5^{\circ}$ aniversário do Govêrno Argemiro de Figueiredo. A União, n ${ }^{\circ}$ 19, 25 jan. 1940, p.3.

${ }^{432}$ RODRIGUES, Gonzaga. A cidade o Rio e o Mar. In Melo, José Octávio de A., e Rodrigues, Gonzaga. Paraíba, Conquista, Patrimônio e Povo. João Pessoa: Grafset, 1993, p.191.

${ }^{433}$ Ibid., p. 188

${ }^{434} \mathrm{Ibid}$.
} 
Esta passa "350 anos comprimida entre a colina e o rio, apertando a largura das ruas e das casas" ${ }^{435}$, esquivando-se da aproximação desse espaço.

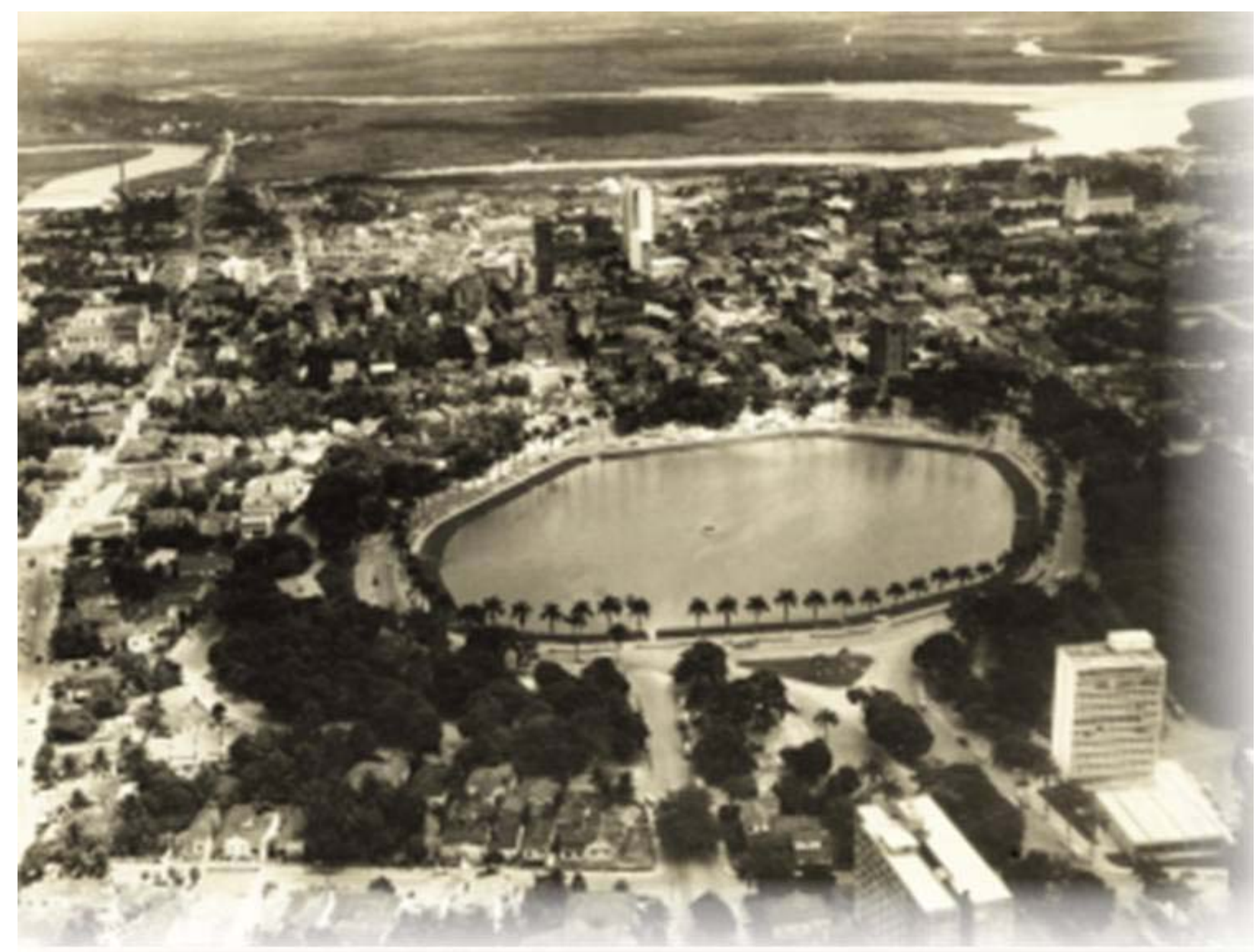

Vista aérea do Parque Solon de Lucena, apresentando a área entre o rio Sanhauá e o Parque, cujo processo de ocupação se consolidada apenas nos anos 30. FONTE: Acervo Humberto Nóbrega

O intenso empenho administrativo ao longo dos anos 20 e 30 em transformar a área de Lagoa em um ambiente agradável e inseri-la na dinâmica urbana, faz com que esse espaço seja urbanizado e transformado em parque urbano. Nesse processo, ela deixa de ser retentora do crescimento urbano para assumir o papel de canal distribuidor e propulsor da expansão da cidade. Assim, a Lagoa dos Irerês passa de área rejeitada a motivo de orgulho tanto por parte da administração como da população, reflexo da sua conversão em parque urbano saneado e 'moderno', "um dos mais aprazíveis logradouros da cidade"436.

Se até os anos 30 é o discurso higienista que guia as intervenções da cidade, sobretudo as relativas a esse logradouro, a partir de então é a questão expansionista que entra em pauta, abordando inclusive esse espaço de forma específica. Nesse período, a Lagoa assume o papel de vetor do processo de expansão urbana, impulsionando e direcionando o crescimento da cidade. Isso se dá a partir da sua inserção estratégica no plano viário, além do caráter monumental a ela atribuído, visível nas perspectivas formadas juntamente com as novas edificações que acentuam sua aparência "moderna", onde áreas "antigamente inhabitadas cobrem-se de prédios residenciais por força dos melhoramentos de iniciativa do poder público"ł37.

\footnotetext{
${ }^{435}$ RODRIGUES, Gonzaga. A cidade o Rio e o Mar. In: MELO, José Octávio de A., e RODRIGUES, Gonzaga. Paraíba, Conquista, Patrimônio e Povo. João Pessoa: Grafset, 1993, p.191.

${ }^{436}$ IGNÁCIO, Joaquim. Notícia de uma viagem à Paraíba, em 1924. Mossoró, 1987, p. 9.

${ }^{437}$ COM A INAUGURAÇÃO de importantes obras e serviços públicos, a Parahyba comemora hoje o $5^{\circ}$ aniversário do Govêrno Argemiro de Figueiredo. A União, n. ${ }^{\circ}$ 19, 25 jan 1940, p.3.
} 


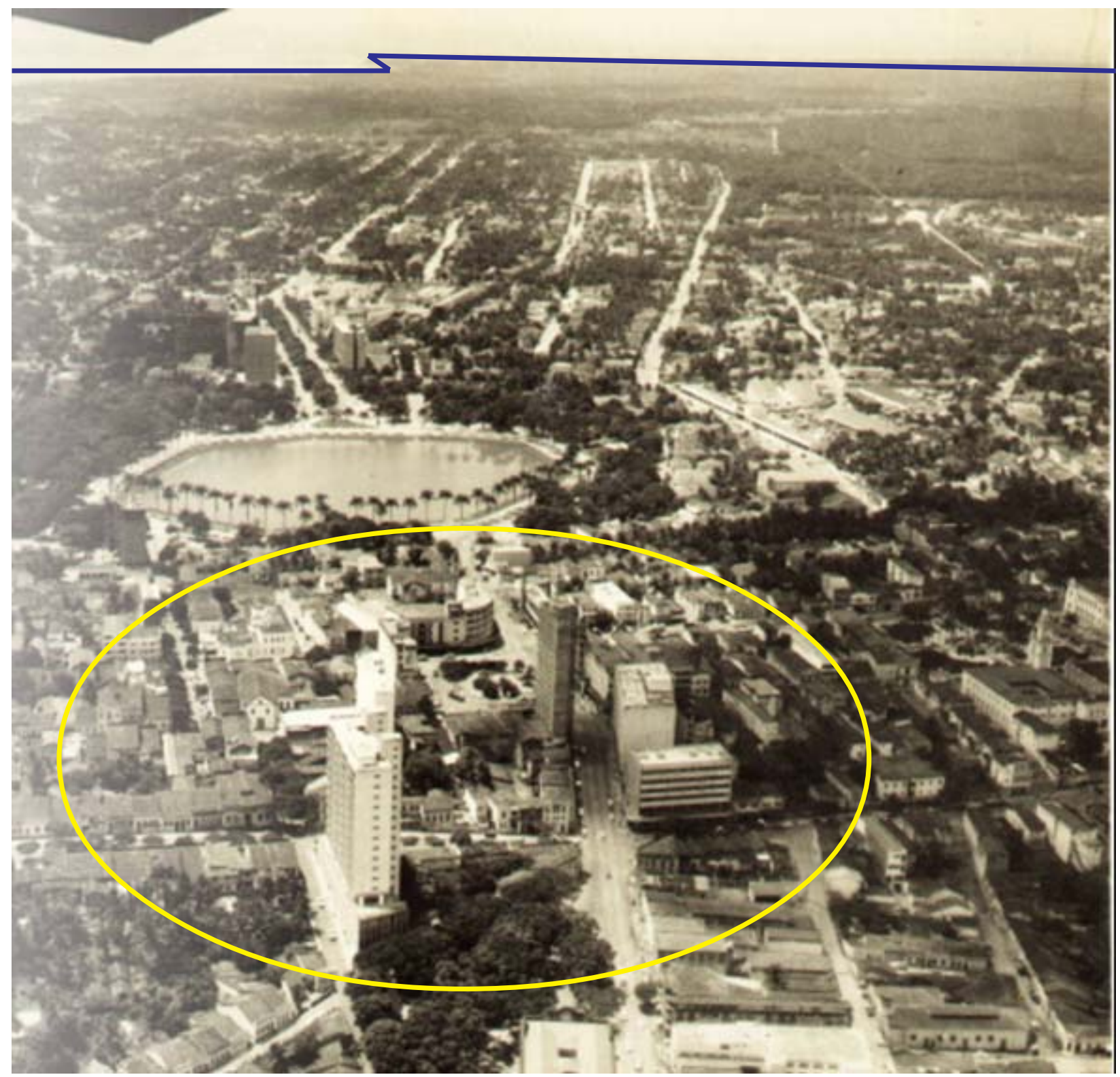

Vista aérea do Parque Solon de Lucena apresentando a área de concentração de edifícios altos e 'modernos' (em amarelo). Depois do parque até a linha do mar (em azul) é a área de expansão rapidamente ocupada após a consolidação desse espaço público como parte constituinte do tecido urbano. FONTE: Acervo Humberto Nóbrega.

Se até então a Lagoa está sempre em evidência, devido à sua imagem negativa, nesse momento ela passa a ser enaltecida pela sua imponência. No entanto, pouco dura seu papel como espaço de permanência ou parque urbano. Após vencê-la como barreira, a cidade a ultrapassa numa fração mínima do tempo necessário para atingi-la, pouco permanecendo o uso de seus arredores que perdem público para as áreas próximas ao mar. A partir da expansão por ela impulsionada, são formados bairros litorâneos e, "à consolidação do nosso extenso e não pouco deslumbrante litoral como local preferencial para o lazer, atraindo uma população que acorre em massa a seu espaço, somou-se em anos mais recentes os shoppings centers que têm constituído outro forte pólo de atração"438.

Com a consolidação da estrutura que possibilita o alcance às áreas praieiras, que são por si atrativos naturais, e a transposição do porto da capital para Cabedelo devido às suas características naturais para esse fim, a relação da cidade com o rio é modificada. Atividades urbanas passam a se deslocar para a região litorânea e a área central da cidade, sobretudo nas proximidades do rio Sanhauá, perde funções e prestígio.

${ }^{438}$ TRAJANO FILHO, Francisco Sales. "A Lagoa no centro das atenções" Revista do I.A.B/PB, n.3, set 2002, p. 5. 


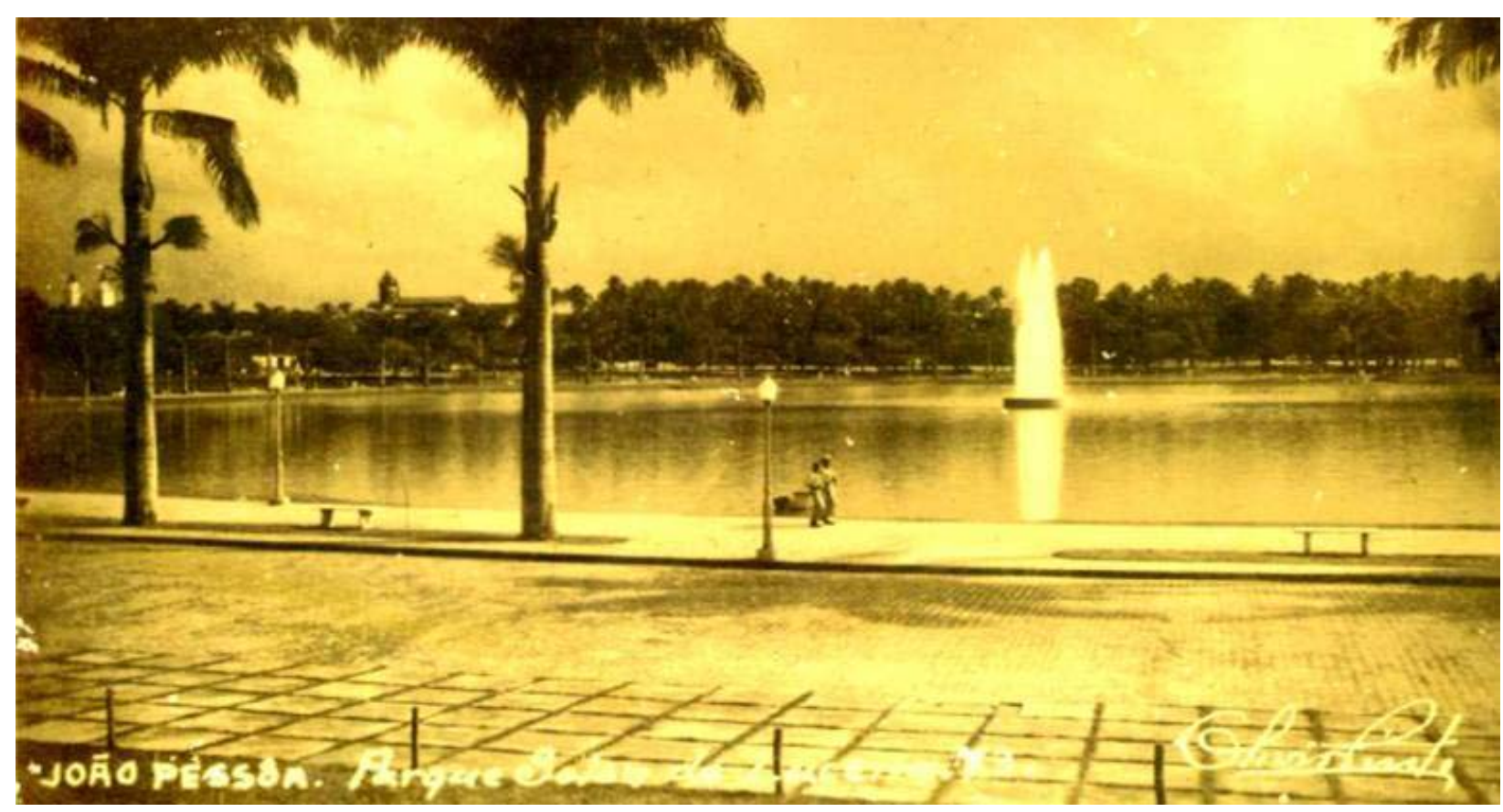

Parque Solon de Lucena. FONTE: Acervo Fotográfico IHGP.

Apesar da transformação do tipo de atividade na área central, o Parque Solon de Lucena, que não se consolida enquanto parque, firma-se de fato como ponto principal do sistema viário da cidade, articulando as diversas regiões do tecido urbano. Ele assume a função de ponto de convergência das principais artérias do sistema viário, recolhendo diariamente a população que se desloca ao centro da cidade e atuando, ainda hoje, como vetor de distribuição do transporte coletivo da cidade, que em sua maioria tem essa área como rota obrigatória.

Quanto à sua utilização, ele concentra as atividades relacionadas à dinâmica comercial característica de seus arredores. Configurado como lugar de passagem e não de permanência, a área do parque abriga atualmente as atividades de comércio informal, estacionamentos, comercialização de veículos e prostituição noturna.

Desta forma, após o longo processo para que a cidade absorvesse a Lagoa como parte do seu tecido urbano, ela é rapidamente ultrapassada e deixada para trás, o que transforma as características e atividades para ela planejadas. Nesse processo, a dinâmica urbana dá as costas para o rio, até então seu referencial, expandindo-se para a área praieira e conquistando áreas muitas vezes mais extensas que o núcleo original.

Como muitas cidades brasileiras hoje litorâneas, a cidade de João Pessoa exemplifica as de implantação portuguesa, que se abrigam em braços de rios, regiões de certa forma "escondidas". Com o tempo, os centros urbanos assim implantados encaminham-se para o mar, alterando na sua configuração em relação à natureza de sua implantação. Apesar desse ser um processo comum a muitas de nossas cidades hoje praieiras, é importante ressaltar o papel da Lagoa dos Irerês nesse trajeto percorrido pela capital paraibana, mostrando suas peculiaridades.

\subsection{O PARQUE NO CENTRO DAS ATENÇÕES}

Se ao longo da formação da cidade de João Pessoa a existência de uma lagoa situada a leste do núcleo urbano original, estabelecido ao final do século XVI como sede da Capitania da Parahyba, aparece ocasionalmente nas pautas das preocupações higienistas acerca dessa capital, atualmente esse espaço 
ainda permanece alvo das propostas urbanas paraibanas. Sua presença constante nos discursos e intervenções ao longo dos seus 420 anos de fundação reafirma sua estreita relação com essa cidade.

Desenvolvendo-se num percurso em que, muitas vezes, as discussões e ações relativas à cidade enfatizam necessariamente esse lugar específico, numa relação que transcende o aspecto meramente funcional, o Parque Solon de Lucena é revestido de sentidos simbólicos, culturais e históricos. Com o espraiamento do tecido urbano, a cidade abre mão das funções e significados de muitos de seus espaços públicos, os quais não resistem ao tempo nem às mudanças estruturais, tanto urbanas como sociais, consolidadas no novo estilo de vida aos poucos incorporado ao cotidiano da capital.

Recentemente, esse Parque sofre novos questionamentos por parte da população e da administração local acerca da sua função e benefício à cidade. As indagações relativas a esse debate resultam na organização de um fórum municipal - A Lagoa no centro das atenções - realizado no ano de 2001 para discutir o futuro desse espaço que, "no centro das atenções", suscita idéias e reune propostas, cujos conteúdos revelam tanto o desconhecimento quanto à desconsideração da importância que esse lugar assume ao longo da história da cidade, refletido inclusive nas funções que ele condensa em relação à configuração da cidade atual.

Apesar de participar do cotidiano da população que de alguma forma utiliza a área central da cidade, a superficialidade com que esse espaço é tratado fica patente não só pelas idéias de intervenção propostas nesse evento, dentre as quais se cogita inclusive o seu aterramento, como também pelo estado de inércia no qual a questão se acomoda com o passar do tempo, não se constatando resultados concretos do debate que, quando não esquecido, é apenas vagamente comentado como um fato passado. Se o que inquieta a cidade em relação a esse espaço, proporcionando tal discussão, é o odor ocasionalmente dele exalado ou o tipo de atividade ora nele desenvolvida (prostituição e comércio informal), o que parece ter ficado à margem do debate é o reconhecimento dos significados a ele aderidos ao longo do tempo.

A história da transformação da Lagoa dos Irerês no atual Parque Solon de Lucena congrega questões pelas quais passam os demais espaços públicos da cidade. Atrelado à história dessa capital desde a sua fundação, o Parque se constitui em um objeto de leitura das reformulações urbanas, expressando ao longo de sua história as preocupações que permeam a construção da cidade, ora enfaticamente sanitárias, ora quase que exclusivamente estética, expansionista eviarista. 


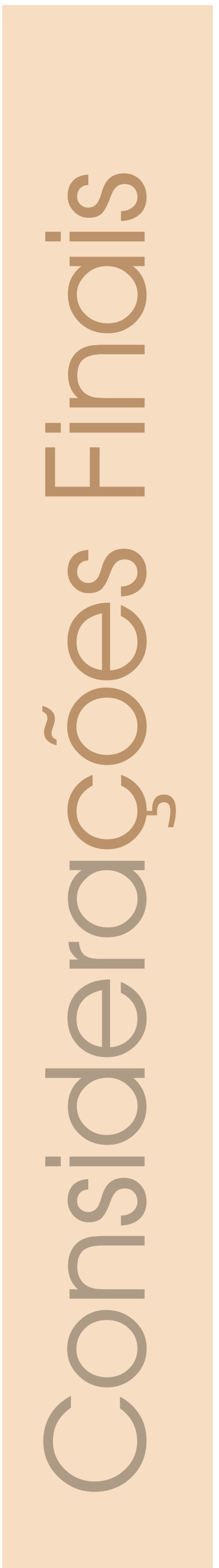




\section{Considerações Finais}

Os primeiros estudos sobre a transformação dos espaços urbanos brasileiros na primeira metade do século XX proporcionam uma ampla divulgação das realizações arquitetônicas e urbanísticas produzidas no eixo Rio - São Paulo, o que as torna referências da história urbana. Posteriormente, o estudo de casos específicos em outras regiões mostra que aquelas idéias e práticas também se difundem em outras localidades, disseminadas por profissionais que trabalham em diferentes cidades do país.

Esse estudo da trajetória urbanística da capital paraibana através da transformação de seus espaços públicos constata que os discursos e ações referentes à modernização dos seus espaços urbanos ocorrem de forma concomitante aos de outras cidades do país. Se em meados do século XIX o Tenente Henrique de Beaurepaire Rohan, governador da Paraíba, altera parte da estrutura da capital desse estado segundo conhecimentos e experiências adquiridas em sua atuação em diversas cidades do país, o período de 1910 a 1930 marca a cidade de João Pessoa com a presença de profissionais também atuantes em várias regiões brasileiras, consagrando um mesmo discurso e revelando soluções fundamentadas em princípios semelhantes. Tem-se a presença, nessa capital, de Saturnino de Brito, implementando um plano norteado por preocupações sanitaristas, e de Nestor de Figueiredo, guiado por demandas expansionistas e viárias.

Os períodos imperial e início da época republicana, apontados em alguns documentos e estudos como momento de desordem na maioria das capitais brasileiras e marcados por uma infra-estrutura inadequada alvo de inúmeras críticas, revelam-se, nessa pesquisa, como parte de um processo contínuo de transformação urbana, que culmina em grandes intervenções no século XX. Apesar de apresentar poucas alterações formais e nos usos dos espaços públicos - quando comparadas com as do século seguinte -, o período oitocentista é essencial para o desencadeamento das reformas urbanas. É um momento rico em críticas e sugestões acerca da organização da cidade, com questionamentos a respeito do seu funcionamento e da sua aparência. As ações desse momento são iniciativas para o melhoramento e a adaptação da estrutura citadina às novas necessidades, mostrando um processo gradativo de reformulação que se intensifica no século XX e não uma ruptura com uma 'inércia' em relação à 'estrutura colonial' a partir da década de 1910, como muitas vezes interpretado. O alinhamento de vias, não necessariamente sua retificação, a implantação de platibandas, o levantamento da cidade através de mapas e descrições revelam a presença dessa preocupação, constituindose exemplos de elementos fundamentais dessa etapa urbanística que impulsionam os ciclos de reformas concentrados entre as décadas de 1910 a 1930.

A relação inaugurada nesse momento entre o discurso urbano e a população, através dos meios de comunicação, apesar de ainda incipientes, torna-se fundamental para a concretização de uma das facetas das intervenções urbanas, que é a reformulação dos usos dos espaços públicos a partir da alteração do cotidiano e dos hábitos de seus usuários. É também um momento de envolvimento da população com as questões urbanas em debate e com seus reflexos nas ações administrativas, efetivando a relação das novas formas vinculadas a novos usos e inovando, gradativamente, os modos de apropriação dos espaços públicos. 
As formas, os usos e as denominações dos espaços públicos da cidade de joão Pessoa, em todo o período estudado, encontram-se fortemente vinculados através de uma interferência mútua, guiada principalmente por questões estéticas, de salubridade e de circulação. O desmonte de "velhos" usos e formas é gradativamente apresentado por novas aparências que respondem às reivindicações formadas e reforçadas ao longo desse trajeto, anunciado também pelas novas denominações atribuídas a esses espaços. Os nomes traduzem esse processo de transformação, mostrando as mudanças referentes a cada época, bem como as permanências que resistem aos novos ideais. Inicialmente, a toponímia explica, muitas vezes, a identidade do lugar, traduzindo-o verbalmente. Ao longo das intervenções, perde-se essa característica. O nome não provém mais das especificidades do lugar a quem ele se refere, mas passa a ser reflexo, sobretudo, de questões outras, revelando novos conceitos urbanísticos e homenageando pessoas ilustres ou datas históricas.

Na capital paraibana, esse processo de transformação dos espaços públicos, aqui interpretado através da dinâmica de suas formas, seus usos e suas denominações, mantém uma relação com a expansão do tecido urbano. Na ocupação das terras da 'cidade alta' até a área portuária estão os espaços que guardam características dos tempos da Colônia e do Império em relação às suas aparências, aos seus modos de ocupação e aos seus nomes, a exemplo dos largos, pátios, travessas e becos, interligados por uma trama que se adapta ao relevo, distanciando-se, por esse motivo, da ortogonalidade. As vias estabelecidas no alinhamento das casas e pela topografia caracterizam a malha urbana que se constrói até fins do século XIX. As formas dos espaços públicos desse momento, sejam eles pátios, largos ou campos, relacionam-se com esse traçado estabelecido, evidenciando-se, muitas vezes, pelas edificações que os circundam. As igrejas e os sobrados vinculados à administração pública são os elementos arquitetônicos de maior interferência na composição formal desses espaços públicos, cuja conformação física proporciona flexibilidade no seu uso, por se constituírem áreas amplas e homogêneas, apropriadas para festas, feiras, jogos e outras atividades.

Com a intensificação das intervenções higienistas já presentes na época imperial e as inovações estéticas, parte da área urbana então consolidada e seus arredores são realinhados e dotados de praças. Esses novos espaços públicos têm sua estrutura física associada às atividades que passam a abrigar, através de coretos, jardins, passeios e equipamentos esportivos. Suas formas inovadoras abrigam novas atividades revestidas de novos conceitos de saúde e moda inseridos nos hábitos cotidianos. A mulher passa a participar ativamente das atividades urbanas e as novidades inseridas nesses espaços selecionam seus usuários, preservando a elite do restante da população. No entorno das praças, erguem-se novas construções administrativas que influenciam na aparência da cidade, anunciando novos conceitos estéticos onde não mais a arquitetura eclesiástica é a fachada principal. Tornando-se elementos representativos desse momento e com o nome de praça anunciam novos conceitos de espaço público.

A capital paraibana amplia sua trama urbana a partir de interesses expansionistas onde avenidas largas, retas e ortogonais, interligadas ao Parque Solon de Lucena e em contraste com as áreas já consolidadas definem duas áreas: a 'cidade existente' e a 'cidade futura'. A questão da circulação e a intensificação do verde na cidade conduzem à formação dos espaços públicos desse momento, anunciados por parques e avenidas-parque. Essas últimas são elementos produzidos para passagem e velocidade, idealizados a partir de um plano viário. O automóvel se sobressai na utilização dessas áreas e a escala humana não corresponde, muitas vezes, à dos espaços públicos. A arquitetura produzida e vinculada a esses espaços é a moderna, com novos conceitos de funcionalidade e novos valores estéticos, produzida para ser vista na velocidade do automóvel.

Esse processo de transformação dos espaços públicos é norteado por planos implantados, mesmo que parcialmente. A expansão urbana vincula-se à especialização funcional prevista no plano de Nestor de Figueiredo, a exemplo da região onde se implanta a Universidade. A escala urbana amplia-se continuamente com a 
construção de avenidas que conduzem o tecido urbano para as praias. Com o espraiamento, a região central da cidade tem sua utilização reduzida. Os espaços públicos construídos anteriormente passam a ser utilizados de modo novo - com comércio informal e estacionamento, como ocorre no parque Solon de Lucena -, parcialmente - a exemplo da praça João Pessoa, que passa a ser palco de reivindicações políticas esporádicas por situar-se em frente ao Palácio do Governo-, ou ainda são convertidos em locais de passagem - como a praça da Independência.

Nas novas áreas urbanas são construídos novos espaços públicos destinados, sobretudo, ao lazer, esporte e turismo. Alguns desses espaços são utilizados cotidianamente pela população residente nas suas proximidades, outros permanecem obsoletos. Apesar da implantação de praças nos diversos bairros da cidade, são os espaços públicos próximos às praias os de maior utilização, sejam ruas, praças ou a praia. Assim como ocorre no centro, a tendência das vias é de especializarem-se, observando-se ruas comerciais, de lazer, de serviços e voltadas para o turismo, essas mais concentradas na região praieira. Na praia de Tambaú, as ruas nas proximidades das praças Santo Antônio e Vicente Trevas, popularmente chamadas de "Feirinha de Tambaú" por abrigar uma feira de artesanato, constituem as mais utilizados para o lazer noturno, com bares, boates e restaurantes. Um das áreas de maior movimentação para lazer e esporte é o calçadão das praias de Tambaú, Cabo Branco e Manaíra. Nessa última, entre a avenida João Murício (beira-mar) e a rua Manoel Moraes, encontra-se uma das áreas mais utilizadas como praça na região, apesar de oficialmente não receber esse nome. Trata-se de uma quadra de esportes construída no leito da rua Manoel Morais, que tem seu último quarteirão, que antecede o calçadão da praia, inteditado para esse fim. Nela instala-se uma lanchonete e uma área pavimentada com bancos, caracterizando uma praça. O local é conhecido como "quadra de Manaíra" e recebe grande número de usuários no fim da tarde e em fins de semana, impulsionando também o uso de seus arredores. Nos bairros mais afastados dessa região e fora do trajeto centro-praia, a exemplo dos bairros dos Bancários e de Mangabeira, localizados na direção da Cidade Universitária, algumas praças se destacam pela utilização da população local. Porém, é muito comum que esses usuários também se desloquem para os espaços públicos da região praieira, sobretudo nos fins de semana.

Nota-se, portanto, nessa trajetória dos espaços públicos da cidade de João Pessoa, mudanças significativas de forma, escala, uso e maneiras de nomear estes lugares. Neste processo, alguns espaços são reformados, outros suprimidos, outros criados. Alguns firmam-se como locais de passagem, outros como áreas de vivência atraindo comércio de rua e usuários que neles desenvolvem formas diversas de sociabilidade em bancos de praças, feirinhas de artesanato, play grounds, quadras de esportes, etc. Na segunda metade do século XX, a orla marítima firma-se como principal núcleo de espaços públicos de permanência, configurados pelas praias, por praças e ruas próximas. Embora absorvam grande número de usuários e tenham uma posição central no cotidiano da população local e na atividade de turismo, no plano simbólico ainda é muito forte o sentido que alguns espaços públicos - parques e praças - hoje considerados degradados e subutilizados assumem para os moradores. 


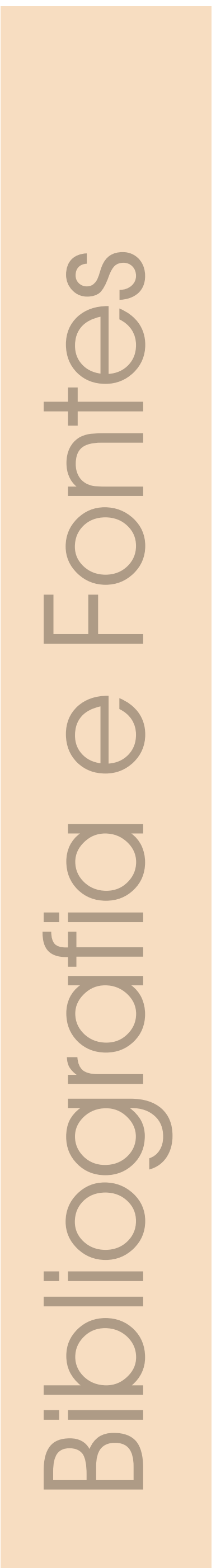




\section{Bibliografia e Fontes}

\subsection{Periódicos}

Almanach do Estado da Parahyba (1911 - João Pessoa)

A Philippéia (1905 - João Pessoa)

Era Nova (1921, 1924, 1925 - João Pessoa)

Illustração (1935 - João Pessoa)

Revista AU

Revista da Academia Paraibana de Letras, n8

Revista do Instituto Histórico e Geográfico da Parahyba

\subsection{Jornais}

Gazeta da Parahyba (João Pessoa, 1889 e 1890)

A República (João Pessoa, 1907)

A União (João Pessoa, 1910 a 1940)

3.3 Bibliografia

AGUIAR, Wellington, MELLO, José Octávio de A. Uma cidade de quatro séculos. Evolução e roteiro. $2^{\mathrm{a}}$ ed. João Pessoa: A União, 1989.

ALMEIDA, Horácio de. História da Paraíba. 3ª ed. João Pessoa: Ed. Universitária UFPB, 1997.

ALMEIDA, José Américo de. A Paraíba e seus problemas. 3ª ed. João Pessoa: A União, 1980.

ALMEIDA, Maria Soares de. Gestores da cidade e seus regulamentos urbanísticos. Porto Alegre de 1893 a 1959. In: LEME, Maria Cristina da Silva. Urbanismo no Brasil 1895-1965. São Paulo: Studio Nobel; FAUSP;FUPAM, 1999.

"De beco à avenida - as políticas públicas e a transformação do espaço morfológico: Porto Alegre na primeira metade do século XX". Anais Eletrônico do VII Seminário de História da cidade e do Urbanismo. Salvador: UFBA, 2002. 
ALMEIDA, Maurílio de. Presença de D. Pedro II na Paraíba. 2ª ed. João Pessoa, 1982.

ANDRADE, Carlos R. M. de. "Dar forma ao informe: o urbanismo e a crise da cidade moderna" In. GONÇALVES, M. F. O novo Brasil urbano: impasses, dilemas, perspectivas. Porto Alegre: Mercado Aberto, 1995.

. A Peste e o Plano: o urbanismo sanitarista do eng. Saturnino de Brito. São Paulo: FAU-USP, 1992 (Dissertação de mestrado).

"Camillo Sitte, Camille Martin e Saturnino de Brito: traduções e transferências de idéias urbanísticas". In RIBEIRO, L. C. Q. e PECHMAN, R. Cidade, povo e nação. Gênese do urbanismo moderno. Rio de Janeiro: Civilização Brasileira, 1996.

. "Saturnino de Brito, um projetista de cidades". Revista AU, N72, jun/jul 1997

ANDRADE, Francisco de Paula Dias de. Subsídios para o estudo da influência da legislação na ordenação e na arquitetura das cidades brasileiras. São Paulo, Escola Politécnica da Universidade de São Paulo,1966. (Tese de livre docência)

ANDRADE, Mário de. O Turista Aprendiz. Belo Horizonte,MG: Itatiaia, 2002.

. "Arquitetura Colonial". In: Arte em Revista. n.4, ago. 1980, pp.12-14

AQUINO, Aécio Vilar de. "O século XIX e a cidade". In: AGUIAR, Wellington \& MELLO, José Octávio. Uma Cidade de quarto séculos. Evolução e roteiro. João pessoa: Grafset,1985.

ARANHA, Gervácio Batista. "Seduções do moderno na Paraíba do norte: trem de ferro, luz elétrica e outras conquistas materiais e simbólicas" (1880-1925). In: AAVV. A Paraíba no Império e na Republica. Estudos de História Social e Cultural. João Pessoa: Idéia, 2003, p.47-78.

ARANTES, Otília B. F. Urbanismo em fim de linha e outros estudos sobre o colapso da modernização econômica. São Paulo: EDUSP, 1998.

ARAÚJO, Fátima. "A Paraíba na efervescência dos anos 20". Revista do Instituto Histórico e Geográfico

AUGÉ, Marc. Não-lugares: introdução a uma antropologia da supermodernidade. Campinas: Papirus, 1994

AVELAR Jr., Odilardo V. Política de combate a seca no Nordeste: uma ideologia para o planejamento regional. São Paulo: FFLCH-USP, 1994 (Tese de doutoramento).

AYMONINO, C. Origenes y desarrollos de la ciudad moderna. Barcelona, Gustavo Gili

AZEVEDO, Heloísa P. Lima. Estudo de desempenho dos espaços públicos para o pedestre: um estudo de caso no centro de Taguatinga. Brasília: UNB/URB, 1992.

BARONE, Ana Cláudia Castilho. Team 10: arquitetura como crítica. São Paulo: Prog. de Pós- Grad. FAUUSP, 2000. (Dissertação de Mestrado)

BARTALINI, Vladimir. Espaços livres públicos. O caso da praça do metro de São Paulo. Prog. Pós-Grad. Arquit. Urb. FAUUSP. São Paulo v.1 n.1 p. 11-22 dez. 1990

BATISTA, Juarez. Caminhos Sombras e Ladeiras. João Pessoa, A União, 1989.

BEGUIN, François. (1977) “As maquinarias inglesas do conforto”. Espaço e Debates, São Paulo, n.34, p.3954, 1991.

BENEVOLO, Leonardo. História da cidade. São Paulo: Perspectiva, 1983.

BERMAN, Marshall. (1982) Tudo que é sólido desmancha no ar: a aventura da modernidade. São Paulo: Companhia das Letras, 1986.

BONDUKI, Nabil. Origens da habitação social no Brasil. São Paulo: Estação liberdade, 1998 
BRESCIANI, Maria S. “As sete portas da cidade”. Espaço e Debates, São Paulo, n.34, ano XI, 1991.

.(org.) Imagens da cidade - séculos XIX e XX. São Paulo: Marco Zero, 1993.

"História e historiografia das cidades, um percurso". In FREITAS, M. C. (org.) Historiografia brasileira em perspectiva. São Paulo: Contexto; Universidade São Francisco, 1998.

BUENO, Beatriz P.Siqueira "Formação e metodologia de trabalho dos engenheiros-militares: a importância da 'ciência do desenho' na construção de edifícios e cidades “. In: TEIXERA, C. Manuel (coord.). A construção da cidade brasileira. Lisboa: Livros horizonte, 2004

BUENO, Beatriz Piccolotto Siqueira. “A Produção de um território chamado Brasil”. In: Laboratório Novo Mundo. São Paulo: Pinacoleca e Imprensa Oficial, 2004

CARVALHO, José Murilo de. Os Bestializados:o Rio de janeiro e a República que não foi. São Paulo: Cia das Letras, 1999.

CAVALCANTI, Itagiba. A cidade da Parahyba na época da independência: aspectos socioeconômicos, culturais e urbanísticos em volta de 1822. João Pessoa: Editora Universitária, 1972

CHALHOUB, Sidney. Cidade Febril: cortiços, epidemias na Corte Imperial. São Paulo: Companhia das Letras, 1996.

CHAUI, Marilena. "Público, Privado, despotismo". In NOVAES, Adauto (org.). Ética. São Paulo: Cia das Letras, 1992.

CHOAY, Françoise. (1965) O Urbanismo: utopias e realidades. uma antologia. 5 ed. São Paulo: Perspectiva, 1998.

CIUCCI, Giogio; DAL CO, Francesco; MANIERI-ELIA, Mario; TAFURI, Manfredo. La Ciudad Americana: de la guerra civil al New Deal. Barcelona: Editorial Gustavo Gili. S.A.

CORREIA, Telma de Barros. "A gestão do tempo e a organização da cidade moderna". Sinopses, São Paulo, n.33 p.22-32, jun 2000.

Pedra: plano e cotidiano operário no sertão. Campinas: Papirus, 1998. COSTA, Wilma P. da; DE LORENZO, Helena, C. (orgs.) A década de 1920 e as origens do Brasil moderno. São Paulo: Ed. Unesp, 1997.

da Paraíba. João Pessoa, n. ${ }^{0}$ 27, p. 77-79, 1995.

DEL BRENNA, Giovanna R. (org.) O Rio de Janeiro de "Pereira Passos": uma cidade em questão II. Rio de Janeiro: Index, 1985.

DICK, Maria Vicentina de Paula do Amaral. A Dinâmica dos Nomes na Cidade de São Paulo 1554-1897. São Paulo: Annablume, 1996.

FARIAS, Ana Maria S. M. Urbanização e modernidade: a construção do espaço urbano de João Pessoa (dos anos 20 aos anos 70). Recife: UFPE, 1997. (Tese de doutoramento)

FELDMAN, Sarah. As instituições de urbanismo no Brasil: espaços de intermediação entre pensamento e prática. Anais Eletrônicos do VII Seminário de História da cidade e do Urbanismo. Salvador: UFBA, 2002.

Planejamento e Zoneamento. São Paulo: 1947-1972. São Paulo: Editora da

Universidade de São Paulo/Fapesp, 2005

FERNANDES, Ana, GOMES, Marco Aurélio A de Filgueiras (org.). Cidade \& História - Modernização das cidades brasileiras nos séculos XIX e XX. Salvador: UFBA; Mestrado em Arquitetura e Urbanismo; ANPUR, 1992.

FERREIRA, Aurélio Buarque de Holanda. Novo Dicionário da Língua Portuguesa. Rio de Janeiro: Nova Fronteira, 1995.

FERREIRA, Lúcia de F. Guerra. Raízes da Indústria da Seca. O caso da Paraíba. João Pessoa: Editora da UFPB, 1993.

FERREIRA, William Rodrigues. O espaço público nas áreas centrais: a rua como referência - um estudo de caso em Uberlândia - MG, São Paulo, FFLCH-GE, 2002. (Tese de Doutorado). 
GALERIA NACIONAL. Vultos proeminentes da história brasileira. $2^{\circ}$ Fascículo. Editado pelo "Jornal do Brasil”. Rio de Janeiro, Officinas Graphicas do “Jornal do Brasil”, 1932. pp. 118 e 119

GORELIK, Adrián. La grilla y el parque. Espacio público y cultura urbana en Buenos Aires. Buenos Aires: Universidad Nacional de Quilmes, 1998.

GUIMARÃES, Berenice M. "A concepção e o projeto de Belo Horizonte: A utopia de Aarão Reis". In RIBEIRO, L. C. Q. e PECHMAN, R. (orgs.) Cidade, Povo e Nação: gênese do urbanismo moderno. Rio de Janeiro: Civilização Brasileira, 1996.

HALL, Peter. Cidades do amanhã. São Paulo: Perspectiva, 1995.

HARDMAN, Francisco Foot (org.). Morte e Progresso. Cultura brasileira como apagamento de rastros. São Paulo: Unesp, 1998.

.Trem Fantasma. A modernidade na selva. São Paulo: Companhia das Letras, 1988.

HERSCHMANN, Micael M. "A arte do operatório: medicina, naturalismo e positivismo - 1900-37". In A invenção do Brasil moderno: medicina, educação e engenharia nos anos 20-30. Rio de Janeiro: Rocco, 1994.

HERSCHMANN, Micael M., PEREIRA, Carlos A. M. "O imaginário moderno no Brasil". In A invenção do Brasil moderno: medicina, educação e engenharia nos anos 20-30. Rio de Janeiro: Rocco, 1994.

HOCHMAN, Gilberto. A Era do Saneamento. As bases da política de Saúde Pública no Brasil. São Paulo: Hucitec; ANPOCS, 1998.

HOWARD, Ebenezer. (1898) Cidades-Jardins de Amanhã. São Paulo: Hucitec, 1996.

JACOBS, Jane. Morte e vida das grandes cidades. São Paulo: Martins Fontes, 2000.

KOSSOY, Boris. Realidades e ficções na trama fotográfica. Cotia: Ateliê Editorial, 1999.

LE GOFF, Jacques. (1997) Por amor às cidades: conversações com Jean Lebrun. São Paulo: Unesp, 1998. LE CORBUSIER. Urbanismo. São Paulo: Martins Fontes, 1992

LEME, Maria C. da S. "A formação do pensamento urbanístico em São Paulo, no início do século XX". Espaço e Debates, São Paulo, n. 34, ano XI, p. 64-70, 1991.

"A formação do urbanismo como disciplina e profissão: São Paulo na primeira metade do século XX". In: RIBEIRO, Luiz César de Queiroz; PECHMAN, Robert (organizadores). Cidade, povo e nação: Gênese do urbanismo moderno. Rio de Janeiro: Civilização Brasileira, 1996.

.(coord.) Urbanismo no Brasil - 1895-1965. São Paulo: Studio Nobel; FAU-USP; FUPAM, 1999.

LEMOS, Carlos A. C. História da Casa Brasileira. São Paulo: Contexto, 1996.

LIRA, Bertrand de Souza. Fotografia na Paraíba. Um inventário dos fotógrafos através do retrato (1850 a 1950). João Pessoa: Editora da UFPB, 1997.

LIRA, José T. C. de. "Freguesias morais e geometria do espaço urbano". In BRESCIANI, Maria S. Palavras da Cidade. Porto Alegre: Ed. Universidade/ UFRGS, 2001.

. "O Urbanismo e o seu outro: raça, cultura e cidade no Brasil (1920-1945)". Rev. Bras. de Estudos Urbanos e Regionais, n.01, p.47-78, maio de 1999.

LORENZO, Helena Carvalho e COSTA, Wilma (org). A década de 20 e as origens do Brasil Moderno. São Paulo. Editora da UNESP, 1997.

LYNCH, Kevin. A imagem da cidade. Edições 70: Lisboa.

MAIA, Prestes, AZEVEDO, Washington. Relatórios dos Drs. Prestes Maia e Washington Azevedo sobre os trabalhos do Dr. Nestor de Figueiredo. Recife: Prefeitura do Recife e Livraria Imperatriz 
MARINS, Paulo César Garcez. Através da Rótula. Sociedade e Arquitetura Urbana no Brasil, séculos XVII a XX. São Paulo: Humanitas/FFLLCH/USP, 2001.

. "Habitação e vizinhança: limites da privacidade no surgimento da metrópole brasileira". In: SEVCENKO, Nicolau (org.) História da vida privada no Brasil. São Paulo: Companhia das Letras, vol. 3, 1998.

MARIZ, Celso. “A cidade de João Pessoa”.In: Anuário da Paraíba. João Pessoa: Imprensa Oficial, 1935. . Evolução econômica da Paraíba. João Pessoa: A União, 1978. Cidades e Homens. João Pessoa: A União, 1945.

MARTINS, Eduardo. “Instituições Paraibanas de Cultura - 1880/1941”. In: Revista da Academia Paraibana de Letras, n8, João Pessoa, A União, 1978, p 175/80.

. Peryllo Doliveira. Obra Poética. João Pessoa:A União Cia Editora, 1983.

MARX, Murilo. Cidades brasileiras - 1945. São Paulo: Melhoramentos: Ed. da Universidade de São Paulo,1980. MATOS, Maria Izilda Santos de. Cotidiano e cultura: história, cidade e trabalho. Bauru: EDUSC, 2002. MELLO, José Octávio de A. História da Paraíba - Lutas e resistências. João Pessoa: A União, 1994. Os coretos no cotidiano de uma cidade (lazer e classes sociais na capital da Paraíba). João Pessoa: Fundação Cultural do Estado da Paraíba, 1990.

MENEGAT, Elizete. "Espaço público e espaço urbano: uma ontologia tentativa”. In PPGAU/UFRN. ANAIS do $6^{\circ}$ Seminário de História da Cidade e do Urbanismo. Natal: 2000.

MENEZES, José Luís Mota. Algumas notas a respeito da evolução urbana de João Pessoa. Recife: Pool Editora, 1985.

MMA - Ministério do Meio Ambiente. Agenda 21 Brasileira - Cidades Sustentáveis. Brasília: Ministério do Meio Ambiente/ IBAM/ISER/REDEH, 2000

MONTANER, Josep Maria. A modernidade Superada. Barcelona: Editorial Gustavo Gili, S.A., 2001.

MONTEIRO, Alice de Azevedo. "Physionomia das Ruas". Illustração. João Pessoa, 15 set 19935, n. 3, s/p.

MOREIRA, Rafael. "AArte da Ruação e a Cidade Luso-brasileira". Cadernos de Pesquisa do LAP. Série Urbanização e Urbanismo. Jan - jun 03, n. 37. São Paulo, FAU- USP

MOREIRA, Fernando Diniz. A construção de uma cidade moderna: Recife (1909 - 1926). Recife: MDUUFPE, 1994. (Dissertação, Mestrado em Desenvolvimento Urbano)

MORRIS, A. E. J. (1979) Historia de la forma urbana: desde sus orígenes hasta la Revolución Industrial. trad. R. Bernet. 6 ed. Barcelona: Gustavo Gili, 1998.

MOURA NETO, Aníbal Victor de L. e, MOURA FILHA, Maria Berthilde de B e, PORDEUS, Thelma Ramalho. Patrimônio Arquitetônico e urbanístico de João Pessoa: um pré-inventário. João Pessoa, UFPB, 1985. (Trabalho Final de Graduação)

MUMFORD, Lewis. (1961) A cidade na História: suas origens, transformações e perspectivas. 4 ed. trad. N. R. Silva. São Paulo: Martins Fontes, 1998.

OLMSTED, Frederick Law. Creating Central Park 1857-1961. Baltimore: The John Hopkins University, 1983 OSELLO, Marcos Antônio. “Planejamento urbano em São Paulo: 1899-1961. Revista Projeto. n. 87, 1986 PECHMAN, Robert Moses. "Os excluídos da rua: ordem urbana e cultura popular". In: BRESCIANI, Stella (org.). Imagens da Cidade: Século XIX e XX. São Paulo: AnpuhD Marco ZeroD†Fapesp, 1994. 
PERROT, Michelle. "Maneiras de morar". In: História da Vida privada, Vol. 4. São Paulo: Companhia das Letras, 1991.

PESAVENTO, Sandra Jatahy. "Era uma vez o beco: origens de um mau lugar". In BRESCIANI, Maria S. Palavras da Cidade. Porto Alegre: Ed. Universidade/ UFRGS, 2001.

PINHEIRO, Heloísa P. Europa, França e Bahia:difusão e adaptação de modelos urbanos. Salvador: EDUFBA, 2002.

PINTO, Irineu F. Datas e notas para a história da Paraíba. $2^{\text {a }}$ ed. João Pessoa: Editora Universitária, 1977.

RAMÓN J., Gabriel. "Com a pátria nas paredes. A regularização da nomenclatura urbana de Lima (1861)". In BRESCIANI, Maria S. Palavras da Cidade. Porto Alegre: Ed. Universidade/ UFRGS, 2001.

REGATTI, Décio. "Apropriação social do espaço público - um estudo comparativo". Paisagem e ambiente: ensaios. São Paulo:n.7, p141-197, 1995.

REIS FILHO, Nestor Goulart. "A Perspectiva do Arquiteto sobre a Cidade". In: PECHMAN, Robert Moses (org.). Olhares sobre a cidade. Rio de Janeiro: Ed. UFRJ, 1994.

. "Sobre a história da urbanização - história urbana". Espaço e Debates, São Paulo, n. 34, ano XI, p. 15-17, 1991.

Contribuição ao estudo da evolução urbana do Brasil (1500-1720). São Paulo : Liv. Pioneira e Ed. da Universidade, 1968.

Quadro da arquitetura no Brasil. 7 ed. São Paulo: Perspectiva, 1995.

Imagens de vilas e cidades do Brasil colonial. São Paulo: FUPAM, 2000.

. "A Urbanização e o Urbanismo na Região das Minas". Cadernos de Pesquisa do LAP. Série Urbanização e Urbanismo. Jul-dez 99, n. 30. São Paulo, FAU- USP

REZENDE, Vera F. Plano e regulamentação urbanística: A dimensão normativa das intervenções na cidade do Rio de Janeiro. In: OLIVEIRA, Lúcia Lippi (org.). Cidade: história e desafios. Rio de Janeiro: FGV,2002.

RIBEIRO, Luiz C. Q. e PECHMAN, Robert (orgs.) Cidade, Povo e Nação: gênese do urbanismo moderno. Rio de Janeiro: Civilização Brasileira, 1996.

ROCHA, Maria Cristina. Imagens da cidade: a idéia de progresso nas fotografias da cidade da Parahyba (1870-1930). João Pessoa: UFPB, 1996. (Dissertação de Mestrado)

RODRIGUES, Gonzaga. "A cidade o rio e o mar". In: MELLO, José Octávio de A., RODRIGUES, Gonzaga. Paraíba, conquista e povo. João Pessoa: Grafset, 1993. 2ed.

RODRIGUES, Walfredo. Roteiro sentimental de uma cidade. $2^{\mathrm{a}}$ ed. João Pessoa, 1984.

ROLNIK, Raquel. "História Urbana: História na cidade?" In: FERNANDEZ, Ana e GOMES, Marco Aurélio A. de Filgueiras. (org.). Cidade e História: modernização das cidades brasileiras nos séculos XIX e XX. Salvador: UFBA, FAU/MAU, ANPUR, 1992.

(1997) A cidade e a Lei: Legislação, política urbana e territórios na cidade de São Paulo. 2 ed. São Paulo: Studio Nobel, FAPESP, 1999.

RYKWERT, Joseph. A sedução do lugar. São Paulo, Martins Fontes, 2004.

SÁ, Lenilde Duarte de. Parahyba: uma cidade entre miasmas e micróbios. O Serviço de Higiene Pública, 1895-1918. Ribeirão Preto: Escola de Enfermagem de Ribeirão Preto - USP, 1999. (Tese de doutoramento)

SALGADO, Ivone. "A modernização da cidade setecentista: o contributo das culturas urbanísticas francesa e 
inglesa". In: TEIXERA, C. Manuel (coord.). A construção da cidade brasileira. Lisboa: Livros horizonte, 2004

SANTOS, Paulo Ferreira. Formação de cidades no Brasil Colonial. Rio de janeiro: editora UFRJ, 2001.

SARMENTO, Cristiane Finizola. Sob o signo da modernidade: arquitetura oficial na Parahyba (19101924) João Pessoa, UFPB, 2000. (Trabalho de graduação)

SCHORSKE, Carl. E. Viena Fin-de-siècle. São Paulo: Cia das Letras, 1988, p. 81.

SEGAWA, Hugo. Ao amor do público: jardins do Brasil. São Paulo: Studio Nobel; FAPESP, 1996.

"Arquiteturas escolares". Revista Projeto, n. 87, 1986, pp. 64-65,

SENNETT, Richard. O declínio do homem público: as tiranias da intimidade. Trad. Lígia Araújo Watanale. São Paulo: Schwarcz, 1989.

SEVCENKO, Nicolau. 'As Muralhas Invisíveis da Babilônia Moderna” Óculum. Campinas: ano II, №1, agosto 1985.

. Literatura como missão. Tensões sociais e criação cultural na Primeira República. $4^{\mathrm{a}}$ ed.

São Paulo: Brasiliense, 1995.

SEVCENKO, Nicolau. "A capital irradiante: técnicas, ritmos e ritos do Rio". in: SEVCENKO, Nicolau. História da Vida Privada no Brasil. Vol. 3. São Paulo: Companhia das Letras, 2003, p. 513-619.

.O prelúdio republicano, astúcias da ordem e ilusão do progresso", in: SEVCENKO, Nicolau. História da Vida Privada no Brasil. Vol. 3. São Paulo: Companhia das Letras, 2003, p. 7-48.

SIEBERT, Claudia. A produção do espaço urbano de Blumenau a partir dos seus instrumentos de controle urbanísticos: 150 anos de história. Anais Eletrônicos do VI Seminário de História da cidade e do Urbanismo. Natal: UFRN, 2000.

SILVA, Antonio de Moraes. Diccionario da Língua portugueza dos vocabulários impressos ate' agora, e nessa segunda edição novamente emendado, e muito accrescentado. Lisboa: Typographia Lacérdina, 1813.

SIMMEL, George. "A Metrópole e a vida mental". In: VELHO, Otávio G. O Fenômeno Urbano. 4 ed. Rio de Janeiro, Zahar, 1979, p.11-25

SITTE, Camillo. A construção das cidades segundo seus princípios artísticos. São Paulo: Editora Ática, 1992.

SOMEKH, Nadia. A cidade vertical e o urbanismo modernizador. São Paulo: EDUSP; Estúdio Nobel; FAPESP, 1997.

SORIANO, Ana Gabriela Wanderley. Cenários Modernizados: os espaços públicos da Parahyba, 19161924. João Pessoa: Universidade Federal da Paraíba, 2001. (Trabalho final de graduação do curso de Arquitetura e Urbanismo).

SOUSA, Fabio Gutemberg Ramos. "Cristino Pimentel: a cidade e civilização em crônicas". In: AAVV. A Paraíba no Império e na Republica. Estudos de História Social e Cultural. João Pessoa: Idéia, 2003, p.79-132.

SOUTO, Jomar Moraes de. "Visão poética numa fundação". In: AGUIAR, Wellington \& MELLO, José Octávio. Uma Cidade de quarto séculos. Evolução e roteiro. João pessoa: Grafset,1985.

SOUZA, Célia Ferraz de. "O sentido das palavras nas ruas da cidade. Entre as práticas populares e o poder do Estado (ou público)". In BRESCIANI, Maria S. Palavras da Cidade. Porto Alegre: Ed. Universidade/ UFRGS, 2001. 
TEIXERA, C. Manuel (coord.). A construção da cidade brasileira. Lisboa: Livros horizonte, 2004

TELLES, Vera da S. A cidadania inexistente: incivilidade e pobreza. São Paulo: FFLCH/USP, 1992. (tese de doutorado)

. Direitos sociais: afinal do que se trata?. Belo Horizonte: Ed.UFMG, 1999.

TINEM, Nelci (org.). Fronteiras, marcos e sinais: Leituras das ruas de João Pessoa. João Pessoa: Ed. Universitária/ Prefeitura Municipal de João Pessoa, 2006

TRAJANO FILHO, Francisco Sales. D.V.O.P.: Arquitetura moderna, Estado e Modernização (Paraíba, década de 1930). São Carlos: Escola de Engenharia de São Carlos, 2003 (Dissertação de mestrado).

.Vanguarda e esquecimento: a arquitetura de Clodoaldo Gouveia. João Pessoa, UFPB, 1999. (Trabalho de graduação) A cidade das sete necessidades. João Pessoa, 2003 (Mimeo).

Prelúdio parahybano: modernização e espaço público em João Pessoa. In

PPGAU/UFRN. ANAIS do $6^{\circ}$ Seminário de História da Cidade e do Urbanismo. Natal: 2000.

VERNANT, J. P. Origens do pensamento grego. Rio de Janeiro: Bertrand Brasil, 1989.

VIEIRA, Frei Domingos. Grande Diccionario Portuguez ou Thesouro da Língua Portugueza. Porto: Casa dos editores Ernesto Chardon e Bartholomeu H. de Moraes,1871.

VILLAÇA, Flávio. Uma Contribuição à História do Planejamento Urbano no Brasil. Anais do III Seminário de História da cidade. São Carlos: EESC - USP, 1994.

WANE, Paul. "Etat de Parahyba” Au Brèsil: du Rio são Francisco à l'Amazone. Paris:E Gurindo, 1910.

\subsection{Fontes}

“A CONSTRUÇÃO de casas nesta capital pelo Instituto de Aposentadoria e Pensões”. A União, ago 1939, n. 183.

ALMEIDA, José Américo de. "A invasão do côco". Era Nova. n.25, 01 mai. 1922, s/p

ANNUARIO da Parahyba. João Pessoa: 1935.

AS CASAS de palha. A União, Parahyba, n 8, p1, 12 jan. 1

AS OBRAS de embelezamento de Capital. A União , n. 93, 28 abr. 1938, ano XLVI.1939, p.01

BEZERRA, Alcides. "A Imprensa na Parahyba” In: Revista do Instituto Histórico e Geográfico Paraibano. Vol.5, Parahyba, Imprensa oficial, 1922, pp 51- 56

BITTENCOURT, Liberato. "Parahybanos Illustres". Homens do Brasil. Vol II, Parahyba Livraria e papelaria Gomes Pereira, Editor, Rua do Ouvidor. N. 91 - RJ 1914

BRITO, Francisco Saturnino Rodrigues de. "Saneamento de Parahyba do Norte". Obras Completas. Volume 5. Rio de Janeiro: Imprensa Oficial, 1943.

“CARNAVAL", A União, 01 fev de 1940, n. 15, p.5

CAVALCANTI, Itagiba. "O 'Ponto de Cem Réis' “. Illustração, n.19, fev. 1936 p.23 e 24.

COM A INALGURAÇÃO de importantes obras e serviços públicos, a Parahyba comemora hoje o $5^{\circ}$ aniversário do Govêrno Argemiro de Figueiredo. A União, n 19, 25 jan. 1940. 
CONCEITOS da imprensa conterranea em torno do governo Argemiro de Figueiredo. A União, n. 312, p. 7, 28 jan. 1937.

CRUZ, João Claudino de Oliveira. "Melhoramentos da capital da Parahyba". Gazeta da Parahyba, n. 192, 9 jan. 1889, p. 01.

DANÍZIO, Paulo “Cidade dos Jardins. Uma idéa”. Era Nova, Parahyba, n. 78, mai. 1925, sD p.

"Refúgio dos que recordam". Era Nova, Parahyba, n. 89, out.. 1925b, sD p.

. "A praça que é o sorriso da cidade". Era Nova, Parahyba, n. 90, nov. 1925c, sD p.

mai. $1924, \mathrm{~s} / \mathrm{p}$. "Cidade dos Jardins. O silêncio dos sinos vencidos". Era Nova, Parahyba, n. 61

1924b, s/ p. "Cidade dos Jardins. A gente humilde da cidade". Era Nova, Parahyba, n. 64, jun. . "Cidade dos Jardins. Os grandes, os medios, os pequeninos". Era Nova, Parahyba,

n. 65 , jun. 1924c, s/p.

n. 66, jul. $1924 d, s / p$.

"Cidade dos Jardins. Quatro palavras a respeito de Mlle. Puresa". Era Nova, Parahyba, "Cidade dos Jardins. A mais pungente das cem mil dores anonymas da cidade". Era Nova, Parahyba, n. 71, dez. 1924e, s/ p.

DELORENZO NETO, A. A Codificação Municipal de João Pessoa. Rio de Janeiro: Serviço de Documentação. 1958.

D'OLIVEIRA, Matheus. "A edificação urbana". A Philippéia, Parahyba do Norte, ano I, n. 2, 9 jul. 1905.

DEPARTAMENTO DE ESTATÍSTICA E PUBLICIDADE DO ESTADO DA PARAÍBA. Realizações do Govêrno Argemiro de Figueirêdo. João Pessoa: Imprensa Oficial, 1939, s/p.

ESTADO DA PARAHYBA. Coleção de leis e decretos de 1918 - Actos dos Poderes Legislativo e Executivo. Parahyba: Imprensa Oficial. 1920.

Coleção de leis e decretos de 1919 - Actos dos Poderes Legislativo e Executivo.

Parahyba: Imprensa Oficial. 1921.

. Coleção de leis e decretos de 1916 - Actos dos Poderes Legislativo e Executivo.

Parahyba: Imprensa Oficial. 1917.

FALCÃO, Americo. "Ressurreição”. A União. Parahyba, n188, s/p 27 ago 1917

HERCKMAN, Elias. Descrição Geral da Capitania da Paraíba - 1939. João Pessoa: A União, 1982.

INÁCIO, Joaquim. Notícias de uma viagem à Paraíba. Mossoró: 1987.

"INSTRUÇÕES da Chefia de Polícia para o carnaval". A União, 01 fev de 1940, n. 15, p.3.

INTELLECTUAES Illustres. A União. Parahyba, n.24, 29 jan. 1929, ano XXXVII, p. 01

JARDIM, Vicente Gomes. "Monographia da Cidade da Parahyba do Norte". Revista do IHGP. João Pessoa, n.3, p.83-111, 1911

LEITE, Ascendino. Minha Cidade. Parahyba: Imprensa Oficial, 1935.

MACHADO, Antônio de Alcântara. "O modernismo da literatura de 1928", A União, Parahyba, n. 26, 31 jan. 1929, ano XXXVII, p. 01-02

MAGALHÃES, Josa."Urbanização de João Pessoa e Cabedelo". A União. João Pessoa, 15 mar 1932, n. 56 
MARTINS, Eduardo. "Instituições Paraibanas de Cultura" - 1880/1941". In: Revista da Academia Paraibana de Letras, n.8, João Pessoa, A União Cia. Editora, 1978, pp.175/80.

MEDEIROS, Coriolano de. "Carnaval de hontem, Carnaval de hoje”. Illustração, João Pessoa, n.20, fev. 1936.

MONTENEGRO, Alice de Azevedo. "A Cidade dos Jardins”. In: Anuário da Paraíba. João Pessoa: Imprensa Oficial, 1934.

O CONSELHO Municiapl da Parahyba decreta. A União, n8, p.2, 11 jan. 1918

O MONTEPIO dos Funcionários estaduaes vae iniciar a construcção do primeiro grupo de casas para os seus contribuintes. A União, 7 fev 1932, n. 30.

"O PLANO de Desenvolvimento Systematico desta Capital e da Villa de Cabedello". A União. João Pessoa, 4 fev 1932, n. 27.

"O QUE SERÁ de futuro a cidade de João Pessoa". A União. João Pessoa, 2 out 1932

PARAÍBA. Administrações dos interventores Anthenor Navarro e Gratuliano da Costa Brito. Decreos de $1^{\circ}$ de Janeiro a 30 de julho de 1932 - Actos do Interventor Federal. João Pessoa: imprensa Oficial, 1932. Decreto n.o 261, de 9 de março de 1932

PARAHYBA DO NORTE. Mensagem apresentada à Assembléia Legislativa do Estado, em 1917, pelo presidente do Estado Dr. Francisco Camilo de Holanda. Parahyba do Norte: Imprensa Oficial, 1917.

Mensagem apresentada à assembléa legislativa do Estado da Parahyba, na abertura da $4^{a}$ sessão ordinaria da $9^{a}$ legislatura, em $1^{\circ}$ de setembro de 1919 , pelo Dr. Francisco Camillo de Hollanda, presidente do Estado. Parahyba do Norte: Imprensa Oficial, 1921.

Mensagem apresentada ao conselho municipal da capital do Estado da Parahyba em dezembro de 1921, pelo prefeito Dr. Walfredo Guedes Pereira. Parahyba do Norte, Imprensa Oficial, 1921.

Mensagem apresentada à Assembléia Legislativa do Estado da Parahyba, na abertura da $1^{a}$ sessão ordinária da $9^{a}$ legislatura, a $1^{\circ}$ de março de 1924, pelo dr. Solon Barbosa de Lucena, presidente do Estado. Parahyba do Norte: Imprensa Oficial, 1924.

Mensagem apresentada ao conselho municipal da capital do Estado da Parahyba em 03 de abril de 1928, pelo prefeito João Maurício de Medeiros. Parahyba do Norte, Imprensa Oficial 1928.

Código de Posturas Municipais. Parahyba do Norte: Imprensa Oficial, 1928.

Mensagem apresentada à Assembéia Legislativa do Estado da Parahyba na abertura da Sessão Ordinaria de 1935 pelo governador Argemiro de Figueiredo. João Pessoa: Imprensa Oficial, 1935.

"PORTO DE Cabedelo". A União, João Pessoa, 12 jan 1932, n. 8, p. 1.

PREFEITURA MUNICIPAL DE JOÃO PESSOA. Mensagem Apresentada à Câmara Municipal de João Pessoa pelo prefeito interino, Dr. Oscar Oliveira Castro. João Pessoa: Imprensa Oficial, 1936.

PINTO, Irineu Ferreira. Datas e notas para a história da Paraíba. João Pessoa: Editora Universitária CCHLA-UFPB, 1977.

PIRAGIBE, Aderbal. "Carnaval de vinte annos passados...”. Illustração, João Pessoa, n.19, fev. 1936, p.1. RIBEIRO, Beatriz. “Rabiscos”. Illustração, João Pessoa, n.03, mai. 1935, p.21.

ROAHN, Beauripaire. Chorografia da Província da Parahyba do Norte.In: revista do Instituto Histórico e Geográfico Parahybano, ano III, vol. 3. Parahyba: Imprensa Oficial, 1911.

SANTOS, Alberto. “A vitrine da cidade”. Illustração, n.10, set. 1935, p.6.

TRAJANO FILHO, Francisco Sales. (Em)torno de um lugar: a Lagoa. Jornal do IAB. João Pessoa: set. 2002.p.4 e 5.

"URBANIZAÇÃo de João Pessôa e Cabedelo". A União. João Pessoa, 10 mar 1932, n. 56

VEIGA JÚNIOR, J. “O Café de Joça Aranha”. In: Illustração, n.03, p.23, 1935.

VIDAL, Adhemar. “Chonica”. Revista Era Nova. Parahyba, n.76, 01 abr. 1925. 


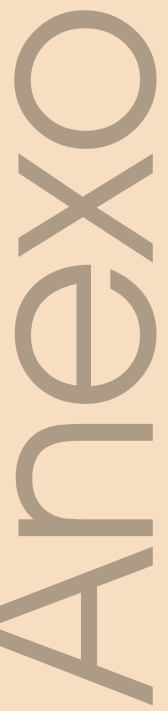


MAPA DA CIDADE - 1940

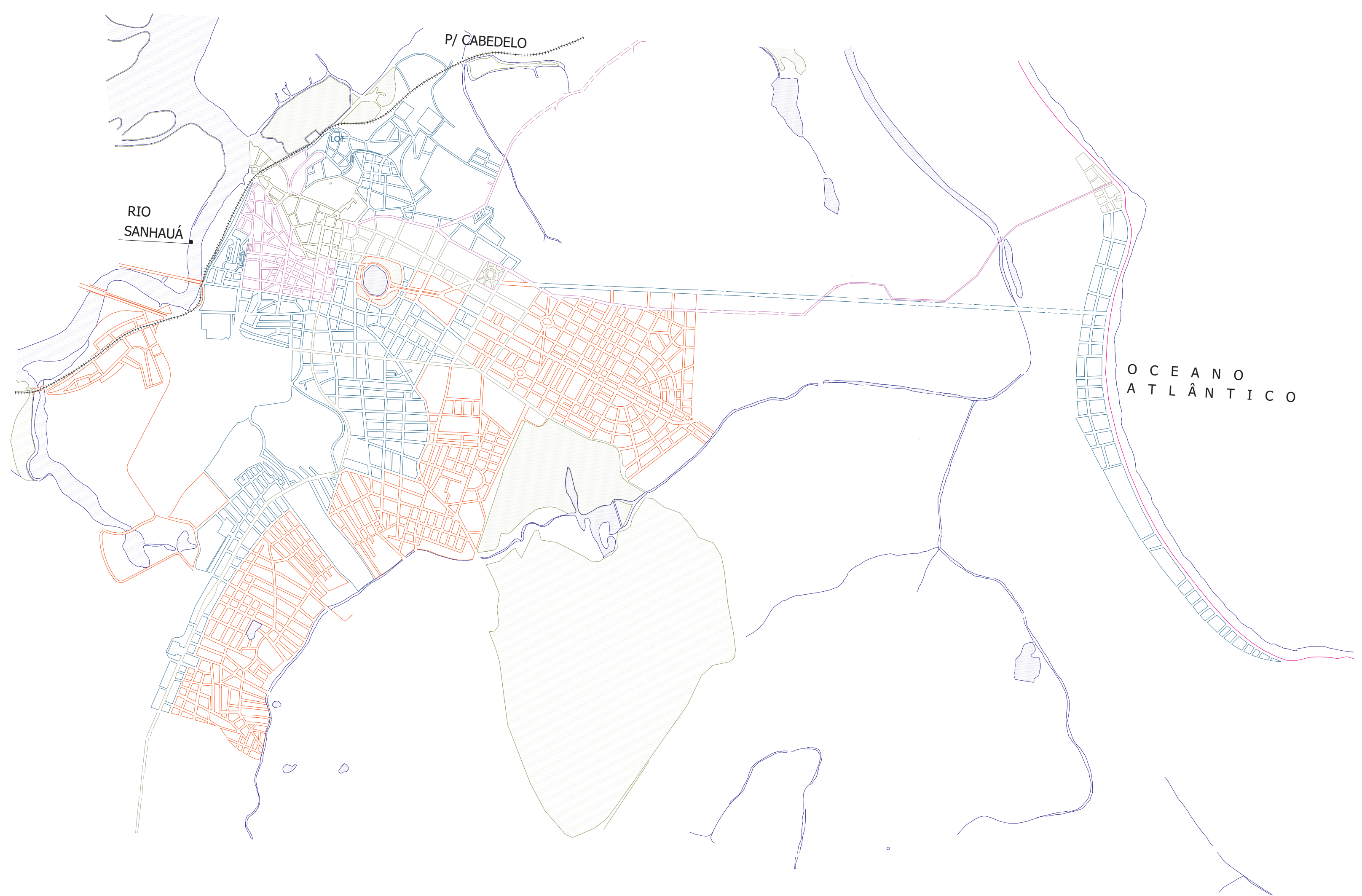

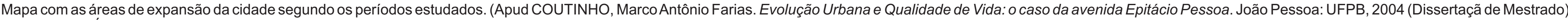
1634 Area referente ao conjunto urbano inicial, formado pelas primeiras ruas da "cidade Alta" e as ladeiras que levam a regiâo do Varadouro.

1855 Area de consolidação do núcleo urbano, ampliando a região do Varadouro, "cidade Baixa "e cidadeAlta", formada sobretudo pela área ingreme entre as partes altas e baixa da cidade.

1910 Pequena área de crescimento, com abertura de algumas ruas retas e largas que direcionam o crescimento futuro da cidade. Ocupação inicial da região praiera.

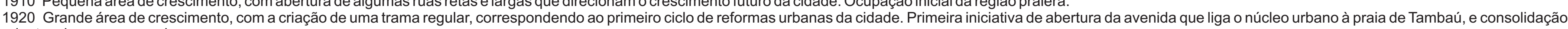
1930 Grande área de cres.

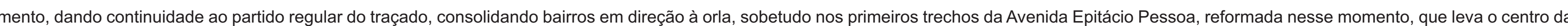
cidade à praia de Tambaú. 


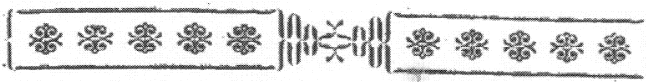

\section{MONOGRAPHIA}

DA

'CIDADE DA PARAHYBA DO NORTE

POR

VICENTE GOMES JARDIM

AORTMTINSOR DOS TERRENOS DE MARINHA DA MESMA IROVINCIA

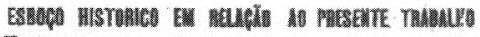

(CONCLUSTO)

RUA DE SÃO BENTO

Esta, partindo da do Tanque em confrontaçàn á casa da da Matriz

Tem a direcçăo de 28.0 nordeste-sudoeste, a extensín de 165 metros; sell plano tem pouca elevaçào, e sua edificação é de

Toma o lado de aeste do largo da Matriz.

RUA MARQUEZ DO HERVAL.

Esta rua começa fazendo angulo com a da Misericordia, do logar onde findou a da Medalha e ladeira das Pedrase vai terminar na na da Matriz, com a qual entesta fazendo outro angulo. 
Tem a direcço de 20.5 sidocsite - nordeste c a extensato de 373 metros com 24 de de 20 srme sin: vacaio e sed alinhamento e mats ou menos em linha recta, tendo pequènas curvaluras pouco sensiveis.

Parlindo de sell comeco, encontra:
A esquerda, o becco do Góes na distancia de 106 metros e ия de 276 meiros a travesa Baräo da Passagem, logar onde finda esie lado; c a direita, no de 128 metros o becco da Companhin; na de 25 metros a emboctura da rua do Carmo e na de 344 metros a espuita da nata da Matriz, deste laco tica a face de leste in largo da Mairiz, partindo da embocadura da rua do Carmo parra ofim, passando pelo oitäo da egreja matriz

Sun edificacalo é de 69 predios dentre os quaes 2 sio sobrados; é telih que está a Matrize convento de Sao Bento, a Matriz,

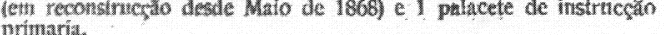
primaria

Chamava-se cm outro tempo rua Nova.

Barĩn $O$ becen do Góces faz a communicacä́o e descida para a rua Barin da laseagem, tem a direct ato de 130 metros e 4 de largura e tres casas de palha,

\section{RLA DA MATRIZ}

lișa rua, conn ficou dito, passa pelo tốpo da precedente com a direção de 65.0 noroeste-sueste', do lado direito, fazendo esunu com as Marquez do Herval e. Duque ide Caxias, tem a exiensio de 78 metros; (parte deste lado faz a face sul da praça coronel I.uiz Ignacio) e do esquerdo, fazendo esquinas com a rus de Sio Bento = a praco acima dita, tem a extensato de 120 metros: paric deste lado faz a face norte do largo da Matriz, passando por leira: da dita igreja ;) sell plano é de elevaçâo pouco sensivel parn leste e sua edificacio ê de $U$ nredios, dos quaes 1 É sobrado fivendo a face norte da sobredita praca do coronel Luiz Ignacio.

\section{RUA DUQUE DE CAXIAS}

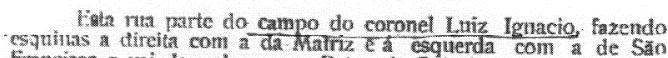
Francisco e vai desembocar no Pateo de Palacio com as da Imperatriz e Trincheiras.

Sen alinhamento é todo composto de curvas, mas fazendo-se dous pontos um no principio e outro no fim, no centro da nu uo sentidio transversal, estes pontos fican em direcção de 17.0 norrem de

a caminhar do set principio, cricontra-se : Na distancia de 96 metros 
com a rua clo Carmo, que a corta transversalmente; na cle 21 ' metros com o becco da Companhia á direita e á esquerda coni largo no cranio, na de 316 metros a esquerda o becese din. Hospital ha 350 a direita com a yua da Misericordia; na de 476 a direits com a ladeira do Rosario e a esquerda com o becco do Rosario na de 80 metros finda na esquina do Palo da metros finda na esyina do Palacio do Governo.

nella que estăo as igrejas: Collegio, Ruaes 34 sĩo soprados : assim como os edificios Palacio do Governo, Lycen c Thcsousaria de Fazenda.

acha-se plano é um pouco îrregular, ora inc

calcada com parallepipedos de granito Tambem já teve tres denominacóes: Chamava-seDireita do $5 e n$ principio a lgreja da Misericordia, Baixa da Igreja da Misericordi ao becco do Rosario e dahi para o fim-Sio Oonçalo.

O becco. da Componhia, que a communica com a min Marquez do Herval, tem a direcçáo de 70 sueste-noroeste, extensăo de 76 meiros, 6 metros de largura e 4 precilos, está calçada de pedras de granito irregulares; e o do Lyceo, que a com-

munica com a da Medalha, tem a mesma direçẽa do procedente

\section{RUA DO CARMO}

Esta rua, partindo da do Marquez de Herval, atravessa Dugte de Caxias na distancia de 83 metros e vai terminar em frente a igreja do Carmo, no Campo do Conselheiro Henriques, com a extensajo total de 160 metros e 8 de largura.

Seu alinhamento é composto de duas linhas rectas, fazendo งIm angulo no sen encontro com a Duque de Caxis partindo $\mathrm{em}$ direcçăo de $720^{\circ}$ sueste- noroeste, acaba na de 70.2 do mesmo rumo; sua edificação é de 11 predios; preenche a maior parte desta rua o prolongamento nas ruas: Marquez de Herval, Duque de Caxins e Visconde de

Seu plano é inclinado para o cobredito Campo do conselheiro Hewriques e acha-se calçada de pedras de granito irregularts.

\section{RUA DA MISERICORDIA}

Esta rua, partindo da ladeira das Pedras, formando angutos, como vimos, com a Marquiez de Herval, vai entestar com a Duque de Caxias em frente a igreja da Misericordia. -

Tem a direção de 70.0 - sueste-noroeste, a extensão de 76 
$\$ 6$

RTV. DO INST. HIST, I: GHOO. PR.

metros e 14 de largura, seu plano é quasi horisontal, tendo ajenas pequenos declives do centro para os extremos; pela mesma rasăo a jo precedente, sua ede calo de pedres de oranilo irrequares No centro, do lado esquerdo, tem um pequeno becco, dấ salida a parte dos quintaes das ruas: Marquez de Herval e Duque de Caxias, o cual é conhecido pclo nome de becco do Inferno.

RUA DE SẢO FRANCISCO

Fista rus, partíndo da praça do coronel Luiz Igracio, onde faz esquina crnm a Duque de Caxias, vai terminar desembocando 1a do Tambiả recta com a dírecção de 68.0 noroestesiesic, tem 156 metros de extensăn e 8 de largura media.

Partindo de sell principio, encontra na distancin de 64 metros a embocadura da Visconde de Pelotas á direita; seu planoé incli-

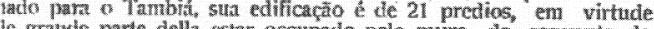

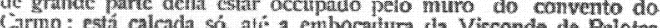
$\mathrm{com}$ pedras de granito irregulares.

RUA VISCONDE DE PEIOTAS

Fisła rua, partindo do seu entroncamento na de Säo Franciscn, val terminar na da Mangueira em frente ao campo do
Cominendador Felizardo; teun a direcçäo de 15 . o nordeste-sudoeste.

Pelo lado direito tem - a extensăo de 552 metros e pelo
e 5 e nordeste-sudoeste. esquerdo a de 675 , stua largura media é de 9 metros. Partindo. pelo lado direito, encontra : na distancia de 80 metros a do Carmo; na de 204 metros o largo do Erario; 11 de de 226 metros o beccoo becco do Rosario; na de 552 metros o becco do Baräo, queigreja das Mercez e vahi segue o becco dasMercêz a desembocar no campo do comma mesma direção, tendo de extensxo 49 metros; este lado é maís I*

a esquina do campo do eqquina do mesmo do conselheiro Henriques; dahi a outra o becco de Santa Thereza ; dahi a metros e e ahi que desemboca lador Silvino da Cunha tem. 86 metros a daça do commen le 48 niteros: dahi a 120 metros está n becco do Diniz; pracha coblionando a passar pelo lado de leste da dita cgreja Mercez, ficando ahi for- 
mado o paten das Mercez, depois de que toma a direcçăo de 25 . nordeste-sudoeste; deste becen a 16 metros está a travessa Visconde ic Pelolas, que antigamente chamava-se becco das Pitombas; dahi 75 metros dahi a becco do 2 dos quaes são sobrados; tem o plano inclio e de 111 predios, para o paleo das Mercéz onde tem um cauno de escốto extremn É nella que está a eqreja e convento de esgóto.

Thes a carmo, a Orden Casa de Misericordia, o Paço Municipal ; um palacete de Instruç" primaria e o Theairo Santa Cniz.

Esta rua já teve tres denommaçōes, chamava-se: do. vrincipio a praça commendador Silvino da chava-se: do seu dahi até o becco do Diniz, nua do Hospital e dahi para o fim,

O becco do Hospital que communica com a Dutue de Caxias, em a direcção de $700^{\circ}$ sueste-noroeste, a extensão de 66 metros c(im 14 de largura 0 do Rosario tem a mesma direcção e extensâo m:sma direção e cextensăo dos precca

$$
\text { …............... }
$$

RUA DA MANGUEIRA

Fìnt rua, principiando na contimuação da Visconde de Pelotas, no campo do commendador Felizardo, vai terminar na embocadura

Tem a direcrăo de 27.0 noroestesudoeste; do lado direito na extensia de 150 metros forma um angulo recio para a esquerda, angulo e segue a continunctio da rua em um pequen um outro anguio e segute a contintraça da rita em uma pequera curva ate de 120 metros faz um angulo tomando a direcço de 72.0 stestenoroeste, tendo este lado do dito angulo 20 metros de comprimento e formando ahi um outro angulo, toma a dirección do outro lado em uma paralella, indo terminar no encontro dá sobredita travessa do Chão-Duro conı a direcção de 5 . o nordeste-sudoeste, depois de deixar formado on largo da Mangueira.

O comprimento total desta rua é de 195 metros, sua largurra metros, seu plano é de elevaçăa para a e sua edificacà̃o é de 34 predios e 10 casas de palha.

Partindo de seu principio, encontra: Na distancin de 120 metros a travessa de sen nome, que a corta transversalmente al itChando-se para um e out

A travessa da Mangueira tem a direccalo de 68.0 sueste-norocste para a rua da Alagoa c a 63.0 do mesmo rumo para a dits Trinchuiras ; a do Chäo-Duro tem a direçäo de 70, o sueste-noroeste; a da Mangueira tem 74 metros de extensio para a rua das Trin- 
88 REV, DO INST. HISF, I: GFOG. PAR.

cliciras, 128 metros para a da Alagoa com 8 de largura e a do Châo-Duro, partindo da rua da Alagoa para a da Mangueira tem de extensăo 64 metros conı 4 de largura; esta năo tem edificação, mas aquella tem 3 predios e uma casa de palha.

RUA DO DINIZ

Esta rua, que tambem é conhecida por becco do Cisco, principia na praça do commendador Silvino da Gunha em frente a casa do mercado e termina no becco do mesmo norue; tem a de 8 de largura ; sell plano é horisontal, só no fim tem uma pequena
inclinaçao c sua edíficacão é de 14 predios.

\section{RUA DAS TRINCHEIRAS}

Esta rua tem sea comeco no campo do commendador Felieardo e é continuacăo da Duque de Caxias; principia na dírecgão ưna curva até a igreja dos Martyrios müaudo de rumo, fazendo apertando mais seu rio a Martyrios, dahi em diante a curva vai onde se encontra com a sahida da rua da Palmeira caminhos, direçăio de 45.o noroeste-sueste; tem de extensăo de 808 metros com 12 de largurn media.

Seu plano é de elevação até a sobredita egreja do Martyrio dahi até alem da embocadura da a sobre (é aqui o logar mais elevado da cidade, ) e dahỉ atể o fim é de (1)

Partindo de seu principio, encontra: A esquerda na distancia Bom metros a travessa da Mangueira; na de 410 metros a de e na de 868 metros a da rua da Palmeadura da rua da Larangeira Do lado opposto ru da Palmeira, sua confinante.

o caminho da Cacimba do Povo que comma da Larangeira está parte da rua do Cajueiro, margeando o mono denominadro, que É neste caminho que tem uma casa de polvom

brados e 22 casas de pallia 82 predios, denire os quaes 2 stío so-

\section{RUA DA PALMEIRA}

Esta rua que é tambem conhecida pelo nome de Boi-chou, parte em continuação da nu da Mangneira e vai findar no logar 
denominado Dois Caminhos, fazendo função com a das Trincheiras, formando um angulo agudn.

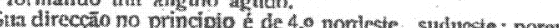
em sua continuaçắo vai formando diversas curvas ora paren direita c ora para a esquerda, até que, no encontro com a Seu plano é de elevação no pros. extensăo é inclínado, o mais é horisontal; stra extensåo é de 646 metros com 8 de largura media,

Partindo de seu começo, encontra: Do lado direito na distancia de 216 metros a travessa do Bom Jesus; na de 338 metros rua da Larangeira e na da 616 o extremo.

Sua edificacăo é de 16 predios e 24 casas de palha. A causa numero de sitios que A travessa do Bom Jesus que a communica com a das Trincheiras, tem a dirccça de 77.0 stueste-noroeste, a exiensia de 168 metros com 12 de largura e a editicação de 3 predios e 13 casav de palha; seu piano é horisonial.

RUA DA LARANGEIRA

Esta rua está parallela á travessa do Bom Jesus e como ell ambern dá communicacăo para as ruhs: Trincheiras e Palmeira; tem o plano horisontal, a extensão de 180 metros com 11 de largura media e a edificaçăo de 4 pr dios e 12 casas de palha.

Coelho de Mello.

$$
\text { RUA DA ALAGOA }
$$

Do alinhamento do lado do sul do campo do conselheiro Henriques, e ao lado da igreja de Santa Thereza parte o becco de de 44 metros e 4 de largura.

Do extremo deste becco, com o qual faz um angulo obtuzo, parte a rua da Lagoa, na direcogano de norte-sul, fazendo depois um anguto até a embocadura da rua da Thesoura, tomando dahi em diante a direcçāo 8. de norte-sudoeste até o fím.

Tem o plano inchinado ao principio até a embocadura d sobredita rua da Thesoura, horisontal dahi até a embocadura da Travessa Visconde de Pelotas $e$ dahi até o fim é de elevaça um pouco ingreme.

Sua edificação é de 98 predios, 36 casas de palha, tem a extensăo de 768 matros

Partindo do seu começo, pelo lado direito, encontra: A 
esquina da face do norte da praça do Commendador Silvino da Cunha na distancia de 88 metros; na de 140 a face sul da mesma praca; na de 256 metros o becco do Diniz; na de 344 metros a na de 560 metros o becco. do Passinho; na de 696 metros a travessa da Alangucira e na de 760 metros a travessa do Chaso-Duro e dabi para o extremio da dita ma 8 metros.

E pero esquerdo a embocadura da rua da Thesonira na disancia de 118 metros; na de 190 metros a da rua da Senzalla ; na de 335 metros o becco das Almas on de Luzia Gaga; na de 424 metros a do Barrancão na de 502 metros o do Cypriano; na de 564 metros a travessa da Lagoa e na 698 metros o de Jaguaribe,

Da travessa da Lagoa para ofim já se chamou Chão-Duro e alguten chamava rua Bella.

Dão communicaçócs desta nua para Visconde de Pelotas : 0 breco do Diviz, a travessa Visconde de Pelotas, a das Mercez, o becco do I'assinho e para a da Mangucira : a travessa deste nome * a do Clitan-Duro.

O hecco do Diniz tem a direccio de 75.0 sueste-noroeste, a cxlenslu te 100 metrs com 8 de largura media, o plano de elevaģin fara a rua Visconde de Pelotas, e edificaçăo de 2 predios A travessa V'isuronde de Pelotas tem a mestma direção do becto pre-edente, o mesmo plano n extensäo de 72 metros com 8 - ling in tin só predio.

$A$ travessi das Mercez ainda tem o mesmo plano e a mesm direccán dia precedicnte e 73 metros de extensão; năo está deter0 beceo do Pasinho tem a directicacio.

iravesa precedente exte 68.0 suesienoroeste, com 8 de largura. quando fravesca da Monmeira e Chăo-Duro já ficaram descriptas RUA DA THESOURA Esha rua parte da rua da Alagoa em frente a casa do Mer-
cado e finda fazendo angulo, com a de dic 70.0 noroeste-sueste, al extensão de 29 mose; tem a direcçäo media, o plano inclinado para a de Săo josć e a edificacilo de predios e 2 casas de palha.

la Partindo de sent começo, encontra: $\mathrm{A}^{\prime}$ direita a embocadum de de Santo Antonio na distancia de 96 metros e á esquerd? le Santo Elias na distancia de 84 metros.

\section{RUA DE SANTO ANTONIO}

Esta rua principia $\mathrm{na}$ da Thesoura e finda no becco das. Almas, onde começa a Nova da Alagoa, que lhe segne. 
238 metros a direçâio de 32,0 nordeste-sudoestc, a extensaio de a metros com 8 de largura media, o plano horisontal e a ediffcaçäo de 3 predios e 5 casas de palia

metros a distancia de 65

metros a rua da Senzala á tlireita, com a qual faz angulo.

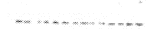

RUA NOVA DA ALAGOA

Fsta rua partindo da continuaçăo da precedeste, "vai terminar em plano de elevaçäo alem do becco do Jaguaribe na extenszide 376 metros, com 11 de largura media ; tem no principio a direcçẫo de $5 .^{\circ}$ nordeste-sudoeste, findando na de 15.0 do mesmo rumo,

Partindo de sent principio, encontra: A direita o becco do Barranção na distancia de 70 metros; na de 140 metros o do Cypriano: ma de 230 metrns o becco do Jaguaribe; ficando dahi E a 20 metros.

netros: o do Macaco becco de Jaăo Carlos na distancia de 140 a distancin de 276 metros cmbocadura da estradia do mesmo nome o Jaguaribe, ficando 20 metros dahi pare sahida. As communicaçóes della com a da Alagoa sian: Os beccos
das Almas, do Barrancio, do Cypriano e Jaguaribe e a travessa da Alagoa.

O becco das Almas tem a dirrcção de 70.0 sueste-noroeste, extensão de 45 metros, com 5 de largura, o plano indinado para

$O$ do Barrancio tem a mesma direccão c plano do prece dente, a extensão de 69 metros com 5 de largura c 1 predio e 3 casas de palha.

$O$ do Cypriano tem a direcção de 80.0 sueste-noroeste, extensão de 88 metros com 2 de largura e o plano dos precedentes. O do Jaguaribe tem a direccio de 72 sueste-noroeste, a extensĩo de 140 metros con 8 de largura, o plano horisontal e edincacáo de 5 predios e 4 casas de palha.

E a travessa da Alagoa tem a direccaro de 68.0 suestenoroeste. a cxtensã̃o de 123 metros com 8 de largura, o plano horisontal - a edificaçato de 6 predios e 4 casas de palha.

RUA DO JAGUARIBE,

Esta rua parte na direção de $720^{\circ}$ norocste-sueste até a distancia de 56 metros, dahi em diante vai obliquando para o su - phando curvas, tomando a direccáo da estrada do me nome: 
donde parte para o norie a travessa de seu nome, sendo dahi em diante de devacio ate as nltimis casas. Fm frente a sobredita travessa faz uma sspecie te praça, .O mais tem a langura de 8 metros. Nain se pode determinar a extensão della em ra
contimando a edificaçấo de tstrada alem.

Sua edificacalo é de $A$ predios e 42 casas de palha. $\Lambda$ travessa dn Jaguaribe, que dấ lesta rua para o becco do Macaco, tem a direccáo de 12.0 sudoeste-nordeste, ${ }^{\circ}$ piano inelia sta edificaçào é de 2 predios e 4 casas de palha.

O becco do Macaco, panindo do fim da precedente travessa, sai desembocar na nua Nova da Alagoa ; tem a direcção de lestecontal extensao de 40 metros conn 5 de langara e a plano hori O becco de Joăo Carlos (naio tem sahida) fem a direcção
de 85,0 noroeste-sueste, e extensaio de 40 metros com 3 de largura.

\section{RUA DO TAMBIÁ}

Esta run começa na continuação da de S. Francisco e embocadura da da Aurora ; formando no principio utm pequeno angulo, Diniz; dahi $\mathrm{cm}$ diante vai obliquando pouco a pouco para o sul, até que finda na esquina de $\mathrm{S}$. José ma direcção de $65^{\circ}$ noroestesuesté; tem de extensî́o 382 metros, sua -largura é irregular, pois comecando com 8 metros, finda no pateo da igreja da Senhora da Mac dos Homes com a de 24

Pecco do Diniz de sett principio, encontra: Na distancia de 150 o

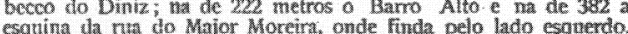
E pelo lado direito na distancia de 137 metros está a embocadura da de Santo Elias e na de 390 /metros a esquina de São José, onde fincta. Com a frente para ocste está abi collocada a igreja da Senhora
Măi dos Homens.

RLA DE SÃO JOSÉ

Esta rua comecando na extremidade da rua da Thesoura, fazendo angulo, vai terminar entestando com a do Tambiá $\mathrm{em}$ frente do pateo da Mae dos Homens; tem o plano inclinado deste para aquella, a extensão de 330 metros com 17 de largura; sua predios e 6 casas de palha. 
RUA DA SENYALA

Esta rua teri a direcçăo de 70,n noroeste-sueste, parte da rta da Alagoa em plano inclinado e cntesta con a de Santo Aninnio, que the passa transversalmente; tem a extensaio de 80 metros com 8 fol aberta por José de Oliveira Dinis

RUA DE SANTO ELIAS

ta rua parte da rua da Thesoura e desemboca na do Tambiá, em o plano inclinado desta para aguella, a extensa de e 17 de largura; principia cort a direcsa de 28 sudoeste-nordeste e depois de formar um an 33 predios e 12 casas de palha. Foi rumo; sua edificacano e de 33 predios e aberta por Frei Albermo.

RUA DA MÃE DOS HOMENS

Esta rua, começando na extremidade da do Tambiá cembocaủuras das de Săo José e Major Moreira, vai prolongando-sé pela estrada de Tambaú. Formando (só do lado Homens, toma depois a diroceảo de roda da igreja da Maté a embocadura da estrada de Mandacarń, forma nma pequena curva e vai dahi em diante tomando as mesmas direcçóes da sobredita estrada de Tambara.
Sua extensăo até a embocadura da estrada de Mandacari ${ }^{k}$. de 258 metros, o resto năo se pode delerninar, chácaras.

a edificaç̆o de estrada a fóra com diversas chacaras edificacằo de 64 predios e 56 casas de palha, semt plano é de elevacio até a sobrepredios e 56 casas de palha, semt Mlanacart, mas dahi em diante inclinada. que se acha o edificio proprio prowincial que servio de collegio de educandos artifices: atraz deste edtício esta o cemiterio da
Cruz do Peixe. Mor detraz da lgre cortando a rua do Emboca vai terminar tha Mac dos Heste becco, na da Bica; este becco, tem a con 3 de largura 
Fista rua parte do pateo da Mäe dos Homens e termina na da Bica, que the corta trasnversalmente; tem a direccâa de $8 . n$ sueste-noroeste, a cxtensáo de 76 metros com e o plano horisontal.

\section{RLA DO EMBOCA}

Esta rua parte da do Major Morcira por um pequeno becen termina no becco da Mẫe dos Homens; tem a dirccção de $85 .{ }^{\circ}$ norneste-sueste, a extensilo de 61 metros, com 6 de largura; na cstrada não tem a mesma largura, pois é, como ficou dito, um pequeno becco: tem. o plann inclinado para leste a edificaçào de 1 predio e 12 casas de palua.

RUA DA ALRORA

Esta rua parte do logar onde termina a de Säo Francisco principia a do Tambiá, em cujo lacal forma um pequeno largo c val terminar na distancia de 172 metros na direcçăo de 45.0 mando $t$ m angulo e unna pequena curva, toma a direccyão de 70.0 noroeste-sueste, encontrando-se na distancia de 35 metros com becco do Beriz, que parte da do Tambiá terido a direccăo de 12. este becco na stia passagem corta a rua da Bica e tem o plano de elevaçio.

Esta rua de que se trata tem o plano inclinado do fin par o principio, a largura de 8 metros, a edificação de 31 predios e casas de palha.

Partindo de seu comeco, encontra: A esquerda na distancis de 28 metros o becco do Xiuxirra e na de 136 metros a sahida denominada Muro de Sãn Francisco. 32 meiros; tambem é conliecida pelo nome de Quatro-Cauto

RUA DA BICA

Esta, partindo do logar acima dito, vai terminar na frentc do Tambiá; começa ma direcrào de 65 . $^{\circ}$ nordeste-sudoeste até a
distancia de 140 metros onde the atravessa o becco do Beriz; dahi 
toma a direcçăo de 85.0 noroeste-sneste até a distancia 82 metros, onde encontra o becco do Barro-alto a direita e seguindo dahi na mesma direcçio encontra do mesmo lado, na distancia de 160 metros, a embocadura da do Major Moreira toma do dahi a direçẫo de $85 .{ }^{\circ}$ nordeste-sudueste alt a distan Homens: dahi en encontra ainda a dircita o becquerda e diretia, até que na dis diante vai formando curvas a esquerradicional "Bica do Tambiá. ancia de 240 metros cucontra 702 metros de comprimento e 8 de largura media, 19 predios

26 casas de palkas. Moreira: dahí até a Bica é uma descida bastante sensivel.

MURO DE SÃO FRANCISCO

Năo é propriamente uma rua, $t$ uma passagem, qte enbocando na praca do Coronel Luiz Ignacio, em frente donde desemboca a rua do Tanque, val margeando ouro do caovento de São Francisco c os fundos dos

e Aurora, até derembocar nesta. Tem a direcção de 60 . 88 metros, tomando metros, onde termina; sua largura media é de a distancia de edificaçăo é de 2 predios e 5 casas de palha e seri plano

é de elevaçâo até a primeira, direcçarte da rua da Aurora, para o

de que se trata, desemboca na frente do portão de dito muro de
Săo francisco (onde presentemente é portao do quartel da compaSajo francisco (onde presentemes) bem a direccalo de $35^{\circ}{ }^{\circ}$ suestenoroesic, a extensa de Auror

\section{PRAÇAS PUBLICAS}

PRACA DE PEDRO II

Fsta rimeiro lado a leste é formado por uuna linha curva, que fas primesta tarte a Visconde de Inhanima; o sngundo ao Sul formado pela continuacajo do predio Hotel d' Europae mais 3 predios que se lhe seguem em linha recta ma dircecalode 5 . formado por uma até a esquina da rua da Gameleirn; o terceiro em direcçâo de 6. linba recta, que parte da sobredita esquina em direçâo de 6. 
$4 y_{1}$ RFV. WO IXST, HIST. F DIOO. PAR.

sueste-noroeste até a margem do rio Sanhauá : (esta linha serve de divisan an primetro lado de ontro pentagono irregular, de que é nordeste e quinto pelo altahemento do trapiche que se denominava anteriormente "trapiche de Viclorino Maia " tem a direcçäo tie $85 .{ }^{n}$ nrroestc-sueste.

A corta da carva convexa de que é formado o primeiro plano lem 108 metros de comprimento; a linha do segundo tem

to quinto 64 metros.

fśra praç é o principal porto de embarque e desembarque.

I.ARGO DA GAMELEIRA

Fsta praça, como já ficou dito, $\hat{\varepsilon}$ tambem como a precetente tm polygono de cinco lados, ou pentagono irregtar: $O$ primeiro lado e a linta divisoria entre esta e a de Pedro II; o scyundo parte da esqualia da rua da dameleira tha direccao de 30,0 norceste-sueste e vai terninar na distancia de 39 metros; tercer palo ma distancin de 69 metros un esquina do becco da Frtacio io quarto partindo dahi na direccrano de 84 o sucste noroeste, fazenilo frente os 5 predios que existem ahi deste lado, vai terminar z margem do rio Sanhauá na distancia de 260 metros; o quinto finalinente a linha que a divide da procedente, este lado tem a direç̧ăo de 65,0 sudonste-nordeste e a extensão de 232 metros

PATEO DA ALFANDEOA

Esta praça ề um pequeno quadrilatero: $O$ primeiro lado é. (moxeformado pela passagem da rua Visconde de Inhaúma, tem a dire-

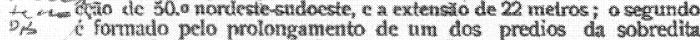
rua, (onde presentemente funcciona o Consulado Provincial) e o

Q14 Jroprio nacional destinado para vigia ou quarte dos guaruas da

PA 6 meiros; o terceiro é formado pelo cies á margem dorio dito tem a dirceiro e lormado pelo cas a margem dorio sobremetros: (na continuac $23: 0$ sudoeste-nordeste e a extensäo de 40

Cq. metros; (na continuaço deste lado e por detras dos predios da quarto formado, como sexundo, pelo prolongamento de outro predio da mesma rua,
a direçăo de 52.0 noroestesueste e a extensăo de 36 metros. 


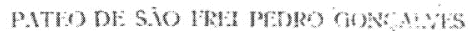

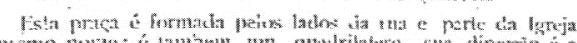

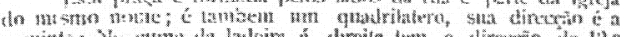

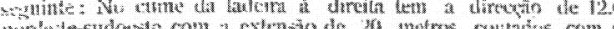
nordere

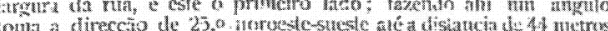

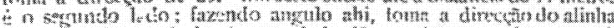

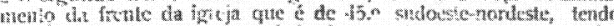

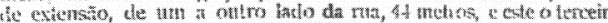

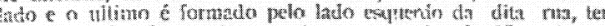

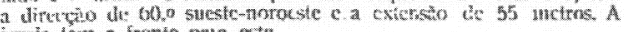
igreja tem a frente para este.

$$
\text { LARGO DA VIRACAO }
$$

Fsta praça $e$ um triangulo acutanguio: 0 primeirn lado

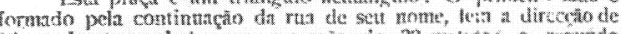
12." sudoeste-thordeste e a exientan de 32 metiss; o segundo fazendo angulo tha embocadtus do becce dla Mlou im.

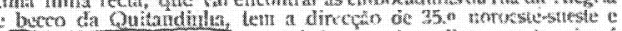

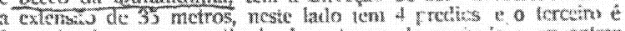
formatio de uma recta tirada do extrems cio segtiotio a cucontrar

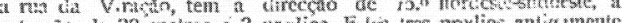

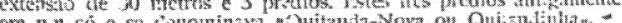

\section{CAHPO DO CONSEIHEIRO DIOGO}

Esta praca, que entigamente chamava-se palco do Quartel é um pentagono irregular, tendo um angulo rentrante $c$ quatro calicutes: $O$ primeiro lado ć formado pela rra do Cunsume, tem a direcçăo de 43. o noroeste-sucste e a extensio ic 85 metros; fazendo angulo no principio da ladeira des pecirs toma $n$ ditecesa nia Baräo da Passouent no centro da dita ladeita dís peciras na distancia de 70 metros onde termina o segunco lato; fizendo ahî um angulo parte $\mathrm{cm}$ direção de 220 nordeste-sutoesie por uma passagem que antigannenle chumtava-se travessa ta run do Fogo, que presentemente nà̉ lem edificayẫo c metros encontra-sc com a rta do-Fogo onde fennista o leceéro lado; o cuarto é formado por un parte da sohredita rua, tem a direcyio de bio sueste-thorbeste e a cxtensio de le linha as enfer-

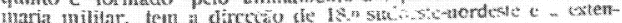
sio de 92 unetros. 
IARCO DA CADEIA NOVA

Fsta praça principin na rta Visconde de Itaprarica na direçä́n de $15 .{ }^{\circ}$ sudoéstc-norieste $e$ depois de 44 metros de distancia forma um quadrado em volta do edif.

lado deste quadrado 80 metros:

direcailo de 15.0 sudoeste-10ordeste. Existem neste quadradn ou largo a edificaçato de 23 predios e 5 casas de palha.

argo 44 metros que principiam na rua Visconcle de. Itaparica tent de langura 24 metros.

I'ATEO DO QUARTEL DE POLICLA

Fista praça é um quadrilatero: Forma o princiro lado a a passagrem da rua Conde d'Eu, tem a dircçăo ce 10.0 nordeste-

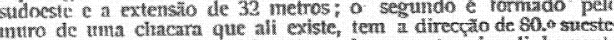
noroeste $c$ a extensăo de 72 metros; forma o terceiro alinhamento do paredấn de oeste da biea do Gravatá, tem a clirecrĩo de 20. stutoeste-nordeste e a extensâo de 34 metros e o quarto é formado pelo alinhamento do Quartel de Policia, tem a direçăa de 80

I.ARGO DO SOBRADINHO

Esta proca é um pequeno triangulo, onde. desembocam as Matinh

O primeiro lado ê formado pelo alinhamento da rua Visconde de Itaparica, tem a direcção de 73,0 sueste-noroeste e a cxtensá de 44. metros; o scgundo pelo alinhamento da Matinha, tem a direç̧ăo de $75 . n$ sudoeste-nordeste e a extensão de 50 metros: forma o lerceir o alinhance 20.0 senfoeste-mordeste a a exterisio de 32 metros.

LARGO DO SANHALÁ

Essta praça é un quadrilongo, formado: Ėntre o rio Strnlauá; alinhamento dos predios $\mathrm{E} \cdot \mathrm{m}$ frente an dito rio; alinhamento da rua

Visconde de Itaparica e corte da cambôa do capitäo Emiliano.
O primeiro lado té 0 alinbamento da rua Visconde de Ita- 
parica, tem a direç̧ăn de 73, o sudoeste-norneste e a extensin de 25 metros; o segundo é o dos predios acima dito, tem a direcpi

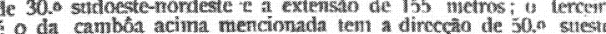
horoeste e a extensão de 52 meiros e maryen do sobreditor ti. Sanhauá forma o quarto lado tem a direogäo de $200^{n}$ suthestenoroeste e a extensĩo de 158 metros. Achi-se quasi toda occupada con a passagem das estrulas

PATEO DE PALACIO

Esta praça é um quadrilatero formado pelas ruas: Trincheira Imperatriz e Medalha e pelo muro da chacara do commendad Silvino da Cunha.

primeiro lado é formado pelo alinhanento da sobredita rua das Trincueiras, tem a direccão de $18 .{ }^{\circ}$ noriteste-sndoeste e a extensao de 108 metros; forma o segnndo al do Governo, tem imperatio 73 . sueste-norneste e a extensio de 116 -meiros: terceíns o alinhamento da rua da Medalha; $\operatorname{tem}$ a direcęấo de 18. nordís ste-sudoeste e a extensảo de lod metros e o quarto é o mur. da sorredita chacara; lem a direccla de 7.0 mateste extensấo de 116 metros.

\section{CAMPO DO COMMENDADOR FEIIZARDO}

Esta praça é tambem como a precedente, um quadrilatero. formado pelas ruas: prolongamento dos predios de esquinas daquella para esta. em cujo alinhamento fazendo frente para a praça acham-se os edificios publicos: Palacio do Governo, Lyceo e a Igreja do Collegio ; tem a direccĕ̃o de 18.0 sudoeste-nordeste e a extensằ de 95 metros; o segundo é o do prolongamento do predio de esquina da mesma rua Duque de Caxias, passando por detraz da Igreja das Mercez; tem a direccaso de alinhamento da rua Visextensa de 110 mi direcro de 250 nordestesudoeste e a conde de Pelotas, tem a dircogiarto é o do alinhamento do muro e prolongamento do predio, gute faz esquina para a rua das Trincheiras; tem a direcçẫo de 70.0 sudoeste-nordeste $\mathrm{c}$ a extensỉo dc

Acha-se occupado com o Jardim Publico, principiado em 1879, por occasião da secca, na administração do Vice-Presidente Ex,mo Sr. Padre Felippe Benicio da Fonseca Galvāo e concinido. 
PRMC IYO COMULDABXI? SUIVINO DA CUNIA

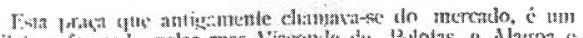

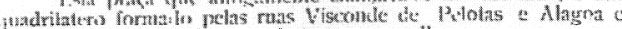
relos laners de mi:s lateraes desta jura aquella.

orimcion lado ê o th rua Visconde de Pelotas, tcm ahi unta das frentes o maficis) "Paço Municipal, r:man direçän de

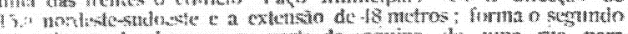
(ai) sil) um das lanees, que parke da esguina de una na para

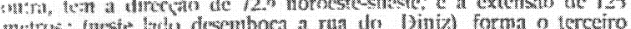

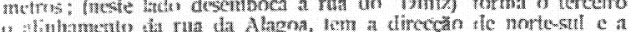
3 :timime norte) de

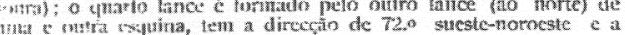
astencis de 11 th matros

Yos doxis lanees de rua desta praça tem a edificação de 26 pistipis

CUWPO DO CONSA IHEIRO UENRIQUFS

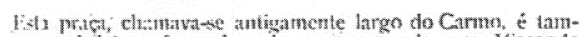

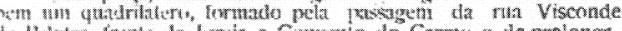
ment" tos prediens de esquinas.

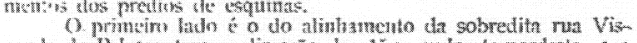

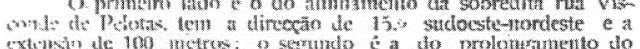
exteinin de 100 metros: o segundo है a do prolonganento do preslin da tsyuna palo atinhamento do becen de Santa Thereza,

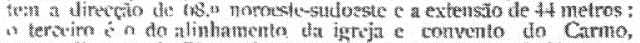
"em a direçâio de 70.0 sudoesic-nordeste e a extensăo de 99 metros

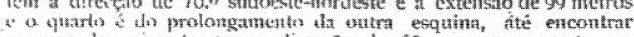
(1) miro do covivento, teon $a$ direceto to $65,{ }^{\circ}$ sueste-noroeste $t$ a txtension de 12 metros.

IRACA DO CORONII. LLIZ IGNACIO

Fisu praça, que tambem é conhecida por Paleo de Săo. Fracises, $z^{2}$ tambem um gthetrlatero, forma-o: a passagem da rat Hrviz, o prolongamento de uma esquina da mesma rua; 0 da tspuina da de Sío Francisco e da frente din igreja deste nome.

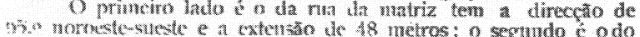

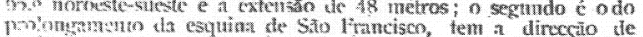


(a)

PRAG I 6 COMHENDAX) SIIVINO DA CUNIA

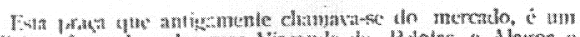
quadrilatero formatio pelas ruas Visconde te Prolas es Alagna o

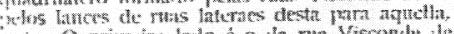

O primein lado é o th nat Visconde de Pelotas, tem ahi

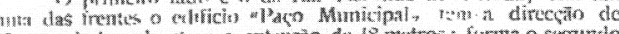
a extensàn de 18 metros; forma o segundo

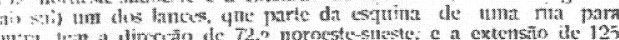
untrus; (neste bads desemboca a rua do Diniz) forma o terceiro " alinitamento sa rua da Alagna, lem a direcçăn tic notte-stl e a (xinhia de 5 metros: (desembnea noste lado a nta da The miris); o yuarto lance ce formato pelo outro lance (tio norte) the

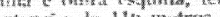
Vos tust lances de rua desta prạ̧ tem a edificação de 26 visitis.

CAWPO DO CONSIIHIIRO UENRIQUTS

Fis prica, clumbavate antigamente largo do Carmo, é lam-

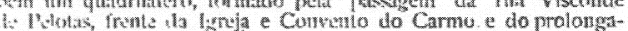
mem: $n$ s elos predies de esquinas.

0. primeins ladn ç o do alinhumento da sobreditn rua Viscom:l: de Pefutas, tem a dircecăo de 15.s sutcloste-nordeste e a xtrithin te 100 metrens os segundo है a do prolongsamento do

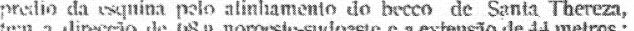
teroim lem a direccio de 70,3 sudoeste-nnrdeste e a extensão de 99 metros

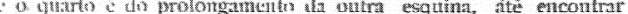

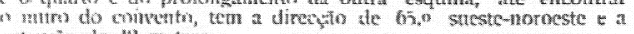

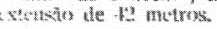

IRALA DO CORONII. LLIZ IGNACIO

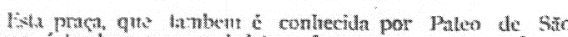
Fr acises, tambem um tqtadinlatero, forma-o: a passsgen da ru

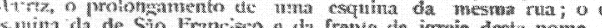
O primciro lado í o da nua la matriz tem a direcção de

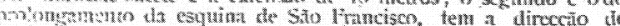


no lado do leste, tem a direçain de 27, sudoeste-nordeste e a 38 metros e o quarto forma a passagem da travessa it Mangueira,

PATEO DA MINE DOS HOMENS

I'sła praça é formada pela aberiura que, do becco to Barroaltu em diante, vai fazendo os lados da rua do Tambiá eo alinhainent's ta igreja $N$. S. Mãe dos Homens.

$O$ alinhamento da dita igreja que teru a frente voltada para sie, tem a direças de tei da rta do Taubia.

I.AROO DA MATRIZ

I'sia praç. $\dot{\varepsilon}$ um quadrilatero formado pelas passagens das rass Marquec do Herval e alinhamento das ruas de Săo Bento c. Hatriz e o do numo de São Bento.

O. primeiro é formado pelo alinhamento da rua Marques (4) Ilenal, tem a direcção de 26.0 studoestenordeste e a extensăo we $10 \mathrm{k}$ me-ros: o segundo pelo alinhamento da rua da Matriz tem at direczăo de 65 , sueste-noroeste e a extensä́o de 98 metros; a terceir pelo aluhaeste e a extensio de 120 metros e o quarto pelo alinhaunento do muro de Sáo Bento, tem a direç̧̃̃o de noroeste-

sileste e extensão de lot metros.
$\mathrm{E}$ dentro do perimetro deste quadrilatero que está collocada a igreja de N.S. das Neves, (matriz) em reconstruccio deste Main

EDIFICIOS PUBLICOS E PARTICULARES COM AS DATAS E PORMENORES A MEU ALCANCE

PALACIO DO GOVERNO

Este edificio, que serve de Palacio do Governo desde 1771 , : :mipo em que era capilào-nór governador Jeronymo José de Mello. " Castro, foi antigamente convento da companhia de Jezus; est. coms is da Impratriz. Tem a frente principal voltada para leste 
nก lado do leste, tem a direcçân de 27.0 sudneste-nordeste e : extensă̈n de 38 metros e o quarto forma a passagcm da travessin ita Mangueiry

PATEO DA MANE DOS HOMENS

Fisla praça ê formada pela abertura que, do becco clo BarroIltur en diante. vai fazcndo os lados da rua do Tambiá eo alinhamentr ta igreja $\mathrm{N}$. S. Mãe dos Homens.

$O$ alinhamento da dita igreja que tem a frente voltada para sile, tem a direccho de 18.0 sudoeste-nordeste e o pateo ali tem a -i da rra do Tambiấ.

\section{I.ARGO DA MATRIZ}

Fisia praça, $\dot{c}$ um quadrilatero formado pelas passagcrs das ruts Marutue do Herval e alinh

O. primeiro é formado pelo alinhamento da rua Marque (4) Herval, tem a direcçao de $260^{\circ}$ studoeste-nordeste e a extensảo the 116 me-ros: os seyundo pelo alinhamento da rua da Matriz tem

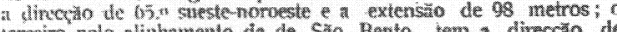
lerceiro pelo alinhamento da de Sãn Bento, tem a direccăo de tlinhanento do mumo de $\mathrm{S}$ io Bento, tem a direçẵo de noroesteuncte $e$ cxtensito de 104 metro. $\mathrm{E}$ dentro do perimetro decte quadrilatero que está collocada a igreja de N. S. das Neves, (matriz) em reconstrucçăo deste Main.

\section{FDIFICIOS PUBUCOS F PARTICULARES COM AS}

DATAS E PORMENORES A MEU ALCANCE

PALACIO DO GOVERNO

Este edificio, que serve de Palacio do Govemo desde 1771 eutpo $\mathrm{cm}$ que era capitào-mór governador Jeronymo José de Mello c. Castro, foi antigamente convento da companhia de Jezns; esta som it da lmperatriz. Tem a frente principal voltada para leste 
() pavinento sumerior para of outros fins par uti: for

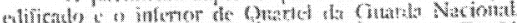

Im 1\$71) ma administracio to $1 \mathrm{xm}$. Sr. Dr. Vertancio fes

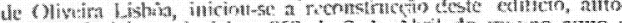
rínda pela lei provincial n. 363 de $\mathrm{S}$ re Abril do misino anno

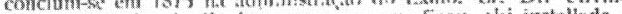

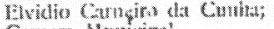

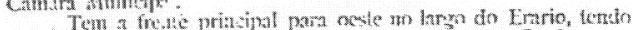

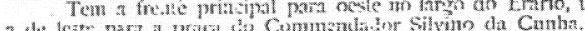

CASA DO MERCADO

Fste coliflin de un wh puimento, acla-se co:lucado na praç do Contmendadur Sitvins da Cunba, tem a frente principa

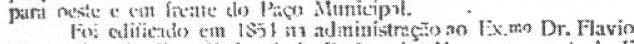

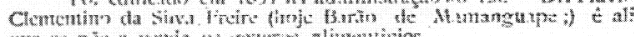

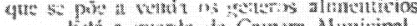
oริ ret:limentos.

REP'ARTICZAO DOS CORREIOS

Kste cdificio foi cilticicado em 1752 n1 Administraçăo do Capitåo-mór governador Jeronymo josé de Melio e. Castro, é de uim so pavimento, acla-se collocado ao lado sul do largo do Erario, Tazendo frente para a Thesouraria de Pazenda; serviu muito tempo
de casa de talhar carne e depois de mercado; passando a servir de casa de talhar carne e depois de mercado passando a servir de repartica de Cotreins em 1869 na Aưuintstraça

PROPRIO PROVINCIAL DA CRUZ DO PEIXE

Fste edificio foi comprado pela provincia $\mathrm{cm} \cdot 1859$ para ser ali installado o Collegio de Educandos Artifices, na administraçäo dola lei provincial no 6 de i de pela lex provincia o Collexio por acto da presidencia de 18 de Setembro de 1875 , ficon esle editicio servindo para as necessidades provinciacs; em 1878 servill de Hospital de Variolosos. de Tambau, é de un só pavimento; no principio de sell estabe- 


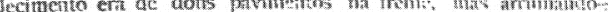

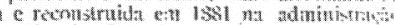
da Fxmy Sr, Dr. Justino lérreira Cameim.

\section{CASA DA POLYOR.}

Este edificio Ioi mandadn construir por Carta Regra de it de Agosto de 1704, setudo capitāo-noór governator Fermande th Barroc e Vasconcellos e conchinse cin itio nu ad Aclia-se collocado do iado do norte da ma do Tanque

Aclia-se collocado do iado do norte da niat dlo Tanque. da rua das Trincheiras; a respeito do qual menlum conthecinumit tertho com relaça a epoca de sua elificagàn.

\section{THESOLFO PROVINCIAL.}

Este edificio foi lançada sta primeira pedra em 28 de Janciro de 1853, na administraçäo do Ex, ${ }^{\text {ñ }}$ Sr. Dr. Antonio Coellw S c Abnguerque.

Era destinado para theatro, chegando para tal fim até a altura do vigamento; mas havendo necessidade de um edificio para Thesouro, em rasaio de ter sido demolido por apresentar rutua,

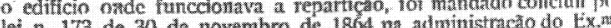
Concluido $\mathrm{em} 1868$ ahy installada a repartição na administraçào do Ex,mo Sr. Dr. Innocencio Seraphico de Assis Caratho.

. E' de dois pavimentos, funciona ; no superior a reparticin
'cerio do Thesouro e secretaria da instruccano publica e no inferior o Tribunal do Jury e a Escola Normal. Dingo e tem a frente principal para oeste.

QUARTEL. DE LINHA Este edificio que se ach pessons que o projectaram destinado a un recolhimento pelas pessoverno, gur fez transichio com os proprietarios, que naquella epoca era a irmandade do Bou Jezus dos Mariyrios, pelo uzo e fructo da igreja em que hoje funcciona dita Irmandade e ahi sobre os mesmos paredổes continuotu-se 
the Albuqueryue, sendo concluido em 1811, na adninistraça to capitáo-mór governador Antonio Caetano Pereira

F: te dous pavimentos, está collocado no campo do Conselheiro Dingo, tem a frente principal para leste e faz esquina ao sul da rua das Flores; acha-se em reconstucçào desde Janeiro de 1834. quando cstava na administração da provincia o Ex.mo $\mathrm{S}$. Ir. jos Ayres do Nacimento.

ENFERMARIA MILTTAR Iśste edificio teve comeco em 1854 na administraçào do Ex,mo
r. Dr. Joân Capistrano Bandeira de Mello e concluiutuse em 1857 na do Ex.mo Sr. Dr. Antonio da Costa Pinto e Silva.

E de dois pavimentos, tem a frente principal para o mesmo ampo do Conselheiro Diogn e voltado para leste, assim como o (Wuartel de lin/ı, cont o qual se acha annexo, faz esquina ao norte a rua cla Boa Vista

Serve de Quartel descie que este se comcenu a reonsiruir.

MUARTEI. DE POLICIA

Fiste edificio de um só pavimento achava-se começado já epercir remota cera de propriedade particular; o govemo da comprouto e mandou-0 concluir em 1850 . m administrador o Expm Sr. coron

rim leererra. Tem a frente principal voltada para ? sul e faz esquina a
leste cum a nua Conte d'Eu.

CADEIA NOVA

Este eilificio que se acha collocado no largo do mesmo novme ic de dois pavimentos e tem a frente principal para leste; foi principiado ou lancou-se a sua primeira pedra em 31 de janeiro
de I 553 na administraco de IS53 na administração do Ex.mo Sr. Dr. Antonio Coelho Sá e Albutquerque e terminou-se $\mathrm{em} 1857 \mathrm{ma}$ administração do Ex.mo Sr. Dr. Antonio da Costa Pinto e Silva, epoca em que foram nu-

ARMAZEM DA ALFANDEGA

Fiste edilicio de um só pavimento está collocado no pateo do messon, ma ria Visconde de Inhauma e tem a frente para oeste. 
E' onde funcciona a reparticăo ua Alfandev

Nenhum esclareciniento puóe obter com relaçào a epoca tm que foi edificado.

(Näo obstante ter sido autorisalo por Carth Reyia de $4 \mathrm{de}$ Setembro de 1690, sendo capitảo-mór governador Manoel Nunes Leitão a edificaçăo da Alfandega que se denominava Alfandega

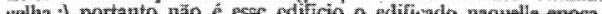

TREM DE GUERRA

Este edificio é um pequena casa onde funtciona a officim de ferreiro encarregado da limpesa e concerto do anmamento extincta a officina passou a servir de repartiçäo do deposito de artigos bellices.

Está collocado na nua das Flores com a frente para o sul Foi edificado em 1858 , na administraçắ do Ex, mo Sr. Dr. Antonio da Costa Pinto e Silva.

$$
\text { VIGIA DA ALFANDEGA }
$$

Esste edificio é um pequeno predio de um pavimento, collocado do lado snl do Trapiche d'Alfandega fazendo frente para Foi edificado em 1841, na vice-presidencia do Ex.mo $\mathrm{Sr}$. Francisco Xavier Monteimo da Franca. d'Allandega e guardas da mesma.

\section{GUARDA DA PONTE}

Este cdificio ế tambem um pequeno predio collocado no extreno da rua Visconde de Itaparica, fazendo frente para o norte e pateo do Sanhauab.
Serve de estabulo ao cobrador do pedagio da ponic do

uá e a guarda da mesma ponte.

of edíficado em 1838, logo depois da conclusio da pont de madeira ua administração do Ex.mo Sr. Dr. Basilio Quaresma Torreäo, e reedíficado em 1852, na do Ex.mo Sr. Dr. Antonio. Cocho Sâ e Albuquerque.

\section{CAPITANIA DO PORTO} Este edificio é de um só pavimiento e tem a freute principal
para leste e praça de Pedro It, foi edificado $\mathrm{em}$ 1860 na adminis 


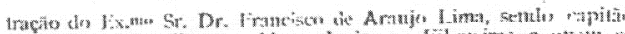
se mar e guerra Cietaun Alets de Some

\section{NATAOOLRO PLIBLACO}

Iste edificio te collucato muito alem da rta do Riacho, na cetrada das Atires tem a frente princijal para leste. Fui constritido

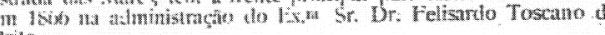
rito.

TR.APICIIF D:AIFANDEG.I

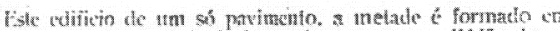
colnmuas, $1 \mathrm{~cm}$ a irente printipal para leste e pateo d'Alfandega

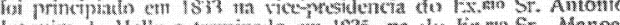

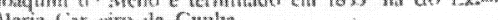

PMACFTES DE INSTRUCCÃO PRIMARI

Existem dous alifrcins destinados a instrucçăo primaria, o primeirn E edificado em tuma espuina da ma Marqtez de Herval, fazendo angulo para a rua tla Misericordia ; tem a frente principal, maqtella rta, voltado para oeste.

O segundo é cm uma esquima da rua Visconde de Pelotas, fizendo angulo com $n$ beces do Rosari

Nâo obstant: terem sido construido o primeiro e reconsIrnido o segundo em mens dias, comitudo não posso dar as datas por taes obras feitas no tempo em que existia nua reporticono de Publicas crada pela lei provincial n. 379 de 20 de Abril de 1570 , estes tous edificios só podem ter sido construidos des'a epoca em diante. O primeiro recordo-me de ter sido inaugurado na adminis-
traça do Ex, wo Sr. Dr. Silvino Flvidio Carneiro da Cunha e concluido na to Ex,mo Dr. Antonis Hereulano de Souza Bandein.

CEMTERTIO PUBLICO

Principiout-se en 185\%, por antorisacăo da lei provincial n. 


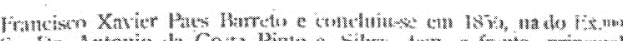
Sr. Dr. Antonio da Costa Pinto e Silvit, tem a f́rente principal

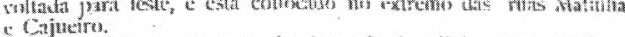
Cajueiro

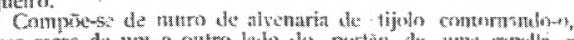
de duns casas de um e oatro late do partato, de uma capdla e cepsio de ossos nt fundo, de um fumnlo a esynerda da contrach

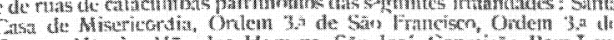

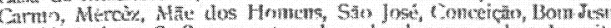
los Martyrios e S. S dramento; alem de algumas pedras de epita-

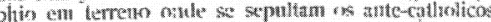

CEMTIERIO DA CRLZ DO PEIXE

Principinu-se cm 1878 por oscasião da sscea, no administagên do Ex.ms Sr. Dr. Ulysssts Machado Pereira Vianna e concluiu-se em 1879 na do Ex.mn Sr. Lr. Jose Rodrignes Pereira Junior; in construído por inicialiva da commissãn de succortros publicos, composta dos bre joũo Leite Ferreira, Ma

As desyezas correram pela verba soconrros publicos.

Consia de muro de alvenaria de pedra e tijollos contornando-o, tendo a frente principal, onde tem itm portico de ordem toseana, tenda a ferte prove provincis da Cruz do P'eixe, ao norte ta estrada do Tamban.

ESTAÇX̃o CENTRAL E. ARMAZENS DA CONDE DEU

Estes dour celificios foram principiadns $\mathrm{em} 1881$, quando administrador da Provincia o Ex, wo Sr. Dr. Justino Ferreira Car政, Sr. Dr. José Ayros do Nascimento, aubos șio collocados no largo da Cameleira.

$O$ primeiro tem a frente principal para o mesmo largo e voltada para lesie, o segundo tem a frente principal olhando para a praça Pedro

HOSPTN DA SANTA CASA

Fste edificio te dala remota é un estabelecimento a cargo 

da irmandade da Santa Casa e subvencionada pela provincia. I: de dois pavimentos, está situado nia rua do Hospital, para onde tem a freute principal, ollando para o norie; compöe-se de duas tern a fretite principal, os sexos no parimento superior, de sala ensultorin dos mediens, no inferior compöe-s de un x:1guão, de diversos cubiculos de alienados e cosinha.

TIIEATRINHO SANTA CRL\%.

E' um pequeno predio síluado na ma Visconde de Pelotas tendo a frente para o pateo das Merces, olhando para leste.

Com it mesma denominação de Santa Cruz deı-se principi para theatro por antorisaçào da lei provincial n. 549 de 2 de Setembro de 1874 e desde 1882 que se acha paralisado, já en muito bom pé e collocado pode-se dizer no centro da cidade con a frente voltada para o sul, no campo do Conselheiro Diogn.

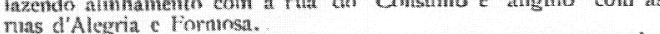

Pnree que os edificos deste genero estẫo escommungadn, pois sempre ha mit vontade para el'es (lsto ét aqui na Parahyba.)

\section{FONTES PUBLICAS}

BICA DO GRAVATÁ

Esta fonte foi crigida em 1781, por ordem da junta de Fazenda de Pertambuco.

Fra capitäo-mór governador Jeronymo Jnsé de Mello c Castro reconstruida $\mathrm{em} 1785$ na mesma administraçio em 1878 por occasiño da secca, na adninistraçoo do Ex.mo Dr. Glysses Machindo Pereira muito yue reclama concerto.

HICA DOS MILAGRES

Lsta fonte de nma agua potavel, faz pena ver-se o moto poryue

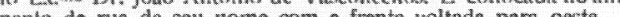
inento da rua de seu nome com a frente voltada para oeste. pequenos concertos. 


\section{BICA DO TAMHIÁ}

Esta fonte fallada em quasi todo Brazil, $\dot{c} \mathrm{~d} e$ uma arua *m rival, foi erigida $\mathrm{em} 1782$. Era capitão mór governador o Ex.m. Jeronymo José de Mello e Castro.

E' uma vertente de grande force a posso dizer sem med. de errar que metade da populaçio da cidade se abastece com sua agua. Está collocada por detraz, da rua do Tambiá já no extremin, da cidacle, com a frente olhando para o norte.

\section{CACIMBA DO POVO}

$E^{\prime}$ um pequeno tanque de pedra de cantaria, sta agua : excellente, nada sei a respeito de sua origem.

Fica por detraz da rua das Trincheiras do tado th neste.

Conclui esta obra $\mathrm{em}$ dias do mez de Fevereiro de : 8 s?

NOTA Depois de haver rondinido a presente obra, demo liu-se quatro predios na ma Visconde de Imhanma para dar passagem a linha do ramal do Cabriello. 
CRUZ, João C. de Oliveira. "Melhoramentos da Capital da Parahyba I", Gazeta da Parahyba, n. 196, Anno II p.3, 09.01.1889

\section{Melhoramentos da Capital da Parahyba I}

A cidade da Parahyba acha-se situada à maré do rio de mesmo nome, a 2100 kilometros do Rio de Janeiro. $\mathrm{O}$ eu solo mais ou menos montanhôso permite que a cidade seja situada em uma parte pouco acidentada nas immediações do rio, prolongando-se por meio de uma collina e terminando em um plateau superiormente collocado.

Esta situação topographica faz dar à cidade os nomes de cidade baixa ou varadouro e cidade alta.

Na primeira existe o commercio em grôsso e mesmo a retalho contando alguns edificios importantes taes como a alfandega, conselho provincila, capitania do porto, estaçao da via ferrea, cadeia, quartel do corpo de pollicia, estação telegraphica etc etc; a segunda é onde se acham o palacio da presidencia , assembléa provincial e lycêo, thesouraria de fazenda, camara municipal, correio, mercado, theatro, matriz etc.

$\mathrm{Na}$ parte media está situado o novo quartel de linha, o edificio destinado à enfermaria militar, onde provisoriamente acha-se aquartelada a força de linha, o thesouro provincial etc.

Toda cidade é rodeada de verdadeiras florestas de coqueiros e outras arvores taes como cajueiros, magueiras, laranjeiras etc., que, não só embelezam a mesma cidade como protegem a sua pequena industria e purificam o ar.

Em planos inferiores ao da cidade alta, e em distancia relativamente pequena, existem algumas fontes, e bem assim rios, cujas aguas em alguns, preenchem as condições necessárias; entre as primeiras citaremos a fonte do Tambiá, e entre os últimos os rios Marés, Macaco, e Jaguaribe.

O porto de embarque e desembarque permitte a approximaçao de navios de alto caládo, que, derectamente da Europa e de outras partes do globo, vêem trazer marcadorias para o abastecimento da cidade.

O trajeto feito da povoação de Cabedello até o porto da cidade, com uma distância mais ou meos de 4 legoas, é a mais Ikinda das diversões, que o homem pode desejar.

A variedade de panorama que, de momento a momento, se desenvolvem a vista do observador, torna-o estupefacto ante a magestade de tentas grandezas naturaes.

A província da Parahyba, se por um lado é infeliz por outro é dotada de elementos que a podem tornar uma das primeiras províncias do Império.

Parece que a natureza caprichando forneceo-lhe poderosos elementos, como que convidando o homem a aproveital-os, para que mais tarde vejam ela erguer-se imponente ante o throno do progresso e altiva esmagar a hyra de quem tanto a acabrunha.

O distincto povo parahybano que tão bem comprehende a serie de melhormantos que podem tornar prolongada e feliz a vida humana, não pode deixar de curtir intimamente a dôr que lhe dilacera, por ver o abandono em que jaz a terra que lhe vão dar o primeiro vagido.

Inútil seria em um só momento querer-se rehender todos os melhoramentos necessarios à cidade, seria isso um ingente esforço que considero muito acima dos recursos que se podem presentemente reunir; mas mhetodicamente procedendo-se, e para isso utililisando-se tambem o auxilio externo, pode-se com facilidade e em tempo muito menor do que supomos, tornar essa codade uma das mais hygienicas e mais confortaveis do mundo.

Chamemos ao nosso seio essa serie de emprehendimentos que tanto ennobrecem a humanidade e procuremos vencer imaginarios obstaculos que se antepõem à nossa vontade, que teremos conseguido o nosso desideratum.

Como se vê está a cidade da Parahyba do Norte mais que predestinada a receber todos os melhoramentos hoje notados nas regiões mais civilizadas do globo. Uma unica causa poderia procurar obstar esses melhoramentos, e essa é a descrença de uma parte da população. Mas, como não haver essa descrença se o povo parahybano vê constantemente mallorados todos os emprehendimentos que são tentados? Precisamos portanto vencer esse obstaculo e tornar uma realidade o que para muitos é considerado uma verdadeira utopia. Pode-se dizer que tudo falta nesta boa terra, até mesmo os principaes elementos da vida, isto é, o ar, a agua e a luz apresentam-se deficientes ás necessidade do povo: o $1^{\circ}$ em relação a sua constituição; a $2^{\mathrm{a}}$ quanto a quantidade de que se faz necessario, e finalmente a $3^{\mathrm{a}}$ por não preencher as condições exigidas por um povo civilisado. É ate onde pode chegar o atraso de uma terra, e nós para banirmos completamente a antiga rotina d'aquelles que não comprehendem o progresso das nações cultas, devemos unir nossos esforços, e procurar vencer a repugnancia dos que illusoriamente estacionam, não querendo marchar a par de seus irmãos que tanto se desvelam no andamento do lar que os vio nascer.

Não tenho a felicidade de poder como vós ufanar-me de aqui ter sido o meu berço, mas nem por isso arrefece-me o desejo que nutro de ver um dia a província da Parahyba aparecer radiante de gloria entre suas irmães, ostentando os mais importantes melhoramentos que tanto ennobrecem a humanidade. Então 
sim, egoístas e aventureiros não procurariam mais opprimil-a, antes ella retribuir-lhes-ia a ironia presente com um futuro sorriso de desdém.

Diversos são os melhoramentos que devem ser introdusidos nesta cidade e considerando-os em relação a seus beneficos effeitos, os classificarei segundo a ordem que elles devem ser adotados.

Se bem que qualquer delles considerado isoladamente seja um gigantesco passo dado no caminho dos commettimentos sociaes, todavia alguns tendem derectamente com as mais urgentes e palpitantes necessidade da vida.

E', portanto, attendendo a essa poderosa circumstancia, que apresento-os na ordem que se segue:

Abastecimento d'agua potavel

Canalisação de esgoto das materias fecaes e aguas servidas

Limpeza publica

Adopção de um systema aperfeiçoado de illuminação

Construcção de um theatro

Construcção de carris de ferro

Jardim publico

Como se vê pela presente classificação são sete os melhoramentos necessarios á cidade, afim de que não só torne-se uma das mais hygienicas, como para que contenha elementos de conforto à população.

Alem dessas vantagens indiscutiveis há ainda a do desenvolvimento do commercio, a qual se manisfestará pela somma de dinheiro que então girará nessa praça.

Está provado que as emprezas são um grande elemento de riqueza para o local onde se acham estabelecidas, em virtude de ahi espalharem grande parte de seus productos monetarios.

Muitas outras vantagens tambem são consequencias desses melhoramentos, mas deixo de mencional-as porque seriam innumeraveis.

Passo portanto a tratar do primeiro trabalho que deve ser emprehendido.

João C de Oliveira Cruz, Engenheiro Militar.

CRUZ, João C. de Oliveira. "Melhoramentos da Capital da Parahyba (continuação) II - Abastecimento d'agua", Gazeta da Parahyba, N197, Anno II p.3, 10.01.1889

E' este o primeiro melhoramento que se deve introduzir em qualquer cidade, muito principalmento quando ella não contem em seu seio abundantes mananciaes que pela pequena distancia onde corram permittam o povo suprir todas as necessidades.

Infelizmente a cidade da Parahyba não se acha a esse respeito em boas condições; as pequenas fontes de suas proximidades, conforme se acham, são deficientes para o abastecimento, accrescento a circunstacia de ser mais ou menos difficil a conducção de suas aguas.

Como então se abastece a cidade desse tão importante liquido?

Em primeiro lugar direi que esse abastecimento não se dá, e que a água obtida mal chegas para as primeiras necessidade da vida, sendo, senão no todo, ao menos em parte, prejudicada a hygiene da população.

Em segundo lugar, essa água adquerida por elevados preço não offerece a menor confiança, porque quase toda é extrahida de poços ou cacimbas situadas em lugares diversos, onde não só em relação a constituição dos terrenos que formam o seu leito, como pela falta de cuidado de alguns de seus proprietários, não podem por for forma alguma preencher as condições exigidas ás aguas potaveis.

Se o serviço de fiscalização dessas aguas estivesse regularmente organizado, ao menos de alguma forma diminuiriam os inconvenientes, que podem resultar da existencia de materias organicas, que se decompõem e se misturam com o liquido.

É preciso confessar que em muitas cacimbas existe o maior cuidado por parte dos respectivos proprietários; mas se esses tornam-se zelosos, e procuram bem servir ao publico fornecendo-lhe água de boa qualidade, outro tanto não acontece com alguns que desprezam-nas completamente, e delas só querem o uso fructo, mui embora o seu produto seja um verdadeiro veneno que se vae inocular no organismo do povo e produzir-lhe desastrosos effeitos.

Reconheço ser essa uma questão importante que só poderia ser discutida pelos distinctos medicos do lugar; mas, como engenheiro, é tambem do meu dever occupar-me com a hygiene do povo, por isso que directamente a minha profissão está ligada essa materia puramente medica.: portanto peço permissão aos dignos facultativos dessa cidade para no correr desse trabalho falar algumas vezes nos principios da hygiene, e bem assim que me desculpem se de qualquer modo commetter algum erro quando me referir a essa importante materia. 
Esse trabalho importância nenhuma teria se eu pozesse de parte a higiene propriamente dita da cidade; portanto precisaria que fosse ele collaborado por uma engenheiro e um medico, para que podesse ficar isento de defeitos.

Vê-se, pois, quão acanhadas não há de ser a esphera das considêrações que fazer, desde que me falta o poderoso auxilio dos distinctos clínicos dessa capital.

Como porem tudo se pode perdoar, desde que quem merece o castigo pede humildemente desculpa dos seus erros, julgo ser com benevolencia tratado pelos homens da sciencia de Hypocrates.

Continuando a tratar das cacimbas direi que são ellas improprias para o fornecimento do liquido em questão.

Qualquer animal ou vegetal que por descuido precipita-se em seu interior será em breve decomposto e viciará a agua.

Como se vê, esse facto poderá prejudicar muito a saude publica, e não será de admirar o apparecimento de alguma febre paiustre nos individuos que dellas fizerem uso.

Alem disso a constituição do leito onde são abertas essas cacimbas pode não ser a mesma em todas ellas, por conter alguma substancia mineral, que venha influir sobre o líquido, e tornal-o pouco próprio aos misteres da vida.

Procuremos portanto livrarmo-nos das cacimbas mui embora tenhamos que vencer a repugnancia que muitos teem da introdução da canalisação d'agua na cidade.

É para admirar o modo porque algumas pessoas se pronunciam a respeito desta importante questão.

Se já não conhecesse plenamente as idéias adiantadas da maior parte dessa população, e se tivesse entretido conversação com algumas das pessoas que vivem entre nós, por ocasião de passar nesse lugar, ver-me-ia na dura necessidade de fazer bem triste juizo a respeito do pensamento do pensamento do povo; mas felizmente isso não se dá, porque a amior parte da população da Parahyba compõe-se de pessoas que pelo grao de civilização que possuem tornam-se dignas dos mais elevados commettimantos.

O povo parahybano quer mas não pode eis o que se conclue da marcha dos acontecimentos sociaes. Fica entendido que, quando digo povo parahybano não comprehendo aqueles que, ou systematicamente ou por ignorancia, persiste em não desejar todo e qualquer melhoramento, attibuindo-os ou a especulações de terceiros, ou temendo que elles tragam prejuizos próprios.

João C. de Oliveira Cruz, Engenheiro Militar.

CRUZ, João C. de Oliveira. "Melhoramentos da Capital da Parahyba II - Abastecimento d'agua (continuação)", Gazeta da Parahyba, N198, Anno II p.2 e 3, 11.01.1889.

Esses individuos ou são descrentes em excesso ou são pyrrhonicos ou então não se querem dar ao trabalho de refletir nas vantagens que estão gosando tantas cidades do mundo.

Condemnadas portando as cacimbas visto não fornecerem agua nas condições desejadas investigaremos as fontes, que também servem para o fornecimento da cidade.

Entre ellas citaremos somente duas: a bica do Gravatá e a do Tambiá; a primeira se bem contenha agua um pouco pesada, contudo poderia servir aos habitantes da cidade baixa, de preferência as cacimbas muitas das quaes tem agua quase salgada, mas como esta abandonada em consequencia de estar obstruida a vala que lhe serve de esgoto, de nada serve a sua permanencia; a segunda ou a do Tambiá é a unica que auxilia o fornecimento d'agua da capital.

Procuremos agora saber se esta ultima fonte se encontra em condições de bem servir ao publico.

$\mathrm{Na}$ base de um morro, a um kilometo mais ou menos de distancia da cidade alta, existe uma vertente cujas aguas, segundo a opinião dos habitantes desse lugar em tempo algum tendem a desaparecer.

Procurando aproveital-as construiram uma especie de deposito de recepção em communicaçao immediata com a mesma vertente, e estabeleceram uma galeria que vai ter a um segundo e pequeno reservatorio que contem 3 bicas de um diametro mais ou menos de $\mathrm{O}=, 02$.

A agua que verte em pequeno filete vae se depositando na primeira caixa e d'ahi passa para a segunda, donde é extrahida pelas torneiras.

Se não fosse a grande quantidade de cacimba existente, essa fonte não satisfaria de forma alguma as exigencias do publico; mas por ser ella situada a maior distancia, não afflui pra alli grande massa de povo, de forma que a agua vae chegando, mais ou menos, para aquelles que a vão buscar. Ainda assim dia há em que pela manhã não existe gotta d'agua, e os aguadeiros teem de esperar que o deposito ajunte, pra então poderem encher seus barris. Essa falta é devida aos banhos que tomam, accrescendo a circunstancia de muitas vezes abrirem as bicas e deixarem de fora os tacos de madeira que as fecham.

É de lamentar que existindo nas immediações da cidade uma unica fonte que fornece excellente agua, seja ella maltratada a ponto de tornar-se uma verdadeira latrina publica. 
O lugar onde se acham situadas as bicas é murado, e para chegar a ellas, é necessario descer uma escada de cantaria de 2 ou 3 metros de altura.

Como se vê, forma-se ao redor das bicas uma pequena praça, onde se reunem os aguadeiros.

Esta praça a todas as horas do dia e da noite está entregue ao povo que não só utilisa-se della como casa de banho, como tambem alli satisfaz certas necessidades.

Pelo que venho de demonstrar a fonte do Tambiá não prima pelo asseio, pois se bem que a agua seja de boa qualidade sua immediações não são respeitadas, pelo que torna-se desagradável o ambiente do lugar onde ella está situada.

É pena que alli não seja observado asseio e precisa decencia.

Se uma família desejar visitar aquêlle local ver-se-ha obrigada a enviar adiante uma pessôa para observar a fonte e avisar as pessoas que alli se acharem da chegada da familia.

Não sendo tomada essa precaução ficara a familia exposta a presenciar scenas bem desagradaveis.

Agora é necessario saber se a agua fornecida pela fonte do Tambia é suficiente para abastecer a cidade. Ainda mesmo que a natureza a transformasse em um caudaloso rio, jamais ella abasteceria a cidade com o systema de fornecimento por maio de barris condusidos ás costas de animaes.

Algumas pessoas que mostram-se satisfeitas com o processo da conducção d'agua por essa forma; mas habituadas como estão a disporem de pouca quantidade desse liquido, porque lhes seria muito oneroso se quizessem tel-o com abundancia, entendem não ser necessario ter qualquer melhoramento, mui embora venho argumentar-lhes na razão decupla a quantidade d'agua que hoje despendem.

Esses individuos que fazem uma tão errônea idéa deste importante melhoramento não attendem a dupla vantagem que elle pode trazer; isto é, de decuplicar-lhes a agua que hoje consomem e de diminuir-lhes a despeza que hoje fazem.

Não ha calculo mais facil de fazer-se do que o que resulta da comparaçao da despeza feita presentemente com a agua despendida n'uma casa de familia, e a que para o futuro se poderá fazer, desde que seja ella trazida ao lar dometico por meio de encanamentos.

João C. de Oliveira Cruz, Engenheiro Militar.

CRUZ, João C. de Oliveira. "Melhoramentos da Capital da Parahyba II - Abastecimento d'agua (continuação)", Gazeta da Parahyba, N199, Anno II p.2 e 3, 12.01.1889.

Quando mais não fosse só a vantagem de todos terem agua em abundancia no interior de suas casas, podendo a qualquer hora do dia ou da noite servir-se della, era bastante para despertar o desejo, e mesmo a iniciativa particular no sentido de conseguir-se este desideratum; quanto mais que a par desse grande melhoramento que tão de perto influe na hygiene dos habitantes da cidade ha a economia que se faz com o consumo, desde que seja elle feito por aquelle systema.

Presentemente uma casa de familia não pode manter-se com menos de duas cargas d'agua, ou oito barrilotes, e ainda assim é necessario que toda roupa seja mandada lavar nas fontes.

Calculando-se a 160 reis a carga, vê-se que no fim do mez a despeza monta a 9:600 reis. Incluindo a depeza feita com a roupa que se manda lavar, reconhece-se que excede 20:000 reis a quantia despendida mensalmente com aquelle serviço.

Dirão os incredulos que nem todas as familias fazem semelhante despeza, porque remedeiam-se com 4 barrilotes e ainda assim aproveitam as aguas das chuvas.

Em primeiro lugar nem sempre chove, e portanto não podemos contar com um elemento de todo incerto; em segundo lugar, as pessoas que assim pensam ver-se-ão obrigadas a privar-se de alguma forma do uso do liquido, para que possa elle satisfazer as mais palpitantes exigecias.

Considerando ainda esse gasto minimo, vê-se que a razão de 4 barrilotes por dia, a despeza mensal é de 4:800 réis afóra a que é feita com a roupa que se manda lavar.

Está portanto fora de duvida que seria uma vantagem immensa uma empreza que viesse dar-nos agua em abundancia por menor preço que o mensionado.

Se algumas famílias despendem menos de 20:000 réis por mez, outra ha que sua depeza eleva-se a maior quantia do que esta no mesmo espaço de tempo.

Entretanto com 4 ou 5:000 réis mensaes poderemos ter agua nas condições que venho de mencionar, com o estabelecimento d'uma penna d'agua no interior dos predios onde habitamos.

Outra vantagem não menos importante é poder estabelecer-se nos proprios predios baheiros ou tanques de lavagem.

Uma casa de família muito lucrará com esse melhoramento, pois é de todo preferível um banho de agua corrente ao único que se pode usar presentemente - o banho de bacia. É verdade que alguns teem em seus predios banheiro de alvenaria, mas estes para funcionarem necessitam de um deposito superior onde por meio de baldeação é alli colocada a água destinada ao banho. 
Este processo alem de incommodo não satisfaz porque esgotado o deposito ficará o banhista sem mais recursos, a menos que algum estranho não venha em seu socorro encjhendo novamente o seu deposito.

Há aqui uma duvida que se apresenta na canalisação d'agua, e esta é a que se refere a classe menos protegida da sorte, isto é, se locrará ella ou não com a introducção do novo systema.

Sem hesitar digo que muito lucrarão os pobres se realisar-se esse importante melhoramento, e para isso não precisa mais que analysar o modo porque elles obtem presentemente a agua, para se reconhecer incontinente que todo e qualquer processo que se adoptar no sentido de facilitar o transporte da mesma agua, será um grande beneficio que lhes virá trazer.

A agua é conduzida de um modo enfadonho, porque nem sempre as cacimbas distam pouco de suas residencias, e obrigão-nos a vencer grande distancia sobre a influência do peso do barril que trazem as costas.

Se agua é procurada na fonte do Tambiá, o sacrifício será maior pela grande distancia onde ella se acha situada.

Agora resta saber se é somente o sacrificio do corpo o necessário para que a classe pobre obtenha a agua nas suas residências, não, ela tambem paga aos cacimbeiros o preço do liquido que conduz. Em geral um barril d'agua que pode conter mais ou menos 20 litros é vendido nas cacimbas pelo preço de 10 réis. São estas as criticas circunstanciais em que se acha a classe pobre da Parahyba em relação a aquisição de um dos primeiros elementos necessarios a vida.

É preciso agora investigar se o abastecimento d'agua por meio de encanamentos traz as vantagens a que me referi.

Construindo-se uma rêde de encanamentos em toda a cidade é obvio, que ella passará nos lugares mais públicos, de sorte que poder-se-há em todas as praças, ou em outros pontos, estabelecer-se chafarizes convenientemente preparados, tendo suas torneiras diametro sufficiente.

Estabelecidos esses chafarizes os pobres irão buscara agua de que precisam, podendo tel-o quasi a porta de sua casa. Mediante uma pequena taxa, por exemplo de 10 reís por 20 litros, cada um abasteça sua residencia, tendo portanto com a mesma quantia de hoje despende obtido a mesma quantidade d'agua e poupando as fadigas do corpo, accrescendo a circumstancia de usarem constantemente excellente qualidade.

Creio ter nestas poucas palavras demonstrado todas as vantagens que pode trazer uma empreza de canalisação d'agua na capital, e bem assim ter provado a imperfeição do systema presentemente adoptado. Agora farei algumas considerações a respeito dos mananciaes que podem ser utilisados, por uma empreza desse genero.

A fonte do Tambiá no estado em que se acha poderá ser um auxiliar para o supprimento de agua a cidade; mas não que por si constitua um abundante manancial, porque, como já disse, apenas é constituida por um pequeno filête que, em communicação directa com um reservatorio permitte durante a noite a reunião de ceryo volume d'agua, que no dia seguinte vae satisfazendo as necessidades dos que a ella recorrem.

Entretanto com um trabalho de arte poder-se-hia transformal-a e augmentar consideravelmente o seo volume d'agua actual.

CRUZ, João C. de Oliveira. "Melhoramentos da Capital da Parahyba II - Abastecimento d'agua (continuação)", Gazeta da Parahyba, N200, Anno II p.1 e 2, 13.01.1889.

Pela exploração que alli procedi, verifiquei que nas circumvizinhanças da fonte existem muitos olhos d'agua, os quaes reunidos em um grande depósito poderão centuplicar a quantidade existente.

Como porem esteja a fonte situada em um plano, inferior de mais de $40^{\circ}$ do ponto mais alto da cidade, só por meio de poderosas mackinas de elevação conseguir-se-hia fazer despejar agua n'um deposito collocado á altura de permittir a destribuição em todos os sentidos.

Este trabalho só podendo ser levado a effeito por uma empreza que disponha de capital avultado, faz mais uma vez convencer da necessidade que tem a provincia de proporcionar este ensejo, afim de conseguir libertar a cidade do estado de verdadeira calamidade em que se acha, pois podemos mesmo dizer que nos é custôso adquerir a agua para bebermos.

Mas se porventura falharem todos os esforços empregados no sentido de constituir-se aqui uma empreza d'aquelle gênero, aconselho a provincia que mande fazer um grande açude nas proximidades da fonte, $e$ em sua parte mais baixa, por isso que a agua do Tambiá é digna de assim ser tratada, por ser de excellente qualidade.

Em falta de arvorêdos que resguardem a agua deverá ella ser coberta superiormente, sendo a cobertura suspensa, afim de não só a agua conservar-se fresca, como para que o ar a lava completamente.

Como se vê, este processo garante á cidade agua de superior qualidade e em maior quantidade. 
Com a adopção de um systema de transporte mais aperfeiçoado ter-se-há conseguido melhorar esse tão importante serviço.

Passando da fonte do Tambiá aos rios temos, como tambem já disse, o Jaguaribe, o Macaco e o Marés. Segundo opiniões competentes este ultimo é o que se acha em melhores condições, por ser a sua agua de qualidade superior a dos outros; mas, qualquer que seja o preferido, uma empreza deverá dirigir suas aguas por meio de encanamentos.

Este importante trabalho não é de difficil realisação porque as garantias que pode a empreza auferir dar-lhehá de sobra para pagar o sacrificio que fizer.

Mas quaes deverão ser as garantias que possam compensar esse grande trabalho?

A provincia responderá: - Isenção de direitos; collocação de agua obrigatoria nos predios; concessão de um praso longo; prohibição da venda d'agua nas cacimbas;e outras vantagens que possão, despertar o enteresse dos emprehendedores.

Relativamente ao modo porque devo-se estabelecer uma empreza desse gênero, abstenho-me de discutir, em consequencia de ter de tratar technicamente da questão, trabalho esse que não estando ao alcance de muitos leitores só serviria para auxiliar a empreza, restrigindo-lhe a despeza que deverá fazer com os trabalhos preliminares; era portanto adiantar o serviço do estabelecimento da mesma empreza, fazendo ella uma economia que estou certo não me agradeceria.

Antes de terminar este capitulo resta-me fazer algumas considerações a respeito da quantidade d'agua que deverá ser fornecida em 24 horas para cada habitante da cidade, tomando como base a que é destribuida em diversas cidades do mundo, inclusive a capital do imperio, e bem assim direi algumas palavras sobre as condições que devem satisfazer a agua destinada ao consumo publico.

Relativamente á primeira parte, grande é a divergencia da quantidade d'agua que se destribue em diversas cidades, sendo para notar que todas procuram $x x x x x x$ de $x x x x x x x$ a que seja destribuida para cada habitante um volume d'agua que satisfaça plenamente a todas as necessidades, mesmo nas occasiões dos grandes abaixamentos dos mananciaes.

Para dar uma idea reproduso o quadro seguinte, extrahido de um importante trabalho sobre abastecimento d'agua á cidade do Rio de Janeiro, trabalho esse que fora apresentado á assembléa geral legislativa em 1873, por uma commissão.

Eis o quadro:

Nomês das cidades

Roma

Nova York.

Marselha.

Carcassone.

Besadçon.

Dijon

Richemon.

Bordeaux

Madrid.

Genova....................................

Laval. ....

Glasgow................................

Cette.....

Londres.

Manchester

Narbonne.

Bruxellas.

Munich.

Genebra.

Philadelphia

Tolosa.......

Pariz.......

Grenoble.

Vienna.

Nantes.

Grenock.

Montpellier.

Clermont.

Edimburgo.
Quantidade de litros por habitante

1.060

500 a 600

400 a 500

300 a 400

250

198 a 678

480

130 a 200

140

120

115

100 a 113

100 a 110

95

80 a 90

80 a 85

80

80

78

70

62 a 78

60 a 120

60 a 65

60 a 65

60

57

50 a 60

50 a 55

50 
Havre.

Gray.

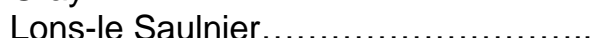

Angouléme.

Chaumont.................................

Liverpool.

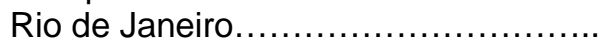

Saint Etienne.

Metz.

Dole.

Bezier
40 a 45

40 a 45

35 a 40

35 a 40

30 a 35

28

20 a 37

20 a 25

20 a 25

15 a 20

12 a 14

Como se vê pelo presente quadro era insignificante a quantidade d'agua destribuida na maior parte das cidades que venho de mencionar; mas a contar dessa data, grandes obras de abastecimento teem sido levadas a effeito, de forma que em muitas dellas, o volume d'agua destribuido a cada habitante tem sido augmentado extraordinariamente.

Haja a vista a cidade de Pariz e bem assim a de Nova York, onde as municipalidades procuram garantir o supprimento de 1000 litros d'agua por dia e por habitante. No Rio de Janeiro tambem muito se tem feito nesse sentido, tanto que, apezar de poder-se contar hoje perto de 200 litros por cada habitante, ainda assim acaba o parlamento de conceder mais um credito de 1:000.0005000 para a compra de mananciaes e outras obras que venhão augmentar o volume d'agua destribuido a cada habitante.

Nessas circumstancias e attendendo as condições desta capital, entendo dever fixar em 160 litros a agua que deverá ser destribuida tambem a cada habitante no período de 24 horas.

Se fossemos a calcular a agua que presentemente é consumida, estou certo, chegariamos á conclusão de que a media do consumo não excederia de 10 litros por pessoa n'aquelle mesmo período.

João C. de Oliveira Cruz, Engenheiro Militar.

\section{CRUZ, João C. de Oliveira. "Melhoramentos da Capital da Parahyba II - Abastecimento d'agua (continuação)"}

Veja-se, portanto, o estado calamitoso da população, e procuremos portanto reunir a maior somma de esforços possivel, para de todo libertal-a do braço que a subjuga e a mantêm estacionaria.

Referindo-me agora ás condições que deve satisfazer a agua potavel, repetirei o que disse o celebre Dr. Koch a respeito desse importante assumpto, conforme foi publicado na Revista dos Constructores, no Rio de Janeiro: Que não devem conter impurezas, porque as que existem sobre as superficies por onde correm as aguas constituem activos agentes de contagio, bem como que se deve evitar nas obras de canalisação a introducção de aguas turvas que contenham organismos em quantidades apreciaveis.

Que a agua não deve conter amoniaco nem acido nitrico, podendo quando muito admettir alguns vestigios destes dous corpos: que não é porque elles sejam nocivos á saude e sim porque a sua presença revela decomposição ainda activa de materias de origem animal.

Que a proporção do chloro, acido sulfurico, ferro, magnesia, materias organicas em dissolução, não deve oxceder da media que dê a analys-do conjucto de aguas da localidade.

Uma quantidade grande de chloro indicaria bem como o amoniaco e o acido nitrico a presença de materias animaes em decomposição.

O ferro inoffensivo por si tem o incoveniente de dar á agua uma colloração amarellenta e ás vezes tambem o de causar perturbações nos conductos de grande extensão, formando depositos.

Que a agua deve ser fresca, de um gosto agradavel, sem durêsa, incolor e clara, sendo que a temperatura para umas deve estar entre 5 e 15 gráos e para outras entre 7 e 11.

Terminando este capitulo com estas importantes observações do Dr. Koch, passo agora a tratar do segundo melhoramento, que tão de perto vem influir no saneamento da capital.

III - Canalisação de esgoto das materias fécaes e aguas servidas

Estabelecida que seja a canalisação d'agua na cidade vem como consequencia immediata a necessidade da canalisação do esgoto das materias fécaes e aguas servidas.

Este melhoramento classificado por mim em segundo lugar, em consequencia de depender do primeiro, é todavia da mesma importancia que aquelle, por ter influencia directa sobre o saneamento da cidade. 
Os poços ou sumidouros existentes nos quintaes das casas, só servem para infeccionar o ar atmospherico e, por conseguinte, concorrerem para a insalubridade da capital.

Os gazes que se desprendem, de cheiro nauseabundo, viciam o ambiente e o tornam improprio a saude.

Apezar de já haverem opiniões em contrario, sou d'aquelles que entendem não poder ser propria á saude a exhalação que se nota nessa classe de depositos; procuremos, portanto, tambem livrarmo-nos desses fócos miasmaticos, que estou certo muito lucrará a cidade com a sua extincção.

Segundo publicaram jornaes na Inglaterra, o Sr. Haldane procedêo a uma serie de observações a respeito da atmosphera das latrinas, e dellas concluio que o ar recolhido nas mesmas era mais puro que o exterior.

Em Bristol o Sr. Haldane recolhêo o ar das latrinas, e segundo diz, não encontrou bacterios que podessem resistir ao volume consideravel de acido carbonico.

Procedendo ainda a analyse do ar das latrinas em diversas cidades, concluio que em vez de estar elle carregado de microbio, como em geral se acredita, não está, sendo mais puro que o ar exterior.

É realmente interessante essa noticia que extrahi da Reveista dos Constructores, mas emquanto não ficar completamente provada esta opinião, pela analyse dos eminentes hygienistas confesso não abraçal-a de nenhuma forma.

João C. de Oliveira Cruz, Engenheiro Militar.

\section{CRUZ, João C. de Oliveira. "Melhoramentos da Capital da Parahyba III - Canalisação de esgoto das materias fécaes e aguas servidas (continuação)" N 202, ANNO II, p 2, 16. jan. 1889.}

A par da opinião de Haldane, vemos a do distincto engenheiro brasileiro Monteiro de Barros, fiscal do governo junto a companhia City Improvements.

Esse engenheiro, tratando dos melhoramentos do systema de esgoto do Rio de Janeiro, pensa pela forma seguinte:

< No intuito de debellar as febres de variados typos que irrompem durante os verões e se manifestam em casos esporadicos no correr do anno, originadas, na opinião de distinctos profissionais, da infiltração de materias fécaes no solo por causa da pessima qualidade do material dos encanamentos de esgoto, insufficiencia de declive, de resistencia e de capacidade dos mesmo para receber, como convinha, a lavagem das aguas pluviaes, suggere o ministério do imperio, no relatorio apresentado a assembléa geral legislativa, no anno de 1886, como medida importante para o saneamento da capita, melhoramentos ou reforma radical do systema de esgoto.

O engenheiro Monteiro de Barros terminando as suas observações, conclue apresentando a opinião de outros distinctos profissonaes á rspeito deste assumpto; assim tratando do relatorio apresentado em 1871 ao ministerio das obras publicas pela commissão nomeada para examinar os trabalhos e serviços de esgôto da cidade, da qual fazia parte o presidente da extincta junta de hygiene, repete elle as seguintes as seguintes palavras da commissão:

No cuidado que reclama a construcção das galerias e encanamentos está o meio de evitar a infiltração, no solo, das aguas corrompidas. Se esse cuidado pres_dio totalmente as construcções a cargo da companhia City Improvements, não pode affirmal-o a commissão.

Entretanto do que se trata em relação ao systema de esgotos já adoptado e funccionando em grande parte da cidade, é minorar todos os incovenientes que porventura se forem manifestando e são elles evidentemente originados em sua quase totalidade na insufficiencia d'agua. Nestes termos é claro que a influencia perniciosa á saude publica derivada dos serviços a cargo da companhia City Improvements não é inherente á naturesa do serviço, modo como foram executados e é custeado o serviço, senão a falta d'agua, cabendo a outrem a responsabilidade dessa falta.

Não precisa mais uma palavra para ficar provada a inconveniencia dos esgotos imperfeitos; fallam bem alto as opiniões destes distinctos profissionaes.

Se o facto de não haver bastante agua ou sufficiente declive é rasão assaz for e para o emprehendimento de melhoramentos no systema de esgoto, por isso que elle assim constituido torna-se pernicioso á saude publica, como deixaremos de condemnar severamente os poços immundos que infestam toda a cidade!?

No caso de ser de todo impossivel, a canalisação do esgoto é preferivel á limpesa feita por meio de cubos condusidos em carroças apropriadas como se adopta na cidade de Porto Alegre, no Rio Grande do Sul e em outros lugares do imperio.

Este processo tem ao menos a vantagem de não accumular nas casa grandes quantidades de materia fecal, que só serve para viciar o ar atmospherico e expôr os habitantes a inoculação dos miasmas desprendidos.

Os gases mephiticos que se desprendem dos poços onde se accumulam essas materias immundas, é um veneno terrivel absorvido por quem se colloca ao seu alcance. Respirado por algum tempo pode provocar nauseas, anciedade, etc e até mesmo a asphyxia. 
Parece que não devia fazer essa observação, por não ser intimamente da minha competencia, mas é facil de desculpar se-me attendendo-se que para condemnar um pessimo systema de serviço necessito provar seus incovenientes.

Aos distinctos facultativos desta capital peço mais uma vez desculpa de tratar de semelhante questão.

Estou certo que deixarei de soffrer qualquer accusação, pois, que, como attenuante, tenho a boa vontade, se bem que em esphera muito limitada, de ser util a esta população.

Afastando-me provisoriamente do assumpto, peço permissão para fazer a seguinte observação: -

Um dos motivos que concorrem para o atraso da provincia, é a ausencia de uma directoria de obras publicas.

Parece que a provincia realisa grande economia não tendo ao menos um engenheiro que se encarregue dos diversos trabalhos que a toda hora apparecem. Seria de todo preferivel ter ella um funccionario que lhe pertencesse, a viver mendigando os serviços de uns e de outros.

De todas as provincias do Imperio é esta a unica talvez que não conta uma repartição de obras publicas, e este é um dos motivos, como disse, que concorrem para a decadencia de varios importantes serviços.

Não se supponha que assim falo por não desejar contribuir com o concurso do meu trabalho, pelo contrario continuarei a estar sempre prompto para esse fim; mas sim, porque entendo não haver vantagem fazendose uma insignificante economia que accarreta prejuizos muito superiores a ella.

João C. de Oliveira Cruz, Engenheiro Militar.

CRUZ, João C. de Oliveira. "Melhoramentos da Capital da Parahyba III - Canalisação de esgoto das materias fécaes e aguas servidas (continuação)" N 203 ANNO II p.2 17.jan.1889.

Voltando a questão que constitue o objecto deste capitulo, direi ainda, que o peior systema de despojo de materia fécal que pode haver é o empregado nesta cidade, precisando portanto que elle seja abolido, logo que consiga-se o abastecimento d'agua por meio de canalisação.

Tratando agora do esgoto da aguas servidas não posso deixar de lamentar o modo porque esse serviço é feito.

Dir-se-ha que, desde que não existem encanamentos, impossivel se tornará o escoamento dessas aguas. E' uma dura verdade esta objecção: mas ella não justifica o facto de serem ditas aguas levadas para ruas e quintaes. Os depositos que se formam nas sargetas das ruas e nos pateos dos quintaes, só attestam grande falta de observancia aos principios da hygiene. Os ardentes raios do sol actuando directamente sobre esse liquido, que em alguns lugares fica estagnado, operam a decomposição de materias animaes e vegetaes que elle contem em mistura: d'ahi o desprendimento de miasmas que vão saturar a atmosphera e, por conseguinte, prejudicar o ar que respiramos.

Seria portanto mais conveniente que em falta de canalisação houvesse um deposito subterraneo que recebesse aquellas aguas. Esse deposito munido em sua parte inferior, de agulheiros que alcançassem a certa distancia prestar-se-hia plenamente a receber as aguas servidas. Comprehende-se facilmente que a superficie de absorpção do deposito e dos agulheiros não permittiria a acumulação de aguas, pois a que fosse lançada durante o dia seria absorvida pelo terreno durante a noite. Uma unica precaução precisaria haver, que era evitar-se a penetração das aguas pluviaes e de outras que não contivessem materia organica em mistura: essas aguas correndo em jórro facilmente encheriam o deposito.

O processo que acabo de indicar não deixa de ter certos incovenientes, mas, attendendo-se a grande vantagem que d'elle resulta, vê-se que seria de todo preferivel ao que é empregado.

Dir-se-há: esse systema é inoxequivel, porque alem da despesa que demandaria, necessitaria ser de grandes dimensões o deposito subterraneo, para que em tempo algum viesse a encher.

Engana-se quem assim pensar, por isso que destinado tão somente ás aguas nas condições que venho demencionar, jamais encheria, a menos que fossem insignificantes suas dimensões.

Com um deposito de $3^{\circ}$, de profundidade e $2^{\circ}, 5$ diametros, revestido lateralmente de tijolo de alvenaria secca e munido de 6 ou mais, agulheiros de $0^{\circ}, 40$ de largura e $2^{\circ}$ ou $2^{\circ}, 5$ de comprimento revestidos tambem superior e lateralmente, conseguir-se-hia o fim desejado.

A despeza se bem que não fosse insignificante, seria compensada pela grande vantagem que elle occasionaria.

A cima de todos os interesses particulares deverá estar a salubridade publica, e toda cidade que não despozer de recursos para realisar trabalhos completos, necessita ao menos procurar minorar tanto quanto possivel os incovenientes resultantes dos defeituosos systemas empregados na realisação de serviços que tendem de perto com o bem estar da população.

Não quero dizer que deve-se hoje executar o trabalho que acabo de indicar, pois sou de opinião que nos tempos presentes, em que vemos por toda parte a humanidade esforçar-se para o emprehendimento dos 
mais importantes melhoramentos, não nos deveremos contentar com um processo que só teria razão de ser no seculo passado: mas sim, quero somente fazer sentir, que, apezar de não existir a galeria de esgoto pode-se todavia fazer encaminhar as aguas servidas para lugares que de todo não prejudicam a saude.

Feitas estas ligeiras considerações a respeito dos prejuizos que podem occasionar o systema actual de esgoto, passarei a dizer algumas palalavras a respeito do modo porque deve-se estabelecer 0 encanamento apropriado para esse mister.

Conforme disse no começo deste trabalho, a cidade da Parahyba do Norte foi dotada pela natureza dos mais importantes elementos. Seu solo elevado, contem entretanto natural declive que permitte 0 estabelecimento de uma rede de encanamentos destinada a receber todas as materias, e aguas servidas que são despejadas pelos prédios.

O assentamento de ventiladores com os apparelhos de desinfecção, e a construcção de galerias hidralicas, permittiriam o despejo sem o menor incoveniente para a população.

Alem disso as aguas das chuvas que cahissem nos pateos e quintaes, poderiam ser levadas para 0 encanamento, permittindo que este ficasse completamente lavado. Se por ventura ainda fosse deficiente a lavagem produzida por essas aguas e pelas que fossem emittidas das torneiras, poder-se-hia tambem fazer encaminhar para alli todas as aguas que cahissem nas ruas.

Este processo é o empregado em Londres, Bruxellas, Vienna e Pariz.

No Rio de Janeiro existem duas redes de encanamentos, umas para as aguas pluviaes e outra para o esgoto da cidade.

Segundo importantes opiniões melhor seria que houvesse somente uma mui embora nas grandes chuvas as materias fossem lançadas a pequena distancia, distancia essa que não influiria em consequencia de serem as mesmas materias levadas pela força d'agua corrente.

Tal é o processo empregado em Londres e outras cidades como disse, processo este, com o qual estão tambem d'accordo os eminentes engenheiros Griflith e Daugtas Galton.

Esboçada, mais ou menos, esta questão, resta-me chamar a attenção dos representantes da provincia, e pedir-Ihes, que, estudando o melhor meio de remediar este e outros males que parecem pesar eternamente sobre o povo parahybano, procurem com as suas luzes garantir a esta terra um futuro muito diverso do que Ihe está reservado.

Não sou dos que pensam dever-se em um só momento procurar obter tudo que é preciso para que esta cidade possa ser apresentada no numero das que se orgulham em ostentar elementos de progresso, ao contrario, sou prudente e methodico e, como tal desejo a realisação dos mais importantes emprehendimentos sem que a provincia veja-se sacrificada em sua parte financeira

Concedendo-se em cada exercicio uma quantia relativamente pequena poderemos em poucos annos vêr conseguido muitos melhoramentos; mas para isso é necessario que da assembléa provincial parta a organisação deste programma, que tanto tem de simples em sua forma como de monumental em sua execução.

Terminando aqui este capitulo passo a tratar do $3^{\circ}$ melhoramento necessário á cidade, melhoramento esse que ainda se refere ao seu saneamento.

João C. de Oliveira Cruz, Engenheiro Militar.

\section{CRUZ, João C. de Oliveira. "Melhoramentos da Capital da Parahyba (continuação) IV - Limpêza publica"}

Sob este titulo comprehendo não só a limpêza das ruas e praças como outros trabalhos que são necessarios para o completo saneamento da cidade.

Começando a tratar portanto da limpêza das ruas e praças, não posso deixar de fazer proceder o estudo dessa importante materia, de algumas considerações, não só com o fim de demonstrar o estado deploravel a que está sugeita esta população, como para de todo condemnar a inercia dos que devendo e podendo, ha muito, contribuir para extincção de tantos males que opprimem este povo digno de feliz sorte, mativeram-se paralisados, e olharam com indifferença para esse lamentavel estado de podridão, como se a ultima palavra já tivesse sido dita em bem da sociedade parahybana.

$\mathrm{O}$ aspecto tristonho que apresenta a accumulação do lixo nos recantos das egrejas, nas sargêtas, das ruas até nas mais publicas, só attestam o pouco cuidado d'aquelles que podiam facilmente contribuir para o melhoramento deste estado de cousas.

Não se trata aqui do emprego de altos capitaes, pois, se assim o fosse, longe estaria de fazer taes accusações; ao contrario seria o primeiro a desculpar as grandes faltas, em consequencia de estarem muito alem das forças da provincia, os meios de remedial-as. Mas se o estabelecimento de canalisação d'agua e esgoto são trabalhos que muito exigem de uma provincia fraca de recursos como esta, outro tanto não se 
deverá dizer do serviço da limpêza das ruas e praças, que se poderá conseguir mediante pequeno dispendio.

Haverá termo de comparação entre o pequeno sacrificio de dinheiro que poderá fazer a provincia com a limpêza das ruas, e a grande vantagem que d'ahi resultará para o saneamento da cidade? De certo que a segunda excediria o primeiro, e abençoados seriam os que se esforçassem para a realisação d'aquelle importantissimo serviço.

O estado da cidade é nojento; assim é que me posso exprimir.

Sei que proposição tão pesada jamais deveria ser por mim avançada, mas considerando que para os grandes males são precisos grandes remedios, vejo-me obrigado a proferir tão dura phrase, que ficando para sempre firmada neste escripto servirá de solemne protesto contra a indolencia dos que deviam melhor ter curado do progresso da provincia.

Não tenho em vista atirar a quem quer que seja a menor offensa, se assim fallo, é porque a minha posição de analysta força-me a censurar o descuido que houve da parte dos que deviam ter procurado livrar a capital desta importante provincia, das chagas que lhe corroem o vigoroso organismo.

Seja-me portanto desculpada esta ou outra qualquer expressão, que no correr deste trabalho possa ferir, mas acreditem todos os que com ellas se chocarem, que não viso absolutamente destinguir este ou aquelle, e sim fallo em these, condemnando somente o pensamento dos homens que ha muitos annos teem tido nas mãos a sorte deste povo.

Apezar de não estarmos em nada adiantados podemos entretanto ainda remediar o mal, e para isso necessitamos que de hoje em diante seja concedido um auxilio, com o fim de ir-se fazendo apagar, se bem que por partes, os erros commetidos pelos nossos antepassados.

Appelando portanto para a solicitude dos prestimosos filhos da provincia, que tão dignamente occupam uma cadeira no conselho julgador dos mais palpitantes interesses da mesma, estou certo que independente destas toscas palavras, não proferidas por um seu comprovinciano, envidarão os mais ardentes esforços, para que em breve seja realisado o pensamento que acabo de esboçar.

Sei tambem que estas minhas palavras em nada influirão directamente sobre esses cultos espiritos, por isso que, estou certo, seus desejos são os mais bem intencionados; mas como a occasião se proporciona a tratar de assumpto tão grave, não me era possivel deixar tambem de externar meu pensamento, que casase perfeitamente com as boas intenções de que elles são dotados.

Feitas estas ligeiras considerações passo a tratar da materia que constitue o objecto do presente capitulo. Como já disse é mais que desagradavel o estado de limpêza desta cidade; suas ruas e praças, principalmente nos logares proximos a alguma egreja, não primam pelo asseio.

O lixo que se ajunta em todos os predios são atirados n'aquelles logares, de formas que, ruas há, que tornase preciso o transeunte desviar-se para não sentir debaixo dos pés o contacto das immundicies que alli são depositadas.

Quanto aos terrenos que ficam dos lados ou nos fundos de alguma egreja, estes, sobre tudo, constituem depositos que obrigam o povo a cobrir o nariz para evitar a absorpção dos gazes que delles se desprendem.

Estando portanto a cidade nestas condições, só podemos attribuir a sua mais ou menos salubridade, a continua corrente de ar que a lava, pode-se dizer, sem interrumpção.

Se como no Rio de Janeiro houvessem aqui grandes calmarias a ponto de não observar o menor movimento, nem mesmo nas mais leves folhagens, estou certo que já teriamos pago, e bem pago, as consequencias dos actos commettidos pelos descuidosos desta terra.

Mas até neste ponto a natureza foi prodiga para com os habitantes do logar, concedendo-lhes previlegios como este, com fim de evitar o desenvolvimento em grande escala, de molestias oriundas de tão activos fócos de infecção.

A grande vegetação é tambem outro elemento poderoso concedido pela natureza, e triste de nós se um dia vier ella a escassear nas circumstancias em que ella se acha a cidade.

Entretanto com despeza relativamente pequena, podemos fazer desapparecer mal causado e o que poderá causar a existencia no recinto da capital de materias tão insalubreis.

A exemplo do que se pratica em tantas cidades do mundo podemos ter aqui um completo serviço de limpêza publica, maxime havendo tantos logares fora do alcance das correntes aereas que directamente lavam esta cidade.

No Rio de Janeiro, por exemplo, existe uma companhia que se occupa exclusivamente com a limpêza da cidade; mas nós para isso não precisaremos de companhia, pois esse serviço poderá ser executado pela câmara municipal.

A obtensão de algumas carroças que recebam o lixo das casas, e de um saveiro que o conduza para longe da cidade, é o sufficiente para a completa resolução do problema.

João C. de Oliveira Cruz, Engenheiro Militar. 


\section{CRUZ, João C. de Oliveira. "Melhoramentos da Capital da Parahyba IV - Limpêza publica"}

Assim, pois, dotada a câmara municipal com um pequeno recurso annual, estou certo satisfaria ella plenamente a esta tão urgente necessidade.

Não é somente a limpêza das ruas e praças que deve occupar a nossa attenção; outros trabalhos não menos importantes são necessarios para que se torne proveitoso todo e qualquer sacrificio que a provincia venha a fazer.

Estes trabalhos consistem na destruição de uma lagôa que fica nos terrenos situados para baixo da rua denominada - da Lagôa; do aterro de alguns lugares pantanosos; finalmente da limpêza do porto e terrenos que margeam o rio.

Estudando o primeiro dos trabalhos mencionados, não posso deixar de tambem fazer algumas considerações, já sobre a existencia desse lago infecto, já sobre os motivos que o originaram.

É mais que sabido que toda e qualquer porção d'agua represada e exposta por longo tempo as influencias dos raios solares, torna-se um perigo á saude poblica, maximé se repousa ella em terreno vegetativo. Pois bem, a lagôa em questão está nessas condições, e mais perigosa se torna, em consequencia de seccar em algumas epochas do anno.

Como é natural, a proporção que se produz a infiltração das aguas vão pouco e pouco descobrindo-se suas margens, até que torna-se o terreno completamente secco, pelo desapparecimento total das mesmas aguas.

Permanecendo por algum tempo cheia dá lugar a que morram os vegetaes não aquaticos, e pela dessecação, permitte que elles se decomponham e venham tambem por essa vez enriquecer o ar atmospherico de corpúsculos destruidores da saude publica.

Não param por ahi os inconvenientes desta lagôa, e para dizer mais alguma cousa sobre este assumpto preciso primeiro avançar as seguintes preposições:

$1^{\circ}$ Não existe lagôa.

$2^{\circ} \mathrm{A}$ impericia dos homens deve-se a existencia de uma porção d'agua no lugar indicado, durante a estação invernosa.

Não existe lagôa porque se ella existisse nunca seccaria a ponto de se atravessal-a a pé enxuto como hoje acontece.

A porção d'agua que alli fica depositada por algum tempo, deve-se somente a impericia ou ao pouco interesse que tomaram por esta cidade, quando trataram de canalisar as aguas pluviaes que cahem nas ruas da cidade alta.

Por ser mais econômico ou menos trabalhoso, em vez de dirigirem as aguas para o varadouro afim de despejar no rio, entenderam dever fazel-as convergir para uma bacia existente em terrenos pertencentes a cidade alta. Para isso uma grande galeria atravessando diversas ruas, dellas recebe todas as aguas produsidas pelas chuvas e vae despejar no lugar mencionado, constituindo um grande lago que mais tarde desapparece pela cessação da estação invernosa. Esta galeria aberta internamente em alguns lugares, é ahi transformada em uma valla para onde converge toda e qualquer especie de despejo, lixo, materia fécal, animaes mortos, roupas immundas etc. etc., que ahi ficam depositados, e mais tarde pelas aguas das chuvas são levados para o lugar em questão.

Oh! triste cidade, é até onde pode chegar o vosso abandono! Parece impossivel, mas desgraçadamente é uma dura verdade.

Se vosso solo fosse tão miseravel que não permittisse o recurso do povo, não haveria mais que elle resignar-se e cumprir o seu destino; mas tão variáveis e tão ricos são os diversos planos que o constituem, que torna-se um crime imperdoavel o deleixo de alguns dos vosso filhos.

Desde que aqui cheguei ouço fallar na existencia de uma lagôa que por muitos hygienistas já tem sido condemnada, mas o que nunca me disseram foi que esta lagôa fora feita pela canalisação das aguas pluviaes.

Se não tivesse eu o genio investigador de ir em pessoa procurar estudar esta questão, de certo que continuaria e suppôr a existencia de um lago permanente.

Pelo que acabo de dizer, vê-se, que não se trata de uma lagôa que é preciso obstruir ou escoar, e sim d'uma porção d'agua que é preciso evitar.

Para isso nada mais simples do que fazer desviar as aguas pluviaes para a cidade baixa ou para outro ponto onde ellas possam facilmente escoar.

Não indicarei aqui a direcção da galeria porque demandaria o previo conhecimento do nivellamento da cidade, trabalho esse que já deveria existir em bem dos interesses da provincia. 
Mas não sendo possivel de todo fazer desviar o encanamento para outros lugares, não é impossivel fazel-o para o rio, pois embora seja necessario obra d'arte de certa importancia, o resultado benefico fará desapparecer o sacrificio que a provincia fizer.

A limpêza do porto tambem é trabalho digno de toda attenção. O accumulo de restos de materias organicas que são arrastadas pela corrente das aguas, torna-se tambem um elemento prejudicial ao povo; portanto, será conveniente removel-os.

Alem disso é vergonhoso para a provincia o aspecto do lugar de desembarque; a lama alli existente é tambem um attestado em desabono desta boa terra.

A impressão agradavel que recebi durante o trajecto do Cabedello á cidade foi substituída pelo tristonho aspecto do porto de desembarque, que alem das difficuldades que offerece seu accesso, faz ao viajante passar por uma verdadeira decepção logo que se observa o estado deploravel em que elle se acha. Seria mais conveniente a construcção de uma ponte onde fosse directamente atracar as embarcações em vez de se fazer o desembarque por meio de baldeação.

Quanto a limpêza do porto direi, que sendo trabalho permanente, exigiria o constante emprego de pessoal encarregado de remover quasi que diariamente a lama que se fosse depositando.

Quero mesmo que não esteja nas forças da provincia costear este trabalho, mui embora seu dispendio não fosse grande, mas ao menos, uma vez por outra, podia effectuar-se uma limpêza d'aquellas materias tão prejudiciaes, que, alem de outros incovenientes, tem o de tornar-se meio productivo de multidão de insectos. È devido a esta causa a existencia do insuportaveis mosquitos que tanto flagelam a população da cidade baixa.

No Rio de Janeiro existe um canal nas mesmas condições em que se acha a parte do rio onde está o porto de desembarque; é elle conhecido pelo nome de "canal do mangue".

$\mathrm{Na}$ extensão de um kilometro, a maré penetra por dentro da cidade formando uma especie de sangradouro. Em virtude do fluxo e refluxo das aguas vão-se formando depositos que são diariamente removidos, por um pessoal empregado especialmente n'aquelle serviço.

De modo que o canal que podia tornar-se prejudicial á saude é um verdadeiro logradouro publico.

Os terrenos por elle comprehendidos são murados, gradeados e plantados, e sua existencia apresenta uma agradavel apparencia, e em nada prejudica os habitantes de sua circumvizinhança.

Em relação aos pantanos que aqui existem direi que é necessario aterral-os, pois, como se sabe, é tambem um grande elemento de destruição.

Terminando esta parte não posso deixar de aconselhar que se evite tanto quanto for possivel o córte das mattas nas proximidades da cidade mui principalmente pela margem do rio.

Os vegetaes derrubados, estando em contacto com a agua, facilmente se decompõem e são nesse estado arrastados pelas correntes.

Se o córte é feito em lugar que pode permittir correr para a cidade, vem não só viciar a agua que a banha como originar depositos de materias improprias à vida.

João C. de Oliveira Cruz, Engenheiro Militar.

\section{CRUZ, João C. de Oliveira. "Melhoramentos da Capital da Parahyba V - Illuminação"}

Talvez que no mundo objecto algum occupasse mais a attenção dos grandes investigadores, que o aperfeiçoamento dos systemas empregados de illuminação.

Assim como das lutas das opiniões surge a luz da intelligencia espargindo seus raios que penetram os cerebros mais obscuros, das trevas do passado ergue-se a luz artificial que nos aclara a vista, e nos proporciona a contemplação de phenomenos antes desconhecidos.

A metamorphose porque tem passado a humanidade ha se manifestado por modos muito diversos.

A civilisação, esta palavra tão sublime, se bem que por um lado inflija á humanidade o fatal castigo de sua curta duração, todavia é o gigante braço que erguendo-a do obscurantismo eleva-a ás eminencias do progresso.

O homem, esse ser incansavel, que tanto tem trabalhado, há produsido inventos, que um só bastaria para firmar a força de seu poder.

Desde a pendula até o vapor, e mesmo depois deste, tem-se desenvolvido tal serie de emprehendimentos que faz tornar perplexo todo aquelle que os contempla. Entre elles está a luz, não a que serve para os domesticos serviços, mas a que nos proporciona o deleite, quando contemplamos os effeitos do braço civilisador.

Assim, caros leitores, de anno a anno, de dia a dia, de momento a momento mesmo, vemos tantos e tantos lutadores esgotarem a ultima parcella de suas forças em querer desvendar o mysterio que nos cerca. 
Se de um lado não foi possivel ainda saber-se a origem de certas grandezas magestaticas, taes como, por exemplo, a da electricidade com tudo já muito se há feito, porque são bastantemente aproveitados os seus effeitos.

Contentemo-nos portanto em utilisarmo-nos de certos elementos que a naturêza nos dá, mui embora não possamos conseguir o pleno conhecimento de sua origem.

Entretanto já não é pequeno o partido que o homem tem tirado, pois muito ha elle feito em prol de seu bem estar, e estou certo, a luta continuará, porque a vida não é mais do que a luta das ambições humanas.

A luz artificial conta um grande numero de phases. Quando em tempos idos foram installados os lampeões de azeite, julgou-se muito haver-se feito; hoje que recebemos a agradavel impressão dos effeitos das lampadas electricas, entendemos não se haver chegado ainda ao aperfeiçoamento desse importante serviço. É para mais uma vez provar o incessante labôr em que se atira o homem avido de emprehendimentos que o engrandeçam.

Depois da descoberta da luz electrica já outros ensaios se tem querido fazer, entre elles os de se extrahir a luz do ar atmospherico e da agua, sendo que para este ultimo processo já existe em Berlim um industrial com o competente privilegio.

Portanto não podemos dizer que a ultima palavra está dita sobre semelhante questão, pois, talvez que as vantagens da luz electrica sejam mais tarde supplantadas pelas de outro systema que se venha aperfeiçoar. Entretanto como a illuminação electrica é á ultima explorada, tomarei ella para o ponto de chegada, e a discutirei em relação aos outros processos que até hoje tem sido empregados.

Todos os systemas usados de illuminação, apresentam incovenientes, já a commodidade, já a segurança do povo. Assim, o azeite, a essencia mineral, a cera, a stearina, o cebo, o gaz, etc., tornam-se prejudiciaes por diversos principios. Esses meios de illuminação operam a decomposição das substancias que entram em combustão, afim de extrahir-lhes o oxigenio, que é quem produz a luz.

Este phenomeno chimico tem o incoveniente de fazer viciar o ar e tornal-o improprio á vida.

O calor produsido, principalmente pelo gaz, torna-se encommodativo maxime nos lugares como este, onde a temperatura não é das mais amenas.

A intensidade ferindo a vista, como se opera no gaz carbonico, não só aborrece, como prejudica o órgão visual, por occasião de diversas occupações da vida.

A facilidade das explosões é outro motivo fortissimo para a condemnação dos meios que a produsem.

Portanto qual não ser a importancia do systema que venha obviar todos esses incovenientes?

A luz electrica virá responder por esse feliz resultado. Não precisando absolutamente do oxigenio para sua alimentação, por isso que no proprio vacuo ella apresenta delicioso brilho, não produz portanto acido carbonico que venha viciar o ar. Seu calor quasi nullo, ou 0/100 proximamente do emittido pelo gaz e seu nenhum perigo de explosão, permittem a approximação de quem quer que seja, sem as precauções oriundas do medo dos desastrosos resultados de semelhantes phenomenos.

A suavidade de sua claridade torna até agradavel a realisação de qualquer trabalho executado sob sua influencia.

Alem disso economicamente fallando não é das mais despendiosas, e pode se mesmo dizer tornar-se-há a mais barata desde que seu uso seja introdusido em mais lata escala.

Considerando-se que por parte parte procura-se melhorar a illuminação publica e particular, mesmo nos logares onde existe a luz emittida pelo gaz carbonico, que é ainda a mais empregada; como a nossa Parahyba não se há de por sua vez tentar qualquer trabalho dessa especie quando ainda mais atrasada, contem em suas ruas os antepassados lampeões de kerosene? Realmente é para lamentar que este estado ainda continue por muito tempo.

A introducção das aperfeiçoadas lampadas electricas é o systema que aconselho, pois entendo que havendo a provincia de dotar sua capital de um melhoramento que esteja d'accordo com o progresso, jamais deverá lançar mão de processos que, empregados em outras paragens, tendem a desapparecer com a introducção de novos inventos.

Assim pois comecemos pelo fim, e empreguemos a luz electrica, que teremos de um só pulo conseguido o nosso desideratum.

A estrada de ferro de P. II, a Bibliotheca Nacional e outros edificios importantes no Rio de Janeiro já experimentam este bello melhoramento, e não está lohge o dia de vermos este moderno systema estender seus braços do Amasonas ao Prata.

Entre outras províncias que se esforçam pela adopção da luz electrica, citaremos a de Alagoas, que pel orgão da opinião publica, já erguéo bem alto um brado de indignação contra os actuaes systemas de illuminação, e dirigio seus rogos á assembléa, para que esta concedesse meios de realisar-se aquelle melhoramento.

CRUZ, João C. de Oliveira. "Melhoramentos da Capital da Parahyba V - Illuminação" 
Alagoas, essa provincia beijada tambem pelo Atlantico, apezar de não estar considerada no plano onde figuram gigantes como Pernambuco e outras, mostra-se por sua vez, como a Parahyba, digna de conter em seo seio os mais sublimes productos da actividade humana; e tanto ella comprehende o futuro risonho que a aguarda, que tem procurado, e procurará sempre marchar pressurosa no caminho do progresso.

Alliando o interesse que sempre me desperta os grandes emprehendimentos á importancia de todo e qualquer escripto que tem por fim a propagação de sublimes idéas, transcrevo o importantissimo trabalho inserto no < Orbe $>$ jornal interessante que se publica na alludida provincia de Alagôas.

O escriptor esboçando perfeitamente a questão relativa a luz electrica dispensa-me de fazer mais algumas considerações a respeito de sua importancia.

Portanto peço aos distinctos leitores que, com a costumada benevolencia, leiam o artigo que se segue:

$<$ Tão palpitante, tão imperiosa para a humanidade como a necessidade das casas de mendicidade, de alienados, de caridade, de orphãos e de instrucção é a necessidade da producção da luz artificial, e tanto que é a sua descoberta um dos grandes caracteristicos da nossa especie e um dos traços que mais distinguem o homem dos muitos animaes.

< Se a satisfação d'aquellas necessidades determinou o amparo, o abrigo à miseria, à loucura, à infermidade, à orphandade e a ignorancia, as necessidades a que satisfaz a arte da illuminação determinaram o aperfeiçoamento deste ramo de industria humana, o qual, no curto lapso de uma vida, elevou-se dos immundos candieros de azeite às lindas lampadas electricas ora existentes.

Quantos progressos realisados, quantos impossiveis vencidos desde o uso dos archotes de páos seccos ou resinosos até aos lindos candelabros de Edison, os quaes nos deslumbram com o esplendor de seo brilho!

< Quando Leban descobriu as qualidades illuminantes do gaz carbonico, os interesses particulares que se achavam presos à producção e consumo das diversas materias destinadas a illuminação ergueram-se, sob a ameaça de uma ruína que reputavam infallivel, contra o novo invento, e sua applicação.

< Como no tempo da apparição do gaz carbonico, na epocha da apparição da luz electrica surgiram de todos os lados embaraços, ardis, falsas noticias, criticas injustas e mal fundadas, com que aquelles que se julgavam ameaçados em seos interesses pretendiam obstar a adopção da luz electrica.

< Felizmente, porêm, para os interesses geraes da humanidade, todos esses manejos turturosos eram apenas dignos de uma satyra igual a interessante petição em que Bastiat figura os interessados na industria da illuminação pedindo ao parlamento a suppressão do sol.

$<$ A illuminação electrica é hoje uma realidade.

< A sciencia desvendará sempre novos horisontes á industria da illuminação, apezar da incredulidade dos espíritos refractarios ao progresso, apezar da grita d'aquelles cujos interesses se chocam diante de um melhoramento.

< Como então, entre nós, e a surdina a vozeira dos insensatos e dos timidos e a celeuma dos que se consideram prejudicados, pretendem aniquilar o tentamento o gigantesco que presentemente se pretende realisar, qual é a installação da luz electrica nesta capital.

< Mas os homens de espiritos sãos e puros que na tranquilidade de suas consciencias pouderem, reflictam calmamente e maduramente a respeito, que se convencerão da puerilidade, da nullidade da argumentação satanica dos inimigos do patriotico commettimento.

< Que se descobram esses que pelas esquinas atiram, á pequena bocca, aphostrofes contra a velocidade da luz electrica na illuminação publica e particular, e venham em qualquer das publicas tribunas creadas e mantidas para a difusão da luz moral, da luz que illumina o espirito, para a discussão reflectida e calma, bater a electricidade em suas vantagens, comodidades, economia, e superioridade a qualquer outro agente de illuminação.

Não o farão, de certo, porque a sciencia não é um invenção nem a arte e a industria umas chimeras.

< Não o farão, porque, como o vampiro que só se alimenta nas trevas, a malignidade só allude, só embaça a boa fé da ignorancia na caligem dos ardis, emboscada na clamyde da propria indignidade.

< Felizmente, porem a parte sensata e criteriosa da população da capital e a sua imprensa, legitima representante de suas opiniões e de seos interesses geraes, unânimes aplaudiram sempre o tentamen grndioso que o eminente electricista xxx da cidade de Pão de Assucar, esse mimoso cysne que banha-se orgulhoso nas aguas saudaes do magestoso e poetico S. Francisco, levará avante, se o patriotismo da assemblée provincial, premiando a pujança e seo talento masculo, consagrar esse melhoramento de que tão urgentemente necessitamos.

Considerada, ha apenas um seculo, com simples curiosidade e recreio, é hoje a electricidade um dos poderosos agentes da industria humana, sendo seos curiosos phenomenos tão vulgarizados que não ha quem ainda não tenha experimentado um choque electrico ou visto funcionar um apparelho telegraphico ou telephonico, um phonographo ou pelo menos uma campanhia electrica avultando entre as innumeras applicações modernas dessa força physica por sua importancia e utilidade pratica a illuminação electrica. 
João C. de Oliveira Cruz, Engenheiro Militar.

CRUZ, João C. de Oliveira. "Melhoramentos da Capital da Parahyba V - Illuminação"

As descobertas monumentaes de Ampêre, Arago, Gramme, Brush, Edison e muitos outros electricistas mechanicos e engenheiros - electricistas relativamente aos effeitos da inducção, rasgando novos e mais vastos horisontes á industria, vieram crear, transformando o trabalho em electricidade, poderosos geradores desse agente para as grandiosas applicações que exigem fortes tenções e grandes quantidades, mas obtidas a preços baixos e custeio moderado.

A combustão luminosa produzida pela combinação de um comburente e um combustivel tem sido sempre a principal fonte de luz até hoje utilisada praticamente pela industria para substituir a do sol, durante a noite e nos lugares, aonde os raios do grande astro não podem penetrar. $O$ comburente tem sido o oxigenio fornecido gratuitamente pelo ar, formado de oxigenio e azoto na proporção de 21 para 79 em volume; o combustivel, porem, tem variado em extremo, desde as madeiras resinosas até o gaz coerente geralmente adoptado hoje.

< Ailuminação electrica, porém, afasta-se completamente deste modo de producção, e, dispensando o auxilio do eterno comburente de todos os systemas de luz artificial, brilha igualmente no ar athmospherico como no vacuo, dentro d'agua como envolvida mesmo pelos gazes improprios a combustão.

< É que o effeito luminoso nas illuminações electricas é apenas o resultado de uma transformação de forças physicas, que tem lugar sempre que uma corrente electrica, não podendo desenvolver-se livremente, determina, em um ponto qualquer do circuito, uma brusca elevação de tensão, a qual se traduz por um effeito de incandescencia inteiramente extranho a toda e qualquer combustão.

$<$ Ha duas maneiras de obter praticamente a luz electrica.

$<$ Uma consiste em prodizil-a de uma pequena haste de carvão intercallada em um circuito electrico, a qual se consomme mais ou menos lentamente, augmentando com o calor de sua combustão, o da corrente electrica, de modo a impedir o resfriamento da haste incandecente e augmentar, portanto, o seo poder luminoso. A outra obtem-se simplesmente pela incandecencia de um filete de qualquer substancia pouco conductora aquecido pela passagem de uma corrente electrica a ponto de tornar-se luminoso.

< As lampadas de primeira classe denominam-se de - incandescencia com combustão, e as da segunda de - incandescencia sem combustão.

< Já está resolvida praticamente a difficuldade da producção deste systema de lampadas, do qual é de presente o melhor typo as do grande Tomaz Edison, que logrou, com a sua tenacidade vencer os obstaculos que se antepunham ao problema, de que é o seo notavel invento o disputador da palma da victoria, no terreno das conquistas praticas da industria moderna.

< O systema Edison de illuminação electrica, abrangendo em todo o seo conjuctoo grande problema de semelhante illuminação, resolveu-o sob todos os pontos de vista, produzindo, destruindo, medindo e utilisando a electricidade de modo especial e novo.

< As vantagens que o systema de illuminação electrica tem sobre os de mais estão evidenciadas nas installações que existem hoje em innumeras cidades, tanto estrangeiras como do paiz, sendo uma das provas mais convinientes dessas vantagens a preferencia que a estrada de ferro D.P.II e a Bibliotheca Nacional fizeram desta luz sobre a do gaz carbonico.

< A economia sobre a superioridade da luz electrica comparada com a do gaz corrente não offerece a menor divida, superioridade que avulta quando considerados estes dois systemas de illuminação relativamente as commodidades que offerecem.

< O gaz carbonico aquece extraordinariamente e corrompe o ar ambiente; axhala cheiri insupportavel quando se escapa sem queimar ; é uma ameaça constante de incendios, e a sua luz oscilla por vezes de tal modo que difficulta e chega mesmo a impossibilitar a leitura, a escripta, a costura ou qualquer outro trabalho delicado; para apagar-se é da mais facil manipulação, mas para accender exige o uso dos phosphoros que, por sua vez, augmentam os incommodos e perigos.

< A luz electrica, ao contrario, é fria; não altera nem vicia de modo algum o ar que se respira; não exhala cheiro algum; não pôde motivar incendios; é de extrema fixidez e intensidade canstante, mas sem offender nem cançar a vista, e dispensa o uso dos phosphoros, sendo xxxxxx e commodo obtel-a como suppo... , para o que basta a manipulação de uma pequena chaveta, sem o menor risco de choque.

João C. de Oliveira Cruz, Engenheiro Militar.

\section{CRUZ, João C. de Oliveira. "Melhoramentos da Capital da Parahyba V - Illuminação"}


< Escondidos pelas cimalhas dos tectos, pelas guarnições dos rodapés, pelas cornijas dos edificios, os fios conductores podem levar a luz aos logares mais recondito do lar domestico, offerecendo commoda e confortavel substituição, quer para os ricos candelabros, quer para as discretas lampadas que mantém os aposentos nessa doce penumbra tão agradavel para os que velam como para o somno placido e sereno dos que dormem. Um globo xxx xxx levemente colorido bastará para guardar os tons da luz e dar-lhe 0 conveniente para este ou aqulelle mister.

< Em vista, pois, de tão poderosas considerações fica comprovado que para a illuminação publica e de edificios particulares e públicos a luz electrica offerece as mais decesivas vantagens e presta-se maravilhosamente, nada deixando a desejar, quer quanto a quantidade e qualidade da luz fornecida, quer quanto ás commodidades e facilidade da installação e funccionamento e preço de installação e custeio.

< Se é exacto que tão só diante da logica é que se curva a soberania da razão, e nunca diante da prepotencia das conveniencias e interesses inconfessaveis, está mais que claramente demonstrado, que a revolução introduzida no problema da illuminação publica da nossa capital deve ser resolvido no sentido de ser autorisado o contracto respeitante a luz electrica, recompensado condignamente o grandioso invento do nosso intelligente e operoso comprovinciano Sr. Argemiro Augusto.

< A imprensa desta capital, maravilhada, extasiada diante da grandiosidade da descoberta operada pelo talento genial de tão illustre comprovinciano, que, na manifestação da potencia de seo grande cérebro, porá não somente o seo torrão natal, mas a patria commum, na vanguarda das nações civilisadas, pela valia de seo invento, a imprensa diziamos, e por igual o publico, foram onanimes em proclamar a importancia, a grandiosidade da descoberta do seo systema de lampadas electricas, o que leva á gloria a nossa Alagôas, e a immortalidade o seo inventor.

< Semelhantemente a impreusa da côrte, aonde abundam os entendidos e os especialistas, na apulencia de sua grandeza e imparcialidade, rejubilou-se orgulhosa de ver surgir do seio da patria, e, o que mais é, da eleiade simpathica e e trabalhadora dos artistas, quem, na applicação da electricidade á illuminação publica viesse fazer estrondosa revolução e supplantar as conquistas gloriosas do grande norte-americano, com um grande invento a todos os titulos dignos dos applausos e auxilios de todos.

Uma como outra, a imprensa alagoana como a grande imprensa fluminense, admirando o talento e a conquista do moço artista, que tem elevado-se pelos merecimentos proprios á bexemerencia dos compatriotas, foram acordes em solicitar do governo auxilios para quem só tem como garantia de seo esforçode seos estudos a applicação a energia da força de vontadee o vigor das abundacias do genio.

Está pois, nas mãos da assembléa provincial, no seio, que deve ser materno e patriotico, da aggremiação dos filhos e representantes da provincia, defensores e guardas de seos interesses, de seos melhoramentos, de suas glorias, na explosão do mais santo patriotismo, fazer desse dinticto comprovinciano que a inveja e a maledecencia deram por doido n'uma das gazetas desta capital a maior, a mais real de nossas glorias provincianas.

< Sim, patriótica e justiceira assembléa, fazer o vosso dever - dotar a capital de Alagôas com o systema de illuminação electrica, porque deste modo recompensareis o trabalho, o estudo, a dedicação de um operoso comprovinciano, galardoareis o genio e a provincia bemdirá o vosso renome. >

João C. de Oliveira Cruz, Engenheiro Militar.

\section{CRUZ, João C. de Oliveira. "Melhoramentos da Capital da Parahyba VI - Theatro"}

Remontando as mais distantes epochas, vemos surgir o palco onde se há travado as lutas das artes representadas pela poesia e a musica.

Essas sublimes artes que elevam a humanidade aos céos das delicias, casam-se, e do seo consorcio fazem nascer a virtude reprimindo o vicio, a sensibilidade esmagando a doresa d'alma e a instrucção supplantando a ignorancia.

Se na antiguidade o recinto do theatro constituia um templo religioso em que os sacerdotes eram os proprios actores, hoje, não só preenchem esta parte pelos bons exemplos a moral, como sua missão é mais lata, poruqe faz distinguir o forte do fraco e o quanto basta para o inteiro conhecimento de tantas miserias espalhadas pelo mundo.

Desde os tempos dos gregos e romanos, até os nossos dias que se utilisa o theatro como meio de distracção e de escola moralisadora; assim os gregos celebravam suas Dionysias em honra ao Deus Dionysio; reuniam-se nesses logares e ahi realisavam todas as solemnidades pertencentes ao culto.

Em vasto recinto a descoberta reunia-se o povo e ouvia a palavra autoritaria dos seos oráculos. Em Athenas o theatro construido dava lugar a 30:000 pessoas e em Megalopolis construiram um theatro que accommodava 40:000 pessoas. 
Os theatros romanos eram mais ou menos do mesmo systema e comportavam trinta mil ou mais espectadores.

Comprehende-se que fácil seria construir um theatro nessas condições, pois, desde que não continham cobertura, obstaculo algum se oppunha ao augmento do recinto.

Depois de descoberto os dramas, as comedias \&, reconheceram a necessidade de cobrir-se o recinto do theatros, o que obrigou a restringil-os de um modo extraordinario, attentas as difficuldades que offereciam a construcção das cobertas; realisadas estas, outra necessidade palpitante apresentou-se que foi a illuminação do recinto.

As tigelinhas e as velas de cêbo ou cera foram os primeiros meios illuminantes adoptados nos theatros fechados, mas a grande quantidade de fumaça que se desprendia, não só incommodava horrivelmente os espectadores, como amortecia os effeitos da scena.

Preocupando sempre a attenção dos architectos foi-se melhorando pouco a pouco o systema de illuminação até os lampeões de kerosene, e depois nos de gaz carbonico, havendo hoje muitos theatros illuminados a luz electrica. Sem ir mais longe, no Rio de Janeiro o governo impressionado com a catrastophe do theatro de Baquet, tem obrigado a effectuar-se certos melhoramentos nos theatros e entre elles figura a substituição do gaz carbonico pela luz electrica. Estes melhoramentos foram aconselhados pelos engenheiros Schreiner e Belfort Duarte.

A respeito da forma que se deve dar aos theatros tem sido esta questão outro ponto de serios estudos.

Desde os gregos até os nossos dias, tem-se procurado adoptar todas as formas, afim de escolher-se a que melhor se preste a propagação do som e a que dê melhor disposição aos espectadores; assim a forma grega dividia o theatro em trez partes: recinto, edificio da scena e lugar destinado a orchesta.

Vitruvio, referindo-se a construcção desse theatro diz: < que no espaço escolhido para o theatro foi traçado um circulo na parte destinada a orchestra; inscrevendo-se nelle um quadrilatero tocando seos cantos e a circunferencia. O espaço comprehendido entre um lado do quadrilatero e a tangente parallela constituia a scena, sendo que o lado do quadrilatero formava a bocca da mesma scena. Comprehende-se por esta ligeira discripção quão acanhada era a scena, mas em nada influía sobre o theatro porque nunca havia em scena mais de trez actores. Em roda da orchestra collocavam os assentos formados de degraos concentricos e, assim, estendiam-se elles a uma distancia tal que comportavam-se 30:000 ou mais espectadores.

Esta forma, a mais antiga, e que era pouco mais ou menos adoptada pelos romanos foi se modificando e de todo reformou-se logo que os theatros foram cobertos.

A principio as difficuldades que se apresentavam na construcção das coberturas, fizeram apertar o recinto e alongal-o de modo que muito difficultava aos espectadores a assistencia dos espectaculos, mais tarde porém com processos mais modernos conseguiram poder alargar o tecto e então novas formas foram sendo intrudusidas, taes como a oblonga a elliptica, formas de ferradura, etc.

A respeito da forma dos tectos tambem muitas e importantes opiniões foram emitidas, ficando provado que a melhor seria a plana ou a de superficie pouco curva.

Tendo ligeiramente tratado da construcção dos antigos theatros, não quero deixar de tambem fallar a respeito dos que se há construido no Brazil, e especialmente me referirei ao Rio de Janeiro, como o grande centro do Imperio.

O governo e os particulares muito trabalharam para que na capital do Imperio se erguesse um theatro digno d'aquella sociedade; mas se por um lado os esforços eram empregados, por outro eram distruidos por circumstancias especiaes e por motivos políticos.

Se fosse a dar uma noticia dos theatros que se levantaram a contar de 1769, quando no vice-reinado de D. Luiz d'Almeida Portugal, Márquez do Lavradio, deram-se as primeiras representações dramaticas no Rio de Janeiro, de certo que enfadaria aos leitores, que é o que desejo evitar neste meo acanhado trabalho; mas se despenso-me de fazer semelhante descripção, não me despensarei de dizer sempre algumas palavras ao menos a respeito de alguns dos theatros que alli foram levantados.

Segundo o illustrado chronista Dr. Moreira Azevedo foi n'aquella epocha que tiveram occasião as primeiras representações dramaticas em uma casa intitulada - Casa da Opera pertencente a um padre de nome Ventura, e situada perto do largo do Capim, hoje conhecido pelo nome de - Praça do general Osorio.

Em uma noite por occasião do espectaculo foi esse theatrinho devorado pelas chammas.

Um musico chamado Manoel Luiz, que viéra de Portugal levantou um theatro perto do palacio do Márquez do Lavradio, que funccionou até o anno de 1779, data em que retirou-se para Portugal o vice-rei. D'ahi em diante o theatro perdeo de importancia até o anno de 1808, que novamente prosperou com a chegada da familia real ao Brazil.

Fernando José de Almeida, nomeado ministro do reino, resolveo tambem edificar um theatro e, apezar de não estar acabado, em 1813 foi solemnisado o anniversario do principe D. Pedro com uma representação. Terminando o theatro recebeo elle o nome de - Real Theatro de S. João - e funccionou até o dia 25 de Março de 1824, dia do juramento da constituição politica do Imperio, pois, depois de se haver representado 
o sacro drama intitulado - Vida de S. Hermenegildo - foi elle devorado pelas chamas ficando reduzido a um montão de ruínas.

Reedificado, recebeo elle o nome de Imperial Theatro de S. Pedro de Alcantara em honra ao Senhor D. Pedro $1^{\circ}$. Dando-lhe alli a primeira representação, sem estar acabado, em 22 de Janeiro de 1826, por ser dia do anniversario natalicio da Rainha D. Maria, fechou-se novamente suas portas e só se as reabrio depois elegantemente acabado, em 4 de Abril do mesmo anno, por occasião do anniversario da princeza D. Maria da Gloria.

Para mostrar o gosto e o fanatismo que no Brazil já havia n'aquelle tempo pelos theatros, bastar-me-há dizer que vendiam bilhetes de camarotes, a cem, dusentos, tresentos e quatrocentos mil reis, e os de cadeiras a dez, vinte e trinta mil reis.

O nome deste theatro foi mudado para o de - Theatro Constitucional Fluminense em 1831.

João C. de Oliveira Cruz, Engenheiro Militar.

\section{CRUZ, João C. de Oliveira. "Melhoramentos da Capital da Parahyba VI - Theatro"}

Alguns artistas do theatro constitucional resolveram edificar outro em um terreno da rua do Cotovello e denominaram-no - Theatro da Praia de D. Manoel - tomando em 1838 o nome de - Theatro de S. Januario. Nesse mesmo anno o artista João Caetano por meio de uma associação chamou a si e a empreza do theatro constitucional e tendo elle se fechado em Outubro, abrio suas portas em 7 de Setembro de 1839, tomando, nessa occasião o nome que anteriormente tinha de S. Pedro de Alcântara.

Em 1851 foi esse theatro reduzido a cinzas.

No mesmo anno incumbiram o constructor Vicente Rodrigues de levantar provisoriamente um theatro no campo de Sant'Anna e em 1852 abrio elle suas portas ao publico para os festejos carnavalescos.

O Dr. Moreira de Azevedo em sua obra < Pequeno Panorama do Rio de Janeiro > em relação ao theatro provisorio expressa-se pela forma seguinte: < Construido sem as regras da arte, este edificio é defeituoso e indigno de servir de theatro em uma capital.

Não deve ser conservado; seria indecoroso para nós deixar viver esse máo edificio. O governo a quem pertence esse theatro, deve demolil-o, erguendo outro, bello, vasto, magestoso, que seja um dos monumentos que tenha de ornar a cidade do Rio de Janeiro.

É necessario perdermos o costume dos remendos; nunca o governo lucra com essas obras temporarias, provisorias; faça-se o que tem de ficar;construa-se um theatro monumental, sumptuoso, onde se possa notar o nosso progresso artístico, intellectual; um theatro que seja digno das artes e desta capital tão extensa e tão illustrada. >

O actor João Caetano reedificando o theatro S. Pedro d'Alcantara, abrio novamente suas portas a 18 de Agosto de 1852, e desgraçadamente passou pela decepção de vel-o novamente em chammas no dia 26 de Janeiro de 1856.

Diz o Dr. Moreira de Azevedo:

< Depois de tanta despeza e trabalho e quando já estavam quasi findas as recitas dos accionistas, quando ia começar a colher o fructo dos seus esforços, o actor João Caetano vio o fogo destruir em poucos momentos todas as suas esperanças.

< Em 26 de Janeiro de 1856, fino o espectaculo, fechou-se o theatro depois de examinado pelo director e emprezario. Eram trez hora e um quarto da manhã, quando se manifestou o fôgo no edificio. $O$ incendio começou por cima do arco do proscenio, proximo a sala de pintura. Nesse mesmo lugar começara o incendio ha 4 annos.

Os trabalhadores, logo que viram o fôgo, correram ao tablado para ver se podiam subir com alguns baldes d'agua, porem as brasas que cahiam afugentavam todos.

< Quando o sino da igreja da Lampadosa deo o signal, já o incendio não podia ser extincto; o fôgo comunicou-se rapidamente ao telhado, que abateu-o em pouco tempo.

< No fim de algumas horas só existiam do theatro quatro paredes e o vacuo, a pedra e a cinza, tudo desapparecera, só restava o esqueleto horrendo do edificio.

$<$ Mas a fatalidade não conseguira abater o animo do artista João Caetano; elle resolveo edificar o theatro S. Pedro de Alcantara.

Deram-se principios as obras. O actor José Romualdo foi encarregado de administrar o trabalho e mostrou tanta actividade, tanta dedicação, que em nove mezes resurgio o theatro bello e magestoso. Em 3 de Janeiro de 1857 esse edificio abrio suas portas ao publico!! >

A respeito do exterior do edificio assim se pronuncia: << Não ha belleza na construcção do theatro S. Pedro de Alcantara, não é um monumento de bôa architectura, as pilastras da frente do edificio são grossas em relação a altura, as janellas são estreitas e pequenas. 
$<O$ theatro mais que qualquer outro edificio deve ser elegante e magestoso, é o templo das artes.

Constituindo um poema de marmore deve haver arte, poesia em cada uma de suas columnas, de seos arcos, de suas abobadas, dos seos capiteis, dos seos lavores. É no theatro, que se pôde estudar o gosto artistico de um povo; com uma tradição de marmore, o theatro, diz aos vindouros que os antepassados presavam as artes. Symbolo, expressão exacta do progresso artistico pode-se lêr no rosto de taes edificios a civilisação de um paiz. Vê-se pois, que devemos ter um theatro digno do seculo em que vivemos; um theatro monumental que seja o livro onde fique estampada a historia da arte nacional !! >

Em 1 de Janeiro de 1870 abrio-se o theatro S. Luiz construido pelo artista Furtado Coêlho.

A 19 de Fevereiro de 1871 foi inaugurado o Imperial Theatro D. Pedro II.

João C. de Oliveira Cruz, Engenheiro Militar.

\section{CRUZ, João C. de Oliveira. "Melhoramentos da Capital da Parahyba VI - Theatro"}

Em 18 de Agosto de 1877 inaugurou-se o theatro das Variedades, que depois tomou o nome de < Recreio Dramatico. >

Neste mesmo anno abrio-se o < Recreio Dramatico Riachuelense. $>$

Em 3 de Janeiro de 1880 abrio tambem as suas portas o theatro Lucinda, construido ainda pelo artista Furtado Coelho.

O theatro Sant'Anna inaugurou-se em Outubro de 18880.

Finalmente o theatro Polytheama e outros, que deixei de tratar, completam os edificios que no Rio de Janeiro são destinados ao cultivo das artese a civilisação do povo.

Sei que com esta resenha fatiguei a paciencia dos leitores, mas não me era possivel deixar de assim proceder desde que esse estudo vem-me servir de base as considerações que tenho agora de apresentar, pois vou me referir a necessidade de um templo d'aquella ordem na capital desta provincia, tão escassa de entretimentos publicos.

Assim como no Rio de Janeiro tem havido uma verdadeira luta para obtensão de um importante theatro, que faça honra a sociedade da capital do imperio, e que venha a servir de at... aos vidouros de que geralmente [...] um verdadeiro culto as artes, aspiração que ainda não foi possivel ser satsfeita devido a transtornos que são filhos do acaso em muitas províncias, $x x$ acanhada esfera de recursos de que dispoem não só o governo como o povo há esforçado-se para tambem possuirem um edificio onde a sociedade possa estudar os vicios através das moralsadoras scenas, revestidas de poesia e belleza.

Como pois não hade a provincia da Parahyba abrir seos braços para em um amplexo colligar-se intimamente com o prototypo do bom gosto, da educação e da civilisação? A Parahyba, como as outras províncias, não pode deixar de ambicionar tudo o que faz tornar um povo grande.

Se a capital desta aprasivel provincia contivesse em seo seio outras fontes, onde o povo fosse beber os conhecimentos dos diversos dramas da vida, e onde fosse tambem encontrar deversões que lhe tocando a alma o elevasse a um verdadeiro céo de delicias, não se tornaria tão urgente um bom theatro que attrahisse a sociedade parahybana, porquanto ella teria meios de fazer desapparecer a monotomia que tão commummente se apresenta durante as horas em que não se entrega aos afazeres da vida.

Mas a capital da provincia não dispõe de meios que facultem essas distracções, de modo que o povo vê-se obrigado a manter-se em um circulo de diversões muito limitado.

O theatro, que constitue uma verdadeira escola para o povo, deverá ser estabelecido aqui, como em outra qualquer parte, sob a proteção da provincia.

Não é se entregando somente as lutas policas que um povo floresce, ao contrario, muitas vezes é esta luta um poderoso elemento de destruição de todos os beneficios destinados ao mesmo povo.

Portanto, apezar dos interesses politicos, devem os representantes de qualquer provincia dispensar uma partícula de interesse em beneficio de todos os emprehendimentos que constituem a grandeza de um povo. Não quero dizer que os dignos filhos da provincia que tão honrosamente fazem parte da assembléa não disponham dos melhores desejos de melhorar a capital, ao contrario, estou mais que convencido de que, se até o presente elles quasi nada teem feito, é tão somente devido aos poucos recursos de que a provincia dispõe.

Dir-se-há: a capital da provincia na está tambem tão atrazada porque contem um theatrinho que esta de accordo com o desenvolvimento da população. È verdade, que existe um edificio destinado a servir de theatro; mas a não ser a xxxx xxxx nada mais há nele que indique um verdadeiro templo das artes. Analysando-se-o interna e externamente, conclue-se, que, antes não existisse, pois, em vez de honrar esta illustrada sociedade, deve fazer coral-a toda em vez de tranpozer a soleira de sua unica e acanhada porta. O edificio em questão, sem architectura, sem belleza, sem condições hygienicas e de esgurança, antes parece uma velha casa do seculo passado, do que theatro da capital de uma provincia. 
O acanhado espaço de seo recinto e a falta de aberturas para ventillação, são inconvenientes prejudissialissimos ás pessoa que alli vão procurar algumas horas de recreio.

João C. de Oliveira Cruz, Engenheiro Militar.

\section{CRUZ, João C. de Oliveira. "Melhoramentos da Capital da Parahyba VI - Theatro"}

A par de todos esses defeitos nota-se nesse theatrinho, por occasião dos espectaculos, um facto digno de nota, que já devia ter sido prohibido pela policia, a bem da segurança do povo, o qual vem a ser, o fechamento da unica porta que dá entrada. Comprehende-se que um edificio destinado ao povo, e que contem uma só porta, edificio que, como disse, resente-se da falta de ventilação, não se deverá por forma alguma interceptar a passagem do ar. Alem disso sendo o theatro illuminado a kerosene, qual não vem a ser o perigo que corre o povo por occasião dos espectaculos? Peçamos sempre a Deus que nos continue a proteger, afim de que esta cidade não seja um dia victima de tantas imprudencias.

A substituição do actual theatro ou a sua transformação, é um melhoramento que urge fazer-se, não só para que o povo parahybano possa orgulhar-se de possuir um edificio que o honre, como para que a par da distracção que alli encontrar, ache todos os meios que lhe confortem e lhe garantam a vida.

É preciso render a verdadeira justiça aos parahybanos, pois elles por si já tem procurado fazer desapparecer este mal tão pesado; mas seus esforços sendo fracos não permittiram vencer as difficuldades que se apresentaram com seu cortêjo desanimador.

Agora o que resta fazer?

Apellar para os representantes da provincia, para que tratem de adquirir o esqueleto do edificio que representa o sacrificio de tantos bons filhos da terra, e completem-o, que já terão prestado a sociedade parahybana importantissimo serviço.

\section{VII - Carril de ferro}

A importancia deste melhoramento é manifesta, portanto escusado será discutil-o espaçadamente, entretanto, como dever a que me impuz para com a illustrada sociedade parahybana, não quero deixar de dizer sempre algumas palavras não só para que fiquem patentes as vantagens que traz ao povo a introducção dos vehiculos sobre trilhos de ferro, como tambem para que de alguma forma venha concorrer para despertar os grandes emprehendedores do esquecimento em que se acham com relação a esta capital.

Não ha nada mais enfadonho e encommodativo do que o percurso de uma distancia, mais ou menos longa, sob o rigor do calor solar ou da influencia das aguas das chuvas. Quando mais não fosse só o facto de expor-se o povo a toda hora as consequencias dos fortes calores ou das humidades, seria bastante para bem demonstrar a necessidade que aqui há de meios de locomoção.

Se ao menos, como em outras cidades, houvesse o recurso dos carros, necessariamente não se tornaria tão urgente esse melhoramento; mas, faltando quasi em absoluto todos os recursos desta especie, fica o povo privado de mais esta commodidade e este meio de conforto.

Os carris de ferro embora contenham alguns inconvenientes, todavia são hoje geralmente empregados como agradaveis e economicos meios de transporte.

Se por um lado torna o povo preguiçoso a ponto de não querer vencer a menor distancia a pé, o que contribue para um verdadeiro estado doentio, as suas vantagens são de tal ordem, que não é possivel com o fim de evitar a indolencia, deixar de parte tão importante melhoramento. Precisamos, portanto, mais uma vez, vencer a repugnancia dos atrasados, e convencel-os de que as suas erradas opiniões não podem e nunca poderão abafar o brado de uma medida civilisadora.

É de suppôr que ainda venham attribuir a especulação de terceiros qualquer tentamen que se haja de fazer para dotar esta cidade de uma empreza d'aquelle genero; mas esses individuos que não comprehendem os elementos civilisadores de um povo, ou por ignorancia ou por especulação, entendem dever tudo embaraçar com as suas theorias falsas, chamando ao seu seio os fracos espititos tão faceis de convencer pelos estudados argumentos filhos de sua astúcia.

Assim, pois, deveremos deixar marchar livremente a Parahyba, e em vez de embaraçarmos o seu progresso, ao contrario procuremos facilital-o pondo a sua disposição as forças de que dispomos.

Não procuremos desanimar todo aquelle que desejar engrandecer esta provincia, antes o auxiliemos porque só assim poderemos estar brevemente a par de outras provincias do imperio.

Aquelle que se mostrar desanimado ou não tiver interesse pela Parahyba, contenha-se, e guarde somente para si o seu egoismo ou ignorancia. 
Continuando a fallar dos carris de ferro direi que não é empreza para grandes lucros no estado actual, mas se presentemente ella não apresenta muito bom resultado mais tarde compensará o sacrificio que for empregado.

A cidade tende a se augmentar, e estou certo que este augmento tomará grandes proporções desde que seja ella cortada pelos trilhos de bonds.

Uma linha simples com o competente desvio, passando pelas principaes ruas, é por enquanto o sufficiente para satisfazer o povo; empregando este systema não será grande a despeza que se tem de fazer para a realisação da empreza.

Poderia fazer um historico deste importante serviço, mas não desejando fatigar os illustrados leitores, limitome a estas unicas palavras que estou certo serão acolhidas com interesse pela sociedade parahybana.

É preciso confessar mais uma vez, que não tenho em vista outro fim a não ser o de concorrer com o meu xxx serviço para o progresso da provincia; portanto, como já disse, sou forçado a assim pronunciar-me para que não pese no espirito de quem quer que seja, que pretendo procurar filiar-me a esta ou a outra qualquer empreza que se venha aqui estabelecer.

João C. de Oliveira Cruz, Engenheiro Militar.

\section{CRUZ, João C. de Oliveira. "Melhoramentos da Capital da Parahyba VIII - Jardim}

É este um melhoramento cuja importancia não se pode contestar.

Já tenho muitas vezes feito ver a falta de meios de recreios para o povo, e não me canso em repetir que, excessivamente insipida é esta cidade, pois, nem ao menos tem um jardim em condições de tornar-se um verdadeiro logradouro publico.

Em terreno situado em frente ao palacio da presidencia, existe uma pequena plantação de palmeiras formando duas ruas que se cruzam.

O centro formado pelo cruzamento das ditas ruas constitue uma disposição circular de uma area mais ou menos de $18^{\circ}$. De diametro. É nesta parte do terreno que, aos domingos e dias santificados, reune-se pequeno numero de pessoas que vão assistir a execução de algumas peças de musica do repertorio da banda musical do corpo de policia.

Todo terreno é cercado por um baixo muro que contem superiormente um gradil simples e de pessimo gosto.

Este muro feito de alvenaria é construido do modo mais extravagante, por isso que acompanha a inclinação do terreno, em vez de seu capeamento achar-se em um só plano horizontal. Esta disposição exquisita faz com que o gradil mostre-se penso, porque devendo seus vergalhões estarem situados segundo a vertical, formam com o capeamento do muro angulos agudos em consequencia da inclinação do mesmo muro.

A não serem as palmeiras de que fallei nada mais existe no terreno murado, que tão impropriamente chamam jardim.

Assim mesmo devemos dar graças ao Creador, porque peior seria se elle não existisse; mas, os louváveis desejos que tiveram os promotores d'aquelle melhoramento, não foram compensados, porquanto, ou por falta de profissionaes que se encarrega-sem da construcção, ou por outro quaquel motivo, à verdade é que levantaram em frente ao palacio não um jardim segundo as regras da arte, mas um trabalho que só servirá para fazer corar esta civilisada sociedade.

A intensão do realisadores da idéafoi a mais nobre e uma das mais sublimes, porem a infelicidade que pesa sobre esta terra mais umas vez mostru-lhes as terriveis garras e disse-lhes:

Apezar dos esforços que fazeis não haveis de conseguir um melhoramento que vos honre.

Está protanto, neste ponto, em pessimas condições a capital da Parahyba: dirão os letores: - Mas nada se pode fazer porque não dispomos d'agua que regue as plantas, e então escusado será cultival-as.

Sou dos primeiros a reconhecer que com a agua canalisada não se pode manter um jardim em boas condições, mas enquanto não se dispõe deste poderoso auxilio deve-se procurar remediar adoptando-se um meio qualquer de fazer chegar a agua áquelle lugar.

Agora resta saber se presentemente pode-se conseguir ou não este resultado. Por dois modos diversos podemos conduzir agua para o serviço do jardim: o primeiro trazendo-a d'uma cisterna que existe na area situada no centro do edificio que serve de palacio da presidencia; o segundo fazendo-se conduzir das fontes ou cacimbas.

Quanto ao primeiro caso ha necessidade de despender-se certa quantia com o estabelecimento de machina, encanamento e deposito.

Este meio é realmente o melhor porque não só o trabalho ficaria mais perfeito como a quantidade d'agua seria relativamente consideravel. 
Mas, estando a provincia com vistas de contratar a canalisação d'agua da capital, entendo não haver vantagem em despender-se dinheiro com um serviço que em breve seria abandonado.

O segundo meio, que é o unico que se deve abraçar, é fazer conduzir agua por fachinas de presos para um deposito qualquer no interior do jardim.

Sendo este um processo que se pode a todo tempo fazer cessar, sem que por isso fique sacrificado capital algum, entendo dever-se empregal-o desde já, afim de que possa em breve haver na Parahyba um jardim, onde o povo encontre horas de verdadeira distracção.

Faz realmente falta sensivel um jardim nesta capital; nos domingos e dias santificados, principalmente, não há um ponto para, onde o povo se encaminhe com o fim de ahi se destrahir.

No logar que actualmente chamam jardim, nem ao menos se pode estar porque não ha bancos onde se possa descansar.

As poucas familias que passam olham-no com indiferença, em vez de por elle se interessarem como ponto de aprasivel recreação.

Os jardins públicos são de tão urgentes necessidades, como os theatros. Nestes, é onde o povo aprende a destinguir o bem do mal, é onde a educação se eleva; n'aquelle, sob a influencia dos perfumes das flores, é onde descansa a intelligencia dos preoccupações da vida; é onde se commenta as mais bellas aventuras; é onde se planeja os mais elevados emprehendimentos; é, enfim, onde se resolve as nobres ações.

Para mostrar o progresso que tem feito esta classe de divertimento, não precisa mais que dizer algumas palavras a respeito do desenvolvimento que ella tem tido no Rio de Janeiro.

Entre os muitos jardins espalhados pela grande cidade, notam-se, sobre tudo, trez dignos de toda admiração: o jardim botanico, situado perto da gavea; o passeio publico perto do convento da Ajuda, e o jardim da praça da Acclamação.

João C. de Oliveira Cruz, Engenheiro Militar.

\section{CRUZ, João C. de Oliveira. "Melhoramentos da Capital da Parahyba VIII - Jardim"}

O primeiro, se bem que digno de todo interesse, não está tão ao alcance da população, pois dista duas leguas a contar do coração da cidade; entretanto, especialmente aos domingos e dias santos, é enorme a concorrencia do povo alli, indo quasi todo passar o dia interio. Os consertos musicaes e os agradaveis passeios pelas suas alvas ruas convidam a todos que sabe apreciar o bello, e fazem banir da imaginação qualquer contrariedade da vida.

O passeio publico, que mais proximo fica do centro da cidade, é diariamente freqüentado; alli, a qualquer hora do dia, encontra-se no labirinto de suas ruas a sociedade que se crusa, indo de vez em quando se chocar contra as flores naturaes a belleza resplandecente do sexo deslumbrante.

O jardim da praça da Acclamação é de todo o mais importante, suas dimensões excede de 100 metros em uma das faces e 200 metros em outra. Dividido em diversas secções, contem lindas ruas, rios e pontes, tudo feito com o melhor gosto e os mais ricos preceitos da arte. Uma immensa cascata toda feita de cimento assemelhando granito, é um trabalho dos mais delicados que podem haver no mundo; nas grutas que se observa; a queda das aguas; a variedade de peixes existentes no lago onde as aguas se pecipitam, tudo emfim faz admirar a perfeição do braço executor!

Alem destes três jardins, ainda há outro na cidade, que servem de logradouros públicos; assim temos o jardim da praça da Constituição onde se ergue imponente a estatua de D. Pedro I; o peuqeno jardim do lado de S. Francisco onde se encontra a estatua de José Bonifácio; o jardim do Rocio pequeno etc. etc.

Vemos portanto que a sociedade da corte do imperio muito bem aquihnoada se acha em relação a esta classe de devirtimento; outro tanto não acontece as pobres províncias, sendo que algumas, como esta, nem ao menos um jardim podem dizer que possuem.

João C. de Oliveira Cruz, Engenheiro Militar.

\section{Melhoramentos da Capital da Parahyba}

Concluímos hoje a publicação d'este interessante trabalho, excripto expressamente para a Gazeta da Parahyba pelo distincto capitão de engenheiros, Dr. João Claudino de Oliveira Cruz.

Os constantes encômios que temos ouvido sobre tão util e opportuna producção constituem: para nós a satisfação de a termos dado á publicidade, demonstrando mais uma vez que nos esforçamos sempre por offerecer ao publico a leitura de tudo quanto possa ser proveitoso a Parahyba; e para o seo intelligente 
author Dr. Oliveira Cruz, a certeza de que S. S. aproveita bem o seo tempo, applicando-o na confecção de trabalhos importantes, que merecem a franca approvação de todos.

O distincto engenheiro militar, dando preferencia a um assumpto de interesse todo local à qualquer outro, prestou um relevante serviço aos nossos patricios, porquanto, com proficiencia e em lingoagem correcta e ao alcance de todos, demonstrou e inoculou em todos os espiritos a necessidade dos principaes melhoramentos de que carece esta capital, para collocar-se à par de muitas das suas irmans de igual cathegoria, e que, entretanto, se acham d'ella distanciadas pelo facto de já possuirem alguns desses melhoramentos.

O nosso maior desejo é que os melhoramentos indicados pelo Dr. Oliveira Cruz sejam em breve prazo, na ordem em que foram enumerados pelo author, uma realidade n'esta capital; para isso bastarão dois unicos elementos: - a boa vontade de presidentes que se interessem realmente pela provincia, e a indispensavel ainimação e o efficaz apoio do publico.

Si não fosse o receio de nos tornarmos importunos, pediriamos ao Dr. João Claudino de Oliveira Cruz que se dispozesse a encetar e concluir um novo trabalho, fructo da sua reconhecida actividade intellectual, para com elle honrarmos ainda as columnas da Gazeta logo que estivesse concluido.

Não Ihe faltam habilitações nem disposição para levar à bom termo um emprehendimento d'essa naturesa, e S. S. prestaria assim mais um favor o nós e aos nossos leitores a quem procuramos sempre servir bem. 